\author{
SANDIA REPORT \\ SAND2005-5297 \\ Unlimited Release \\ Printed August 2005
}

\title{
Corrective Measures Evaluation Report for Tijeras Arroyo Groundwater
}

Jonathan L. Witt; M. Hope Howard; Kevin A. Hall; Robert C. Starr; Dana L. Dettmers

Prepared by

Sandia National Laboratories

Albuquerque, New Mexico 87185 and Livermore, California 94550

Sandia is a multiprogram laboratory operated by Sandia Corporation, a Lockheed Martin Company, for the United States Department of Energy's

National Nuclear Security Administration under Contract DE-AC04-94AL85000.

Approved for public release; further dissemination unlimited.

Sandia National Laboratories 
Issued by Sandia National Laboratories, operated for the United States Department of Energy by Sandia Corporation.

NOTICE: This report was prepared as an account of work sponsored by an agency of the United States Government. Neither the United States Government, nor any agency thereof, nor any of their employees, nor any of their contractors, subcontractors, or their employees, make any warranty, express or implied, or assume any legal liability or responsibility for the accuracy, completeness, or usefulness of any information, apparatus, product, or process disclosed, or represent that its use would not infringe privately owned rights. Reference herein to any specific commercial product, process, or service by trade name, trademark, manufacturer, or otherwise, does not necessarily constitute or imply its endorsement, recommendation, or favoring by the United States Government, any agency thereof, or any of their contractors or subcontractors. The views and opinions expressed herein do not necessarily state or reflect those of the United States Government, any agency thereof, or any of their contractors.

Printed in the United States of America. This report has been reproduced directly from the best available copy.

Available to DOE and DOE contractors from

U.S. Department of Energy

Office of Scientific and Technical Information

P.O. Box 62

Oak Ridge, TN 37831

$\begin{array}{ll}\text { Telephone: } & \text { (865) 576-8401 } \\ \text { Facsimile: } & \text { (865) 576-5728 } \\ \text { E-Mail: } & \text { reports@adonis.osti.gov } \\ \text { Online ordering: } & \text { http://www.osti.gov/bridge/ }\end{array}$

Online ordering: $\quad$ http://www.osti.gov/bridge/

Available to the public from

U.S. Department of Commerce

National Technical Information Service

5285 Port Royal Rd

Springfield, VA 22161

Telephone: (800) 553-6847

Facsimile: (703) 605-6900

E-Mail: orders@ntis.fedworld.gov

Online order: http://www.ntis.gov/help/ordermethods.asp?loc=7-4-0\#online

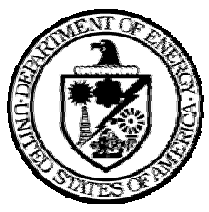


SAND2005-5297

Unlimited Release

Printed August 2005

\title{
Corrective Measures Evaluation Report For Tijeras Arroyo Groundwater
}

\author{
Jonathan L. Witt; M. Hope Howard; Kevin A. Hall; \\ Brennon R. Orr; Dana L. Dettmers \\ North Wind, Inc. \\ Idaho Falls, Idaho
}

\begin{abstract}
This Corrective Measures Evaluation report was prepared as directed by a Compliance Order on Consent issued by the New Mexico Environment Department to document the process of selecting the preferred remedial alternative for Tijeras Arroyo Groundwater. Supporting information includes background concerning the site conditions and potential receptors and an overview of work performed during the Corrective Measures Evaluation. The evaluation of remedial alternatives included identifying and describing four remedial alternatives, an overview of the evaluation criteria and approach, comparing remedial alternatives to the criteria, and selecting the preferred remedial alternative. As a result of the Corrective Measures Evaluation, monitored natural attenuation of the contaminants of concern (trichloroethene and nitrate) is the preferred remedial alternative for implementation as the corrective measure for Tijeras Arroyo Groundwater. Design criteria to meet cleanup goals and objectives and the corrective measures implementation schedule for the preferred remedial alternative are also presented.
\end{abstract}


This Page Intentionally Left Blank 


\section{Contents}

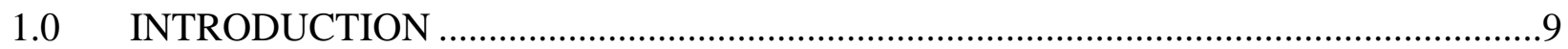

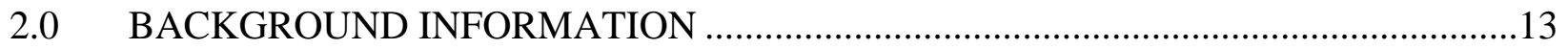

2.1 Tijeras Arroyo Groundwater .................................................................. 13

2.2 SNL/NM Area of Responsibility for Tijeras Arroyo Groundwater......................15

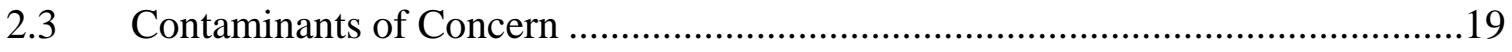

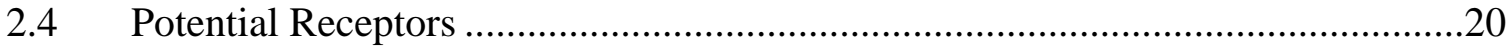

3.0 EVALUATION OF REMEDIAL ALTERNATIVES ..............................................21

3.1 Overview of the Corrective Measures Evaluation .............................................21

3.1.1 Remedial Alternatives Data Gaps Review............................................24

3.1.2 Evaluation of Contaminant Transport in Groundwater ............................25

3.1.3 Investigation of Intrinsic Anaerobic Biodegradation................................26

3.1.4 Evaluation of an Intrinsic Aerobic Biodegradation Mechanism................26

3.2 Identification and Description of Remedial Alternatives .................................27

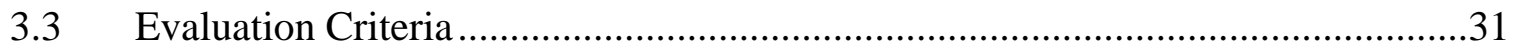

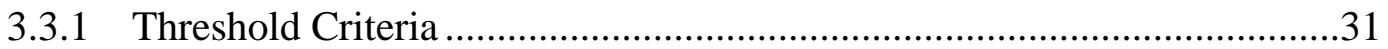

3.3.2 Remedial Alternative Evaluation Criteria..............................................32

3.4 Selection of a Preferred Remedial Alternative ................................................33

4.0 REMEDIAL ALTERNATIVE DESIGN CRITERIA TO MEET CLEANUP GOALS

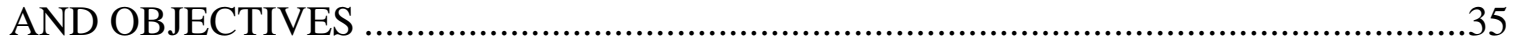

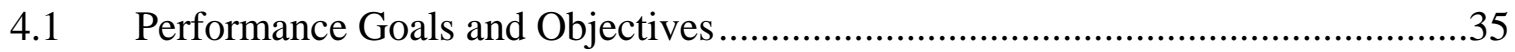

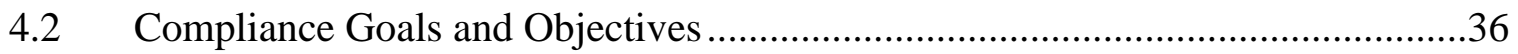

5.0 CORRECTIVE MEASURES IMPLEMENTATION PLAN .......................................37

5.1 Corrective Measures Implementation Plan Outline ..........................................37

5.2 Corrective Measures Implementation Schedule .............................................38

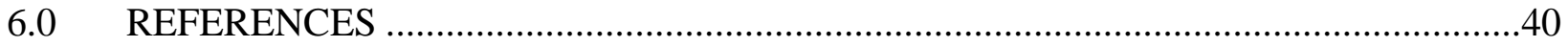


Attachment A. Contaminant Distribution in Groundwater.................................................. A-1

Attachment B. Remedial Alternatives Data Gaps Review ....................................................1

Attachment C. Evaluation of Contaminant Transport in Groundwater .....................................

Attachment D. Investigation of Anaerobic Biodegradation ........................................... D-1

Attachment E. Evaluation of an Intrinsic Aerobic Degradation Mechanism ...........................E-1

\section{Figures}

1-1. Tijeras Arroyo Groundwater SNL/NM CME area of responsibility............................ 10

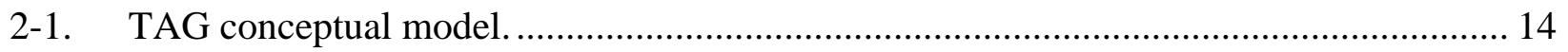

2-2. Monitoring and water supply wells and potential release sites in the area of

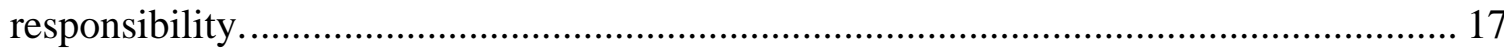

3-1. Illustration of the process of identifying remedial alternatives from the CME

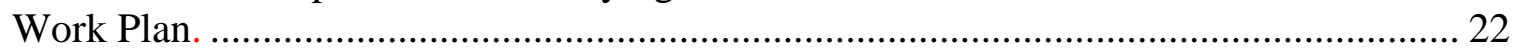

3-2. Illustration of the staged process of data gathering activities and production of informal

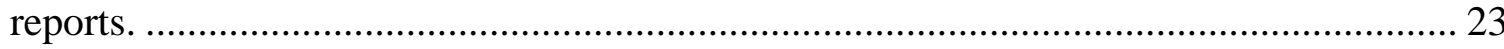

3-3. Illustration of remedial alternative evaluations performed during the paper study.......... 25

3-4. Decision framework for evaluating MNA......................................................... 28

5-1. Corrective measures implementation schedule.................................................... 39

\section{Tables}

1-1. CME Report crosswalk table. ........................................................................... 11

2-1. COCs in the TAG SNL/NM area of responsibility................................................ 19

3-1. Documents produced in support of the CME. ........................................................... 23

3-2. Technical and functional requirements for MNA................................................. 30

3-3. Cost elements for the MNA remedial alternative. ............................................... 31

3-4. Summary of MNA applicability considering threshold criteria. .................................. 34

3-5. Summary of MNA effectiveness considering remedial alternative criteria..................... 34

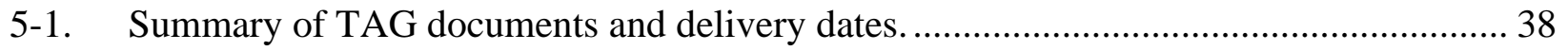




\section{Acronyms}

\begin{tabular}{|c|c|}
\hline AOR & area of responsibility \\
\hline ARG & ancestral Rio Grande \\
\hline bgs & below ground surface \\
\hline CME & Corrective Measures Evaluation \\
\hline COA & City of Albuquerque \\
\hline $\mathrm{COC}$ & contaminant of concern \\
\hline COOC & Compliance Order on Consent \\
\hline CMI & Corrective Measures Implementation \\
\hline DOE & U.S. Department of Energy \\
\hline EPA & U.S. Environmental Protection Agency \\
\hline $\mathrm{ES} \& \mathrm{H}$ & environment, safety, and health \\
\hline $\mathrm{ft}$ & feet \\
\hline FY & fiscal year \\
\hline ISB & in situ bioremediation \\
\hline KAFB & Kirtland Air Force Base \\
\hline $\mathrm{mg} / \mathrm{L}$ & milligrams per liter \\
\hline MCL & maximum contaminant level \\
\hline MNA & monitored natural attenuation \\
\hline NMED & New Mexico Environment Department \\
\hline RCRA & Resource Conservation and Recovery Act \\
\hline sMMO & soluble methane monooxygenase \\
\hline SNL/NM & Sandia National Laboratories/New Mexico \\
\hline SWMU & Solid Waste Management Unit \\
\hline TAG & Tijeras Arroyo Groundwater \\
\hline TCE & trichloroethene \\
\hline T\&FR & technical and functional requirement \\
\hline$\mu \mathrm{g} / \mathrm{L}$ & micrograms per liter \\
\hline
\end{tabular}


This Page Intentionally Left Blank 


\subsection{INTRODUCTION}

Sandia National Laboratories, New Mexico (SNL/NM) is a government-owned, contractoroperated, multi-program laboratory overseen by the U.S. Department of Energy (DOE), National Nuclear Security Administration through the Sandia Site Office in Albuquerque, New Mexico. Sandia Corporation, a wholly owned subsidiary of Lockheed Martin Corporation, operates SNL/NM under Contract DE-AC04-94AL85000. Activities conducted at the facility include:

- Research and development of advanced nuclear reactors,

- Simulation sources,

- Reactor safety,

- Energy-related programs, and

- Nuclear weapons systems.

The Tijeras Arroyo Groundwater (TAG) study area encompasses approximately 40 square miles $\left(\mathrm{mi}^{2}\right)$ located on the northwest portion of Kirtland Air Force Base (KAFB) (Figure 1-1). The name of the area is derived from Tijeras Arroyo, which is the most significant surface-water drainage feature within this area. There are three principal parties potentially responsible for groundwater contamination within the TAG study area: SNL/NM, KAFB, and the City of Albuquerque (COA). This Corrective Measures Evaluation (CME) report addresses groundwater contamination in the SNL/NM area of responsibility (AOR) within the TAG study area, as defined in Section 2.2.

Groundwater investigations conducted during the last 10 years by the SNL/NM Environmental Restoration Project have identified trichloroethene (TCE) and nitrate as the contaminants of concern (COCs) in the TAG SNL/NM AOR. The New Mexico Environment Department (NMED) issued a Compliance Order on Consent (COOC) (NMED 2004) to the DOE in which TAG was identified as an area of groundwater contamination requiring a CME. The COOC directed that a CME Work Plan be developed to identify and outline a process to evaluate remedial alternatives. The CME Work Plan was formally approved by the NMED in November 2004. Results of activities performed under the TAG CME Work Plan are documented in this CME Report.

The purpose of this CME Report is to select a preferred remedial alternative for the SNL/NM AOR based on the results of information gathered during the CME process. The CME was conducted to ascertain which remedial alternative would most effectively meet the project goals and objectives for cleanup within the regulatory framework. The performance and compliance goals and objectives were developed in the TAG CME Work Plan (SNL/NM 2004).

This document is organized in accordance with the COOC (NMED 2004) and the TAG CME Work Plan (SNL/NM 2004). Table 1-1 shows a crosswalk between the sections specified by the guidance of the COOC (as well as the CME Work Plan) and the sections of this document. Section 2.0 summarizes background information. Section 3.0 describes the remedial alternatives evaluation while Section 4.0 presents remedial alternative design criteria to meet the cleanup goals and objectives. Section 5.0 presents an outline for the Corrective Measures Implementation (CMI) Plan and presents the schedule for the CMI. 


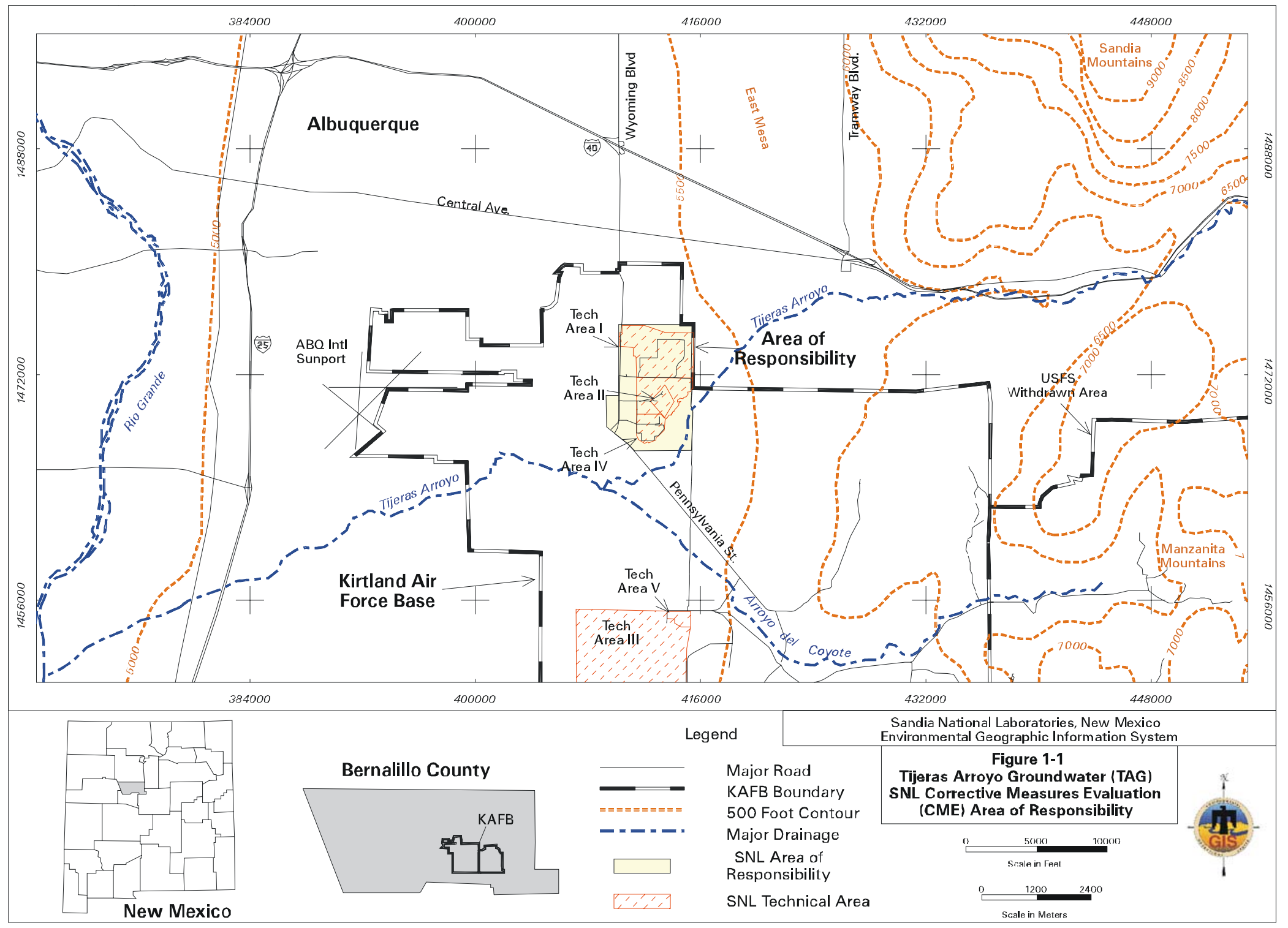

Figure 1-1. Tijeras Arroyo Groundwater SNL/NM area of responsibility. 
Table 1-1. CME Report crosswalk table.

\begin{tabular}{l|ll}
$\begin{array}{c}\text { CME Report Requirements } \\
\text { (as stated in the CME Work Plan and } \\
\text { the COOC) }\end{array}$ & & \multicolumn{1}{c}{$\begin{array}{c}\text { TAG CME Report } \\
\text { (Section) }\end{array}$} \\
\hline Introduction & 1.0 & Introduction \\
\hline Background Information & 2.0 & Background Information \\
\hline Site Conditions & 2.1 & Tijeras Arroyo Groundwater \\
\hline Potential Receptors & 2.2 & $\begin{array}{l}\text { SNL/NM Area of Responsibility for } \\
\text { Tijeras Arroyo Groundwater }\end{array}$ \\
\hline Regulatory Criteria & 3.3 & Evaluation Criteria \\
\hline Identification of Remedial Alternatives & 3.2 & $\begin{array}{l}\text { Identification and Description of Remedial } \\
\text { Alternatives }\end{array}$ \\
\hline Evaluation of Remedial Alternatives & 3.0 & Evaluation of Remedial Alternatives \\
\hline $\begin{array}{l}\text { Selection of a Preferred Remedial } \\
\text { Alternative }\end{array}$ & 3.4 & $\begin{array}{l}\text { Selection of a Preferred Remedial } \\
\text { Alternative }\end{array}$ \\
\hline $\begin{array}{l}\text { Design Criteria to Meet Cleanup } \\
\text { Objectives }\end{array}$ & 4.0 & $\begin{array}{l}\text { Remedial Alternative Design Criteria to } \\
\text { Meet Cleanup Goals and Objectives }\end{array}$ \\
\hline Schedule & 5.0 & Corrective Measures Implementation Plan \\
\hline
\end{tabular}


This Page Intentionally Left Blank 


\subsection{BACKGROUND INFORMATION}

This section provides background information concerning the TAG study area (Section 2.1), the SNL/NM AOR within the TAG study area (Section 2.2), and COCs in the SNL/NM AOR (Section 2.3). Descriptions of site conditions and the project background, including delineation of SNL/NM responsibilities for contaminants in TAG, are included in the CME Work Plan (SNL/NM 2004).

This CME was completed as required by the COOC (NMED 2004) and under the direction of the CME Work Plan (SNL/NM 2004). Additional characterization activities at Tijeras Arroyo were performed simultaneously with the CME, in accordance with the Tijeras Arroyo Groundwater Investigation Work Plan (SNL/NM 2003), which is separate from the CME Work Plan. The TAG CME Work Plan and the TAG Investigation Work Plan both contain schedules that define dates for the delivery of plans and reports related to TAG. A Final TAG Investigation Report and the TAG CME Report were both scheduled for completion by September 30, 2005.

Although these schedules coincide, the COOC (NMED 2004) states that the CME process cannot proceed until characterization is sufficient. To meet the COOC schedule, SNL/NM proceeded with the CME assuming that the existing groundwater data were sufficient to commence the CME process. Throughout the CME process, the analytical data collected under the provisions of the TAG Investigation Work Plan were used to verify and supplement historical data. The groundwater analytical data collected under the provisions of the TAG Investigation Work Plan (SNL/NM 2003) are in agreement with historical concentrations (see Section 2.3 and Attachment A for details).

\subsection{Tijeras Arroyo Groundwater}

The TAG conceptual model is summarized in the CME Work Plan and illustrated in Figure 2-1. Two groundwater systems in the Upper Santa Fe Group have been identified in the TAG study area: (1) a perched groundwater system, and (2) the regional aquifer. In the northern portion of the TAG study area, the depth to potentiometric surface of the perched groundwater system ranges from approximately 220 to $330 \mathrm{ft}$ below ground surface (bgs), whereas the depth to potentiometric surface of the regional aquifer is approximately 440 to $570 \mathrm{ft}$ bgs. The perched groundwater system may merge with the regional aquifer in the southeastern portion of the perched groundwater system, although this connection has not been conclusively demonstrated. The upper-most saturated interval of the perched groundwater system is between 10 and $30 \mathrm{ft}$ thick. Water in the perched system moves to the southeast and recharges the underlying regional aquifer southeast of Tijeras Arroyo. Groundwater in the regional aquifer migrates towards production wells. 


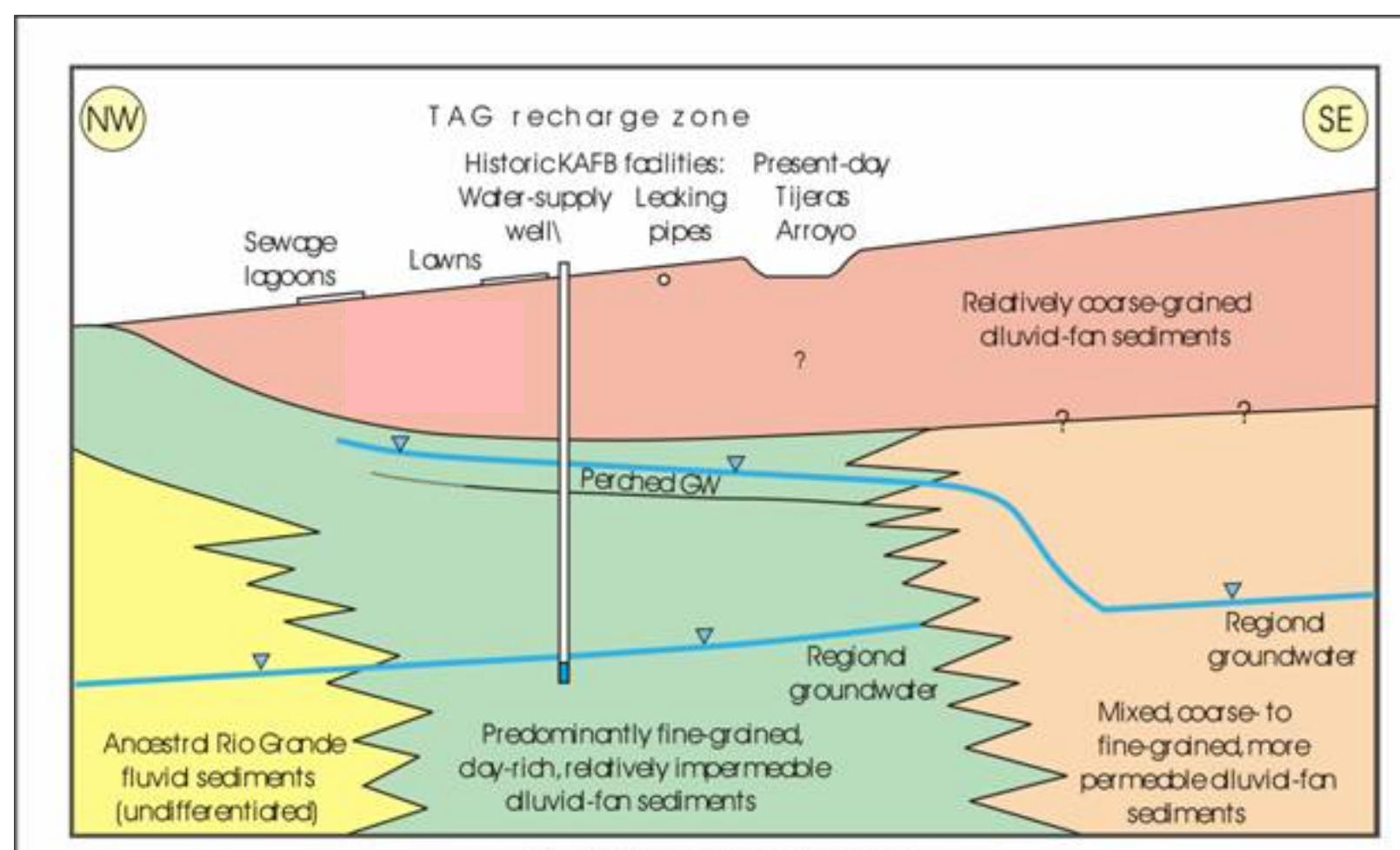

A. Stratigaphicrelctionships.

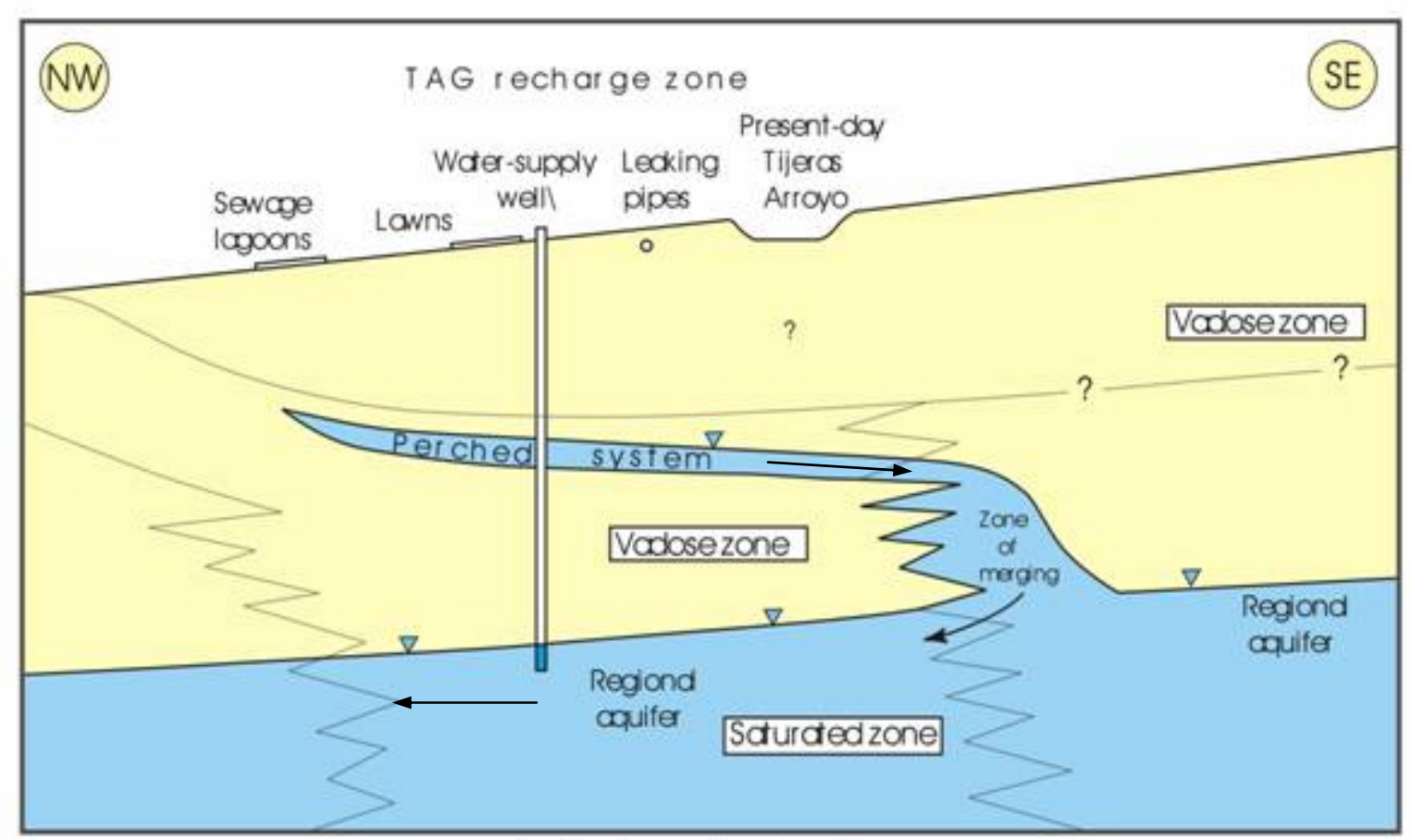

B. TAGconcoptud model.

DVH, Nov. 2002

Figure 2-1. TAG conceptual model (see SNL/NM 2004 for details). 


\subsection{SNL/NM Area of Responsibility for Tijeras Arroyo Groundwater}

The scope of the SNL/NM CME includes only part of the TAG study area. Characterization of the TAG study area was undertaken by three potentially responsible parties: (1) SNL/NM, (2) the COA, and (3) KAFB. As a result, it was necessary for each party to clearly define their contribution to overall TAG remediation. The CME Work Plan (SNL/NM 2004) identified the specific area within the overall TAG study area for which SNL/NM has remediation responsibility. In order to clearly distinguish it from the overall TAG study area, the area that the CME addresses is referred to as the SNL/NM AOR.

The SNL/NM AOR encompasses an approximately two square miles area in the north-central part of KAFB. Figure 2-2 illustrates the location of 13 potential release sites within the SNL/NM AOR, as well as COA and KAFB potential release sites that are considered to be outside of the SNL/NM AOR. All of these potential release sites were included in the scope of the TAG study area investigations (SNL/NM 2002). For the SNL/NM AOR, only the 13 $\mathrm{SNL} / \mathrm{NM}$ potential release sites were considered. These release sites are described in the CME Work Plan (SNL/NM 2004).

Based on a screening of potential release sites presented in the TAG Continuing Investigation Report (SNL/NM 2002), the potential SNL/NM AOR sources designated as a high concern level include:

- Solid Waste Management Unit (SWMU) 46 (Old Acid Waste Line Outfall)—TCE and nitrate,

- SWMU 227 (Bunker 904 Outfall)—TCE,

- SWMU 165 (Building 901 Septic System) —TCE and nitrate, and

- SWMU 187 (TA-I Sanitary Sewer System)—nitrate.

Historically, TCE and/or nitrate have been detected at sporadic locations in the SNL/NM monitoring well network (Figure 2-2). Data collected as part of the TAG Investigation indicate that TCE and/or nitrate at concentrations above their respective maximum contaminant levels (MCLs) have been detected in groundwater samples from five SNL/NM AOR monitoring wells, including TA2-W-26 (TCE), TA2-W-19 (TCE and nitrate), TJA-7 (nitrate), TA2-SW1-320 (nitrate), and TJA-2 (nitrate). TCE and nitrate contamination detected in samples from two other SNL/NM wells, WYO-4 (TCE) and TJA-4 (nitrate), are attributed to contaminant releases from KAFB, and therefore, were not included in the scope of this CME. Contamination detected in TA2-W-26 was considered as part of the SNL/NM AOR during the CME; however, it is noteworthy that this well is located cross-gradient of a potential TCE source operated by the COA (Eubank landfill), and cross-gradient or up-gradient of the potential TCE sources mentioned in the SNL/NM AOR. 
This Page Intentionally Left Blank 


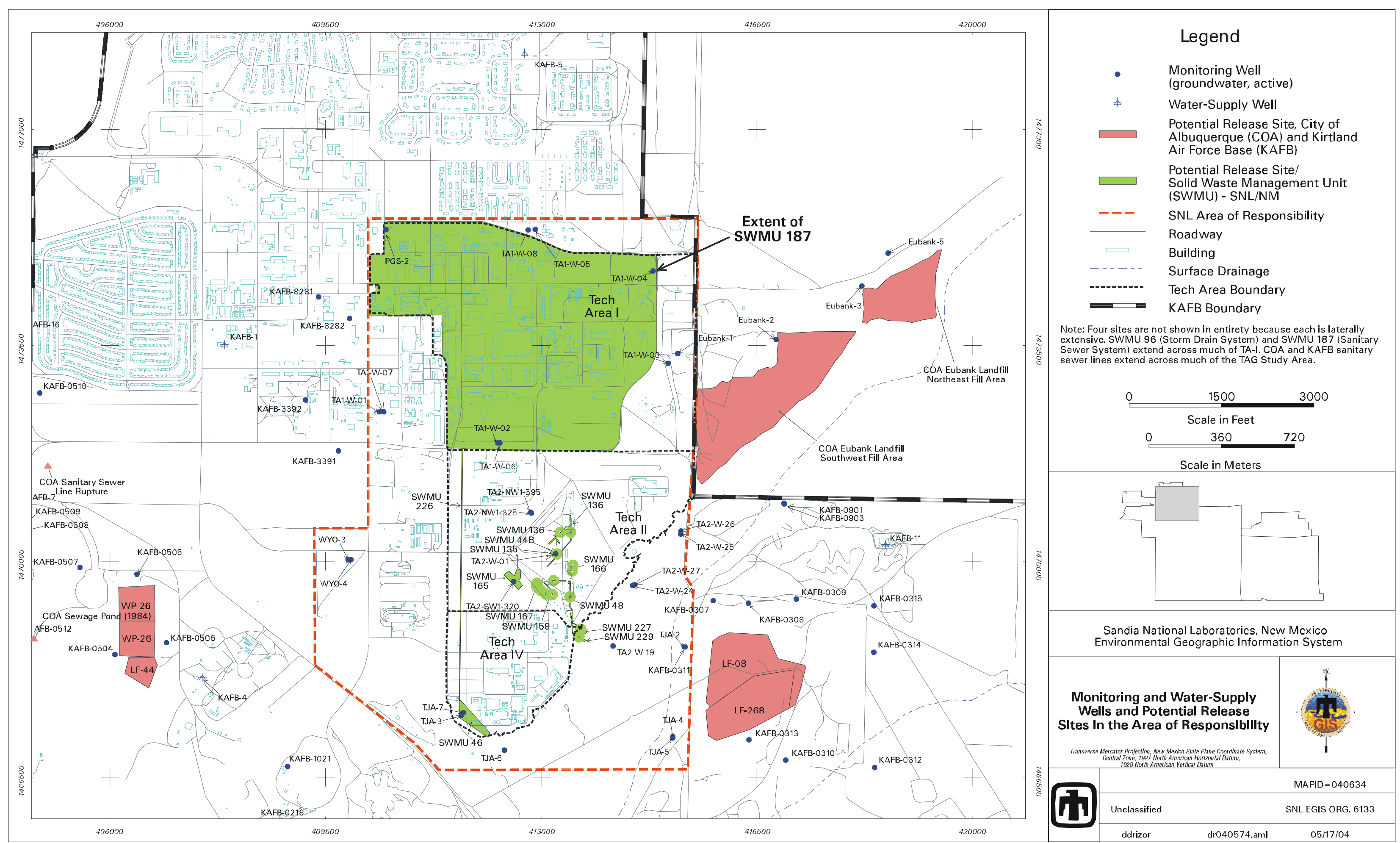

Figure 2-2. Monitoring and water supply wells and potential release sites in the area of responsibility. 
This Page Intentionally Left Blank 


\subsection{Contaminants of Concern}

TCE and nitrate are the COCs for the TAG SNL/NM AOR. These contaminants have been identified based on historical groundwater monitoring results. The Environmental Protection Agency (EPA) and State of New Mexico drinking water standards (MCLs) for TCE and nitrate are $5 \mu \mathrm{g} / \mathrm{L}$ and $10 \mathrm{mg} / \mathrm{L}$ (as nitrogen), respectively. The SNL/NM AOR maximum historical concentrations and the maximum concentrations from a more recent sampling event are shown in Table 2-1.

Table 2-1. COCs in the TAG SNL/NM area of responsibility.

\begin{tabular}{cccc}
\hline & & Maximum & Federal/ New \\
& Maximum & Concentration from & Mexico Drinking \\
& Historical & October 2004 & Water Standard \\
Contaminant & Concentrations & Sampling & (MCL) \\
\hline \hline
\end{tabular}

VOLATILE ORGANIC COMPOUND (Perched System)
Trichloroethene (TCE)
$9.6 \mu \mathrm{g} / \mathrm{L}^{\mathrm{a}}$
$4.7 \mu \mathrm{g} / \mathrm{L}^{\mathrm{b}}$
$5 \mu \mathrm{g} / \mathrm{L}^{\mathrm{d}}$

\section{INORGANIC CHEMICAL (Perched System)}

$\begin{array}{llll}\text { Nitrate (as nitrogen) } \quad 44 \mathrm{mg} / \mathrm{L}^{\mathrm{a}} & 27.1 \mathrm{mg} / \mathrm{L}^{\mathrm{c}} & 10 \mathrm{mg} / \mathrm{L}^{\mathrm{e}}\end{array}$

$\mu \mathrm{g} / \mathrm{L}=$ micrograms per liter

$\mathrm{mg} / \mathrm{L}=$ milligrams per liter

a. Maximum concentrations detected in samples from any SNL/NM AOR well reported as of October 2004.

b. This was the maximum concentration detected in samples from any SNL/NM AOR well during the October 2004 sampling round and was detected in a sample from well TA2-W-19.

c. This was the maximum concentration detected in samples from any SNL/NM AOR well during the October 2004 sampling round and was detected in a sample from well TJA-7.

d. 40 CFR 141.61, "Maximum Contaminant Levels for Organic Contaminants"

e. 40 CFR 141.62, "Maximum Contaminant Levels for Inorganic Contaminants"

The CME addresses COCs found in the SNL/NM AOR. Attachment A contains time series COC concentration plots from five SNL/NM AOR wells from which concentrations of COCs have been detected above the MCL since 1999. These wells are:

- TA2-W-26 (TCE),

- TA2-W-19 (TCE and nitrate),

- $\quad$ TJA-7 (nitrate),

- TA2-SW1-320 (nitrate), and

- $\quad$ TJA-2 (nitrate). 
No samples collected from SNL/NM AOR wells completed in the regional aquifer exceeded the MCL for either TCE or nitrate; therefore, no COCs have been identified for the regional aquifer. The CME focused exclusively on TCE and nitrate contamination in the perched groundwater system.

Maximum historical concentrations were used for the CME; however, it is noteworthy that more recent concentrations of these COCs have been substantially lower than historical maximum concentrations, as shown in Table 2-1 and Attachment A. The most current analytical data show that concentrations of both COCs are not increasing. Future groundwater monitoring data will be necessary to identify any declining trend because of the relatively slow rate of natural attenuation processes and the need for a longer sampling period using consistent methods. The historical data indicate that the extent of TCE and nitrate-contaminated groundwater is stable, or not expanding, because concentration trends are not increasing in perched system monitoring wells, and there are no continuing sources of contamination (SNL/NM 2004).

\subsection{Potential Receptors}

Production wells completed in the regional aquifer of the Albuquerque Basin are the only exposure pathways for COCs (TCE and nitrate) from the SNL/NM AOR to reach human receptors. These production wells are owned and operated by the COA, KAFB, and the Veterans Administration. Currently, there are no production wells in the perched system that access COC-contaminated groundwater from the SNL/NM AOR for domestic or industrial uses. The perched system does not discharge to any springs, and the depth to groundwater ranges from approximately 220 to $330 \mathrm{ft}$ bgs. Therefore, COCs are inaccessible to human and ecological receptors. Although the COCs are currently inaccessible, the perched groundwater system probably merges with the regional aquifer southeast of the SNL/NM AOR. Evaluating the potential for transport of contaminants to production wells in the regional aquifer is summarized in Section 3.1.2 and presented in detail as Attachment C. 


\subsection{EVALUATION OF REMEDIAL ALTERNATIVES}

This section presents detailed information gathered during the CME to evaluate the remedial alternatives. This work was directed by the CME Work Plan (SNL/NM 2004), which is summarized in Section 3.1. The remedial alternatives evaluated in this CME Report are identified and described in Section 3.2; an overview of the evaluation criteria and approach is provided in Section 3.3; and Section 3.4 identifies the preferred remedial alternative.

\subsection{Overview of the Corrective Measures Evaluation}

An initial list of 13 TCE and 7 nitrate treatment technologies was identified in the CME Work Plan (SNL/NM 2004). These technologies were screened based on applicability of each technology to the site. Following this technology screening, four technologies remained. These four technologies (Section 3.2) were identified as the four remedial alternatives to be considered for evaluation during the CME process, as shown in Figure 3-1.

The CME Work Plan identified four potential data-gathering activities that may be performed during the CME, as follows:

1. Paper study,

2. Numerical modeling,

3. Laboratory studies, and

4. Field-scale studies.

In accordance with the CME Work Plan (SNL/NM 2004), only activities that were determined to be necessary were performed. The utility of each data-gathering activity was determined in the Remedial Alternatives Data Gaps Review, which is summarized in Section 3.1.1 and included as Attachment B. Reports were prepared to document the results of each of the data-gathering activities. A summary of each report is presented in Sections 3.1.1 through 3.1.4. The reports are included in this CME Report as Attachments B through E. Figure 3-2 and Table 3-1 illustrate the CME process and list the reports, respectively.

The purpose of these reports was to:

- Report results and interpretation of results to the project leader, technical peer review panel, and technical support personnel;

- Document decisions made during the CME process and the results of the data-gathering stages; and

- $\quad$ Provide supporting information for the CME Report. 
CME Work Plan (SNL/NM 2004) Section 3.2:

A list of 13 technologies that are potentially applicable to remediation of TCE and/or nitrate were identified and described.

\section{Technologies}

1. Air Sparging

2. Groundwater Monitoring

3. In Situ Bioremediation

4. In Situ Chemical Oxidation

5. In Situ Flushing

6. Monitored Natural Attenuation

7. Monolithic Confinement

8. Nanoscale Iron Injection

9. Permeable Reactive Barriers

10. Phytoremediation

11. Pump-and-Treat

12. Soil Vapor Extraction

13. Thermal Technologies

CME Work Plan

\section{Section 3.3:}

Initial technology screening identified

which technologies were applicable for

TAG (shown in bold).

\section{CME Work Plan}

Section 4.0:

Remedial Alternatives were identified based on the technologies recommended from the screening.
Remedial Alternatives for TAG

1. Groundwater Monitoring

2. Monitored Natural Attenuation

3. In Situ Bioremediation

4. Pump-and-Treat

Figure 3-1. Illustration of the process of identifying remedial alternatives from the CME Work Plan (SNL/NM 2004). 


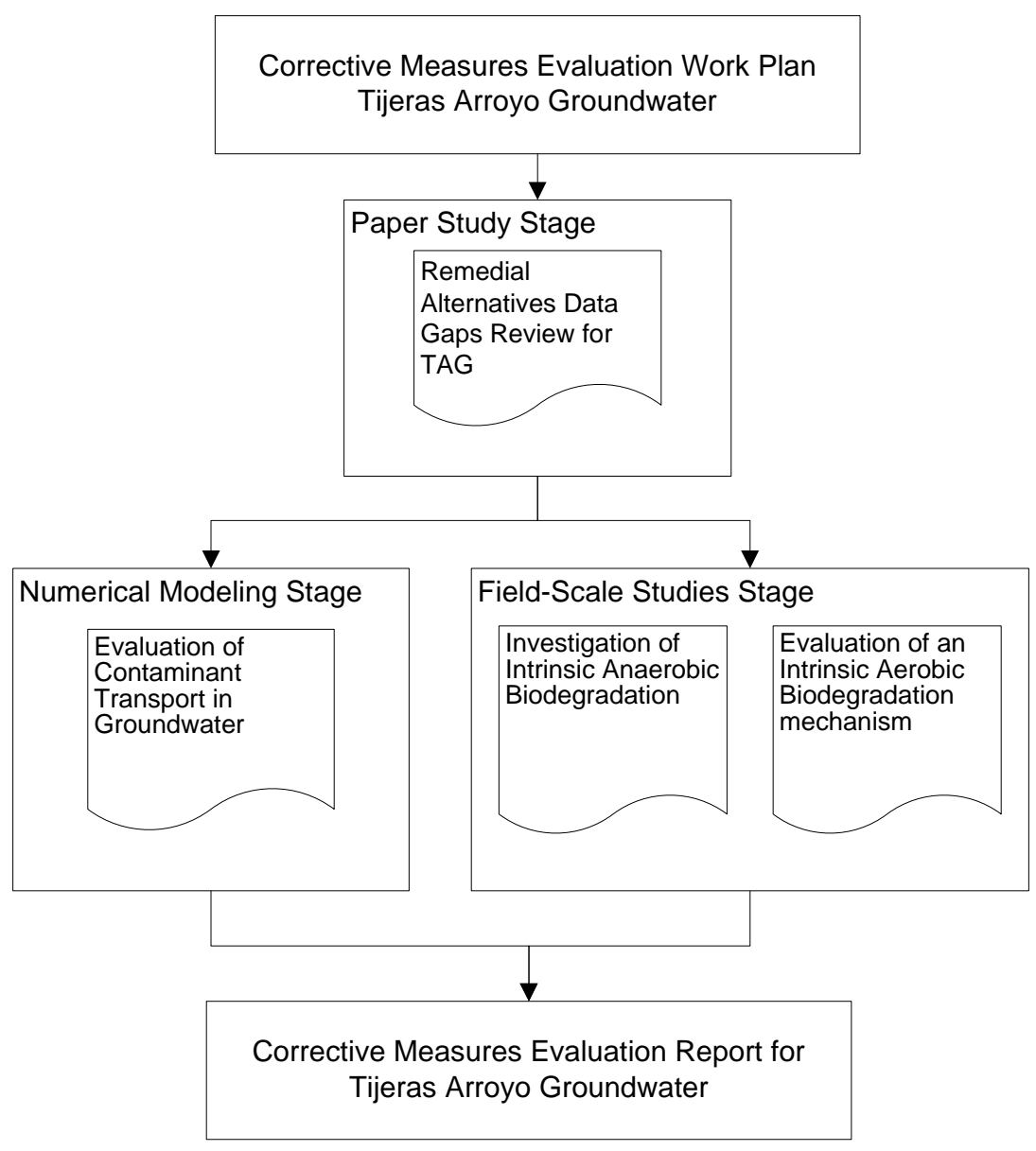

Figure 3-2. Illustration of the staged process of data gathering activities and production of informal reports.

Table 3-1. Documents produced in support of the CME.

\begin{tabular}{l|l|l|l}
\hline \multicolumn{1}{c|}{ CME Stage } & \multicolumn{1}{c|}{$\begin{array}{c}\text { Section in } \\
\text { CME Report }\end{array}$} & \multicolumn{1}{c}{ Document Title } & Attachment \\
\hline Paper Study & Section 3.1.1 & Remedial Alternatives Data Gaps Review & Attachment B \\
\hline $\begin{array}{l}\text { Numerical } \\
\text { Modeling }\end{array}$ & Section 3.1.2 & $\begin{array}{l}\text { Evaluation of Contaminant Transport in } \\
\text { Groundwater }\end{array}$ & Attachment C \\
\hline $\begin{array}{l}\text { Field-scale } \\
\text { Studies }\end{array}$ & Section 3.1.3 & $\begin{array}{l}\text { Investigation of Intrinsic Anaerobic } \\
\text { Biodegradation }\end{array}$ & Attachment D \\
\hline $\begin{array}{l}\text { Field-scale } \\
\text { Studies }\end{array}$ & Section 3.1.4 & $\begin{array}{l}\text { Evaluation of an Intrinsic Aerobic } \\
\text { Biodegradation Mechanism }\end{array}$ & Attachment E \\
\hline
\end{tabular}




\subsubsection{Remedial Alternatives Data Gaps Review}

The Remedial Alternatives Data Gaps Review documents the results of the paper study. The Remedial Alternatives Data Gaps Review presents conceptual designs for each remedial alternative. These conceptual designs include an overview of the remedial alternative, a description of the technical and functional requirements (T\&FRs), and a list of the expected costs. The complete report is included as Attachment B.

A preliminary remedial alternative evaluation was performed based on information gathered during the paper study stage, which was the first stage of the CME process. This preliminary remedial alternative evaluation was intended to be updated upon completion of subsequent CME stages. The final remedial alternative evaluation is presented in Section 3.4. Completion of this Remedial Alternatives Data Gaps Review resulted in the following two conclusions:

1. Of the initial list of four remedial alternatives stated in the CME Work Plan (SNL/NM 2004), two remedial alternatives (groundwater monitoring and monitored natural attenuation [MNA]) were recommended for continued evaluation during the remainder of the CME (Figure 3-3).

2. Data-gathering activities for the two remaining alternatives were recommended for two of the CME stages (numerical modeling and field-scale studies). Several of the data gathering activities discussed as possibilities in the CME Work Plan were determined to be unnecessary because they would provide data to evaluate alternatives that were not recommended for further evaluation (as shown in Figure 3-3).

Based on the information gathered, assessed, and summarized in the Remedial Alternatives Data Gaps Review, recommendations were made regarding the need to conduct activities to evaluate the two remaining remedial alternatives during the final three CME stages, as follows:

- Numerical modeling to determine the fate and transport of contaminants in the perched groundwater system of the SNL/NM AOR,

- Field-scale studies:

o Investigation of anaerobic mechanisms of biodegradation during natural attenuation, and

o Investigation of aerobic TCE biodegradation mechanisms during natural attenuation, as planned in the CME Work Plan (SNL/NM 2004).

The following activities were described in the CME Work Plan as potential activities but were not recommended because the remedial alternatives they support were eliminated in the Data Gaps Review:

- Laboratory studies to determine if microbes can be induced to degrade TCE,

- Field-scale studies:

o An amendment injection field demonstration to evaluate in situ bioremediation (ISB) and estimate design parameters, and

o Aquifer tests to determine pumping rates in a new extraction well for pump-and-treat implementation. 


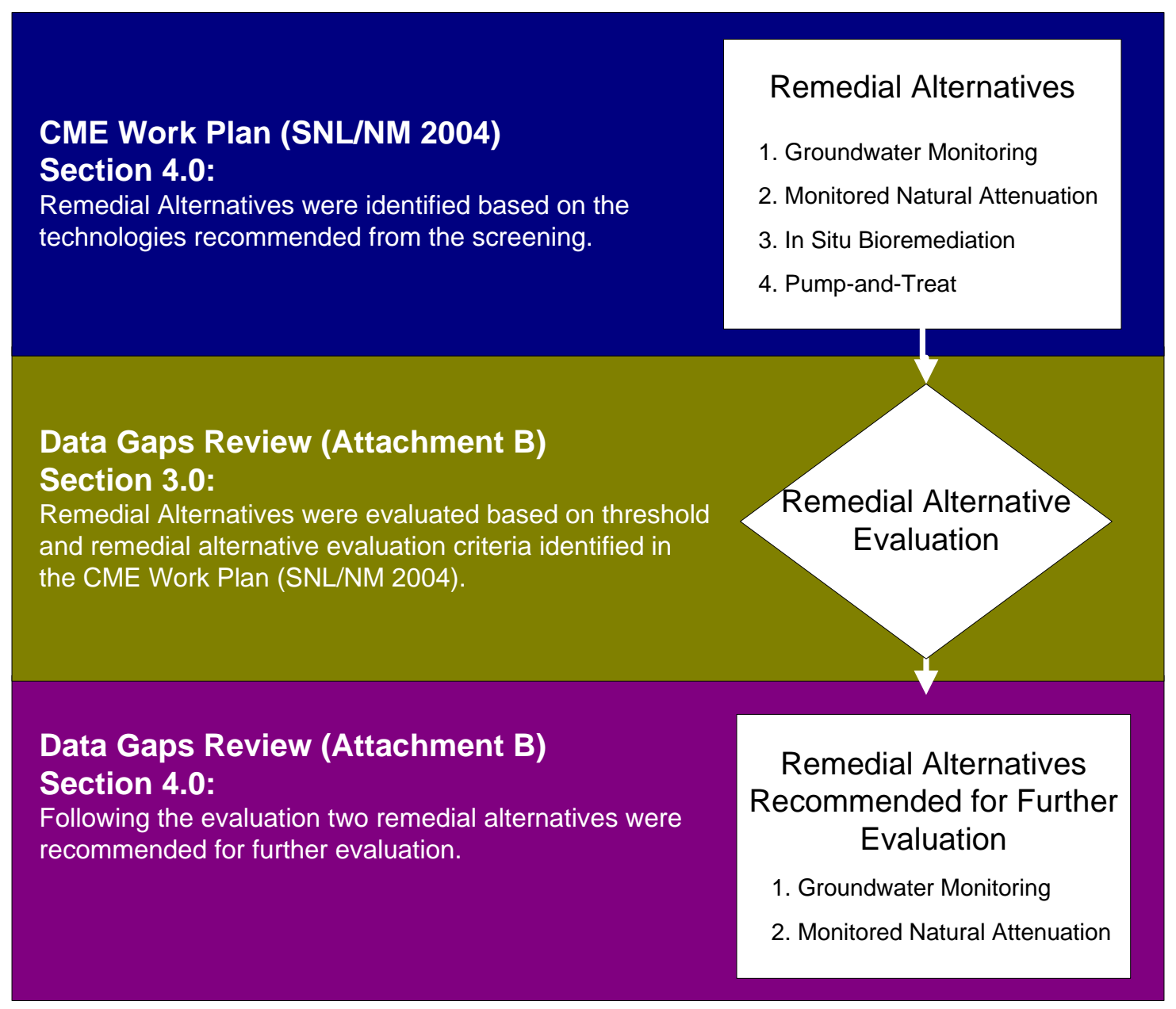

Figure 3-3. Illustration of remedial alternative evaluations performed during the paper study.

\subsubsection{Evaluation of Contaminant Transport in Groundwater}

A numerical modeling study was performed to evaluate potential for a change in contaminant concentrations during transport to production wells located within the regional aquifer. The complete Evaluation of Contaminant Transport report is included as Attachment C.

This evaluation utilized a cross-sectional analysis to assess downgradient transport and dilution of nitrate and TCE, which were simulated as conservative solutes. The effects of dispersion, degradation, and sorption were intentionally neglected. Recognizing that the cross-sectional numerical flow and transport models would not be a rigorous representation of the system, several conservative assumptions were made so that the effects of dilution would be intentionally underestimated. The analysis consisted of the following three parts: (1) an estimate of discharge from the perched groundwater system, (2) simulation of transport through the alluvial fan lithofacies, and (3) simulation of transport through the ancestral Rio Grande (ARG) deposits. Contaminant concentrations were estimated for potential human receptors via production wells completed in the ARG lithofacies. The conclusions are as follows: 
- The historical maximum nitrate concentration in the perched groundwater system (44 mg/L) will be reduced to $0.24 \mathrm{mg} / \mathrm{L}$ (as nitrogen) before reaching production wells completed in the ARG.

- The historical maximum TCE concentration in the perched groundwater system $(9.6 \mu \mathrm{g} / \mathrm{L}$ ) will be reduced to $<0.03 \mu \mathrm{g} / \mathrm{L}$ before reaching production wells in the ARG.

The estimated travel times from the current locations of nitrate and TCE in the perched groundwater system to the ARG lithofacies where production wells are completed are at least 130 years for nitrate and at least 140 years for TCE. These travel times represent the arrival of the maximum predicted concentration at the production wells; however, as predicted, these maximum concentrations will not exceed MCLs. The estimated travel times are slightly different because the contaminants are currently in two different locations in the perched groundwater system. These travel times represent minimum or conservative estimates because solute retardation, travel time through the zone of merging, and travel time through the ARG were intentionally neglected.

\subsubsection{Investigation of Intrinsic Anaerobic Biodegradation}

An investigation of anaerobic contaminant biodegradation was performed as part of the CME to evaluate MNA. The complete Investigation of Intrinsic Anaerobic Biodegradation report is included as Attachment $\mathrm{D}$. This evaluation was performed using the volatile organic compound contaminant biodegradation screening assessment described in the Technical Protocol for Evaluating Natural Attenuation of Chlorinated Solvents in Ground Water (EPA 1998) and a biodegradation evaluation for nitrate.

The evaluation used sample data collected during six quarterly sampling rounds, beginning with the fourth quarter of Fiscal Year (FY) 2003 and ending with the first quarter of FY 2005. For each parameter, the significance of the data relative to assessing biodegradation and general observations was evaluated. The results indicated that biodegradation of TCE via the process of anaerobic reductive dechlorination is not occurring. In addition, biodegradation of nitrate via denitrification is not occurring.

\subsubsection{Evaluation of an Intrinsic Aerobic Biodegradation Mechanism}

As part of the CME, a field-scale study was performed to investigate the natural attenuation mechanism of aerobic biodegradation via cometabolic oxidation. The complete Evaluation of Intrinsic Aerobic Degradation report is included as Attachment E. This field study coupled enzyme activity probes (evidence of cometabolic enzyme activity) with DNA analysis (evidence of cometabolic gene presence) to evaluate cometabolic activity, or the potential for such activity in TAG.

Enzyme activity probes provide direct evidence that the mechanism for aerobic cometabolic oxidation of chlorinated ethenes is present and active in a given sample. Organisms that oxidize substrates (i.e., toluene or methane) also oxidize TCE. Thus, cometabolism of TCE will occur if the appropriate enzymes are both present and active. Probes that serve as alternate substrates for TCE cometabolizing enzymes have been developed for several of the toluene oxygenases and for the soluble methane monooxygenase (sMMO). These non-fluorescent probes are transformed by oxygenase enzymes into strongly fluorescent products, providing a clear, quantifiable signal only when the enzyme of interest is actively functioning. In addition to the enzyme probes, a series of control and inhibition studies were performed to verify the detected oxygenase activity. 
The results of the analysis determined the presence and activity of at least one toluene oxygenase or sMMO enzyme in all but one (WYO-4) of the 12 wells sampled based on the application of enzyme activity probes. Fifty percent of the wells showed activity with the sMMO enzyme probe, while $92 \%$ (11 out of 12) showed a response with the toluene probes. Any positive response, even with only one probe, provides direct evidence of enzyme activity in the groundwater sample. Control studies confirmed the findings of the enzyme probe data, specifically that the probes accurately and efficiently targeted specific oxidative pathways. Inhibition studies confirmed that the activity measured was a result of the enzyme targeted and other oxygenase enzymes.

The detection of both sMMO and toluene oxygenase enzyme activity, as determined by enzyme activity probes in TAG samples, identifies cometabolism as a mechanism of natural attenuation. Active enzymes were found throughout the tested area, including samples taken from both inside and outside the TCE contamination area, in the perched groundwater system, and at all regional aquifer wells. These data provide conclusive evidence of active enzyme systems capable of TCE degradation and, more importantly, represent an active mechanism for the natural attenuation of TCE.

\subsection{Identification and Description of Remedial Alternatives}

Four remedial alternatives were identified in the CME Work Plan (SNL/NM 2004). These remedial alternatives included: (1) groundwater monitoring, (2) MNA, (3) ISB, and (4) pumpand-treat. Following a remedial alternative evaluation performed as part of the paper study (see Section 3.1.1 and Attachment B), two of the four remedial alternatives, Groundwater Monitoring and MNA, were recommended for further evaluation. ISB and pump-and-treat were determined to be significantly less effective than the other remedial alternatives and were therefore eliminated (Attachment B, Section 3.2). Analysis of contaminant transport (Section 3.1.2) and determination of the presence of an aerobic biodegradation mechanism for TCE (Section 3.1.4) demonstrated that natural attenuation mechanisms are present for both COCs. Evidence of these natural attenuation mechanisms no longer allows for an accurate comparison of groundwater monitoring and MNA as separate remedial alternatives. Evidence of these mechanisms precludes the need to evaluate groundwater monitoring, which is a remedial alternative that does not consider natural attenuation. Therefore, groundwater monitoring is no longer being considered. The remaining remedial alternative, MNA, is described in this section.

Implementation of MNA requires careful consideration of site conditions, including identifying natural attenuation mechanisms and potential receptors. MNA is not a default or presumptive remedial alternative but rather is an acceptable remedial alternative to be evaluated with other alternatives (EPA 1999). The EPA has provided policy and guidance on the use of MNA as a remedy in Use of MNA at Superfund, RCRA Corrective Action, and Underground Storage Tank Sites (EPA 1999). The DOE used principles set forth in EPA's directive as a foundation for a decision-making framework for evaluating the effectiveness of MNA. This framework is set forth in the Decision-Making Framework Guide for the Evaluation and Selection of Monitored Natural Attenuation Remedies at Department of Energy Sites (DOE 1999). This decision-making framework was used when considering the MNA remedial alternative during the CME. Figure 3-4 is an illustration of DOE’s tiered approach to evaluating MNA. 


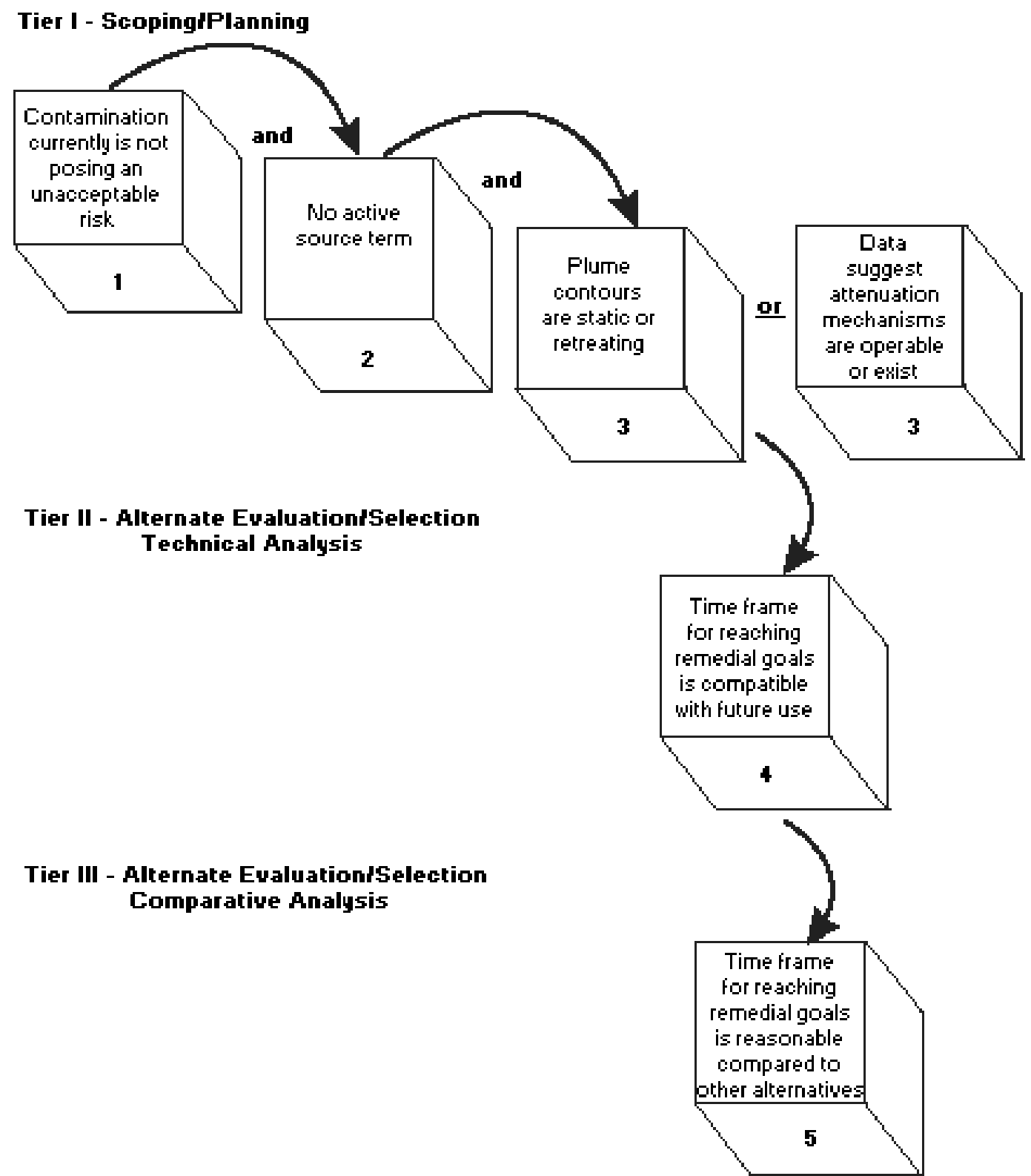

Figure 3-4. Decision framework for evaluating MNA (from DOE 1999).

MNA has been found to be an appropriate and applicable remedial alternative for the TAG SNL/NM AOR. Determinations made concerning each of the tiers of the decision-making framework are as follows:

1. Tier I. Item 1. Contamination currently is not posing an unacceptable risk-The contaminated groundwater in the perched system is currently inaccessible to potential receptors, because depth to potentiometric surface of the perched system ranges from approximately 220 to $330 \mathrm{ft}$ bgs (SNL/NM 2004). In addition, the evaluation of contaminant transport in groundwater (Section 3.1.2 and Attachment C) demonstrated that contaminants do not pose an unacceptable risk to potential receptors via regional aquifer production wells in the future. 
2. Tier I. Item 2. There is no active source term-An active source term is defined as a source inventory of contaminant that is being released to groundwater where the rate of contaminant release is greater than attenuation rates such that the inventory of mobile contaminants is increasing over time (DOE 1999). The approved CME Work Plan (SNL/NM 2004) identified four potential COC release sites of high concern. As summarized in the CME Work Plan, soil and soil vapor sampling and analyses have demonstrated that there are no continuing sources of COCs to groundwater in the vadose zone. Releases of wastewater to the groundwater have ceased, and all potential release sites are described in detail in the Tijeras Arroyo Groundwater Continuing Investigation Report (SNL/NM 2002).

3. Tier I. Item 3. Plume contours are static or are retreating or data suggests that attenuation mechanisms are operable or exist-COC concentration data (presented in Attachment A) show that COC concentrations are not increasing in groundwater within the SNL/NM AOR. In addition, natural attenuation mechanisms have been demonstrated. Natural attenuation processes or mechanisms may include biodegradation, dispersion, dilution, sorption, volatilization, stabilization, transformation, or destruction of contaminants (EPA 1999). The approach used during the CME process to evaluate MNA was to focus on investigating two of these natural attenuation mechanisms, dilution and biodegradation. Although other natural attenuation mechanisms may be operable, further reducing contaminant concentrations, they were not evaluated. Evaluation of dilution during transport (Section 3.1.2 and Attachment C) has demonstrated that this mechanism will reduce COC concentrations to well below their respective MCLs before reaching production wells. Evaluation of biodegradation mechanisms (Section 3.1.4 and Attachment E) has demonstrated that a mechanism for aerobic biodegradation of TCE exists.

4. Tier II. Item 4. Timeframe for reaching remedial goals is compatible with future useThere is no current use of TAG; however, in the future, perched system groundwater may migrate into the regional aquifer and then west and north off of KAFB where it could be extracted from the aquifer for potable water. The transport evaluation (Section 3.1.2 and Attachment C) demonstrates that contaminants derived from the SNL/NM AOR will never exceed the MCL at production wells completed in the ARG facies; hence, the remedial timeframe is compatible with future uses.

5. Tier III. Item 5. Timeframe for reaching remedial goals is reasonable compared to other alternatives - Consideration of the remedial timeframe is part of the criteria used to evaluate remedial alternatives (Section 3.3). A preliminary evaluation of remedial alternatives was performed using these criteria (see Section 3.1.1 and Attachment B). Natural attenuation processes are slower than the more active remediation strategies considered during the CME; however, considering the physical site constraints to implementing these other remedies, the longer timeframe for MNA is reasonable (see Attachment B for a discussion and comparison of these remedial alternatives).

Given these criteria and site-specific information, MNA is an appropriate remedial alternative for the SNL/NM AOR. The T\&FRs that apply to the MNA remedial alternative are presented in Table 3-2. Assumptions of these T\&FRs include the capability to monitor for the appropriate remedial timeframe, which will require maintaining the necessary equipment, utilities, personnel availability, and a sufficient monitoring well network. Cost elements to be considered for implementing MNA are outlined in Table 3-3 and include capital equipment and operations and maintenance cost items, as defined in Section 3.3.2. 
Table 3-2. Technical and functional requirements for MNA.

\begin{tabular}{|c|c|}
\hline Parameter & Requirement \\
\hline Duration of monitoring & $\begin{array}{l}\text { Groundwater monitoring will continue until it is demonstrated that } \\
\text { contaminants are below MCLs for a period of time that will be } \\
\text { determined during preparation of the CMI Plan. }\end{array}$ \\
\hline Frequency of monitoring & Annual. \\
\hline Analytes & All COCs (nitrate and TCE), water levels, and other parameters. \\
\hline Analyses & $\begin{array}{l}\text { The monitoring data will be analyzed and interpreted. This data } \\
\text { will be used to monitor attenuation mechanisms and track COC } \\
\text { concentration changes. }\end{array}$ \\
\hline Reporting & $\begin{array}{l}\text { Annual reporting for an initial performance operations period, } \\
\text { followed by less frequent reporting during a long-term operations } \\
\text { period. Reports will include analysis of concentration trends and } \\
\text { comparison to predicted trends of attenuation, which will be } \\
\text { included in the CMI Plan. }\end{array}$ \\
\hline $\begin{array}{l}\text { Replacement monitoring } \\
\text { wells }\end{array}$ & $\begin{array}{l}\text { The monitoring well network will be maintained throughout the } \\
\text { remedial timeframe. Replacement of wells may be necessary due } \\
\text { to regional water-level decline or other factors. }\end{array}$ \\
\hline Equipment & $\begin{array}{l}\text { All equipment necessary for monitoring, including pumps, sample } \\
\text { bottles, power (generator or utilities), shipping supplies, purge } \\
\text { water tanks, personal protection equipment, and any other } \\
\text { necessary equipment shall be maintained for the duration of the } \\
\text { monitoring program. }\end{array}$ \\
\hline Equipment storage & Storage for field sampling equipment. \\
\hline Waste storage & Storage of purge water until authorized to dispose. \\
\hline Institutional controls & $\begin{array}{l}\text { Institutional controls consist of engineering and administrative } \\
\text { controls to protect current and future users from health risks } \\
\text { associated with exposure to contaminated groundwater. } \\
\text { Engineering controls consist of methods to restrict access to } \\
\text { contaminated water, including locking devices on wellheads. } \\
\text { Administrative controls include postings on wellheads identifying } \\
\text { potential hazards and placing written notification of this corrective } \\
\text { measure in the facility land-use master plan. }\end{array}$ \\
\hline Operations & $\begin{array}{l}\text { Operations consist of groundwater monitoring and maintenance } \\
\text { associated with institutional controls. }\end{array}$ \\
\hline Facilities & No additional facilities are required. \\
\hline
\end{tabular}


Table 3-3. Cost elements for the MNA remedial alternative.

\begin{tabular}{l|l}
\hline \multicolumn{1}{c|}{ Capital } & \multicolumn{1}{c}{ Operations and Maintenance } \\
\hline - Costs associated with designing a \\
$\begin{array}{l}\text { long-term groundwater monitoring } \\
\text { program }\end{array}$ & - Costs of maintaining an adequate monitoring \\
- $\begin{array}{l}\text { well network for the duration of the remedy. } \\
\text { (legal and permitting fees) }\end{array}$ & - Sampling and analyses costs. \\
& - Costs for data analyses and interpretation. \\
& - Reporting costs for the duration of the remedy. \\
& $\begin{array}{l}\text { - Indirect operational costs, including } \\
\text { institutional controls, contingency allowances, } \\
\text { and administrative costs. }\end{array}$ \\
\hline
\end{tabular}

\subsection{Evaluation Criteria}

As presented in Section 3.2, MNA is an applicable remedial alternative for the SNL/NM AOR based on EPA guidance (EPA 1999) and DOE's decision-making framework guide (DOE 1999). This section is a presentation of how the MNA remedial alternative compares to the threshold and remedial alternative evaluation criteria described in the CME Work Plan (SNL/NM 2004) and specified in the COOC (Section VII.C.3, CME Criteria [NMED 2004]).

\subsubsection{Threshold Criteria}

As stated in the COOC (NMED 2004), in order to be selected, a remedy must meet the following threshold criteria:

- Protective of human health and the environment. Any proposed remedy must be protective of human health and the environment. As stated in the Resource Conservation and Recovery Act (RCRA) Corrective Action Plan (EPA 1994), "Remedies may include those measures that are needed to be protective, but are not directly related to media cleanup, source control, or management of wastes." Components of remedies considered for the TAG SNL/NM AOR include evaluating protection of human health and the environment for air emissions, potential formation of hazardous degradation products, hazards associated with operations and maintenance of the remedy, and remediation within an appropriate timeframe.

- Attain media cleanup standard or alternative, approved risk-based cleanup goals. Any proposed remedy must attain groundwater cleanup standards or goals. As stated in the RCRA Corrective Action Plan (EPA 1994), "Remedies will be required to attain media cleanup standards set by the implementing agency, which may be derived from existing state or federal regulations (e.g., groundwater standards) or other standards. The media cleanup standards for a remedy will often play a large role in determining the extent of, and technical approaches to, the remedy.” The cleanup goals and objectives for the SNL/NM AOR are described in Section 4.0. If a remedy cannot meet any one of these goals or objectives, it should no longer be considered. 
- Control the source or sources of releases so as to reduce or eliminate, to the extent practicable, further releases of contaminants that may pose a threat to human health and the environment. Any proposed remedy must control the original source of the contamination in order to prevent any further releases. As stated in the RCRA Corrective Action Plan (EPA 1994), "Unless source control measures are taken, efforts to clean up releases may be ineffective or, at best, will essentially involve a perpetual cleanup.”

According to Section 1.4.3 of the CME Work Plan (SNL/NM 2004), source control is not a required component of the SNL/NM AOR because there is no ongoing source of contamination to the groundwater. Therefore, corrective measures and any technologies designed for source zone control or remediation are not needed.

- Comply with standards for management of wastes. Any proposed remedy must comply with all applicable state or federal regulations. As stated in the RCRA Corrective Action Plan (EPA 1994), "Waste management activities will be conducted in compliance with all applicable state or federal regulations (e.g., closure requirements, land disposal restrictions).” In addition, waste is to be managed according to the requirements of SNL/NM's Environment, Safety, and Health (ES\&H) Manual, "Chapter 19 - Waste Management” (SNL/NM 2005) that describes the main institutional requirements relevant to waste management on SNL/NM-controlled premises. Wastes resulting from sampling, including purge water and equipment, are the only wastes that will result from the MNA remedial alternative.

\subsubsection{Remedial Alternative Evaluation Criteria}

The remedial alternative evaluation criteria were used in an evaluation presented in the Data Gaps Review (Section 3.1.1 and Attachment B) that resulted in two recommended remedies for further evaluation (groundwater monitoring and MNA). However, as stated in Section 3.2, the groundwater monitoring alternative is no longer considered; therefore, the remedial alternative evaluation criteria are summarized in this section and a summary of how effectively the MNA remedial alternative meets these criteria is included in Section 3.4. The remedial alternative evaluation criteria are as follows:

- Long-term reliability and effectiveness. In general, this criterion evaluates the reliability of the remedy for meeting cleanup standards and reducing risk. As stated in the COOC, "Each remedy shall be evaluated for long-term reliability and effectiveness. This factor includes consideration of the magnitude of the risks that will remain after implementation of the remedy; the extent of long-term monitoring or other management that will be required after implementation of the remedy; the uncertainties associated with leaving contaminants in place; and the potential for failure of the remedy. A remedy that reduces risks with little long-term management, and that has proven effective under similar conditions, shall be preferred" (NMED 2004). This criterion includes defining the institutional controls to be established for each remedy.

- Reduction of toxicity, mobility, or volume. This criterion is intended to evaluate the effectiveness of the remedy for reducing TCE and nitrate concentrations in TAG. As stated in the COOC, "Each remedy shall be evaluated for its reduction in the toxicity, mobility, and volume of contaminants. A remedy that more completely and permanently reduces the toxicity, mobility, and volume of contaminants shall be preferred” (NMED 2004). 
- Short-term effectiveness. In general, short-term effectiveness applies to the ability of the remedy to reduce risks during the remediation process. These risks include exposure to contaminants during remedy implementation and risks and hazards introduced by remedy implementation. As stated in the COOC, "Each remedy shall be evaluated for its short-term effectiveness. This factor includes consideration of the short-term reduction in existing risks that the remedy would achieve; the time needed to achieve that reduction; and the short-term risks that might be posed to the community, workers, and the environment during implementation of the remedy. A remedy that quickly reduces short-term risks, without creating significant additional risks, shall be preferred” (NMED 2004).

- Feasibility. As stated in the COOC, "Each remedy shall be evaluated for its feasibility, or the difficulty of implementing the remedy. This factor includes consideration of installation and construction difficulties; operation and maintenance difficulties; difficulties with cleanup technology; permitting and approvals; and the availability of necessary equipment, services, expertise, and storage and disposal capacity. A remedy that can be implemented quickly and easily and poses fewer and lesser difficulties shall be preferred" (NMED 2004).

- Cost. As stated in the COOC, "Each remedy shall be evaluated for its cost. This factor includes a consideration of both capital costs and operation and maintenance costs. A remedy that is less costly, but does not sacrifice protection of health and the environment, shall be preferred" (NMED 2004).

- Capital costs shall include, without limitation, construction and installation costs; equipment costs; land development costs; and indirect costs, including engineering costs, legal fees, permitting fees, startup and shakedown costs, and contingency allowances.

- Operation and maintenance costs shall include, without limitation, operating labor and materials costs; maintenance labor and materials costs; replacement costs; utilities; monitoring and reporting costs; administrative costs; indirect costs; and contingency allowances" (NMED 2004).

\subsection{Selection of a Preferred Remedial Alternative}

As stated in Section 3.2, the MNA remedial alternative is an applicable remedial alternative for both nitrate and TCE in the SNL/NM AOR. The CME process of data gathering activities and ongoing evaluations has demonstrated that none of the other three remedial alternatives identified in the CME Work Plan (groundwater monitoring, ISB, and pump-and-treat) are as effective or applicable; therefore, MNA is the preferred remedial alternative.

Given all of the information gathered during the CME, the MNA remedial alternative must meet the threshold criteria (Section 3.3.1). Table 3-4 summarizes how the MNA remedial alternative meets each of the threshold criteria. Over the course of the CME, the MNA remedial alternative has been shown to meet the remedial alternative criteria more effectively than the other remedial alternatives. Table 3-5 is a summary of how the MNA remedial alternative meets the evaluation criteria. 
Table 3-4. Summary of MNA applicability considering threshold criteria.

\begin{tabular}{l|l}
\hline \multicolumn{1}{c|}{ Threshold Criterion } & \multicolumn{1}{c}{ MNA Applicability } \\
\hline $\begin{array}{l}\text { Protective of human health and the } \\
\text { environment. }\end{array}$ & $\begin{array}{l}\text { The MNA remedial alternative will involve } \\
\text { continued monitoring and institutional controls } \\
\text { that will be protective of human health and the } \\
\text { environment. Transport analysis demonstrated } \\
\text { that there is no unacceptable risk to receptors. }\end{array}$ \\
\hline $\begin{array}{l}\text { Attain media cleanup standard or } \\
\text { alternative, approved risk-based cleanup } \\
\text { goals. }\end{array}$ & $\begin{array}{l}\text { Natural attenuation mechanisms will reduce } \\
\text { contaminant concentrations to below MCLs. }\end{array}$ \\
\hline $\begin{array}{l}\text { Control the source or sources of releases } \\
\text { so as to reduce or eliminate, to the extent } \\
\text { practicable, further releases of } \\
\text { contaminants that may pose a threat to } \\
\text { human health and the environment. }\end{array}$ & There are no ongoing sources of contamination. \\
\hline $\begin{array}{l}\text { Comply with standards for management of } \\
\text { wastes. }\end{array}$ & $\begin{array}{l}\text { The only waste streams that will be generated are } \\
\text { purge water from sampling, which is currently } \\
\text { and will continue to be disposed of in compliance } \\
\text { with standards and regulations. }\end{array}$ \\
\hline
\end{tabular}

Table 3-5. Summary of MNA effectiveness considering remedial alternative criteria.

\begin{tabular}{l|l}
\hline $\begin{array}{l}\text { Remedial Alternative } \\
\text { Criterion }\end{array}$ & \multicolumn{1}{c}{ MNA Applicability } \\
\hline $\begin{array}{l}\text { Long-term reliability } \\
\text { and effectiveness }\end{array}$ & $\begin{array}{l}\text { Natural attenuation mechanisms are operable. An intrinsic aerobic } \\
\text { TCE biodegradation mechanism has been found in TAG and } \\
\text { transport analysis has demonstrated that nitrate and TCE will be } \\
\text { reduced to below MCLs before reaching production wells. }\end{array}$ \\
\hline $\begin{array}{l}\text { Reduction of toxicity, } \\
\text { mobility, or volume }\end{array}$ & $\begin{array}{l}\text { Natural attenuation mechanisms will reduce COC concentrations to } \\
\text { below MCLs, thus reducing toxicity. }\end{array}$ \\
\hline $\begin{array}{l}\text { Short-term } \\
\text { effectiveness }\end{array}$ & $\begin{array}{l}\text { MNA relies on natural attenuation mechanisms to meet clean-up } \\
\text { goals. These processes are operable; however, they are slower than } \\
\text { more active alternatives. }\end{array}$ \\
\hline Feasibility & $\begin{array}{l}\text { MNA is significantly more feasible than other remedial alternatives. } \\
\text { Overcoming the physical constraints of the site is a significant } \\
\text { obstacle to other more active alternatives, while the infrastructure } \\
\text { (monitoring network and equipment) is already in place for MNA. }\end{array}$ \\
\hline Capital costs & Wells and equipment already exist. \\
\hline $\begin{array}{l}\text { Operations and } \\
\text { maintenance costs }\end{array}$ & $\begin{array}{l}\text { The only operations and maintenance will be monitoring and well } \\
\text { maintenance, which will need to occur throughout the remedial } \\
\text { timeframe. }\end{array}$ \\
\hline
\end{tabular}




\subsection{REMEDIAL ALTERNATIVE DESIGN CRITERIA TO MEET CLEANUP GOALS AND OBJECTIVES}

The remedial alternative strategy for MNA (presented in Section 3.2) identifies T\&FRs and itemized cost elements. This strategy was developed during the CME process and will be expanded and further developed in the CMI Plan.

MNA was selected as the preferred remedial alternative for the SNL/NM AOR. Cleanup goals and objectives are criteria used to evaluate performance and can be divided into two types (performance and compliance) based on when the goal or objective is to be achieved. Goals are established as the milestones to meet upon completion of remediation. Objectives are tasks to be completed in order to meet the goals.

Performance goals and objectives are defined to support remedy performance evaluation during implementation and before final closure of the site. Compliance goals and objectives are defined to support decision making at the end of the remedy and to provide the framework for determining whether the remedy has restored groundwater to beneficial use within the restoration timeframe. Because the type of data collected may be quite different, it is important to distinguish between performance and compliance goals and objectives. The performance and compliance goals and objectives were developed in the TAG CME Work Plan (SNL/NM 2004) and are also stated below.

\subsection{Performance Goals and Objectives}

Performance goals and objectives are criteria and actions used to evaluate remedy performance during the operations phase to support evaluation of system performance data relative to end-state objectives. Performance monitoring data analysis leads to periodic decisions that the remedy is performing as expected and that the remedy will ultimately achieve the final remediation goal. The performance goals and objectives include:

Performance Goals:

- Establish and operate a remedy intended to reduce COC concentrations,

- Monitor distribution and changes in COC concentrations, and

- Collect sufficient data to support a decision to move into the compliance phase.

Performance Objectives:

- Collect groundwater samples for performance parameters (in addition to COCs) from TAG wells,

- Compile and analyze groundwater monitoring data to evaluate trends in COC concentrations,

- Compare trends to the COC cleanup standards, and

- Recommend continued operation of the remediation system or strategy and proceed to compliance evaluation. 


\subsection{Compliance Goals and Objectives}

Compliance goals and objectives are criteria and actions used to evaluate remediation system or strategy effectiveness both during and at completion of the corrective measure. Compliance requirements may be imposed during remediation system or strategy operations (e.g., air emissions or waste management). In addition, compliance requirements exist for final closure of the site. These compliance goals and objectives serve to show that (1) the remedy is being implemented in a fashion that is consistent with the COOC (NMED 2004) during implementation, and (2) the remedy has accomplished the remediation goals at the end of the corrective measure. Groundwater cleanup levels are defined in Section VI.K.1.a of the COOC as the more restrictive of EPA MCLs or Water Quality Control Commission standards. The cleanup levels for COCs are defined by the MCLs, as these are the more restrictive of the two standards. The remedial timeframe will be defined in the CMI Plan. The compliance goals and objectives include:

\section{Compliance Goals:}

- Operate all remediation systems or strategies in compliance with applicable requirements,

- $\quad$ Reduce COC concentrations throughout the plume to below MCLs, and

- Implement institutional controls to protect human health and the environment during the remediation timeframe.

Compliance Objectives:

- Monitor all remediation systems or strategies for compliance with applicable requirements,

- Collect groundwater samples at TAG wells for COCs,

- Compare COC concentrations to cleanup standards, and

- Recommend site closure or continuation of long-term operations. 


\subsection{CORRECTIVE MEASURES IMPLEMENTATION PLAN}

As stated in the Section VII.D.2 of the COOC (NMED 2004), the CMI Plan will outline the "design, construction, operation, maintenance, and performance monitoring for the selected remedy, and a schedule for implementation.”

\subsection{Corrective Measures Implementation Plan Outline}

The following is a draft outline of the key components of the CMI Plan and includes the required CMI Plan elements listed in the COOC. Some of the elements stated in the COOC (i.e., results of pilot tests, construction work plan, and engineering design drawings and specifications) are not included in this outline because they are not applicable to the MNA remedial alternative. The outline is as follows:

I. Introduction

II. Background Information

III. Description of Selected Final Remedy

a. Remediation System Objectives

b. Cleanup Goals

IV. Remedy Implementation
a. Implementation Team Qualifications
b. Operation and Maintenance Plan
c. Waste Management Plan

V. Remedy Performance Monitoring
a. Sampling
b. Contingency

VI. Schedule
a. Implementation Schedule
b. Reporting Schedule

VII. Appendices 


\subsection{Corrective Measures Implementation Schedule}

The basis for the CMI schedule (Figure 5-1) is the logical development of project tasks and activities that will support the implementation of corrective measures under the COOC. This schedule includes corrective measure tasks and milestones. Specific documents that have been, or will be, produced as part of the CME process are summarized in Table 5-1. This CME Report and the CMI Plan require NMED review and approval. These documents are identified deliverables and have clearly defined agency review and comment resolution periods. SNL/NM will proceed at risk with the corrective measures implementation, as outlined in the schedule.

Table 5-1. Summary of TAG documents and delivery dates.

\begin{tabular}{l|l}
\hline \multicolumn{1}{c|}{ Document } & \multicolumn{1}{c}{ Status } \\
\hline TAG CME Work Plan & $\begin{array}{l}\text { Completed and submitted to NMED in July 2004, } \\
\text { the NMED approved the CME Work Plan in } \\
\text { October 2004 pending a few modifications, these } \\
\text { modifications were made in November 2004, and } \\
\text { the final document was submitted to NMED in } \\
\text { December 2004. }\end{array}$ \\
\hline $\begin{array}{l}\text { TAG Remedial Alternatives Data Gaps } \\
\text { Review }\end{array}$ & Completed December 2004 \\
\hline $\begin{array}{l}\text { TAG Investigation of an Intrinsic } \\
\text { Aerobic Biodegradation Mechanism }\end{array}$ & Completed April 2005 \\
\hline $\begin{array}{l}\text { TAG Evaluation of Intrinsic Anaerobic } \\
\text { Biodegradation }\end{array}$ & Completed June 2005 \\
\hline $\begin{array}{l}\text { TAG Evaluation of Contaminant } \\
\text { Transport in Groundwater }\end{array}$ & Completed May 2005 \\
\hline TAG CME Report & Planned early submittal to NMED in August 2005. \\
\hline $\begin{array}{l}\text { TAG Corrective Measures } \\
\text { Implementation Plan }\end{array}$ & $\begin{array}{l}\text { Currently on schedule to meet September 30, 2006 } \\
\text { NMED submittal date. }\end{array}$ \\
\hline
\end{tabular}




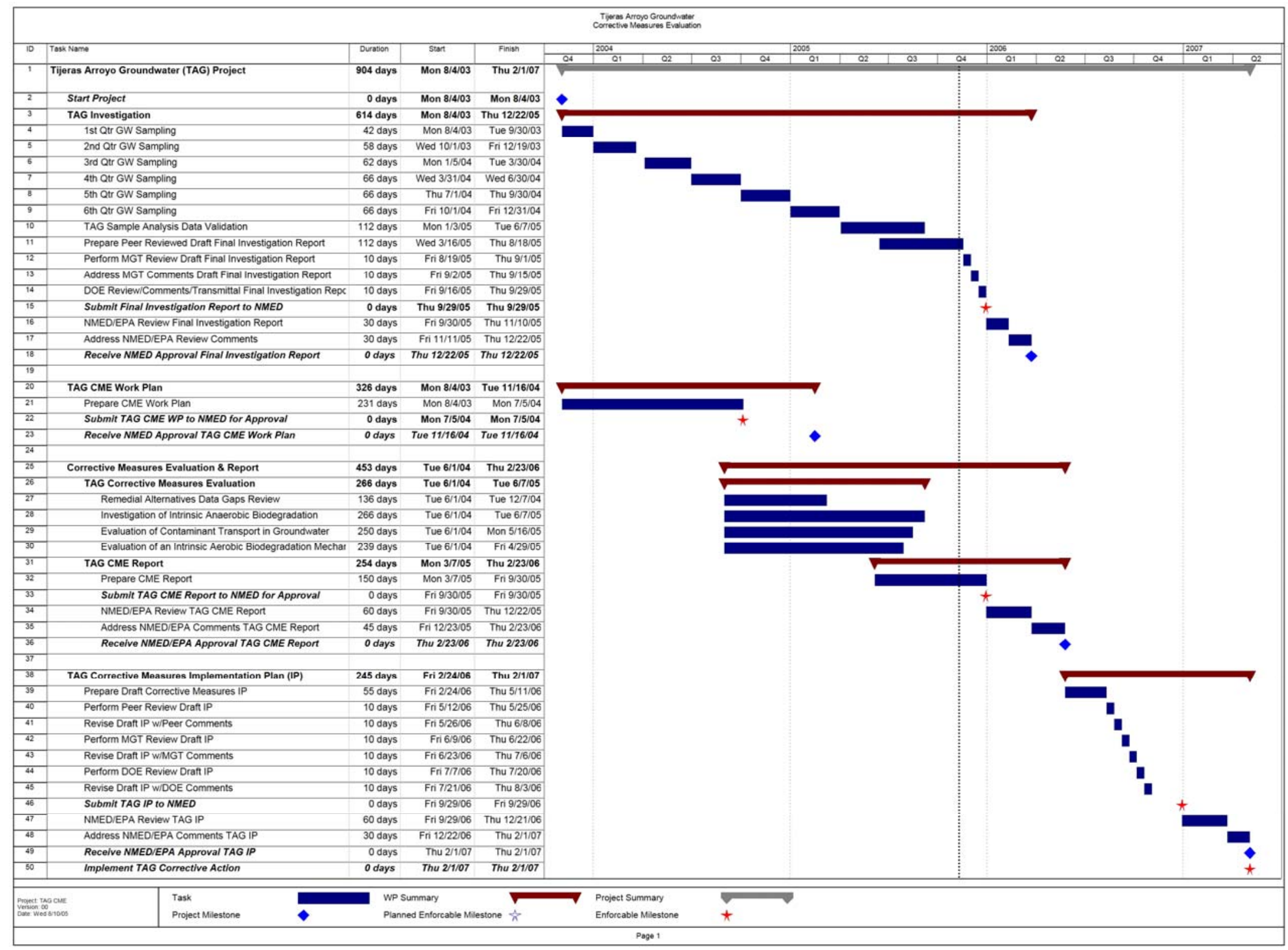

Figure 5-1. Corrective measures implementation schedule. 
This Page Intentionally Left Blank 


\subsection{REFERENCES}

1. DOE, 1999, Decision-Making Framework Guide for the Evaluation and Selection of Monitored Natural Attenuation Remedies at Department of Energy Sites, Department of Energy, Office of Environmental Restoration, May 1999.

2. EPA, 1999, Use of Monitored Natural Attenuation at Superfund, RCRA Corrective Action, and Underground Storage Tank Sites, OSWER Directive 9200.4-17P, http://www.epa.gov/swerust1/directiv/d9200417.pdf.

3. EPA, 1998, Technical Protocol for Evaluating Natural Attenuation of Chlorinated Solvents in Ground Water, EPA/600/R-98/128, http://www.clu-in.org/download/remed/protocol.pdf.

4. EPA, 1994, RCRA Corrective Action Plan (Final), OSWER 9902.3-2A, U.S. Environmental Protection Agency, Office of Solid Waste and Emergency Response, May 1994.

5. NMED, 2004, "Compliance Order on Consent Pursuant to the New Mexico Hazardous Waste Act 74-4-10: Sandia National Laboratories Consent Order,” New Mexico Environment Department, April 24, 2004.

6. SNL/NM, 2002, Tijeras Arroyo Groundwater Continuing Investigation Report, Sandia National Laboratories Environmental Restoration Project for U.S. Department of Energy, Albuquerque Operations Office, Albuquerque, New Mexico, November 2002.

7. SNL/NM, 2003, Tijeras Arroyo Groundwater Investigation Work Plan, Sandia National Laboratories New Mexico, National Nuclear Security Administration Site Office.

8. SNL/NM, 2004, Corrective Measures Evaluation Work Plan Tijeras Arroyo Groundwater, SAND2004-3247P, Sandia National Laboratories/New Mexico, November 2004.

9. SNL/NM, 2005, Environment, Safety, and Health (ES\&H) Manual, CPR400.1.1, MN471001, Issue EZ, revision date May 31, 2005, Sandia National Laboratories, Albuquerque, New Mexico. 
This Page Intentionally Left Blank 
Attachment A

Contaminant Distribution in Groundwater 
This Page Intentionally Left Blank 


\subsection{CONTAMINANT DISTRIBUTION IN GROUNDWATER}

During the course of the corrective measures evaluation (CME) groundwater monitoring has continued as governed by the Tijeras Arroyo Groundwater Investigation Work Plan (SNL/NM 2003). The results of this investigation will be reported in the Final TAG Investigation Report, which is scheduled for completion by September 30, 2005. This attachment presents historical (SNL/NM 2004b) and more recent (SNL/NM 2004a, SNL/NM 2005) concentrations of the contaminants of concern (COCs), observed in samples from selected wells in the Sandia National Laboratories/ New Mexico (SNL/NM) Area of Responsibility (AOR).

Data are presented for wells where contaminants of concern (COCs) have been observed on at least one occasion since 1999 above the U.S. Environmental Protection Agency (EPA) maximum contaminant level (MCL) for drinking water, which is $5 \mu \mathrm{g} / \mathrm{L}$ for trichloroethene (TCE) and $10 \mathrm{mg} / \mathrm{L}$ (as nitrogen) for nitrate. The groundwater monitoring well network is shown on Figure A-1. Figures A-2 and A-3 are plots of concentration vs. time for TCE and nitrate respectively. Non-detect results are not shown in these plots. The groundwater analytical data collected under the provisions of the TAG Investigation Work Plan (SNL/NM 2003) are in agreement with historical concentrations. Observations from the data are:

- Concentrations of TCE have sporadically been greater than the MCL in samples from well TA2-W-19, and TCE was routinely detected above the MCL in samples from well TA2-W-26. More recent detections of TCE in both wells sampled using high flow sampling techniques have been below the MCL.

- Nitrate is widely distributed across the site at concentrations below the MCL and has routinely been detected, at concentrations above the MCL in samples from wells TJA-7 and TA2-SW-320. Nitrate has routinely been detected at concentrations near the MCL in samples from wells TA2-W-19 and TJA-2.

Concentration trends of TCE and nitrate in the SNL/NM AOR monitoring well network have shown that concentrations are not increasing and appear to be stable. Variation in observed concentrations over time is due to the change in sampling methods and other factors.

Concentrations of both TCE and nitrate are not significantly increasing and are not expected to significantly increase as wastewater disposals to the environment have ceased. Future groundwater monitoring data will be necessary to discern a declining trend because of the relatively slow rate of natural attenuation processes and the need for a longer sampling period using consistent methods. The historical data indicate that the extent of TCE and nitrate contaminated groundwater is stable or not expanding, because concentration trends are not increasing as observed in samples form the SNL/NM TAG perched system monitoring wells and there are no continuing sources of contamination (SNL/NM 2004b. 
This Page Intentionally Left Blank 


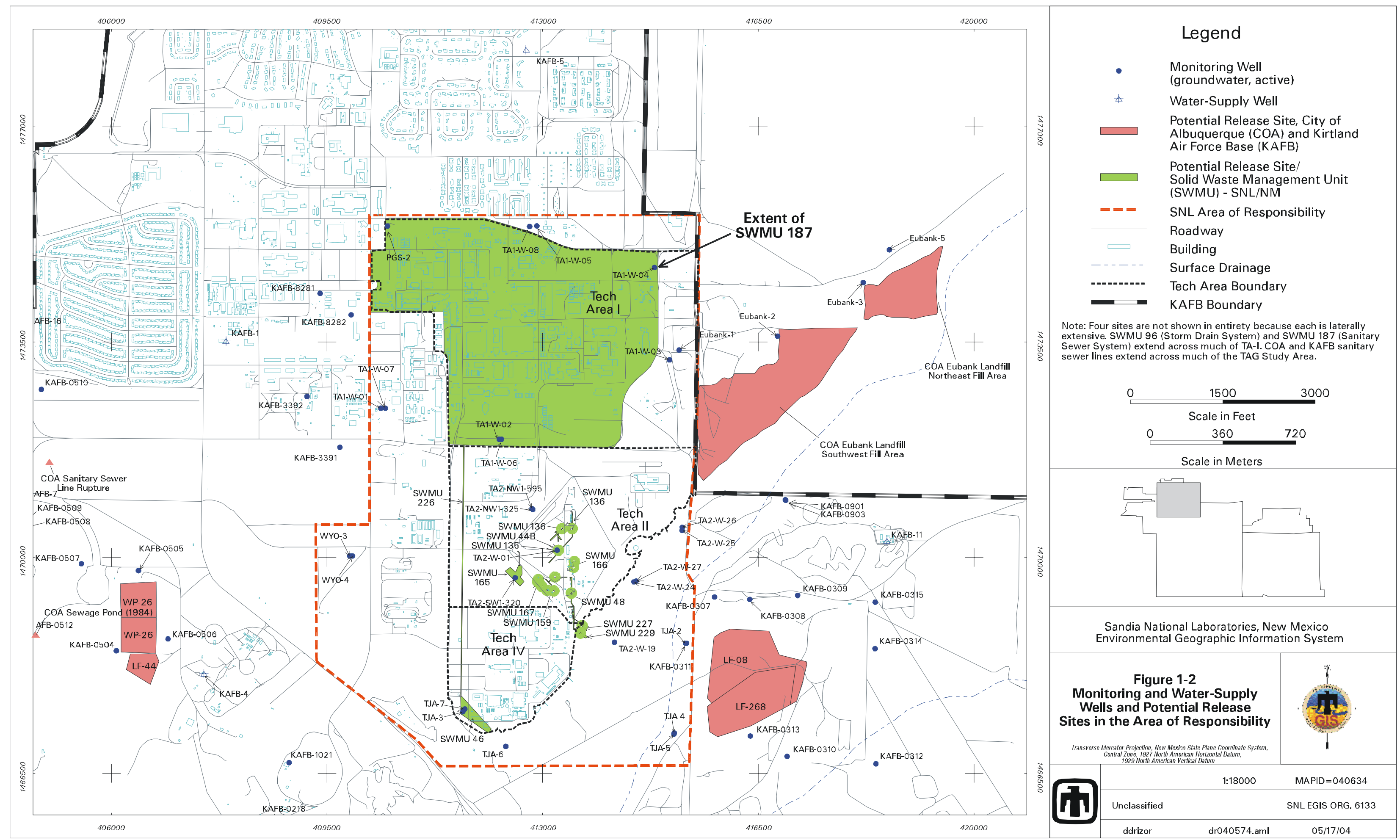

Figure A-1. Monitoring and Water Supply Wells and Potential Release Sites in the Area of Responsibility. 
This Page Intentionally Left Blank 


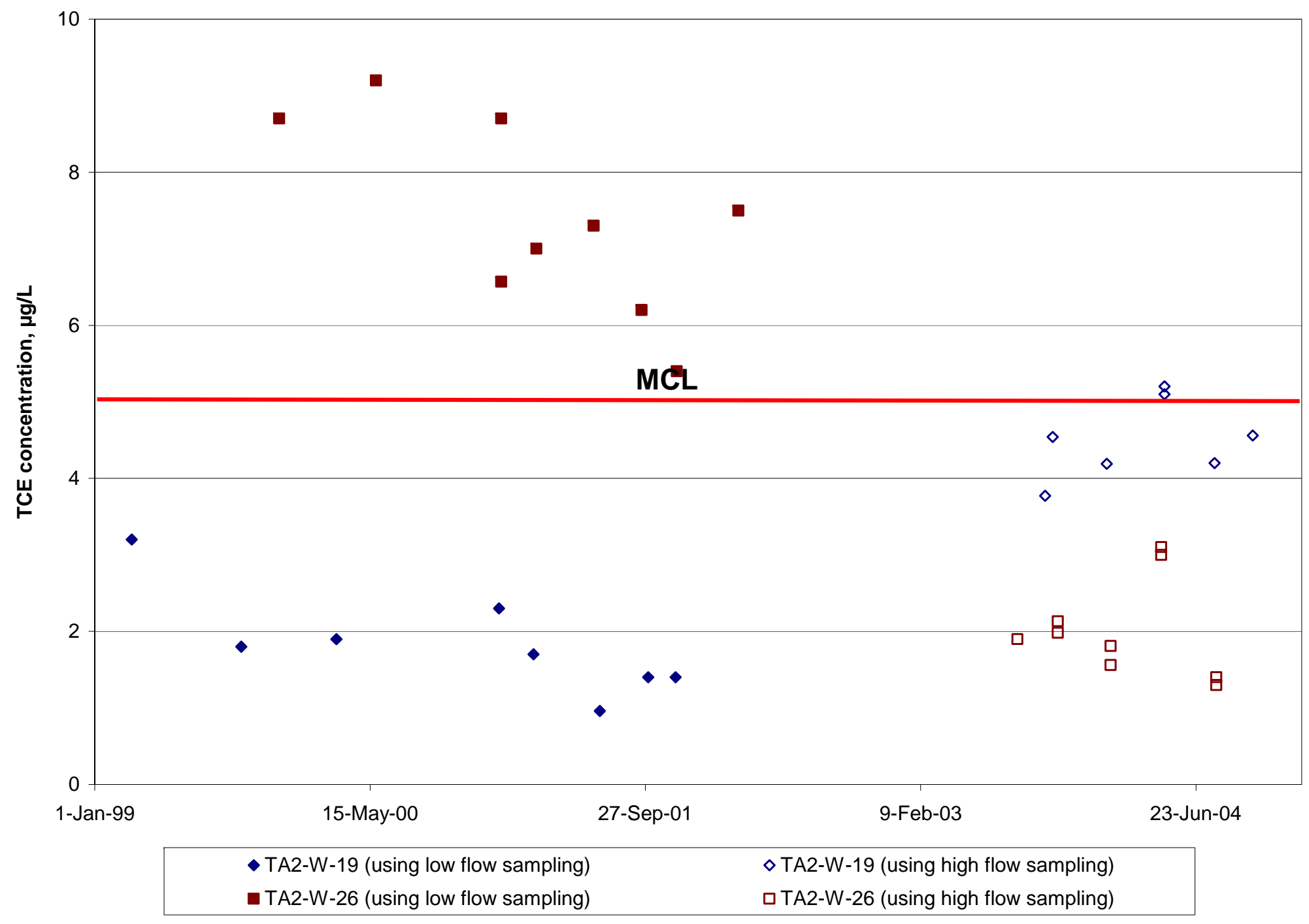

Figure A-2. TCE concentrations over time. 


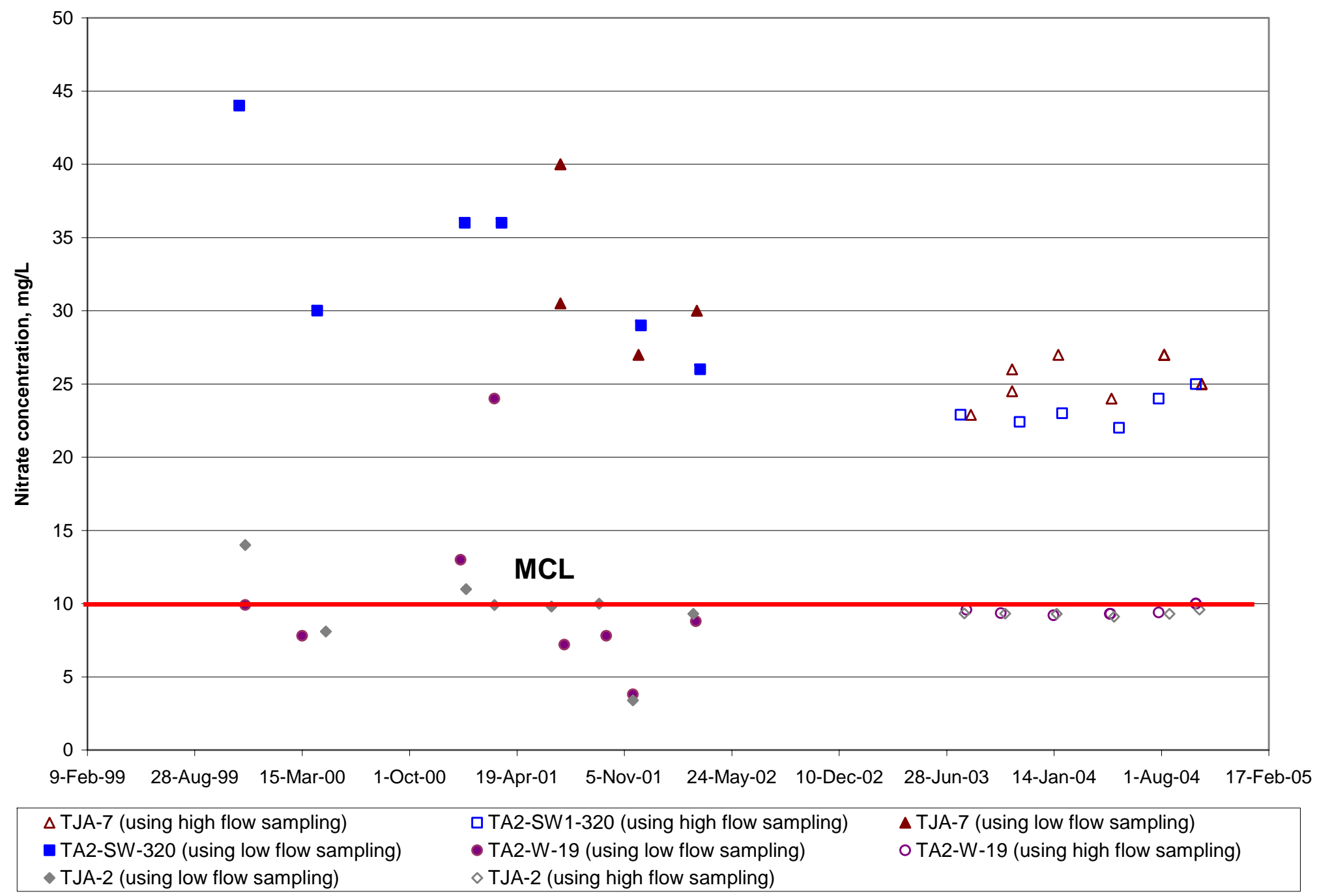

Figure A-3. Nitrate concentrations over time. 


\subsection{REFERENCES}

1. SNL/NM, 2003, Tijeras Arroyo Groundwater Investigation Work Plan (Final Version), National Nuclear Security Administration Sandia Site Office, Sandia National Laboratories/New Mexico Environmental Restoration Project, June 2003.

2. SNL/NM, 2004a, Annual Groundwater Monitoring Report, Fiscal Year 2003. Groundwater Protection Program Sandia National Laboratories, New Mexico. March 2004.

3. SNL/NM, 2004b Corrective Measures Evaluation Work Plan Tijeras Arroyo Groundwater, SAND2004-3247P, November 2004, Sandia National Laboratories/New Mexico.

4. SNL/NM, 2005, Annual Groundwater Monitoring Report, Fiscal Year 2004. Groundwater Protection Program Sandia National Laboratories, New Mexico. July 2005. 
This Page Intentionally Left Blank 
Attachment B

Remedial Alternatives Data Gaps Review 
This Page Intentionally Left Blank 


\title{
Remedial Alternatives Data Gaps Review for Tijeras Arroyo Groundwater at Sandia National Laboratories/New Mexico
}

\author{
December 2004
}

Prepared by

Sandia National Laboratories

Albuquerque, New Mexico 87185 and Livermore, California 94550

Sandia is a multiprogram laboratory operated by Sandia Corporation,

a Lockheed Martin Company, for the United States Department of Energy's

National Nuclear Security Administration under Contract DE-AC04-94AL85000.

Approved for public release; further dissemination unlimited. 


\begin{abstract}
The objective of this report is to continue the assessment of alternative technologies to support the Corrective Measures Evaluation (CME) process for remediation of Tijeras Arroyo Groundwater (TAG). This Remedial Alternative Data Gap Review is an informal report that documents decisions made as a result of the assessment and recommends activities to address the data gaps and provide sufficient information to complete the CME Report. Four remedial alternatives were identified in the TAG CME Work Plan. This report presents conceptual designs for the remedial alternatives which are used to perform an assessment based on the threshold and remedial alternative evaluation criteria from the Compliance Order on Consent. The four remedial alternatives, including a summary of decisions regarding each, are:
\end{abstract}

1. Groundwater monitoring - Groundwater monitoring will continue to be evaluated.

2. Monitored natural attenuation (MNA) - MNA will continue to be evaluated through numerical modeling and field scale studies.

3. In situ bioremediation (ISB) - No further data gathering activities are recommended for ISB because it has been demonstrated to be significantly less effective compared to other remedial alternatives.

4. Pump and treat - No further data gathering activities are recommended for pump and treat because it has been demonstrated to be significantly less effective compared to other remedial alternatives.

It is recommended that evaluation of data gaps for two remedial alternatives, groundwater monitoring and MNA, be performed. Characterization activities for the TAG study area are recommended field scale studies for both groundwater monitoring and MNA. However, these activities are not directed by nor conducted as part of this CME process but the data generated can be used as appropriate. For MNA, numerical modeling is recommended to investigate the fate and transport of contaminants in the perched groundwater system. Other field scale studies recommended for MNA include investigating anaerobic mechanisms of TCE and nitrate biodegradation and performing enzyme probe analyses to provide direct evidence of an aerobic cometabolic TCE degradation mechanism. 


\section{CONTENTS}

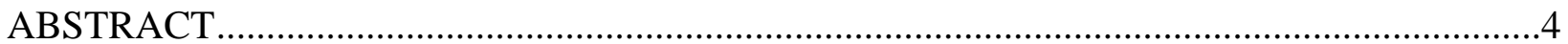

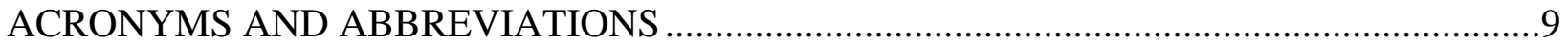

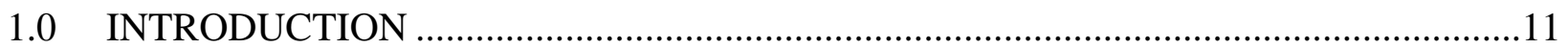

1.1 CME Interim Documentation ...........................................................................12

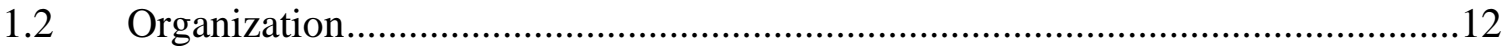

$1.3 \quad$ Current Conceptual Model Summary ……………...................................................14

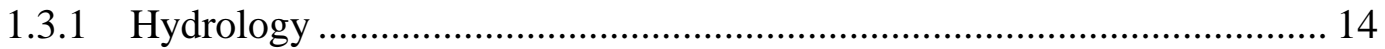

1.3.2. Contaminant Releases..................................................................... 17

1.3.3. Contaminant Transport through the Vadose Zone.................................... 18

1.3.4. Contaminant Distribution and Transport through the Perched System .... 18

1.3.5 Contaminant Distribution and Transport through the Regional Aquifer .. 19

1.3.6 Contaminants of Concern ...................................................................... 20

1.3.7 Information Compiled for the Data Gaps Review ………………………... 20

2.0 REMEDIAL ALTERNATIVE CONCEPTUAL DESIGNS.............................................23

$2.1 \quad$ Groundwater Monitoring .....................................................................................23

2.1.1 Considerations for Evaluation of Groundwater Monitoring ...................... 23

2.1.2 Implementation of Groundwater Monitoring at SNL/NM AOR ............... 23

2.1.3 Technical and Functional Requirements..................................................... 24

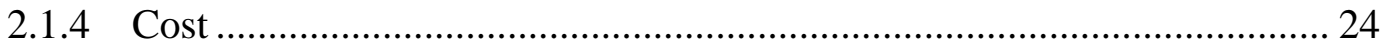

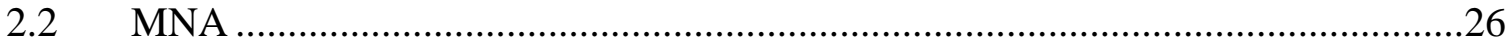

2.2.1 Considerations for Evaluation of MNA .................................................... 26

2.2.2 Implementation of MNA at SNL/NM AOR …..................................... 26

2.2.3 Natural Attenuation Mechanisms .............................................................. 28

2.2.4 Technical and Functional Requirements..................................................... 30

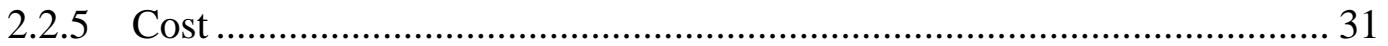

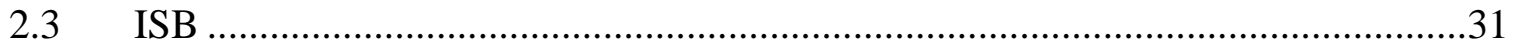

2.3.1 Considerations for Evaluation of ISB ....................................................... 32

2.3.2 Implementation of ISB Technology at SNL/NM AOR ............................. 32

2.3.3 Technical and Functional Requirements.................................................. 33

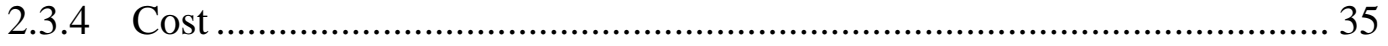

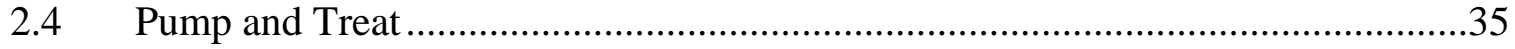

2.4.1 Considerations for Evaluation of Pump and Treat.................................... 35

2.4.2 Considerations for Implementing Pump and Treat at SNL/NM AOR ..... 36 
2.4.3 Scoping Treatment Options ........................................................................ 37

2.4.4 Technical and Functional Requirements..................................................... 39

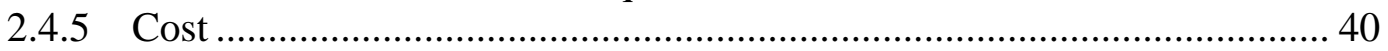

3.0 REMEDIAL ALTERNATIVE EVALUATION ..............................................................

$3.1 \quad$ Threshold Criteria Evaluation .............................................................................41

3.2 Remedial Alternative Evaluation.........................................................................42

3.3 Summary of the Remedial Alternative Evaluation ..................................................45

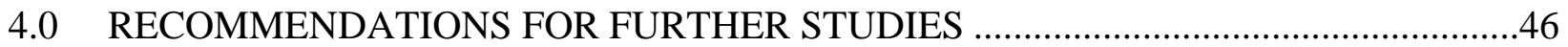

$4.1 \quad$ Recommended Activities ...............................................................................

4.1.1 Numerical Modeling ............................................................................ 47

4.1.2 Field Scale Studies................................................................................ 48

4.2 Activities No Longer Recommended..................................................................48

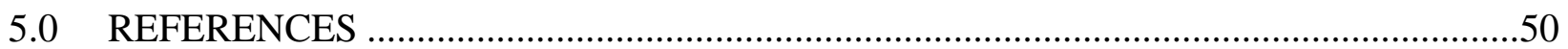

Appendix A. Scoping Estimates of Operations and Timeframe for Pump and Treat Appendix B. Treatment and Disposal Options for Pump and Treat

\section{FIGURES}

1-1. Illustration of the staged process of data gathering activities and production of associated

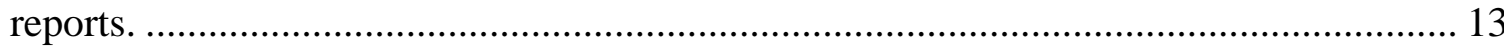

1-2. Potentiometric Surface Map for the Perched System in the Area of Responsibility,

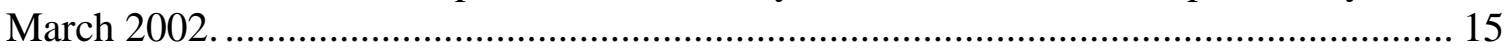

2-1. Process diagram for groundwater monitoring.................................................................. 24

2-2. Decision framework for evaluating MNA (from DOE 1999). .......................................... 27

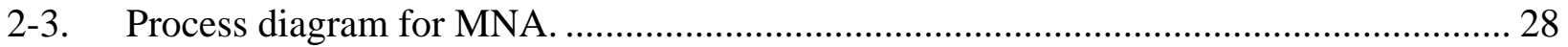

2-4. Energy available from typical microbially mediated redox reactions, and their relationship to reductive dechlorination........................................................................... 29

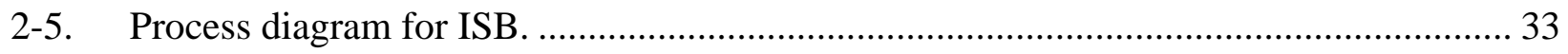

2-6. Process diagram for implementation of pump and treat. ................................................. 38 


\section{TABLES}

1-1. Summary of perched system properties for SNL/NM AOR ........................................ 15

2-1. Groundwater monitoring operational phases....................................................... 24

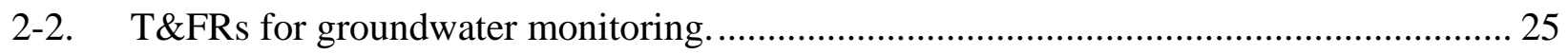

2-3. Itemized cost elements for the groundwater monitoring. .......................................... 25

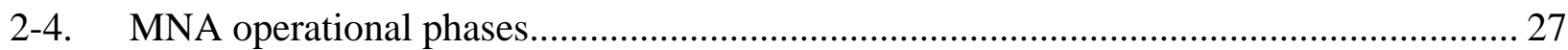

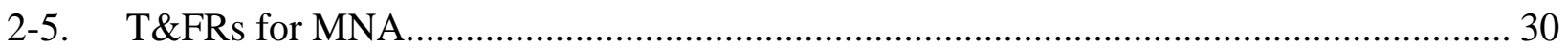

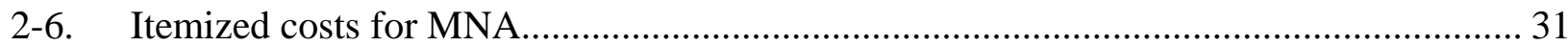

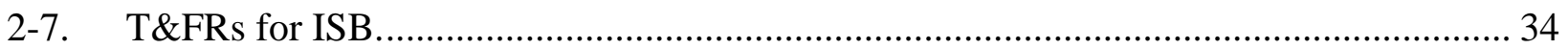

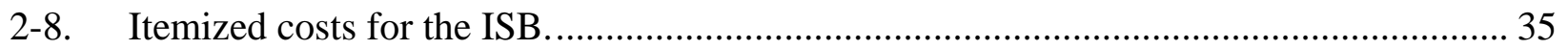

2-10. T\&FRs for pump and treat using GAC and ion-exchange. ......................................... 39

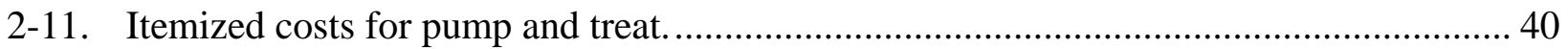

3-1. Threshold criteria evaluation. ............................................................................. 41

3-2. Information supporting comparative analysis of the remedial alternatives................... 43

3-3. Comparative analysis of remedial alternatives for SNL/NM AOR............................... 45

4-1. Recommended numerical modeling, field, and laboratory studies.............................. 49 
This Page Intentionally Left Blank

B-8 


\section{ACRONYMS AND ABBREVIATIONS}

AOR

ARD

ARG

bgs

$\mathrm{CME}$

COA

COC

COOC

DCE

DOE

EPA

$\mathrm{ft}$

$\mathrm{ft} / \mathrm{ft}$

$\mathrm{ft} / \mathrm{min}$

GAC

in.

ISB

KAFB

MCL

MMO

MNA

NMED

RCRA

sMMO
Area of Responsibility

anaerobic reductive dechlorination

ancestral Rio Grande

below ground surface

Corrective Measures Evaluation

City of Albuquerque

contaminant of concern

Compliance Order on Consent

dichloroethene

United States Department of Energy

United States Environmental Protection Agency

feet or foot

feet per foot

feet per minute

granular activated carbon

inch or inches

in-situ bioremediation

Kirtland Air Force Base

maximum contaminant level

methane monooxygenase

monitored natural attenuation

New Mexico Environmental Department

Resource Conservation and Recovery Act

soluble methane monooxygenase 
SNL/NM Sandia National Laboratories/ New Mexico

TAG Tijeras Arroyo Groundwater

TBD to be determined

TCE trichloroethene

T\&FRs technical and functional requirements

VA Veterans Administration 


\subsection{INTRODUCTION}

The Corrective Measures Evaluation Work Plan Tijeras Arroyo Groundwater (SNL/NM 2004a), referred to in this data gap review as the Tijeras Arroyo Groundwater (TAG) Corrective Measures Evaluation (CME) Work Plan, was prepared as specified in the Compliance Order on Consent (COOC) issued by the New Mexico Environment Department (NMED) (NMED 2004). The TAG CME Work Plan outlines a process to evaluate remedial alternatives to identify a corrective measure for the Sandia National Laboratories/New Mexico (SNL/NM) Area of Responsibility (AOR). Four remedial alternatives were identified:

1. Groundwater monitoring,

2. Monitored natural attenuation (MNA),

3. In situ bioremediation (ISB), and

4. Pump and treat (ex situ treatment technology to be determined).

The objective of implementing these remedial alternatives is to meet the cleanup goals, objectives, and requirements stated in the TAG CME Work Plan, which include the following compliance goals:

- Operating all remediation systems or strategies in compliance with applicable requirements,

- Reducing contaminant of concern (COC) concentrations in groundwater to below maximum contaminant levels (MCLs), and

- Implementing institutional controls to protect human health and the environment during the remediation timeframe.

Reducing COC concentrations in groundwater to below MCLs is the main challenge for selecting the most effective and cost efficient remedial alternative; therefore, throughout this data gap review a remedial alternative that is potentially successful is one that will reduce COC concentrations to below MCLs.

Section 5.0 of the TAG CME Work Plan, "Remedial Alternative Evaluation Plan,” provides guidance on activities to be used for evaluating the four remedial alternatives (SNL/NM 2004a). The Remedial Alternative Evaluation Plan identifies data gathering activities to be carried out in four stages, as follows:

1. Paper study,

2. Numerical modeling,

3. Laboratory studies, and

4. Field scale studies. 


\subsection{CME Interim Documentation}

As the four stages of data gathering activities are carried out, individual informal reports will be created to document the results of each stage in the evaluation process. These reports will be prepared by the CME implementation team to be reviewed by the project leader, technical peer review panel, and technical support personnel (project organizational structure is discussed in Section 7.2 of the TAG CME Work Plan (SNL/NM 2004a). The informal reports will be produced for project team internal review and discussion to define and document activities necessary to complete the TAG CME Report. The informal reports will not be officially published with Sandia document numbers and will be superseded by the data analysis and remedy selection presented in the CME report when it is published. The purpose of the informal reports includes:

- Reporting results and interpretation of results to the project leader, technical peer review panel and technical support personnel,

- Documenting decisions made during the data collection and analysis process for each of the four evaluation stages, and

- Providing supporting information that will eventually be included in the CME Report to be submitted to the NMED.

Figure 1-1 illustrates the four stage process of data gathering activities and the reports associated with each stage.

\subsection{Organization}

The TAG CME Work Plan presented objectives for the paper study stage to focus on the continuing assessment of available data and information on the alternative remedies being considered. The primary objectives for this assessment include presentation of conceptual designs, completion of a data gap review, and providing recommendations for additional activities needed to fill these data gaps to support completion of the CME Report. This report addresses the objectives of the paper study stage. The outcome of the process is a group of recommended data gathering activities. This data gap review is organized into the following sections:

- Section 1. Introduction. This section includes a presentation of the remedial alternatives being considered, a description of the objectives of this report, and a summary of the current conceptual model, as presented in the TAG CME Work Plan. Also, included in this section is a presentation of additional site data compiled during this data gap review.

- Section 2. Remedial Alternative Conceptual Designs. This section presents conceptual designs for the four remedial alternatives, consisting of considerations for evaluation, implementation information, process diagrams with associated technical and functional requirements (T\&FRs) and assumptions, and cost descriptions.

- Section 3. Remedial Alternative Evaluation. This section presents the evaluation methods and results for each of the four remedial alternatives. The outcome of the evaluation is a list of remedial alternatives that will be considered for future data gathering activities.

- Section 4. Recommendations for Further Studies. Data gaps regarding individual remedial alternatives and application to TAG have been identified. This section identifies numerical modeling and field scale studies that will provide the necessary information to choose a preferred remedy. 


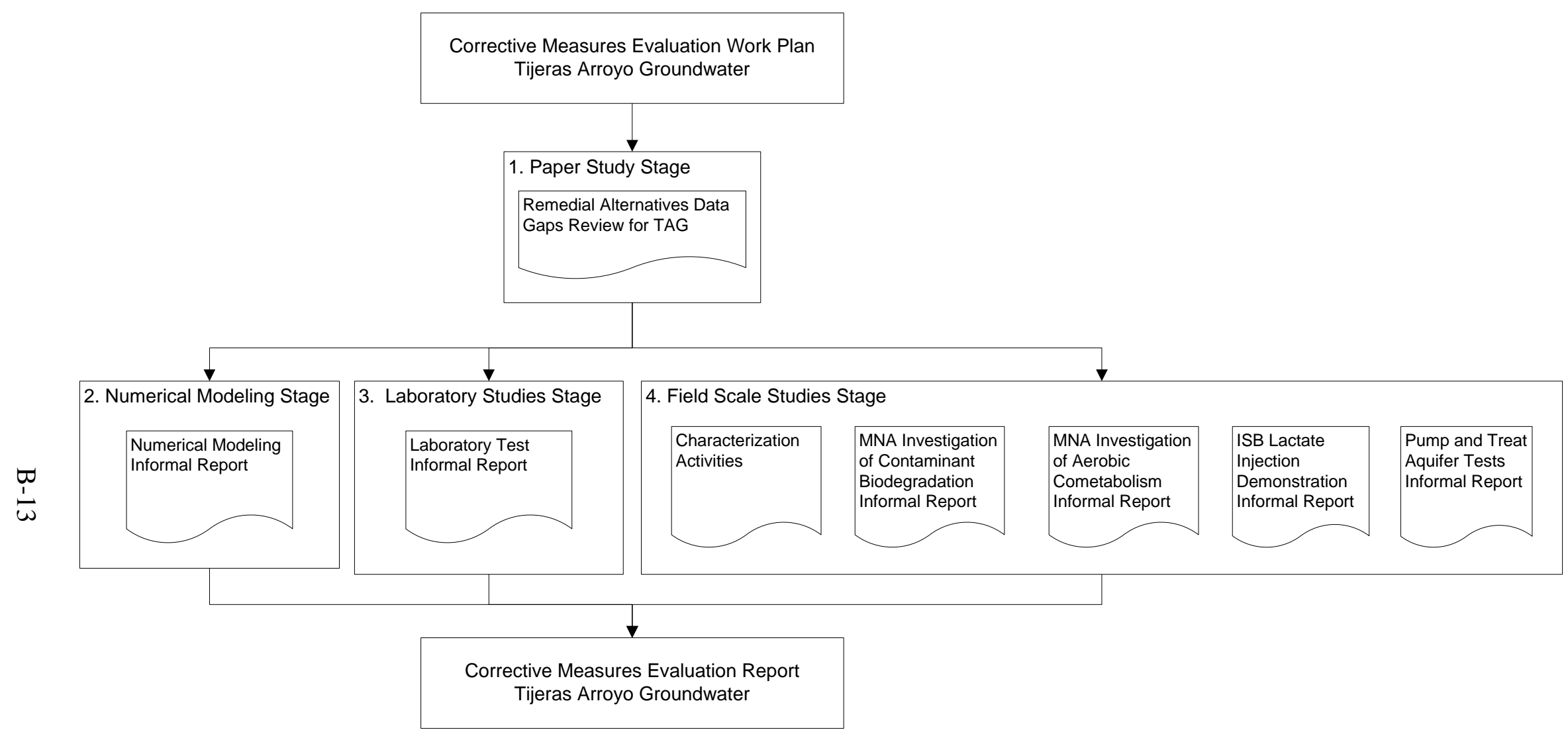

Figure 1-1. Illustration of the staged process of data gathering with potential activities and subsequent reports. 


\subsection{Current Conceptual Model Summary}

Characterization of the TAG study area has been undertaken by three separate potentially responsible parties: SNL/NM, the City of Albuquerque (COA), and Kirtland Air Force Base (KAFB). As a result, it is necessary for each party to clearly define their contribution to overall TAG remediation. The TAG CME Work Plan identifies the specific area within the overall TAG study area for which SNL/NM has remediation responsibility. In order to clearly distinguish it from the overall TAG study area, the area that the TAG CME Work Plan and this report address will be referred to as the SNL/NM AOR. The SNL/NM AOR encompasses an approximately 2-square mile area in the north central part of KAFB (Figure 1-2).

Evaluation of remedial alternatives for contaminants of concern (COCs) in groundwater at SNL/NM AOR requires a current conceptual model of contaminant transport that will provide the basis for a technically defensible evaluation. The following summary includes information summarized from the TAG CME Work Plan (SNL/NM 2004a).

\subsubsection{Hydrology}

The TAG study area is situated within the Albuquerque Basin, which is bounded on both the eastern and western margins by north-south trending faults related to the Rio Grande rift. The study area overlies the eastern margin of the Albuquerque Basin where the faults mostly trend parallel to the Sandia-Manzanita-Manzano mountain front. For the TAG SNL/NM AOR, the stratigraphic unit of greatest interest is the Upper Santa Fe Group, which is composed mostly of two interfingering lithofacies: an alluvial-fan lithofacies and a fluvial lithofacies.

Both lithofacies are less than five million years old and are composed of unconsolidated to poorly-cemented gravel, sand, silt, and clay (Stone et al. 2000). The alluvial-fan lithofacies consists of poorly sorted piedmont-slope deposits derived from the Sandia, Manzanita, and Manzano Mountains east of the study area. Fine-grained units within the alluvial-fan lithofacies produce low-permeability zones that are capable of perching groundwater. The fluvial lithofacies is derived from the ancestral Rio Grande (ARG) to the north and is typically well sorted and medium- to coarse-grained.

Two aquifers in the Upper Santa Fe Group have been identified in the TAG study area: a perched system and the regional aquifer. In the northern portion of the study area, the upper surface of the perched system is present at depths ranging from approximately 220 to $330 \mathrm{ft}$ below ground surface (bgs), whereas the upper surface of the regional aquifer is present at approximately 440 to $570 \mathrm{ft}$ bgs. The regional aquifer is used as a potable water source by KAFB, COA, and the Veterans Administration (VA).

The perched system is presently understood to cover approximately 3.5 square miles. Monitoring wells bound the perched system on the western and southern margins. The northern margin of the perched system has not been fully defined and may extend across the KAFB boundary north of the Wyoming Gate and east to the Eubank Landfill. A southeastern margin is not discernible because the perched system merges with the regional aquifer. The direction of groundwater flow in the perched system is inferred to be principally to the southeast, with a horizontal gradient of approximately $0.007 \mathrm{ft} / \mathrm{ft}$. The vertical gradient is approximately $0.95 \mathrm{ft} / \mathrm{ft}$ over most of the perched system, and continuous vertical flow is suggested by the merging of the two groundwater systems to the southeast. 


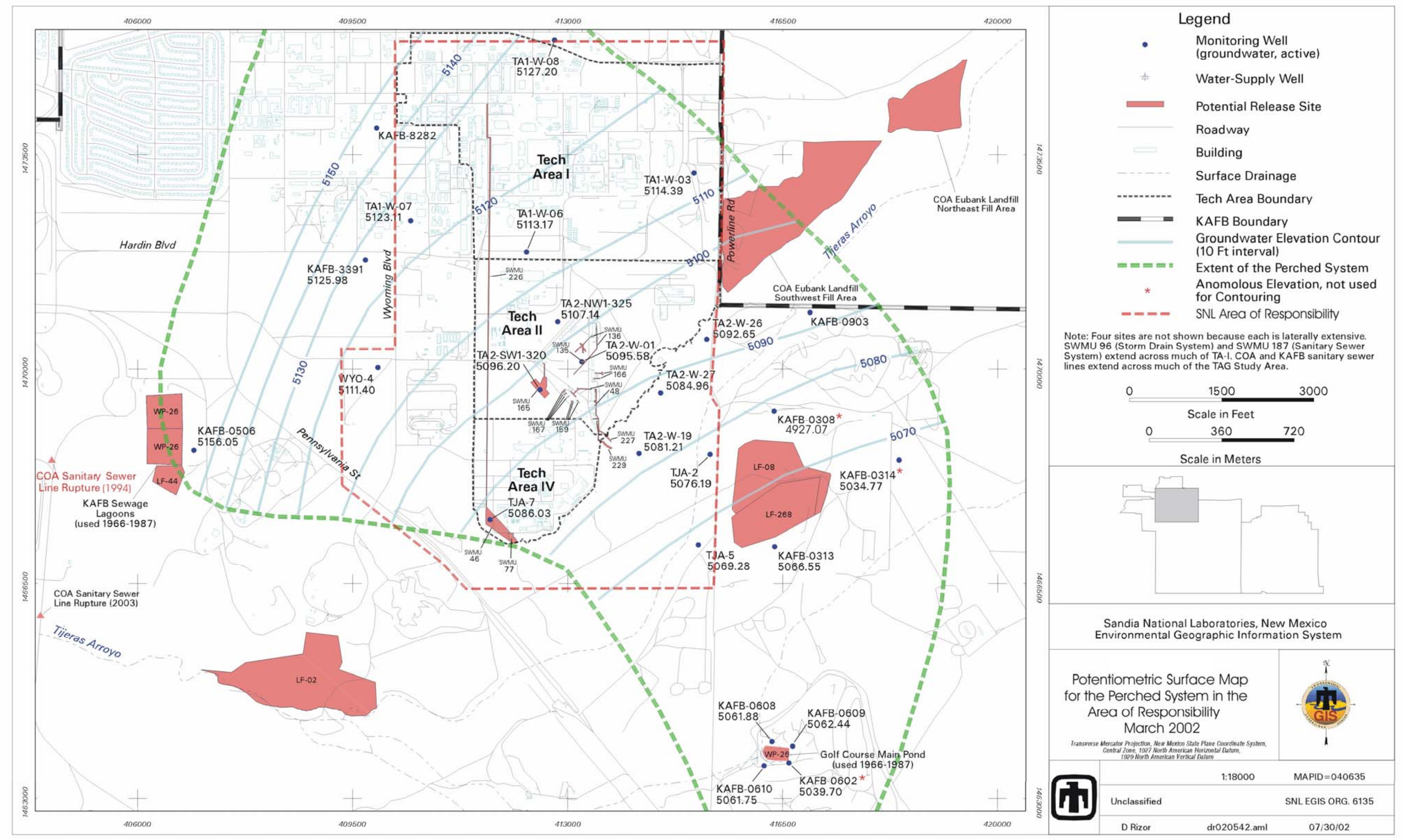

Figure 1-2. Potentiometric Surface Map for the Perched System in the Area of Responsibility, March 2002. 
This Page Intentionally Left Blank 
Historically, water levels in the perched system have fluctuated across the study area (SNL/NM 2002). In the vicinity of the sewage lagoons and other areas northwest of Tijeras Arroyo, water levels have been declining since 1987, apparently in response to the lagoons being removed from service. Conversely, water levels have increased southeast of Tijeras Arroyo.

The direction of groundwater flow in the regional aquifer is to the northwest toward the KAFB, COA, and VA water-supply wells. The horizontal gradient of the regional aquifer across the central portion of the study area is approximately $0.009 \mathrm{ft} / \mathrm{ft}$ with steeper gradients evident near the mountain front. Vertical flow gradients within the TAG study area have not been measured but are inferred to be downward, consistent with TA-III/V groundwater studies.

Historically, water levels in the regional aquifer have fluctuated across the study area (SNL/NM 2002). A line of demarcation between increasing water levels and declining water levels is evident along the eastern extent of the ARG-fluvial lithofacies, which coincidentally trends along Wyoming Boulevard. Declining water levels approaching $1.5 \mathrm{ft} /$ year are apparently associated with the KAFB, COA, and VA water-supply wells. Increases in groundwater elevations of up to $1.8 \mathrm{ft} / \mathrm{year}$ in the southeast portion of the study area probably reflect recharge of the regional aquifer from the perched system, Tijeras Arroyo, the golf course, and the mountain front.

The conceptual model shows that the thickness of the vadose zone is reduced in the central portion of the TAG study area where the perched system is present. Discontinuous, yet overlapping multiple lenses of unsaturated alluvial-fan sediments serve as a perching horizon beneath the perched system in that area. The perched system is present at approximately 220 to $330 \mathrm{ft}$ bgs, and the regional aquifer system is present at approximately 440 to $570 \mathrm{ft}$ bgs. Groundwater in the perched system most likely merges with the regional aquifer southeast of Tijeras Arroyo where the alluvial-fan sediments are slightly more permeable.

Tijeras Arroyo is the most significant surface-water drainage feature on KAFB and trends southwest across KAFB, eventually draining into the Rio Grande, approximately 6 miles west of KAFB. Surface water flows in the arroyo several times per year as a result of storm events. The annual precipitation for the area, as measured at the Albuquerque International Sunport, is $8.2 \mathrm{in}$. (SNL/NM 2001a). During most rainfall events, rainfall quickly infiltrates into the soil in the study area. However, virtually all of the moisture subsequently undergoes evapotranspiration. Estimates of evapotranspiration for the KAFB area range from 95 to $99 \%$ of the annual rainfall (SNL/NM 1998).

\subsubsection{Contaminant Releases}

A variety of potentially contaminated sites were evaluated within the TAG SNL/NM AOR. Three potential trichloroethene (TCE) sources and three potential nitrate sources were identified within the SNL/NM AOR, including potential TCE and nitrate sources at SWMU 46 (Old Acid Waste Line Outfall) and SWMU 165 (Building 901 Septic System), a potential TCE source at SWMU 227 (Bunker 904 Outfall), and a potential nitrate source at SWMU 187 (TA-I Sanitary Sewer System) (SNL/NM 2004a). 


\subsubsection{Contaminant Transport through the Vadose Zone}

There is evidence of vapor-phase contaminants in the vadose zone; however, no free-phase TCE products and no water-saturated core samples have been detected in any of the soil samples collected from the boreholes. The original source of the TCE was from the aqueous phase (i.e., wastewater), and from the current vapor phase contaminants partitioned from the aqueous phase. All anthropogenic sources of recharge (i.e., wastewater) have been removed from service and no longer contribute water to the vadose zone.

Based on soil vapor and groundwater data collected in the vicinity of SWMU 227 (as stated in the TAG CME Work Plan) a residual TCE vapor plume does exist beneath SWMU 227. The primary mechanism for transporting these contaminants to the aquifer would be through partitioning back into the aqueous phase of additional recharge that might move through the system. During operations at SWMU 227, a recharge mechanism did exist (i.e. the wastewater disposal) to transport TCE from the vapor phase to the groundwater, which may have caused the groundwater contamination that is currently observed at TA2-W-19. However, since wastewater disposals have ceased, no recharge mechanism currently exists, and it is unlikely that additional TCE mass will be transported to the aquifer. The latest observations in vapor well 227-VW-01 and in perched system monitoring well TA2-W-19 are consistent with this hypothesis.

Nitrate was present in sewage wastewater disposed to septic systems and sanitary sewer lines in the area. The nitrate was transported to the perched system water table by high volumes of wastewater disposed at the sites. Because nitrate is extremely soluble and cannot exist as a separate phase (i.e., vapor or non-aqueous phase liquid [NAPL]), and because no water-saturated core samples have been encountered in any of the soil samples collected from boreholes, a secondary source of anthropogenic nitrate contamination does not exist in the vadose zone.

\subsubsection{Contaminant Distribution and Transport through the Perched System}

Overall, the distribution of TCE is discontinuous across the perched system and does not indicate a single release site. Based upon the historic use of chlorinated solvents across SNL/NM and KAFB, the known extent of TCE in groundwater is probably associated with multiple releases of aqueous-phase solvents and subsequent transport through the vadose zone.

The maximum historical concentration of TCE in the perched system was $9.6 \mu \mathrm{g} / \mathrm{L}$, detected in TA2-W-26, and concentrations in only three SNL/NM wells have exceeded the maximum contaminant level (MCL) of $5.0 \mu \mathrm{g} / \mathrm{L}$ for TCE (TA2-W-19, TA2-W-26, and WYO-4). In the March/April 2002 groundwater sampling round, two of these three monitoring wells contained water with TCE concentrations that exceeded $5 \mu \mathrm{g} / \mathrm{L}$; water from well TA2-W-26 had a concentration of $7.5 \mu \mathrm{g} / \mathrm{L}$, while the duplicate samples at WYO-4 had TCE concentrations of 4.9 and $5.3 \mu \mathrm{g} / \mathrm{L}$ (refer to Figure 1-2 for well locations). In the three quarterly sampling events from July 2003 through February 2004, only water from WYO-4 had TCE concentrations exceeding $5 \mu \mathrm{g} / \mathrm{L}$, ranging from 6.06 to $7.05 \mu \mathrm{g} / \mathrm{L}$.

Well WYO-4 is an SNL/NM monitoring well that is located on KAFB property (Figure 1-2). Given that none of the SNL/NM potential release sites are near well WYO-4 and that groundwater flow in the perched system is to the southeast, the TCE concentrations present in water from WYO-4 are considered to represent contamination from an upgradient KAFB source. 
Therefore, the TCE contamination present at this well is not considered to be within the scope of this CME.

The maximum historical concentration of nitrate in the perched system within the TAG SNL/NM AOR was $44 \mathrm{mg} / \mathrm{L}$ in water from wells TA2-W-19 and TA2-SW1-320, and a total of $9 \mathrm{SNL} / \mathrm{NM}$ wells have exceeded the MCL for nitrate during at least one sampling event. In March and April of 2002, two of the perched-system monitoring wells had nitrate concentrations that exceeded the MCL of $10 \mathrm{mg} / \mathrm{L}$, with the highest concentration being $30 \mathrm{mg} / \mathrm{L}$ in well TJA-7. In the three quarterly sampling events from July 2003 through February 2004, four of the perched-system wells had nitrate concentrations that exceeded $10 \mathrm{mg} / \mathrm{L}$, with the highest concentration being $29.8 \mathrm{mg} / \mathrm{L}$ in well TJA-7. Overall, concentrations of nitrate in the perched system exceeding MCLs are scattered across the SNL/NM AOR.

According to KAFB-IRP terminology, the nitrate contamination in the perched system forms what is referred to as Plume 3 (MWH Americas, Inc., 2003). Plume 3, which is centered on monitoring well TA2-SW1-320, is located under the southwest portion of TA-II and may extend southward to TJA-7. Monitoring wells in the perched system that have nitrate concentrations below the MCL surround these wells. The plume is 0.3 miles long and 0.2 miles wide (MWH Americas, Inc., 2003) and is thought to emanate from SWMU 165, the Building 901 Septic System.

\subsubsection{Contaminant Distribution and Transport through the Regional Aquifer}

Overall, the regional aquifer monitoring wells have generally yielded no samples with detectable TCE concentrations except for a historic peak in TCE of $3.2 \mu \mathrm{g} / \mathrm{L}$ in well PGS-2. At no time has an SNL/NM regional aquifer well exceeded the MCL for TCE. During March/April 2002, twelve SNL/NM regional-aquifer monitoring wells were sampled for TCE; none of the samples had detectable concentrations of TCE except for TJA-3 with $0.639 \mu \mathrm{g} / \mathrm{L}$ (an estimated value). The groundwater sample from merging-zone well TJA-4 did not contain TCE. In the three quarterly sampling events from July 2003 through February 2004, ten SNL/NM regional aquifer monitoring wells were sampled for TCE; none of the samples had detectable concentrations of TCE.

The maximum historical concentration of nitrate within the SNL/NM AOR for wells completed in the regional aquifer system was $49 \mathrm{mg} / \mathrm{L}$ in merging zone well TJA-4. However, this is the only SNL/NM AOR regional aquifer monitoring well that has ever had nitrate concentrations that exceed the MCL. During the March/April 2002 sampling round, TJA-4 had a nitrate concentration of $28 \mathrm{mg} / \mathrm{L}$. In the three quarterly sampling events from July 2003 through February 2004, nitrate concentrations in TJA-4 ranged from 22.8 to $27.0 \mathrm{mg} / \mathrm{L}$. The nitrate contamination in the regional aquifer southeast of TA-II forms what is referred to as Plume 4 (MWH Americas, Inc., 2003). Plume 4 is most likely responsible for the nitrate concentrations in TJA-4, a well completed in the zone of merging. The plume is 1.9 miles long and 1 mile wide and is associated with the active KAFB Landfill (MWH Americas, Inc., 2003). 


\subsubsection{Contaminants of Concern}

Both TCE and nitrate are considered COCs for the perched system. Because no AOR regional aquifer wells have exceeded MCLs for either TCE or nitrate, no COCs are defined for the regional aquifer (SNL/NM 2004a). Therefore, the CME Work Plan and the CME process focus exclusively on TCE and nitrate contamination in the perched system.

Perched system wells with TCE concentrations that exceed MCLs, based on the results of the March/April 2002 sampling round, include WYO-4 and TA2-W-26 (Figure 1-2). Because the TCE contamination in well WYO-4 is attributed to KAFB releases, this well is not considered within the scope of the TAG CME Work Plan. Well TA2-W-19 has shown detections of TCE above the MCL; however, these detections have been sporadic over time with four detections at or above the MCL of $5 \mu \mathrm{g} / \mathrm{L}$ out of a total of 46 TCE concentration results reported since 1995. Based on data stated in the TAG CME Work Plan, a residual TCE vapor plume beneath SWMU 227 is not a continuing source to groundwater because recharge has ceased. Therefore, remedial alternatives for the SWMU 227 area will not be evaluated during the CME process. Therefore, only TCE contamination in the vicinity of TA2-W-26 will be addressed during the CME process. The TCE concentration at TA2-W-26 was $7.5 \mu \mathrm{g} / \mathrm{L}$ in March/April 2002.

Perched system wells with nitrate concentrations that exceed MCLs, based on the results of the March/April 2002 sampling round, include TJA-7 and TA2-SW1-320. Nitrate contamination in the vicinity of these two wells is within the scope of the CME and will be addressed during the CME process. Nitrate concentrations at these two wells were $30 \mathrm{mg} / \mathrm{L}$ (TJA-7) and $26 \mathrm{mg} / \mathrm{L}$ (TA2-SW1-320) in March/April 2002.

This report refers to three wells to illustrate the locations and distribution of COCs within the SNL/NM AOR. These three wells are:

- TA2-W-26 (TCE),

- $\quad$ TJA-7 (nitrate), and

- TA2-SW1-320 (nitrate).

\subsubsection{Information Compiled for the Data Gaps Review}

Table 1-1 is a compilation of properties for the perched groundwater system of the SNL/NM AOR. Most of these properties are discussed in more detail in the CME Work Plan (SNL/NM 2004a). However, the specific capacity of a hypothetical extraction well completed in the perched groundwater system had not been presented in the CME Work Plan and is presented here as part of the paper study. 
Table 1-1. Summary of perched system properties for SNL/NM AOR.

\begin{tabular}{l|cc}
\hline \multicolumn{1}{c|}{ Property } & Minimum & Maximum \\
\hline $\begin{array}{l}\text { Horizontal hydraulic conductivity } \\
\text { (K)(ft/min) }\end{array}$ & $\begin{array}{c}3.69 \times 10^{-5} \\
\text { (SNL/NM 2004b) }\end{array}$ & $\begin{array}{c}2.12 \times 10^{-3} \\
\text { (SNL/NM 2004b) }\end{array}$ \\
$\begin{array}{l}\text { Vertical hydraulic conductivity (K) } \\
\text { Hydraulic gradient }\end{array}$ & \multicolumn{2}{|c}{0.007} \\
(ft/ft) & \multicolumn{2}{|c}{ (SNL/NM 2003) } \\
Effective porosity & \multicolumn{2}{|c}{ 25\% (SNL/NM 2004a) } \\
$\begin{array}{l}\text { Groundwater velocity } \\
\text { ft/yr) }\end{array}$ & 4 & 10 \\
$\begin{array}{l}\text { Estimated Specific capacity of } \\
\text { potential wells (gpm/ft of drawdown) }\end{array}$ & (SNL/NM 2004a) & (SNL/NM 2004a) \\
\hline
\end{tabular}

Understanding the rate at which water can be extracted from or injected into a potential well is useful when evaluating remedial alternatives involving pumping or injection. A rough estimate of the specific capacities in each of three monitoring wells (TJA-7, TA2-W-26, and TA2-SW1320) was calculated from purge monitoring data during recent sampling events. These estimations are not intended to be used in a remedial alternative design; rather, they have been used to demonstrate the relative feasibility of implementing remedial alternatives involving pumping or extraction. Relative drawdown was calculated as the difference between an initial water level reading prior to pumping and the corresponding water level after a stable pumping rate is achieved. Specific capacity was calculated for the last three measurements prior to sampling. The resulting specific capacities ranged from 0.1 (TJA-7) to $3.5 \mathrm{gpm} / \mathrm{ft}$ of drawdown (TA2-W-26). 
This Page Intentionally Left Blank 


\subsection{REMEDIAL ALTERNATIVE CONCEPTUAL DESIGNS}

The purpose of this section is to provide details about each remedial alterative, including considerations for evaluation and implementation at SNL/NM AOR, and to present conceptual designs of the four remedial alternatives. Considerations for evaluation and implementation information are compiled from a review of the current literature, professional experience, and from calculations performed during the paper study stage (Appendices A, B, and C). Conceptual designs for each remedial alternative include an overview of the remedial alternative, a description of the T\&FRs, and a list of the expected cost elements for each remedial alternative. The conceptual designs provide information for performing a remedial alternative evaluation and will be updated as laboratory, numerical modeling, and field studies provide more information. The expected duration of each remedial alternative is addressed as it relates to other remedial alternatives.

\subsection{Groundwater Monitoring}

Implementation of a groundwater monitoring remedial alternative consists of monitoring COCs. This section includes considerations for evaluation, implementation at SNL/NM AOR, T\&FRs, and cost for groundwater monitoring of TCE and nitrate.

\subsubsection{Considerations for Evaluation of Groundwater Monitoring}

Advantages of groundwater monitoring, relative to more active remediation technologies, include a small secondary waste stream and no construction of treatment facilities. The existing monitoring well network would need to be maintained and consideration must be given to the need of replacing monitoring wells due to possible changes in the depth to water in the perched system.

\subsubsection{Implementation of Groundwater Monitoring at SNL/NM AOR}

The conceptual design for implementing a groundwater monitoring technology includes a description of the monitoring well network and a preliminary design of the monitoring strategy. It is assumed that implementation of groundwater monitoring as a long-term corrective action would include two operational phases: performance operations and long-term operations (Table 2-1). Performance operations include annual sampling and reporting during a period when performance is monitored and a long-term strategy is devised. Long-term operations include annual monitoring of these wells with an annual data review and a reporting requirement every 5 years. Remedy implementation would continue until compliance objectives are met. Figure 2-1 illustrates the process of implementing groundwater monitoring for TCE and nitrate. This figure illustrates the necessary inputs and waste streams that will be part of the implementation. 
Table 2-1. Groundwater monitoring operational phases.

\begin{tabular}{lccc}
\hline \multicolumn{1}{c}{ Operational Phase } & Monitoring Frequency & Reporting Frequency & Timeframe \\
\hline Performance Operations & Annual & Annual & TBD \\
Long-term Operations & Annual & 5 Years & TBD \\
\hline
\end{tabular}

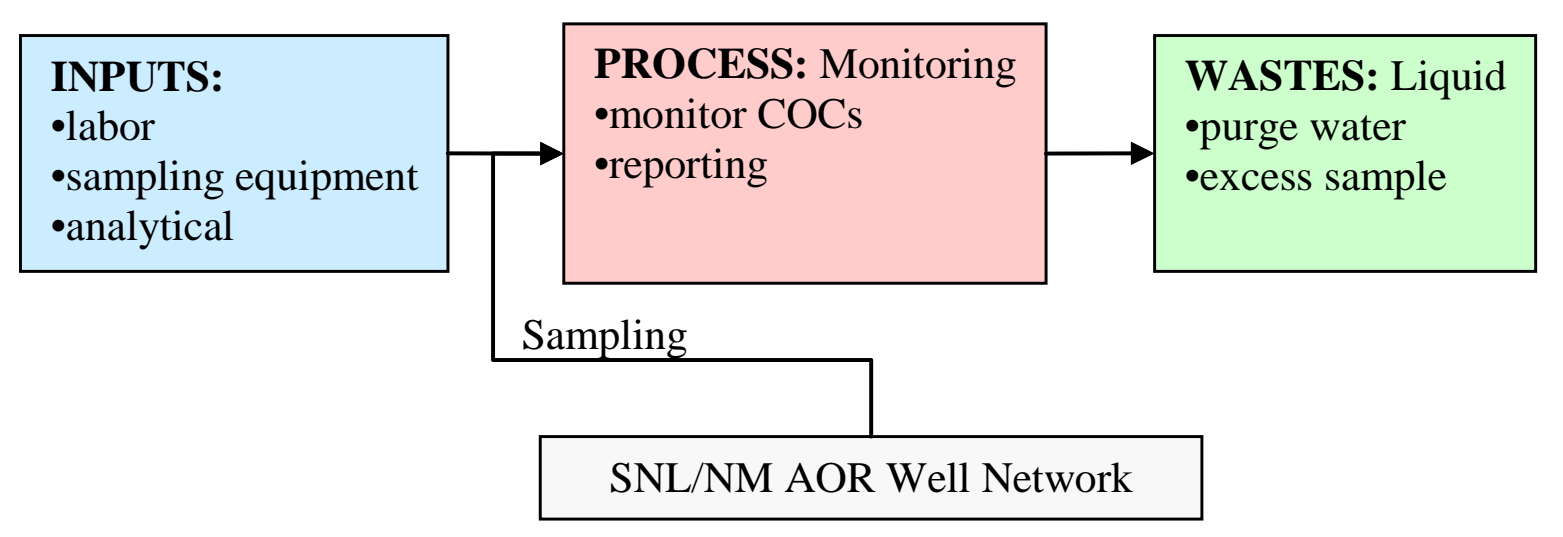

Figure 2-1. Process diagram for groundwater monitoring.

\subsubsection{Technical and Functional Requirements}

Implementation of this approach requires the ability to monitor the contaminants (TCE and nitrate) in groundwater. This requires that the existing monitoring well network be maintained. Monitoring would need to occur until it can be demonstrated that COCs are below MCLs. This would require no detections of COCs in monitoring wells for a period of time to be determined in the implementation work plan. Table 2-2 details the T\&FRs.

Assumptions include:

- It can be determined during the CME that there is no risk to potential receptors.

- Groundwater monitoring as performed under the current program would be continued. This would include maintaining equipment, wells, utilities, and personnel resources.

- A sufficient monitoring well network exists.

\subsubsection{Cost}

Cost elements to be considered for implementing groundwater monitoring include capital equipment and operations and maintenance costs, as outlined in Table 2-3. 
Table 2-2. T\&FRs for groundwater monitoring.

\begin{tabular}{l|l}
\hline \multicolumn{1}{c|}{ Parameter } & \multicolumn{1}{c}{ Requirement } \\
\hline $\begin{array}{l}\text { Duration of groundwater } \\
\text { monitoring }\end{array}$ & $\begin{array}{l}\text { A remedy duration was not determined as part of the paper study. } \\
\text { Monitoring would be conducted throughout the duration of the } \\
\text { remedy. }\end{array}$ \\
\hline $\begin{array}{l}\text { Frequency of } \\
\text { groundwater monitoring }\end{array}$ & Annual \\
\hline $\begin{array}{l}\text { Analytes and field } \\
\text { parameters }\end{array}$ & TCE, nitrate, and water levels \\
\hline Reporting & $\begin{array}{l}\text { Annual reporting during performance operations; may be annual or } \\
\text { every 5 years for long-term operations. }\end{array}$ \\
\hline Equipment & $\begin{array}{l}\text { All equipment necessary for monitoring, including pumps, sample } \\
\text { bottles, power (generator or utilities), shipping supplies, purge water } \\
\text { tanks, personal protection equipment, and any other necessary } \\
\text { equipment. }\end{array}$ \\
\hline Equipment storage & Storage for field sampling and waste containing equipment. \\
\hline Waste storage & Storage of purge water until authorized to dispose. \\
\hline Institutional controls & $\begin{array}{l}\text { Institutional controls would consist of engineering and administrative } \\
\text { controls to protect current and future users from health risks } \\
\text { associated with contaminated groundwater. Engineering controls } \\
\text { would include methods to restrict access to contaminated water, } \\
\text { including locking devices on wellheads. Administrative controls } \\
\text { would include postings on wellheads identifying potential hazards } \\
\text { and placement of written notification of this corrective measure in } \\
\text { the facility land-use master plan. }\end{array}$ \\
\hline
\end{tabular}

Table 2-3. Itemized cost elements for groundwater monitoring.

\begin{tabular}{l|c}
\hline \multicolumn{1}{c|}{ Capital } & \multicolumn{1}{c}{ Operations and Maintenance } \\
\hline $\begin{array}{l}\text { - Costs associated with designing a } \\
\text { long-term groundwater monitoring } \\
\text { program }\end{array}$ & $\begin{array}{l}\text { Costs of maintaining an adequate monitoring well } \\
\text { network for the duration of the remedy }\end{array}$ \\
$\begin{array}{l}\text { - Indirect costs (legal and permitting } \\
\text { fees) }\end{array}$ & $\begin{array}{l}\text { Sampling and analyses costs for the duration of } \\
\text { the remedy }\end{array}$ \\
- Reporting costs for the duration of the remedy \\
- Indirect operational costs including institutional \\
controls, contingency allowances, and \\
administrative costs
\end{tabular}




\subsection{MNA}

MNA is the reliance on natural attenuation processes to achieve site-specific remedial objectives within a reasonable timeframe (DOE 1999). This section includes considerations for evaluation, implementation at SNL/NM AOR, natural attenuation mechanisms, T\&FRs, and cost for application of MNA for TCE and nitrate.

\subsubsection{Considerations for Evaluation of MNA}

Guidance for determining favorable conditions for MNA is stated in:

- Use of MNA at Superfund, RCRA Corrective Action, and Underground Storage Tank Sites (EPA 1999), and

- Decision-Making Framework Guide for Evaluation and Selection of Monitored Natural Attenuation Remedial Alternatives at Department of Energy Sites (DOE 1999).

Source control technologies are to be used to control an active source term, which has been defined as a source inventory of contaminant that is being released to the groundwater where the rate of contaminant release is greater than attenuation rates such that the inventory of mobile contaminants is increasing over time (DOE 1999). As stated in the TAG CME Work Plan, two potential TCE and three potential nitrate sources have been identified within the SNL/NM AOR. However, none of these sources are actively contributing COCs to the perched system at concentrations above MCLs. Based on data stated in the TAG CME Work Plan, the mass of TCE that the vapor phase is contributing to the aquifer is minimal and the TCE vapor plume is immobile. Nitrate present in sewage wastewater has been transported to the perched system by high volumes of wastewater disposed at the sites and a secondary source of nitrate contamination in the vadose zone does not exist (SNL/NM 2004a). Therefore, source control technologies are not a necessary component of a remedial alternative for TCE or nitrate at SNL/NM AOR.

Figure 2-2 is a decision framework for implementing MNA (DOE 1999). The first tier of decision-making includes two options: (1) the contamination currently does not pose an unacceptable risk, there is no active source term, and plume contours are static or retreating or (2) data suggest attenuation mechanisms are operable or exist. Given these criteria and site-specific information, MNA can be a viable remedial alternative for SNL/NM AOR and a remedy involving MNA will be compared to the second and third tier criteria as the CME progresses. The applicability of MNA to reduce COC concentrations to below MCLs in a reasonable timeframe is evaluated as part of the paper study stage and the ongoing remedial alternative evaluation process.

\subsubsection{Implementation of MNA at SNL/NM AOR}

Implementation of MNA as a stand-alone remedial alternative would occur in two phases: 1) the performance operations phase and 2) the long-term operations phase (Table 2-4). The timeframe of these phases would be determined based on the capability to demonstrate that MNA will reduce COC concentrations to below MCLs. Prior to MNA implementation, characterization activities would be performed to determine whether intrinsic contaminant attenuation is taking place in the subsurface and to determine an appropriate monitoring strategy. Numerical groundwater models could be used to predict contaminant transport and the effects of dilution and dispersion of the contaminants. Indications of limited active biodegradation of TCE at TA2-W-26 include aerobic conditions and concentrations of cis-DCE slightly above the detection limit of $0.5 \mu \mathrm{g} / \mathrm{L}$. 


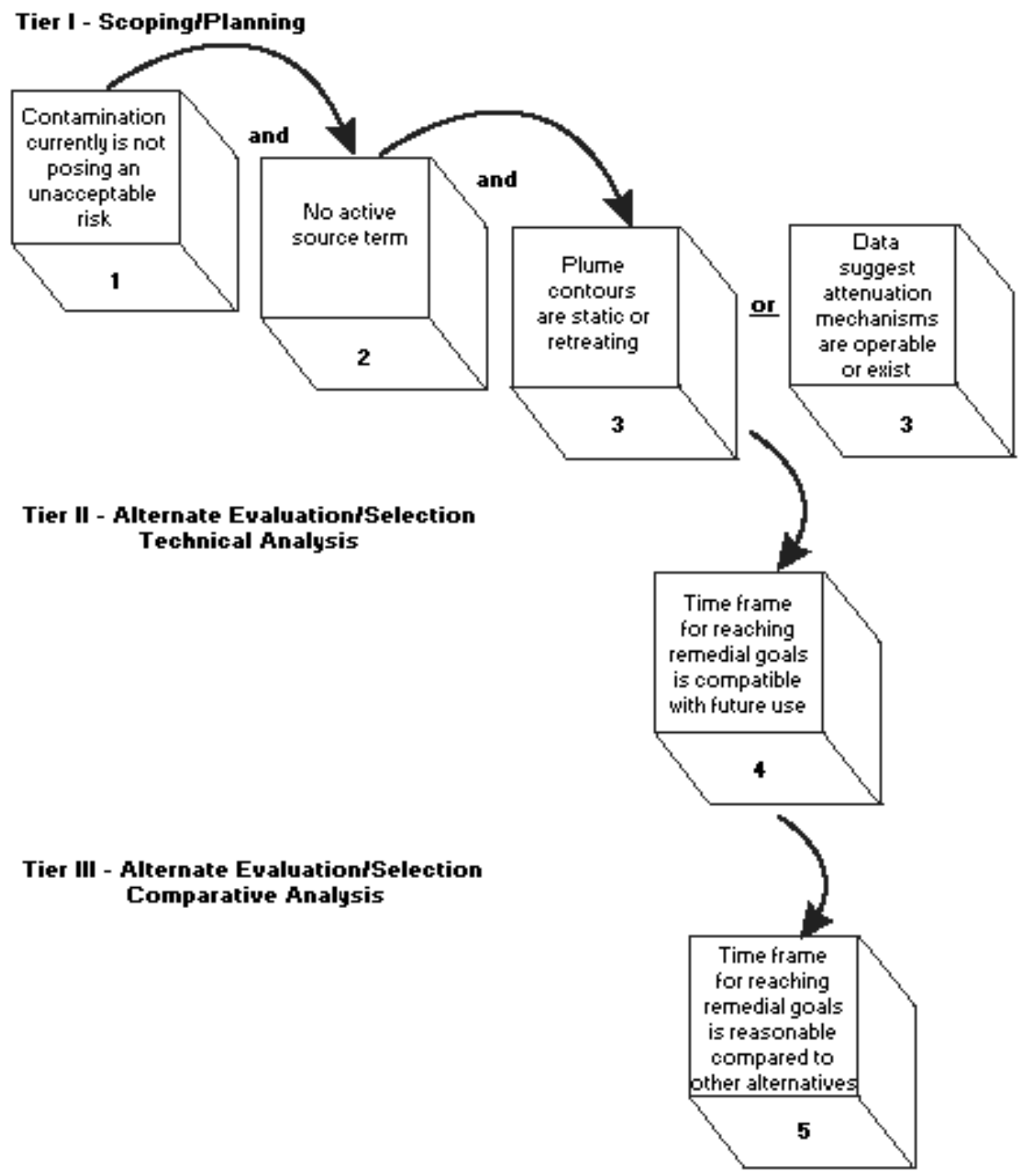

Figure 2-2. Decision framework for evaluating MNA (from DOE 1999).

Table 2-4. MNA operational phases.

\begin{tabular}{c|c|c|c}
\hline \multicolumn{1}{c|}{ Operational Phase } & Monitoring Frequency & Reporting Frequency & Timeframe \\
\hline Performance Operations & Annual & Annual & TBD \\
\hline Long-Term Operations & Annual & 5 Years & TBD \\
\hline
\end{tabular}

Monitoring is a key component of any MNA remedial alternative. Monitoring would begin during performance operations with the purpose of confirming natural attenuation processes and would continue through long-term operations to track the progress of MNA. The monitoring strategy would include clearly defined sampling frequency utilizing the current monitoring well network. A preliminary monitoring frequency is summarized in Table 2-4. Changes in the perched system water levels would be considered when determining the useful life of the existing monitoring well network. Analytes would include COCs and possibly other parameters to assess MNA performance. 
Implementation of this remedial alternative would consist of characterization and monitoring of natural attenuation mechanisms and monitoring attenuation of contaminants in the subsurface without active remediation. Figure 2-3 illustrates the process of implementing MNA for TCE and nitrate. This figure illustrates the necessary inputs and waste streams that will be part of the implementation.

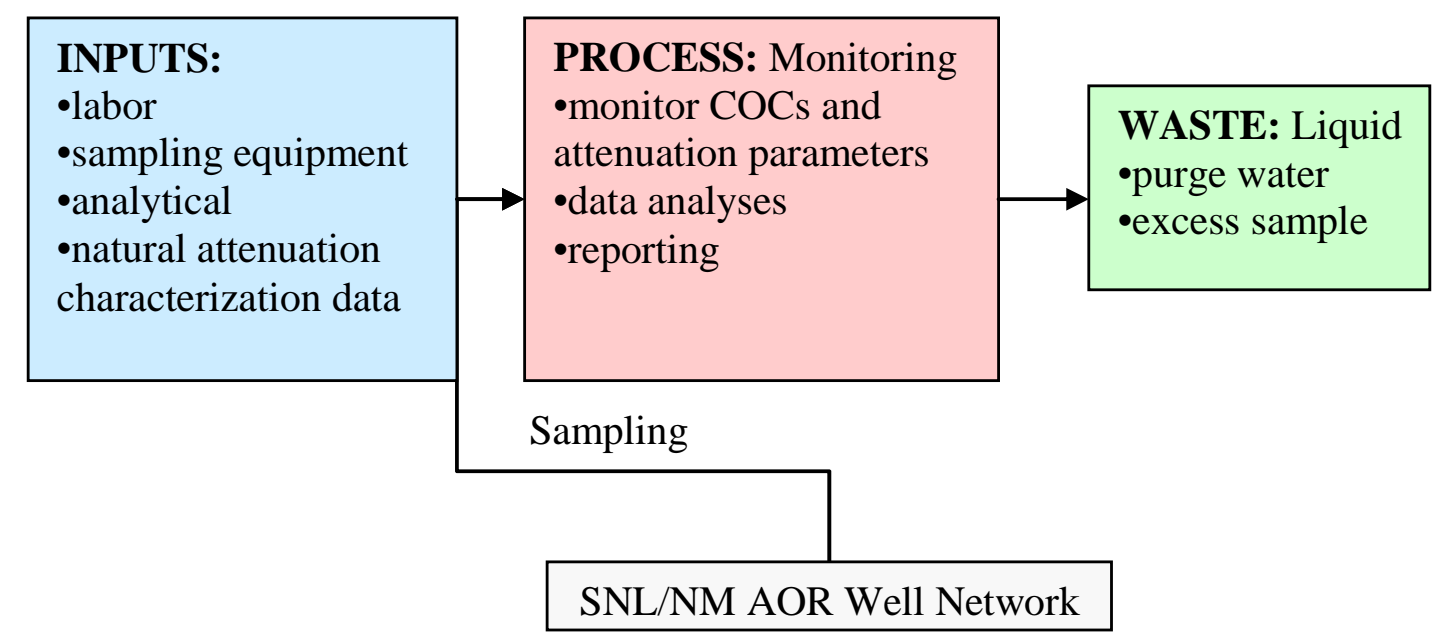

Figure 2-3. Process diagram for MNA.

\subsubsection{Natural Attenuation Mechanisms}

Natural attenuation mechanisms may include degradation, volatilization, sorption, dilution, and dispersion. Dilution and dispersion are attenuation mechanism for nitrate, although under certain conditions degradation of nitrate may also occur. TCE is susceptible to attenuation through the mechanisms of sorption, dilution, dispersion, volatilization, and degradation through natural biological processes (biodegradation). Biodegradation mechanisms may include aerobic and anaerobic processes, including aerobic cometabolism and anaerobic reductive dechlorination (ARD).

Cometabolism is defined as the transformation of an organic compound by a microorganism that is unable to use the substrate as a source of energy or as one of its constituent elements (Alexander 1967). Cometabolism, as the name implies, occurs in conjunction with the metabolism of another substrate which the microorganisms use for carbon and/or energy. Thus, aerobic cometabolism requires the presence of the primary substrate and the cometabolic substrate. The primary substrate is required because the same enzyme that transforms the primary substrate also fortuitously transforms the cometabolic substrate. If the primary substrate is absent, the enzyme required for cometabolic transformation would not be induced and the cometabolic transformation would not occur.

TCE, cis-1,2-dichloroethene (cis-DCE), trans-1,2-dichloroethene (trans-DCE), and vinyl chloride have all been shown to be susceptible to cometabolic oxidation under aerobic conditions (e.g., Wilson and Wilson 1985; Semprini et. al. 1990). In addition, cis-DCE, trans-DCE, 1,1-dichloroethene, and vinyl chloride have been shown to be susceptible to direct oxidation under both aerobic (Vogel, Criddle, and McCarty 1987; Bradley and Chapelle 2000; Klier et al. 1999; Coleman et al. 2002) and anoxic conditions (Bradley and Chapelle 1998). Tetrachloroethene has 
been shown to be resistant to both direct and cometabolic oxidation (McCarty 1996). Several primary substrates induce aerobic cometabolism of chlorinated ethenes. Among them are methane, propane, butane, phenol, toluene, and ammonia. The enzyme methane monooxygenase (MMO), present in methanotrophs, is known to cometabolize TCE. One form of MMO, soluble MMO (sMMO), has been shown to catalyze rapid oxidation of chlorinated ethenes on the order of minutes to hours (e.g., Oldenhuis et. al. 1989; Aziz et. al. 1999).

Anaerobic biodegradation processes may include denitrification and ARD. Both processes are mechanisms through which indigenous microorganisms facilitate the degradation of contaminants to innocuous products. In zero-oxygen environments, microorganisms carry out respiration through reactions utilizing chemicals other than oxygen as terminal electron acceptors. Electron acceptors typically include nitrate, oxidized metals, sulfate, and carbon dioxide (Figure 2-4). Under strictly anaerobic conditions, TCE has been shown to be subject to microbial degradation under conditions where these compounds serve as a growth-linked electron acceptor. Denitrification is the process by which nitrate is utilized as a growth-linked electron acceptor.

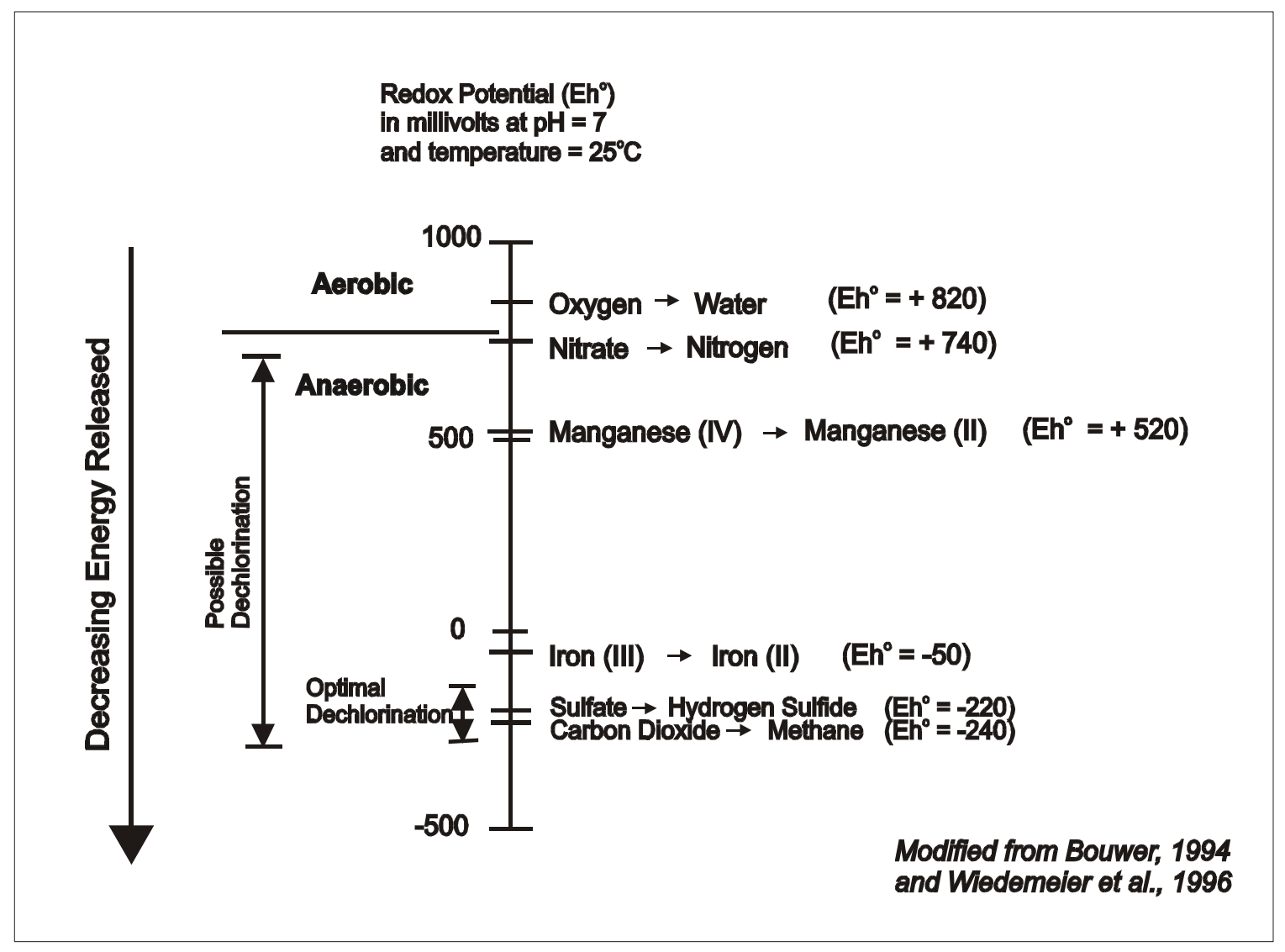

Figure 2-4. Energy available from typical microbial mediated redox reactions, and their relationship to reductive dechlorination. 


\subsubsection{Technical and Functional Requirements}

Implementation of this approach must allow monitoring of contaminant attenuation mechanisms in the subsurface and the contaminant plume. This entails monitoring TCE, nitrate, and parameters to monitor attenuation mechanisms (i.e., redox parameters or dissolved gases). This monitoring would continue for the duration of the remedy. As mechanisms of natural attenuation are identified and numerical modeling is performed to predict contaminant transport, the number of wells to be monitored would be determined and predictions would be made to determine the duration of monitoring. Table 2-5 details the T\&FRs.

Table 2-5. T\&FRs for MNA.

\begin{tabular}{|c|c|}
\hline Parameter & Requirement \\
\hline Duration of monitoring & $\begin{array}{l}\text { A remedy duration was not determined as part of the paper study. } \\
\text { Monitoring would be conducted throughout the duration of the } \\
\text { remedy. }\end{array}$ \\
\hline Frequency of monitoring & Annual \\
\hline $\begin{array}{l}\text { Analytes and field } \\
\text { parameters }\end{array}$ & $\begin{array}{l}\text { COCs (TCE and nitrate), water levels, and other parameters } \\
\text { necessary to monitor attenuation mechanisms (i.e., redox } \\
\text { conditions and/or enzyme probes). }\end{array}$ \\
\hline Analyses & $\begin{array}{l}\text { The groundwater monitoring data would be analyzed and } \\
\text { interpreted. This data would be used to monitor attenuation } \\
\text { mechanisms and track COC concentration changes. }\end{array}$ \\
\hline Reporting & $\begin{array}{l}\text { Annual reporting for the first } 5 \text { years, followed by reporting every } \\
5 \text { years until the end of long-term operations. Reports would } \\
\text { include analysis of concentration trends and comparison to } \\
\text { predicted trends of attenuation. }\end{array}$ \\
\hline Equipment & $\begin{array}{l}\text { All equipment necessary for monitoring, including pumps, sample } \\
\text { bottles, power (generator or utilities), shipping supplies, purge } \\
\text { water tanks, personal protection equipment, and any other } \\
\text { necessary equipment. }\end{array}$ \\
\hline Equipment storage & Storage for field sampling and waste containing equipment. \\
\hline Waste storage & Storage of purge water until authorized to dispose. \\
\hline Institutional controls & $\begin{array}{l}\text { Institutional controls would consist of engineering and } \\
\text { administrative controls to protect current and future users from } \\
\text { health risks associated with contaminated groundwater. } \\
\text { Engineering controls would consist of methods to restrict access to } \\
\text { contaminated water, including locking devices on wellheads. } \\
\text { Administrative controls would include postings on wellheads } \\
\text { identifying potential hazards and placing written notification of this } \\
\text { corrective measure in the facility land-use master plan. }\end{array}$ \\
\hline
\end{tabular}


Assumptions include:

- The CME demonstrates that there is no unacceptable risk to potential receptors,

- Natural attenuation mechanisms for both TCE and nitrate are identified,

- Necessary equipment, utilities, and personnel are available, and

- A sufficient monitoring well network exists.

\subsubsection{Cost}

Cost elements of implementing MNA for TCE and nitrate would include capital equipment and operations and maintenance costs as listed in Table 2-6.

Table 2-6. Itemized cost elements for MNA.

\begin{tabular}{l|l}
\hline \multicolumn{1}{c|}{ Capital } & \multicolumn{1}{c}{ Operations and Maintenance } \\
\hline $\begin{array}{l}\text { - Costs associated with designing } \\
\text { a long-term groundwater } \\
\text { monitoring program }\end{array}$ & $\begin{array}{l}\text { - Costs of maintaining an adequate monitoring well } \\
\text { network for the duration of the remedy }\end{array}$ \\
$\begin{array}{l}\text { - Costs of characterizing natural } \\
\text { attenuation }\end{array}$ & - Sampling and analyses costs \\
- Indirect costs (legal and \\
$\begin{array}{l}\text { permitting fees) } \\
\text { - Reporting costs for the duration of the remedy }\end{array}$ \\
- Costs for data analyses and interpretation \\
- Indirect operational costs, including institutional \\
controls, contingency allowances, and administrative \\
costs
\end{tabular}

\section{$2.3 \quad I S B$}

ISB is implemented by adding degradable organic carbon and/or nutrients to the aquifer. Indigenous microorganisms then increase in population and utilize available electron acceptors as they degrade organic carbon. The free energy yielded by redox reactions varies substantially depending upon the electron acceptor, as shown in Figure 2-4. During respiration, microorganisms preferentially utilize the electron acceptors yielding the greatest free energy. Figure 2-4 shows that the order of preference for the most common inorganic electron acceptors is oxygen, nitrate, manganese (IV), iron (III), sulfate, and carbon dioxide. Therefore, the dominant microbial community in a groundwater system is largely dependent upon the distribution of electron acceptors. Where oxygen is plentiful, aerobic bacteria will predominate; where oxygen is depleted but nitrate is plentiful, nitrate-reducing bacteria will predominate; and so on. Once highly reducing conditions are created (i.e., methanogenic), ARD becomes energetically favorable and complete dechlorination of chloroethenes to ethene is facilitated if dechlorinating microorganisms are present in sufficient number. 


\subsubsection{Considerations for Evaluation of ISB}

ISB technology would be implemented by injecting an aqueous phase electron donor into several injection wells placed within the areas of highest contamination. A significant challenge to successful implementation of ISB for the SNL/NM AOR is distributing the electron donor to contaminated zones within the perched system. The following factors were considered when evaluating the feasibility of electron donor distribution:

- $\quad$ As stated in Section 1.3.6, TCE and nitrate concentrations higher than their respective MCLs have been observed in many locations across the two-square mile AOR. At three of these locations TCE and nitrate concentrations have recently been observed greater than the MCL; therefore, a minimum of three injection wells will be needed to distribute electron donor to these high concentration contaminated zones.

- Distribution of electron donor in the perched groundwater will be achieved by injecting electron donor solutions into injection wells. The extent over which electron donor will be distributed from a single injection well is limited by the volume of solution injected. The volume of solution injected will be very large considering the distribution of the contaminants in groundwater. The ability to inject these large volumes is limited by the number of injection points (wells) and the rate at which these injection wells will accept the injection. The estimated specific capacities (Section 1.3.7) suggest that the achievable injection rate may be limiting, thus requiring the construction of more than three injection wells.

- Unlike TCE, nitrate does not sorb to aquifer materials. When injecting electron donor solutions into high nitrate concentration zones, displacement of the nitrate contaminated groundwater may increase mobility of the contaminant. Injections would partially displace nitrate-contaminated water, and the contact between the amendments and the contaminated water would be limited to mixing during injections.

\subsubsection{Implementation of ISB Technology at SNL/NM AOR}

ISB implementation would target the high concentration locations. Figure 2-5 illustrates the process of implementing ISB for TCE and nitrate. The figure illustrates the necessary inputs and waste streams that will be part of the implementation. As demonstrated, implementation of ISB would require more inputs than the MNA or groundwater monitoring remedial alternatives. In addition ISB implementation would require constructing at least three injection wells. 


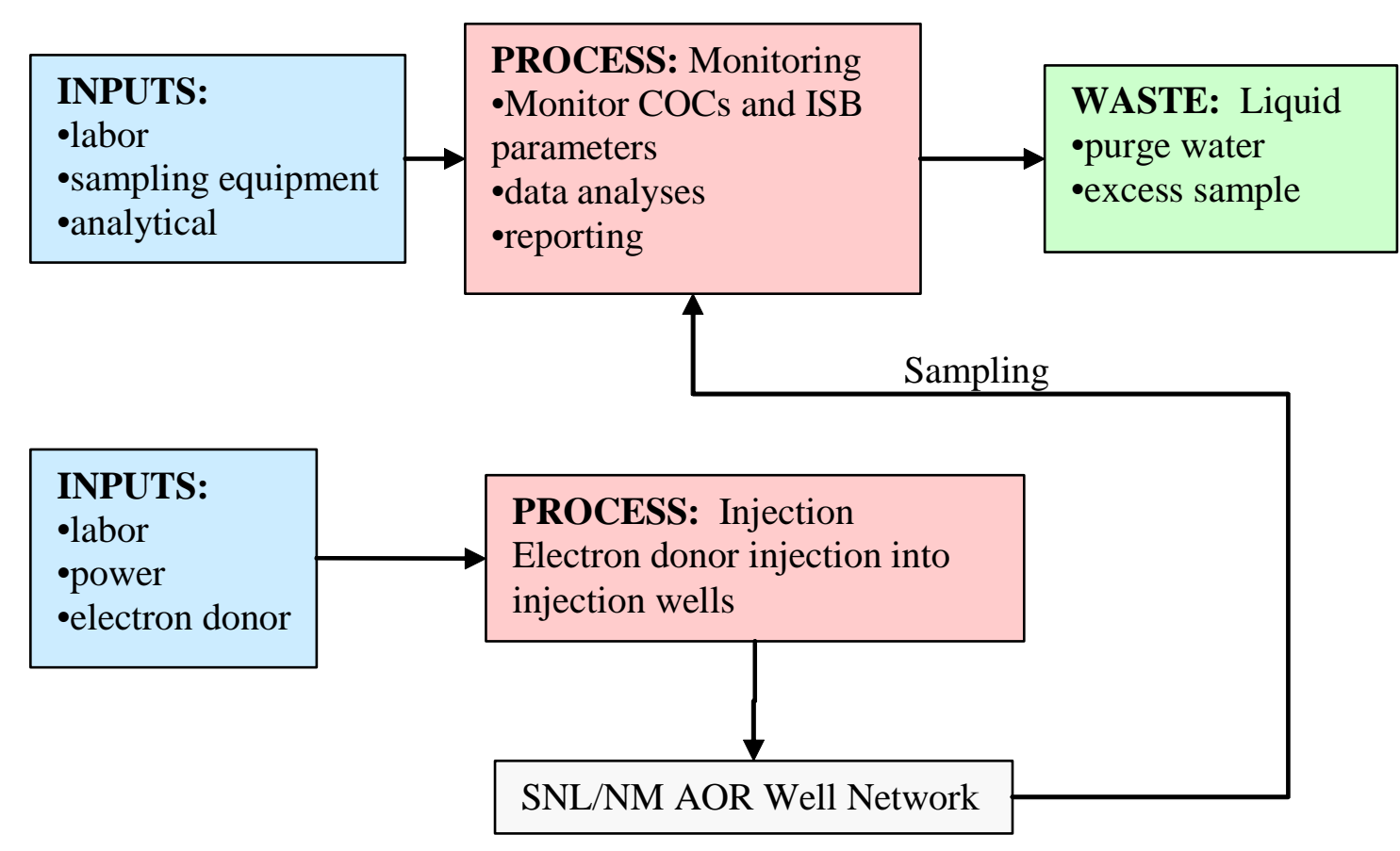

Figure 2-5. Process diagram for ISB.

\subsubsection{Technical and Functional Requirements}

Implementation of ISB would require injecting amendments to induce biological activity, which would change aquifer conditions from aerobic to anaerobic and induce anaerobic processes of biodegradation. The targeted aquifer zone will include groundwater containing TCE at concentrations greater than $5 \mu \mathrm{g} / \mathrm{L}$ and nitrate concentrations greater than $10 \mathrm{mg} / \mathrm{L}$. The electron donor addition system must emplace enough electron donor to cause denitrification and ARD. This system would be composed of electron donor injection wells and would include electron donor injection facilities. Table 2-7 lists the T\&FRs for this remedial alternative. Assumptions include:

- Necessary equipment, utilities, and personnel are available.

- A dechlorinating and/or denitrifying microbial community can be induced by addition of electron donor.

- A sufficient number of injection wells will be constructed in order to distribute the electron donor. 
Table 2-7. T\&FRs for ISB.

\begin{tabular}{|c|c|}
\hline Parameter & Requirement \\
\hline Remedy duration & $\begin{array}{l}\text { Duration of ISB operations would be determined prior to implementation. It } \\
\text { is estimated that ISB would require an implementation period followed by } \\
\text { confirmatory monitoring. }\end{array}$ \\
\hline $\begin{array}{l}\text { Injection operations } \\
\text { duration }\end{array}$ & $\begin{array}{l}\text { One or two injections of electron donor should produce conditions conducive } \\
\text { to ARD and denitrification. Therefore, injection operations may only last for } \\
\text { a short time, provided that distribution of electron donor is achieved. }\end{array}$ \\
\hline Injection wells & At least three injection wells will be necessary. \\
\hline $\begin{array}{l}\text { Injection facilities/ } \\
\text { injection equipment }\end{array}$ & $\begin{array}{l}\text { The injection facility would be capable of mixing sodium lactate into potable } \\
\text { water. The facility can be temporary. } \\
\text { Injection equipment will include a water supply (tanks or pumping), mixing } \\
\text { equipment, and other necessary plumbing and equipment. }\end{array}$ \\
\hline Duration of monitoring & $\begin{array}{l}\text { Monitoring of groundwater would increase in frequency during and for a } \\
\text { short period of time after the injection(s). It is estimated that monitoring } \\
\text { would continue at a reduced frequency for several years after the beginning } \\
\text { of remedy implementation. }\end{array}$ \\
\hline Frequency of monitoring & $\begin{array}{l}\text { ISB monitoring would include sampling and analyses necessary to monitor } \\
\text { the effect of electron donor injections. A period of groundwater monitoring } \\
\text { following ISB injections would be required to confirm that TCE and nitrate } \\
\text { concentrations are below MCLs. }\end{array}$ \\
\hline $\begin{array}{l}\text { Analytes and field } \\
\text { parameters }\end{array}$ & $\begin{array}{l}\text { COCs (TCE and nitrate), water levels, and parameters necessary to monitor } \\
\text { ISB operations (i.e., chemical oxygen demand to monitor electron donor } \\
\text { distribution and utilization). }\end{array}$ \\
\hline Analyses & $\begin{array}{l}\text { The groundwater monitoring data would be analyzed and interpreted. Data } \\
\text { would be used to track the performance of ISB and monitor contaminant } \\
\text { reduction. }\end{array}$ \\
\hline Reporting & $\begin{array}{l}\text { Annual reporting for first } 5 \text { years, followed by annual data summaries with } \\
\text { formal reports submitted every } 5 \text { years until the end of long-term operations. } \\
\text { Reports would include analysis of concentration trends. }\end{array}$ \\
\hline Sampling equipment & $\begin{array}{l}\text { All equipment necessary for monitoring, including pumps, sample bottles, } \\
\text { power (generator or utilities), shipping supplies, purge water tanks, personal } \\
\text { protection equipment, and any other necessary equipment. }\end{array}$ \\
\hline Equipment storage & Storage for field sampling and waste containing equipment \\
\hline Waste storage & Storage of purge water until authorized to dispose. \\
\hline Institutional controls & $\begin{array}{l}\text { Institutional controls would consist of engineering and administrative } \\
\text { controls to protect current and future users from health risks associated with } \\
\text { contaminated groundwater. Engineering controls would consist of methods } \\
\text { to restrict access to contaminated water, including locking devices on } \\
\text { wellheads. Administrative controls would include postings on wellheads } \\
\text { identifying potential hazards and placing written notification of this } \\
\text { corrective measure in the facility land-use master plan. }\end{array}$ \\
\hline
\end{tabular}




\subsubsection{Cost}

Cost elements for implementing ISB would include capital and operations and maintenance costs, as listed in Table 2-8.

Table 2-8. Itemized cost elements for the ISB.

\begin{tabular}{l|l}
\hline \multicolumn{1}{c|}{ Capital } & \multicolumn{1}{c}{ Operations and Maintenance } \\
\hline $\begin{array}{l}\text { - Engineering costs to design ISB } \\
\text { implementation }\end{array}$ & $\begin{array}{l}\text { - Includes labor, material, and equipment costs to } \\
\text { inject and cost of purchasing electron donor }\end{array}$ \\
- Construction of injection wells. & $\begin{array}{l}\text { Sampling and analyses costs (sampling and } \\
\text { analyses may be more extensive to monitor redox } \\
\text { conditions) }\end{array}$ \\
$\begin{array}{l}\text { - Construction of injection facilities } \\
\text { and injection equipment. }\end{array}$ & $\begin{array}{l}\text { Reporting costs for the duration of the remedy } \\
\text { (the remedy may require less time and fewer } \\
\text { reports) }\end{array}$ \\
$\begin{array}{l}\text { Indirect costs (legal and permitting } \\
\text { fees) }\end{array}$ & $\begin{array}{l}\text { Costs for data analyses and interpretation } \\
\text { - Indirect operational costs including institutional } \\
\text { controls, contingency allowances, and } \\
\text { administrative costs }\end{array}$ \\
\hline
\end{tabular}

\subsection{Pump and Treat}

Pump and treat is a broad term used to describe the pumping of contaminated groundwater to the surface where it can be treated. The general goal of pump and treat implementation at SNL/NM AOR would be to restore the aquifer by removing the mass of COCs from groundwater. The system would consist of extraction wells, ex-situ treatment systems for TCE and nitrate, and a disposal method for the treated water for each location where COC concentrations are above MCLs. Disposal of treated water could occur onsite through injection to the aquifer or by some other method.

\subsubsection{Considerations for Evaluation of Pump and Treat}

Pump and treat is one of the most widely used groundwater technologies, as it is implemented at about three-quarters of the Superfund sites with contaminated groundwater and at most sites where cleanup is conducted under the Resource Conservation and Recovery Act (RCRA) and state laws (EPA 1996). It is a well-developed technology that is applicable for TCE and nitrate. Pump and treat is appropriate for both contaminant reduction and containment of a plume. 
A review of Environmental Protection Agency (EPA) literature on pump and treat reveals that this technology can have several significant disadvantages. The general goal of pump and treat is to remove contaminant mass from groundwater to restore the aquifer to beneficial use. Favorable conditions for accomplishing cleanup using pump and treat include the presence of contaminants that do not sorb and a homogeneous permeable aquifer. Neither condition is present at SNL/NM AOR, since TCE is a contaminant that tends to sorb and the aquifer is characterized by low permeability and heterogeneity.

Slow contaminant transport and interphase transfer has caused many pump and treat systems to continue to operate for decades. Sorption of TCE to aquifer materials retards the movement of these contaminants toward extraction wells, resulting in the need to flush multiple pore volumes of water through the contaminated aquifer zone to remove the contaminant mass (EPA 1997). An evaluation of 32 selected pump and treat systems showed that these systems require on average $\$ 4.9$ million in capital costs and $\$ 730,000$ in annual operating costs. Despite this, only two of the sites surveyed have been cleaned up (EPA 2001).

\subsubsection{Considerations for Implementing Pump and Treat at SNL/NM AOR}

Site-specific characteristics must be considered to evaluate implementation of pump and treat at SNL/NM AOR. Additional site characterization may need to take place to identify appropriate locations for installation of new wells and impacts of pumping to hydrogeology of the perched system and the regional aquifer underlying the TAG study area. Testing may be conducted to estimate or verify predicted capture zones, compare observed contaminant distribution to capture zones, and obtain well yield information to estimate treatment volumes.

Approximate order-of-magnitude scoping calculations, using site-specific information, have been performed to develop pump and treat conceptual designs. Two approaches to pump and treat described in EPA guidance (EPA 1997) were initially considered applicable for SNL/NM AOR. These two approaches were:

- Removing a sufficient number of pore volumes from within the contaminated aquifer volume to restore the aquifer, and

- Capturing the contaminant plume as it is transported across a downgradient transect or plane.

The first approach involves removing groundwater from the contaminated zone and essentially flushing that zone with uncontaminated groundwater from outside to remove dissolved contaminants and contaminants that are sorbed to aquifer materials or located within pore water that is not readily accessible. Extraction well(s) may be placed strategically to both contain the plume and remove contaminants. At a minimum three extraction wells, corresponding to the three locations of high concentrations discussed in Section 1.3.6, would be required to remove the contaminated groundwater from the SNL/NM AOR. Treatment systems would be designed to remove TCE and nitrate. Aquifer restoration is accomplished by removing multiple pore volumes of water. It has been suggested that it may be necessary to pump between 10 and 100 pore volumes to remove contaminants from an aquifer (EPA 1997). Scoping calculations of achievable extraction rates using the specific capacity range presented in Table 1-1, suggest that maximum achievable extraction rates may range from 0.4 to $200 \mathrm{gpm}$. This wide range of extraction rates is dependent on site constraints such as perched groundwater system thickness. 
The second approach involves capturing the contaminant plume by creating a sufficient downgradient capture zone. The capture zone width was estimated according to the method summarized in EPA guidance (EPA 2002) and assuming a capture zone thickness of $30 \mathrm{ft}$ (Appendix A). Calculations revealed that, given the range of perched system properties, a well pumped at its maximum capacity would create a sufficiently wide capture zone. However, as a result of the relatively slow groundwater velocity (4-10 ft/year) (SNL/NM 2004a), remediation using this method would require an unreasonably long time compared to other remedial alternatives.

\subsubsection{Scoping Treatment Options}

Several treatment options were considered for removal or degradation of TCE and/or nitrate contamination. These options include:

- Sorption of TCE to granular activated carbon (GAC),

- Volatilization of TCE using an air stripper,

- Treatment of both TCE and nitrate in an ex-situ bioreactor, and

- Removal of nitrate using ion exchange.

Two of the options listed above were found to not be practical for implementation. The options that were not considered practical are:

- Removal of TCE using an air stripper. Both air stripping and treatment with GAC are only applicable to TCE. These treatment options do not degrade the TCE, but rather transfer the contaminant to another media or phase. The major disadvantage of treatment using air stripping is that cost and commitment of resources would be significantly more than using GAC. Because air stripping requires a large reactor size that has a blower constantly running, it is more appropriate for higher concentrations than those present at SNL/NM AOR. Because it is more practical to use GAC to achieve removal of TCE, air stripping will no longer be considered.

- Treatment of both TCE and nitrate in an ex-situ bioreactor. There are several designs for treatment of both TCE and nitrate in an ex-situ biological reactor. The major advantage of this option is treatment by degrading both TCE and nitrate to innocuous products. However, this type of treatment has several major disadvantages that make it impractical for use at SNL/NM AOR. First, the presence of competing electron acceptors (oxygen, nitrate, and sulfate) and the relatively slow rate of dechlorination combine to require a long hydraulic retention time making the required reactor size very large. Second, it is difficult to maintain an active dechlorinating microbial community given the low chlorinated ethene concentrations. The ability to maintain this community is unknown and would be experimental. Third, waste streams (i.e., treated water and settled sludge) would contain biomass and would require disposing. Finally, the system requires the continued cost of extensive monitoring and constantly adding electron donor. 
The other treatment options would be evaluated during pump and treat design. A conceptual design for each option is presented in Appendix B, including a list of advantages and disadvantages of each. Treatment options considered for the CME are sorption of TCE to GAC and removal of nitrate using ion exchange. The two treatment options would be applied to the pump and treat remedial alternative in the following manner:

- Pump and treat for TCE using GAC and nitrate using ion-exchange. Treatment of contaminated water would involve removal of TCE using GAC and removal of nitrate using ion exchange.

Application of this remedial alternative at SNL/NM AOR would involve extraction of contaminated groundwater and treating the water to remove TCE or nitrate. The water would be extracted sufficiently long to remove contaminants in the aquifer to below MCLs. Figure 2-6 illustrates the process of implementing pump and treat for TCE using GAC, and nitrate using ion-exchange. This figure illustrates the necessary inputs and waste streams that will be part of the implementation. As demonstrated, implementation of this remedial alternative would require more inputs than the MNA or groundwater monitoring remedial alternatives and would produce additional waste streams.

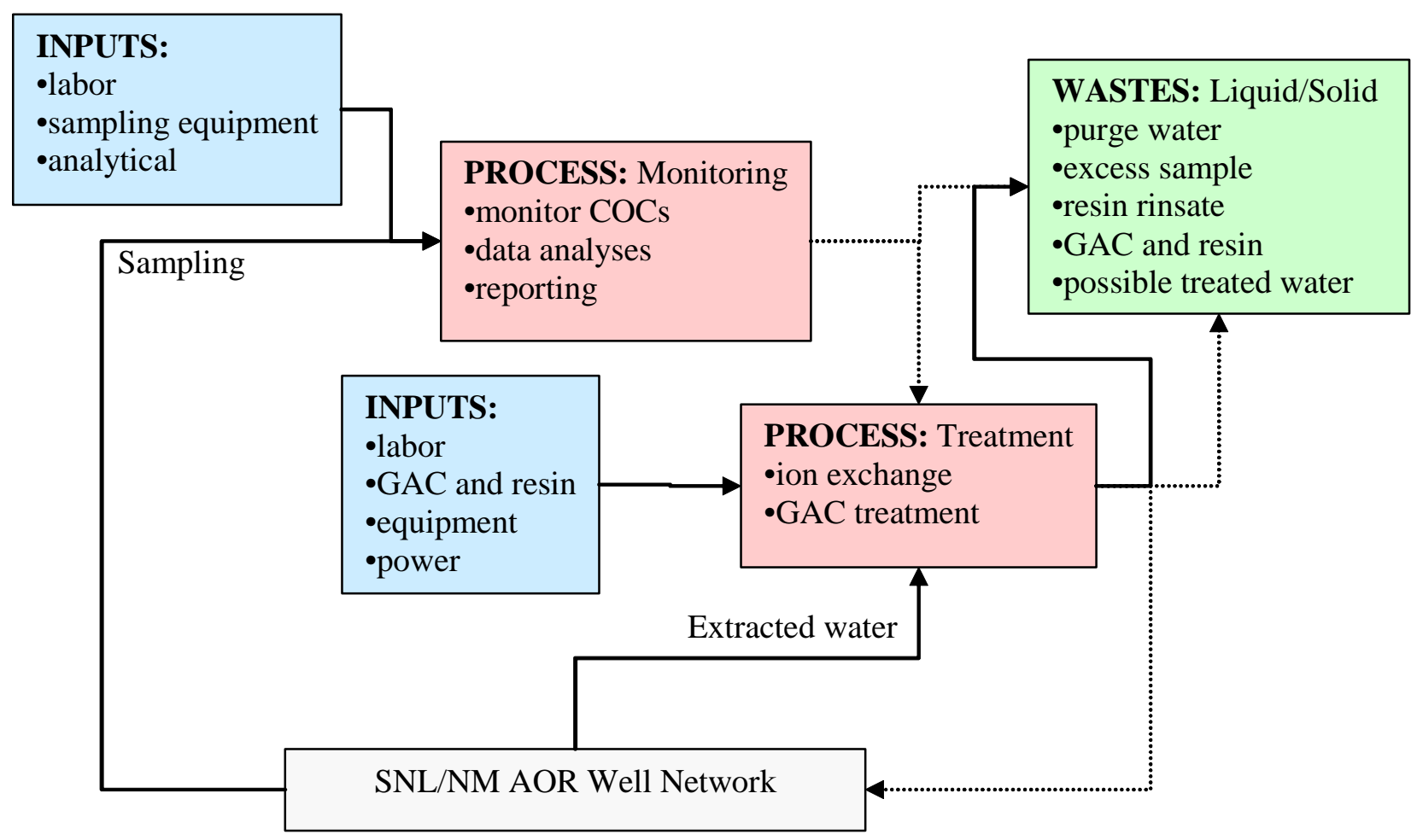

Figure 2-6. Process diagram for implementation of pump and treat. 


\subsubsection{Technical and Functional Requirements}

Implementation of this remedial alternative would require pumping contaminated groundwater to the surface, treating the water for COCs to concentrations below MCLs, and disposing the water. The system would be composed of extraction wells, a treatment facility, and, depending on the disposal option chosen, may also require an injection well. Table 2-10 illustrates the T\&FRs for this remedial alternative.

Assumptions include:

- $\quad$ Necessary equipment, utilities, and personnel are available.

- The treatment facility would be able to remove TCE and nitrate to below MCLs.

Table 2-10. T\&FRs for pump and treat using GAC and ion-exchange.

\begin{tabular}{|c|c|}
\hline Parameter & Requirement \\
\hline Extraction wells & $\begin{array}{l}\text { Extraction wells would be constructed that penetrate and are screened } \\
\text { across the contaminated zone of the perched system. }\end{array}$ \\
\hline Treatment facilities & $\begin{array}{l}\text { The treatment facilities would be composed of a prefabricated building } \\
\text { equipped with electric power. }\end{array}$ \\
\hline Treatment equipment & $\begin{array}{l}\text { GAC and ion exchange would be used to remove TCE and nitrate. } \\
\text { Replacement of GAC and regeneration of resins will also be necessary. }\end{array}$ \\
\hline Extraction rate & Extraction rate ranging from 0.38 to 52.5 gpm per well. \\
\hline $\begin{array}{l}\text { Pump and treat } \\
\text { duration }\end{array}$ & $\begin{array}{l}\text { Pumping operations would continue until contaminants are removed } \\
\text { from the groundwater. Experience suggests that this will require } \\
\text { removing several pore volumes from the entire contaminated zone. } \\
\text { Treatment would need to occur as long as groundwater is being } \\
\text { extracted. }\end{array}$ \\
\hline $\begin{array}{l}\text { Duration of } \\
\text { monitoring }\end{array}$ & $\begin{array}{l}\text { Groundwater monitoring would continue throughout pumping } \\
\text { operations and for a period of } 5 \text { years following or until concentrations } \\
\text { are below MCLs. }\end{array}$ \\
\hline $\begin{array}{l}\text { Frequency of } \\
\text { monitoring }\end{array}$ & $\begin{array}{l}\text { Regular monitoring of treatment facility influent, effluent, and } \\
\text { intermediate sampling ports would be required. Groundwater } \\
\text { monitoring would also be required during pump and treat operations and } \\
\text { following pump and treat operations until COCs are below MCLs. }\end{array}$ \\
\hline $\begin{array}{l}\text { Analytes and field } \\
\text { parameters }\end{array}$ & COCs (TCE and nitrate) and water levels \\
\hline Analyses & $\begin{array}{l}\text { The groundwater monitoring data would be analyzed and interpreted. } \\
\text { Data would be used to track the performance of pump and treat and } \\
\text { monitor contaminant reduction. }\end{array}$ \\
\hline Reporting & $\begin{array}{l}\text { Annual reporting for first } 5 \text { years, followed by reporting every } 5 \text { years } \\
\text { until the end of long-term operations. Reports would include analysis of } \\
\text { concentration trends and comparison to predicted trends of attenuation. }\end{array}$ \\
\hline
\end{tabular}


Table 2-10. (continued).

\begin{tabular}{l|l}
\hline \multicolumn{1}{c|}{ Parameter } & \multicolumn{1}{c}{ Requirement } \\
\hline Sampling equipment & $\begin{array}{l}\text { All equipment necessary for monitoring, including Bennett pumps, } \\
\text { sample bottles, power (generator or utilities), shipping supplies, purge } \\
\text { water tanks, personal protection equipment, and any other necessary } \\
\text { equipment. }\end{array}$ \\
\hline Equipment storage & Storage for field sampling and waste containing equipment \\
\hline Waste storage & Storage for spent GAC containing sorbed TCE. \\
\hline & $\begin{array}{l}\text { Institutional controls would consist of engineering and administrative } \\
\text { controls to protect current and future users from health risks associated } \\
\text { with contaminated groundwater. Engineering controls would consist of } \\
\text { methods to restrict access to contaminated water, including locking } \\
\text { devices on wellheads. Administrative controls would include postings } \\
\text { on wellheads identifying potential hazards and placing written } \\
\text { notification of this corrective measure in the facility land-use master } \\
\text { plan. }\end{array}$ \\
\hline
\end{tabular}

\subsubsection{Cost}

Cost elements of implementing pump and treat for TCE and nitrate would include capital and operations and maintenance costs, as listed in Table 2-11.

Table 2-11. Itemized cost elements for pump and treat.

\begin{tabular}{|c|c|}
\hline Capital & Operations and Maintenance \\
\hline $\begin{array}{l}\text { Engineering costs to design } \\
\text { pump and treat implementation }\end{array}$ & $\begin{array}{l}\text { Costs associated with operations and maintenance of the } \\
\text { treatment facilities. These would include replacement of } \\
\text { GAC, regeneration of resin, labor, power, and other } \\
\text { equipment costs. }\end{array}$ \\
\hline $\begin{array}{l}\text { Construction of extraction wells. } \\
\text { May also include construction of } \\
\text { an injection well(s). }\end{array}$ & $\begin{array}{l}\text { Sampling and analyses costs. In addition to monitoring } \\
\text { groundwater sampling and analyses would also include } \\
\text { monitoring influent, effluent and other water samples from } \\
\text { the treatment facility. }\end{array}$ \\
\hline $\begin{array}{l}\text { Construction of treatment facility } \\
\text { and installation of treatment } \\
\text { equipment (GAC drums and ion } \\
\text { exchange unit). }\end{array}$ & Costs for data analyses and interpretation \\
\hline \multirow[t]{2}{*}{$\begin{array}{l}\text { Indirect costs (legal and } \\
\text { permitting fees) }\end{array}$} & $\begin{array}{l}\text { Reporting costs for the duration of the remedy (the remedy } \\
\text { may require less time and fewer reports) }\end{array}$ \\
\hline & $\begin{array}{l}\text { Indirect operational costs including institutional controls, } \\
\text { contingency allowances, and administrative costs }\end{array}$ \\
\hline
\end{tabular}




\subsection{REMEDIAL ALTERNATIVE EVALUATION}

The remedial alternative conceptual designs provided in this report summarize implementation strategies for remedial alternatives to support completion of a remedial alternative evaluation. The remedial alternative evaluation is intended to identify remedial alternatives that should be investigated through field, laboratory, or numerical modeling studies. Each remedial alternative is evaluated using the threshold and remedial alternative criteria, as stated in the TAG CME Work Plan (SNL/NM 2004a). The outcome of this evaluation is a list of remedial alternatives that pass the evaluation and recommendations of additional studies to fill data gaps identified for those remedial alternatives.

\subsection{Threshold Criteria Evaluation}

As specified in the COOC (NMED 2004), each remedial alternative must be evaluated based on the threshold criteria. Descriptions of the threshold criteria are stated in the TAG CME Work Plan (SNL/NM 2004a). The following threshold criteria were evaluated:

- Protect human health and the environment,

- Attain media cleanup standard or alternative, approved risk-based cleanup goals, and

- Comply with standards for management of wastes.

As discussed in the TAG CME Work Plan (SNL/NM 2004a), source control technologies are not a necessary component of a remedial alternative for TCE or nitrate at SNL/NM AOR; therefore, the source control threshold criterion was not evaluated. Remedial alternative conceptual design information was used to determine if the remedial alternative meets the threshold criterion. This evaluation was a YES/NO evaluation. The results of this evaluation are presented in Table 3-1. As demonstrated, all of the remedial alternatives received a YES rating for each of the three categories.

Table 3-1. Threshold criteria evaluation.

\begin{tabular}{l|c|c|c}
\hline \multicolumn{1}{c|}{ Remedial Alternatives } & $\begin{array}{c}\text { Protective of } \\
\text { Human } \\
\text { Health and } \\
\text { Environment }\end{array}$ & $\begin{array}{c}\text { Attain } \\
\text { Media } \\
\text { Cleanup } \\
\text { Standards }\end{array}$ & $\begin{array}{c}\text { Waste } \\
\text { Management } \\
\text { Standards } \\
\text { Compliance }\end{array}$ \\
\hline Groundwater Monitoring & YES & YES & YES \\
MNA & YES & YES & YES \\
ISB & YES & YES & YES \\
Pump and Treat & YES & YES & YES \\
\hline $\begin{array}{l}\text { YES = the remedial alternative meets the threshold criterion } \\
\text { NO }=\text { the remedial alternative does not meet the threshold criterion } \\
\text { Note: The threshold criterion, Source Control, is not included. }\end{array}$
\end{tabular}




\subsection{Remedial Alternative Evaluation}

Because all remedial alternatives passed the threshold criteria evaluation, they were evaluated based on the remedial alternative evaluation criteria. The remedial alternative evaluation criteria are described in the TAG CME Work Plan (SNL/NM 2004a). As specified in the COOC (NMED 2004), the remedial alternative evaluation must be balanced and includes the following:

- Long-term reliability and effectiveness,

- Reduction of toxicity, mobility, or volume,

- Short-term effectiveness,

- Feasibility,

- Capital cost, and

- Operations and maintenance cost.

The remedial alternative conceptual design information was used to perform a comparative analysis for each remedial alternative using the remedial alternative threshold criteria. The comparative analysis was performed using the following ratings:

"Not effective" = = Does not effectively meet the remedial alternative criterion within a timeframe comparable to other remedial alternatives,

“+” $\quad$ = $\quad$ Effectively meets the remedial alternative criterion, and

“+” $\quad=\quad$ More effectively meets the remedial alternative criterion.

The total number of pluses represents how effectively the remedial alternative meets the criterion. A "Not effective" rating receives no score. Therefore, with six categories, the possible scores range from $0-12$. This approach balances the critieria in order to evaluate each remedial alternative in a simple, comparative manner. Information supporting comparative analysis of the remedial alternatives is presented in Table 3-2, and the results of the analyses are presented in Table 3-3. The supporting information states a rationale for the comparative analysis rating assigned to each remedial alternative for each criterion. This includes comparison of remedial alternatives and identifying data gaps. Data gaps are identified where additional information is needed to accurately rate the criterion and this information can be collected in a cost- and time-efficient manner.

The comparative analyses shown in Table 3-3 demonstrate that the ISB and pump and treat remedial alternatives are considerably less effective than the other remedial alternatives. For both ISB and pump and treat, three facilities (i.e. injection wells, extraction wells, treatment facilities) would need to be constructed in order to implement the remedy at the three separate locations with COC concentrations above MCLs within the SNL/NM AOR. Although ISB will degrade contaminants in situ, there is a risk that nitrate may be displaced by electron donor injections resulting in increased mobility and volume of nitrate-contaminated water. 


\begin{tabular}{|c|c|c|c|c|c|c|}
\hline \multirow[b]{2}{*}{$\begin{array}{l}\text { Remedial } \\
\text { Alternatives }\end{array}$} & \multirow[b]{2}{*}{ 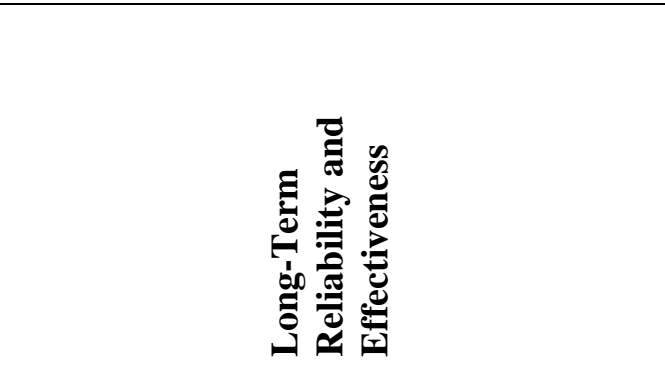 } & \multirow[b]{2}{*}{ 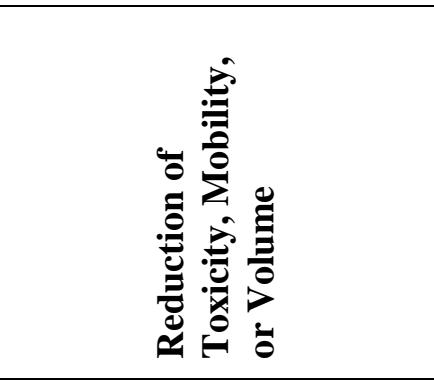 } & \multirow[b]{2}{*}{ 焉 } & \multirow[b]{2}{*}{ 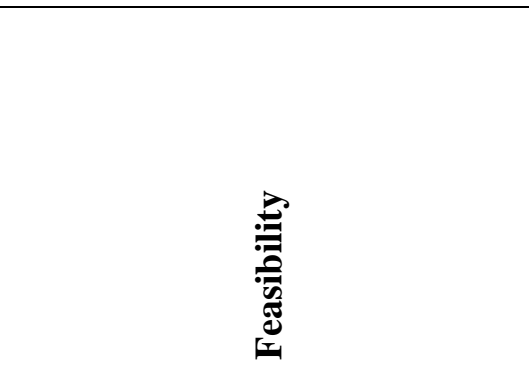 } & \multicolumn{2}{|r|}{ Cost } \\
\hline & & & & & Uू & 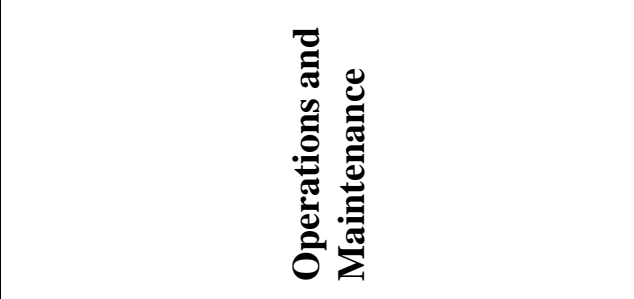 \\
\hline $\begin{array}{l}\text { Groundwater } \\
\text { monitoring }\end{array}$ & $\begin{array}{l}\text { Data gap. The CME process must } \\
\text { demonstrate that there is no risk to } \\
\text { receptors without natural attenuation. If } \\
\text { it is demonstrated that there is no long- } \\
\text { term risk in leaving contaminants in } \\
\text { place, then the remedy is effective } \\
\text { because the process of monitoring } \\
\text { groundwater is reliable and is effective at } \\
\text { tracking contaminants. }\end{array}$ & $\begin{array}{l}\text { Would not consider } \\
\text { toxicity reduction. }\end{array}$ & $\begin{array}{l}\text { There is no immediate } \\
\text { reduction in contaminant } \\
\text { concentration. Short-term risk } \\
\text { is less than pump and treat } \\
\text { since contaminants are not } \\
\text { brought to the surface. }\end{array}$ & $\begin{array}{l}\text { Ready to implement } \\
\text { immediately. }\end{array}$ & $\begin{array}{l}\text { Costs less to implement than } \\
\text { more active remedies }\end{array}$ & $\begin{array}{l}\text { The timeframe of continued monitoring } \\
\text { may be longer than more active } \\
\text { remedial alternatives. There is a } \\
\text { possible need to replace monitoring } \\
\text { wells. }\end{array}$ \\
\hline MNA & $\begin{array}{l}\text { Data gap. If numerical modeling and/or } \\
\text { field studies demonstrate that natural } \\
\text { attenuation mechanisms are operable, } \\
\text { then this remedial alternative will be } \\
\text { effective. }\end{array}$ & $\begin{array}{l}\text { Data gap. Need to identify } \\
\text { natural attenuation } \\
\text { mechanisms. }\end{array}$ & $\begin{array}{l}\text { There is no immediate } \\
\text { reduction in contaminant } \\
\text { concentration. Short-term risk } \\
\text { is less than pump and treat } \\
\text { since contaminants are not } \\
\text { brought to the surface. }\end{array}$ & $\begin{array}{l}\text { Ready to implement } \\
\text { immediately. }\end{array}$ & $\begin{array}{l}\text { Costs less to implement than } \\
\text { more active remedies }\end{array}$ & $\begin{array}{l}\text { The timeframe of continued monitoring } \\
\text { may be longer than more active } \\
\text { remedial alternatives. There is a } \\
\text { possible need to replace monitoring } \\
\text { wells. }\end{array}$ \\
\hline ISB & $\begin{array}{l}\text { Successful implementation of ISB will } \\
\text { degrade contaminants and remove long- } \\
\text { term risk of exposure; however, there is } \\
\text { also a risk that nitrate may be displaced } \\
\text { by electron donor injections. }\end{array}$ & $\begin{array}{l}\text { Reduces toxicity in situ, } \\
\text { by degrading COCs; } \\
\text { however, some nitrate may } \\
\text { potentially be displaced } \\
\text { resulting in temporary } \\
\text { increased mobility and } \\
\text { volume. }\end{array}$ & $\begin{array}{l}\text { Reduces contaminant } \\
\text { concentrations with minimal } \\
\text { short-term risk from bringing } \\
\text { contaminants to the surface. }\end{array}$ & $\begin{array}{l}\text { Technically less feasible than } \\
\text { MNA or groundwater } \\
\text { monitoring due to the physical } \\
\text { constraints of the aquifer and the } \\
\text { distribution of contaminants. }\end{array}$ & $\begin{array}{l}\text { Requires construction of new } \\
\text { injection wells and injection } \\
\text { equipment in several locations } \\
\text { within the SNL/NM AOR. }\end{array}$ & $\begin{array}{l}\text { Requires purchase of large amounts of } \\
\text { electron donor and intensive operations. }\end{array}$ \\
\hline Pump and treat & $\begin{array}{l}\text { Pump and treat with the goal of restoring } \\
\text { the groundwater to beneficial use would } \\
\text { not be effective at this site based on } \\
\text { experience at other sites and site specific } \\
\text { constraints. } \\
\text { Requires disposal of significant volumes } \\
\text { of waste streams for the duration of } \\
\text { operations. }\end{array}$ & $\begin{array}{l}\text { Contaminants are } \\
\text { transferred to a different } \\
\text { media instead of destroyed } \\
\text { in groundwater. }\end{array}$ & $\begin{array}{l}\text { There may be an immediate } \\
\text { reduction in concentration, but } \\
\text { contaminants are brought to the } \\
\text { surface increasing risk of } \\
\text { exposure. }\end{array}$ & $\begin{array}{l}\text { Technically less feasible than } \\
\text { MNA or groundwater } \\
\text { monitoring due to the physical } \\
\text { constraints of the aquifer and the } \\
\text { distribution of contaminants. }\end{array}$ & $\begin{array}{l}\text { Requires well drilling and } \\
\text { construction of infrastructure in } \\
\text { several locations within the } \\
\text { SNL/NM AOR. }\end{array}$ & $\begin{array}{l}\text { Operation duration could be very long } \\
\text { requiring considerable cost in } \\
\text { maintaining a treatment system and } \\
\text { pumping wells. Changes in water levels } \\
\text { may also affect the remedial alternative. }\end{array}$ \\
\hline
\end{tabular}


This Page Intentionally Left Blank 
Table 3-3. Comparative analysis of remedial alternatives for SNL/NM AOR.

\begin{tabular}{|c|c|c|c|c|c|c|c|}
\hline \multirow[b]{2}{*}{$\begin{array}{c}\text { Remedial } \\
\text { Alternatives }\end{array}$} & \multirow[b]{2}{*}{ 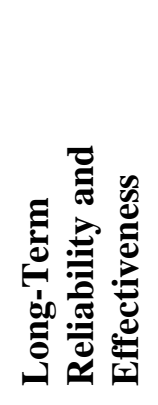 } & \multirow{2}{*}{ 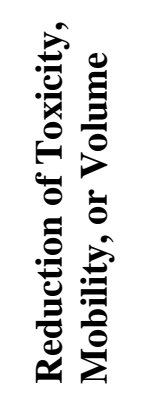 } & \multirow[b]{2}{*}{ 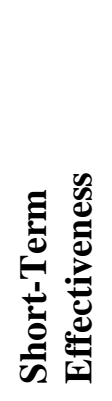 } & \multirow[b]{2}{*}{ 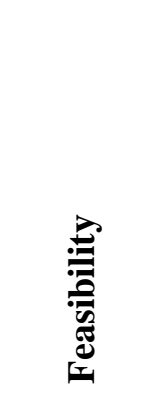 } & \multicolumn{2}{|c|}{ Cost } & \multirow[b]{2}{*}{ Totals } \\
\hline & & & & & 矛 & 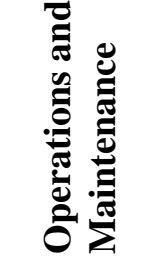 & \\
\hline $\begin{array}{l}\text { Groundwater } \\
\text { monitoring }\end{array}$ & ++ & $\begin{array}{c}\text { Not } \\
\text { effective }\end{array}$ & + & ++ & ++ & + & 8 \\
\hline MNA & ++ & + & + & ++ & ++ & + & 9 \\
\hline ISB & ++ & + & ++ & $\begin{array}{c}\text { Not } \\
\text { effective }\end{array}$ & $\begin{array}{c}\text { Not } \\
\text { effective }\end{array}$ & $\begin{array}{c}\text { Not } \\
\text { effective }\end{array}$ & 5 \\
\hline Pump and treat & $\begin{array}{c}\text { Not } \\
\text { effective }\end{array}$ & + & + & + & $\begin{array}{c}\text { Not } \\
\text { effective }\end{array}$ & $\begin{array}{c}\text { Not } \\
\text { effective }\end{array}$ & 3 \\
\hline
\end{tabular}

For pump and treat, the contamination will be transferred to a different media (i.e. resin used in ion exchange) instead of being destroyed in situ. This results in the additional cost of disposing of the spent GAC containing TCE and concentrated nitrate brine waste in the spent resin. Pump and treat may be an effective means of removing mass from the extracted water; however, observations from application of pump and treat at other sites indicates that it has not been an efficient means of restoring contaminated aquifers. Also, operations for pump and treat will involve a long operational timeframe with considerable maintenance costs.

As discussed in the TAG CME Work Plan (SNL/NM 2004a), if a remedial alternative is determined to be significantly less effective than the other remedial alternatives, then it will no longer be considered. It is recommended that the two remedial alternatives, ISB and pump and treat, no longer be evaluated as part of the CME.

The evaluation demonstrated that groundwater monitoring and MNA are comparable in effectiveness and cost. Small changes in rankings will not significantly change the overall score of the remedial alternatives. These two remaining remedial alternatives are still considered suitable for implementation at SNL/NM AOR but have different strengths and weaknesses, and will continue to be evaluated.

\subsection{Summary of the Remedial Alternative Evaluation}

Based on the information presented in this report, the list of remedial alternatives has been revised from the initial list of four, as stated in the TAG CME Work Plan (SNL/NM 2004a), to two remedial alternatives, groundwater monitoring and MNA. These alternatives that will be evaluated by conducting further studies are described in Section 4. 
This Page Intentionally Left Blank 


\subsection{RECOMMENDATIONS FOR FURTHER STUDIES}

Data gaps regarding individual remedial alternatives and their application at SNL/NM AOR have been identified. Numerical modeling, field, and laboratory, studies have been identified to provide this information. A decision was made regarding the utility of performing each of these studies considering the results of the evaluation presented in Section 3 of this report. Table 4-1 presents specific activities and a recommendation of which activities should be performed. These activities correspond to stages of data gathering activities identified in the TAG CME Work Plan (SNL/NM 2004a). Based on the information and evaluation of remedial alternative data gaps presented in this report, it is recommended that numerical modeling be conducted for MNA and field scale studies be conducted for groundwater monitoring and MNA. It is also recommended that the following studies not be conducted:

- Laboratory and field scale studies for ISB, and

- Field scale studies for pump and treat.

\subsection{Recommended Activities}

It is recommended that evaluation of data gaps for two remedial alternatives, groundwater monitoring and MNA, be performed. Characterization activities for the greater TAG study area are recommended field scale studies for both groundwater monitoring and MNA; however, these activities are not directed by nor conducted as part of this CME process; however, the data generated can be used as appropriate. For MNA, numerical modeling is recommended to investigate the fate and transport of contaminants in the perched groundwater system. Other field scale studies recommended for MNA include investigating anaerobic mechanisms of TCE and nitrate biodegradation and performing enzyme probe analyses to provide direct evidence of an aerobic cometabolic TCE degradation mechanism.

\subsubsection{Numerical Modeling}

Past numerical modeling has been performed to determine the fate and transport of contaminants to downgradient receptors for the greater TAG study area (SNL/NM 2004a). However, additional information may be needed to adequately determine the fate and transport for the SNL/NM AOR because past modeling only included the regional system and did not include transport through the perched system. In order for contaminants within the SNL/NM AOR to reach downgradient receptors, they would have to travel through the perched system, to the merging zone, and then into the regional system. Obviously, any attenuation processes and travel time for these contaminants would be in addition to those predicted for particles released in the regional system during previous simulations. The merging zone between the perched and regional systems is thought to be southeast of TA-II and TA-IV. Given that predicted travel times from the regional system in this area are in excess of 90 years, and that particles must travel through some portion of the perched system in order to reach the regional system, it is unlikely that contaminants in the perched system will reach downgradient receptors (SNL/NM 2004a). However, a simplified numerical modeling approach will be implemented to estimate the potential for contaminant dilution during transport through the perched system, merging zone, and regional aquifer. 


\subsubsection{Field Scale Studies}

The TAG Investigation Work Plan (SNL/NM 2003) has identified several characterization activities for the greater TAG study area. These activities include additional groundwater monitoring and soil vapor sampling at various locations throughout the greater TAG study area. These characterization activities are recommended field scale studies for both groundwater monitoring and MNA; however, these activities are not directed by nor conducted as part of this CME process, but the data generated can be used as appropriate.

These ongoing characterization activities for the greater TAG study area may be augmented as appropriate to investigate mechanisms for contaminant degradation to establish whether natural attenuation of COCs will occur. This may include investigating anaerobic mechanisms of TCE and nitrate biodegradation and performing enzyme probe analyses to provide direct evidence of an aerobic cometabolic TCE degradation mechanism.

\subsection{Activities No Longer Recommended}

Several laboratory and field scale activities were initially identified to fill anticipated data gaps regarding the ISB and pump and treat remedial alternatives. These included laboratory microcosm studies and field scale injection tests for ISB, and aquifer tests for pump and treat. A brief description of these activities is included in Table 4-1. It has been determined that the ISB and pump and treat remedial alternatives are significantly less effective than MNA or groundwater monitoring, and will no longer be considered as remedial alternatives. Therefore, these laboratory and field studies are no longer necessary. 
Table 4-1. Recommended numerical modeling, field, and laboratory studies.

\begin{tabular}{|c|c|c|}
\hline $\begin{array}{c}\text { Stage } \\
\text { (Remedial } \\
\text { Alternative) } \\
\end{array}$ & Activity/Purpose & Perform? \\
\hline$\frac{\text { Numerical Modeling }}{\text { (MNA) }}$ & $\begin{array}{l}\text { Fate and transport of contaminants in the perched } \\
\text { groundwater system. }\end{array}$ & $\begin{array}{l}\text { Yes. Numerical modeling goals and objectives will be } \\
\text { determined by January 14, 2005, followed by the start of } \\
\text { modeling activities. }\end{array}$ \\
\hline$\frac{\text { Laboratory Study }}{\text { (ISB) }}$ & $\begin{array}{l}\text { Laboratory microcosm studies to determine if } \\
\text { dechlorinating microbes can be induced with } \\
\text { electron donor in the perched system to degrade } \\
\text { TCE to ethene. }\end{array}$ & $\begin{array}{l}\text { No. The ISB remedial alternative is no longer being } \\
\text { considered. }\end{array}$ \\
\hline $\begin{array}{l}\text { Field Scale Study } \\
\text { (Groundwater Monitoring } \\
\text { and MNA) }\end{array}$ & $\begin{array}{l}\text { Characterization activities for the TAG study area } \\
\text { including additional groundwater monitoring and } \\
\text { soil vapor sampling. }\end{array}$ & $\begin{array}{l}\text { Yes. Although these activities are not directed by nor } \\
\text { conducted as a part of this CME process, the data generated } \\
\text { will be used to support this CME as appropriate. }\end{array}$ \\
\hline$\frac{\text { Field Scale Study }}{\text { (MNA) }}$ & $\begin{array}{l}\text { Groundwater monitoring to investigate anaerobic } \\
\text { mechanisms of TCE and nitrate biodegradation } \\
\text { (potential additions to ongoing TAG study area } \\
\text { characterization). }\end{array}$ & $\begin{array}{l}\text { Yes. Goals and objectives will be determined by January } \\
\text { 12, 2005, followed by the start of groundwater monitoring } \\
\text { activities. }\end{array}$ \\
\hline$\frac{\text { Field Scale Study }}{\text { (MNA) }}$ & $\begin{array}{l}\text { Groundwater sampling and analyses to perform } \\
\text { enzyme probe analyses to provide direct evidence } \\
\text { of an aerobic cometabolic TCE degradation } \\
\text { mechanism (potential additions to ongoing TAG } \\
\text { study area characterization) }\end{array}$ & $\begin{array}{l}\text { Yes. Goals and objectives will be determined by December } \\
\text { 22, 2004, followed by the start of groundwater monitoring } \\
\text { activities. }\end{array}$ \\
\hline$\frac{\text { Field Scale Study }}{\text { (ISB) }}$ & $\begin{array}{l}\text { Lactate injection demonstration to provide } \\
\text { evidence that TCE degradation can be induced by } \\
\text { injecting electron donor, and provide estimates for } \\
\text { injection rate, injection frequency, and other design } \\
\text { estimates for full scale implementation. }\end{array}$ & $\begin{array}{l}\text { No. The ISB remedial alternative is no longer being } \\
\text { considered. }\end{array}$ \\
\hline$\frac{\text { Field Scale Study }}{\text { (Pump and Treat) }}$ & $\begin{array}{l}\text { Aquifer tests to determine pumping rates in a new } \\
\text { extraction well for a pump and treat system and } \\
\text { provide more information on aquifer properties. }\end{array}$ & $\begin{array}{l}\text { No. The pump and treat remedial alternative is no longer } \\
\text { being considered. }\end{array}$ \\
\hline
\end{tabular}


This Page Intentionally Left Blank 


\subsection{REFERENCES}

1. Alexander, M., 1967, In “Agriculture and the Quality of Our Environment” (N.C. Brady ed.), American Association for the Advancement of Science, Washington D.C., pp. 331-342.

2. Aziz, C.E., G. Georgiou, and G.E. Speitel, Jr., 1999, “Cometabolism of Chlorinated Solvents and Binary Chlorinated Solvent Mixtures Using M. trichosporium OB3b PP358,” Biotechnology and Bioengineering, Vol. 65, No. 1, pp. 100-107.

3. Bradley, P.M. and F.H. Chapelle, 1998, "Humic Acids as Electron Acceptors for Anaerobic Microbial Oxidation of Vinyl Chloride and Dichloroethene,” Applied and Environmental Microbiology, Volume 64, Number 8, pp. 3102-3105.

4. Bradley, P.M. and F.H. Chapelle, 2000, “Aerobic Microbial Mineralization of Dichloroethene as Sole Carbon Substrate,” Environmental Science and Technology, Volume 34, Issue 1, pp. 221-223.

5. Coleman, N. V., T. E. Mattes, J. M. Gossett, and J. C. Spain, 2002. "Biodegradation of cisDichloroethene as the Sole Carbon Source by a ß-Proteobacterium,” Applied and Environmental Microbiology, 68(6):2726-2730.

6. DOE 1999, Decision-Making Framework Guide for the Evaluation and Selection of Monitored Natural Attenuation Remedies at Department of Energy Sites, Department of Energy, Office of Environmental Restoration, May 1999.

7. DOE-ID, 2003, Monitored Natural Attenuation Remedial Action Work Plan for Test Area North Final Groundwater Remediation, Operable Unit 1-07B. DOE/ID-11055, Revision 0, U.S. Department of Energy Idaho Operations Office, June 2003.

8. Droste, Ronald L, 1997, “Theory and Practice of Water and Wastewater Treatment,” John Wiley \& Sons, Inc. New York. pp. 485.

9. EPA, 2002, Elements for Effective Management of Operating Pump and Treat Systems. United States Environmental Protection Agency, Solid Waste and Emergency Response, Cincinnati, OH. December 2002.

10. EPA, 2001, Cost Analyses for Selected Groundwater Cleanup Projects: Pump and Treat Systems and Permeable Reactive Barriers. EPA 542-R-00-013. Solid Waste and Emergency Response.

11. EPA, 1999, Use of Monitored Natural Attenuation at Superfund, RCRA Corrective Action, and Underground Storage Tank Sites, OSWER Directive 9200.4-17P, http://www.epa.gov/swerust1/directiv/d9200417.pdf.

12. EPA, 1997, Ground Water Issue: Design Guidelines for Conventional Pump-and-Treat Systems. EPA/540/S-97/504, September 1997, Office of Research and Development, Washington D.C. 
13. EPA, 1996, "Pump-and-Treat Ground-Water Remediation: A Guide for Decision Makers and Practitioners,” EPA/625/R-95/005, July 1996, Office of Research and Development, Washington D.C., http://www.epa.gov/ORD/WebPubs/pumptreat/.

14. Klier, N. J., R. J. West, and P. A. Donberg, 1999. “Aerobic biodegradation of dichloroethylenes in surface and subsurface soils,” Chemosophere, 38:1175-1188.

15. LLNL, 2000, “ERD SOP 4.17: Change of Water Phase Granular Activated Carbon-Revision 0,” LLNL Environamnetal Restoration Division (ERD) Standard Operating Procedure (SOP), Lawrence Livermore National Laboratory, California.

16. McCarty, P.L., 1996, "Biotic and Abiotic Transformations of Chlorinated Solvents in Ground Water,” In: Symposium on Natural Attenuation of Chlorinated Organics in Ground Water, Office of Research and Development, U.S. Environmental Protection Agency, Washington, D.C., EPA/540/R-97/504, pp. 7-11.

17. MWH Americas, Inc., 2003, "Stage I Abatement Report for Nitrate-Impacted Groundwater at Kirtland Air Force Base, New Mexico,” Environmental Compliance Program, Kirtland Air Force Base Albuquerque, New Mexico, July 2003.

18. NMED, 2004, "Compliance Order on Consent Pursuant to the New Mexico Hazardous Waste Act 74-4-10: Sandia National Laboratories Consent Order,” New Mexico Environment Department, April 24, 2004.

19. Oldenhuis, R., R.L.J.M. Vink, D.B. Janssen, and B.Witholt, 1989, “Degradation of Chlorinated Aliphatics by Methylosinus trichosproium OB3b Expressing Soluble Methane Monoxygenase,” Applied and Environmental Microbiology. Vol. 55, No. 11, pp. 2819-2826.

20. Semprini, L., Roberts, P.V., Hopkins, G.D., and P.L. McCarty, 1990, “A Field Evaluation of In-Situ Biodegradation of Chlorinated Ethenes: Part 2, Results of Biostimulation and Biotransformation Experiments,” Ground Water, Vol. 28, No. 5, pp. 715-727.

21. SNL/NM, 2004a, Corrective Measures Evaluation Work Plan Tijeras Arroyo Groundwater, SAND2004-3247P, July 2004, Sandia National Laboratories/New Mexico.

22. SNL/NM, 2004b, Technical Memorandum_Field Report, Slug Tests at Tijeras Arroyo Groundwater Investigation Wells, SNL/NM Environmental Restoration Project.

23. SNL/NM, 2003, Tijeras Arroyo Groundwater Investigation Work Plan (Final Version), National Nuclear Security Administration Sandia Site Office, Sandia National Laboratories/New Mexico Environmental Restoration Project, June 2003.

24. SNL/NM, 2002, Tijeras Arroyo Groundwater Continuing Investigation Report, Sandia National Laboratories Environmental Restoration Project for U.S. Department of Energy, Albuquerque Operations Office, Albuquerque, New Mexico, November 2002. 
25. SNL/NM, 2001, 1999 Annual Site Environmental Report Sandia National Laboratories Albuquerque, New Mexico, Sandia Report SAND2000-2228, Sandia National Laboratories/New Mexico, February 2001.

26. SNL/NM, 1998, Sandia North Groundwater Investigation, Annual Report, Fiscal year 1997, Environmental Restoration Project, Sandia National Laboratories, Albuquerque, New Mexico, March 1998.

27. Stone, B.D., J.C. Cole, and D.A. Sawyer, 2000, "Regional Stratigraphic Framework for an Integrated Three-Dimensional Geologic Model of the Rio Grande Rift,” in U.S. Geological Survey Middle Rio Grande Basin Study_Proceedings of the Fourth Annual Workshop, Albuquerque, New Mexico, February 15-16, 2000. U.S. Geological Survey Open File Report 00-488. U.S. Geological Survey, February 2000.

28. Vogel, T.M., C.S. Criddle, and P.L. McCarty, 1987, “Transformations of Halogenated Aliphatic Compounds,” Environmental Science and Technology, Vol. 21, No. 8, pp. 722736.

29. Wilson, J.T. and Wilson, B. H., 1985, "Biotransformation of Trichoroethylene in Soil, Applied and Environmental Microbiology, 49: 242-243. 
This Page Intentionally Left Blank 


\section{APPENDIX A}

Capture Zone Analyses

B-55 
This Page Intentionally Left Blank 
Equation 1 describes the method used to calculate the capture zone width (W). This method is adopted from Elements for Effective Management of Operating Pump and Treat Systems (EPA 2002).

$W=\frac{Q}{C \times B \times K \times i}$

where:

$$
\begin{array}{lll}
\mathrm{Q} & = & \text { extraction rate }(\mathrm{gpm}) \\
\mathrm{C} & = & \text { volume conversion factor }\left(7.481 \mathrm{gal} / \mathrm{ft}^{3}\right) \\
\mathrm{B} & = & \text { saturated thickness }(\mathrm{ft}) \\
\mathrm{K} & = & \text { hydraulic conductivity }(\mathrm{ft} / \mathrm{min}) \\
\mathrm{i} & = & \text { hydraulic gradient }(\mathrm{ft} / \mathrm{ft}) .
\end{array}
$$

This calculation assumed the following:

1. The horizontal hydraulic conductivity $(\mathrm{K})$ ranges from $3.69 \times 10^{-5}$ to $2.12 \times 10^{-3} \mathrm{ft} / \mathrm{min}$ (SNL/NM 2004b).

2. The thickness (B) of the saturated zone is 10 to $30 \mathrm{ft}$ (SNL/NM 2004a). The wells are screened over a $20 \mathrm{ft}$ interval (SNL/NM 2003), $5 \mathrm{ft}$ of drawdown was assumed for the minimum contaminant thickness of $10 \mathrm{ft}$ and $15 \mathrm{ft}$ of drawdown was assumed for the maximum contaminant thickness of $30 \mathrm{ft}$.

3. Effective porosity is assumed to be $25 \%$ (Table $1-2$ of this report).

4. The horizontal hydraulic gradient (i) is $0.007 \mathrm{ft} / \mathrm{ft}$ (SNL/NM 2003).

5. The aquifer is homogenous and isotropic.

6. This analysis takes into account properties observed in three wells (TA2-W-26, TJA-7, and TA2-SW1-320).

7. The well is pumped continuously.

8. Effects of multiple extraction wells on each other are neglected.

9. There is no recharge. 
As is shown in Table A-1, the estimated capture zone widths are large compared to the extent of contamination in the perched system. It can be concluded from these calculations that capturing the contaminant plume as it is transported across a downgradient location will not be a significant challenge if a sufficient number of wells are drilled. A more pertinent question may be: Is capturing the contaminant plume in this way an effective means of remediation? There is no contaminant source, and it may take many years for the plume to move past this downgradient capture zone as groundwater velocities range from 4-10 ft/year. Therefore, it is concluded that this approach to pump and treat remediation is not an effective approach when the goal of pump and treat is remediation of the aquifer.

Table A-1. Capture zone width calculation.

\begin{tabular}{lcc}
\hline & \multicolumn{2}{c}{ Capture Zone Width (W), miles } \\
& $\begin{array}{c}\text { Max. Specific Capacity and } \\
\mathrm{K}=3.69 \times 10^{-5} \mathrm{ft} / \mathrm{min}\end{array}$ & $\begin{array}{c}\text { Min. Specific Capacity and } \\
\mathrm{K}=2.12 \times 10^{-3} \mathrm{ft} / \mathrm{min}\end{array}$ \\
\hline $\mathrm{B}=10 \mathrm{ft}$. & $\sim 172$ & $\sim 0.06$ \\
$\mathrm{~B}=30 \mathrm{ft}$. & $\sim 172$ & $\sim 0.06$ \\
\hline
\end{tabular}




\section{APPENDIX B}

\section{TREATMENT AND DISPOSAL OPTIONS FOR PUMP AND TREAT}


This Page Intentionally Left Blank 
This appendix provides details on ex-situ treatment and treated water disposal options that are being considered for implementation of pump and treat. These technologies or a combination of these technologies may be applied if a remedial alternative involving pump and treat is chosen as the preferred remedial alternative for SNL/NM AOR. The following sections provide details on two treatment options including granular activated carbon (GAC) and ion exchange.

\section{B-1. Granular Activated Carbon Treatment for TCE}

This treatment option uses sorption to GAC to treat contaminated groundwater. The technology effectiveness is well characterized for treatment of TCE. GAC treatment is not effective at removing nitrate. A treatment design is given here to provide estimates on the operating requirements. However, if the technology were implemented, the system would be designed based on more accurate data than the wide range of results presented here.

\section{Design}

The treatment unit will consist of a series of three 55-gallon drums of GAC (Figure B-1). The series of drums may be connected such that the down hole pumps will provide sufficient head for flow through the system. This design will require the following:

- A portable storage unit to house the treatment units. The storage unit will need to be equipped with a door, ventilation, electricity, and plumbing to the COA sewer system or on-site disposal system (i.e., injection well).

- Three 55-gal drums of GAC.

- A framework to support a tiered series of drums.

- Piping, fittings, and plumbing equipment. This should include a flow meter on the effluent line and sampling ports on all influent lines (coming from the wells), prior to each GAC drum, and on the effluent line.

Scoping calculations have been performed to estimate treatment unit size, design, and operation needs. Assumptions used in these calculations include:

- Constant influent of TCE concentrations is assumed. The concentrations are the maximum observed concentrations divided by the number of pore volumes that will be flushed.

- Literature values for isotherm constants were used (LLNL, 2000).

- The GAC density was assumed considering literature values (Droste 1997) and manufacturer's specifications.

The GAC would be regenerated every 7 to 86 days. Competing adsorbates may also limit the useful life of the GAC. Therefore, a large safety factor (5) has been applied to the calculations to account for these effects and provide a scoping estimation of operating parameters for evaluation of the alternative (not intended for remedial alternative design). 
Influent from

Extraction

Well

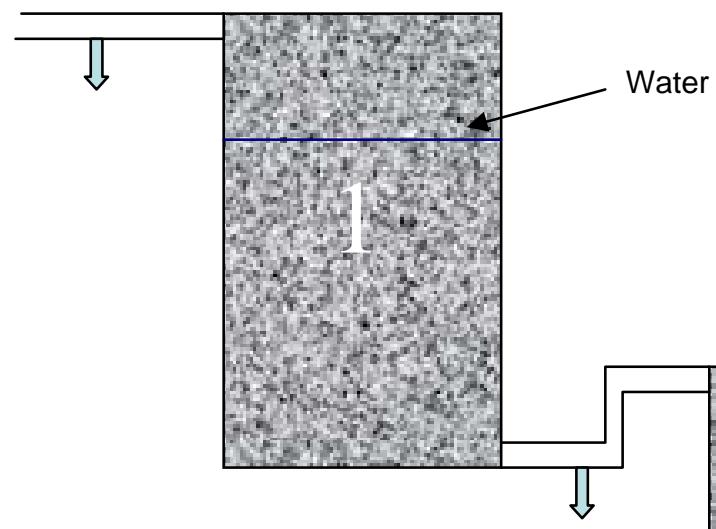

ஸ্র

$\Longrightarrow$ Sampling Ports

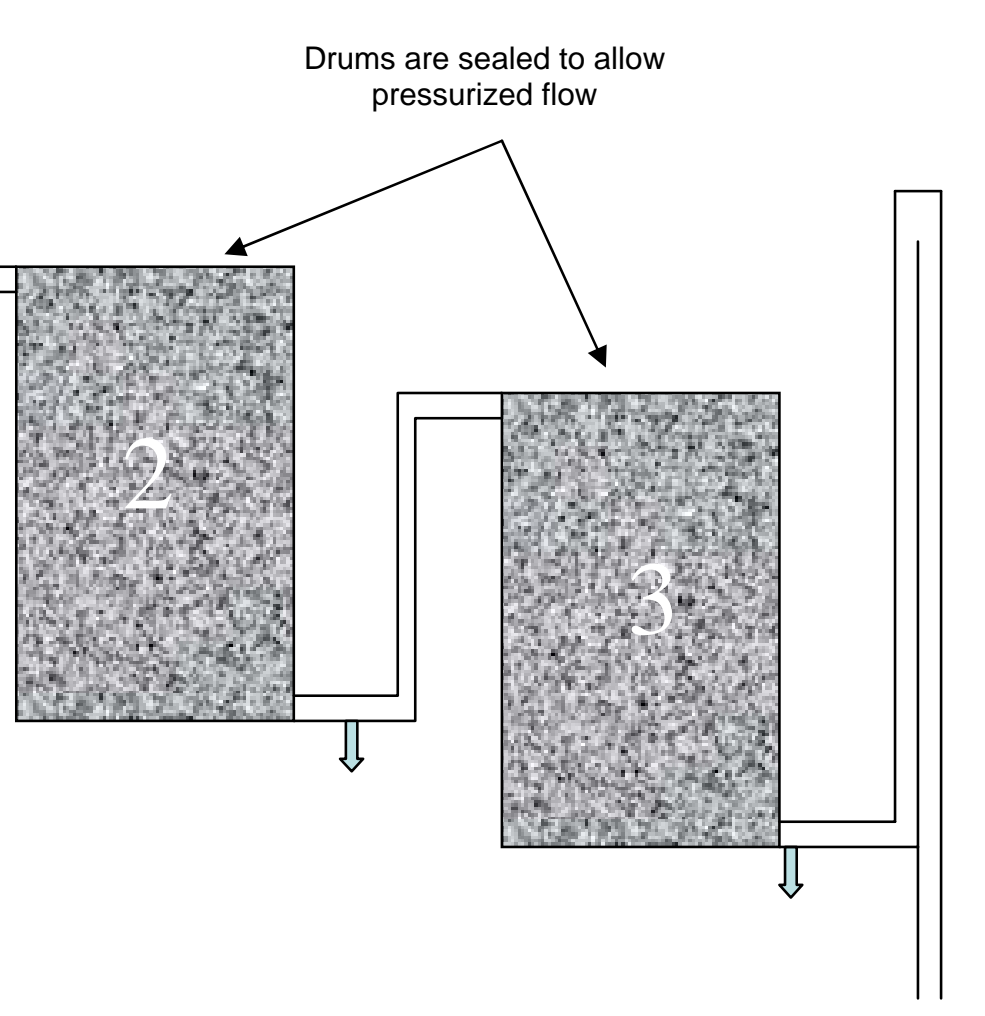

Effluent

Figure B-1. Schematic of GAC treatment unit. 
Operation will include regular monitoring of the influent, two sampling ports between the barrels, and effluent, and when necessary disposal and replacement of GAC. If TCE is detected in the sampling port between the second and third GAC container, then the system will be recharged with fresh GAC. This will likely be done by removing the GAC in the first container (the container attached to the influent line), and rotating the second container to the first place, the third container to the second place, and placing the fresh GAC in the third place (Figure C-1).

\section{Advantages and Disadvantages Compared to Other Treatment Options}

Advantages of implementing this treatment design include:

- Requires little maintenance,

- The risk of failure is small, considering the well-characterized effectiveness of activated carbon at removing TCE, and

- The activated carbon is capable of removing low concentrations of TCE.

Disadvantages include:

- Will not remove nitrate,

- A solid waste is produced, and

- The effect of competing sorbates on useful life of the GAC is unknown and will need to be characterized during remedial alternative implementation.

\section{B-2. Ion Exchange Unit for Nitrate Removal}

A treatment design is given here to provide estimates on the operating requirements for a nitrate removal system using ion exchange. However, if the technology were implemented, the system would be designed based on more accurate data than the wide range of results presented here.

\section{Design}

The technology uses anion exchange resins to remove nitrates. The resins are periodically recharged using a salt solution. The system used to calculate the results presented is a 1- $\mathrm{ft}^{3}$ system. If flow into the system is high, the system volume will likely be increased in order to reduce the regeneration frequency; however, the total volume of brine will be the same in either case.

Qualities of the groundwater at SNL/NM AOR that may affect implementation of this technology include the presence of sulfate and hardness. Sulfate in the groundwater will compete with nitrate on the anion exchange resin. An average sulfate concentration of $40 \mathrm{mg} / \mathrm{L}$ was used in scoping calculations for which the results are presented in Table C-2. A safety factor of three was applied and there is significant uncertainty associated with these estimates. However, the estimated operating parameters provide a scoping estimation of ion exchange 
operating needs. Each regeneration will require flushing the resins with several pore volumes of salt solution. Hardness in the groundwater may interfere with the nitrate removal. Hardness in the groundwater at SNL/NM AOR is generally greater than $100 \mathrm{mg} / \mathrm{L}$ as calcium carbonate, and

it may be necessary to remove this hardness. The average regeneration rate is approximately 0.3 to 3.1 hours between each regeneration.

\section{Advantages and Disadvantages Compared to Other Treatment Options}

Advantages of implementing this treatment design include:

- Low risk of failure and expected to remove nitrates up to $80 \%$.

Disadvantages include:

- Hardness is present in the groundwater at levels greater than $100 \mathrm{mg} / \mathrm{L}$ as $\mathrm{CaCO}_{3}$, which will likely interfere with effective operation of an ion exchange unit and may require a separate hardness removal step,

- Produces a concentrated nitrate brine waste stream, and

- Regeneration is frequent and may require significant maintenance. 
Attachment C

Evaluation of Contaminant Transport in Groundwater 
This Page Intentionally Left Blank C-2 


\section{Evaluation of Contaminant Transport, Tijeras Arroyo Groundwater, Sandia National Laboratories/New Mexico}

May 2005

Prepared by

Sandia National Laboratories

Albuquerque, New Mexico 87185 and Livermore, California 94550

Sandia is a multiprogram laboratory operated by Sandia Corporation,

a Lockheed Martin Company, for the United States Department of Energy's

National Nuclear Security Administration under Contract DE-AC04-94AL85000.

Approved for public release; further dissemination unlimited.

Sandia National laboratories 


\section{EXECUTIVE SUMMARY}

The Corrective Measures Evaluation Work Plan Tijeras Arroyo Groundwater outlines a staged process for evaluating remedial alternatives for Tijeras Arroyo groundwater at Sandia National Laboratories/New Mexico (SNL/NM). The numerical modeling study described herein was performed as part of the Corrective Measures Evaluation to determine the effects of dilution on contaminants of concern in Tijeras Arroyo groundwater as they are transported downgradient.

A cross-sectional analysis was used to assess downgradient transport and dilution of a conservative solute. The analysis included the following three parts: (1) an estimate of discharge from the perched groundwater system, (2) an alluvial fan model section, and (3) an ancestral Rio Grande (ARG) model section. Solute concentrations were estimated for potential human receptors at pumping centers near Albuquerque, New Mexico, which are completed in the ARG lithofacies.

The flow models were used to simulate the effects of dilution on a solute that originates in the perched groundwater system and is transported with groundwater to production wells located in the ARG lithofacies. Recognizing that the cross-sectional numerical flow and transport models would not be a rigorous representation of the system, several conservative assumptions were made so that the effects of dilution would be intentionally underestimated.

The maximum concentration of a conservative solute at these production wells was simulated relative to the concentration of solute in groundwater leaving the perched system. When compared to observed concentrations in the perched groundwater system, these results led to the following conclusions:

- $\quad$ The historical maximum nitrate concentration in the SNL/NM area of responsibility is 44 $\mathrm{mg} / \mathrm{L}$ (as nitrogen). The maximum concentration will be reduced to $0.24 \mathrm{mg} / \mathrm{L}$ (as nitrogen) before reaching production wells completed in the ARG. For comparison, the federal drinking water standard for nitrate is $10 \mathrm{mg} / \mathrm{L}$ (as nitrogen).

- The historical maximum trichloroethene concentration in the SNL/NM area of responsibility is $9.6 \mu \mathrm{g} / \mathrm{L}$. The maximum concentration will be reduced to less than 0.03 $\mu \mathrm{g} / \mathrm{L}$ before reaching production wells in the ARG. For comparison, the federal drinking water standard for TCE is $5 \mu \mathrm{g} / \mathrm{L}$.

These estimates represent conservative estimates of concentration that intentionally neglect the effects of dispersion, degradation, and sorption on contaminant concentrations.

The travel time from the current locations of nitrate and TCE in the perched groundwater system to the ARG lithofacies where production wells are completed is at least 140 years for nitrate and at least 130 years for TCE. The estimated travel times are slightly different because the contaminants are currently in two different locations in the perched groundwater system. These travel times represent minimum or conservative estimates, because retardation, travel time through the zone of merging, and travel time through the ARG are intentionally neglected. 


\section{CONTENTS}

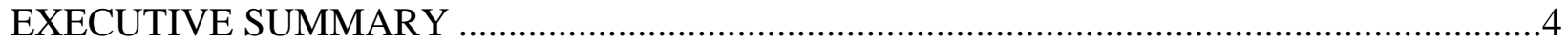

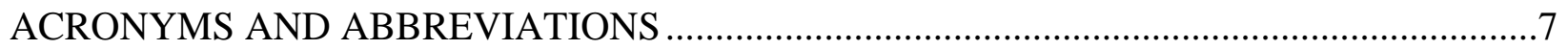

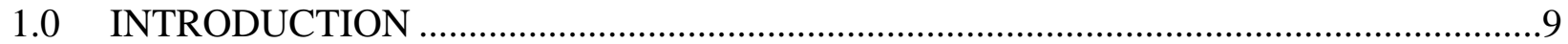

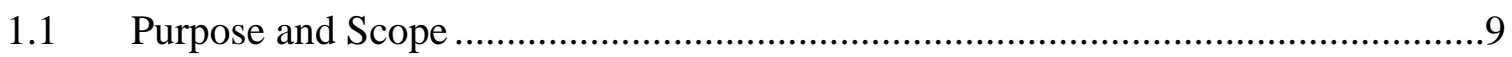

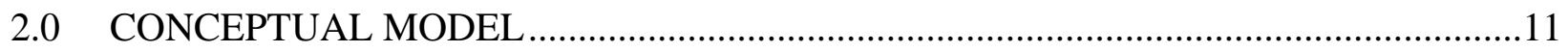

$2.1 \quad$ Perched System ......................................................................................................11

2.2 Regional Aquifer..........................................................................................15

2.2.1 Large-Scale Geologic Features ....................................................................... 16

2.2.2 Hydrostratigraphic Framework ....................................................................... 17

2.2.3 Regional Recharge .......................................................................................... 17

2.2.4 Regional Discharge .................................................................................... 17

2.2.5 Regional Groundwater Flow ................................................................... 17

2.2.6 Hydrostratigraphic Units.................................................................................... 19

2.2.7 Groundwater Flow in Alluvial Fan Lithofacies .................................................... 19

2.3 Distribution of Groundwater Contaminants..........................................................19

2.3.1 Implications of Contaminant Distribution to Numerical Modeling....................... 23

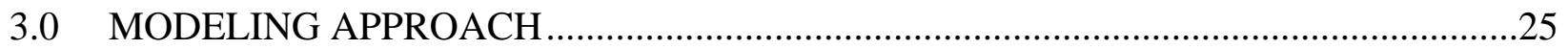

3.1 Estimate of Flow from the Perched Groundwater System ...................................30

3.1.1 Estimate of Perched Groundwater System Discharge ........................................... 33

3.1.2 Estimate of Transport Time ..................................................................................... 34

3.2 Alluvial Fan Model Section ...................................................................................35

3.3 Ancestral Rio Grande Model Section .......................................................................37

4.0 RESULTS AND INTERPRETATIONS …………....................................................

4.1 Simulation of Solute Transport to Production Wells ................................................41

4.2 Interpretations of Modeling Relative to Observed Concentrations .........................42

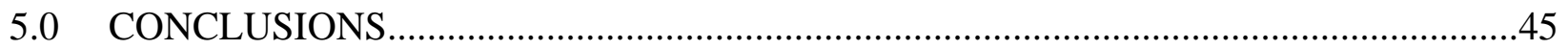

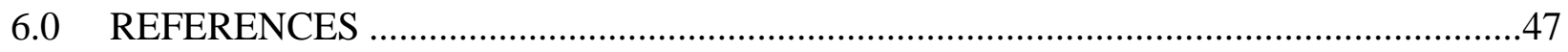




\section{FIGURES}

1-1. Illustration of the staged process of data gathering activities and production of subsequent reports.

2-1. Potentiometric surface map for the perched system in the TAG Area of Responsibility, March 2002 (SNL/NM 2004a).

2-2. Configuration of the regional groundwater surface in the Albuquerque Basin, 1994-1995.

2-3. Subregional potentiometric surface elevation contour map for basin fill deposits, 2000. 20

2-4. Potentiometric surface map for the regional aquifer in the TAG area, March 2002........ 21

3-1. Regional potentiometric surface map and location of simulated regions.......................... 26

3-2. Local potentiometric surface map and location of simulated regions. ............................ 27

3-3. Perched system illustration. ........................................................................................... 31

3-4. Comparison of simulated and observed potentiometric head along the alluvial fan model section.

3-5. Comparison of simulated and observed potentiometric head along the ARG model section

3-6. Illustration of solute flux simulation from the alluvial fan model section into the ARG model section.

4-1. Plot of solute arrival at the ARG/ alluvial fan model section interface and at the Ridgecrest well field.

\section{TABLES}

2-1. Summary of perched system properties....................................................................... 15

2-2. Summary of regional aquifer properties...................................................................... 16

3-1. Summary information and input parameters.................................................................. 30

3-2. Estimate of contaminant travel time in the perched system. …..................................... 35

4-1. Interpretations of solute transport simulation relative to nitrate contamination................ 43

4-2. Interpretations of solute transport simulation relative to TCE contamination................... 43 


\section{ACRONYMS AND ABBREVIATIONS}

\begin{tabular}{|c|c|}
\hline AOR & area of responsibility \\
\hline ARG & ancestral Rio Grande \\
\hline bgs & below ground surface \\
\hline $\mathrm{CME}$ & Corrective Measures Evaluation \\
\hline $\mathrm{COA}$ & City of Albuquerque \\
\hline $\mathrm{COC}$ & contaminant of concern \\
\hline $\mathrm{ft}$ & foot or feet \\
\hline $\mathrm{ft} /$ day & feet per day \\
\hline $\mathrm{ft} / \mathrm{yr}$ & feet per year \\
\hline $\mathrm{ft}^{3} /$ day & cubic feet per day \\
\hline $\mathrm{ft} / \mathrm{yr}$ & feet per year \\
\hline GMS & Department of Defense Groundwater Modeling System \\
\hline KAFB & Kirtland Air Force Base \\
\hline MCL & maximum contaminant level \\
\hline $\mathrm{mg} / \mathrm{L}$ & milligrams per liter \\
\hline$\mu g / L$ & microgram per liter \\
\hline NMED & New Mexico Environmental Department \\
\hline SNL/NM & Sandia National Laboratories/ New Mexico \\
\hline SWMU & solid waste management unit \\
\hline TA & technical area \\
\hline TAG & Tijeras Arroyo groundwater \\
\hline TCE & trichloroethene \\
\hline USGS & United States Geological Survey \\
\hline VA & Veterans Administration \\
\hline
\end{tabular}


This Page Intentionally Left Blank 


\subsection{INTRODUCTION}

This report presents the approach and results of a numerical modeling study performed to evaluate dilution of contaminants of concern (COCs) during transport from the Tijeras Arroyo Groundwater (TAG) area of responsibility (AOR) at Sandia National Laboratories/New Mexico (SNL/NM) to production wells completed in the regional aquifer, which are potential exposure points for human receptors.

The Corrective Measures Evaluation Work Plan Tijeras Arroyo Groundwater (SNL/NM 2004a), which was prepared as directed by the Compliance Order on Consent issued by the New Mexico Environment Department (NMED) (NMED 2004), outlines a staged process for evaluating remedial alternatives. This numerical modeling study has been performed as part of the Corrective Measures Evaluation (CME) process.

Characterization of the TAG Study Area has been undertaken by three potentially responsible parties: SNL/NM, the City of Albuquerque (COA), and Kirtland Air Force Base (KAFB). As a result, it is necessary for each party to clearly define their contribution to overall TAG remediation. The CME Work Plan (SNL/NM 2004a) identifies the specific area within the overall TAG study area for which SNL/NM has remediation responsibility. In order to clearly distinguish it from the overall TAG area, the area that the CME and this numerical modeling study addresses is referred to as the SNL/NM AOR. The SNL/NM AOR encompasses an approximately 2-square mile area in the north-central part of KAFB.

The "Remedial Alternatives Data Gaps Review for Tijeras Arroyo Groundwater" (SNL/NM 2005b) was prepared as part of the paper study stage of the CME. During the paper study stage, data gaps in the CME were identified. These data gaps include evaluating the potential for contaminants in the TAG SNL/NM AOR to reach production wells, and evaluating the effects of natural attenuation mechanisms on contaminant concentrations. Identification of these and other data gaps resulted in the revised CME process illustrated in Figure 1-1.

The evaluation of contaminant transport and dilution described in this document is the numerical modeling step of the CME process. This report presents a conceptual model upon which the modeling approach is based (Section 2.0), the methods and assumptions of the numerical modeling evaluation (Section 3.0), results and interpretations (Section 4.0), and conclusions (Section 5.0).

\subsection{Purpose and Scope}

This report describes a numerical modeling study performed to evaluate reduction in concentrations along the groundwater flow path between the current location of contaminants in the perched system and potential downgradient receptors at production wells completed in the regional aquifer. Steady-state, cross-sectional numerical flow models were developed. These numerical models were used to address dilution, which is one of the abiotic processes that contribute to reduction of contaminant concentrations as the contaminants are transported through the aquifer. Additional processes that may further reduce contaminant concentrations (i.e., dispersion, sorption, and biodegradation) were not simulated and thus, the simulated concentrations presented here are greater than concentrations that might actually be observed. 


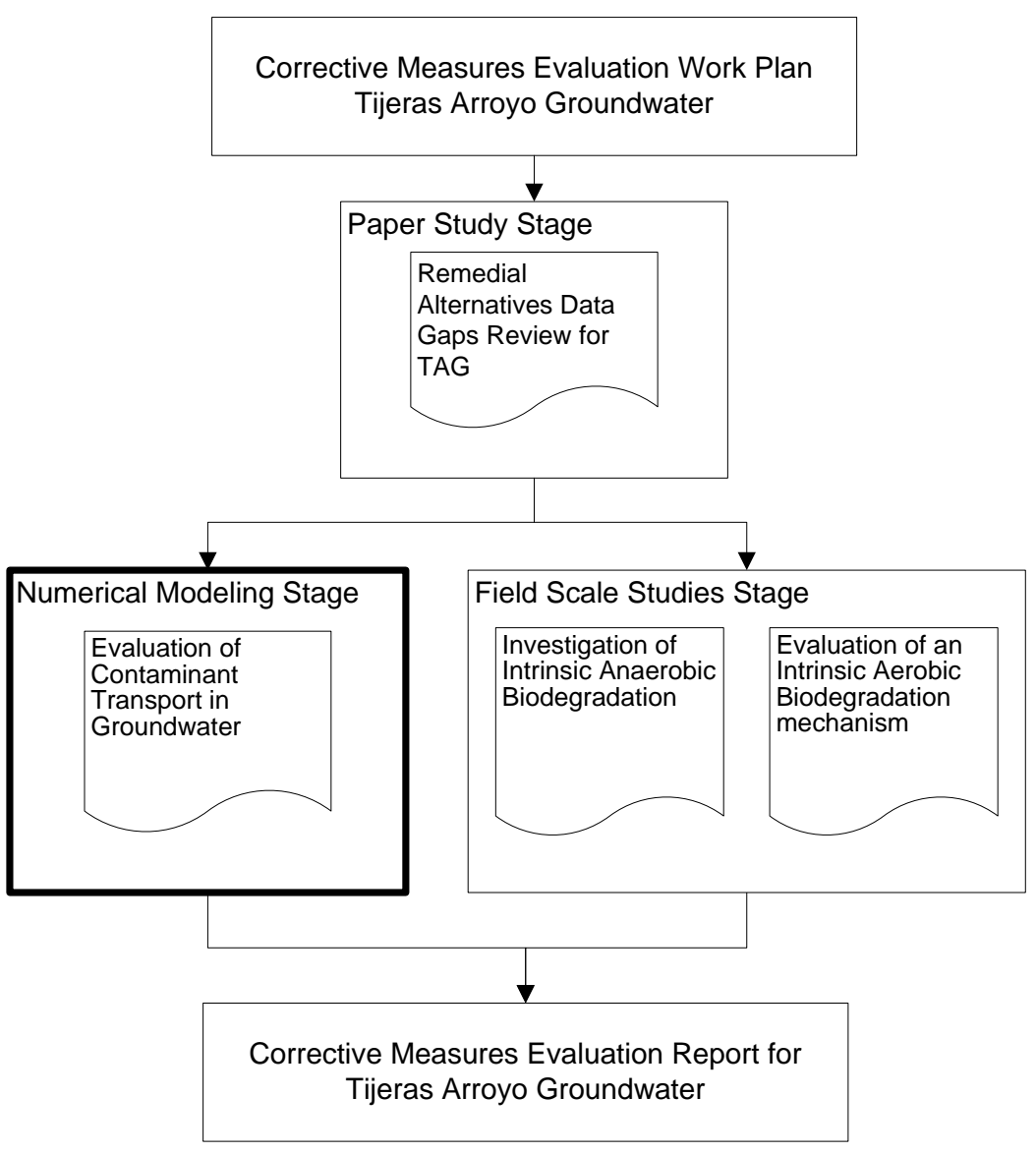

Figure 1-1. Illustration of the staged process of data gathering activities and production of subsequent reports. 


\subsection{CONCEPTUAL MODEL}

The numerical modeling approach described in Section 3 is based on the conceptual model summarized here. This conceptual model includes a discussion of the hydrogeology of the perched system (Section 2.1), hydrogeology of the regional aquifer (Section 2.2), and contaminant sources and transport within the SNL/NM AOR (Section 2.3). The primary sources of the information presented in this section include the TAG CME Work Plan (SNL/NM 2004a) and the Current Conceptual Model of Groundwater Flow and Contaminant Transport at Sandia National Laboratories/ New Mexico Technical Area V (SNL/NM 2004b). The Technical Area V Conceptual Model is referenced here because the document summarizes the regional hydrogeologic context of the Albuquerque Basin.

Two aquifers in the Upper Santa Fe Group have been identified in the TAG study area: a perched system and the regional aquifer. In the northern portion of the TAG area, the depth to potentiometric surface of the perched system ranges from approximately 220 to $330 \mathrm{ft}$ below ground surface (bgs), whereas the depth to potentiometric surface of the regional aquifer is approximately 440 to $570 \mathrm{ft}$ bgs. The regional aquifer is used as a potable water source by KAFB, COA, and the Veterans Administration (VA).

Water moves to the southeast within the perched system and probably migrates from the perched system into the underlying regional aquifer southeast of Tijeras Arroyo. For this evaluation it is assumed that groundwater moves from the perched system into the regional aquifer, however, this has not been definitively proven. Groundwater in the regional aquifer migrates to the west and northwest in the alluvial fan lithofacies toward the highly permeable ancestral Rio Grande (ARG) lithofacies. After reaching the ARG lithofacies of the regional aquifer, groundwater flows northward toward pumping centers.

It is expected that trichloroethene (TCE) and nitrate present in the perched system will follow these groundwater flow paths. These contaminants will be diluted during transport to production wells in the ARG lithofacies. Dilution will occur first when perched groundwater recharges the regional aquifer in the alluvial fan lithofacies, and second as groundwater in the lower permeability alluvial fan lithofacies enters the higher permeability ARG lithofacies.

\subsection{Perched Groundwater System}

The perched groundwater system is present beneath the TAG study area, as shown in Figure 2-1. Discontinuous, yet overlapping multiple lenses of alluvial-fan clay and silt serve as a perching layer. Vertical groundwater flow is considered to be minimal because of these lenticular clay units. Table 2-1 summarizes hydrogeologic characteristics of the perched system.

Based on present information, the perched system extends over at least 3.5 square miles. Monitoring wells bound the perched system on the western and southern margins. The northern margin of the perched system has not been fully defined and may extend across the KAFB boundary north of the Wyoming Gate and east to the Eubank Landfill. A southeastern margin is not discernible because the perched system merges with the regional aquifer (i.e., the potentiometric surface of the perched system and the regional aquifer coincide). The direction of groundwater flow in the perched system is inferred to be principally to the southeast, with a horizontal gradient of approximately $0.008 \mathrm{ft} / \mathrm{ft}$ (SNL/NM 2002). 
This Page Intentionally Left Blank C-12 


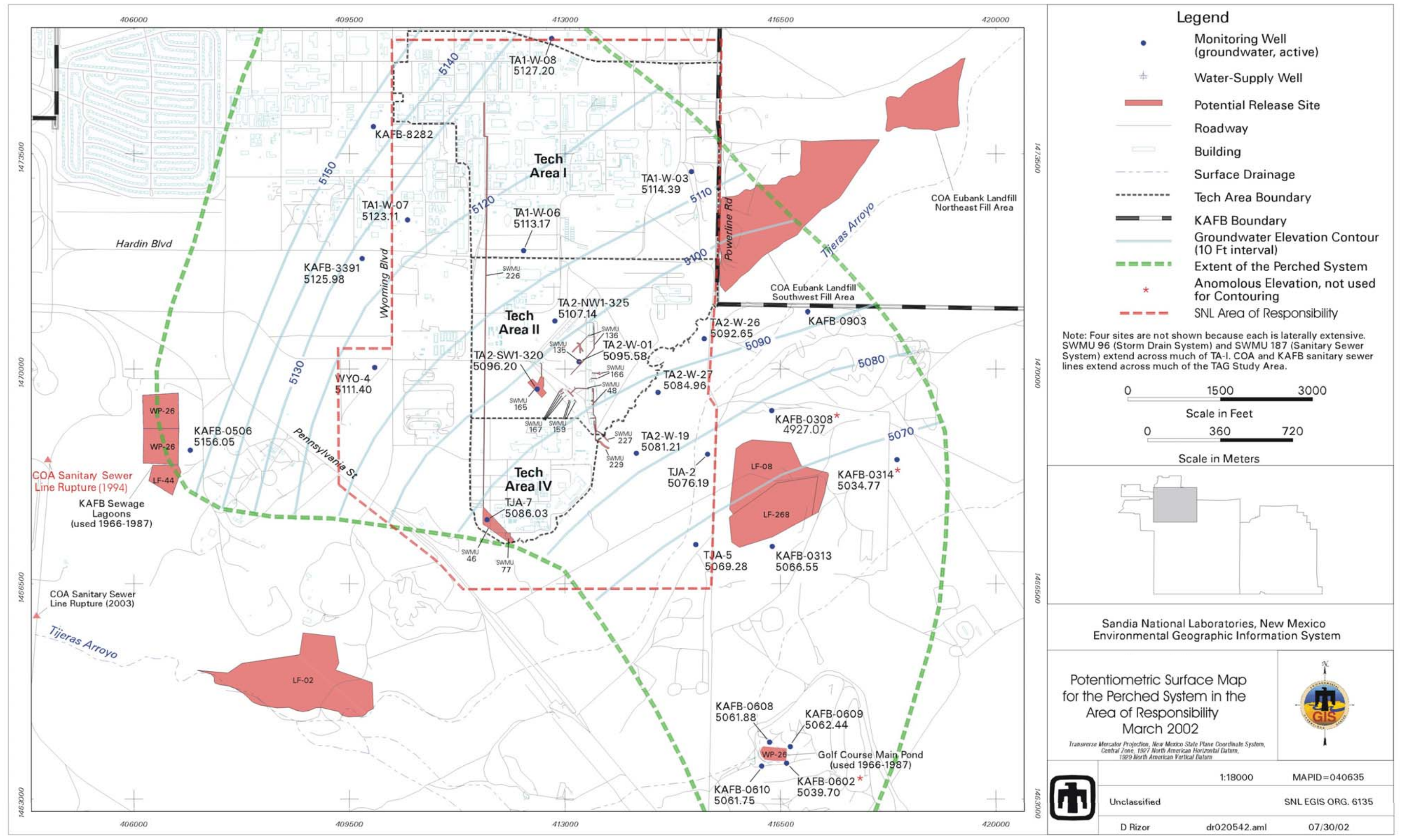

Figure 2-1. Potentiometric surface map for the perched system in the SNL/NM Area of Responsibility, March 2002 (SNL/NM 2004a). 
This Page Intentionally Left Blank 
Table 2-1. Summary of perched system properties.

\begin{tabular}{l|c}
\hline \multicolumn{1}{c|}{ Property } & Value or Range \\
\hline Horizontal hydraulic conductivity (SNL/NM 2004c) & $0.05-3.1 \mathrm{ft} / \mathrm{day}$ \\
Hydraulic gradient (SNL/NM 2002) & $0.008 \mathrm{ft} / \mathrm{ft}$ \\
Assumed effective porosity (SNL/NM 2004a) & $25 \%$ \\
Saturated thickness (SNL/NM 2004a) & $10-30 \mathrm{ft}$ \\
Groundwater flow direction (SNL/NM 2004a) & primarily to the southeast \\
\hline
\end{tabular}

Previous conceptual and numerical modeling supported an interpretation that the perched groundwater system is a result of past and ongoing water-management on a system primed for saturation by natural sources (Balleau Groundwater, Inc. 2002). Significant sources of past and present recharge to the perched groundwater system may include Tijeras Arroyo, Arroyo del Coyote, sewage lagoons, a golf course pond, SNL/NM waste disposal sites, leaking sewer lines, and irrigation of the Tijeras Arroyo Golf Course, parade grounds, and lawns.

Historically, water levels in the perched system have fluctuated across the TAG study area (SNL/NM 2002). Water levels have been declining since 1987 in the vicinity of the sewage lagoons and other areas northwest of Tijeras Arroyo, apparently in response to the lagoons being removed from service. Conversely, water levels have increased southeast of Tijeras Arroyo.

Tijeras Arroyo is the most significant surface-water drainage feature on KAFB and trends southwest across KAFB, eventually draining into the Rio Grande approximately six miles west of KAFB. Surface water flows in the arroyo several times per year as a result of storm events. The annual precipitation for the area, as measured at the Albuquerque International Sunport, is 8.2 in. (SNL/NM 2001a). During most rainfall events, rainfall quickly infiltrates into the soil; however, virtually all of the moisture subsequently undergoes evapotranspiration. Estimates of evapotranspiration for the KAFB area range from 95 to $99 \%$ of the annual rainfall (SNL/NM 1998).

\subsection{Regional Aquifer}

The geologic and hydrologic conditions of the regional aquifer in the Albuquerque Basin control groundwater flow and contaminant migration to potential human receptors at production wells. This section briefly describes the hydrogeologic setting (as defined by large-scale geologic features) (Section 2.2.1), the hydrostratigraphic framework of the Albuquerque Basin and the basin-fill sedimentary units of the Santa Fe Group (Section 2.2.2), recharge (Section 2.2.3), discharge (Section 2.2.4), and groundwater flow (Section 2.2.5). A summary of parameters pertinent to the numerical modeling effort is shown in Table 2-2. 
Table 2-2. Summary of regional aquifer properties.

\begin{tabular}{l|c}
\hline \multicolumn{1}{c|}{ Property } & Value \\
\hline Horizontal hydraulic conductivity (SNL/NM 2002) & $\begin{array}{c}0.001-44.7 \mathrm{ft} / \mathrm{day} \text { (alluvial fan } \\
\text { lithofacies) and } 10-150 \mathrm{ft} / \mathrm{day} \\
\text { (ARG lithofacies) }\end{array}$ \\
Hydraulic gradient (SNL/NM 2002) & $\begin{array}{c}\text { approximately } 0.009 \mathrm{ft} / \mathrm{ft} \\
\text { Assumed effective porosity (SNL/NM 2004a) }\end{array}$ \\
$\begin{array}{l}\text { Saturated thickness (SNL/NM 2004a) } \\
\text { Groundwater flow direction (SNL/NM 2004a) }\end{array}$ & in excess of $1,000 \mathrm{ft}$ \\
\hline
\end{tabular}

\subsubsection{Large-Scale Geologic Features}

The Rio Grande Rift is a relatively continuous regional structural feature that extends north from Mexico, across New Mexico, and into southern Colorado. Formation of this feature began 25 million years ago in northern Mexico when tectonic forces began to pull apart the brittle upper crust of the North American Plate and continued toward the north.

The Rio Grande Rift is marked by a series of sediment-filled structural basins and adjoining uplifted mountain ranges. One of these basins, the Albuquerque Basin (also known as the Middle Rio Grande Basin), covers about 3,060 square miles in central New Mexico and extends from the Cochiti Reservoir on the north to San Acacia, New Mexico on the south. The Albuquerque Basin includes the COA and parts of Santa Fe, Sandoval, Bernalillo, Valencia, Socorro, Torrance, and Cibola Counties.

The major fault systems that bound the Albuquerque Basin have dominated the development of geologic and hydrologic features within the basin. These fault systems consist of sets of subparallel, high-angle, large-displacement normal faults that separate the subsided basin from adjoining uplifted mountain blocks. Fault blocks on the inside of the rift zone typically have dropped down relative to uplifted fault blocks on the eastern and western edges of the rift.

Rift zone faulting has controlled sedimentary deposition within the Albuquerque Basin throughout its history. Continued movement along faults has modified local drainage systems and formed topographically high areas that provided a ready source of newly-eroded sediments. Fault offsets brought Santa Fe Group sediments into contact with upfaulted Paleozic rocks along the basin margins. Because active faulting was occurring at the same time as sedimentary deposition, faults also have offset stratigraphic units within the Santa Fe Group. In addition, fault zones have served as conduits for vertical groundwater flow and as regional hydrologic boundaries of the Santa Fe Group aquifer.

The uplifted mountains to the east of the Albuquerque Basin act as groundwater flow boundaries and provide a source of streamflow and alluvial sediments to the basin from mountain drainages. Streamflow originating from these drainages furnishes a source of surface-water recharge to alluvial fan sedimentary deposits along the basin margins. Chemical interactions between water and rocks in these drainages affect the chemistry of water recharged to the Santa Fe Group aquifer. 


\subsubsection{Hydrostratigraphic Framework}

The Albuquerque Basin is filled with sedimentary deposits of the Santa Fe Group. Basin-fill deposits of the Santa Fe Group within the Albuquerque Basin are composed of distinct lithofacies, defined by depositional mode and characterized largely by texture. The ARG lithofacies consists of well-sorted, coarse-grained, fluvial sands and gravels that were transported from distant sources to the north during the development of the through-flowing drainage of the Rio Grande. ARG sediments typically are highly permeable. The alluvial-fan lithofacies consists of poorly sorted piedmont-slope deposits derived from the Sandia, Manzanita, and Manzano Mountains east of the TAG study area. These sediments typically are much less permeable than the coarser sediments of the ARG.

\subsubsection{Regional Recharge}

Recharge to the Santa Fe Group aquifer occurs from infiltration of streamflow from the Rio Grande and arroyos, from infiltration of precipitation, and from underflow originating from mountain-front recharge. On the federal property that includes SNL/NM, Tijeras Arroyo and other ephemeral drainages provide limited recharge, as does mountain-front recharge, where it connects across the fault complexes. Infiltration of precipitation through the vadose zone is estimated to provide a negligible contribution to groundwater within the Albuquerque Basin, as 95 to $99 \%$ or more is estimated to be lost to evapotranspiration.

\subsubsection{Regional Discharge}

Regional discharge occurs as groundwater moves out of the Albuquerque Basin into downgradient basins in the Rio Grande Rift as underflow or through discharge to the Rio Grande. Discharge also occurs from pumping at the COA municipal production well fields. The discharge is greater than the recharge and effectively dewaters the aquifer on the federal property.

\subsubsection{Regional Groundwater Flow}

Prior to development of water resources in the Albuquerque area, groundwater in the Albuquerque Basin flowed generally from the north to the south, with a westward component of flow from recharge areas along mountain-front boundaries to the east. As the Santa Fe Group aquifer has been developed as a source for municipal and industrial water supplies, groundwater flow directions have been altered toward pumping centers (Figure 2-2).

Historically, water levels in the regional aquifer have fluctuated across the TAG study area (SNL/NM 2002). A line of demarcation between increasing water levels and declining water levels is evident along the eastern extent of the ARG lithofacies, which coincidentally trends along Wyoming Boulevard. Declining water levels approaching $1.5 \mathrm{ft} /$ year are apparently associated with the COA, KAFB, and VA water-supply wells. Increases in groundwater elevations of up to $1.8 \mathrm{ft} /$ year in the southeast portion of the TAG study area probably reflect recharge of the regional aquifer from the perched system, Tijeras Arroyo, the golf course, and the mountain front. 

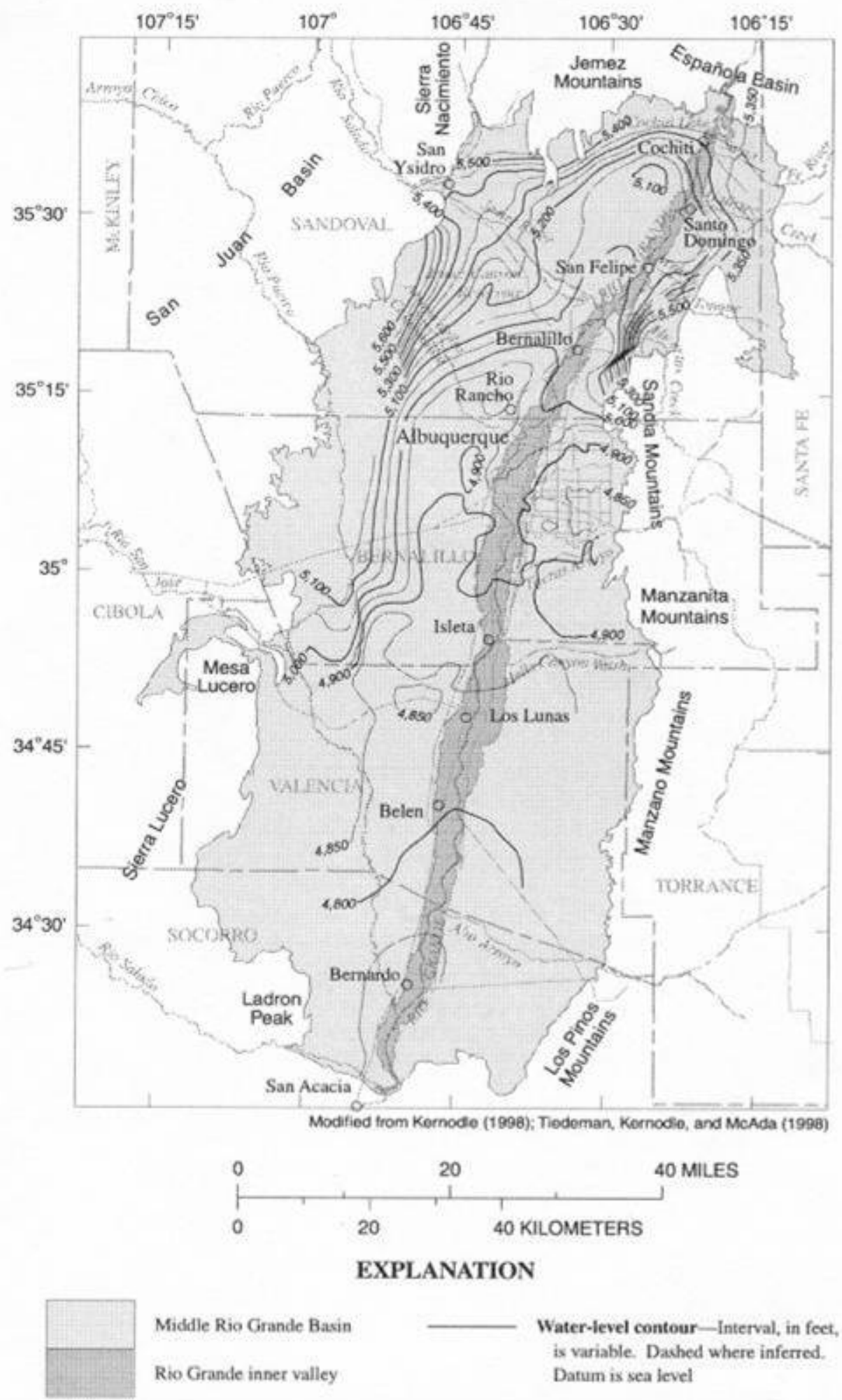

Water-ievel contour-Interval, in foet. is variable. Dashed where inferred. Datum is sea level

From Bartolino and Cole 2002

Figure 2-2. Configuration of the regional groundwater surface in the Albuquerque Basin, 1994-1995. 
The direction of groundwater flow in the regional aquifer is to the northwest toward the KAFB, COA, and VA water-supply wells. The horizontal hydraulic gradient in the regional aquifer across the central portion of the TAG study area is approximately $0.009 \mathrm{ft} / \mathrm{ft}$ with steeper gradients evident near the mountain front. Potentiometric surface elevation contours are shown on Figure 2-3 for the regional scale of the federal property and Figure 2-4 at the more local scale of the Tijeras Arroyo area.

On SNL/NM and KAFB property, the predominant groundwater flow was westward prior to water resources development (Bexfield and Anderholm 2000). Recent potentiometric surface elevation contour maps and numerical modeling studies show the significant hydrologic influence of the pumping centers just north of the federal boundaries. The Ridgecrest supply wells, in particular, are completed less than 1 mile north of the federal boundary and are screened in the north-south trending fluvial deposits (ARG). The capture zones of these wells extend south onto federal property (SNL/NM 2001b; Plate 3-2). The U.S. Air Force owns and operates a less influential network of supply wells within the federal boundaries. Together, these pumping centers contribute to the present post-development north-northwest groundwater flow direction in the ARG lithofacies.

\subsubsection{Hydrostratigraphic Units}

The aquifer in the alluvial fan lithofacies consists of fine-grained, layered, clay-rich sediments of the alluvial fan lithofacies of the Santa Fe Group. These sediments interfinger with the highly permeable sediments of the ARG to the west. The horizontal hydraulic conductivity of the alluvial fan lithofacies ranges from about 0.001 to $44.7 \mathrm{ft} / \mathrm{day}$ (SNL/NM 2002). The horizontal hydraulic conductivity of the ARG is as high as $150 \mathrm{ft} /$ day. The vertical hydraulic conductivity of both lithofacies is considered to be much lower because of the layered characteristics of the sediments. The effective porosity (a measure of the interconnected pore spaces in the alluvial fan lithofacies) is approximated from measurements of total porosity and moisture content to be $25 \%$.

\subsubsection{Groundwater Flow in Alluvial Fan Lithofacies}

Groundwater in the alluvial fan lithofacies is derived principally from mountain-front recharge to the east. Groundwater in the regional aquifer flows generally to the northwest in the TAG study area through the low-permeability alluvial fan lithofacies. Potentiometric contours indicate that groundwater flowpaths intercept the high-permeability ARG lithofacies and turn to the north in response to pumping at the large municipal well fields north of KAFB.

\subsection{Distribution of Groundwater Contaminants}

Contaminants of concern within the SNL/NM AOR include nitrate and TCE located within the perched system. The distribution of TCE is discontinuous across the perched system and does not indicate a single release site. Based upon the historic use of chlorinated solvents across $\mathrm{SNL} / \mathrm{NM}$ and KAFB, the known extent of TCE in groundwater is probably associated with multiple releases of aqueous-phase solvents and subsequent transport through the vadose zone. 


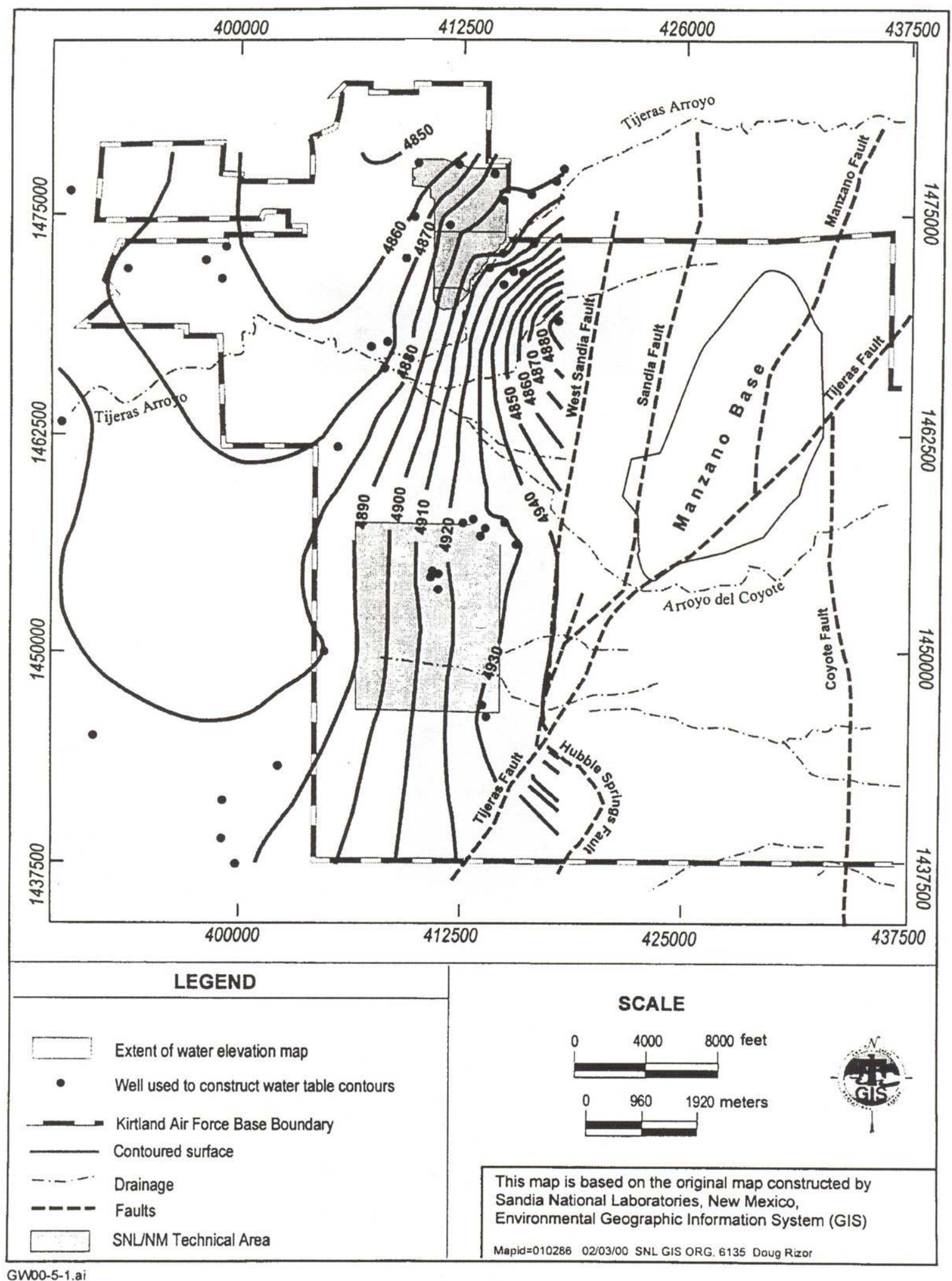

From SNL/NM 2000

Figure 2-3. Subregional potentiometric surface elevation contour map for basin fill deposits, 2000. 


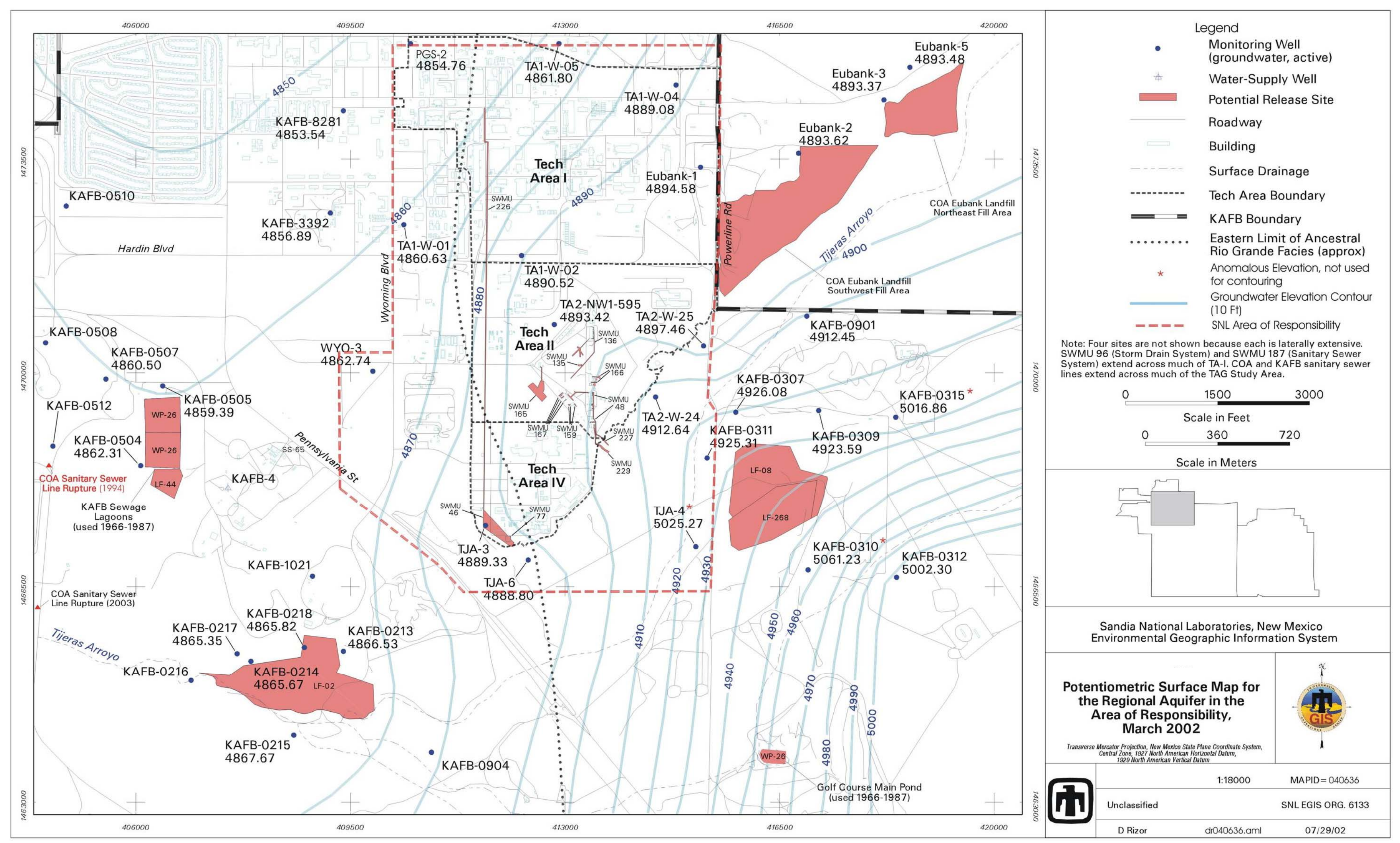

Figure 2-4. Potentiometric surface map for the regional aquifer in the TAG study area, March 2002. 
This Page Intentionally Left Blank 
TCE concentrations in samples from three SNL/NM perched system wells (TA2-W-19, TA2-W26, and WYO-4) have exceeded the maximum contaminant level (MCL) of $5.0 \mu \mathrm{g} / \mathrm{L}$ for TCE. The maximum historical concentration of TCE in the perched system was $9.6 \mu \mathrm{g} / \mathrm{L}$, detected in March 1998 in a sample from well TA2-W-26. TCE detected in samples from well WYO-4 are not considered to be within the scope of the CME. Well WYO-4 is an SNL/NM monitoring well that is located on KAFB property. Given that none of the SNL/NM potential release sites are near well WYO-4 and that groundwater flow in the perched system is to the southeast, the TCE concentrations present in WYO-4 are considered to represent contamination from an upgradient KAFB source. Therefore, concentrations observed in samples from this well are not considered in this transport evaluation. More recently, (October 2004) the maximum detected TCE concentration in samples from SNL/NM AOR wells (not including WYO-4) was $4.65 \mu \mathrm{g} / \mathrm{L}$ in a sample from TA2-W-19 (SNL/NM 2005a).

According to KAFB Installation Restoration Program terminology, nitrate contamination in the perched system forms what is referred to as “Plume 3" (MWH Americas, Inc., 2003). Plume 3, which is centered on monitoring well TA2-SW1-320, is located under the southwest portion of TA-II and may extend southward to TJA-7. Monitoring wells in the perched system that have nitrate concentrations below the MCL surround these wells. The plume is 0.3 miles long and 0.2 miles wide (MWH Americas, Inc., 2003) and is thought to emanate from Solid Waste Management Unit (SWMU)-165, the Building 901 Septic System. The maximum historical concentration of nitrate in the perched system within the SNL/NM AOR was $44 \mathrm{mg} / \mathrm{L}$ in water from wells TA2-W-19 (in January 1996) and TA2-SW1-320 (in November 2001). More recently, (October 2004) the maximum detected nitrate concentration in a SNL/NM perched zone well was $27.1 \mathrm{mg} / \mathrm{L}$ (as nitrogen) in a sample from well TJA-7 (SNL/NM 2005a).

At no time has an SNL/NM regional aquifer or merging zone well exceeded the MCL for TCE, and generally, TCE has not been detected in regional aquifer monitoring wells (with the exception of a historic peak of $3.2 \mu \mathrm{g} / \mathrm{L}$ in well PGS-2 and an estimated value of $0.6 \mu \mathrm{g} / \mathrm{L}$ in TJA-3).

The maximum historical concentration of nitrate within the SNL/NM AOR for wells completed in the regional aquifer system was $49 \mathrm{mg} / \mathrm{L}$ in merging zone well TJA-4. However, this is the only SNL/NM regional aquifer monitoring well that has ever had nitrate concentrations that exceed the MCL $(10 \mathrm{mg} / \mathrm{L})$. The nitrate contamination in the regional aquifer southeast of TA-II forms what is referred to as "Plume 4" (MWH Americas, Inc., 2003). Plume 4 is most likely responsible for the nitrate concentrations in TJA-4, a well completed in the zone of merging. The plume is 1.9 miles long and 1 mile wide and is associated with the active KAFB Landfill (MWH Americas, Inc., 2003).

\subsubsection{Implications of Contaminant Distribution to Numerical Modeling}

Nitrate and TCE are the COCs considered in the numerical modeling study. These contaminants are likely distributed in various locations within the SNL/NM AOR perched zone. The locations of concern for the current study are defined by the monitoring wells in which historical concentrations have exceeded MCLs. These monitoring wells are TA2-W-26 (TCE), TJA-7 (nitrate), and TA2-SW1-320 (nitrate). The historical maximum observed concentrations were considered when interpreting the results of the modeling study, even though the most recently observed concentrations in samples from these wells are substantially lower. 
This Page Intentionally Left Blank 


\subsection{MODELING APPROACH}

A numerical modeling study was performed to evaluate reduction in contaminant concentrations during transport from the perched system to potential downgradient receptors at pumping centers in the ARG lithofacies, including the Ridgecrest well field (COA municipal water production) and other potential pumping wells associated with KAFB and the VA.

The flow path from the perched system to potential pumping wells was estimated based on potentiometric data and hydrogeologic properties, as described in Section 2.0. A numerical modeling approach was devised for estimating the effects of dilution during transport on a conservative solute. This approach involved simulating three regions, including: (1) an estimate of flow out of the perched system, (2) transport through an alluvial fan model section, and (3) transport through an ARG model section. These simulated regions are shown in Figures 3-1 and $3-2$, and the following is a short description of each:

1. Perched Groundwater System Estimate of Flow. This region included the perched groundwater system between the current location of contaminants and the zone of merging of the perched system and regional aquifer. This section was simulated as flow into the alluvial fan model section, which was estimated from observed aquifer parameters.

2. Alluvial Fan Model Section. This region included northwestern groundwater flow in alluvial fan lithofacies. A 1.4-mile long cross-sectional model was devised for this section in which the estimate of flow from the perched system comprises a portion (2.2\%) of the total flow through the alluvial fan model section.

3. ARG Model Section. Groundwater flows northward through this region toward COA pumping centers. This region was simulated using a 10-mile long cross-sectional approach in which flow from the alluvial fan section formed a portion (11.5\%) of the total flow through the ARG section.

The following are the general methods, assumptions, and limitations of the numerical modeling approach:

- The cross-sectional models developed for the alluvial fan and ARG model sections used the Department of Defense Groundwater Modeling System (GMS), employing the MODFLOW groundwater model (Harbaugh et al. 2000) and the MT3DMS transport model (Zheng and Wang 1999) with GMS pre- and post-processors (BYU 2003).

- The numerical modeling approach intentionally did not account for the processes of dispersion, sorption, or degradation. Therefore, the approach is conservative and concentrations are intentionally overestimated because these processes will decrease concentrations further (where active on a particular contaminant). 


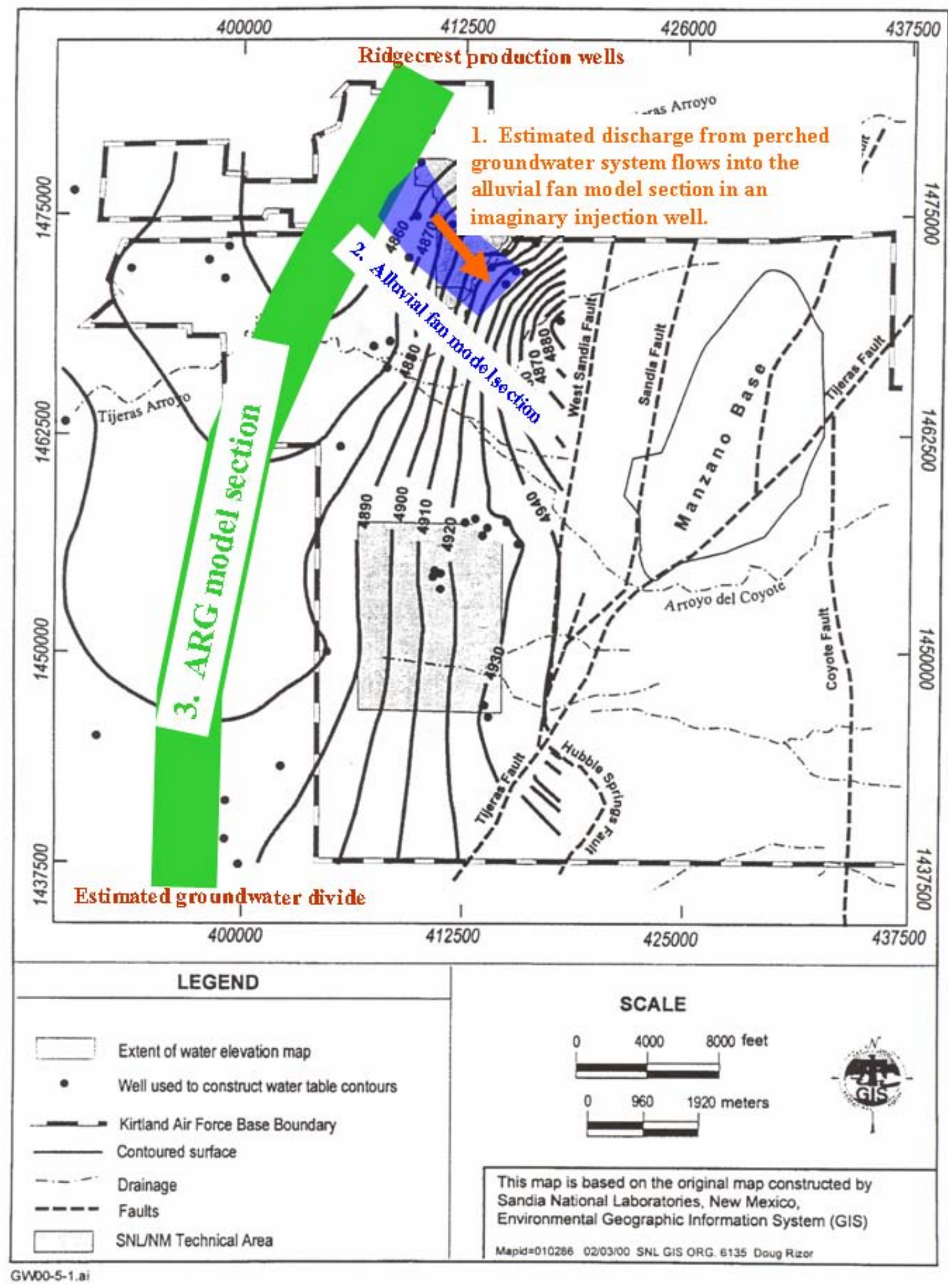

Figure 3-1. Regional potentiometric surface map and location of simulated regions. 


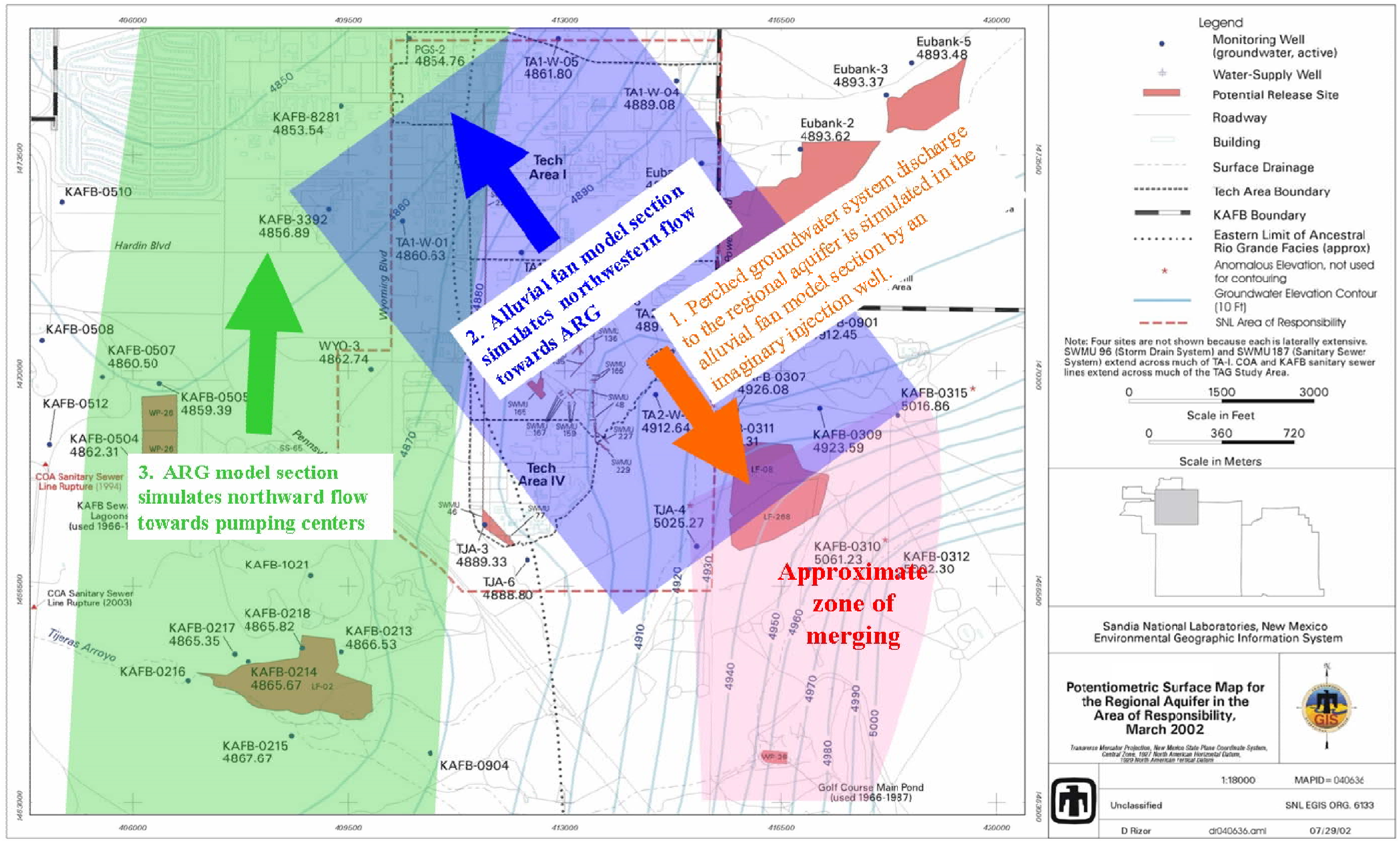

Figure 3-2. Local potentiometric surface map and location of simulated regions. 
This Page Intentionally Left Blank 
- The numerical modeling approach simulated groundwater flow in the upper portion of the regional aquifer. This aquifer is estimated to have a saturated thickness in excess of 1,000 ft (SNL/NM 2004a). The approach assumed transport through single-layer numerical models that are 100 and $600 \mathrm{ft}$ deep. This approach is conservative because it neglects additional dilution that might occur as groundwater from shallow and deep aquifer zones is mixed at production wells.

- As the solute moved from one hydrogeologic simulation to the next (i.e., from the alluvial fan model section into the ARG model section), the solute was simulated to be instantaneously mixed with pristine water throughout the model cells. This mixing is more likely to occur along the flow path or during withdrawal at pumping centers. As a consequence, the numerical modeling is useful for evaluating the relative reduction in concentration as it pertains to pumping wells completed in the ARG lithofacies, but should not be used for interpreting concentration changes at more localized scales.

- No flow was assumed to move across the transverse boundaries of the cross-sectional models because the sections were considered to be parallel to the flow path derived from the potentiometric surface.

- The width (cross-gradient dimension) of the cross sections was simulated to be 6,000 ft. This width is the width over which flow is estimated from the perched system (Section 3.1) and is used for each of the model sections (Sections 3.2 and 3.3).

- The simulated porosity of the material (25\%) was constant throughout the numerical modeling sections. This value is a reasonable and accepted value for porous media (SNL/NM 2004a).

- Solute concentrations were simulated relative to an initial concentration of 1 unit (or 100\%). The concentration in the simulated flow from the perched system was 1 unit concentration for the duration of the simulation. The numerical models were run until steady state concentrations were achieved at the downgradient boundary of the ARG model section simulating the Ridgecrest well field.

- The expected maximum concentration of contaminants at potential and existing production wells in the ARG lithofacies was estimated in Section 4.0. These estimates were based on applying the relative simulated concentration of solute in the ARG model section to observed historical maximum concentrations in the SNL/NM AOR. The concentrations are conservative estimates of the contribution of nitrate and TCE that may be transported from the SNL/NM AOR to production wells.

Table 3-1 provides summary information and input parameters for each of the three modeled regions. Sections 3.1 through 3.3 provide detailed information and input parameters about the simulation. 
Table 3-1. Summary information and input parameters.

\begin{tabular}{|c|c|c|c|}
\hline & $\begin{array}{l}\text { Perched System } \\
\text { Estimate of Flow } \\
\text { (Section 3.1) }\end{array}$ & $\begin{array}{l}\text { Alluvial Fan } \\
\text { Model Section } \\
\text { (Section 3.2) }\end{array}$ & $\begin{array}{l}\text { ARG Model } \\
\text { Section } \\
\text { (Section 3.3) }\end{array}$ \\
\hline Flow model length & $\mathrm{N} / \mathrm{A}^{\mathrm{a}}$ & 1.4 miles & 10.0 miles \\
\hline Cell width & $6,000 \mathrm{ft}$ & $6,000 \mathrm{ft}$ & $6,000 \mathrm{ft}$ \\
\hline $\begin{array}{l}\text { Vertical saturated } \\
\text { Thickness }\end{array}$ & $20 \mathrm{ft}$ & $100 \mathrm{ft}$ & $600 \mathrm{ft}$ \\
\hline Number of cells & $\mathrm{N} / \mathrm{A}^{\mathrm{a}}$ & 15 & 88 \\
\hline Upgradient boundary type & $\mathrm{N} / \mathrm{A}^{\mathrm{a}}$ & constant head & $\begin{array}{c}\text { no flow, simulating } \\
\text { groundwater flow } \\
\text { divide }\end{array}$ \\
\hline $\begin{array}{l}\text { Downgradient boundary } \\
\text { type }\end{array}$ & $\begin{array}{c}\text { Is an approximation } \\
\text { of the zone of } \\
\text { merging as shown } \\
\text { on Figure 3-2 }\end{array}$ & constant head & constant head \\
\hline Hydraulic conductivity & $1.6 \mathrm{ft} / \mathrm{day}$ & $14.1 \mathrm{ft} /$ day & $150 \mathrm{ft} /$ day \\
\hline Effective porosity & $\mathrm{N} / \mathrm{A}^{\mathrm{a}}$ & $25 \%$ & $25 \%$ \\
\hline Potential receptor locations & None & None & $\begin{array}{l}\text { Ridgecrest municipal } \\
\text { pumping wells, } \\
\text { KAFB supply wells, } \\
\text { and VA supply wells }\end{array}$ \\
\hline
\end{tabular}

a. The perched system flow was estimated using the approach outlined in Section 3.1, which did not involve the use of a MODFLOW numerical model.

\subsection{Estimate of Flow from the Perched Groundwater System}

As stated in Section 2.0, the SNL/NM AOR includes perched system groundwater contaminated with TCE and nitrate. Groundwater in the perched system is known to merge with the regional aquifer within the zone of merging depicted on Figure 3-3. This section summarizes an estimate of discharge from the perched groundwater system through the zone of merging and into the alluvial fan lithofacies of the regional aquifer (Section 3.1.1) and an estimate of transport time of contaminants to the zone of merging (Section 3.1.2). 


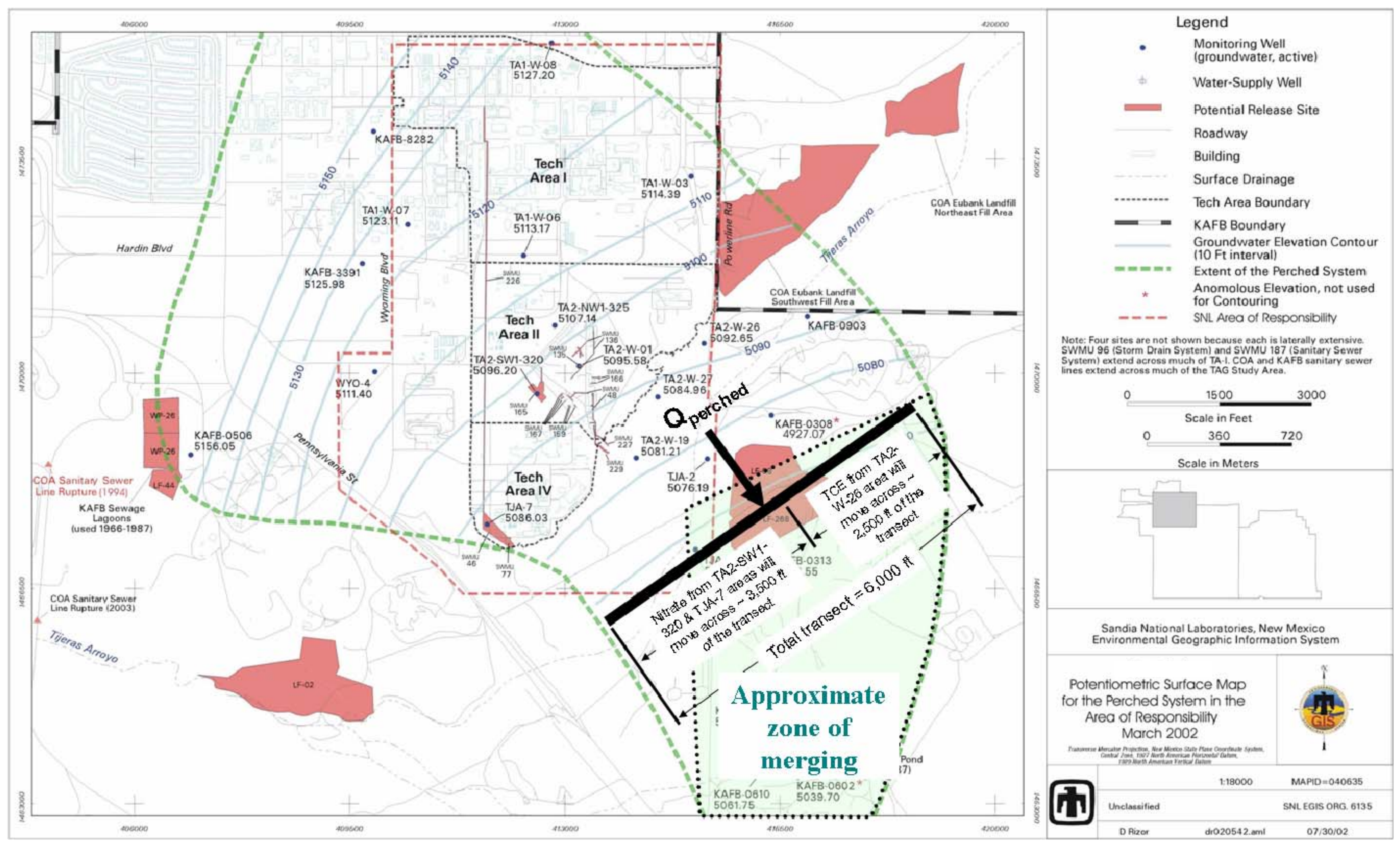

Figure 3-3. Perched system illustration. 
This Page Intentionally Left Blank 


\subsubsection{Estimate of Perched Groundwater System Discharge}

Contaminants in the perched groundwater system will continue to move with ambient groundwater flow southeast to the zone of merging. At the zone of merging groundwater from the perched groundwater system discharges into the alluvial fan lithofacies of the regional aquifer. A conservative approach to estimating this discharge is based on the following assumptions:

- Groundwater from the perched system was assumed to move instantaneously into the regional aquifer where flow lines cross the transect (shown on Figure 3-3) as if the perching layer suddenly ended. It is recognized that the zone of merging more likely occurs gradually as the perching horizon becomes more permeable. However, the assumption is conservative with respect to downgradient solute concentration and travel time because the transect was chosen to intentionally minimize the total distance of the flow path in both the perched system and the regional aquifer.

- The width (W) over which the merging occurs is approximately 6,000 ft, which is based on the distribution of nitrate and TCE and the extent of the perched system. This width is shown in Figure 3-3 as the cross-gradient transect of the perched system at the northern end of the zone of merging. The potential contribution of TCE and nitrate contaminated groundwater to the total flux across the 6,000-ft transect is also illustrated in Figure 3-3, which is used for interpretations in Section 4.2.

- The saturated thickness (D) of the perched groundwater system at the zone of merging ranges from 10 to $30 \mathrm{ft}$ (see Section 2.0).

- The hydraulic gradient (i) within the perched system is $0.008 \mathrm{ft} / \mathrm{ft}$. This estimate is based on the distance between the 5,090-ft and the 5,070-ft potentiometric surface elevation contours, but the estimated gradient is also the same as the overall average gradient for the perched system (see Section 2.0).

- Horizontal hydraulic conductivity $\left(\mathrm{K}_{\mathrm{H}}\right)$ ranges from 0.05 to $3.1 \mathrm{ft} /$ day (see Section 2.0).

Given the assumptions listed above, the discharge of groundwater out of the perched groundwater system was estimated using the following equation derived from Darcy's Law (Equation 1):

$\mathrm{Q}=\mathrm{K}_{\mathrm{H}} \mathrm{iA}=\mathrm{K}_{\mathrm{H}} \mathrm{iWD}$

Equation 1.

where

$\begin{array}{lll}\mathrm{Q} & = & \text { flow in } \mathrm{ft}^{3} / \text { day } \\ \mathrm{K}_{\mathrm{H}} & = & \text { horizontal hydraulic conductivity in } \mathrm{ft} / \text { day } \\ \mathrm{i} & = & \text { hydraulic gradient } \\ \mathrm{A} & = & \text { area in } \mathrm{ft}^{2}\end{array}$




$$
\begin{array}{lll}
\mathrm{W} & = & \text { width in } \mathrm{ft} \\
\mathrm{D} & = & \text { saturated thickness in } \mathrm{ft} .
\end{array}
$$

Considering the range of hydraulic conductivity and saturated thickness, the discharge from the perched system ranges from $24 \mathrm{ft}^{3} /$ day $\left(\mathrm{D}=10 \mathrm{ft}\right.$ and $\mathrm{K}_{\mathrm{H}}=0.05 \mathrm{ft} / \mathrm{day}$ ) to $4,460 \mathrm{ft}^{3} /$ day $(\mathrm{D}=$ $30 \mathrm{ft}$ and $\mathrm{K}_{\mathrm{H}}=3.1 \mathrm{ft} /$ day) across the $6,000 \mathrm{ft}$ wide transect. The value used as flow input into the alluvial fan model section is $4,460 \mathrm{ft}^{3} / \mathrm{day}$. The highest estimated value was used for subsequent model inputs in order to intentionally estimate the upper limit of perched groundwater system discharge to the regional aquifer. As a consequence, the overall transport evaluation is made more conservative (i.e., intentionally estimates the upper limit of solute concentration) because the upper limit of solute flux into the alluvial fan section is used.

The concentration in the simulated flow from the perched system into the alluvial fan model section was 1 unit concentration for the duration of the simulation. This approach allows for a conservative evaluation of solute concentration reduction as it is transported to potential receptors but is recognized to overestimate the mass of both TCE and nitrate, as neither of these contaminants is distributed at the maximum concentration over the 6,000-ft cross-gradient length. The results of the transport simulation were interpreted using actual observed concentrations in Section 4.2.

\subsubsection{Estimate of Transport Time}

An estimate of transport time of contaminants through the perched system was made using the same assumptions stated in Section 3.1.1. Additional assumptions necessary for this estimate are:

- The porosity ( $\eta$ ) of the material is $25 \%$, which is the accepted value for the perched system materials (SNL/NM 2004a) and is assumed to represent effective porosity.

- The length of travel (L) of contaminants is the shortest distance between the three monitoring wells of concern (TA2-W-26 [TCE], TJA-7 [nitrate], and TA2-SW1-320 [nitrate]) and the transect shown in Figure 3-3. The estimated distances are shown in Table 3-2.

- Contaminants are conservatively transported with ambient groundwater flow without retardation.

The groundwater velocity is estimated using the following equation:

$v=\frac{K_{H} i}{\eta}$

Equation 2.

where

$v=$ velocity of the groundwater and contaminants in the groundwater, $\mathrm{ft} / \mathrm{day}$

$\mathrm{K}_{\mathrm{H}}=$ Horizontal hydraulic conductivity, $\mathrm{ft} /$ day

$\mathrm{i} \quad=\quad$ hydraulic gradient, $\mathrm{ft} / \mathrm{ft}$

$\eta \quad=\quad$ porosity. 
The travel time is then given by solving the equation for velocity ( $v=\mathrm{L} /$ time) for time. As shown on Table 3-2, the estimated travel times range from less than 100 years to several thousand years based on the horizontal hydraulic conductivity used. In order to be conservative (intentionally estimate the minimum travel time), the minimum travel times for each contaminant have been used for the interpretations summarized in Section 4.2. These travel times are 70 years for TCE and 60 years for nitrate.

Table 3-2. Estimate of contaminant travel time in the perched system.

\begin{tabular}{ccccc}
\hline & $\begin{array}{c}\text { Horizontal Hydraulic } \\
\text { Conductivity } \\
\left(\mathrm{K}_{\mathrm{H}}\right), \mathrm{ft} / \text { day }\end{array}$ & $\begin{array}{c}\text { Velocity } \\
(\mathrm{v}), \\
\mathrm{ft} / \text { day }\end{array}$ & $\begin{array}{c}\text { Length }(\mathrm{L}), \\
\mathrm{ft}\end{array}$ & $\begin{array}{c}\text { Time, } \\
\text { years }\end{array}$ \\
\hline $\begin{array}{c}\text { TJA-7 area (nitrate) } \\
\text { TA2-SW1-320 area } \\
\text { (nitrate) }\end{array}$ & 0.05 & 0.002 & 2,200 & 3,800 \\
TA2-W26 area (TCE) & 0.05 & 0.002 & 3,500 & 6,000 \\
\hline $\begin{array}{c}\text { TJA-7 area (nitrate) } \\
\text { TA2-SW1-320 area } \\
\text { (nitrate) }\end{array}$ & 0.05 & 0.002 & 2,700 & 4,600 \\
\hline $\begin{array}{c}\text { TA2-W26 area (TCE) } \\
\text { Th }\end{array}$ & 3.1 & 0.10 & 2,200 & 60 \\
\hline
\end{tabular}

\subsection{Alluvial Fan Model Section}

The alluvial fan model section represents the groundwater flow system that extends west and northwest through the low-permeability alluvial fan lithofacies of the Albuquerque Basin from the mountain front to the high-permeability ARG lithofacies, as observed on the local potentiometric surface map (Figure 3-2). Flow through the alluvial fan lithofacies is horizontally preferential because of the layered, lenticular nature of these deposits. Water along this flowpath generally originates from mountain-front recharge to the east and infiltrating recharge in the vicinity of the zone of merging from Tijeras Arroyo and other sources.

Model Grid-The numerical model represents a groundwater flowpath that extends 1.4 miles northwest from an arbitrary location in the zone of merging to a location representing the junction between the alluvial fan and the ARG, as shown in Figure 3-2. The model section consists of a single layer, with the top approximately $10 \mathrm{ft}$ above the altitude of the simulated potentiometric surface and the bottom at an altitude $100 \mathrm{ft}$ lower than the top (approximately $90 \mathrm{ft}$ of saturated thickness). The model section consists of a single row (with 15 cell columns from southeast to northwest) with cell dimensions $500 \mathrm{ft}$ long (in the direction of flow) and $6,000 \mathrm{ft}$ wide. 
Model Boundaries and Hydrologic Properties-The flow system was simulated with an average horizontal hydraulic gradient of $0.009 \mathrm{ft} / \mathrm{ft}$. An upgradient constant head boundary $(4,944 \mathrm{ft})$ represented mountain front recharge, and a downgradient constant head boundary $(4,880 \mathrm{ft})$ represented the intersection of the alluvial fan lithofacies and the ARG lithofacies. Actual observations of the potentiometric heads at these locations were not available and were furthermore complicated by the anomalous water levels in the zone of merging monitoring wells. Therefore, the constant heads at the boundaries were interpolated from the observed water levels in five monitoring wells (KAFB-0311, KAFB-0307, TA2-W-24, TA2-NW1-595, and TA1-W-02).

The horizontal hydraulic conductivity of $14.1 \mathrm{ft} /$ day was determined by adjusting the model to produce the calibrated flow into the ARG model cells, which represents underflow into the ARG lithofacies from mountain front recharge (see Section 3.3). This hydraulic conductivity value is considered a reasonable representation given that the horizontal hydraulic conductivity in the alluvial fan lithofacies of the regional aquifer is expected to range from 0.001 to $44.7 \mathrm{ft} / \mathrm{day}$ (SNL/NM 2002). In addition, a United States Geological Survey (USGS) regional flow model used an east-west range of hydraulic conductivity ranging from 8 to $15 \mathrm{ft} /$ day in cells simulating alluvial fan deposits (Bexfield and McAda 2003).

Calibration-Simulated heads were compared to observed water levels in five monitoring wells (see Figure 3-4). The constant head elevations were intentionally chosen to produce a hydraulic gradient of approximately $0.009 \mathrm{ft} / \mathrm{ft}$ and simulate a gradient approximated by these water level observations. The relatively minor deviation in observed water levels from simulated head is likely a result of heterogeneity of the alluvial fan lithofacies, while the model assumed homogeneous properties. The cross-sectional flow model permitted a reasonable representation of flow and transport.

Flow Model Results-Simulated flow through the cross-sectional model moved from southeast to northwest. An average flow of approximately $70,000 \mathrm{ft}^{3} /$ day moved out of the model at the downgradient constant-head boundary during the simulation, representing flow out of a 6,000-ft wide section of the alluvial fan deposits into the ARG. 


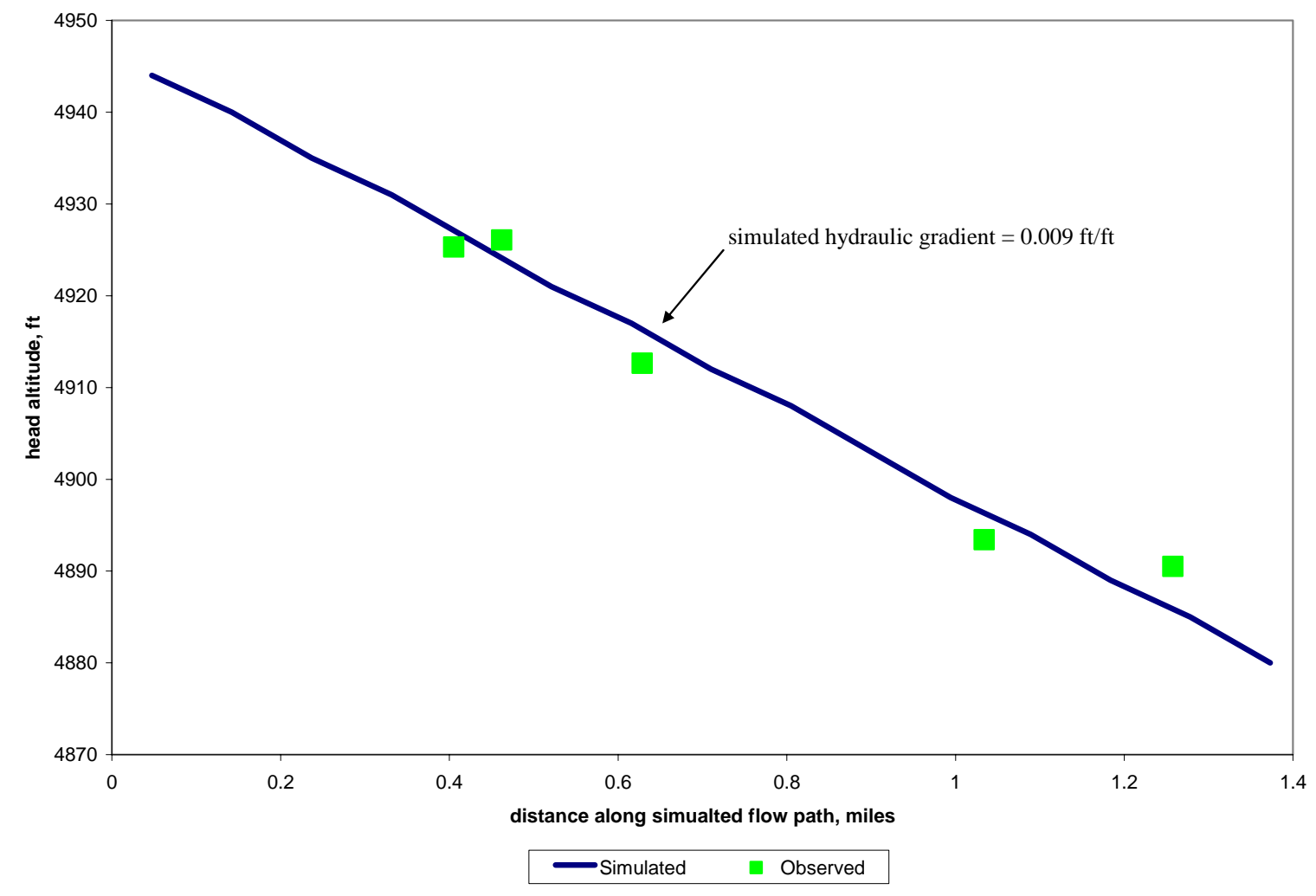

Figure 3-4. Comparison of simulated and observed potentiometric head along the alluvial fan model section.

\subsection{Ancestral Rio Grande Model Section}

The ARG model section begins south and west of KAFB near an estimated groundwater divide separating flow toward pumping centers to the north from natural system flow to the south. The section represents flow northward through the high-permeability ARG lithofacies, as inferred from water-table contour maps (Figure 3-1). Groundwater along this flowpath generally accretes from underflow out of alluvial fan deposits to the east and recharge from the Rio Grande to the west. The ARG model section simulated accretion of underflow out of the alluvial fan lithofacies to the east.

Grid-The ARG model section represents a groundwater flowpath that extends 10 miles north from the estimated groundwater flow divide to the Ridgecrest well field. The model section consists of one layer, with the bottom at an altitude of $4,400 \mathrm{ft}$. This bottom elevation includes most of the aquifer thickness presently utilized by pumping wells but does not account for flow within underlying Santa Fe Group sediments.

The model section consists of 88 cells, with cell dimensions $600 \mathrm{ft}$ long (direction of groundwater flow) and 6,000 ft wide (cross-gradient). The width dimension represents most of the flow through the ARG that would be derived from accreted flows from the east. 
Model Boundaries and Hydrologic Properties-The estimated groundwater divide to the south was simulated as a no-flow boundary. The cumulative cone of depression in the water table in the vicinity of the Ridgecrest well field has steadily developed over time because of continuous pumpage to meet municipal requirements. In the cross-sectional model, this well field was represented at the northern terminus of the flowpath by a constant head at an altitude of 4,850 ft, which was the approximate water level in well Ridgecrest 4 in 2000. Accreted underflow originating from mountain fronts east of the ARG was represented by injection wells in each cell along the section.

A previous regional flow model used a hydraulic conductivity of $150 \mathrm{ft} /$ day to represent the ARG (Bexfield and McAda 2003). This hydraulic conductivity was used uniformly in the steady-state ARG model section. Horizontal to vertical anisotropy was not represented in the one-layer model. An effective porosity of $25 \%$ was assigned to model cells based on the regional numerical model.

Calibration-The model was calibrated to observed water levels by adjusting injection-well contributions representing accreted underflow in each cell. Simulated heads were compared to observed water levels in five wells along the section (Figure 3-5). The cross-sectional flow model was not calibrated further because the intent was not to exactly reproduce distribution of head but to permit a reasonable, representation of flow and transport to the Ridgecrest well field. The calibrated injection rate representing underflow was $7,000 \mathrm{ft}^{3} /$ day into each cell.

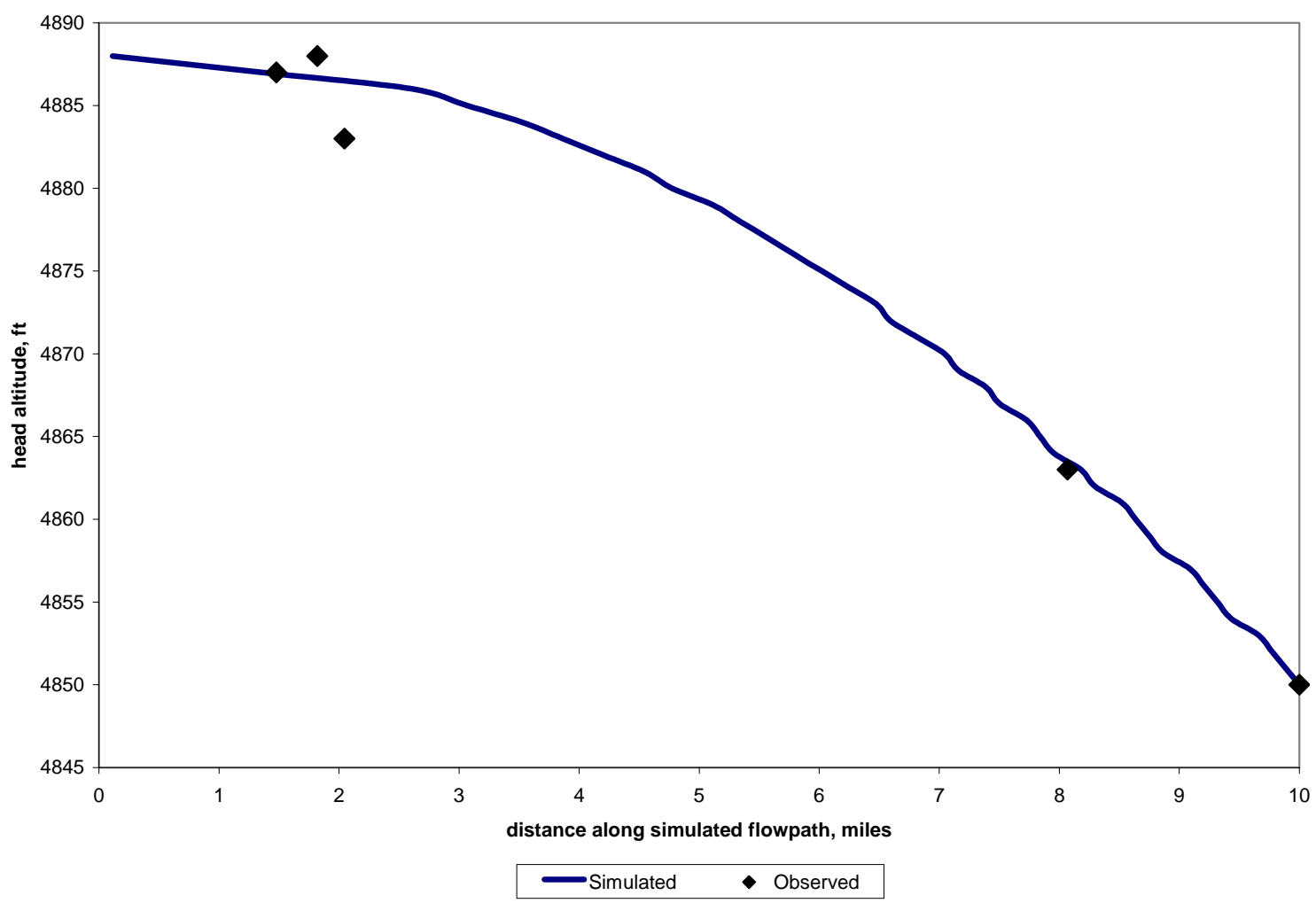

Figure 3-5. Comparison of simulated and observed potentiometric head along the ARG model section 
Simulation of the Alluvial Fan/ARG Model Section Interface-Groundwater flow and solute transport from the alluvial fan into the ARG were simulated by using the flow and concentration out of the alluvial fan model section as direct input into the ARG model section. This was possible due to the following characteristics of these two flow models:

- Flow out of the alluvial fan model section was approximately $70,000 \mathrm{ft}^{3} /$ day,

- Calibrated injection rate into each ARG model section cell was $7,000 \mathrm{ft}^{3} /$ day, which was meant to simulate underflow from alluvial fan lithofacies,

- Width (cross-gradient) of the alluvial fan model section was 6,000 ft, and

- Length (with the gradient) of the ARG model section cells was $600 \mathrm{ft}$.

Therefore, the flow out of the alluvial fan model section into the ARG model section was simulated as $7,000 \mathrm{ft}^{3} /$ day into imaginary injection wells located in 10 cells of the ARG model section. These 10 cells were between 0.8 and 1.9 miles upgradient of the Ridgecrest well field. This location is shown in Figures 3-1 and 3-2.

This simulated solute bearing underflow represents the flux of contaminants from the alluvial fan lithofacies into the ARG lithofacies. As shown in Figure 3-6, the solute flux out of the alluvial fan model section into the ARG model section was simulated by stepping concentrations up throughout the breakthrough period and holding constant at the maximum concentration for the rest of the simulation. Solute injected into the ARG wells was assumed to mix completely with ambient water in the cell. This mixing will more likely occur as the solute is transported downgradient or during withdrawal at pumping centers. The assumption was not considered to be conservative with respect to downgradient concentrations but provided a qualitative assessment of the overall effect of dilution in the ARG prior to reaching potential receptors where groundwater is withdrawn.

Flow Model Results-Simulated flow through the ARG model section moved from south to north. A flux of $609,000 \mathrm{ft}^{3} /$ day moved out of the model at the downgradient constant-head boundary, representing flow out of a 6,000-ft wide strip of the ARG deposits into the area of influence of the Ridgecrest well field. For comparison, the annual withdrawal for all COA municipal wells for 2000 was estimated to be 110,000 acre-ft, or 13.1 million $\mathrm{ft}^{3} / \mathrm{day}$. The model of ARG groundwater flow represented less than $5 \%$ of total COA withdrawals. This representation was considered to be reasonable given the known distribution of head, hydraulic conductivity values, and water-withdrawal data. 


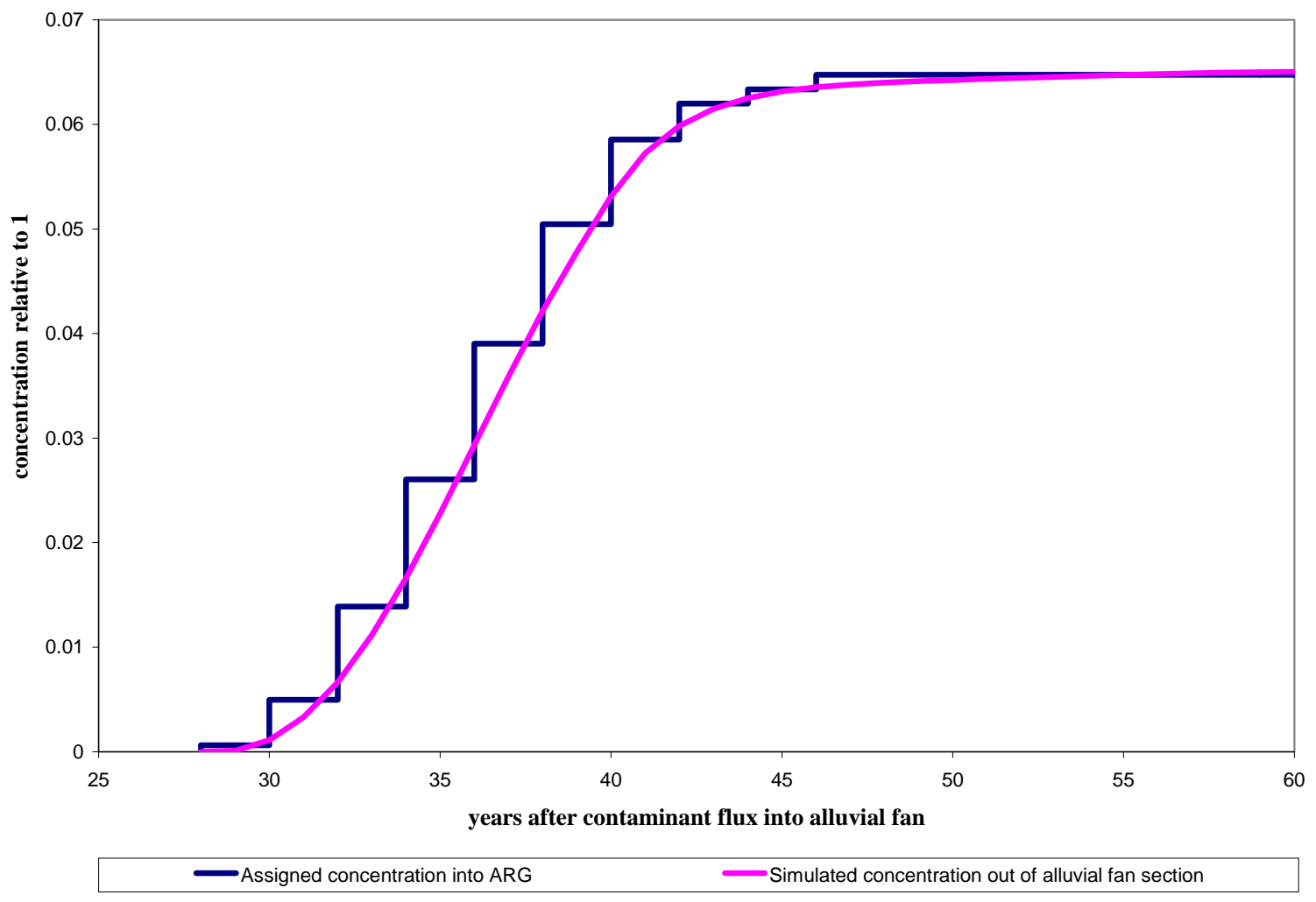

Figure 3-6. Illustration of solute flux simulation from the alluvial fan model section into the ARG model section. 


\subsection{RESULTS AND INTERPRETATIONS}

The modeling approach outlined in Section 3.0 incorporates the conceptual model summarized in Section 2.0 into a conservative numerical model for evaluating reduction in a simulated solute concentration. This section presents results of transport modeling using the alluvial fan and ARG model sections. Section 4.1 presents results of the conservative solute transport, and Section 4.2 presents interpretation of these results relative to observed contaminant concentration and distribution in the SNL/NM AOR.

\subsection{Simulation of Solute Transport to Production Wells}

The numerical model of groundwater flow was used to simulate a conservative solute that moves out of the perched system through the alluvial fan and ARG lithofacies of the regional aquifer and is extracted in production wells located in the ARG lithofacies. The solute concentration in flow from the perched system into the regional aquifer was simulated at a constant concentration of 1 unit for the duration of the simulation.

Figure 4-1 illustrates the simulated solute arrival at two locations. The first is the location where the maximum solute concentration is observed, which is adjacent to the intersection of the alluvial fan and the ARG model sections. The second is the downgradient boundary of the ARG model section, which represents the Ridgecrest well field.

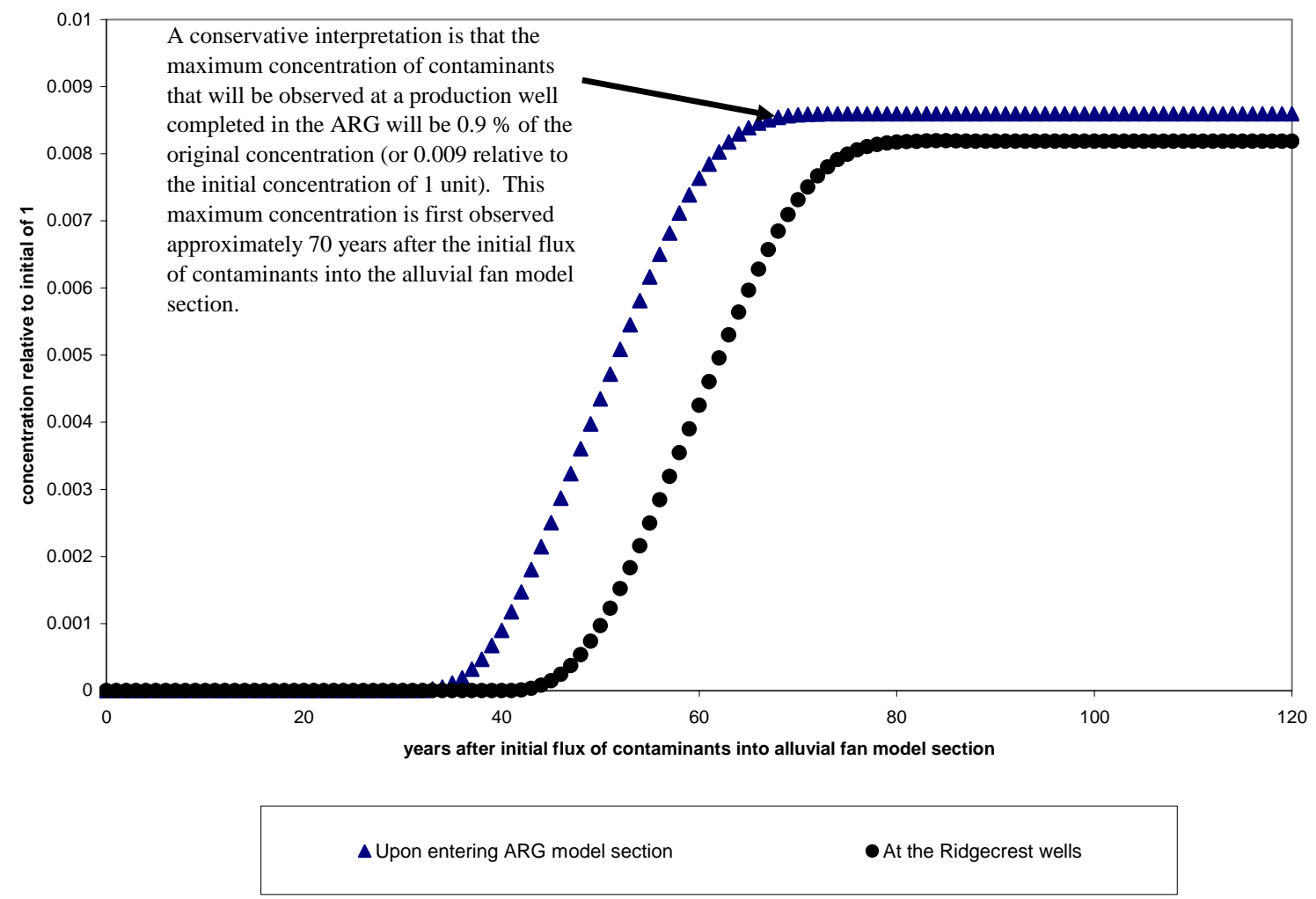

Figure 4-1. Plot of solute arrival at the ARG/ alluvial fan model section interface and at the Ridgecrest well field. 
The maximum concentration of solute observed in the ARG model section was 0.009 or $0.9 \%$ of the initial concentration of 1 unit in the perched groundwater system discharge. The solute was further attenuated to $0.008(0.8 \%)$ before reaching the downgradient boundary of the ARG model section. A conservative estimate of the solute concentration reduction before withdrawal at any production well completed in the ARG lithofacies is $0.9 \%$ of the original concentration in the perched groundwater system discharge to the regional aquifer.

Travel time estimated through the alluvial fan model section and the ARG model section does not account for travel through the perched system, which was estimated in Section 3.1. Simulated concentrations of solute began to breakthrough into the ARG model section after about 35 years after the initial flux of contaminants into the alluvial fan model section. The maximum concentration occurred in the ARG model section after approximately 70 years. The maximum concentration moved across the downgradient ARG model section boundary approximately 80 years after initial flux of contaminants into the alluvial fan model section.

\subsection{Interpretations of Modeling Relative to Observed Concentrations}

The simulated relative solute concentrations presented in Section 4.1 can be compared to actual observed concentrations of nitrate and TCE in samples from various wells completed in the perched groundwater system of the SNL/NM AOR. This comparison provides an estimate of the contribution of nitrate and TCE derived from the AOR that might be expected at production wells. A very conservative interpretation neglects travel through the perched system and assumes that all of the flow out of the perched system (estimated in Section 3.1) contains dissolved TCE or nitrate at the historical maximum observed concentration in any perched system monitoring well. Therefore, an estimate of the maximum concentration that would be expected at the production wells can be obtained by multiplying the maximum relative concentration simulated in the ARG (0.009) by the historical maximum observed concentrations. Interpretation of concentrations and travel time in this manner overestimates the total mass of contaminants within the perched system and underestimates the travel time but is included in the summary of interpretations shown in Table 4-1 as the most conservative estimate.

Based on observed distribution of TCE and nitrate in the perched system, these contaminants are distributed over smaller areas that would not be transported across the entire 6,000-ft transect used to estimate the total flow out of the perched system. As part of the modeling approach, it is assumed that the solute is instantaneously mixed with the ambient flow in the alluvial fan model section. This assumption is only valid if the results are interpreted at the point of groundwater withdrawal. Given this assumption, a more accurate interpretation of the solute transport results relative to nitrate and TCE concentrations would account for the fraction of contaminated water relative to the total flow across the $6,000-\mathrm{ft}$ transect used to estimate perched system discharge (see Section 3.1). The 6,000-ft transect was divided into two zones: a 3,500-ft section representing the portion of the total transect through which nitrate will move and a 2,500-ft section representing the portion through which TCE will be transported (see Figure 3-3). Thus, an additional multiplication factor of $0.6(3,500 \mathrm{ft} / 6,000 \mathrm{ft})$ should be applied when interpreting the solute transport results relative to nitrate and $0.4(2,500 \mathrm{ft} / 6,000 \mathrm{ft})$ should be applied when interpreting relative to TCE. 
Maximum historical concentrations of both nitrate and TCE were used when interpreting the solute transport results presented in Section 4.1, even though more recent observations suggest that concentrations have declined. Maximum historical concentrations of TCE and nitrate are $9.6 \mu \mathrm{g} / \mathrm{L}$ and $44 \mathrm{mg} / \mathrm{L}$ (as nitrogen), respectively. As shown in Tables 4-1 and 4-2, the most conservative estimate (i.e., concentrations are intentionally overestimated) of nitrate and TCE concentrations that might be observed at production wells in the ARG are $0.40 \mathrm{mg} / \mathrm{L}$

(as nitrogen) and $0.09 \mu \mathrm{g} / \mathrm{L}$, respectively. If observed distribution of contaminant in the perched zone is accounted for, the simulated concentrations of nitrate and TCE at the production wells are $0.24 \mathrm{mg} / \mathrm{L}$ (as nitrogen) and $0.03 \mu \mathrm{g} / \mathrm{L}$, respectively. The actual concentrations are expected to be lower given the conservative assumptions built into the numerical model.

Travel time estimates are also shown on Tables 4-1 and 4-2 for each contaminant. The estimates are the arrival time of the maximum concentration of contaminant in the ARG deposits where production wells are located. The most conservative estimate of the travel time is 70 years, which only accounts for travel through the alluvial fan model section. When travel through the perched system is accounted for, travel times for nitrate and TCE are 140 and 130 years, respectively, which are also conservative estimates. The estimated travel times are slightly different because the contaminants are in two different locations and must travel different distances through the perched groundwater system.

Table 4-1. Interpretations of solute transport simulation relative to nitrate contamination.

\begin{tabular}{l|c|c|c|c|c}
\hline & $\begin{array}{c}\text { Relative } \\
\text { simulated } \\
\text { solute } \\
\text { concentration }\end{array}$ & $\begin{array}{c}\text { Maximum } \\
\text { contaminant } \\
\text { concentration, } \\
\text { mg/L as } \\
\text { nitrogen }\end{array}$ & $\begin{array}{c}\text { Fraction of } \\
\text { total perched } \\
\text { flow }\end{array}$ & $\begin{array}{c}\text { Maximum } \\
\text { concentration } \\
\text { in production } \\
\text { well, mg/L } \\
\text { (as nitrogen) }\end{array}$ & $\begin{array}{c}\text { Time of } \\
\text { maximum } \\
\text { concentration } \\
\text { arrival into ARG } \\
\text { model section, } \\
\text { years }\end{array}$ \\
\hline $\begin{array}{l}\text { Most } \\
\text { conservative }\end{array}$ & 0.009 & 44 & $1^{\mathrm{a}}$ & 0.40 & $70^{\mathrm{b}}$ \\
\hline $\begin{array}{l}\text { Less } \\
\text { conservative }\end{array}$ & 0.009 & 44 & 0.6 & 0.24 & 130 \\
\hline
\end{tabular}

a. Assumes that all flow out of the perched system contains $44 \mathrm{mg} / \mathrm{L}$ (as nitrogen) nitrate.

b. Neglects travel time through the perched system.

Table 4-2. Interpretations of solute transport simulation relative to TCE contamination.

\begin{tabular}{l|c|c|c|c|c}
\hline & $\begin{array}{c}\text { Relative } \\
\text { simulated } \\
\text { solute } \\
\text { concentration }\end{array}$ & $\begin{array}{c}\text { Maximum } \\
\text { contaminant } \\
\text { concentration, } \\
\mu \mathrm{g} / \mathrm{L}\end{array}$ & $\begin{array}{c}\text { Fraction of } \\
\text { total perched } \\
\text { flow }\end{array}$ & $\begin{array}{c}\text { Time of } \\
\text { maximum } \\
\text { concentration } \\
\text { in production } \\
\text { well, } \mu \mathrm{g} / \mathrm{L}\end{array}$ & $\begin{array}{c}\text { Maximum } \\
\text { arrival into ARG } \\
\text { model section, } \\
\text { years }\end{array}$ \\
\hline $\begin{array}{l}\text { Most } \\
\text { conservative }\end{array}$ & 0.009 & 9.6 & $1^{\mathrm{a}}$ & 0.09 & $70^{\mathrm{b}}$ \\
\hline $\begin{array}{l}\text { Less } \\
\text { conservative }\end{array}$ & 0.009 & 9.6 & 0.4 & 0.03 & 140 \\
\hline
\end{tabular}

a. Assumes that all flow out of the perched system contains 9.6 $\mu \mathrm{g} / \mathrm{L}$ TCE.

b. Neglects travel time through the perched system. 
This Page Intentionally Left Blank 


\subsection{CONCLUSIONS}

A cross-sectional modeling approach was used to simulate transport and dilution of a conservative solute between the SNL/NM AOR in the perched zone to production wells completed in the ARG lithofacies. The simulated concentration of a conservative solute at these production wells was $0.9 \%$ of the original concentration in the perched system. When compared to observed concentrations in the perched system, these results led to the following conclusions:

- Nitrate originating from the SNL/NM AOR will be reduced to $0.24 \mathrm{mg} / \mathrm{L}$ (as nitrogen) before reaching production wells in the ARG lithofacies. For comparison, the MCL for nitrate is $10 \mathrm{mg} / \mathrm{L}$ (as nitrogen).

- TCE originating from the SNL/NM AOR will be reduced to $0.03 \mu \mathrm{g} / \mathrm{L}$ before reaching production wells in the ARG. For comparison, the MCL for TCE is $5 \mu \mathrm{g} / \mathrm{L}$.

These estimates represent conservative estimates of concentration that intentionally neglect the effects of dispersion, degradation, and sorption on contaminant concentrations.

The travel time from the current location of contaminants in the perched groundwater system to the ARG lithofacies where production wells are completed is at least 130 years for nitrate and at least 140 years for TCE. The estimated travel times are slightly different because the contaminants are currently in two different locations in the perched groundwater system. These travel times represent minimum or conservative estimates, because retardation, travel time through the zone of merging, and travel time through the ARG are intentionally neglected. 
This Page Intentionally Left Blank 


\subsection{REFERENCES}

Balleau Groundwater, Inc. 2002, "Model of a Perched Zone of Saturation at Sandia National Laboratories, New Mexico,” Prepared for Sandia National Laboratories, September 2002.

Bartolino, J.R., and J.C. Cole, 2002, “Groundwater Resources of the Middle Rio Grande Basin,” U.S. Geological Survey, Circular 1222, http://water.usgs.gov/pubs/circ/2002/circ1222/.

Bexfield, L.M., and Anderholm, S.K., 2000, "Predevelopment water-level map of the Santa Fe Group aquifer system in the Middle Rio Grande Basin between Cochiti Lake and San Acacia, New Mexico,” U.S. Geological Survey Water-Resources Investigations Report 00-4249, 1 map sheet with text, scale approximately 1:400,000.

Bexfield, L.M., and D.P. McAda, 2003, "Simulated effects of ground-water management scenarios on the Santa Fe Group Aquifer System, Middle Rio Grande Basin, New Mexico, 2001-40,” U.S. Geological Survey Water-Resources Investigations Report 03-4040, 39 p.

BYU, 2003, Department of Defense Groundwater Modeling System, Version 4.0, developed by the Environmental Modeling Research Laboratory at Brigham Young University for the U.S. Department of Defense, Army Corps of Engineers Waterways Experiment Station, Vicksburg, Mississippi. See http://chl.wes.army.mil/software/gms and http://www.emrl.byu.edu/gms.htm.

City of Albuquerque, 2003, “Water Quality Report 2003,” Available online at: http://www.cabq.gov/waterquality/results/pdf/2003_CABQ_Water_Quality_Report.pdf.

Harbaugh, A.W., E.R. Banta, M.C. Hill, and M.G. McDonald, 2000, MODFLOW-2000, the U.S. Geological Survey Modular Ground-Water Model—User guide to modularization concepts and the ground-water flow process, Open-File Report 00-92, U.S. Geological Survey, Branch of Information Services, Box 25286, Denver, CO 80225-0425 or http://water.usgs.gov/software/ground_water.html/.

MWH Americas, Inc., 2003, "Stage I Abatement Report for Nitrate-Impacted Groundwater at Kirtland Air Force Base, New Mexico,” Environmental Compliance Program, Kirtland Air Force Base, Albuquerque, New Mexico, July 2003.

NMED, 2004, "Compliance Order on Consent Pursuant to the New Mexico Hazardous Waste Act 74-4-10: Sandia National Laboratories Consent Order,” New Mexico Environment Department, April 24, 2004.

SNL/NM, 1998, Sandia North Groundwater Investigation Plan, Annual Report, Fiscal Year 1997, Environmental Restoration Project, Sandia National Laboratories, Albuquerque, New Mexico, March 1998.

SNL/NM, 2001a, 1999 Annual Site Environmental Report Sandia National Laboratories Albuquerque, New Mexico, Sandia Report SAND2000-2228, Sandia National Laboratories / New Mexico, February 2001. 
SNL/NM, 2001b, "SNL/NM Environmental Restoration Project Long-Term Monitoring Strategy for Groundwater,” Environmental Restoration Project, U.S. Department of Energy, Albuquerque Operations Office, Sandia National Laboratories/New Mexico, February 2001.

SNL/NM, 2002, Tijeras Arroyo Groundwater Continuing Investigation Report, Sandia National Laboratories Environmental Restoration Project for U.S. Department of Energy, Albuquerque Operations Office, Albuquerque, New Mexico, November 2002.

SNL/NM, 2004a, Corrective Measures Evaluation Work Plan Tijeras Arroyo Groundwater, SAND2004-3247P, November 2004, Sandia National Laboratories/New Mexico.

SNL/NM 2004b, Current Conceptual Model of Groundwater Flow and Contaminant Transport at Sandia National Laboratories/New Mexico Technical Area V, Sandia Report SAND2004-1470, April 2004.

SNL/NM 2004c, Technical Memorandum - Field Report, Slug Tests at Tijeras Arroyo Groundwater Investigation Wells, SNL/NM Environmental Restoration Project.

SNL/NM 2005a, Monitored Natural Attenuation Field Studies, Investigation of Anaerobic Contaminant Biodegradation in Tijeras Arroyo Groundwater, in press.

SNL/NM, 2005b, "Remedial Alternatives Data Gaps Review for Tijeras Arroyo Groundwater," Sandia National Laboratories/New Mexico, in press.

Zheng, C., and P.P. Wang, 1999, "MT3DMS, A Modular Three-Dimensional Multi-species Transport Model”, U.S. Army Corps of Engineers, Strategic Environmental Research and Development Program (SERDP). 
Attachment D

Investigation of Intrinsic Anaerobic Biodegradation 
This Page Intentionally Left Blank 


\section{Investigation of Intrinsic Anaerobic Biodegradation in Tijeras Arroyo Groundwater at Sandia National Laboratories/ New Mexico}

\section{June 2005}

Prepared by

Sandia National Laboratories

Albuquerque, New Mexico 87185 and Livermore, California 94550

Sandia is a multiprogram laboratory operated by Sandia Corporation,

a Lockheed Martin Company, for the United States Department of Energy's

National Nuclear Security Administration under Contract DE-AC04-94AL85000.

Approved for public release; further dissemination unlimited.

\section{Sandia National Laboratories}




\section{CONTENTS}

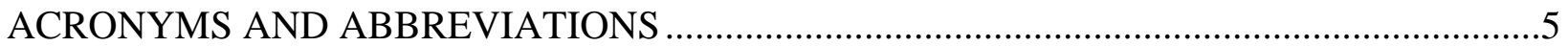

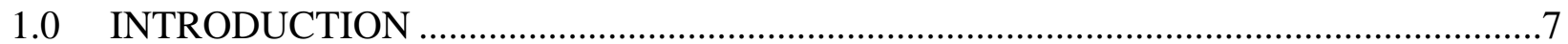

2.0 CONTAMINANT BIODEGRADATION ASSESSMENT DATA ………….......................

3.0 CONTAMINANT BIODEGRADATION SCREENING ASSESSMENT ..........................12

3.1 VOC Biodegradation Screening Assessment Process ...............................................13

3.2 TAG VOC Biodegradation Screening Assessment and Results.............................15

3.3 Biodegradation of Nitrate ………………………................................................15

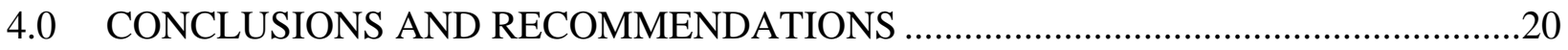

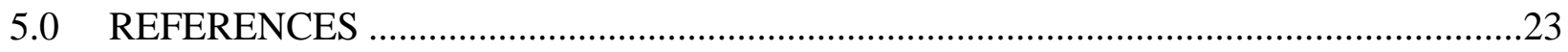

Appendix A—Last quarter FY 2003 to first Quarter FY 2005 Biodegradation Assessment Data

\section{TABLES}

2-1. Parameters for assessment of contaminant biodegradation. ............................................. 10

3-1. Analytical Parameters and Weighting for Anaerobic Biodegradation Screening Assessment Processes (modified from EPA 1998)............................................................. 13

3-2. Interpretation of Points Awarded During Screening. ........................................................ 14

3-3. Anaerobic biodegradation screening for TAG perched system wells. ............................... 16

3-4. Anaerobic biodegradation screening for TAG regional aquifer wells............................... 18 


\section{ACRONYMS AND ABBREVIATIONS}

COC contaminant of concern

COOC Compliance Order on Consent

DO dissolved oxygen

DOC dissolved organic carbon

FY fiscal year

KAFB Kirtland Air Force Base

MNA monitored natural attenuation

NMED New Mexico Environment Department

ORP oxidation reduction potential

SNL/NM Sandia National Laboratories/New Mexico

TAG Tijeras Arroyo groundwater

TCE trichloroethene

TKN Total Kjeldahl Nitrogen

TOC total organic carbon

VOC volatile organic compound 
This Page Intentionally Left Blank 


\subsection{INTRODUCTION}

The Corrective Measures Evaluation Work Plan Tijeras Arroyo Groundwater (SNL/NM 2004) was prepared as directed by the Compliance Order on Consent (COOC) issued by the New Mexico Environment Department (NMED) (NMED 2004). This Work Plan outlines a process for evaluation of remedial alternatives in order to identify a corrective measure for the contaminants of concern (COCs) in Sandia National Laboratories/New Mexico (SNL/NM) Tijeras Arroyo groundwater (TAG). The COCs include trichloroethene (TCE) and nitrate. The Corrective Measures Evaluation Work Plan (SNL/NM 2004) identifies data gathering activities to be carried out in four stages. These stages consist of the Paper Study, Numerical Modeling, Laboratory Studies, and Field Scale Studies. In order to determine the effectiveness of implementing monitored natural attenuation (MNA), the Field Scale Studies stage includes investigating natural attenuation mechanisms in TAG.

Sampling is conducted by the SNL/NM Environmental Restoration Project as part of a voluntary monitoring program. Additional sampling work was performed under the Sandia National Laboratories Tijeras Arroyo Groundwater Investigation Work Plan (SNL/NM 2003), referred to in this report as the TAG Investigation Work Plan. The purpose of the additional sampling was to characterize the nature and extent of TCE and nitrate contamination. A total of six quarterly sampling events are described in the TAG Investigation Work Plan. The information from these sampling events is used to provide data for a volatile organic compound (VOC) anaerobic biodegradation screening assessment, as defined by the Technical Protocol for Evaluating Natural Attenuation of Chlorinated Solvents in Ground Water (EPA 1998), and for an assessment of the potential for nitrate biodegradation via denitrification.

The purpose of this document is to present the biodegradation screening assessment for VOCs and nitrate as applied to TAG sampling and analyses results. The data used to perform this assessment are presented in Section 2.0 and Appendix A, the biodegradation screening assessment is presented in Section 3.0, and conclusions are presented in Section 4.0. 
This Page Intentionally Left Blank 


\subsection{CONTAMINANT BIODEGRADATION ASSESSMENT DATA}

Water samples were collected under the TAG Investigation Work Plan during the quarterly sampling rounds beginning with the fourth quarter of Fiscal Year (FY) 2003 and ending with the first quarter of FY 2005. Data collected under the TAG Investigation Work Plan include:

- VOCs,

- Alkalinity,

- Oxidation reduction potential (ORP),

- Dissolved oxygen (DO),

- $\mathrm{pH}$,

- Temperature,

- $\quad$ Nitrate (as nitrogen),

- $\quad$ Nitrate plus nitrite (as nitrogen),

- Ammonia (as nitrogen),

- Total Kjeldahl Nitrogen (TKN),

- Chloride,

- Sulfate,

- Orthophosphate (as phosphorous),

- $\quad$ Manganese II,

- Ferrous iron, and

- Other anions and cations.

The sampling results for all these analyses are presented in Appendix A. For each parameter used in the assessment of contaminant biodegradation, the significance of the data relative to the assessment and general observations are presented in Table 2-1. 
Table 2-1. Parameters for assessment of contaminant biodegradation.

\begin{tabular}{|c|c|c|c|}
\hline Parameters & Data Significance & Data Observation & $\begin{array}{c}\text { Table in } \\
\text { Appendix A }\end{array}$ \\
\hline $\begin{array}{l}\text { VOCs (PCE, TCE, } \\
\text { cis-1,2-DCE, trans- } \\
1,2-D C E \text {, and VC) }\end{array}$ & $\begin{array}{l}\text { Contaminants and dechlorination } \\
\text { products; required to assess } \\
\text { chlorinated solvent biodegradation }\end{array}$ & $\begin{array}{l}\text { PCE was detected at a maximum concentration of } 2.63 \mu \mathrm{g} / \mathrm{L} \text {; TCE was } \\
\text { detected at a maximum concentration of } 7.7 \mu \mathrm{g} / \mathrm{L} \text {; DCE was detected at a } \\
\text { maximum concentration of } 3.4 \mu \mathrm{g} / \mathrm{L} \text {; VC was not detected. }\end{array}$ & Tables A-1 to A-6 \\
\hline Nitrate (as nitrogen) & $\begin{array}{l}\text { Contaminant (compliance } \\
\text { requirement) and redox parameter }\end{array}$ & $\begin{array}{l}\text { Nitrate was detected above the MCL of } 10 \mathrm{mg} / \mathrm{L} \text { in three wells TA2- } \\
\text { SW1-320 ( } 25 \mathrm{mg} / \mathrm{L}) \text {, TJA-4 ( } 26 \mathrm{mg} / \mathrm{L}) \text {, and TJA-7 ( } 27 \mathrm{mg} / \mathrm{L}) \text {. All other } \\
\text { wells had nitrate detections below the MCL. }\end{array}$ & Tables A-7 to A-12 \\
\hline Chloride & $\begin{array}{l}\text { Dechlorination product; released } \\
\text { during chlorinated solvent } \\
\text { biodegradation }\end{array}$ & Chloride results ranged from 11.5 to $263 \mathrm{mg} / \mathrm{L}$. & Tables A-14 to A-19 \\
\hline TOC & $\begin{array}{l}\text { Measure for bioavailable electron } \\
\text { donor }\end{array}$ & TOC is present in all samples at less than $2 \mathrm{mg} / \mathrm{L}$. & Table A-20 \\
\hline Ferrous Iron & $\begin{array}{l}\text { Redox parameter; electron acceptor } \\
\text { (ferric iron) is reduced to the product } \\
\text { (ferrous iron); required to assess } \\
\text { active anaerobic reaction pathways }\end{array}$ & Ferrous iron results ranged from 0.0 to $0.57 \mathrm{mg} / \mathrm{L}$. & Table A-13 \\
\hline Manganese II & $\begin{array}{l}\text { Redox parameter; required to assess } \\
\text { active anaerobic oxidation pathways }\end{array}$ & Manganese II results ranged from 0.0 to $0.098 \mathrm{mg} / \mathrm{L}$. & Table A-21 \\
\hline Sulfate & $\begin{array}{l}\text { Redox parameter; electron acceptor; } \\
\text { required to assess active anaerobic } \\
\text { reaction pathways }\end{array}$ & $\begin{array}{l}\text { Sulfate results ranged from } 8 \text { to } 672 \mathrm{mg} / \mathrm{L} \text {. These results are similar to } \\
\text { historic average concentrations for each well. }\end{array}$ & Tables A-14 to A-19 \\
\hline ORP & $\begin{array}{l}\text { Redox parameter; required to assess } \\
\text { active anaerobic reaction pathways }\end{array}$ & ORP ranged between 97.9 to $346.1 \mathrm{mV}$. & Table A-22 \\
\hline DO & $\begin{array}{l}\text { Redox parameter; required to assess } \\
\text { active anaerobic reaction pathways }\end{array}$ & DO ranged between 0.28 to $11.92 \mathrm{mg} / \mathrm{L}$. & Table A-22 \\
\hline
\end{tabular}


Table 2-1. (continued).

\begin{tabular}{|c|c|c|c|}
\hline Parameters & Data Significance & Data Observation & $\begin{array}{c}\text { Table in } \\
\text { Appendix A }\end{array}$ \\
\hline Orthophosphate & $\begin{array}{l}\text { Microbial nutrient; required to assess } \\
\text { potential nutrient limitations }\end{array}$ & All orthophosphate (as phosphorus) results were below the PQL. & Table A-20 \\
\hline $\begin{array}{l}\text { Ammonia } \\
\text { (as nitrogen) }\end{array}$ & $\begin{array}{l}\text { Microbial nutrient; required to assess } \\
\text { potential nutrient limitations }\end{array}$ & $\begin{array}{l}\text { All ammonia results were below the MDL except for one detection at } \\
\text { TJA-7 of } 0.080 \mathrm{mg} / \mathrm{L} \text {. }\end{array}$ & Table A-20 \\
\hline Alkalinity & $\begin{array}{l}\text { Indicator of microbial respiration; } \\
\text { may be useful for evaluating } \\
\text { biostimulation }\end{array}$ & Alkalinity results ranged from 44.8 to $289 \mathrm{mg} / \mathrm{L}$. & Tables A-14 to A-19 \\
\hline pH and Temperature & $\begin{array}{l}\text { Water quality parameters; may be } \\
\text { useful for evaluating biostimulation } \\
\text { and suitability of conditions for } \\
\text { anaerobic reductive dechlorination }\end{array}$ & $\begin{array}{l}\text { The range for } \mathrm{pH} \text { was from } 6.81 \text { to } 8.48 \text {. Temperature ranged from } 13.29 \\
\text { to } 22.40^{\circ} \mathrm{C} \text {. }\end{array}$ & Table A-22 \\
\hline \multicolumn{4}{|c|}{$\begin{array}{l}\mathrm{mg} / \mathrm{L}=\text { milligrams per liter, } \mu \mathrm{g} / \mathrm{L}=\text { micrograms per liter } \\
\mathrm{mV}=\text { millivolt } \\
{ }^{\circ} \mathrm{C}=\text { degrees Celsius }\end{array}$} \\
\hline \multicolumn{2}{|c|}{$\begin{array}{l}\text { COD = chemical oxygen demand } \\
\text { DCE = dichloroethene } \\
\text { DO = dissolved oxygen } \\
\text { DOC = dissolved organic carbon } \\
\text { MCL = maximum contaminant level } \\
\text { MDL = method detection limit }\end{array}$} & $\begin{array}{l}\text { ORP }=\text { oxidation reduction potential } \\
\text { PCE }=\text { tetrachloroethene } \\
\text { TCE }=\text { trichloroethene } \\
\text { TOC = total organic carbon } \\
\text { VC = vinyl chloride } \\
\text { VOC = volatile organic compound }\end{array}$ & \\
\hline
\end{tabular}


This Page Intentionally Left Blank

D-12 


\subsection{CONTAMINANT BIODEGRADATION SCREENING ASSESSMENT}

The contaminant biodegradation assessment data, presented in Section 2.0 and Appendix A, and historical data were used to perform the VOC contaminant biodegradation screening assessment described in the Technical Protocol for Evaluating Natural Attenuation of Chlorinated Solvents in Ground Water (EPA 1998). This section details the biodegradation screening assessment process (Section 3.1) and summarizes the results of the VOC screening using data from TAG monitoring (Section 3.2). An assessment of nitrate biodegradation is presented in Section 3.3.

\subsection{VOC Biodegradation Screening Assessment Process}

The purpose of this screening is to determine if evidence is available to show that anaerobic biodegradation of VOCs is occurring in TAG. This biodegradation screening assessment process consists of analyzing the data using the information presented in Table 3-1. For each parameter, a concentration criterion, interpretation of the criterion, and a scoring value are listed. For the perched system and regional aquifer wells, a value was assigned for each parameter. The sentry/background wells were used as a basis of comparison for some of the parameters. The total scoring value for all parameters at each well was compared to the interpretation information presented in Table 3-2.

Table 3-1. Analytical Parameters and Weighting for Anaerobic Biodegradation Screening Assessment Processes (modified from EPA 1998).

\begin{tabular}{l|l|l|c}
\hline \multicolumn{1}{c|}{ Parameters } & $\begin{array}{c}\text { Concentration in } \\
\text { Most Contaminated } \\
\text { Zone }\end{array}$ & \multicolumn{1}{c}{ Interpretation } & Value \\
\hline Oxygen & $<0.5 \mathrm{mg} / \mathrm{L}$ & $\begin{array}{l}\text { Tolerated, suppresses the reductive } \\
\text { pathway at higher concentrations }\end{array}$ & 3 \\
\hline Nitrate & $>5 \mathrm{mg} / \mathrm{L}$ & $\begin{array}{l}\text { Not tolerated; however, VC may be } \\
\text { oxidized aerobically }\end{array}$ & -3 \\
\hline Iron II & $>1 \mathrm{mg} / \mathrm{L}$ & $\begin{array}{l}\text { At higher concentrations may compete } \\
\text { with reductive pathway }\end{array}$ & 2 \\
\hline Sulfate & $<20 \mathrm{mg} / \mathrm{L}$ & $\begin{array}{l}\text { Reductive pathway possible; VC may } \\
\text { be oxidized under Fe (III)-reducing } \\
\text { conditions }\end{array}$ & 3 \\
\hline ORP against & $<50 \mathrm{mV}$ & $\begin{array}{l}\text { At higher conditions may compete } \\
\text { with reductive pathway }\end{array}$ & 2 \\
\hline Ag/AgCl electrode & $<-100 \mathrm{mV}$ & $\begin{array}{l}\text { Reductive pathway possible } \\
\text { Reductive pathway likely }\end{array}$ & 1 \\
\hline pH & $5<\mathrm{pH}<9$ & $\begin{array}{l}\text { Optimal range for reductive pathway } \\
\text { Outside optimal range for reductive }\end{array}$ & 0 \\
\hline TOC & $\mathrm{pH}<5 \mathrm{or} \mathrm{pH}>9$ & $\begin{array}{l}\text { pathway } \\
\text { Carbon and energy source; drives } \\
\text { dechlorination; can be natural or } \\
\text { anthropogenic }\end{array}$ & 2 \\
\hline
\end{tabular}


Table 3-1. (continued).

\begin{tabular}{|c|c|c|c|}
\hline Parameters & $\begin{array}{l}\text { Concentration in } \\
\text { Most Contaminated } \\
\text { Zone } \\
\end{array}$ & Interpretation & Value \\
\hline Temperature & $>20^{\circ} \mathrm{C}$ & $\begin{array}{l}\text { At } \mathrm{T}>20^{\circ} \mathrm{C} \text { biochemical process is } \\
\text { accelerated }\end{array}$ & 1 \\
\hline Alkalinity & $>2 \times$ background & $\begin{array}{l}\text { Results from interaction between } \mathrm{CO}_{2} \\
\text { and aquifer minerals }\end{array}$ & 1 \\
\hline Chloride & $>2 \times$ background & Daughter product of organic chlorine & 2 \\
\hline BTEX & $>0.1 \mathrm{mg} / \mathrm{L}$ & $\begin{array}{l}\text { Carbon and energy source; drives } \\
\text { dechlorination }\end{array}$ & 2 \\
\hline PCE & Not Applicable & Material release & 0 \\
\hline TCE & Not Applicable & $\begin{array}{l}\text { Material release } \\
\text { Daughter product of PCE }\end{array}$ & 0 \\
\hline DCE & Not Applicable & $\begin{array}{l}\text { Material release } \\
\text { Daughter product of TCE } \\
\text { If cis is }>80 \% \text { of total DCE it is likely } \\
\text { a daughter product }\end{array}$ & 0 \\
\hline $\mathrm{VC}$ & Not Applicable & Material release & 0 \\
\hline \multicolumn{4}{|c|}{$\begin{array}{l}\mathrm{mg} / \mathrm{L}=\text { milligrams per liter } \\
\mathrm{mV}=\text { millivolt }\end{array}$} \\
\hline \multicolumn{4}{|c|}{$\begin{array}{l}\text { BTEX = benzene, toluene, et } \\
\text { DCE = dichloroethene } \\
\text { ORP = oxidation reduction p } \\
\text { PCE = tetrachloroethene } \\
\text { TCE = trichloroethene } \\
\text { TOC = total organic carbon } \\
\text { VC = vinyl chloride }\end{array}$} \\
\hline
\end{tabular}

Table 3-2. Interpretation of Points Awarded During Screening.

\begin{tabular}{l|l}
\hline \multicolumn{1}{c|}{ Score } & \multicolumn{1}{c}{ Interpretation } \\
\hline 0 to 5 & Inadequate evidence for anaerobic biodegradation (reductive dechlorination) \\
\hline 6 to 14 & Limited evidence for anaerobic biodegradation (reductive dechlorination) \\
\hline 15 to 20 & Adequate evidence for anaerobic biodegradation (reductive dechlorination) \\
\hline$>20$ & Strong evidence for anaerobic biodegradation (reductive dechlorination) \\
\hline
\end{tabular}




\subsection{VOC Biodegradation Screening Assessment and Results}

The biodegradation screening was performed for both perched system and regional aquifers in the Tijeras Arroyo area. Perched system and regional aquifer wells are identified in the Tijeras Arroyo Groundwater Investigation Work Plan (SNL/NM 2003) and Tables 3-3 and 3-4. Groundwater monitoring data from regional aquifer wells Eubank-1, Eubank-2, Eubank-3, Eubank-5, PGS-2, TA1-W-04, and TA1-W-05 were used to represent background conditions. When available, historical data, along with the most recent data, were analyzed against the evaluation criteria (Table 3-1) in order to make general assessments of conditions within each well. Kirtland Air Force Base (KAFB) wells were sampled but the data were not used in this evaluation.

Table 3-3 summarizes the results of the VOC biodegradation screening assessment. This table presents a scoring value for each parameter at each well and a general explanation for the scoring value assignments. The total scoring value for each well is also shown. Total scores range from

-3 to 2 . Comparisons of these total values to the interpretations of the values presented in Table 3-2 show that all wells fall within or below the scoring range of 0 to 5 . This leads to the interpretation that there is inadequate evidence to demonstrate that biodegradation, through anaerobic processes of reductive dechlorination, is occurring in TAG. Because there is inadequate evidence to demonstrate anaerobic biodegradation and the observed aerobic conditions are not conducive to anaerobic biodegradation of VOCs, it is concluded that anaerobic biodegradation will not be a significant mechanism of natural attenuation.

\subsection{Biodegradation of Nitrate}

Transformation of nitrate in the environment is part of the natural nitrogen cycle. Under the right environmental conditions, nitrate can be transformed to nitrogen gas through the biologically mediated process of denitrification. Denitrification can occur in low oxygen environments and in the presence of an electron donor where nitrate can act as an electron acceptor in the microbial respiration process (ITRC 2002). Oxygen is a more thermodynamically favorable electron acceptor than nitrate. In the presence of oxygen, aerobically respiring organisms will constitute the dominant microbial community; therefore, DO is inhibitory to the process of denitrification. Denitrification also requires the presence of both carbon and energy sources to sustain biological activity within groundwater.

There is not a biodegradation screening assessment for nitrate similar to the screening presented for VOCs (Section 3.2). However, a qualitative evaluation of the data demonstrates that denitrification is not likely to act as a natural attenuation mechanism. This is confirmed by the following observations:

- DO inhibits the process of denitrification. DO concentrations in samples from most of the wells were greater than $5 \mathrm{mg} / \mathrm{L}$.

- A source of carbon and energy must be available to sustain biological activity. Very low dissolved organic carbon (DOC) concentrations $(<2 \mathrm{mg} / \mathrm{L}$ ) and low total organic carbon (TOC) concentrations $(<4 \mathrm{mg} / \mathrm{L})$ suggest that organic carbon and energy sources are limited. 
Table 3-3. Anaerobic biodegradation screening for TAG perched system wells.

\begin{tabular}{|c|c|c|c|c|c|c|c|c|c|c|c|c|c|}
\hline \multirow[b]{2}{*}{ Parameters } & \multicolumn{12}{|c|}{ Perched System Wells } & \multirow[b]{2}{*}{ Reason for Scoring } \\
\hline & \begin{tabular}{l}
$n$ \\
0 \\
1 \\
3 \\
1 \\
\multirow{1}{1}{} \\
\multirow{1}{1}{} \\
1
\end{tabular} & \begin{tabular}{l}
0 \\
0 \\
1 \\
3 \\
1 \\
\multirow{1}{1}{} \\
1
\end{tabular} & \begin{tabular}{l}
$\infty$ \\
0 \\
1 \\
3 \\
1 \\
1 \\
\multirow{1}{1}{} \\
-1
\end{tabular} & 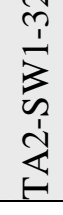 & 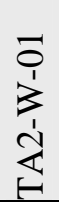 & 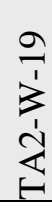 & 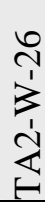 & 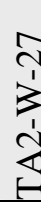 & & & & 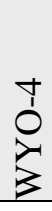 & \\
\hline $\begin{array}{l}\text { Dissolved } \\
\text { Oxygen }\end{array}$ & -3 & -3 & -3 & -3 & -3 & -3 & -3 & -3 & - & & & -3 & All wells in the perched system had average DO concentrations of $>5 \mathrm{mg} / \mathrm{L}$. \\
\hline Nitrate & 0 & 0 & 0 & 0 & 0 & 0 & 0 & 0 & & & & 0 & All wells in the perched system had average nitrate concentrations of $>1 \mathrm{mg} / \mathrm{L}$. \\
\hline Iron II & 0 & 0 & 0 & 0 & 0 & 0 & 0 & 0 & & & & 0 & $\begin{array}{l}\text { All wells in the perched system had average ferrous iron concentrations of } \\
<1 \mathrm{mg} / \mathrm{L} \text {. }\end{array}$ \\
\hline Sulfate & 0 & 0 & 0 & 2 & 0 & 0 & 0 & 0 & & & & 0 & $\begin{array}{l}\text { Average sulfate concentrations are }>20 \mathrm{mg} / \mathrm{L} \text { in all perched system wells except } \\
\text { two (TA2-SW1-320 and TJA-7). }\end{array}$ \\
\hline ORP & 0 & 0 & 0 & 0 & 0 & 0 & 0 & 0 & & & & 0 & All wells in the perched system had average ORP of $>50 \mathrm{mV}$. \\
\hline $\mathrm{pH}$ & 0 & 0 & 0 & 0 & 0 & 0 & 0 & 0 & & & & 0 & $\begin{array}{l}\text { The } \mathrm{pH} \text { in all wells has remained within the optimal range for the reductive } \\
\text { pathway. }\end{array}$ \\
\hline TOC & 0 & 0 & 0 & 0 & 0 & 0 & 0 & 0 & & & & 0 & Very low average TOC concentrations ( $<1 \mathrm{mg} / \mathrm{L}$ ) for all wells. \\
\hline Temperature & 0 & 0 & 0 & 0 & 0 & 0 & 0 & 0 & & & & 0 & $\begin{array}{l}\text { During seasonal temperature variations, the groundwater temperature has been } \\
>20^{\circ} \mathrm{C} \text {. However, the average temperature was not }>20^{\circ} \mathrm{C} \text { in any of the perched } \\
\text { system wells. }\end{array}$ \\
\hline Alkalinity & 0 & 0 & 0 & 0 & 0 & 0 & 0 & 0 & & & & 0 & $\begin{array}{l}\text { Alkalinity is less than two times the average concentration in background wells } \\
\text { (Eubank-1, Eubank-2, Eubank-3, Eubank-5, PGS-2, TA1-W-04, and TA1-W- } \\
\text { 05). }\end{array}$ \\
\hline
\end{tabular}


Table 3-3. (continued).

\begin{tabular}{|c|c|c|c|c|c|c|c|c|c|c|c|c|}
\hline \multirow[b]{2}{*}{ Parameters } & \multicolumn{11}{|c|}{ Perched System Wells } & \multirow[b]{2}{*}{ Reason for Scoring } \\
\hline & 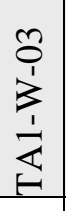 & $\begin{array}{l}0 \\
0 \\
1 \\
3 \\
1 \\
\\
\\
E \\
\end{array}$ & 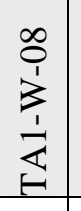 & 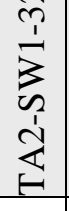 & 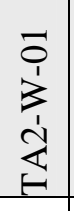 & 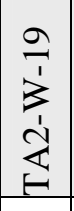 & 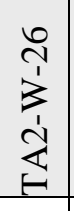 & 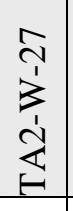 & $\underset{\substack{N\\
}}{\stackrel{N}{\leftrightarrows}}$ & 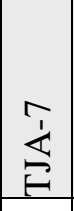 & $\begin{array}{c}+ \\
0 \\
\vdots \\
3\end{array}$ & \\
\hline Chloride & 0 & 0 & 0 & 0 & 0 & 0 & 0 & 0 & 0 & 0 & 0 & $\begin{array}{l}\text { Chloride concentrations are variable in different wells. Although some chloride } \\
\text { concentrations are greater than two times background, chloride is not believed to } \\
\text { be a result of chlorinated organic compound degradation. }\end{array}$ \\
\hline BTEX & 0 & 0 & 0 & 0 & 0 & 0 & 0 & 0 & 0 & 0 & 0 & $\begin{array}{l}\text { No BTEX constituents were detected above } 0.1 \mathrm{mg} / \mathrm{L} \text { in any of the perched } \\
\text { system wells. }\end{array}$ \\
\hline PCE & 0 & 0 & 0 & 0 & 0 & 0 & 0 & 0 & 0 & 0 & 0 & PCE in groundwater is a material released from the source. \\
\hline TCE & 0 & 0 & 0 & 0 & 0 & 0 & 0 & 0 & 0 & 0 & 0 & $\begin{array}{l}\text { TCE in groundwater is a material released from the source and is not suspected } \\
\text { to be a degradation product of PCE reduction. }\end{array}$ \\
\hline DCE & 0 & 0 & 0 & 0 & 0 & 2 & 2 & 0 & 2 & 0 & 2 & $\begin{array}{l}\text { DCE has been detected in various wells; however, cis-DCE was }>80 \% \text { of total } \\
\text { DCE in only four wells. }\end{array}$ \\
\hline VC & 0 & 0 & 0 & 0 & 0 & 0 & 0 & 0 & 0 & 0 & 0 & VC was not detected above the MDL. \\
\hline Total Score & -3 & -3 & -3 & -1 & -3 & -1 & -1 & -3 & -1 & -1 & -1 & \\
\hline \multicolumn{10}{|c|}{$\begin{array}{l}\text { BTEX = benzene, toluene, ethylbenzene, and xylene } \\
\text { DCE = dichloroethene } \\
\text { DO = dissolved oxygen }\end{array}$} & $\begin{array}{l}\text { PCE } \\
\text { TCE } \\
\text { TOC } \\
\text { VC }=\end{array}$ & $\begin{array}{l}=\text { tetra } \\
=\text { trich } \\
=\text { tota } \\
\text { vinyl }\end{array}$ & $\begin{array}{l}\text { achloroethene } \\
\text { hloroethene } \\
\text { al organic carbon } \\
\text { l chloride }\end{array}$ \\
\hline
\end{tabular}


Table 3-4. Anaerobic biodegradation screening for TAG regional aquifer wells.

\begin{tabular}{|c|c|c|c|c|c|c|c|c|c|c|c|c|c|c|c|}
\hline \multirow[b]{2}{*}{ Parameters } & \multicolumn{7}{|c|}{ Regional Aquifer Wells } & \multicolumn{7}{|c|}{ Sentry/Background Wells } & \multirow[b]{2}{*}{ Reason for Scoring } \\
\hline & 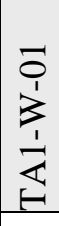 & 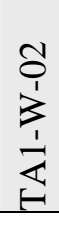 & 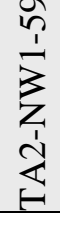 & 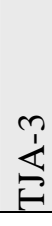 & 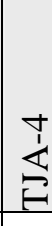 & $\sum_{\substack{L\\
}}^{1}$ & $\bigcup_{\substack{\infty \\
\vdots}}^{\infty}$ & 党 & 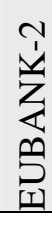 & 点 & 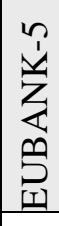 & 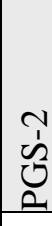 & 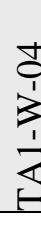 & & \\
\hline $\begin{array}{l}\text { Dissolved } \\
\text { Oxygen }\end{array}$ & -3 & -3 & -3 & -3 & 0 & 0 & 0 & -3 & -3 & -3 & -3 & 0 & -3 & . & $\begin{array}{l}\text { Most wells in the regional aquifer had average DO concentrations } \\
>5 \mathrm{mg} / \mathrm{L} \text {, and none had DO concentrations }<0.5 \mathrm{mg} / \mathrm{L} \text {. }\end{array}$ \\
\hline Nitrate & 0 & 0 & 0 & 0 & 0 & 0 & 0 & 0 & 0 & 0 & 0 & 2 & 0 & ( & $\begin{array}{l}\text { All wells in the regional aquifer had average nitrate concentrations of } \\
>1 \mathrm{mg} / \mathrm{L} \text {, except for PGS-2 }(0.85 \mathrm{mg} / \mathrm{L}) \text {. }\end{array}$ \\
\hline Iron II & 0 & 0 & 0 & 0 & 0 & 0 & 0 & 0 & 0 & 0 & 0 & 0 & 0 & ( & Ferrous iron has not been detected in any wells $>1 \mathrm{mg} / \mathrm{L}$. \\
\hline Sulfate & 0 & 0 & 0 & 0 & 2 & 0 & 0 & 0 & 0 & 0 & 0 & 0 & 0 & ( & $\begin{array}{l}\text { Average sulfate concentrations are }>20 \mathrm{mg} / \mathrm{L} \text { in all perched system wells } \\
\text { except one (TJA-4). }\end{array}$ \\
\hline ORP & 0 & 0 & 0 & 0 & 0 & 0 & 0 & 0 & 0 & 0 & 0 & 0 & 0 & ( & The ORP for all wells is greater than $50 \mathrm{mV}$. \\
\hline $\mathrm{pH}$ & 0 & 0 & 0 & 0 & 0 & 0 & 0 & 0 & 0 & 0 & 0 & 0 & 0 & ( & $\begin{array}{l}\text { The } \mathrm{pH} \text { in all wells has remained within the optimal range for the } \\
\text { reductive pathway. }\end{array}$ \\
\hline TOC & 0 & 0 & 0 & 0 & 0 & 0 & 0 & 0 & 0 & 0 & 0 & 0 & 0 & ( & Very low TOC concentrations $(<1 \mathrm{mg} / \mathrm{L})$ for all wells. \\
\hline Temperature & 1 & 0 & 0 & 0 & 0 & 1 & 0 & 0 & 0 & 0 & 0 & 0 & 0 & ( & $\begin{array}{l}\text { During seasonal temperature variations, the groundwater temperature } \\
\text { has been }>20^{\circ} \mathrm{C} \text {. However, the average temperature was }>20^{\circ} \mathrm{C} \text { in only } \\
\text { two wells (TA1-W-01 and TJA-6). }\end{array}$ \\
\hline Alkalinity & 0 & 0 & 0 & 0 & 0 & 0 & 0 & 0 & 0 & 0 & 0 & 0 & 0 & ( & $\begin{array}{l}\text { Alkalinity is less than two times the average concentration in } \\
\text { background wells (Eubank-1, Eubank-2, Eubank-3, Eubank-5, PGS-2, } \\
\text { TA1-W-04, and TA1-W-05). }\end{array}$ \\
\hline
\end{tabular}


Table 3-4. (continued).

\begin{tabular}{|c|c|c|c|c|c|c|c|c|c|c|c|c|c|c|c|}
\hline \multirow[b]{2}{*}{ Parameters } & \multicolumn{7}{|c|}{ Regional Aquifer Wells } & \multicolumn{7}{|c|}{ Sentry/Background Wells } & \multirow[b]{2}{*}{ Reason for Scoring } \\
\hline & 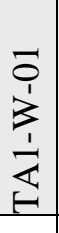 & 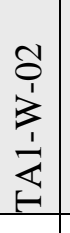 & 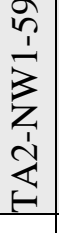 & 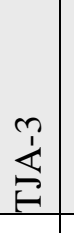 & 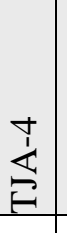 & 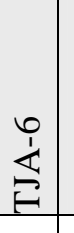 & $\begin{array}{l}m \\
0 \\
\vdots \\
\vdots\end{array}$ & 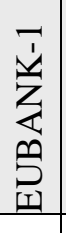 & 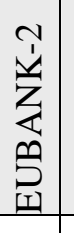 & 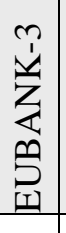 & 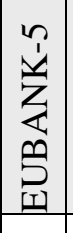 & 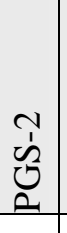 & 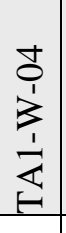 & 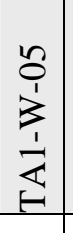 & \\
\hline Chloride & 0 & 0 & 0 & 0 & 0 & 0 & 0 & 0 & 0 & 0 & 0 & 0 & 0 & 0 & $\begin{array}{l}\text { Chloride concentrations are variable in different wells. Although some } \\
\text { chloride concentrations are greater than two times background, chloride } \\
\text { is not believed to be a result of chlorinated organic compound } \\
\text { degradation. }\end{array}$ \\
\hline BTEX & 0 & 0 & 0 & 0 & 0 & 0 & 0 & 0 & 0 & 0 & 0 & 0 & 0 & 0 & No BTEX were detected above $>0.1 \mathrm{mg} / \mathrm{L}$. \\
\hline PCE & 0 & 0 & 0 & 0 & 0 & 0 & 0 & 0 & 0 & 0 & 0 & 0 & 0 & 0 & PCE in groundwater is a material released from the source. \\
\hline TCE & 0 & 0 & 0 & 0 & 0 & 0 & 0 & 0 & 0 & 0 & 0 & 0 & 0 & 0 & $\begin{array}{l}\text { TCE in groundwater is a material released from the source and is not } \\
\text { suspected to be a degradation product of PCE reduction. }\end{array}$ \\
\hline DCE & 0 & 0 & 0 & 0 & 0 & 0 & 0 & 0 & 0 & 0 & 0 & 0 & 0 & 0 & cis-DCE was not detected in any of the regional aquifer/sentry wells. \\
\hline VC & 0 & 0 & 0 & 0 & 0 & 0 & 0 & 0 & 0 & 0 & 0 & 0 & 0 & 0 & VC was not detected above the MDL. \\
\hline Total Score & -2 & -3 & -3 & -3 & 2 & 1 & $\mathbf{0}$ & -3 & -3 & -3 & -3 & 2 & -3 & -3 & \\
\hline $\begin{array}{l}\text { BTEX = benzen } \\
\text { DCE = dichloro€ } \\
\text { DO = dissolved } \\
\text { MDL = method } \\
\text { ORP = oxidation }\end{array}$ & $\begin{array}{l}\text { olue } \\
\text { ene } \\
\text { ygen } \\
\text { ectio } \\
\text { duct }\end{array}$ & $\begin{array}{l}\text { ne, et } \\
\text { on lim } \\
\text { ion } p\end{array}$ & it & nzene & , and & xylen & & & & & $\begin{array}{l}\text { PCE }= \\
\text { TCE }= \\
\text { TOC }= \\
\text { VC }=\end{array}$ & $\begin{aligned} &= \text { tetra } \\
&= \text { trich } \\
&= \text { tota } \\
& \text { vinyl }\end{aligned}$ & $\begin{array}{l}\text { achloo } \\
\text { hloro } \\
1 \text { org } \\
\text { chlo }\end{array}$ & $\begin{array}{l}\text { roethe } \\
\text { ethene } \\
\text { anic c } \\
\text { ride }\end{array}$ & $\begin{array}{l}\text { ene } \\
\text { e } \\
\text { carbon }\end{array}$ \\
\hline
\end{tabular}


This Page Intentionally Left Blank 


\subsection{CONCLUSIONS AND RECOMMENDATIONS}

The purpose of this document is to present the biodegradation screening assessment for VOCs and nitrate at TAG. The results of this screening will be used in the Tijeras Arroyo Groundwater CME Report. Based on the screening process, the conclusions of this report are as follows:

1. Conditions in Tijeras Arroyo groundwater are not conducive to anaerobic biodegradation of VOCs; therefore, anaerobic biodegradation is not a significant natural attenuation mechanism.

2. Conditions conducive to denitrification are not present in Tijeras Arroyo groundwater; therefore, natural attenuation via denitrification is not is not a significant natural attenuation mechanism. 
This Page Intentionally Left Blank 


\subsection{REFERENCES}

5. EPA, 1998, “Technical Protocol for Evaluating Natural Attenuation of Chlorinated Solvents in Ground Water,” United States Environmental Protection Agency, Office of Research and Development, Washington DC.

6. ITRC, 2002, Interstate Technology and Regulatory Cooperation (ITRC) Work Group, 2002. “Technical and Regulatory Guidance for In Situ Bioremediation in Groundwater,” 129 pp.

7. NMED, 2004, "Compliance Order on Consent Pursuant to the New Mexico Hazardous Waste Act 74-4-10: Sandia National Laboratories Consent Order,” New Mexico Environment Department, April 24, 2004.

8. SNL/NM, 2003, Tijeras Arroyo Groundwater Investigation Work Plan, Sandia National Laboratories/New Mexico, June 2003.

9. SNL/NM, 2004, Corrective Measures Evaluation Work Plan Tijeras Arroyo Groundwater, Sandia National Laboratories/New Mexico. 
This Page Intentionally Left Blank 
Appendix A

Last quarter FY 2003 to first Quarter FY 2005

Biodegradation Assessment Data 
This Page Intentionally Left Blank 
Table A-1

\section{Summary of Detected Volatile Organic Compounds}

(EPA Method 8260)

\section{Tijeras Arroyo Groundwater Investigation}

\section{$4^{\text {th }}$ Quarter 2003}

\begin{tabular}{|c|c|c|c|c|c|c|c|}
\hline Well ID & Analyte & $\begin{array}{l}\text { Result } \\
(\mu \mathrm{g} / \mathrm{L})\end{array}$ & $\begin{array}{c}\text { MDL } \\
(\mu \mathrm{g} / \mathrm{L})\end{array}$ & $\begin{array}{c}\text { PQL } \\
(\mu \mathrm{g} / \mathrm{L})\end{array}$ & $\begin{array}{c}\text { Laboratory } \\
\text { Qualifier }\end{array}$ & $\begin{array}{c}\text { Validation } \\
\text { Qualifier }\end{array}$ & Sample No. \\
\hline $\mid \begin{array}{l}\text { TA1-W-03 } \\
\text { 24-Jul-03 }\end{array}$ & Acetone & 13.1 & 4.5 & 5 & & $\mathrm{~J}$ & 062684-001 \\
\hline \begin{tabular}{|l|} 
TA1-W-06 \\
29-Jul-03
\end{tabular} & 1,1-Dichloroethene & 0.48 & 0.41 & 1 & $\mathrm{~J}$ & & 062690-001 \\
\hline $\mid \begin{array}{l}\text { TA2-W-01 } \\
\text { 07-Aug-03 }\end{array}$ & Trichloroethene & 1.29 & 0.36 & 1 & & & 062700-001 \\
\hline \multirow{2}{*}{$\begin{array}{l}\text { TA2-W-19 } \\
\text { 23-Sep-03 }\end{array}$} & Trichloroethene & 3.77 & 0.36 & 1 & & & 063272-001 \\
\hline & cis-1,2-Dichloroethene & 0.661 & 0.3 & 1 & $\mathrm{~J}$ & & 063272-001 \\
\hline \multirow{3}{*}{$\begin{array}{l}\text { TA2-W-26 } \\
\text { 04-Aug-03 }\end{array}$} & Tetrachloroethene & 2.67 & 0.33 & 1 & & & 062704-001 \\
\hline & Trichloroethene & 1.9 & 0.36 & 1 & & & 062704-001 \\
\hline & cis-1,2-Dichloroethene & 0.925 & 0.3 & 1 & $\mathrm{~J}$ & & 062704-001 \\
\hline \begin{tabular}{|l|} 
TA2-W-27 \\
06-Aug-03
\end{tabular} & Tetrachloroethene & 0.421 & 0.33 & 1 & $\mathrm{~J}$ & & 062707-001 \\
\hline $\mid$\begin{tabular}{|} 
TJA-2 \\
$31-J u l-03$
\end{tabular} & Trichloroethene & 2.59 & 0.36 & 1 & & & 062709-001 \\
\hline \begin{tabular}{|l} 
TJA-7 \\
12-Aug-03
\end{tabular} & Trichloroethene & 1.46 & 0.36 & 1 & & & 062717-001 \\
\hline \multirow{3}{*}{$\begin{array}{l}\text { WYO-4 } \\
\text { 14-Aug-03 }\end{array}$} & 1,1-Dichloroethane & 0.709 & 0.41 & 1 & $\mathrm{~J}$ & & 062721-001 \\
\hline & Trichloroethene & 6.57 & 0.36 & 1 & & & 062721-001 \\
\hline & cis-1,2-Dichloroethene & 1.63 & 0.3 & 1 & & & 062721-001 \\
\hline \multirow{3}{*}{$\begin{array}{l}\text { WYO-4 } \\
\text { (Duplicate) } \\
\text { 14-Aug-03 }\end{array}$} & 1,1-Dichloroethane & 0.757 & 0.41 & 1 & $\mathrm{~J}$ & & 062722-001 \\
\hline & Trichloroethene & 6.39 & 0.36 & 1 & & & 062722-001 \\
\hline & cis-1,2-Dichloroethene & 1.66 & 0.3 & 1 & & & 062722-001 \\
\hline
\end{tabular}


Table A-2

Summary of Detected Volatile Organic Compounds

(EPA Method 8260)

Tijeras Arroyo Groundwater Investigation

$1^{\text {st }}$ Quarter 2004

\begin{tabular}{|c|c|c|c|c|c|c|c|}
\hline Well ID & Analyte & $\begin{array}{l}\text { Result } \\
(\mu \mathrm{g} / \mathrm{L})\end{array}$ & $\begin{array}{l}\text { MDL } \\
(\mu \mathrm{g} / \mathrm{L})\end{array}$ & $\begin{array}{c}\text { PQL } \\
(\mu \mathrm{g} / \mathrm{L})\end{array}$ & $\begin{array}{c}\text { Laboratory } \\
\text { Qualifier }\end{array}$ & $\begin{array}{c}\text { Validation } \\
\text { Qualifier }\end{array}$ & Sample No. \\
\hline $\begin{array}{l}\text { TA1-W-03 } \\
\text { 13-Oct-03 }\end{array}$ & Chloroform & 0.364 & 0.36 & 1 & $\mathrm{~J}$ & & 063281-001 \\
\hline $\begin{array}{l}\text { TA1-W-06 } \\
\text { 09-Oct-03 }\end{array}$ & Trichloroethene & 0.438 & 0.36 & 1 & $\mathrm{~J}$ & & 063284-001 \\
\hline $\begin{array}{l}\text { TA2-W-01 } \\
\text { 01-Dec-03 }\end{array}$ & Trichloroethene & 1.96 & 0.36 & 1 & & $\mathrm{~J}$ & 063290-001 \\
\hline \multirow{3}{*}{$\begin{array}{l}\text { TA2-W-19 } \\
\text { 07-Oct-03 }\end{array}$} & 1,1-Dichloroethane & 0.725 & 0.41 & 1 & $\mathrm{~J}$ & & 063291-001 \\
\hline & Trichloroethene & 4.54 & 0.36 & 1 & & & 063291-001 \\
\hline & cis-1,2-Dichloroethene & 0.845 & 0.3 & 1 & $\mathrm{~J}$ & & 063291-001 \\
\hline \multirow{3}{*}{\begin{tabular}{|} 
TA2-W-26 \\
16-Oct-03
\end{tabular}} & Tetrachloroethene & 2.50 & 0.33 & 1 & & & 063292-001 \\
\hline & Trichloroethene & 1.98 & 0.36 & 1 & & $\mathrm{~J}$ & 063292-001 \\
\hline & cis-1,2-Dichloroethene & 0.820 & 0.3 & 1 & $\mathrm{~J}$ & & 063292-001 \\
\hline \multirow{3}{*}{$\begin{array}{l}\text { TA2-W-26 } \\
\text { (Duplicate) } \\
\text { 16-Oct-03 }\end{array}$} & Tetrachloroethene & 2.59 & 0.33 & 1 & & & 063293-001 \\
\hline & Trichloroethene & 2.13 & 0.36 & 1 & & $\mathrm{~J}$ & 063293-001 \\
\hline & cis-1,2-Dichloroethene & 0.770 & 0.3 & 1 & $\mathrm{~J}$ & & 063293-001 \\
\hline $\begin{array}{l}\text { TA2-W-27 } \\
\text { 23-Oct-03 }\end{array}$ & Tetrachloroethene & 0.436 & 0.33 & 1 & $\mathrm{~J}$ & & 063294-001 \\
\hline $\begin{array}{l}\text { TJA-2 } \\
\text { 15-Oct-03 }\end{array}$ & Trichloroethene & 2.36 & 0.36 & 1 & & $\mathrm{~J}$ & 063295-001 \\
\hline \multirow{2}{*}{$\begin{array}{l}\text { WYO-4 } \\
\text { 03-Nov-03 }\end{array}$} & Trichloroethene & 6.06 & 0.36 & 1 & & $\mathrm{~J}$ & 063301-001 \\
\hline & cis-1,2-Dichloroethene & 1.43 & 0.3 & 1 & & & 063301-001 \\
\hline \multirow{2}{*}{$\begin{array}{l}\text { WYO-4 } \\
\text { (Duplicate) } \\
\text { 03-Nov-03 }\end{array}$} & Trichloroethene & 7.05 & 0.36 & 1 & & $\mathrm{~J}$ & 063302-001 \\
\hline & cis-1,2-Dichloroethene & 1.55 & 0.3 & 1 & & & 063302-001 \\
\hline
\end{tabular}


Table A-3

Summary of Detected Volatile Organic Compounds

(EPA Method 8260)

Tijeras Arroyo Groundwater Investigation

$2^{\text {nd }}$ Quarter 2004

\begin{tabular}{|c|c|c|c|c|c|c|c|}
\hline Well ID & Analyte & $\begin{array}{l}\text { Result } \\
(\mu \mathrm{g} / \mathrm{L})\end{array}$ & $\begin{array}{l}\text { MDL } \\
(\mu g / L)\end{array}$ & $\begin{array}{c}\text { PQL } \\
(\mu \mathrm{g} / \mathrm{L})\end{array}$ & $\begin{array}{c}\text { Laboratory } \\
\text { Qualifier }\end{array}$ & $\begin{array}{c}\text { Validation } \\
\text { Qualifier }\end{array}$ & Sample No. \\
\hline $\begin{array}{l}\text { Eubank-5 } \\
\text { 19-Feb-04 }\end{array}$ & Acetone & 5.52 & 4.5 & 5 & & $5.52 \cup, B 1$ & 063911-001 \\
\hline \multirow{2}{*}{$\begin{array}{l}\text { TA1-W-06 } \\
\text { O9-Feb-04 }\end{array}$} & 1,1-Dichloroethene & 0.784 & 0.41 & 1 & $\mathrm{~J}$ & & 063864-001 \\
\hline & Trichloroethene & 0.362 & 0.36 & 1 & $\mathrm{~J}$ & $\mathrm{~J}$ & 063864-001 \\
\hline $\begin{array}{l}\text { TA2-W-01 } \\
\text { 12-Jan-04 }\end{array}$ & Trichloroethene & 1.63 & 0.36 & 1 & & & 063876-001 \\
\hline \multirow{2}{*}{$\begin{array}{l}\text { TA2-W-19 } \\
\text { 13-Jan-04 }\end{array}$} & Trichloroethene & 4.19 & 0.36 & 1 & & & 063878-001 \\
\hline & cis-1,2-Dichloroethene & 0.886 & 0.3 & 1 & $\mathrm{~J}$ & & 063878-001 \\
\hline \multirow{3}{*}{$\begin{array}{l}\text { TA2-W-26 } \\
\text { 20-Jan-04 }\end{array}$} & Tetrachloroethene & 2.31 & 0.33 & 1 & & & 063880-001 \\
\hline & Trichloroethene & 1.81 & 0.36 & 1 & & $\mathrm{~J}$ & 063880-001 \\
\hline & cis-1,2-Dichloroethene & 0.726 & 0.3 & 1 & $\mathrm{~J}$ & & 063880-001 \\
\hline \multirow{3}{*}{$\begin{array}{l}\text { TA2-W-26 } \\
\text { (Duplicate) } \\
\text { 20-Jan-04 }\end{array}$} & Tetrachloroethene & 2.04 & 0.33 & 1 & & & 063881-001 \\
\hline & Trichloroethene & 1.56 & 0.36 & 1 & & $\mathrm{~J}$ & 063881-001 \\
\hline & cis-1,2-Dichloroethene & 0.724 & 0.3 & 1 & $\mathrm{~J}$ & & 063881-001 \\
\hline \multirow{2}{*}{$\begin{array}{l}\text { TA2-W-27 } \\
\text { 15-Jan-04 }\end{array}$} & Tetrachloroethene & 0.577 & 0.33 & 1 & $\mathrm{~J}$ & & 063885-001 \\
\hline & Trichloroethene & 0.519 & 0.36 & 1 & $\mathrm{~J}$ & $\mathrm{~J}$ & 063885-001 \\
\hline \multirow{2}{*}{$\begin{array}{l}\text { TJA-2 } \\
\text { 19-Jan-04 }\end{array}$} & Trichloroethene & 3.08 & 0.36 & 1 & & $\mathrm{~J}$ & 063887-001 \\
\hline & cis-1,2-Dichloroethene & 0.626 & 0.626 & 1 & $\mathrm{~J}$ & & 063887-001 \\
\hline \begin{tabular}{|l} 
TJA-7 \\
22-Jan-04
\end{tabular} & Trichloroethene & 0.430 & 0.36 & 1 & $\mathrm{~J}$ & $\mathrm{~J}$ & 063895-001 \\
\hline \multirow{3}{*}{$\begin{array}{l}\text { WYO-4 } \\
\text { 03-Feb-04 }\end{array}$} & 1,1-Dichloroethane & 0.773 & 0.41 & 1 & $\mathrm{~J}$ & & 063899-001 \\
\hline & Trichloroethene & 6.99 & 0.36 & 1 & & $\mathrm{~J}$ & 063899-001 \\
\hline & cis-1,2-Dichloroethene & 1.58 & 0.3 & 1 & & & 063899-001 \\
\hline \multirow{3}{*}{$\begin{array}{l}\text { WYO-4 } \\
\text { (Duplicate) } \\
\text { 03-Feb-04 }\end{array}$} & 1,1-Dichloroethane & 0.729 & 0.41 & 1 & $\mathrm{~J}$ & & 063900-001 \\
\hline & Trichloroethene & 6.60 & 0.36 & 1 & & $\mathrm{~J}$ & 063900-001 \\
\hline & cis-1,2-Dichloroethene & 1.62 & 0.3 & 1 & & & 063900-001 \\
\hline \multicolumn{8}{|c|}{$\begin{array}{l}\mu \mathrm{g} / \mathrm{L}=\text { micrograms per liter } \\
\mathrm{J}=\text { Amount detected is below the practical quantitation limit. The associated value is an estimated quantity. } \\
\mathrm{B} 1=\text { Analyte present in associated trip blank sample. } \\
\# \mathrm{H}=\text { Analyte was qualified as not detected at the listed value. }\end{array}$} \\
\hline
\end{tabular}


Table A-4

Summary of Detected Volatile Organic Compounds

(EPA Method 8260)

Tijeras Arroyo Groundwater Investigation

$3^{\text {rd }}$ Quarter 2004

\begin{tabular}{|c|c|c|c|c|c|c|c|}
\hline Well ID & Analyte & $\begin{array}{c}\text { Result } \\
(\mu \mathrm{g} / \mathrm{L})\end{array}$ & $\begin{array}{l}\text { MDL } \\
(\mu \mathrm{g} / \mathrm{L})\end{array}$ & $\begin{array}{c}\text { PQL } \\
(\mu \mathrm{g} / \mathrm{L})\end{array}$ & $\begin{array}{l}\text { Laboratory } \\
\text { Qualifier }\end{array}$ & $\begin{array}{c}\text { Validation } \\
\text { Qualifier }\end{array}$ & Sample No. \\
\hline \begin{tabular}{|l} 
Eubank-1 \\
20-May-04
\end{tabular} & Acetone & 4.2 & 1.3 & 20 & $\mathrm{~B}, \mathrm{~J}$ & $\begin{array}{c}\text { 20UJ, B, } \\
\text { B1, P2 }\end{array}$ & 064600-001 \\
\hline \multirow{2}{*}{$\begin{array}{l}\text { Eubank-2 } \\
\text { O6-May-04 }\end{array}$} & Acetone & 4.6 & 1.3 & 20 & $\mathrm{~J}$ & $\mathrm{~J}$ & 064602-001 \\
\hline & Toluene & 0.72 & 0.59 & 5 & $\mathrm{~J}$ & & 064602-001 \\
\hline \multirow{2}{*}{\begin{tabular}{|l} 
Eubank-3 \\
04-May-04
\end{tabular}} & Acetone & 4.3 & 1.3 & 20 & $\mathrm{~J}$ & 20UJ, B1 & 064604-001 \\
\hline & Chloromethane & 0.32 & 0.23 & 10 & $\mathrm{~J}$ & 10U, B1 & 064604-001 \\
\hline $\begin{array}{l}\text { Eubank-5 } \\
\text { 03-May-04 }\end{array}$ & Methylene chloride & 14 & 2.6 & 5 & & $\begin{array}{c}\text { 14UJ, A2, } \\
\text { B1 }\end{array}$ & 064607-001 \\
\hline \multirow{2}{*}{$\begin{array}{l}\text { PGS-2 } \\
12-M a y-04\end{array}$} & Acetone & 6.5 & 1.3 & 20 & $\mathrm{~B}, \mathrm{~J}$ & 20UJ, B, B1 & 064551-001 \\
\hline & Methylene chloride & 4.0 & 2.6 & 5 & $\mathrm{~B}, \mathrm{~J}$ & $\begin{array}{c}\text { 5.0UJ, B, } \\
\text { B1 }\end{array}$ & 064551-001 \\
\hline $\begin{array}{l}\text { TA1-W-01 } \\
\text { 10-May-04 }\end{array}$ & Acetone & 3.9 & 1.3 & 20 & $\mathrm{~J}$ & 20UJ, B1 & 064553-001 \\
\hline $\begin{array}{l}\text { TA1-W-02 } \\
\text { 11-May-04 }\end{array}$ & Acetone & 4.5 & 1.3 & 20 & $\mathrm{~B}, \mathrm{~J}$ & $\begin{array}{c}\text { 20UJ, B, } \\
\text { B1, P1 }\end{array}$ & 064556-001 \\
\hline \multirow{3}{*}{$\begin{array}{l}\text { TA1-W-03 } \\
\text { 28-Apr-04 }\end{array}$} & Acetone & 3.8 & 1.3 & 20 & $\mathrm{~B}, \mathrm{~J}$ & 20UJ, B & 064558-001 \\
\hline & Chloroform & 0.60 & 0.12 & 5 & $\mathrm{~J}$ & $5.0 \mathrm{U}, \mathrm{B} 3$ & 064558-001 \\
\hline & Toluene & 1.0 & 0.59 & 5 & $\mathrm{~B}, \mathrm{~J}$ & $5.0 \mathrm{U}, \mathrm{B}$ & 064558-001 \\
\hline \multirow{4}{*}{$\begin{array}{l}\text { TA1-W-04 } \\
\text { 26-Apr-04 }\end{array}$} & Acetone & 6.5 & 1.3 & 20 & $\mathrm{~B}, \mathrm{~J}$ & 20UJ, B & 064560-001 \\
\hline & Trichloroethene & 0.30 & 0.06 & 5 & $\mathrm{~J}$ & & 064560-001 \\
\hline & $\begin{array}{l}\text { 1,2-Dichloroethene } \\
\text { (total) }\end{array}$ & 0.73 & 0.61 & 10 & J & $\begin{array}{c}\text { 10UJ, A2, } \\
\text { B3 }\end{array}$ & 064560-001 \\
\hline & trans-1,2-Dichloroethene & 0.73 & 0.31 & 5 & $\mathrm{~J}$ & $5.0 \mathrm{U}, \mathrm{B} 3$ & 064560-001 \\
\hline $\begin{array}{l}\text { TA1-W-05 } \\
\text { 07-May-04 }\end{array}$ & Acetone & 4.7 & 1.3 & 20 & J & 20UJ, B1 & 064562-001 \\
\hline \multirow{3}{*}{$\begin{array}{l}\text { TA1-W-06 } \\
\text { 21-May-04 }\end{array}$} & Acetone & 4.9 & 1.3 & 20 & $\mathrm{~B}, \mathrm{~J}$ & $\begin{array}{c}\text { 20UJ, A1, } \\
\text { B, B1 }\end{array}$ & 064564-001 \\
\hline & Chloroform & 0.30 & 0.12 & 5 & $\mathrm{~J}$ & $\mathrm{~J}, \mathrm{~A} 1$ & 064564-001 \\
\hline & 1,1-Dichloroethene & 1.0 & 0.68 & 5 & $\mathrm{~J}$ & $\mathrm{~J}, \mathrm{~A} 1$ & 064564-001 \\
\hline
\end{tabular}




\begin{tabular}{|c|c|c|c|c|c|c|c|}
\hline Well ID & Analyte & $\begin{array}{l}\text { Result } \\
(\mu \mathrm{g} / \mathrm{L})\end{array}$ & $\begin{array}{c}\text { MDL } \\
(\mu \mathrm{g} / \mathrm{L})\end{array}$ & $\begin{array}{c}\text { PQL } \\
(\mu \mathrm{g} / \mathrm{L})\end{array}$ & $\begin{array}{c}\text { Laboratory } \\
\text { Qualifier }\end{array}$ & \begin{tabular}{|c|} 
Validation \\
Qualifier
\end{tabular} & Sample No. \\
\hline \multirow{5}{*}{$\begin{array}{l}\text { TA1-W-08 } \\
\text { 23-Apr-04 }\end{array}$} & Acetone & 5.3 & 1.3 & 20 & $\mathrm{~B}, \mathrm{~J}$ & $20 U \mathrm{~J}, \mathrm{~B}, \mathrm{~B} 1$ & 064566-001 \\
\hline & Chloroform & 0.22 & 0.12 & 5 & $\mathrm{~J}$ & $\begin{array}{c}\text { 5.0UJ, A2, } \\
\text { B1, P1 }\end{array}$ & 064566-001 \\
\hline & Trichloroethene & 0.44 & 0.06 & 5 & $\mathrm{~J}$ & & 064566-001 \\
\hline & $\begin{array}{l}\text { 1,2-Dichloroethene } \\
\text { (total) }\end{array}$ & 0.64 & 0.61 & 10 & $\mathrm{~J}$ & & 064566-001 \\
\hline & trans-1,2-Dichloroethene & 0.64 & 0.31 & 5 & $\mathrm{~J}$ & & 064566-001 \\
\hline \multirow{3}{*}{$\begin{array}{l}\text { TA2-NW1-595 } \\
\text { (QED) } \\
\text { 13-May-04 }\end{array}$} & Acetone & 7.9 & 1.3 & 20 & $\mathrm{~B}, \mathrm{~J}$ & 20U, B & 064568-001 \\
\hline & Chloroform & 0.42 & 0.12 & 5 & $\mathrm{~J}$ & $5.0 \mathrm{U}, \mathrm{B} 1$ & 064568-001 \\
\hline & Methylene chloride & 6.4 & 2.6 & 5 & & $6.4 \mathrm{UJ}, \mathrm{B} 1$ & 064568-001 \\
\hline \multirow{2}{*}{\begin{tabular}{|l} 
TA2-NW1-595 \\
(Bennett) \\
19-May-04
\end{tabular}} & Acetone & 4.4 & 1.3 & 20 & $\mathrm{~B}, \mathrm{~J}$ & $20 U, B, P 2$ & 064571-001 \\
\hline & Chloroform & 0.28 & 0.12 & 5 & $\mathrm{~J}$ & $\mathrm{P} 2$ & 064571-001 \\
\hline \multirow{3}{*}{$\begin{array}{l}\text { TA2-SW1-320 } \\
\text { 14-May-04 }\end{array}$} & Acetone & 11 & 1.3 & 20 & $\mathrm{~B}, \mathrm{~J}$ & $20 U \mathrm{~J}, \mathrm{~B}, \mathrm{~B} 1$ & 064573-001 \\
\hline & Chloromethane & 0.38 & 0.23 & 10 & $\mathrm{~J}$ & & 064573-001 \\
\hline & Methylene chloride & 5.7 & 2.6 & 5 & & $5.7 \mathrm{UJ}, \mathrm{B} 1$ & 064573-001 \\
\hline \multirow{4}{*}{$\begin{array}{l}\text { TA2-W-01 } \\
\text { 17-May-04 }\end{array}$} & Acetone & 9.6 & 1.3 & 20 & $\mathrm{~B}, \mathrm{~J}$ & $20 \mathrm{UJ}, \mathrm{B}, \mathrm{B} 1$ & $064575-001$ \\
\hline & Chloroform & 0.30 & 0.12 & 5 & $\mathrm{~J}$ & & 064575-001 \\
\hline & Methylene chloride & 6.7 & 2.6 & 5 & & 6.7UJ, B1 & 064575-001 \\
\hline & Trichloroethene & 1.8 & 0.06 & 5 & $\mathrm{~J}$ & & 064575-001 \\
\hline \multirow{6}{*}{$\begin{array}{l}\text { TA2-W-19 } \\
\text { 27-Apr-04 }\end{array}$} & Acetone & 5.1 & 1.3 & 20 & $\mathrm{~B}, \mathrm{~J}$ & $20 U J, B$ & 064577-001 \\
\hline & Trichloroethene & 5.2 & 0.06 & 5 & & & 064577-001 \\
\hline & 1,1-Dichloroethane & 0.92 & 0.21 & 5 & $\mathrm{~J}$ & & 064577-001 \\
\hline & $\begin{array}{l}\text { 1,2-Dichloroethene } \\
\text { (total) }\end{array}$ & 1.7 & 0.61 & 10 & $\mathrm{~J}$ & $10 U, B 3$ & 064577-001 \\
\hline & cis-1,2-Dichloroethene & 0.99 & 0.20 & 5 & $\mathrm{~J}$ & & 064577-001 \\
\hline & trans-1,2-Dichloroethene & 0.70 & 0.31 & 5 & $\mathrm{~J}$ & & 064577-001 \\
\hline \multirow{6}{*}{$\begin{array}{l}\text { TA2-W-19 } \\
\text { (Duplicate) } \\
\text { 27-Apr-04 }\end{array}$} & Acetone & 4.5 & 1.3 & 20 & $\mathrm{~B}, \mathrm{~J}$ & $20 U J, B$ & 064578-001 \\
\hline & Trichloroethene & 5.1 & 0.06 & 5 & & & 064578-001 \\
\hline & 1,1-Dichloroethane & 0.96 & 0.21 & 5 & $\mathrm{~J}$ & & 064578-001 \\
\hline & $\begin{array}{l}\text { 1,2-Dichloroethene } \\
\text { (total) }\end{array}$ & 1.7 & 0.61 & 10 & $\mathrm{~J}$ & 10U, B3 & 064578-001 \\
\hline & cis-1,2-Dichloroethene & 1.0 & 0.20 & 5 & $\mathrm{~J}$ & & 064578-001 \\
\hline & trans-1,2-Dichloroethene & 0.62 & 0.31 & 5 & $\mathrm{~J}$ & & 064578-001 \\
\hline \multirow{2}{*}{$\begin{array}{l}\text { TA2-W-26 } \\
\text { 21-Apr-04 }\end{array}$} & Acetone & 4.1 & 1.3 & 20 & $\mathrm{~B}, \mathrm{~J}$ & $20 U J, B$ & 064580-001 \\
\hline & Carbon tetrachloride & 0.87 & 0.14 & 5 & $\mathrm{~B}, \mathrm{~J}$ & $5.0 \mathrm{U}, \mathrm{B}$ & 064580-001 \\
\hline
\end{tabular}




\begin{tabular}{|c|c|c|c|c|c|c|c|}
\hline Well ID & Analyte & $\begin{array}{l}\text { Result } \\
(\mu \mathrm{g} / \mathrm{L})\end{array}$ & $\begin{array}{l}\text { MDL } \\
(\mu \mathrm{g} / \mathrm{L})\end{array}$ & $\begin{array}{l}\text { PQL } \\
(\mu \mathrm{g} / \mathrm{L})\end{array}$ & $\begin{array}{c}\text { Laboratory } \\
\text { Qualifier }\end{array}$ & $\begin{array}{c}\text { Validation } \\
\text { Qualifier }\end{array}$ & Sample No. \\
\hline & Chloroform & 0.32 & 0.12 & 5 & $\mathrm{~J}$ & & 064580-001 \\
\hline & Tetrachloroethene & 1.9 & 0.20 & 5 & $\mathrm{~J}$ & & 064580-001 \\
\hline & Trichloroethene & 3.1 & 0.06 & 5 & $\mathrm{~B}, \mathrm{~J}$ & $5.0 U, \mathrm{~B}$ & 064580-001 \\
\hline & $\begin{array}{l}\text { 1,2-Dichloroethene } \\
\text { (total) }\end{array}$ & 0.69 & 0.61 & 10 & $\mathrm{~J}$ & & 064580-001 \\
\hline & cis-1,2-Dichloroethene & 0.69 & 0.20 & 5 & $\mathrm{~J}$ & & 064580-001 \\
\hline \multirow{7}{*}{$\begin{array}{l}\text { TA2-W-26 } \\
\text { (Duplicate) } \\
\text { 21-Apr-04 }\end{array}$} & Acetone & 4.1 & 1.3 & 20 & $\mathrm{~B}, \mathrm{~J}$ & $20 U J, B$ & 064581-001 \\
\hline & Carbon tetrachloride & 0.88 & 0.14 & 5 & $\mathrm{~B}, \mathrm{~J}$ & $5.0 U, \mathrm{~B}$ & 064581-001 \\
\hline & Chloroform & 0.37 & 0.12 & 5 & $\mathrm{~J}$ & & 064581-001 \\
\hline & Tetrachloroethene & 2.0 & 0.20 & 5 & $\mathrm{~J}$ & & 064581-001 \\
\hline & Trichloroethene & 3.0 & 0.06 & 5 & $\mathrm{~B}, \mathrm{~J}$ & $5.0 U, B$ & 064581-001 \\
\hline & $\begin{array}{l}\text { 1,2-Dichloroethene } \\
\text { (total) }\end{array}$ & 0.70 & 0.61 & 10 & $\mathrm{~J}$ & & 064581-001 \\
\hline & cis-1,2-Dichloroethene & 0.70 & 0.20 & 5 & $\mathrm{~J}$ & & 064581-001 \\
\hline \multirow{6}{*}{$\begin{array}{l}\text { TA2-W-27 } \\
\text { 19-Apr-04 }\end{array}$} & Acetone & 4.6 & 1.3 & 20 & $\mathrm{~J}$ & 20UJ, B1 & 064583-001 \\
\hline & Chloromethane & 0.46 & 0.23 & 10 & $\mathrm{~J}$ & $\mathrm{~J}$ & 064583-001 \\
\hline & Methylene chloride & 6.1 & 2.6 & 5 & B & $5.0 \mathrm{U}, \mathrm{B}$ & 064583-001 \\
\hline & Tetrachloroethene & 0.62 & 0.20 & 5 & $\mathrm{~J}$ & & 064583-001 \\
\hline & Trichloroethene & 1.3 & 0.06 & 5 & $\mathrm{~J}$ & $5.0 U$, B1 & 064583-001 \\
\hline & 4-Methyl-2-pentanone & 3.6 & 0.90 & 20 & $\mathrm{~J}$ & 20UJ, B1 & 064583-001 \\
\hline \multirow{6}{*}{$\begin{array}{l}\text { TJA-2 } \\
\text { 05-May-04 }\end{array}$} & Acetone & 3.3 & 1.3 & 20 & $\mathrm{~J}$ & 20UJ, B1 & 064585-001 \\
\hline & Chloromethane & 0.38 & 0.23 & 10 & $\mathrm{~J}$ & 10U, B1 & 064585-001 \\
\hline & Trichloroethene & 3.3 & 0.06 & 5 & $\mathrm{~J}$ & & 064585-001 \\
\hline & 1,1-Dichloroethane & 0.50 & 0.21 & 5 & $\mathrm{~J}$ & & 064585-001 \\
\hline & $\begin{array}{l}\text { 1,2-Dichloroethene } \\
\text { (total) }\end{array}$ & 0.67 & 0.61 & 10 & $\mathrm{~J}$ & & 064585-001 \\
\hline & cis-1,2-Dichloroethene & 0.67 & 0.20 & 5 & $\mathrm{~J}$ & & 064585-001 \\
\hline $\begin{array}{l}\text { TJA-3 } \\
\text { 27-Apr-04 }\end{array}$ & Acetone & 4.3 & 1.3 & 20 & $\mathrm{~B}, \mathrm{~J}$ & $20 U J, B$ & 064587-001 \\
\hline \multirow{3}{*}{$\begin{array}{l}\text { TJA-4 } \\
\text { 20-Apr-04 }\end{array}$} & Acetone & 5.7 & 1.3 & 20 & $\mathrm{~J}$ & $\begin{array}{l}\text { 20UJ, A1, } \\
\text { B1 }\end{array}$ & 064589-001 \\
\hline & Methylene chloride & 2.9 & 2.6 & 5 & $\mathrm{~B}, \mathrm{~J}$ & $\begin{array}{c}5.0 \mathrm{UJ}, \mathrm{A} 1, \\
\mathrm{~B}\end{array}$ & 064589-001 \\
\hline & 4-Methyl-2-pentanone & 3.0 & 0.90 & 20 & $\mathrm{~J}$ & $\begin{array}{l}\text { 20UJ, B1 } \\
\text { A1 }\end{array}$ & 064589-001 \\
\hline TJA-6 & Acetone & 5.0 & 1.3 & 20 & $\mathrm{~B}, \mathrm{~J}$ & $20 U J, B$ & 064591-001 \\
\hline
\end{tabular}




\begin{tabular}{|c|c|c|c|c|c|c|c|}
\hline Well ID & Analyte & $\begin{array}{l}\text { Result } \\
(\mu \mathrm{g} / \mathrm{L})\end{array}$ & $\begin{array}{l}\text { MDL } \\
(\mu g / L)\end{array}$ & $\begin{array}{l}\text { PQL } \\
(\mu \mathrm{g} / \mathrm{L})\end{array}$ & $\begin{array}{c}\text { Laboratory } \\
\text { Qualifier }\end{array}$ & $\begin{array}{c}\text { Validation } \\
\text { Qualifier }\end{array}$ & Sample No. \\
\hline \multirow[t]{2}{*}{ 22-Apr-04 } & Carbon tetrachloride & 0.88 & 0.14 & 5 & $\mathrm{~B}, \mathrm{~J}$ & $5.0 U, B$ & 064591-001 \\
\hline & Trichloroethene & 1.2 & 0.06 & 5 & $\mathrm{~B}, \mathrm{~J}$ & $5.0 U, \mathrm{~B}$ & 064591-001 \\
\hline \multirow{2}{*}{$\begin{array}{l}\text { TJA-7 } \\
\text { 30-Apr-04 }\end{array}$} & Acetone & 4.4 & 1.3 & 20 & $\mathrm{~B}, \mathrm{~J}$ & $20 U \mathrm{~J}, \mathrm{~B}, \mathrm{~B} 1$ & 064593-001 \\
\hline & Methylene chloride & 23 & 2.6 & 5 & & $\begin{array}{l}23 \cup J, A 2, \\
B 1\end{array}$ & 064593-001 \\
\hline \multirow{3}{*}{$\begin{array}{l}\text { WYO-3 } \\
\text { 28-Apr-04 }\end{array}$} & Acetone & 4.0 & 1.3 & 20 & $\mathrm{~B}, \mathrm{~J}$ & $20 \cup J, B$ & 064595-001 \\
\hline & Chloromethane & 0.35 & 0.23 & 10 & $\mathrm{~J}$ & 10U, B3 & 064595-001 \\
\hline & Toluene & 1.0 & 0.59 & 5 & $\mathrm{~B}, \mathrm{~J}$ & $5.0 U, \mathrm{~B}$ & 064595-001 \\
\hline \multirow{6}{*}{$\begin{array}{l}\text { WYO-4 } \\
\text { 30-Apr-04 }\end{array}$} & Acetone & 3.8 & 1.3 & 20 & $\mathrm{~B}, \mathrm{~J}$ & $20 U \mathrm{~J}, \mathrm{~B}, \mathrm{~B} 1$ & 064597-001 \\
\hline & Methylene chloride & 3.2 & 2.6 & 5 & $\mathrm{~J}$ & $\begin{array}{c}5.0 \cup J, A 2, \\
\text { B1 }\end{array}$ & 064597-001 \\
\hline & Trichloroethene & 7.7 & 0.06 & 5 & & & 064597-001 \\
\hline & 1,1-Dichloroethane & 0.99 & 0.21 & 5 & $\mathrm{~J}$ & & 064597-001 \\
\hline & $\begin{array}{l}\text { 1,2-Dichloroethene } \\
\text { (total) }\end{array}$ & 2.1 & 0.61 & 10 & $\mathrm{~J}$ & & 064597-001 \\
\hline & cis-1,2-Dichloroethene & 2.1 & 0.20 & 5 & $\mathrm{~J}$ & & 064597-001 \\
\hline \multirow{6}{*}{$\begin{array}{l}\text { WYO-4 } \\
\text { (Duplicate) } \\
\text { 30-Apr-04 }\end{array}$} & Acetone & 3.7 & 1.3 & 20 & $\mathrm{~B}, \mathrm{~J}$ & $20 U \mathrm{~J}, \mathrm{~B}, \mathrm{~B} 1$ & 064598-001 \\
\hline & Methylene chloride & 3.2 & 2.6 & 5 & $\mathrm{~J}$ & $\begin{array}{c}5.0 \mathrm{UJ}, \mathrm{A} 2, \\
\mathrm{~B} 1\end{array}$ & 064598-001 \\
\hline & Trichloroethene & 7.6 & 0.06 & 5 & & & 064598-001 \\
\hline & 1,1-Dichloroethane & 0.95 & 0.21 & 5 & $\mathrm{~J}$ & & 064598-001 \\
\hline & $\begin{array}{l}\text { 1,2-Dichloroethene } \\
\text { (total) }\end{array}$ & 1.9 & 0.61 & 10 & $\mathrm{~J}$ & & 064598-001 \\
\hline & cis-1,2-Dichloroethene & 1.9 & 0.20 & 5 & $\mathrm{~J}$ & & 064598-001 \\
\hline \multicolumn{8}{|c|}{$\begin{array}{l}\mu \mathrm{g} / \mathrm{L}=\text { micrograms per liter } \\
\mathrm{J}=\text { Amount detected is below the practical quantitation limit. The associated value is an estimated quantity. } \\
\mathrm{A} 1=\text { Laboratory accuracy and/or bias measurements for the associated surrogate spike do not meet acceptance criteria. } \\
\mathrm{A} 2=\text { Laboratory accuracy and/or bias measurements for the associated matrix spike and/or duplicate do not meet acceptance } \\
\text { criteria. } \\
\mathrm{B}=\text { Analyte is detected in associated laboratory method blank. } \\
\mathrm{B} 1=\text { Analyte present in associated trip blank sample. } \\
\mathrm{B} 3=\text { Analyte present in associated continuing calibration blank. } \\
\mathrm{P} 1=\text { Laboratory precision measurement for the associated matrix spike and/or duplicate samples do not meet acceptance } \\
\text { criteria. } \\
\mathrm{P} 2 \text { = Insufficient quality control data to determine laboratory precision. } \\
\mathrm{UJ}=\text { Associated value is an estimate and may be inaccurate or imprecise. } \\
\# \mathrm{U}=\text { Analyte was qualified as not detected at the listed value. }\end{array}$} \\
\hline
\end{tabular}


Table A-5

Summary of Detected Volatile Organic Compounds

(EPA Method 8260)

Tijeras Arroyo Groundwater Investigation

$4^{\text {th }}$ Quarter 2004

\begin{tabular}{|c|c|c|c|c|c|c|c|}
\hline Well ID & Analyte & $\begin{array}{c}\text { Result } \\
(\mu \mathrm{g} / \mathrm{L})\end{array}$ & $\begin{array}{c}\text { MDL } \\
(\mu \mathrm{g} / \mathrm{L})\end{array}$ & $\begin{array}{c}\text { PQL } \\
(\mu \mathrm{g} / \mathrm{L})\end{array}$ & $\begin{array}{l}\text { Laboratory } \\
\text { Qualifier }\end{array}$ & $\begin{array}{c}\text { Validation } \\
\text { Qualifier }\end{array}$ & Sample No. \\
\hline $\begin{array}{l}\text { Eubank-1 } \\
\text { 19-Aug-04 }\end{array}$ & Methylene chloride & 4.5 & 2.6 & 5 & $\mathrm{~B}, \mathrm{~J}$ & $\begin{array}{c}5.0 \mathrm{U}, \mathrm{A}, \mathrm{B}, \\
\mathrm{B} 1\end{array}$ & 065416-001 \\
\hline \begin{tabular}{|l|} 
PGS-2 \\
28-Jul-04
\end{tabular} & Acetone & 3.7 & 1.3 & 20 & $B, J$ & $20 U J, B$ & 065360-001 \\
\hline \begin{tabular}{|l|} 
TA1-W-01 \\
17-Aug-04
\end{tabular} & Methylene chloride & 4.8 & 2.6 & 5 & $\mathrm{~B}, \mathrm{~J}$ & $\begin{array}{c}5.0 \mathrm{UJ}, \mathrm{A}, \mathrm{B}, \\
\mathrm{B} 1\end{array}$ & 065362-001 \\
\hline \multirow{3}{*}{$\begin{array}{l}\text { TA1-W-02 } \\
\text { 13-Aug-04 }\end{array}$} & Acetone & 4.9 & 1.3 & 20 & $\mathrm{~J}$ & 20UJ, B1 & 065364-001 \\
\hline & Chloromethane & 0.49 & 0.23 & 10 & $\mathrm{~J}$ & $10 U, \mathrm{~B} 1$ & 065364-001 \\
\hline & Methylene chloride & 4.8 & 2.6 & 5 & $\mathrm{~J}$ & $5.0 \mathrm{U}, \mathrm{B} 1$ & 065364-001 \\
\hline \multirow{2}{*}{$\begin{array}{l}\text { TA1-W-03 } \\
\text { 18-Aug-04 }\end{array}$} & Chloroform & 0.47 & 0.12 & 5 & $\mathrm{~J}$ & & 065366-001 \\
\hline & Methylene chloride & 4.5 & 2.6 & 5 & $\mathrm{~B}, \mathrm{~J}$ & $\begin{array}{c}5.0 \mathrm{UJ}, \mathrm{A}, \mathrm{B} \\
\mathrm{B} 1\end{array}$ & 065366-001 \\
\hline \multirow{3}{*}{$\begin{array}{l}\text { TA1-W-04 } \\
\text { 26-Jul-04 }\end{array}$} & Acetone & 3.9 & 1.3 & 20 & $\mathrm{~B}, \mathrm{~J}$ & $20 \mathrm{UJ}, \mathrm{B}, \mathrm{B} 1$ & 065368-001 \\
\hline & Chloromethane & 0.48 & 0.23 & 10 & $\mathrm{~J}$ & J, P1 & 065368-001 \\
\hline & Methylene chloride & 2.7 & 2.6 & 5 & $\mathrm{~B}, \mathrm{~J}$ & $5.0 \mathrm{UJ}, \mathrm{B}$ & 065368-001 \\
\hline \multirow{5}{*}{$\begin{array}{l}\text { TA1-W-06 } \\
\text { 06-Aug-04 }\end{array}$} & 1,1-Dichloroethene & 0.92 & 0.68 & 5 & $\mathrm{~J}$ & & $065372-001$ \\
\hline & Bromomethane & 4.1 & 0.89 & 10 & $\mathrm{~B}, \mathrm{~J}$ & 10UJ, B & 065372-001 \\
\hline & Chloroform & 0.35 & 0.12 & 5 & $\mathrm{~J}$ & & 065372-001 \\
\hline & Methylene chloride & 4.2 & 2.6 & 5 & $\mathrm{~B}, \mathrm{~J}$ & $5.0 \mathrm{UJ}, \mathrm{B}$ & 065372-001 \\
\hline & Trichloroethene & 0.32 & 0.06 & 5 & $\mathrm{~J}$ & & $065372-001$ \\
\hline $\begin{array}{l}\text { TA1-W-08 } \\
\text { 13-Aug-04 }\end{array}$ & Methylene chloride & 8.3 & 2.6 & 5 & $\mathrm{~B}$ & $\begin{array}{c}\text { 8.3UJ, B, } \\
\mathrm{B} 1\end{array}$ & 065374-001 \\
\hline \multirow{2}{*}{$\begin{array}{l}\text { TA2-NW1-595 } \\
\text { (QED) } \\
\text { 26-Jul-04 } \\
\end{array}$} & Acetone & 4.1 & 1.3 & 20 & $\mathrm{~J}$ & $\mathrm{~J}$ & 065377-001 \\
\hline & Methylene chloride & 3.8 & 2.6 & 5 & $\mathrm{~J}$ & $5.0 \mathrm{UJ}, \mathrm{B} 1$ & 065377-001 \\
\hline $\begin{array}{l}\text { TA2-SW1-320 } \\
\text { 27-Jul-04 }\end{array}$ & Acetone & 4.3 & 1.3 & 20 & $B, J$ & $20 U J, B$ & 065381-001 \\
\hline $\begin{array}{l}\text { TA2-W-01 } \\
\text { 12-Aug-04 }\end{array}$ & Trichloroethene & 1.3 & 0.06 & 5 & $\mathrm{~J}$ & & 065383-001 \\
\hline \multirow{3}{*}{$\begin{array}{l}\text { TA2-W-19 } \\
\text { 27-Jul-04 }\end{array}$} & 1,1-Dichloroethane & 0.73 & 0.21 & 5 & $\mathrm{~J}$ & $\mathrm{P} 1, \mathrm{UJ}$ & 065385-001 \\
\hline & Chloromethane & 0.49 & 0.23 & 10 & $\mathrm{~J}$ & $\begin{array}{c}\text { 10UJ, B1, } \\
\text { P1 }\end{array}$ & 065385-001 \\
\hline & Trichloroethene & 4.2 & 0.06 & 5 & $\mathrm{~J}$ & & 065385-001 \\
\hline \multirow{7}{*}{$\begin{array}{l}\text { TA2-W-26 } \\
\text { 30-Jul-04 }\end{array}$} & 1,2-Dichloroethene & 0.61 & 0.18 & 10 & $\mathrm{~J}$ & P2 & 065387-001 \\
\hline & Acetone & 4.1 & 0.21 & 20 & $\mathrm{~J}$ & $\begin{array}{c}\text { 20UJ, B1, } \\
\text { P2 }\end{array}$ & 065387-001 \\
\hline & Bromomethane & 1.2 & 0.1 & 10 & $\mathrm{~J}$ & $\mathrm{~J}, \mathrm{P} 2$ & 065387-001 \\
\hline & Methylene chloride & 1.8 & 0.17 & 5 & $\mathrm{~J}$ & $\begin{array}{c}\text { 5.0UJ, B1, } \\
\text { P2 }\end{array}$ & 065387-001 \\
\hline & Tetrachloroethene & 2.0 & 0.08 & 5 & $\mathrm{~J}$ & $\mathrm{P} 2$ & 065387-001 \\
\hline & Trichloroethene & 1.4 & 0.09 & 5 & $\mathrm{~J}$ & $\mathrm{P} 2$ & 065387-001 \\
\hline & cis-1,2-Dichloroethene & 0.61 & 0.1 & 5 & $\mathrm{~J}$ & $\mathrm{P} 2$ & 065387-001 \\
\hline TA2-W-26 & 1,2-Dichloroethene & 0.6 & 0.18 & 10 & $\mathrm{~J}$ & $\mathrm{P} 2$ & 065388-001 \\
\hline
\end{tabular}




\begin{tabular}{|c|c|c|c|c|c|c|c|}
\hline Well ID & Analyte & $\begin{array}{c}\text { Result } \\
(\mu \mathrm{g} / \mathrm{L})\end{array}$ & $\begin{array}{l}\text { MDL } \\
(\mu g / L)\end{array}$ & $\begin{array}{l}\text { PQL } \\
(\mu \mathrm{g} / \mathrm{L})\end{array}$ & $\begin{array}{l}\text { Laboratory } \\
\text { Qualifier }\end{array}$ & $\begin{array}{l}\text { Validation } \\
\text { Qualifier }\end{array}$ & Sample No. \\
\hline \multirow{5}{*}{$\begin{array}{l}\text { 30-Jul-04 } \\
\text { (Duplicate) }\end{array}$} & Bromomethane & 1.2 & 0.1 & 10 & $\mathrm{~J}$ & $\mathrm{~J}, \mathrm{P} 2$ & 065388-001 \\
\hline & Methylene chloride & 2.1 & 0.17 & 5 & $\mathrm{~J}$ & $\begin{array}{c}\text { 5.0UJ, B1, } \\
\text { P2 }\end{array}$ & 065388-001 \\
\hline & Tetrachloroethene & 2.0 & 0.08 & 5 & $\mathrm{~J}$ & P2 & 065388-001 \\
\hline & Trichloroethene & 1.3 & 0.09 & 5 & $\mathrm{~J}$ & P2 & 065388-001 \\
\hline & cis-1,2-Dichloroethene & 0.6 & 0.1 & 5 & $\mathrm{~J}$ & $\mathrm{P} 2$ & 065388-001 \\
\hline \multirow{5}{*}{$\begin{array}{l}\text { TAG-W-27 } \\
\text { 28-Jul-04 }\end{array}$} & Acetone & 3.8 & 1.3 & 20 & $\mathrm{~B}, \mathrm{~J}$ & $20 \mathrm{UJ}, \mathrm{B}$ & 065392-001 \\
\hline & Chloroform & 0.24 & 0.12 & 5 & $\mathrm{~J}$ & $5.0 \mathrm{U}, \mathrm{B1}$ & 065392-001 \\
\hline & Methylene chloride & 2.8 & 2.6 & 5 & $\mathrm{~B}, \mathrm{~J}$ & $5.0 \mathrm{UJ}, \mathrm{B}$ & 065392-001 \\
\hline & Tetrachloroethene & 0.65 & 0.2 & 5 & $\mathrm{~J}$ & P1, UJ & 065392-001 \\
\hline & Trichloroethene & 0.51 & 0.06 & 5 & $\mathrm{~J}$ & & 065392-001 \\
\hline \multirow{5}{*}{$\begin{array}{l}\text { TJA-2 } \\
\text { 16-Aug-04 }\end{array}$} & 1,1-Dichloroethane & 0.53 & 0.21 & 5 & $\mathrm{~J}$ & $A, J$ & 065394-001 \\
\hline & 1,2-Dichloroethene & 0.63 & 0.61 & 10 & $\mathrm{~J}$ & & 065394-001 \\
\hline & Methylene chloride & 3.6 & 2.6 & 5 & $\mathrm{~B}, \mathrm{~J}$ & $\begin{array}{c}5.0 \mathrm{UJ}, \mathrm{A}, \mathrm{B}, \\
\mathrm{B} 1\end{array}$ & 065394-001 \\
\hline & Trichloroethene & 3.1 & 0.06 & 5 & $\mathrm{~J}$ & & 065394-001 \\
\hline & cis-1,2-Dichloroethene & 0.63 & 0.2 & 5 & $\mathrm{~J}$ & & 065394-001 \\
\hline $\begin{array}{l}\text { TJA-3 } \\
\text { 09-Aug-04 }\end{array}$ & Methylene chloride & 8.9 & 2.6 & 5 & & $\begin{array}{c}\text { 8.9UJ, A, } \\
\text { B1 }\end{array}$ & 065397-001 \\
\hline \multirow[b]{2}{*}{$\begin{array}{l}\text { TJA-6 } \\
\text { 04-Aug-04 }\end{array}$} & Bromomethane & 1.7 & 0.1 & 10 & $\mathrm{~B}, \mathrm{~J}$ & $10 \mathrm{UJ}, \mathrm{B}$ & 065401-001 \\
\hline & Methylene chloride & 2.6 & 0.17 & 5 & $\mathrm{~B}, \mathrm{~J}$ & $\begin{array}{l}\text { 5.0UJ, B, } \\
\text { B1 }\end{array}$ & 065401-001 \\
\hline \multirow{5}{*}{$\begin{array}{l}\text { TJA-7 } \\
\text { 6-Aug-04 } \\
\text { (Duplicate) }\end{array}$} & Acetone & 2.7 & 1.3 & 20 & $\mathrm{~B}, \mathrm{~J}, \mathrm{H}$ & $\begin{array}{c}\text { 20UJ, B, } \\
\text { HT }\end{array}$ & 065403-R01 \\
\hline & Acetone & 4.7 & 1.3 & 20 & $\mathrm{~J}$ & 20UJ, B1 & 065403-001 \\
\hline & Bromomethane & 4.1 & 0.89 & 10 & $\mathrm{~B}, \mathrm{~J}$ & $10 U \mathrm{~J}, \mathrm{~B}$ & 065403-001 \\
\hline & Methylene chloride & 3.5 & 2.6 & 5 & $\mathrm{~B}, \mathrm{~J}$ & $5.0 \cup J, B$ & 065403-001 \\
\hline & Trichloroethene & 0.53 & 0.06 & 5 & $\mathrm{~J}$ & & 065403-001 \\
\hline \multirow{2}{*}{$\begin{array}{l}\text { TJA-7 } \\
\text { 06-Aug-04 }\end{array}$} & Methylene chloride & 3.7 & 2.6 & 5 & $\mathrm{~B}, \mathrm{~J}$ & $5.0 \mathrm{UJ}, \mathrm{B}$ & 065404-001 \\
\hline & Trichloroethene & 0.55 & 0.06 & 5 & $\mathrm{~J}$ & & 065404-001 \\
\hline \multirow{5}{*}{$\begin{array}{l}\text { WYO-4 } \\
\text { 03-Aug-04 }\end{array}$} & 1,2-Dichloroethene & 1.7 & 0.18 & 10 & $\mathrm{~J}$ & & 065411-001 \\
\hline & Bromomethane & 1.6 & 0.1 & 10 & $\mathrm{~B}, \mathrm{~J}$ & $10 U \mathrm{~J}, \mathrm{~B}, \mathrm{~B} 1$ & 065411-001 \\
\hline & Methylene chloride & 2.6 & 0.17 & 5 & $\mathrm{~B}, \mathrm{~J}$ & \begin{tabular}{|c|}
$5.0 U \mathrm{~J}, \mathrm{~B}$ \\
$\mathrm{~B} 1, \mathrm{~B} 2$
\end{tabular} & 065411-001 \\
\hline & Trichloroethene & 6.7 & 0.09 & 5 & & & 065411-001 \\
\hline & cis-1,2-Dichloroethene & 1.7 & 0.1 & 5 & $\mathrm{~J}$ & & 065411-001 \\
\hline \multirow{4}{*}{$\begin{array}{l}\text { WYO-4 } \\
\text { 03-Aug-04 } \\
\text { (Duplicate) }\end{array}$} & 1,2-Dichloroethene & 1.5 & 0.18 & 10 & $\mathrm{~J}$ & & 065412-001 \\
\hline & Methylene chloride & 2.7 & 0.17 & 5 & $\mathrm{~B}, \mathrm{~J}$ & $\begin{array}{c}5.0 \cup J, B, \\
\text { B1, B2 }\end{array}$ & 065412-001 \\
\hline & Trichloroethene & 6.0 & 0.09 & 5 & & & $065412-001$ \\
\hline & cis-1,2-Dichloroethene & 1.5 & 0.1 & 5 & $\mathrm{~J}$ & & 065412-001 \\
\hline \multicolumn{8}{|c|}{$\begin{array}{l}\mu \mathrm{g} / \mathrm{L}=\text { micrograms per liter } \\
\mathrm{J}=\text { Amount detected is below the practical quantitation limit. The associated value is an estimated quantity. } \\
\mathrm{A}=\text { Laboratory accuracy and/or bias measurements do not meet acceptance criteria. } \\
\mathrm{B}=\text { Analyte is detected in associated laboratory method blank. } \\
\mathrm{B} 1=\text { Analyte present in associated trip blank sample. } \\
\mathrm{B} 2 \text { = Analyte present in associated equipment blank sample. } \\
\mathrm{H}=\text { The holding time was exceeded for the associated sample analysis. } \\
\mathrm{P} 1=\text { Laboratory precision measurement for the associated matrix spike and/or duplicate samples do not meet acceptance } \\
\mathrm{criteria} . \\
\mathrm{P} 2 \text { = Insufficient quality control data to determine laboratory precision. } \\
\mathrm{UJ}=\text { Associated value is an estimate and may be inaccurate or imprecise. } \\
\# \mathrm{U}=\text { Analyte was qualified as not detected at the listed value. }\end{array}$} \\
\hline
\end{tabular}


Table A-6

Summary of Detected Volatile Organic Compounds

(EPA Method 8260)

Tijeras Arroyo Groundwater Investigation

$1^{\text {st }}$ Quarter 2005

\begin{tabular}{|c|c|c|c|c|c|c|c|}
\hline Well ID & Analyte & $\begin{array}{l}\text { Result } \\
(\mu \mathrm{g} / \mathrm{L})\end{array}$ & $\begin{array}{c}\text { MDL } \\
(\mu \mathrm{g} / \mathrm{L})\end{array}$ & $\begin{array}{c}\text { PQL } \\
(\mu \mathrm{g} / \mathrm{L})\end{array}$ & $\begin{array}{c}\text { Laboratory } \\
\text { Qualifier }\end{array}$ & $\begin{array}{c}\text { Validation } \\
\text { Qualifier }\end{array}$ & Sample No. \\
\hline \begin{tabular}{|l|} 
Eubank-1 \\
20-Oct-04
\end{tabular} & Acetone & 6.5 & 4.5 & 5.0 & & $6.50 \mathrm{UJ}$ & 066077-001 \\
\hline $\begin{array}{l}\text { TA1-W-03 } \\
\text { 19-Oct-04 }\end{array}$ & Chloroform & 0.372 & 0.36 & 1.0 & $\mathrm{~J}$ & & 066031-001 \\
\hline $\begin{array}{l}\text { TA2-W-01 } \\
18-O c t-04\end{array}$ & Trichloroethene & 1.38 & 0.36 & 1.0 & & & 066048-001 \\
\hline \multirow{2}{*}{$\begin{array}{l}\text { TA2-W-19 } \\
\text { 04-Oct-04 }\end{array}$} & Trichloroethene & 4.56 & 0.36 & 1.0 & & $\mathrm{~J}$ & 066050-001 \\
\hline & cis-1,2-Dichloroethene & 0.866 & 0.30 & 1.0 & J & & 066050-001 \\
\hline \multirow{3}{*}{$\begin{array}{l}\text { TA2-W-19 } \\
\text { (Duplicate) } \\
\text { 04-Oct-04 }\end{array}$} & 1,1-Dichloroethane & 0.722 & 0.41 & 1.0 & $\mathrm{~J}$ & & 066051-001 \\
\hline & Trichloroethene & 4.65 & 0.36 & 1.0 & & $\mathrm{~J}$ & 066051-001 \\
\hline & cis-1,2-Dichloroethene & 0.873 & 0.30 & 1.0 & $\mathrm{~J}$ & & 066051-001 \\
\hline \multirow{2}{*}{$\begin{array}{l}\text { TA2-W-27 } \\
14-O c t-04\end{array}$} & Tetrachloroethene & 0.631 & 0.33 & 1.0 & $\mathrm{~J}$ & & 066056-001 \\
\hline & Trichloroethene & 0.412 & 0.36 & 1.0 & $\mathrm{~J}$ & & 066056-001 \\
\hline \multirow{2}{*}{$\begin{array}{l}\text { TJA-2 } \\
11-O c t-04\end{array}$} & Trichloroethene & 3.1 & 0.36 & 1.0 & & $\mathrm{~J}$ & 066059-001 \\
\hline & cis-1,2-Dichloroethene & 0.504 & & & $\mathrm{~J}$ & & 066059-001 \\
\hline \multirow{3}{*}{$\begin{array}{l}\text { TJA-6 } \\
13-O c t-04\end{array}$} & Bromodichloromethane & 0.445 & 0.38 & 1.0 & $\mathrm{~J}$ & & 066065-001 \\
\hline & Bromoform & 0.83 & 0.50 & 1.0 & $\mathrm{~J}$ & & 066065-001 \\
\hline & Dibromochloromethane & 0.832 & 0.29 & 1.0 & J & & 066065-001 \\
\hline \multirow{2}{*}{$\begin{array}{l}\text { WYO-4 } \\
\text { 06-Oct-04 }\end{array}$} & Trichloroethene & 7.35 & 0.36 & 1.0 & & & 066073-001 \\
\hline & cis-1,2-Dichloroethene & 1.61 & 0.30 & 1.0 & & & 066073-001 \\
\hline \multirow{2}{*}{$\begin{array}{l}\text { WYO-4 } \\
\text { (Duplicate) } \\
\text { 06-Oct-04 }\end{array}$} & Trichloroethene & 7.43 & 0.36 & 1.0 & & & 066074-001 \\
\hline & cis-1,2-Dichloroethene & 1.69 & 0.30 & 1.0 & & & 066074-001 \\
\hline
\end{tabular}


Table A-7

Summary of Nitrate and Nitrate plus Nitrite Results

Tijeras Arroyo Groundwater Investigation

Fiscal Year 2003, $4^{\text {th }}$ Quarter

\begin{tabular}{|c|c|c|c|c|c|c|c|c|}
\hline Well ID & Analyte & $\begin{array}{l}\text { Result } \\
\text { (mg/L) }\end{array}$ & $\begin{array}{c}\text { MDL } \\
\text { (mg/L) }\end{array}$ & $\begin{array}{c}\text { PQL } \\
\text { (mg/L) }\end{array}$ & $\begin{array}{l}\text { Laboratory } \\
\text { Qualifier }\end{array}$ & $\begin{array}{c}\text { Validation } \\
\text { Qualifier }\end{array}$ & Sample No. & $\begin{array}{l}\text { Analytical } \\
\text { Method }\end{array}$ \\
\hline \multirow{3}{*}{$\begin{array}{l}\text { EUBANK-1 } \\
\text { 18-Aug-03 }\end{array}$} & Nitrate & 2.07 & 0.0341 & 0.1 & & & 062724-045 & SW846 9056 \\
\hline & Nitrate & 3.5 & 0.5 & NA & & None & Field & $\mathrm{HACH} 8039$ \\
\hline & $\begin{array}{l}\text { Nitrate plus } \\
\text { nitrite as N }\end{array}$ & 2.55 & 0.03 & 0.15 & & & 062724-016 & EPA 353.1 \\
\hline \multirow{3}{*}{$\begin{array}{l}\text { PGS-2 } \\
\text { 22-Jul-03 }\end{array}$} & Nitrate & 0.828 & 0.0341 & 0.1 & $\mathrm{H}$ & $\mathrm{HT}, \mathrm{J}$ & 062678-045 & SW846 9056 \\
\hline & Nitrate & ND & 0.5 & NA & & None & Field & $\mathrm{HACH} 8039$ \\
\hline & $\begin{array}{l}\text { Nitrate plus } \\
\text { nitrite as N }\end{array}$ & 0.89 & 0.01 & 0.05 & B & & 062678-016 & EPA 353.1 \\
\hline \multirow{3}{*}{$\begin{array}{l}\text { TA1-W-01 } \\
\text { 22-Jul-03 }\end{array}$} & Nitrate & 2.23 & 0.0341 & 0.1 & $\mathrm{H}$ & $\mathrm{HT}, \mathrm{J}$ & 062680-045 & SW846 9056 \\
\hline & Nitrate & 3.1 & 0.5 & NA & & None & Field & HACH 8039 \\
\hline & $\begin{array}{l}\text { Nitrate plus } \\
\text { nitrite as N }\end{array}$ & 2.46 & 0.02 & 0.1 & B & & 062680-016 & EPA 353.1 \\
\hline \multirow{3}{*}{\begin{tabular}{|l} 
TA1-W-02 \\
23-Jul-03
\end{tabular}} & Nitrate & 0.993 & 0.0341 & 0.1 & $\mathrm{H}$ & $\mathrm{HT}, \mathrm{J}$ & 062682-045 & SW846 9056 \\
\hline & Nitrate & 0.2 & 0.5 & NA & & None & Field & $\mathrm{HACH} 8039$ \\
\hline & $\begin{array}{l}\text { Nitrate plus } \\
\text { nitrite as N }\end{array}$ & 1 & 0.01 & 0.05 & & & 062682-016 & EPA 353.1 \\
\hline \multirow{3}{*}{\begin{tabular}{|l} 
TA1-W-03 \\
24-Jul-03
\end{tabular}} & Nitrate & 6.83 & 0.0341 & 0.1 & & & 062684-045 & SW846 9056 \\
\hline & Nitrate & 0.6 & 0.5 & NA & & None & Field & HACH 8039 \\
\hline & $\begin{array}{l}\text { Nitrate plus } \\
\text { nitrite as N }\end{array}$ & 7.3 & 0.05 & 0.25 & & & 062684-016 & EPA 353.1 \\
\hline \multirow{3}{*}{$\begin{array}{l}\text { TA1-W-04 } \\
\text { 29-Jul-03 }\end{array}$} & Nitrate & 1.7 & 0.0341 & 0.1 & & & 062686-045 & SW846 9056 \\
\hline & Nitrate & 2.5 & 0.5 & NA & & None & Field & HACH 8039 \\
\hline & $\begin{array}{l}\text { Nitrate plus } \\
\text { nitrite as N }\end{array}$ & 1.68 & 0.01 & 0.05 & & & 062686-016 & EPA 353.1 \\
\hline \multirow{3}{*}{$\begin{array}{l}\text { TA1-W-05 } \\
\text { 28-Jul-03 }\end{array}$} & Nitrate & 0.997 & 0.0341 & 0.1 & & & 062688-045 & SW846 9056 \\
\hline & Nitrate & ND & 0.5 & NA & & None & Field & HACH 8039 \\
\hline & $\begin{array}{l}\text { Nitrate plus } \\
\text { nitrite as N }\end{array}$ & 1.06 & 0.01 & 0.05 & & B2, J & 062688-016 & EPA 353.1 \\
\hline \multirow{3}{*}{$\begin{array}{l}\text { TA1-W-06 } \\
\text { 29-Jul-03 }\end{array}$} & Nitrate & 3.05 & 0.0341 & 0.1 & & & $062690-045$ & SW846 9056 \\
\hline & Nitrate & 2.9 & 0.5 & NA & & None & Field & HACH 8039 \\
\hline & $\begin{array}{l}\text { Nitrate plus } \\
\text { nitrite as N }\end{array}$ & 2.59 & 0.01 & 0.05 & & & 062690-016 & EPA 353.1 \\
\hline
\end{tabular}




\begin{tabular}{|c|c|c|c|c|c|c|c|c|}
\hline Well ID & Analyte & $\begin{array}{l}\text { Result } \\
(\mathrm{mg} / \mathrm{L})\end{array}$ & $\begin{array}{c}\text { MDL } \\
\text { (mg/L) }\end{array}$ & $\begin{array}{c}\text { PQL } \\
\text { (mg/L) }\end{array}$ & $\begin{array}{c}\text { Laboratory } \\
\text { Qualifier }\end{array}$ & $\begin{array}{c}\text { Validation } \\
\text { Qualifier }\end{array}$ & Sample No. & $\begin{array}{l}\text { Analytical } \\
\text { Method }\end{array}$ \\
\hline \multirow{3}{*}{$\begin{array}{l}\text { TA1-W-08 } \\
\text { 30-Jul-03 }\end{array}$} & Nitrate & 6.92 & 0.0341 & 0.1 & & & 062692-045 & SW846 9056 \\
\hline & Nitrate & 5.5 & 0.5 & NA & & None & Field & HACH 8039 \\
\hline & $\begin{array}{l}\text { Nitrate plus } \\
\text { nitrite as N }\end{array}$ & 7.35 & 0.05 & 0.25 & & & 062692-016 & EPA 353.1 \\
\hline $\begin{array}{l}\text { TA1-W-08 } \\
\text { (Duplicate) } \\
\text { 30-Jul-03 }\end{array}$ & $\begin{array}{l}\text { Nitrate plus } \\
\text { nitrite as N }\end{array}$ & 7.3 & 0.05 & 0.25 & & & 062693-016 & EPA 353.1 \\
\hline \multirow{3}{*}{$\begin{array}{l}\text { TA2-NW1- } \\
595 \\
30-J u l-03\end{array}$} & Nitrate & 3.09 & 0.0341 & 0.1 & & & 062695-A45 & SW846 9056 \\
\hline & Nitrate & 3.9 & 0.5 & NA & & None & Field & HACH 8039 \\
\hline & $\begin{array}{l}\text { Nitrate plus } \\
\text { nitrite as N }\end{array}$ & 2.7 & 0.01 & 0.05 & & & 062695-A16 & EPA 353.1 \\
\hline \multirow{3}{*}{$\begin{array}{l}\text { TA2-NW1- } \\
595 \\
05-A u g-03\end{array}$} & Nitrate & 3.02 & 0.0341 & 0.1 & & & 062695-045 & SW846 9056 \\
\hline & Nitrate & 3.4 & 0.5 & NA & & None & Field & HACH 8039 \\
\hline & $\begin{array}{l}\text { Nitrate plus } \\
\text { nitrite as N }\end{array}$ & 2.76 & 0.01 & 0.05 & & & 062695-016 & EPA 353.1 \\
\hline \multirow{3}{*}{$\begin{array}{l}\text { TA2-SW1- } \\
320 \\
24-J u l-03\end{array}$} & Nitrate & 22.9 & 0.171 & 0.5 & $\mathrm{H}$ & $\mathrm{HT}, \mathrm{J}$ & 062698-045 & SW846 9056 \\
\hline & Nitrate & 17.2 & 0.5 & NA & & None & Field & HACH 8039 \\
\hline & $\begin{array}{l}\text { Nitrate plus } \\
\text { nitrite as N }\end{array}$ & 25 & 0.25 & 1.25 & & & 062698-016 & EPA 353.1 \\
\hline \multirow{3}{*}{$\begin{array}{l}\text { TA2-W-01 } \\
\text { 07-Aug-03 }\end{array}$} & Nitrate & 5.14 & 0.0341 & 0.1 & & & 062700-045 & SW846 9056 \\
\hline & Nitrate & 4.3 & 0.5 & NA & & None & Field & HACH 8039 \\
\hline & $\begin{array}{l}\text { Nitrate plus } \\
\text { nitrite as N }\end{array}$ & 5.58 & 0.03 & 0.15 & & & 062700-016 & EPA 353.1 \\
\hline \multirow{3}{*}{$\begin{array}{l}\text { TA2-W-19 } \\
\text { 04-Aug-03 }\end{array}$} & Nitrate & 9.58 & 0.0341 & 0.1 & $\mathrm{H}$ & & 062702-045 & SW846 9056 \\
\hline & Nitrate & 7.4 & 0.5 & NA & & None & Field & HACH 8039 \\
\hline & $\begin{array}{l}\text { Nitrate plus } \\
\text { nitrite as N }\end{array}$ & 10.4 & 0.1 & 0.5 & & & 062702-016 & EPA 353.1 \\
\hline \multirow{3}{*}{$\begin{array}{l}\text { TA2-W-26 } \\
\text { 04-Aug-03 }\end{array}$} & Nitrate & 4.67 & 0.0341 & 0.1 & & & 062704-045 & SW846 9056 \\
\hline & Nitrate & 5.2 & 0.5 & NA & & None & Field & HACH 8039 \\
\hline & $\begin{array}{l}\text { Nitrate plus } \\
\text { nitrite as N }\end{array}$ & 5.22 & 0.03 & 0.15 & & & 062704-016 & EPA 353.1 \\
\hline $\begin{array}{l}\text { TA2-W-26 } \\
\text { (Duplicate) } \\
\text { 04-Aug-03 }\end{array}$ & $\begin{array}{l}\text { Nitrate plus } \\
\text { nitrite as N }\end{array}$ & 5.1 & 0.03 & 0.15 & & & 062705-016 & EPA 353.1 \\
\hline \multirow{3}{*}{ TA2-W-27 } & Nitrate & 4.14 & 0.0341 & 0.1 & & & 062707-045 & SW846 9056 \\
\hline & Nitrate & 3.2 & 0.5 & NA & & None & Field & HACH 8039 \\
\hline & $\begin{array}{l}\text { Nitrate plus } \\
\text { nitrite as N }\end{array}$ & 4.53 & 0.03 & 0.15 & & & 062707-016 & EPA 353.1 \\
\hline
\end{tabular}




\begin{tabular}{|c|c|c|c|c|c|c|c|c|}
\hline Well ID & Analyte & $\begin{array}{l}\text { Result } \\
\text { (mg/L) }\end{array}$ & $\begin{array}{c}\text { MDL } \\
\text { (mg/L) }\end{array}$ & $\begin{array}{c}\text { PQL } \\
\text { (mg/L) }\end{array}$ & $\begin{array}{c}\text { Laboratory } \\
\text { Qualifier }\end{array}$ & $\begin{array}{c}\text { Validation } \\
\text { Qualifier }\end{array}$ & Sample No. & $\begin{array}{l}\text { Analytical } \\
\text { Method }\end{array}$ \\
\hline \multirow{3}{*}{$\begin{array}{l}\text { TJA-2 } \\
31-J u l-03\end{array}$} & Nitrate & 9.34 & 0.0341 & 0.1 & & & 062709-045 & SW846 9056 \\
\hline & Nitrate & 9.8 & 0.5 & NA & & None & Field & HACH 8039 \\
\hline & $\begin{array}{l}\text { Nitrate plus } \\
\text { nitrite as N }\end{array}$ & 10.1 & 0.1 & 0.5 & & & 062709-016 & EPA 353.1 \\
\hline \multirow{3}{*}{$\begin{array}{l}\text { TJA-3 } \\
\text { 06-Aug-03 }\end{array}$} & Nitrate & 2.52 & 0.0341 & 0.1 & & & 062711-045 & SW846 9056 \\
\hline & Nitrate & 3.7 & 0.5 & NA & & None & Field & HACH 8039 \\
\hline & $\begin{array}{l}\text { Nitrate plus } \\
\text { nitrite as N }\end{array}$ & 2.55 & 0.01 & 0.05 & & B2, J & 062711-016 & EPA 353.1 \\
\hline \multirow{3}{*}{$\begin{array}{l}\text { TJA-4 } \\
\text { 11-Aug-03 }\end{array}$} & Nitrate & 23.2 & 0.171 & 0.5 & & & 062713-045 & SW846 9056 \\
\hline & Nitrate & 20.5 & 0.5 & NA & & None & Field & $\mathrm{HACH} 8039$ \\
\hline & $\begin{array}{l}\text { Nitrate plus } \\
\text { nitrite as N }\end{array}$ & 25 & 0.25 & 1.25 & & & 062713-016 & EPA 353.1 \\
\hline \multirow{3}{*}{$\begin{array}{l}\text { TJA-6 } \\
11-A u g-03\end{array}$} & Nitrate & 2.17 & 0.0341 & 0.1 & & & 062715-045 & SW846 9056 \\
\hline & Nitrate & 0.4 & 0.5 & NA & & None & Field & HACH 8039 \\
\hline & $\begin{array}{l}\text { Nitrate plus } \\
\text { nitrite as N }\end{array}$ & 2.49 & 0.03 & 0.15 & & & 062715-016 & EPA 353.1 \\
\hline \multirow{3}{*}{$\begin{array}{l}\text { TJA-7 } \\
12-\text { Aug-03 }\end{array}$} & Nitrate & 22.9 & 0.0341 & 0.1 & $\mathrm{H}$ & $\mathrm{HT}, \mathrm{J}$ & 062717-045 & SW846 9056 \\
\hline & Nitrate & 21.7 & 0.5 & NA & & None & Field & HACH 8039 \\
\hline & $\begin{array}{l}\text { Nitrate plus } \\
\text { nitrite as N }\end{array}$ & 26 & 0.5 & 2.5 & & & 062717-016 & EPA 353.1 \\
\hline \multirow{3}{*}{$\begin{array}{l}\text { WYO-3 } \\
\text { 13-Aug-03 }\end{array}$} & Nitrate & 1.71 & 0.0341 & 0.1 & $\mathrm{H}$ & $\mathrm{HT}, \mathrm{J}$ & 062719-045 & SW846 9056 \\
\hline & Nitrate & 2.0 & 0.5 & NA & & None & Field & HACH 8039 \\
\hline & $\begin{array}{l}\text { Nitrate plus } \\
\text { nitrite as N }\end{array}$ & 1.92 & 0.01 & 0.05 & & & 062719-016 & EPA 353.1 \\
\hline \multirow{3}{*}{$\begin{array}{l}\text { WYO-4 } \\
14-A u g-03\end{array}$} & Nitrate & 2.54 & 0.0341 & 0.1 & & & 062721-045 & SW846 9056 \\
\hline & Nitrate & 1.7 & 0.5 & NA & & None & Field & HACH 8039 \\
\hline & $\begin{array}{l}\text { Nitrate plus } \\
\text { nitrite as N }\end{array}$ & 2.72 & 0.01 & 0.05 & & & 062721-016 & EPA 353.1 \\
\hline $\begin{array}{l}\text { WYO-4 } \\
\text { (Duplicate) } \\
\text { 14-Aug-03 }\end{array}$ & $\begin{array}{l}\text { Nitrate plus } \\
\text { nitrite as N }\end{array}$ & 2.7 & 0.01 & 0.05 & & & 062722-016 & EPA 353.1 \\
\hline \multicolumn{9}{|c|}{$\begin{array}{l}\mathrm{mg} / \mathrm{L}=\text { milligrams per liter } \\
\mathrm{J}=\text { Amount detected is below the practical quantitation limit. The associated value is an estimated quantity. } \\
\mathrm{B}=\text { Analyte is detected in associated laboratory method blank. } \\
\mathrm{B} 2=\text { Analyte is detected in associated equipment blank sample. } \\
\mathrm{HT} / \mathrm{H}=\text { The holding time was exceeded for the associated sample analysis. }\end{array}$} \\
\hline
\end{tabular}


Table A-8

Summary of Nitrate and Nitrate plus Nitrite Results

Tijeras Arroyo Groundwater Investigation

Fiscal Year 2004, $1^{\text {st }}$ Quarter

\begin{tabular}{|c|c|c|c|c|c|c|c|c|}
\hline Well ID & Analyte & $\begin{array}{l}\text { Result } \\
\text { (mg/L) }\end{array}$ & $\begin{array}{c}\mathrm{MDL} \\
(\mathrm{mg} / \mathrm{L})\end{array}$ & $\begin{array}{c}\mathrm{PQL} \\
\text { (mg/L) }\end{array}$ & $\begin{array}{c}\text { Laboratory } \\
\text { Qualifier }\end{array}$ & $\begin{array}{c}\text { Validation } \\
\text { Qualifier }\end{array}$ & Sample No. & $\begin{array}{l}\text { Analytical } \\
\text { Method }\end{array}$ \\
\hline \multirow{3}{*}{$\begin{array}{l}\text { Eubank-1 } \\
10-N o v-03\end{array}$} & Nitrate & 1.99 & 0.0341 & 0.1 & $\mathrm{H}$ & $\mathrm{HT}, \mathrm{J}$ & 063303-045 & SW846 9056 \\
\hline & Nitrate & 2.3 & 0.5 & NA & None & None & Field & HACH 8039 \\
\hline & $\begin{array}{l}\text { Nitrate plus } \\
\text { nitrite as N }\end{array}$ & 2.50 & 0.05 & 0.25 & & & 063303-016 & EPA 353.1 \\
\hline $\begin{array}{l}\text { Eubank-1 } \\
\text { (Sample Split) } \\
\text { 10-Oct-03 }\end{array}$ & Nitrate & 2.40 & 0.1 & 0.1 & & & 063302-A45 & EPA 300.0 \\
\hline \multirow{3}{*}{$\begin{array}{l}\text { Eubank-2 } \\
\text { 12-Nov-03 }\end{array}$} & Nitrate & 1.23 & 0.0341 & 0.1 & & & 063304-045 & SW846 9056 \\
\hline & Nitrate & 1.0 & 0.5 & NA & None & None & Field & $\mathrm{HACH} 8039$ \\
\hline & $\begin{array}{l}\text { Nitrate plus } \\
\text { nitrite as N }\end{array}$ & 0.950 & 0.01 & 0.050 & & & 063304-016 & EPA 353.1 \\
\hline \multirow{3}{*}{$\begin{array}{l}\text { Eubank-3 } \\
18-N o v-03\end{array}$} & Nitrate & 3.03 & 0.0341 & 0.1 & $\mathrm{H}$ & $\mathrm{HT}, \mathrm{J}$ & 063305-045 & SW846 9056 \\
\hline & Nitrate & 4.1 & 0.5 & NA & None & None & Field & HACH 8039 \\
\hline & $\begin{array}{l}\text { Nitrate plus } \\
\text { nitrite as N }\end{array}$ & 3.40 & 0.05 & 0.25 & & & 063305-016 & EPA 353.1 \\
\hline \multirow{3}{*}{$\begin{array}{l}\text { Eubank-5 } \\
19-N o v-03\end{array}$} & Nitrate & 3.02 & 0.0341 & 0.1 & $\mathrm{H}$ & $\mathrm{HT}, \mathrm{J}$ & 063306-045 & SW846 9056 \\
\hline & Nitrate & 3.6 & 0.5 & NA & None & None & Field & HACH 8039 \\
\hline & $\begin{array}{l}\text { Nitrate plus } \\
\text { nitrite as N }\end{array}$ & 3.70 & 0.05 & 0.25 & & & 063306-016 & EPA 353.1 \\
\hline \multirow{3}{*}{$\begin{array}{l}\text { PGS-2 } \\
10-\text { Nov-03 }\end{array}$} & Nitrate & 0.628 & 0.0341 & 0.1 & $\mathrm{H}$ & $\mathrm{HT}, \mathrm{J}$ & 063278-045 & SW846 9056 \\
\hline & Nitrate & 0.2 & 0.5 & NA & None & None & Field & $\mathrm{HACH} 8039$ \\
\hline & $\begin{array}{l}\text { Nitrate plus } \\
\text { nitrite as N }\end{array}$ & 0.710 & 0.01 & 0.05 & & & 063278-016 & EPA 353.1 \\
\hline \multirow{3}{*}{$\begin{array}{l}\text { TA1-W-01 } \\
\text { 06-Nov-03 }\end{array}$} & Nitrate & 2.27 & 0.0341 & 0.1 & & & 063279-045 & SW846 9056 \\
\hline & Nitrate & 2.3 & 0.5 & NA & None & None & Field & HACH 8039 \\
\hline & $\begin{array}{l}\text { Nitrate plus } \\
\text { nitrite as N }\end{array}$ & 2.50 & 0.05 & 0.25 & & & 063279-016 & EPA 353.1 \\
\hline \multirow{3}{*}{$\mid \begin{array}{l}\text { TA1-W-02 } \\
\text { 08-Oct-03 }\end{array}$} & Nitrate & 0.921 & 0.0341 & 0.1 & $\mathrm{H}$ & $\mathrm{HT}, \mathrm{J}$ & 063280-045 & SW846 9056 \\
\hline & Nitrate & 1.5 & 0.5 & NA & None & None & Field & $\mathrm{HACH} 8039$ \\
\hline & $\begin{array}{l}\text { Nitrate plus } \\
\text { nitrite as N }\end{array}$ & 1.00 & 0.05 & 0.25 & & & 063280-016 & EPA 353.1 \\
\hline \multirow{3}{*}{$\begin{array}{l}\text { TA1-W-03 } \\
\text { 13-Oct-03 }\end{array}$} & Nitrate & 6.79 & 0.0341 & 0.1 & & & 063281-045 & SW846 9056 \\
\hline & Nitrate & 5.1 & 0.5 & NA & None & None & Field & HACH 8039 \\
\hline & $\begin{array}{l}\text { Nitrate plus } \\
\text { nitrite as N }\end{array}$ & 6.40 & 0.05 & 0.25 & & & 063281-016 & EPA 353.1 \\
\hline \multirow{3}{*}{$\begin{array}{l}\text { TA1-W-04 } \\
14-O c t-03\end{array}$} & Nitrate & 1.54 & 0.0341 & 0.1 & & & 063282-045 & SW846 9056 \\
\hline & Nitrate & 2.5 & 0.5 & NA & None & None & Field & HACH 8039 \\
\hline & $\begin{array}{l}\text { Nitrate plus } \\
\text { nitrite as N }\end{array}$ & 1.39 & 0.01 & 0.05 & & & 063282-016 & EPA 353.1 \\
\hline
\end{tabular}




\begin{tabular}{|c|c|c|c|c|c|c|c|c|}
\hline Well ID & Analyte & $\begin{array}{l}\text { Result } \\
\text { (mg/L) }\end{array}$ & $\begin{array}{c}\text { MDL } \\
\text { (mg/L) }\end{array}$ & $\begin{array}{c}\mathrm{PQL} \\
(\mathrm{mg} / \mathrm{L})\end{array}$ & $\begin{array}{l}\text { Laboratory } \\
\text { Qualifier }\end{array}$ & $\begin{array}{c}\text { Validation } \\
\text { Qualifier }\end{array}$ & Sample No. & $\begin{array}{c}\text { Analytical } \\
\text { Method }\end{array}$ \\
\hline \multirow{3}{*}{$\begin{array}{l}\text { TA1-W-05 } \\
\text { 20-Oct-03 }\end{array}$} & Nitrate & 0.967 & 0.0341 & 0.1 & & & 063283-045 & SW846 9056 \\
\hline & Nitrate & 0.9 & 0.5 & NA & None & None & Field & $\mathrm{HACH} 8039$ \\
\hline & $\begin{array}{l}\text { Nitrate plus } \\
\text { nitrite as N }\end{array}$ & 1.05 & 0.05 & 0.25 & & & 063283-016 & EPA 353.1 \\
\hline \multirow{3}{*}{$\mid \begin{array}{l}\text { TA1-W-06 } \\
\text { o9-Oct-03 }\end{array}$} & Nitrate & 2.96 & 0.0341 & 0.1 & & & 063284-045 & SW846 9056 \\
\hline & Nitrate & 3.3 & 0.5 & NA & None & None & Field & $\mathrm{HACH} 8039$ \\
\hline & $\begin{array}{l}\text { Nitrate plus } \\
\text { nitrite as N }\end{array}$ & 3.30 & 0.05 & 0.25 & & & 063284-016 & EPA 353.1 \\
\hline \multirow{3}{*}{$\mid \begin{array}{l}\text { TA1-W-08 } \\
\text { 21-Oct-03 }\end{array}$} & Nitrate & 7.00 & 0.0341 & 0.1 & & & 063285-045 & SW846 9056 \\
\hline & Nitrate & 5.6 & 0.5 & NA & None & None & Field & $\mathrm{HACH} 8039$ \\
\hline & $\begin{array}{l}\text { Nitrate plus } \\
\text { nitrite as N }\end{array}$ & 6.25 & 0.05 & 0.25 & & & 063285-016 & EPA 353.1 \\
\hline $\begin{array}{l}\text { TA1-W-08 } \\
\text { (Duplicate) } \\
\text { 21-Oct-03 }\end{array}$ & $\begin{array}{l}\text { Nitrate plus } \\
\text { nitrite as N }\end{array}$ & 6.25 & 0.05 & 0.25 & & & 063286-016 & EPA 353.1 \\
\hline \multirow{3}{*}{$\begin{array}{l}\text { TA2-NW1-595 } \\
\text { 12-Nov-03 }\end{array}$} & Nitrate & 3.34 & 0.0341 & 0.1 & & & 063287-045 & SW846 9056 \\
\hline & Nitrate & 3.0 & 0.5 & NA & None & None & Field & $\mathrm{HACH} 8039$ \\
\hline & $\begin{array}{l}\text { Nitrate plus } \\
\text { nitrite as N }\end{array}$ & 3.40 & 0.05 & 0.25 & & & 063287-016 & EPA 353.1 \\
\hline \multirow{3}{*}{$\begin{array}{l}\text { TA2-NW1-595 } \\
\text { 11-Nov-03 }\end{array}$} & Nitrate & 2.96 & 0.0341 & 0.1 & & & 063288-045 & SW846 9056 \\
\hline & Nitrate & 3.6 & 0.5 & NA & None & None & Field & $\mathrm{HACH} 8039$ \\
\hline & $\begin{array}{l}\text { Nitrate plus } \\
\text { nitrite as N }\end{array}$ & 3.20 & 0.05 & 0.25 & & & 063288-016 & EPA 353.1 \\
\hline \multirow{3}{*}{$\begin{array}{l}\text { TA2-SW1-320 } \\
\text { 11-Nov-03 }\end{array}$} & Nitrate & 22.4 & 0.171 & 0.5 & $\mathrm{H}$ & $\mathrm{HT}, \mathrm{J}$ & 063289-045 & SW846 9056 \\
\hline & Nitrate & 19.8 & 0.5 & NA & None & None & Field & $\mathrm{HACH} 8039$ \\
\hline & $\begin{array}{l}\text { Nitrate plus } \\
\text { nitrite as N }\end{array}$ & 24.0 & 0.5 & 2.5 & & & 063289-016 & EPA 353.1 \\
\hline \multirow{3}{*}{$\mid \begin{array}{l}\text { TA2-W-01 } \\
\text { 01-Dec-03 }\end{array}$} & Nitrate & 5.16 & 0.0341 & 0.1 & & & 063290-045 & SW846 9056 \\
\hline & Nitrate & 6.3 & 0.5 & NA & None & None & Field & $\mathrm{HACH} 8039$ \\
\hline & $\begin{array}{l}\text { Nitrate plus } \\
\text { nitrite as N }\end{array}$ & 5.70 & 0.05 & 0.25 & & & 063290-016 & EPA 353.1 \\
\hline \multirow{3}{*}{$\begin{array}{l}\text { TA2-W-19 } \\
07-O c t-03\end{array}$} & Nitrate & 9.35 & 0.0682 & 0.2 & $\mathrm{H}$ & $\mathrm{HT}, \mathrm{J}$ & 063291-045 & SW846 9056 \\
\hline & Nitrate & 10.3 & 0.5 & NA & None & None & Field & $\mathrm{HACH} 8039$ \\
\hline & $\begin{array}{l}\text { Nitrate plus } \\
\text { nitrite as N }\end{array}$ & 9.50 & 0.1 & 0.5 & & & 063291-016 & EPA 353.1 \\
\hline \multirow{3}{*}{$\mid \begin{array}{l}\text { TA2-W-26 } \\
16-O c t-03\end{array}$} & Nitrate & 4.84 & 0.0341 & 0.1 & & & 063292-045 & SW846 9056 \\
\hline & Nitrate & 3.5 & 0.5 & NA & None & None & Field & $\mathrm{HACH} 8039$ \\
\hline & $\begin{array}{l}\text { Nitrate plus } \\
\text { nitrite as N }\end{array}$ & 5.00 & 0.05 & 0.25 & & & 063292-016 & EPA 353.1 \\
\hline $\begin{array}{l}\text { TA2-W-26 } \\
\text { (Duplicate) } \\
\text { 16-Oct-03 }\end{array}$ & $\begin{array}{l}\text { Nitrate plus } \\
\text { nitrite as N }\end{array}$ & 4.75 & 0.05 & 0.25 & & & 063293-016 & EPA 353.1 \\
\hline \multirow{3}{*}{$\begin{array}{l}\text { TA2-W-27 } \\
23-O c t-03\end{array}$} & Nitrate & 4.19 & 0.0341 & 0.1 & & & 063294-045 & SW846 9056 \\
\hline & Nitrate & 4.3 & 0.5 & NA & None & None & Field & $\mathrm{HACH} 8039$ \\
\hline & \begin{tabular}{|l|} 
Nitrate plus \\
nitrite as N
\end{tabular} & 4.50 & 0.05 & 0.25 & & & 063294-016 & EPA 353.1 \\
\hline
\end{tabular}




\begin{tabular}{|c|c|c|c|c|c|c|c|c|}
\hline Well ID & Analyte & $\begin{array}{l}\text { Result } \\
\text { (mg/L) }\end{array}$ & $\begin{array}{c}\text { MDL } \\
\text { (mg/L) }\end{array}$ & $\begin{array}{c}\text { PQL } \\
\text { (mg/L) }\end{array}$ & $\begin{array}{c}\text { Laboratory } \\
\text { Qualifier }\end{array}$ & $\begin{array}{c}\text { Validation } \\
\text { Qualifier }\end{array}$ & Sample No. & $\begin{array}{l}\text { Analytical } \\
\text { Method }\end{array}$ \\
\hline \multirow{3}{*}{$\mid \begin{array}{l}\text { TJA-2 } \\
15-O c t-03\end{array}$} & Nitrate & 9.32 & 0.0341 & 0.1 & & & 063295-045 & SW846 9056 \\
\hline & Nitrate & 9.6 & 0.5 & NA & None & None & Field & HACH 8039 \\
\hline & $\begin{array}{l}\text { Nitrate plus } \\
\text { nitrite as N }\end{array}$ & 9.70 & 0.1 & 0.5 & & & 063295-016 & EPA 353.1 \\
\hline \multirow{3}{*}{$\begin{array}{l}\text { TJA-3 } \\
22-O c t-03\end{array}$} & Nitrate & 2.51 & 0.0341 & 0.1 & & & 063296-045 & SW846 9056 \\
\hline & Nitrate & 3.8 & 0.5 & NA & None & None & Field & HACH 8039 \\
\hline & $\begin{array}{l}\text { Nitrate plus } \\
\text { nitrite as } \mathrm{N}\end{array}$ & 2.75 & 0.05 & 0.25 & & & 063296-016 & EPA 353.1 \\
\hline \multirow{3}{*}{$\mid \begin{array}{l}\text { TJA-4 } \\
27-O c t-03\end{array}$} & Nitrate & 22.8 & 0.341 & 1.0 & $\mathrm{H}$ & & 063297-045 & SW846 9056 \\
\hline & Nitrate & 17.7 & 0.5 & NA & None & None & Field & НАCH 8039 \\
\hline & $\begin{array}{l}\text { Nitrate plus } \\
\text { nitrite as } \mathrm{N}\end{array}$ & 25.8 & 0.25 & 1.25 & & & 063297-016 & EPA 353.1 \\
\hline \multirow{3}{*}{$\mid \begin{array}{l}\text { TJA-6 } \\
05-N o v-03\end{array}$} & Nitrate & 2.26 & 0.0341 & 0.1 & & & 063298-045 & SW846 9056 \\
\hline & Nitrate & 2.6 & 0.5 & NA & None & None & Field & HАCH 8039 \\
\hline & $\begin{array}{l}\text { Nitrate plus } \\
\text { nitrite as N }\end{array}$ & 2.50 & 0.05 & 0.25 & & $\mathrm{~B} 2, \mathrm{~J}$ & 063298-016 & EPA 353.1 \\
\hline \multirow{3}{*}{$\mid \begin{array}{l}\text { TJA-7 } \\
28-O c t-03\end{array}$} & Nitrate & 24.5 & 0.341 & 1.00 & $\mathrm{H}$ & $\mathrm{HT}, \mathrm{J}$ & 063299-045 & SW846 9056 \\
\hline & Nitrate & 20.4 & 0.5 & NA & None & None & Field & HACH 8039 \\
\hline & $\begin{array}{l}\text { Nitrate plus } \\
\text { nitrite as } \mathrm{N}\end{array}$ & 25.0 & 0.250 & 1.25 & & & 063299-016 & EPA 353.1 \\
\hline $\begin{array}{l}\text { TJA-7 (Sample } \\
\text { Split) } \\
\text { 28-Oct-03 }\end{array}$ & Nitrate & 26.0 & 0.5 & 0.5 & & P2 & 063299-A45 & EPA 300.0 \\
\hline \multirow{3}{*}{$\begin{array}{l}\text { WYO-3 } \\
29-O c t-03\end{array}$} & Nitrate & 1.80 & 0.0341 & 0.1 & & & $063300-045$ & SW846 9056 \\
\hline & Nitrate & 2.1 & 0.5 & NA & None & None & Field & HACH 8039 \\
\hline & $\begin{array}{l}\text { Nitrate plus } \\
\text { nitrite as N }\end{array}$ & 1.61 & 0.01 & 0.05 & & & 063300-016 & EPA 353.1 \\
\hline $\begin{array}{l}\text { WYO-3 } \\
\text { (Sample Split) } \\
29-O c t-03\end{array}$ & Nitrate & 2.0 & 0.1 & 0.1 & & P2 & 063300-A45 & EPA 300.0 \\
\hline \multirow{3}{*}{$\begin{array}{l}\text { WYO-4 } \\
\text { 03-Nov-03 }\end{array}$} & Nitrate & 2.86 & 0.0341 & 0.1 & & & 063301-045 & SW846 9056 \\
\hline & Nitrate & 2.2 & 0.5 & NA & None & None & Field & HACH 8039 \\
\hline & $\begin{array}{l}\text { Nitrate plus } \\
\text { nitrite as } \mathrm{N}\end{array}$ & 2.20 & 0.01 & 0.05 & & & 063301-016 & EPA 353.1 \\
\hline $\begin{array}{l}\text { WYO-4 } \\
\text { (Duplicate) } \\
\text { 03-Nov-03 }\end{array}$ & $\begin{array}{l}\text { Nitrate plus } \\
\text { nitrite as } \mathrm{N}\end{array}$ & 2.21 & 0.01 & 0.05 & & & $063302-016$ & EPA 353.1 \\
\hline $\begin{array}{l}\text { WYO-4 } \\
\text { (Sample Split) } \\
\text { 03-Nov-03 }\end{array}$ & Nitrate & 3.0 & 0.1 & 0.1 & & & 063301-A45 & EPA 300.0 \\
\hline \multicolumn{9}{|c|}{$\begin{array}{l}\mathrm{mg} / \mathrm{L}=\text { milligrams per liter } \\
\mathrm{J}=\text { Amount detected is below the practical quantitation limit. The associated value is an estimated quantity. } \\
\mathrm{B}=\text { Analyte is detected in associated laboratory method blank. } \\
\mathrm{B} 2=\text { Analyte is detected in associated equipment blank sample. } \\
\mathrm{P} 2=\text { Insufficient quality control data to determine laboratory precision. } \\
\mathrm{HT} / \mathrm{H}=\text { The holding time was exceeded for the associated sample analysis. }\end{array}$} \\
\hline
\end{tabular}


Table A-9

Summary of Nitrate and Nitrate plus Nitrite Results

Tijeras Arroyo Groundwater Investigation

Fiscal Year 2004, $2^{\text {nd }}$ Quarter

\begin{tabular}{|c|c|c|c|c|c|c|c|c|}
\hline Well ID & Analyte & $\begin{array}{l}\text { Result } \\
\text { (mg/L) }\end{array}$ & $\begin{array}{c}\text { MDL } \\
\text { (mg/L) }\end{array}$ & $\begin{array}{c}\text { PQL } \\
\text { (mg/L) }\end{array}$ & $\begin{array}{c}\text { Laboratory } \\
\text { Qualifier }\end{array}$ & $\begin{array}{c}\text { Validation } \\
\text { Qualifier }\end{array}$ & Sample No. & $\begin{array}{l}\text { Analytical } \\
\text { Method }\end{array}$ \\
\hline Eubank-1 & Nitrate & 2.3 & 0.054 & 0.1 & & & 063904-016 & EPA 300.0 \\
\hline \multirow[t]{2}{*}{ 16-Feb-04 } & Nitrate & 4.1 & 0.5 & NA & None & None & Field & $\mathrm{HACH} 8039$ \\
\hline & $\begin{array}{l}\text { Nitrate plus } \\
\text { nitrite as N }\end{array}$ & 2.20 & 0.05 & 0.25 & & & 063904-015 & EPA 353.1 \\
\hline Eubank-2 & Nitrate & 1.3 & 0.054 & 0.1 & & & 063906-016 & EPA 300.0 \\
\hline \multirow[t]{2}{*}{ 18-Feb-04 } & Nitrate & 1.1 & 0.5 & NA & None & None & Field & $\mathrm{HACH} 8039$ \\
\hline & $\begin{array}{l}\text { Nitrate plus } \\
\text { nitrite as N }\end{array}$ & 1.03 & 0.01 & 0.05 & & & 063906-015 & EPA 353.1 \\
\hline Eubank-3 & Nitrate & 3.2 & 0.054 & 0.1 & & & 063909-016 & EPA 300.0 \\
\hline \multirow[t]{2}{*}{ 17-Feb-04 } & Nitrate & 2.7 & 0.5 & NA & None & None & Field & $\mathrm{HACH} 8039$ \\
\hline & $\begin{array}{l}\text { Nitrate plus } \\
\text { nitrite as N }\end{array}$ & 2.34 & 0.01 & 0.05 & & & 063909-015 & EPA 353.1 \\
\hline Eubank-5 & Nitrate & 3.3 & 0.054 & 0.1 & & & 063911-016 & EPA 300.0 \\
\hline \multirow[t]{2}{*}{ 19-Feb-04 } & Nitrate & 3.6 & 0.5 & NA & None & None & Field & $\mathrm{HACH} 8039$ \\
\hline & $\begin{array}{l}\text { Nitrate plus } \\
\text { nitrite as N }\end{array}$ & 3.40 & 0.05 & 0.25 & & & 063911-015 & EPA 353.1 \\
\hline PGS-2 & Nitrate & 0.85 & 0.054 & 0.1 & & & 063851-016 & EPA 300.0 \\
\hline \multirow[t]{3}{*}{ 03-Feb-04 } & Nitrate & 1.7 & 0.5 & NA & None & None & Field & $\mathrm{HACH} 8039$ \\
\hline & $\begin{array}{l}\text { Nitrate plus } \\
\text { nitrite as N }\end{array}$ & 0.80 & 0.01 & 0.05 & & $A 2, J$ & 063851-015 & EPA 353.1 \\
\hline & $\begin{array}{l}\text { Nitrate plus } \\
\text { nitrite as N } \\
\text { (lab re- } \\
\text { analysis) }\end{array}$ & 0.73 & 0.01 & 0.05 & & & 063851-R15 & EPA 353.1 \\
\hline TA1-W-01 & Nitrate & 2.5 & 0.054 & 0.1 & & & 063853-016 & EPA 300.0 \\
\hline \multirow[t]{3}{*}{ 05-Feb-04 } & Nitrate & 2.0 & 0.5 & NA & None & None & Field & $\mathrm{HACH} 8039$ \\
\hline & $\begin{array}{l}\text { Nitrate plus } \\
\text { nitrite as N }\end{array}$ & 1.85 & 0.01 & 0.05 & & $A 2, J$ & 063853-015 & EPA 353.1 \\
\hline & $\begin{array}{l}\text { Nitrate plus } \\
\text { nitrite as N } \\
\text { (lab re- } \\
\text { analysis) } \\
\end{array}$ & 2.40 & 0.05 & 0.25 & & & 063853-R15 & EPA 353.1 \\
\hline TA1-W-02 & Nitrate & 1.0 & 0.054 & 0.1 & & & 063855-016 & EPA 300.0 \\
\hline \multirow[t]{2}{*}{ 28-Jan-04 } & \begin{tabular}{|l|} 
Nitrate \\
\end{tabular} & 1.1 & 0.5 & NA & None & None & Field & $\mathrm{HACH} 8039$ \\
\hline & $\begin{array}{l}\text { Nitrate plus } \\
\text { nitrite as N }\end{array}$ & 1.00 & 0.05 & 0.25 & & & 063855-015 & EPA 353.1 \\
\hline TA1-W-03 & Nitrate & 6.8 & 0.054 & 0.1 & & & 063857-016 & EPA 300.0 \\
\hline \multirow[t]{2}{*}{ 07-Jan-04 } & \begin{tabular}{|l|} 
Nitrate \\
\end{tabular} & 5.6 & 0.5 & NA & None & None & Field & $\mathrm{HACH} 8039$ \\
\hline & $\begin{array}{l}\text { Nitrate plus } \\
\text { nitrite as N }\end{array}$ & 2.09 & 0.01 & 0.05 & & $A 2, J$ & 063857-015 & EPA 353.1 \\
\hline TA1-W-04 & Nitrate & 1.6 & 0.054 & 0.1 & & & 063860-016 & EPA 300.0 \\
\hline 06-Jan-04 & Nitrate & 2.7 & 0.5 & NA & None & None & Field & $\mathrm{HACH} 8039$ \\
\hline
\end{tabular}




\begin{tabular}{|c|c|c|c|c|c|c|c|c|}
\hline Well ID & Analyte & $\begin{array}{l}\text { Result } \\
\text { (mg/L) }\end{array}$ & $\begin{array}{c}\text { MDL } \\
\text { (mg/L) }\end{array}$ & $\begin{array}{c}\text { PQL } \\
\text { (mg/L) }\end{array}$ & $\begin{array}{c}\text { Laboratory } \\
\text { Qualifier }\end{array}$ & $\begin{array}{c}\text { Validation } \\
\text { Qualifier } \\
\end{array}$ & Sample No. & $\begin{array}{c}\text { Analytical } \\
\text { Method }\end{array}$ \\
\hline & $\begin{array}{l}\text { Nitrate plus } \\
\text { nitrite as N }\end{array}$ & 1.30 & 0.01 & 0.05 & & $A 2, \mathrm{~J}$ & 063860-015 & EPA 353.1 \\
\hline TA1-W-05 & Nitrate & 1.0 & 0.054 & 0.1 & & & 063862-016 & EPA 300.0 \\
\hline \multirow[t]{2}{*}{ 12-Feb-04 } & Nitrate & 0.4 & 0.5 & NA & None & None & Field & $\mathrm{HACH} 8039$ \\
\hline & $\begin{array}{l}\text { Nitrate plus } \\
\text { nitrite as N }\end{array}$ & 1.0 & 0.05 & 0.25 & & & 063862-015 & EPA 353.1 \\
\hline TA1-W-06 & Nitrate & 3.2 & 0.054 & 0.1 & & & 063864-016 & EPA 300.0 \\
\hline \multirow[t]{3}{*}{ o9-Feb-04 } & Nitrate & 2.29 & 0.5 & NA & None & None & Field & $\mathrm{HACH} 8039$ \\
\hline & $\begin{array}{l}\text { Nitrate plus } \\
\text { nitrite as N }\end{array}$ & 1.96 & 0.01 & 0.05 & & $A 2, \mathrm{~J}$ & 063864-015 & EPA 353.1 \\
\hline & $\begin{array}{l}\text { Nitrate plus } \\
\text { nitrite as N } \\
\text { (lab re- } \\
\text { analysis) }\end{array}$ & 3.25 & 0.05 & 0.25 & & & 063864-R15 & EPA 353.1 \\
\hline TA1-W-08 & Nitrate & 7.1 & 0.054 & 0.1 & & & 063866-016 & EPA 300.0 \\
\hline \multirow{2}{*}{ 10-Feb-04 } & Nitrate & 5.1 & 0.5 & NA & None & None & Field & $\mathrm{HACH} 8039$ \\
\hline & $\begin{array}{l}\text { Nitrate plus } \\
\text { nitrite as N }\end{array}$ & 7.00 & 0.05 & 0.25 & & & 063866-015 & EPA 353.1 \\
\hline $\begin{array}{l}\text { TA1-W-08 } \\
\text { (Duplicate) }\end{array}$ & Nitrate & 7.0 & 0.054 & 0.1 & & & 063867-016 & EPA 300.0 \\
\hline 10-Feb-04 & $\begin{array}{l}\text { Nitrate plus } \\
\text { nitrite as N }\end{array}$ & 7.10 & 0.05 & 0.25 & & & 063867-015 & EPA 353.1 \\
\hline TA2-NW1-595 & Nitrate & 3.3 & 0.054 & 0.1 & & & 063869-016 & EPA 300.0 \\
\hline 26-Jan-04 & Nitrate & 3.4 & 0.5 & NA & None & None & Field & $\mathrm{HACH} 8039$ \\
\hline (Bennett) & $\begin{array}{l}\text { Nitrate plus } \\
\text { nitrite as N }\end{array}$ & 1.85 & 0.05 & 0.25 & & & 063869-015 & EPA 353.1 \\
\hline TA2-NW1-595 & Nitrate & 3.3 & 0.054 & 0.1 & & & 063871-016 & EPA 300.0 \\
\hline 04-Feb-04 & Nitrate & 2.9 & 0.5 & NA & None & None & Field & $\mathrm{HACH} 8039$ \\
\hline (QED) & $\begin{array}{l}\text { Nitrate plus } \\
\text { nitrite as N }\end{array}$ & 3.25 & 0.05 & 0.25 & & & 063871-015 & EPA 353.1 \\
\hline TA2-SW1-320 & Nitrate & 23.0 & 0.27 & 0.50 & & & 063873-016 & EPA 300.0 \\
\hline \multirow[t]{2}{*}{ 29-Jan-04 } & Nitrate & 17.5 & 0.5 & NA & None & None & Field & $\mathrm{HACH} 8039$ \\
\hline & $\begin{array}{l}\text { Nitrate plus } \\
\text { nitrite as N }\end{array}$ & 25.0 & 0.5 & 2.5 & & & 063873-015 & EPA 353.1 \\
\hline TA2-W-01 & Nitrate & 5.1 & 0.054 & 0.1 & & & 063876-016 & EPA 300.0 \\
\hline \multirow[t]{2}{*}{ 12-Jan-04 } & Nitrate & 4.1 & 0.5 & NA & None & None & Field & $\mathrm{HACH} 8039$ \\
\hline & $\begin{array}{l}\text { Nitrate plus } \\
\text { nitrite as N }\end{array}$ & 4.50 & 0.05 & 0.25 & & $A 2, J$ & 063876-015 & EPA 353.1 \\
\hline TA2-W-19 & Nitrate & 9.2 & 0.054 & 0.1 & & & 063878-016 & EPA 300.0 \\
\hline \multirow[t]{2}{*}{ 13-Jan-04 } & Nitrate & 7.8 & 0.5 & NA & None & None & Field & $\mathrm{HACH} 8039$ \\
\hline & $\begin{array}{l}\text { Nitrate plus } \\
\text { nitrite as N }\end{array}$ & 10 & 0.1 & 0.5 & & $\mathrm{~A} 2, \mathrm{~J}$ & 063878-015 & EPA 353.1 \\
\hline TA2-W-26 & Nitrate & 4.8 & 0.054 & 0.1 & & & 063880-016 & EPA 300.0 \\
\hline \multirow[t]{2}{*}{ 20-Jan-04 } & Nitrate & 4.1 & 0.5 & NA & None & None & Field & $\mathrm{HACH} 8039$ \\
\hline & $\begin{array}{l}\text { Nitrate plus } \\
\text { nitrite as N }\end{array}$ & 5.15 & 0.05 & 0.25 & & & 063880-015 & EPA 353.1 \\
\hline $\begin{array}{l}\text { TA2-W-26 } \\
\text { (Duplicate) }\end{array}$ & Nitrate & 4.9 & 0.054 & 0.1 & & & 063881-016 & EPA 300.0 \\
\hline 20-Jan-04 & $\begin{array}{l}\text { Nitrate plus } \\
\text { nitrite as N }\end{array}$ & 5.30 & 0.05 & 0.25 & & & 063881-015 & EPA 353.1 \\
\hline
\end{tabular}




\begin{tabular}{|c|c|c|c|c|c|c|c|c|}
\hline Well ID & Analyte & $\begin{array}{l}\text { Result } \\
\text { (mg/L) }\end{array}$ & $\begin{array}{c}\text { MDL } \\
\text { (mg/L) }\end{array}$ & $\begin{array}{c}\text { PQL } \\
(\mathrm{mg} / \mathrm{L})\end{array}$ & $\begin{array}{c}\text { Laboratory } \\
\text { Qualifier }\end{array}$ & $\begin{array}{c}\text { Validation } \\
\text { Qualifier }\end{array}$ & Sample No. & $\begin{array}{c}\text { Analytical } \\
\text { Method }\end{array}$ \\
\hline TA2-W-27 & Nitrate & 4.4 & 0.054 & 0.1 & & & 063885-016 & EPA 300.0 \\
\hline \multirow[t]{2}{*}{ 15-Jan-04 } & Nitrate & 3.8 & 0.5 & NA & None & None & Field & $\mathrm{HACH} 8039$ \\
\hline & $\begin{array}{l}\text { Nitrate plus } \\
\text { nitrite as N }\end{array}$ & 2.16 & 0.01 & 0.05 & & $\mathrm{~A} 2, \mathrm{~B} 2, \mathrm{~J}$ & 063885-015 & EPA 353.1 \\
\hline \multirow{3}{*}{$\begin{array}{l}\text { TJA-2 } \\
\text { 19-Jan-04 }\end{array}$} & Nitrate & 9.3 & 0.054 & 0.1 & & $\mathrm{~A} 2, \mathrm{~J}$ & 063887-016 & EPA 300.0 \\
\hline & Nitrate & 6.0 & 0.5 & NA & None & None & Field & HACH 8039 \\
\hline & $\begin{array}{l}\text { Nitrate plus } \\
\text { nitrite as N }\end{array}$ & 10 & 0.05 & 0.25 & & & 063887-015 & EPA 353.1 \\
\hline TJA-3 & Nitrate & 2.9 & 0.054 & 0.1 & & & 063889-016 & EPA 300.0 \\
\hline \multirow[t]{2}{*}{ 22-Oct-03 } & \begin{tabular}{|l|} 
Nitrate \\
\end{tabular} & 2.6 & 0.5 & NA & None & None & Field & HACH 8039 \\
\hline & $\begin{array}{l}\text { Nitrate plus } \\
\text { nitrite as N }\end{array}$ & 1.89 & 0.01 & 0.25 & & & 063889-015 & EPA 353.1 \\
\hline \multirow{3}{*}{$\mid \begin{array}{l}\text { TJA-4 } \\
\text { 29-Jan-04 }\end{array}$} & Nitrate & 26.0 & 0.27 & 0.50 & & & 063891-016 & EPA 300.0 \\
\hline & Nitrate & 17.4 & 0.5 & NA & None & None & Field & HACH 8039 \\
\hline & $\begin{array}{l}\text { Nitrate plus } \\
\text { nitrite as N }\end{array}$ & 27.0 & 0.25 & 1.25 & & & 063891-015 & EPA 353.1 \\
\hline TJA-6 & Nitrate & 2.5 & 0.054 & 0.1 & & & 063893-016 & EPA 300.0 \\
\hline \multirow[t]{2}{*}{ 04-Feb-04 } & Nitrate & 2.1 & 0.5 & NA & None & None & Field & HACH 8039 \\
\hline & $\begin{array}{l}\text { Nitrate plus } \\
\text { nitrite as N }\end{array}$ & 2.35 & 0.05 & 0.25 & & & 063893-015 & EPA 353.1 \\
\hline TJA-7 & Nitrate & 27.0 & 0.27 & 0.50 & & & 063895-016 & EPA 300.0 \\
\hline \multirow[t]{2}{*}{ 22-Jan-04 } & Nitrate & 15 & 0.5 & NA & None & None & Field & HACH 8039 \\
\hline & $\begin{array}{l}\text { Nitrate plus } \\
\text { nitrite as N }\end{array}$ & 29.8 & 0.250 & 1.25 & & & 063895-015 & EPA 353.1 \\
\hline \multirow{3}{*}{$\begin{array}{l}\text { WYO-3 } \\
\text { 21-Jan-04 }\end{array}$} & Nitrate & 2.0 & 0.054 & 0.1 & & & 063897-016 & EPA 300.0 \\
\hline & Nitrate & 1.9 & 0.5 & NA & None & None & Field & $\mathrm{HACH} 8039$ \\
\hline & $\begin{array}{l}\text { Nitrate plus } \\
\text { nitrite as N }\end{array}$ & 1.38 & 0.01 & 0.05 & & B2, J & 063897-015 & EPA 353.1 \\
\hline WYO-4 & Nitrate & 2.9 & 0.054 & 0.1 & & & 063899-016 & EPA 300.0 \\
\hline \multirow[t]{3}{*}{ 03-Feb-04 } & Nitrate & 3.6 & 0.5 & NA & None & None & Field & HACH 8039 \\
\hline & $\begin{array}{l}\text { Nitrate plus } \\
\text { nitrite as N }\end{array}$ & 2.06 & 0.01 & 0.05 & & $A 2, J$ & 063899-015 & EPA 353.1 \\
\hline & $\begin{array}{l}\text { Nitrate plus } \\
\text { nitrite as N } \\
\text { (lab re- } \\
\text { analysis) }\end{array}$ & 2.11 & 0.01 & 0.05 & & & 063899-R15 & EPA 353.1 \\
\hline $\begin{array}{l}\text { WYO-4 } \\
\text { (Duplicate) }\end{array}$ & Nitrate & 2.9 & 0.054 & 0.1 & & & 063900-016 & EPA 300.0 \\
\hline \multirow[t]{2}{*}{ 03-Feb-04 } & $\begin{array}{l}\text { Nitrate plus } \\
\text { nitrite as N }\end{array}$ & 2.09 & 0.01 & 0.05 & & $A 2, J$ & 063900-015 & EPA 353.1 \\
\hline & $\begin{array}{l}\text { Nitrate plus } \\
\text { nitrite as N } \\
\text { (lab re- } \\
\text { analysis) }\end{array}$ & 2.12 & 0.01 & 0.05 & & & 063900-R15 & EPA 353.1 \\
\hline \multicolumn{9}{|c|}{$\begin{array}{l}\mathrm{mg} / \mathrm{L}=\text { milligrams per liter } \\
\mathrm{J}=\text { Amount detected is below the practical quantitation limit. The associated value is an estimated quantity. } \\
\text { A2= Laboratory accuracy and/or bias measurements for the associated matrix spike and/or duplicate do not meet acceptance } \\
\text { criteria. } \\
\mathrm{B} 2=\text { Analyte is detected in associated equipment blank sample. }\end{array}$} \\
\hline
\end{tabular}


Table A-10

Summary of Nitrate and Nitrate plus Nitrite Results

Tijeras Arroyo Groundwater Investigation

Fiscal Year 2004, $3^{\text {rd }}$ Quarter

\begin{tabular}{|c|c|c|c|c|c|c|c|c|}
\hline Well ID & Analyte & $\begin{array}{l}\text { Result } \\
\text { (mg/L) }\end{array}$ & $\begin{array}{c}\text { MDL } \\
\text { (mg/L) }\end{array}$ & $\begin{array}{c}\text { PQL } \\
\text { (mg/L) }\end{array}$ & $\begin{array}{c}\text { Laboratory } \\
\text { Qualifier }\end{array}$ & $\begin{array}{c}\text { Validation } \\
\text { Qualifier }\end{array}$ & Sample No. & $\begin{array}{l}\text { Analytical } \\
\text { Method }\end{array}$ \\
\hline Eubank-1 & Nitrate & 2.3 & 0.054 & 0.10 & & & 064600-016 & EPA 300.0 \\
\hline \multirow[t]{2}{*}{ 20-May-04 } & Nitrate & 3.2 & 0.5 & NA & None & None & Field & HACH 8039 \\
\hline & $\begin{array}{l}\text { Nitrate plus } \\
\text { nitrite as N }\end{array}$ & 2.34 & 0.0144 & 0.20 & & & 064600-015 & EPA 353.1 \\
\hline Eubank-2 & Nitrate & 1.2 & 0.054 & 0.10 & & & 064602-016 & EPA 300.0 \\
\hline \multirow[t]{2}{*}{ 06-May-04 } & Nitrate & 1.7 & 0.5 & NA & None & None & Field & $\mathrm{HACH} 8039$ \\
\hline & $\begin{array}{l}\text { Nitrate plus } \\
\text { nitrite as N }\end{array}$ & 1.29 & 0.0144 & 0.20 & & & 064602-015 & EPA 353.1 \\
\hline Eubank-3 & Nitrate & 3.1 & 0.054 & 0.10 & & & 064604-016 & EPA 300.0 \\
\hline \multirow[t]{2}{*}{ 04-May-04 } & Nitrate & 3.8 & 0.5 & NA & None & None & Field & $\mathrm{HACH} 8039$ \\
\hline & $\begin{array}{l}\text { Nitrate plus } \\
\text { nitrite as N }\end{array}$ & 3.18 & 0.0359 & 0.05 & & & 064604-015 & EPA 353.1 \\
\hline Eubank-5 & Nitrate & 3.3 & 0.054 & 0.10 & & & 064607-016 & EPA 300.0 \\
\hline \multirow[t]{2}{*}{ 03-Мау-04 } & Nitrate & 3.0 & 0.5 & NA & None & None & Field & HACH 8039 \\
\hline & $\begin{array}{l}\text { Nitrate plus } \\
\text { nitrite as N }\end{array}$ & 3.51 & 0.0359 & 0.05 & & & 064607-015 & EPA 353.1 \\
\hline PGS-2 & Nitrate & 0.90 & 0.054 & 0.10 & & & 064551-016 & EPA 300.0 \\
\hline \multirow[t]{2}{*}{ 12-May-04 } & Nitrate & 1.7 & 0.50 & NA & None & None & Field & $\mathrm{HACH} 8039$ \\
\hline & $\begin{array}{l}\text { Nitrate plus } \\
\text { nitrite as N }\end{array}$ & 0.837 & 0.0144 & 0.20 & & & 064551-015 & EPA 353.1 \\
\hline TA1-W-01 & Nitrate & 2.4 & 0.054 & 0.10 & & & 064553-016 & EPA 300.0 \\
\hline \multirow[t]{2}{*}{ 10-May-04 } & Nitrate & 2.7 & 0.50 & NA & None & None & Field & HACH 8039 \\
\hline & $\begin{array}{l}\text { Nitrate plus } \\
\text { nitrite as N }\end{array}$ & 2.34 & 0.0144 & 0.20 & & & 064553-015 & EPA 353.1 \\
\hline TA1-W-02 & Nitrate & 1.0 & 0.054 & 0.10 & & & 064556-016 & EPA 300.0 \\
\hline \multirow[t]{2}{*}{ 11-May-04 } & Nitrate & 0.8 & 0.50 & NA & None & None & Field & HACH 8039 \\
\hline & $\begin{array}{l}\text { Nitrate plus } \\
\text { nitrite as N }\end{array}$ & 1.04 & 0.0144 & 0.20 & & & 064556-015 & EPA 353.1 \\
\hline TA1-W-03 & Nitrate & 6.5 & 0.054 & 0.10 & & & 064558-016 & EPA 300.0 \\
\hline \multirow[t]{2}{*}{ 28-Apr-04 } & Nitrate & 5.1 & 0.5 & NA & None & None & Field & HACH 8039 \\
\hline & $\begin{array}{l}\text { Nitrate plus } \\
\text { nitrite as N }\end{array}$ & 7.4 & 0.0359 & 0.50 & & & 064558-015 & EPA 353.1 \\
\hline TA1-W-04 & Nitrate & 1.6 & 0.054 & 0.10 & & & 064560-016 & EPA 300.0 \\
\hline \multirow[t]{2}{*}{ 26-Apr-04 } & Nitrate & 2.3 & 0.5 & NA & None & None & Field & $\mathrm{HACH} 8039$ \\
\hline & $\begin{array}{l}\text { Nitrate plus } \\
\text { nitrite as N }\end{array}$ & 1.61 & 0.0359 & 0.05 & $N$ & & 064560-015 & EPA 353.1 \\
\hline
\end{tabular}




\begin{tabular}{|c|c|c|c|c|c|c|c|c|}
\hline Well ID & Analyte & $\begin{array}{l}\text { Result } \\
\text { (mg/L) }\end{array}$ & $\begin{array}{c}\text { MDL } \\
\text { (mg/L) }\end{array}$ & $\begin{array}{c}\mathrm{PQL} \\
(\mathrm{mg} / \mathrm{L})\end{array}$ & $\begin{array}{c}\text { Laboratory } \\
\text { Qualifier }\end{array}$ & $\begin{array}{c}\text { Validation } \\
\text { Qualifier }\end{array}$ & Sample No. & $\begin{array}{c}\text { Analytical } \\
\text { Method }\end{array}$ \\
\hline TA1-W-05 & Nitrate & 1.1 & 0.054 & 0.10 & & & 064562-016 & EPA 300.0 \\
\hline \multirow[t]{2}{*}{ 07-May-04 } & Nitrate & 3.0 & 0.5 & NA & None & None & Field & $\mathrm{HACH} 8039$ \\
\hline & $\begin{array}{l}\text { Nitrate plus } \\
\text { nitrite as N }\end{array}$ & 0.923 & 0.0144 & 0.20 & & & 064562-015 & EPA 353.1 \\
\hline TA1-W-06 & Nitrate & 3.2 & 0.054 & 0.10 & & & 064564-016 & EPA 300.0 \\
\hline \multirow[t]{2}{*}{ 21-May-04 } & Nitrate & 3.1 & 0.5 & NA & None & None & Field & $\mathrm{HACH} 8039$ \\
\hline & $\begin{array}{l}\text { Nitrate plus } \\
\text { nitrite as N }\end{array}$ & 3.14 & 0.0144 & 0.20 & & & 064564-015 & EPA 353.1 \\
\hline TA1-W-08 & Nitrate & 6.9 & 0.054 & 0.10 & & & 064566-016 & EPA 300.0 \\
\hline \multirow[t]{2}{*}{ 23-Apr-04 } & Nitrate & 6.1 & 0.5 & NA & None & None & Field & $\mathrm{HACH} 8039$ \\
\hline & $\begin{array}{l}\text { Nitrate plus } \\
\text { nitrite as N }\end{array}$ & 6.59 & 0.0359 & 0.50 & & & 064566-015 & EPA 353.1 \\
\hline TA2-NW1-595 & Nitrate & 3.3 & 0.054 & 0.10 & & & 064568-016 & EPA 300.0 \\
\hline 13-May-04 & Nitrate & 3.3 & 0.5 & NA & None & None & Field & $\mathrm{HACH} 8039$ \\
\hline (QED) & $\begin{array}{l}\text { Nitrate plus } \\
\text { nitrite as N }\end{array}$ & 3.12 & 0.0144 & 0.20 & & & 064568-015 & EPA 353.1 \\
\hline TA2-NW1-595 & Nitrate & 3.3 & 0.054 & 0.10 & & & 064571-016 & EPA 300.0 \\
\hline 19-May-04 & Nitrate & 4.0 & 0.5 & NA & None & None & Field & HACH 8039 \\
\hline (Bennett) & $\begin{array}{l}\text { Nitrate plus } \\
\text { nitrite as N }\end{array}$ & 3.24 & 0.0144 & 0.20 & & & 064571-015 & EPA 353.1 \\
\hline TA2-SW1-320 & Nitrate & 22 & 0.27 & 0.50 & & & 064573-016 & EPA 300.0 \\
\hline \multirow[t]{2}{*}{ 14-May-04 } & Nitrate & 16.5 & 0.5 & NA & None & None & Field & $\mathrm{HACH} 8039$ \\
\hline & $\begin{array}{l}\text { Nitrate plus } \\
\text { nitrite as N }\end{array}$ & 24.2 & 0.144 & 2 & $\mathrm{H}$ & $\mathrm{HT}, \mathrm{J}$ & 064573-015 & EPA 353.1 \\
\hline TA2-W-01 & Nitrate & 4.9 & 0.054 & 0.10 & & & 064575-016 & EPA 300.0 \\
\hline \multirow[t]{2}{*}{ 17-May-04 } & Nitrate & 2.3 & 0.5 & NA & None & None & Field & HACH 8039 \\
\hline & $\begin{array}{l}\text { Nitrate plus } \\
\text { nitrite as N }\end{array}$ & 3.46 & 0.0359 & 0.50 & & & 064575-015 & EPA 353.1 \\
\hline TA2-W-19 & Nitrate & 9.3 & 0.054 & 0.10 & & & 064577-016 & EPA 300.0 \\
\hline \multirow[t]{2}{*}{ 27-Apr-04 } & Nitrate & 7.6 & 0.5 & NA & None & None & Field & $\mathrm{HACH} 8039$ \\
\hline & $\begin{array}{l}\text { Nitrate plus } \\
\text { nitrite as N }\end{array}$ & 9.23 & 0.0359 & 0.50 & & & 064577-015 & EPA 353.1 \\
\hline $\begin{array}{l}\text { TA2-W-19 } \\
\text { (Duplicate) }\end{array}$ & Nitrate & 9.3 & 0.054 & 0.10 & & & 064578-016 & EPA 300.0 \\
\hline 27-Apr-04 & $\begin{array}{l}\text { Nitrate plus } \\
\text { nitrite as N }\end{array}$ & 9.39 & 0.0359 & 0.50 & & & 064578-015 & EPA 353.1 \\
\hline TA2-W-26 & Nitrate & 4.8 & 0.054 & 0.10 & & & 064580-016 & EPA 300.0 \\
\hline \multirow[t]{2}{*}{ 21-Apr-04 } & Nitrate & 3.8 & 0.5 & NA & None & None & Field & HACH 8039 \\
\hline & $\begin{array}{l}\text { Nitrate plus } \\
\text { nitrite as N }\end{array}$ & 4.70 & 0.0359 & 0.50 & & J, B2 & 064580-015 & EPA 353.1 \\
\hline $\begin{array}{l}\text { TA2-W-26 } \\
\text { (Duplicate) }\end{array}$ & Nitrate & 4.7 & 0.054 & 0.10 & & & 064581-016 & EPA 300.0 \\
\hline 21-Apr-04 & Nitrate plus & 4.80 & 0.0359 & 0.50 & & J, B2 & 064581-015 & EPA 353.1 \\
\hline
\end{tabular}




\begin{tabular}{|c|c|c|c|c|c|c|c|c|}
\hline Well ID & Analyte & $\begin{array}{l}\text { Result } \\
(\mathrm{mg} / \mathrm{L})\end{array}$ & $\begin{array}{c}\text { MDL } \\
\text { (mg/L) }\end{array}$ & $\begin{array}{c}\mathrm{PQL} \\
\text { (mg/L) }\end{array}$ & $\begin{array}{c}\text { Laboratory } \\
\text { Qualifier }\end{array}$ & $\begin{array}{c}\text { Validation } \\
\text { Qualifier }\end{array}$ & Sample No. & $\begin{array}{c}\text { Analytical } \\
\text { Method }\end{array}$ \\
\hline & nitrite as $\mathrm{N}$ & & & & & & & \\
\hline TA2-W-27 & Nitrate & 5.0 & 0.054 & 0.10 & & & 064583-016 & EPA 300.0 \\
\hline \multirow[t]{2}{*}{ 19-Apr-04 } & Nitrate & 4.3 & 0.5 & NA & None & None & Field & $\mathrm{HACH} 8039$ \\
\hline & $\begin{array}{l}\text { Nitrate plus } \\
\text { nitrite as N }\end{array}$ & 4.17 & 0.0359 & 0.50 & & & 064583-015 & EPA 353.1 \\
\hline TJA-2 & Nitrate & 9.1 & 0.054 & 0.10 & & & 064585-016 & EPA 300.0 \\
\hline \multirow[t]{2}{*}{ 05-Мay-04 } & Nitrate & 8.0 & 0.5 & NA & None & None & Field & $\mathrm{HACH} 8039$ \\
\hline & $\begin{array}{l}\text { Nitrate plus } \\
\text { nitrite as N }\end{array}$ & 8.65 & 0.144 & 0.05 & & & 064585-015 & EPA 353.1 \\
\hline TJA-3 & Nitrate & 2.5 & 0.054 & 0.10 & & & 064587-016 & EPA 300.0 \\
\hline \multirow[t]{2}{*}{ 27-Apr-04 } & Nitrate & 4.0 & 0.5 & NA & None & None & Field & $\mathrm{HACH} 8039$ \\
\hline & $\begin{array}{l}\text { Nitrate plus } \\
\text { nitrite as N }\end{array}$ & 2.8 & 0.0359 & 0.50 & & & 064587-015 & EPA 353.1 \\
\hline TJA-4 & Nitrate & 24 & 0.27 & 0.50 & & & 064589-016 & EPA 300.0 \\
\hline \multirow[t]{2}{*}{ 20-Apr-04 } & Nitrate & 17.3 & 0.5 & NA & None & None & Field & $\mathrm{HACH} 8039$ \\
\hline & $\begin{array}{l}\text { Nitrate plus } \\
\text { nitrite as N }\end{array}$ & 26.4 & 0.144 & 2 & & & 064589-015 & EPA 353.1 \\
\hline TJA-6 & Nitrate & 2.4 & 0.054 & 0.10 & & & 064591-016 & EPA 300.0 \\
\hline \multirow[t]{2}{*}{ 22-Apr-04 } & Nitrate & 2.5 & 0.5 & NA & None & None & Field & $\mathrm{HACH} 8039$ \\
\hline & $\begin{array}{l}\text { Nitrate plus } \\
\text { nitrite as N }\end{array}$ & 2.42 & 0.0359 & 0.05 & & J, B2 & 064591-015 & EPA 353.1 \\
\hline TJA-7 & Nitrate & 24 & 0.27 & 0.50 & & & 064593-016 & EPA 300.0 \\
\hline \multirow[t]{2}{*}{ 30-Apr-04 } & Nitrate & 16.3 & 0.5 & NA & None & None & Field & HACH 8039 \\
\hline & $\begin{array}{l}\text { Nitrate plus } \\
\text { nitrite as N }\end{array}$ & 17.9 & 0.287 & 4 & & & 064593-015 & EPA 353.1 \\
\hline WYO-3 & Nitrate & 1.9 & 0.054 & 0.10 & & & 064595-016 & EPA 300.0 \\
\hline \multirow[t]{2}{*}{ 28-Apr-04 } & Nitrate & 2.8 & 0.5 & NA & None & None & Field & $\mathrm{HACH} 8039$ \\
\hline & $\begin{array}{l}\text { Nitrate plus } \\
\text { nitrite as N }\end{array}$ & 2.12 & 0.0359 & 0.50 & & & 064595-015 & EPA 353.1 \\
\hline WYO-4 & Nitrate & 2.7 & 0.054 & 0.10 & & & 064597-016 & EPA 300.0 \\
\hline \multirow[t]{2}{*}{ 30-Apr-04 } & Nitrate & 2.7 & 0.5 & NA & None & None & Field & $\mathrm{HACH} 8039$ \\
\hline & $\begin{array}{l}\text { Nitrate plus } \\
\text { nitrite as N }\end{array}$ & 2.81 & 0.0359 & 0.50 & & & 064597-015 & EPA 353.1 \\
\hline $\begin{array}{l}\text { WYO-4 } \\
\text { (Duplicate) }\end{array}$ & Nitrate & 2.7 & 0.054 & 0.10 & & & 064598-016 & EPA 300.0 \\
\hline 30-Apr-04 & $\begin{array}{l}\text { Nitrate plus } \\
\text { nitrite as N }\end{array}$ & 2.86 & 0.0359 & 0.05 & & & 064598-015 & EPA 353.1 \\
\hline
\end{tabular}


Table A-11

Summary of Nitrate and Nitrate plus Nitrite Results

Tijeras Arroyo Groundwater Investigation

Fiscal Year 2004, $4^{\text {th }}$ Quarter

\begin{tabular}{|c|c|c|c|c|c|c|c|c|}
\hline Well ID & Analyte & $\begin{array}{l}\text { Result } \\
\text { (mg/L) }\end{array}$ & $\begin{array}{c}\text { MDL } \\
\text { (mg/L) }\end{array}$ & $\begin{array}{c}\text { PQL } \\
\text { (mg/L) }\end{array}$ & $\begin{array}{l}\text { Laboratory } \\
\text { Qualifier }\end{array}$ & $\begin{array}{c}\text { Validation } \\
\text { Qualifier }\end{array}$ & Sample No. & $\begin{array}{l}\text { Analytical } \\
\text { Method }\end{array}$ \\
\hline Eubank-1 & Nitrate & 2.3 & 2.8 & 0.054 & & & 065416-016 & EPA 300.0 \\
\hline \multirow[t]{2}{*}{ 19-Aug-04 } & Nitrate & 1.7 & 0.5 & NA & None & None & Field & HACH 8039 \\
\hline & $\begin{array}{l}\text { Nitrate plus } \\
\text { nitrite as N }\end{array}$ & 2.17 & 0.0144 & 0.20 & & & 065416-015 & EPA 353.1 \\
\hline PGS-2 & Nitrate & 0.82 & 0.054 & 0.10 & & & 065360-016 & EPA 300.0 \\
\hline \multirow[t]{2}{*}{ 28-Jul-04 } & Nitrate & 1.6 & 0.5 & NA & None & None & Field & $\mathrm{HACH} 8039$ \\
\hline & $\begin{array}{l}\text { Nitrate plus } \\
\text { nitrite as N }\end{array}$ & 0.62 & 0.0036 & 0.05 & & & 065360-015 & EPA 353.1 \\
\hline TA1-W-01 & Nitrate & 2.6 & 0.054 & 0.10 & & & 065362-016 & EPA 300.0 \\
\hline \multirow[t]{2}{*}{ 17-Aug-04 } & Nitrate & 2.5 & 0.5 & NA & None & None & Field & HACH 8039 \\
\hline & $\begin{array}{l}\text { Nitrate plus } \\
\text { nitrite as N }\end{array}$ & 2.32 & 0.0144 & 0.20 & & & 065362-015 & EPA 353.1 \\
\hline TA1-W-02 & Nitrate & 1.0 & 0.054 & 0.10 & & A2, J & 065364-016 & EPA 300.0 \\
\hline \multirow[t]{2}{*}{ 13-Aug-04 } & Nitrate & 1.7 & 0.5 & NA & None & None & Field & HACH 8039 \\
\hline & $\begin{array}{l}\text { Nitrate plus } \\
\text { nitrite as N }\end{array}$ & 0.921 & 0.0144 & 0.20 & & & 065364-015 & EPA 353.1 \\
\hline TA1-W-03 & Nitrate & 6.8 & 0.054 & 0.10 & & & 065366-016 & EPA 300.0 \\
\hline \multirow[t]{2}{*}{ 18-Aug-04 } & Nitrate & 5.4 & 0.5 & NA & None & None & Field & $\mathrm{HACH} 8039$ \\
\hline & $\begin{array}{l}\text { Nitrate plus } \\
\text { nitrite as N }\end{array}$ & 6.53 & 0.0144 & 0.20 & & & 065366-015 & EPA 353.1 \\
\hline TA1-W-04 & Nitrate & 1.6 & 0.054 & 0.10 & & & 065368-016 & EPA 300.0 \\
\hline \multirow[t]{2}{*}{ 26-Jul-04 } & Nitrate & 1.3 & 0.5 & NA & None & None & Field & HACH 8039 \\
\hline & $\begin{array}{l}\text { Nitrate plus } \\
\text { nitrite as N }\end{array}$ & 1.53 & 0.0036 & 0.05 & & & 065368-015 & EPA 353.1 \\
\hline TA1-W-05 & Nitrate & 1.1 & 0.054 & 0.10 & & & 065370-016 & EPA 300.0 \\
\hline \multirow[t]{2}{*}{ 20-Aug-04 } & Nitrate & 2.7 & 0.5 & NA & None & None & Field & $\mathrm{HACH} 8039$ \\
\hline & $\begin{array}{l}\text { Nitrate plus } \\
\text { nitrite as N }\end{array}$ & 0.596 & 0.0036 & 0.05 & & & 065370-015 & EPA 353.1 \\
\hline TA1-W-06 & Nitrate & 3.2 & 0.054 & 0.10 & & & $065372-016$ & EPA 300.0 \\
\hline \multirow[t]{2}{*}{ 06-Aug-04 } & Nitrate & 4.5 & 0.5 & NA & None & None & Field & HACH 8039 \\
\hline & $\begin{array}{l}\text { Nitrate plus } \\
\text { nitrite as N }\end{array}$ & 2.72 & 0.0144 & 0.20 & & & 065372-015 & EPA 353.1 \\
\hline
\end{tabular}




\begin{tabular}{|c|c|c|c|c|c|c|c|c|}
\hline Well ID & Analyte & $\begin{array}{l}\text { Result } \\
\text { (mg/L) }\end{array}$ & $\begin{array}{c}\text { MDL } \\
(\mathrm{mg} / \mathrm{L})\end{array}$ & $\begin{array}{c}P Q L \\
\text { (mg/L) }\end{array}$ & $\begin{array}{l}\text { Laboratory } \\
\text { Qualifier }\end{array}$ & $\begin{array}{c}\text { Validation } \\
\text { Qualifier }\end{array}$ & Sample No. & $\begin{array}{c}\text { Analytical } \\
\text { Method }\end{array}$ \\
\hline TA1-W-08 & Nitrate & 6.8 & 0.054 & 0.10 & & A2, J & 065374-016 & EPA 300.0 \\
\hline \multirow[t]{2}{*}{ 13-Aug-04 } & Nitrate & 3.7 & 0.5 & NA & None & None & Field & $\mathrm{HACH} 8039$ \\
\hline & $\begin{array}{l}\text { Nitrate plus } \\
\text { nitrite as N }\end{array}$ & 7.31 & 0.144 & 2.0 & & & 065374-015 & EPA 353.1 \\
\hline TA2-NW1-595 & Nitrate & 3.3 & 0.054 & 0.10 & & & 065377-016 & EPA 300.0 \\
\hline 26-Jul-04 & Nitrate & 4.7 & 0.5 & NA & None & None & Field & HACH 8039 \\
\hline (QED) & $\begin{array}{l}\text { Nitrate plus } \\
\text { nitrite as N }\end{array}$ & 3.21 & 0.0036 & 0.05 & & & 065377-015 & EPA 353.1 \\
\hline TA2-NW1-595 & Nitrate & 3.3 & 0.054 & 0.10 & & & 065379-016 & EPA 300.0 \\
\hline 23-Aug-04 & Nitrate & 2.7 & 0.5 & NA & None & None & Field & $\mathrm{HACH} 8039$ \\
\hline (Bennett) & $\begin{array}{l}\text { Nitrate plus } \\
\text { nitrite as N }\end{array}$ & 3.01 & 0.0144 & 0.20 & & & 065379-015 & EPA 353.1 \\
\hline TA2-SW1-320 & Nitrate & 24.0 & 0.27 & 0.50 & & $\mathrm{~A} 2, \mathrm{~J}$ & 065381-016 & EPA 300.0 \\
\hline \multirow[t]{2}{*}{ 27-Jul-04 } & Nitrate & 34.2 & 0.5 & NA & & & Field & HACH 8039 \\
\hline & $\begin{array}{l}\text { Nitrate plus } \\
\text { nitrite as N }\end{array}$ & 24.0 & 0.0036 & 0.05 & & & 065381-015 & EPA 353.1 \\
\hline TA2-W-01 & Nitrate & 5.0 & 0.054 & 0.10 & & & 065383-016 & EPA 300.0 \\
\hline \multirow[t]{2}{*}{ 12-Aug-04 } & Nitrate & 3.8 & 0.5 & NA & None & None & Field & $\mathrm{HACH} 8039$ \\
\hline & $\begin{array}{l}\text { Nitrate plus } \\
\text { nitrite as N }\end{array}$ & 4.71 & 0.144 & 2.0 & & & 065383-015 & EPA 353.1 \\
\hline TA2-W-19 & Nitrate & 9.4 & 0.054 & 0.10 & & $\mathrm{~A} 2, \mathrm{~J}$ & 065385-016 & EPA 300.0 \\
\hline \multirow[t]{2}{*}{ 27-Jul-04 } & Nitrate & 8.1 & 0.5 & NA & None & None & Field & $\mathrm{HACH} 8039$ \\
\hline & $\begin{array}{l}\text { Nitrate plus } \\
\text { nitrite as N }\end{array}$ & 9.53 & 0.0036 & 0.05 & & & 065385-015 & EPA 353.1 \\
\hline TA2-W-26 & Nitrate & 4.7 & 0.054 & 0.10 & & P2 & 065387-016 & EPA 300.0 \\
\hline \multirow[t]{2}{*}{ 30-Jul-04 } & Nitrate & 5.0 & 0.5 & NA & None & None & Field & HACH 8039 \\
\hline & $\begin{array}{l}\text { Nitrate plus } \\
\text { nitrite as N }\end{array}$ & 3.55 & 0.144 & 2.0 & & & 065387-015 & EPA 353.1 \\
\hline $\begin{array}{l}\text { TA2-W-26 } \\
\text { (Duplicate) }\end{array}$ & Nitrate & 4.6 & 0.054 & 0.10 & & P2 & 065388-016 & EPA 300.0 \\
\hline 30-Jul-04 & $\begin{array}{l}\text { Nitrate plus } \\
\text { nitrite as N }\end{array}$ & 3.31 & 0.144 & 2.0 & & & 065388-015 & EPA 353.1 \\
\hline TA2-W-27 & Nitrate & 4.3 & 0.054 & 0.10 & & & 065392-016 & EPA 300.0 \\
\hline \multirow[t]{2}{*}{ 28-Jul-04 } & Nitrate & 3.8 & 0.5 & NA & None & None & Field & $\mathrm{HACH} 8039$ \\
\hline & $\begin{array}{l}\text { Nitrate plus } \\
\text { nitrite as N }\end{array}$ & 4.32 & 0.0359 & 0.50 & & & 065392-015 & EPA 353.1 \\
\hline TJA-2 & Nitrate & 9.3 & 0.054 & 0.10 & & $A 2, \mathrm{~J}$ & 065394-016 & EPA 300.0 \\
\hline \multirow[t]{2}{*}{ 16-Aug-04 } & Nitrate & 8.5 & 0.5 & NA & None & None & Field & $\mathrm{HACH} 8039$ \\
\hline & $\begin{array}{l}\text { Nitrate plus } \\
\text { nitrite as N }\end{array}$ & 9.96 & 0.144 & 2.0 & & & 065394-015 & EPA 353.1 \\
\hline
\end{tabular}




\begin{tabular}{|c|c|c|c|c|c|c|c|c|}
\hline Well ID & Analyte & $\begin{array}{l}\text { Result } \\
\text { (mg/L) }\end{array}$ & $\begin{array}{c}\text { MDL } \\
\text { (mg/L) }\end{array}$ & $\begin{array}{c}\mathrm{PQL} \\
(\mathrm{mg} / \mathrm{L})\end{array}$ & $\begin{array}{c}\text { Laboratory } \\
\text { Qualifier }\end{array}$ & $\begin{array}{c}\text { Validation } \\
\text { Qualifier }\end{array}$ & Sample No. & $\begin{array}{c}\text { Analytical } \\
\text { Method }\end{array}$ \\
\hline TJA-3 & Nitrate & 2.7 & 0.054 & 0.10 & & & 065397-016 & EPA 300.0 \\
\hline \multirow[t]{2}{*}{ 09-Aug-03 } & Nitrate & 2.6 & 0.5 & NA & None & None & Field & $\mathrm{HACH} 8039$ \\
\hline & $\begin{array}{l}\text { Nitrate plus } \\
\text { nitrite as N }\end{array}$ & 2.52 & 0.0144 & 0.20 & & & 065397-015 & EPA 353.1 \\
\hline TJA-4 & Nitrate & 26.0 & 0.27 & 0.50 & & $\mathrm{~A} 2, \mathrm{~J}$ & 065399-016 & EPA 300.0 \\
\hline \multirow[t]{2}{*}{ 10-Aug-04 } & Nitrate & 21.3 & 0.5 & NA & None & None & Field & $\mathrm{HACH} 8039$ \\
\hline & $\begin{array}{l}\text { Nitrate plus } \\
\text { nitrite as N }\end{array}$ & 25.4 & 0.144 & 2.0 & & & 065399-015 & EPA 353.1 \\
\hline TJA-6 & Nitrate & 2.5 & 0.054 & 0.10 & & & 065401-016 & EPA 300.0 \\
\hline \multirow[t]{2}{*}{ 09-Aug-04 } & Nitrate & 2.9 & 0.5 & NA & None & None & Field & $\mathrm{HACH} 8039$ \\
\hline & $\begin{array}{l}\text { Nitrate plus } \\
\text { nitrite as N }\end{array}$ & 2.20 & 0.0144 & 0.20 & & & 065397-015 & EPA 353.1 \\
\hline TJA-7 & Nitrate & 27.0 & 0.054 & 0.10 & E & $\mathrm{J}$ & 065403-016 & EPA 300.0 \\
\hline \multirow[t]{3}{*}{ 06-Aug-04 } & $\begin{array}{l}\text { Nitrate (re- } \\
\text { analysis) }\end{array}$ & 24.0 & 0.27 & 0.50 & $\mathrm{H}$ & $\mathrm{HT}, \mathrm{J}$ & 065403-R16 & EPA 300.0 \\
\hline & Nitrate & 20.9 & 0.5 & NA & None & None & Field & HACH 8039 \\
\hline & $\begin{array}{l}\text { Nitrate plus } \\
\text { nitrite as N }\end{array}$ & 24.3 & 0.144 & 2.0 & & & 065403-015 & EPA 353.1 \\
\hline $\begin{array}{l}\text { TJA-7 } \\
\text { (Duplicate) }\end{array}$ & Nitrate & 27.0 & 0.054 & 0.10 & E & $\mathrm{J}$ & 065404-016 & EPA 300.0 \\
\hline \multirow[t]{2}{*}{ 06-Aug-04 } & $\begin{array}{l}\text { Nitrate (re- } \\
\text { analysis) }\end{array}$ & 25.0 & 0.27 & 0.50 & $\mathrm{H}$ & $\mathrm{HT}, \mathrm{J}$ & 065404-R16 & EPA 300.0 \\
\hline & $\begin{array}{l}\text { Nitrate plus } \\
\text { nitrite as N }\end{array}$ & 24.6 & 0.144 & 2.0 & & & 065404-015 & EPA 353.1 \\
\hline WYO-3 & Nitrate & 2.0 & 0.054 & 0.10 & & & 065408-016 & EPA 300.0 \\
\hline \multirow[t]{2}{*}{ 11-Aug-04 } & Nitrate & 2.1 & 0.5 & NA & None & None & Field & $\mathrm{HACH} 8039$ \\
\hline & $\begin{array}{l}\text { Nitrate plus } \\
\text { nitrite as N }\end{array}$ & 1.89 & 0.0144 & 0.20 & & & 065408-015 & EPA 353.1 \\
\hline WYO-4 & Nitrate & 2.8 & 0.054 & 0.10 & & & 065411-016 & EPA 300.0 \\
\hline \multirow[t]{2}{*}{ 03-Aug-04 } & Nitrate & 1.9 & 0.5 & NA & None & None & Field & $\mathrm{HACH} 8039$ \\
\hline & $\begin{array}{l}\text { Nitrate plus } \\
\text { nitrite as N }\end{array}$ & 2.04 & 0.0144 & 0.20 & & B2, J & 065411-015 & EPA 353.1 \\
\hline $\begin{array}{l}\text { WYO-4 } \\
\text { (Duplicate) }\end{array}$ & Nitrate & 2.8 & 0.054 & 0.10 & & & 065412-016 & EPA 300.0 \\
\hline 03-Aug-04 & $\begin{array}{l}\text { Nitrate plus } \\
\text { nitrite as N }\end{array}$ & 2.71 & 0.0144 & 0.20 & & B2, J & $065412-015$ & EPA 353.1 \\
\hline \multicolumn{9}{|c|}{$\begin{array}{l}\mathrm{mg} / \mathrm{L}=\text { milligrams per liter } \\
\mathrm{J}=\text { Amount detected is below the practical quantitation limit. The associated value is an estimated quantity. } \\
\mathrm{B} 2=\text { Analyte is detected in associated equipment blank sample. } \\
\mathrm{P} 2=\text { Insufficient quality control data to determine laboratory precision. } \\
\mathrm{HT} / \mathrm{H}=\text { The holding time was exceeded for the associated sample analysis. } \\
\mathrm{E}=\text { Concentration exceeds calibration range of instrument and/or estimated quantity due to matrix interference. }\end{array}$} \\
\hline
\end{tabular}


Table A-12

Summary of Nitrate and Nitrate plus Nitrite Results

Tijeras Arroyo Groundwater Investigation

Fiscal Year 2005, $1^{\text {st }}$ Quarter

\begin{tabular}{|c|c|c|c|c|c|c|c|c|}
\hline Well ID & Analyte & $\begin{array}{l}\text { Result } \\
\text { (mg/L) }\end{array}$ & $\begin{array}{c}\text { MDL } \\
\text { (mg/L) }\end{array}$ & $\begin{array}{c}\text { PQL } \\
\text { (mg/L) }\end{array}$ & $\begin{array}{l}\text { Laboratory } \\
\text { Qualifier }\end{array}$ & $\begin{array}{c}\text { Validation } \\
\text { Qualifier }\end{array}$ & Sample No. & $\begin{array}{l}\text { Analytical } \\
\text { Method }\end{array}$ \\
\hline Eubank-1 & Nitrate & 2.3 & 0.054 & 0.10 & & & 066077-016 & EPA 300.0 \\
\hline \multirow[t]{2}{*}{ 20-Oct-04 } & Nitrate & 1.8 & 0.5 & NA & None & None & Field & HACH 8039 \\
\hline & $\begin{array}{l}\text { Nitrate plus } \\
\text { nitrite as N }\end{array}$ & 2.62 & 0.003 & 0.02 & & & 066077-015 & EPA 353.1 \\
\hline Eubank-2 & Nitrate & 1.3 & 0.054 & 0.10 & & & 066080-016 & EPA 300.0 \\
\hline \multirow[t]{2}{*}{ 21-Oct-04 } & Nitrate & 1.1 & 0.5 & NA & None & None & Field & $\mathrm{HACH} 8039$ \\
\hline & $\begin{array}{l}\text { Nitrate plus } \\
\text { nitrite as N }\end{array}$ & 0.689 & 0.03 & 0.20 & & & 066080-015 & EPA 353.1 \\
\hline Eubank-3 & Nitrate & 3.2 & 0.054 & 0.10 & & & 066082-016 & EPA 300.0 \\
\hline \multirow[t]{2}{*}{ 20-Oct-04 } & Nitrate & 3.5 & 0.5 & NA & None & None & Field & $\mathrm{HACH} 8039$ \\
\hline & $\begin{array}{l}\text { Nitrate plus } \\
\text { nitrite as N }\end{array}$ & 3.49 & 0.003 & 0.02 & & & 066082-015 & EPA 353.1 \\
\hline Eubank-5 & Nitrate & 3.2 & 0.054 & 0.10 & & & 066084-016 & EPA 300.0 \\
\hline \multirow[t]{2}{*}{ 25-Oct-04 } & Nitrate & 3.0 & 0.5 & NA & None & None & Field & $\mathrm{HACH} 8039$ \\
\hline & $\begin{array}{l}\text { Nitrate plus } \\
\text { nitrite as N }\end{array}$ & 3.61 & 0.003 & 0.02 & & & 066084-015 & EPA 353.1 \\
\hline PGS-2 & Nitrate & 1.1 & 0.054 & 0.10 & & & 066025-016 & EPA 300.0 \\
\hline \multirow[t]{2}{*}{ 05-Oct-04 } & Nitrate & 1.7 & 0.5 & NA & None & None & Field & $\mathrm{HACH} 8039$ \\
\hline & $\begin{array}{l}\text { Nitrate plus } \\
\text { nitrite as N }\end{array}$ & 1.02 & 0.003 & 0.02 & & $\mathrm{~A} 2, \mathrm{~J}$ & 066025-015 & EPA 353.1 \\
\hline TA1-W-01 & Nitrate & 2.5 & 0.054 & 0.10 & & P2 & 066027-016 & EPA 300.0 \\
\hline \multirow[t]{2}{*}{ 06-Oct-04 } & Nitrate & 3.3 & 0.5 & NA & None & None & Field & HACH 8039 \\
\hline & $\begin{array}{l}\text { Nitrate plus } \\
\text { nitrite as N }\end{array}$ & 2.97 & 0.003 & 0.02 & & & 066027-015 & EPA 353.1 \\
\hline TA1-W-02 & Nitrate & 1.1 & 0.054 & 0.10 & & & 066029-016 & EPA 300.0 \\
\hline \multirow[t]{2}{*}{ 11-Oct-04 } & Nitrate & 1.0 & 0.5 & NA & None & None & Field & $\mathrm{HACH} 8039$ \\
\hline & $\begin{array}{l}\text { Nitrate plus } \\
\text { nitrite as } \mathrm{N}\end{array}$ & 1.24 & 0.003 & 0.02 & & & 066029-015 & EPA 353.1 \\
\hline TA1-W-03 & Nitrate & 7.0 & 0.054 & 0.10 & & & 066031-016 & EPA 300.0 \\
\hline \multirow[t]{2}{*}{ 19-Oct-04 } & Nitrate & 5.4 & 0.5 & NA & None & None & Field & $\mathrm{HACH} 8039$ \\
\hline & $\begin{array}{l}\text { Nitrate plus } \\
\text { nitrite as N }\end{array}$ & 0.545 & 0.003 & 0.02 & & & 066031-015 & EPA 353.1 \\
\hline TA1-W-04 & Nitrate & 1.6 & 0.054 & 0.10 & & P2 & 066033-016 & EPA 300.0 \\
\hline \multirow[t]{2}{*}{ 07-Oct-04 } & Nitrate & 2.7 & 0.5 & NA & None & None & Field & HACH 8039 \\
\hline & Nitrate plus & 1.82 & 0.003 & 0.02 & & & 066033-015 & EPA 353.1 \\
\hline
\end{tabular}




\begin{tabular}{|c|c|c|c|c|c|c|c|c|}
\hline Well ID & Analyte & $\begin{array}{l}\text { Result } \\
\text { (mg/L) }\end{array}$ & $\begin{array}{c}\text { MDL } \\
\text { (mg/L) }\end{array}$ & $\begin{array}{c}\text { PQL } \\
(\mathrm{mg} / \mathrm{L})\end{array}$ & $\begin{array}{c}\text { Laboratory } \\
\text { Qualifier }\end{array}$ & $\begin{array}{l}\text { Validation } \\
\text { Qualifier }\end{array}$ & Sample No. & $\begin{array}{c}\text { Analytical } \\
\text { Method }\end{array}$ \\
\hline & nitrite as $\mathrm{N}$ & & & & & & & \\
\hline TA1-W-05 & Nitrate & 1.1 & 0.054 & 0.10 & & & 066035-016 & EPA 300.0 \\
\hline \multirow[t]{2}{*}{ 26-Oct-04 } & Nitrate & 1.4 & 0.5 & NA & None & None & Field & $\mathrm{HACH} 8039$ \\
\hline & $\begin{array}{l}\text { Nitrate plus } \\
\text { nitrite as N }\end{array}$ & 1.16 & 0.003 & 0.02 & & & 066035-015 & EPA 353.1 \\
\hline TA1-W-06 & Nitrate & 3.2 & 0.054 & 0.10 & & & 066037-016 & EPA 300.0 \\
\hline \multirow[t]{2}{*}{ 26-Oct-04 } & Nitrate & 3.3 & 0.5 & NA & None & None & Field & $\mathrm{HACH} 8039$ \\
\hline & $\begin{array}{l}\text { Nitrate plus } \\
\text { nitrite as N }\end{array}$ & 3.54 & 0.003 & 0.02 & & & 066037-015 & EPA 353.1 \\
\hline TA1-W-08 & Nitrate & 7.0 & 0.054 & 0.10 & & P2 & 066039-016 & EPA 300.0 \\
\hline \multirow[t]{2}{*}{ 08-Oct-04 } & Nitrate & 5.3 & 0.5 & NA & None & None & Field & HACH 8039 \\
\hline & $\begin{array}{l}\text { Nitrate plus } \\
\text { nitrite as N }\end{array}$ & 0.337 & 0.003 & 0.020 & & & 066039-015 & EPA 353.1 \\
\hline TA2-NW1-595 & Nitrate & 3.3 & 0.054 & 0.10 & & & 066042-016 & EPA 300.0 \\
\hline \multirow{2}{*}{$\begin{array}{l}\text { 25-Oct-04 } \\
\text { (QED) }\end{array}$} & Nitrate & 2.5 & 0.5 & NA & None & None & Field & $\mathrm{HACH} 8039$ \\
\hline & $\begin{array}{l}\text { Nitrate plus } \\
\text { nitrite as N }\end{array}$ & 2.57 & 0.03 & 0.20 & & & 066042-015 & EPA 353.1 \\
\hline \multirow{3}{*}{$\begin{array}{l}\text { TA2-NW1-595 } \\
\text { 07-Oct-04 } \\
\text { (Bennett) }\end{array}$} & Nitrate & 3.3 & 0.054 & 0.10 & & $\mathrm{P} 2$ & 066044-016 & EPA 300.0 \\
\hline & Nitrate & 3.3 & 0.5 & NA & None & None & Field & HACH 8039 \\
\hline & $\begin{array}{l}\text { Nitrate plus } \\
\text { nitrite as N }\end{array}$ & 3.38 & 0.003 & 0.02 & & $\mathrm{~B} 2, \mathrm{~J}$ & 066044-015 & EPA 353.1 \\
\hline \multirow{3}{*}{$\begin{array}{l}\text { TA2-SW1-320 } \\
\text { 04-Oct-04 }\end{array}$} & Nitrate & 25 & 0.27 & 0.50 & & & 066046-016 & EPA 300.0 \\
\hline & Nitrate & 17.4 & 0.5 & NA & & & Field & $\mathrm{HACH} 8039$ \\
\hline & $\begin{array}{l}\text { Nitrate plus } \\
\text { nitrite as N }\end{array}$ & 25.1 & 0.03 & 0.20 & & $A 2, \mathrm{~J}$ & 066046-015 & EPA 353.1 \\
\hline \multirow{3}{*}{$\begin{array}{l}\text { TA2-W-01 } \\
18-O c t-04\end{array}$} & Nitrate & 4.8 & 0.054 & 0.10 & & & 066048-016 & EPA 300.0 \\
\hline & Nitrate & 3.7 & 0.5 & NA & None & None & Field & $\mathrm{HACH} 8039$ \\
\hline & $\begin{array}{l}\text { Nitrate plus } \\
\text { nitrite as N }\end{array}$ & 4.75 & 0.003 & 0.02 & & & 066048-015 & EPA 353.1 \\
\hline \multirow{3}{*}{$\begin{array}{l}\text { TA2-W-19 } \\
\text { 04-Oct-04 }\end{array}$} & Nitrate & 10 & 0.054 & 0.10 & & & 066050-016 & EPA 300.0 \\
\hline & Nitrate & 7.4 & 0.5 & NA & None & None & Field & HACH 8039 \\
\hline & $\begin{array}{l}\text { Nitrate plus } \\
\text { nitrite as N }\end{array}$ & 10.3 & 0.03 & 0.20 & & $A 2, \mathrm{~J}$ & 066050-015 & EPA 353.1 \\
\hline \multirow{2}{*}{$\begin{array}{l}\text { TA2-W-19 } \\
\text { (Duplicate) } \\
\text { 04-Oct-04 }\end{array}$} & Nitrate & 10 & 0.054 & 0.10 & & & 066051-016 & EPA 300.0 \\
\hline & $\begin{array}{l}\text { Nitrate plus } \\
\text { nitrite as N }\end{array}$ & 9.93 & 0.03 & 0.20 & & $A 2, \mathrm{~J}$ & 066051-015 & EPA 353.1 \\
\hline TA2-W-26 & Nitrate & 4.6 & 0.054 & 0.10 & & & 066053-016 & EPA 300.0 \\
\hline \multirow[t]{2}{*}{ 13-Oct-04 } & Nitrate & 4.0 & 0.5 & NA & None & None & Field & HACH 8039 \\
\hline & $\begin{array}{l}\text { Nitrate plus } \\
\text { nitrite as N }\end{array}$ & 3.32 & 0.003 & 0.02 & & & 066053-015 & EPA 353.1 \\
\hline TA2-W-27 & Nitrate & 4.2 & 0.054 & 0.10 & & & 066056-016 & EPA 300.0 \\
\hline
\end{tabular}




\begin{tabular}{|c|c|c|c|c|c|c|c|c|}
\hline Well ID & Analyte & $\begin{array}{l}\text { Result } \\
\text { (mg/L) }\end{array}$ & $\begin{array}{c}\text { MDL } \\
(\mathrm{mg} / \mathrm{L})\end{array}$ & $\begin{array}{c}\text { PQL } \\
\text { (mg/L) }\end{array}$ & $\begin{array}{c}\text { Laboratory } \\
\text { Qualifier }\end{array}$ & $\begin{array}{c}\text { Validation } \\
\text { Qualifier } \\
\end{array}$ & Sample No. & $\begin{array}{c}\text { Analytical } \\
\text { Method }\end{array}$ \\
\hline \multirow[t]{2}{*}{ 14-Oct-04 } & Nitrate & 3.4 & 0.5 & NA & None & None & Field & HACH 8039 \\
\hline & $\begin{array}{l}\text { Nitrate plus } \\
\text { nitrite as N }\end{array}$ & 3.91 & 0.03 & 0.20 & & & $066056-015$ & EPA 353.1 \\
\hline \multirow{3}{*}{$\begin{array}{l}\text { TJA-2 } \\
11-O c t-04\end{array}$} & Nitrate & 9.6 & 0.054 & 0.10 & & & 066059-016 & EPA 300.0 \\
\hline & Nitrate & 14.9 & 0.5 & NA & None & None & Field & HACH 8039 \\
\hline & $\begin{array}{l}\text { Nitrate plus } \\
\text { nitrite as } \mathrm{N}\end{array}$ & 7.51 & 0.03 & 0.20 & & & 066059-015 & EPA 353.1 \\
\hline \multirow{3}{*}{$\begin{array}{l}\text { TJA-3 } \\
12-O c t-04\end{array}$} & Nitrate & 2.6 & 0.054 & 0.10 & & & 066061-016 & EPA 300.0 \\
\hline & Nitrate & 3.0 & 0.5 & NA & None & None & Field & HACH 8039 \\
\hline & $\begin{array}{l}\text { Nitrate plus } \\
\text { nitrite as } \mathrm{N}\end{array}$ & 3.12 & 0.003 & 0.02 & & & 066061-015 & EPA 353.1 \\
\hline \multirow{3}{*}{$\begin{array}{l}\text { TJA-4 } \\
12-\text { Oct-04 }\end{array}$} & Nitrate & 25 & 0.27 & 0.50 & & & 066063-016 & EPA 300.0 \\
\hline & Nitrate & 15.9 & 0.5 & NA & None & None & Field & HACH 8039 \\
\hline & $\begin{array}{l}\text { Nitrate plus } \\
\text { nitrite as } \mathrm{N}\end{array}$ & 20.2 & 0.03 & 0.20 & & & 066063-015 & EPA 353.1 \\
\hline \multirow{3}{*}{$\begin{array}{l}\text { TJA-6 } \\
13-\text { Oct-04 }\end{array}$} & Nitrate & 2.5 & 0.054 & 0.10 & & & $066065-016$ & EPA 300.0 \\
\hline & Nitrate & 2.1 & 0.5 & NA & None & None & Field & HACH 8039 \\
\hline & $\begin{array}{l}\text { Nitrate plus } \\
\text { nitrite as } \mathrm{N}\end{array}$ & 2.94 & 0.003 & 0.02 & & & $066065-015$ & EPA 353.1 \\
\hline \multirow{3}{*}{$\begin{array}{l}\text { TJA-7 } \\
\text { 15-Oct-04 }\end{array}$} & Nitrate & 25 & 0.27 & 0.50 & & & $066067-016$ & EPA 300.0 \\
\hline & Nitrate & 5.6 & 0.5 & NA & None & None & Field & HACH 8039 \\
\hline & $\begin{array}{l}\text { Nitrate plus } \\
\text { nitrite as } \mathrm{N}\end{array}$ & 27.1 & 0.03 & 0.20 & & & 066067-015 & EPA 353.1 \\
\hline \multirow{2}{*}{$\begin{array}{l}\text { TJA-7 } \\
\text { (Duplicate) } \\
15-\text { Oct-04 }\end{array}$} & Nitrate & 25 & 0.27 & 0.50 & & & 066068-016 & EPA 300.0 \\
\hline & $\begin{array}{l}\text { Nitrate plus } \\
\text { nitrite as } \mathrm{N}\end{array}$ & 23.2 & 0.03 & 0.20 & & & 066068-015 & EPA 353.1 \\
\hline \multirow{3}{*}{$\begin{array}{l}\text { WYO-3 } \\
\text { o8-Oct-04 }\end{array}$} & Nitrate & 2.0 & 0.054 & 0.10 & & & 066071-016 & EPA 300.0 \\
\hline & Nitrate & 2.4 & 0.5 & NA & None & None & Field & HACH 8039 \\
\hline & $\begin{array}{l}\text { Nitrate plus } \\
\text { nitrite as } \mathrm{N}\end{array}$ & 2.38 & 0.003 & 0.02 & & & 066071-015 & EPA 353.1 \\
\hline \multirow{3}{*}{$\begin{array}{l}\text { WYO-4 } \\
\text { 06-Oct-04 }\end{array}$} & Nitrate & 2.8 & 0.054 & 0.10 & & $\mathrm{P} 2$ & 066073-016 & EPA 300.0 \\
\hline & Nitrate & 2.1 & 0.5 & NA & None & None & Field & HACH 8039 \\
\hline & $\begin{array}{l}\text { Nitrate plus } \\
\text { nitrite as } \mathrm{N}\end{array}$ & 3.30 & 0.003 & 0.02 & & & 066073-015 & EPA 353.1 \\
\hline \multirow{2}{*}{$\begin{array}{l}\text { WYO-4 } \\
\text { (Duplicate) } \\
\text { 06-Oct-04 }\end{array}$} & Nitrate & 2.8 & 0.054 & 0.10 & & P2 & 066074-016 & EPA 300.0 \\
\hline & $\begin{array}{l}\text { Nitrate plus } \\
\text { nitrite as } \mathrm{N}\end{array}$ & 3.29 & 0.003 & 0.02 & & & 066074-015 & EPA 353.1 \\
\hline \multicolumn{9}{|c|}{$\begin{array}{l}\mathrm{mg} / \mathrm{L}=\text { milligrams per liter } \\
\mathrm{J}=\text { Amount detected is below the practical quantitation limit. The associated value is an estimated quantity. } \\
\mathrm{A} 2=\text { Laboratory accuracy and/or bias measurements for the associated matrix spike and/or duplicate do not meet acceptance } \\
\text { criteria. } \\
\mathrm{B} 2=\text { Analyte is detected in associated equipment blank sample. } \\
\mathrm{P} 2=\text { Insufficient quality control data to determine laboratory precision. }\end{array}$} \\
\hline
\end{tabular}


Table A-13

Summary of Ferrous Iron Results

\section{Tijeras Arroyo Groundwater Investigation}

July 2003 through December 2004

\begin{tabular}{|c|c|c|c|c|c|c|c|c|}
\hline Well ID & Sample Date & $\begin{array}{c}\text { Ferrous Iron } \\
\text { Result } \\
\text { (mg/L) }\end{array}$ & $\begin{array}{c}\text { MDL } \\
(\mathrm{mg} / \mathrm{L})\end{array}$ & $\begin{array}{c}\text { PQL } \\
\text { (mg/L) }\end{array}$ & $\begin{array}{c}\text { Laboratory } \\
\text { Qualifier }\end{array}$ & $\begin{array}{c}\text { Validation } \\
\text { Qualifier }\end{array}$ & Sample No. & $\begin{array}{c}\text { Analytical } \\
\text { Method }\end{array}$ \\
\hline \multirow[t]{11}{*}{ Eubank-1 } & \multirow[t]{2}{*}{ 18-Aug-03 } & ND & 0.0284 & 0.05 & $\mathrm{U}, \mathrm{H}$ & None & 062724-040 & SM 3500-Fe \\
\hline & & ND & 0.03 & NA & & None & Field & HACH 8146 \\
\hline & \multirow[t]{2}{*}{ 10-Nov-03 } & ND & 0.0284 & 0.05 & $\mathrm{U}, \mathrm{H}$ & None & 063303-040 & $3500 \mathrm{Fe} 2+$ \\
\hline & & ND & 0.03 & NA & None & None & Field & HACH 8146 \\
\hline & \multirow[t]{2}{*}{ 16-Feb-04 } & ND & 0.028 & 0.10 & & None & 063904-012 & $3500 \mathrm{Fe} 2+$ \\
\hline & & ND & 0.03 & NA & None & None & Field & HACH 8146 \\
\hline & \multirow[t]{2}{*}{ 20-May-04 } & ND & 0.028 & 0.10 & $U$ & None & 064600-012 & $3500 \mathrm{Fe} 2+$ \\
\hline & & 0.02 & 0.03 & NA & None & None & Field & HACH 8146 \\
\hline & 19-Aug-04 & ND & 0.028 & 0.10 & & None & 065416-012 & $3500 \mathrm{Fe} 2+$ \\
\hline & \multirow[t]{2}{*}{ 20-Oct-04 } & ND & 0.028 & 0.10 & & None & 066077-012 & $3500 \mathrm{Fe} 2+$ \\
\hline & & ND & 0.03 & NA & None & None & Field & HACH 8146 \\
\hline \multirow[t]{10}{*}{ Eubank-2 } & 09-Jul-03 & ND & 0.0284 & 0.05 & $\mathrm{U}, \mathrm{H}$ & None & 062585-040 & SM 3500-Fe \\
\hline & \multirow[t]{2}{*}{ 12-Nov-03 } & ND & 0.0284 & 0.05 & $\mathrm{U}, \mathrm{H}$ & None & 063304-040 & $3500 \mathrm{Fe} 2+$ \\
\hline & & ND & 0.03 & NA & None & None & Field & HACH 8146 \\
\hline & \multirow[t]{2}{*}{ 18-Feb-04 } & ND & 0.028 & 0.10 & & None & 063906-012 & $3500 \mathrm{Fe} 2+$ \\
\hline & & 0.01 & 0.03 & NA & None & None & Field & HACH 8146 \\
\hline & \multirow[t]{2}{*}{ 06-May-04 } & ND & 0.028 & 0.10 & U & None & 064602-012 & $3500 \mathrm{Fe} 2+$ \\
\hline & & 0.01 & 0.03 & NA & None & None & Field & HACH 8146 \\
\hline & 13-Jul-04 & ND & 0.028 & 0.10 & None & None & 065418-012 & $3500 \mathrm{Fe} 2+$ \\
\hline & \multirow[t]{2}{*}{ 21-Oct-04 } & ND & 0.028 & 0.10 & & None & 066080-012 & $3500 \mathrm{Fe} 2+$ \\
\hline & & ND & 0.03 & NA & None & None & Field & HACH 8146 \\
\hline \multirow[t]{9}{*}{ Eubank-3 } & 10-Jul-03 & ND & 0.0284 & 0.05 & $\mathrm{U}, \mathrm{H}$ & None & 062586-040 & SM 3500-Fe \\
\hline & \multirow[t]{2}{*}{ 18-Nov-03 } & ND & 0.0284 & 0.05 & $\mathrm{U}, \mathrm{H}$ & None & 063305-040 & $3500 \mathrm{Fe} 2+$ \\
\hline & & ND & 0.03 & NA & None & None & Field & HACH 8146 \\
\hline & \multirow[t]{2}{*}{ 17-Feb-04 } & ND & 0.028 & 0.10 & & None & 063909-012 & $3500 \mathrm{Fe} 2+$ \\
\hline & & ND & 0.03 & NA & None & None & Field & HACH 8146 \\
\hline & \multirow[t]{2}{*}{ 04-May-04 } & ND & 0.028 & 0.10 & $\mathrm{U}$ & None & 064604-012 & 3500 Fe2+ \\
\hline & & 0.01 & 0.03 & NA & None & None & Field & HACH 8146 \\
\hline & 13-Jul-04 & ND & 0.028 & 0.10 & None & None & 065419-012 & $3500 \mathrm{Fe} 2+$ \\
\hline & 20-Oct-04 & ND & 0.028 & 0.10 & & None & 066082-012 & 3500 Fe2+ \\
\hline
\end{tabular}




\begin{tabular}{|c|c|c|c|c|c|c|c|c|}
\hline Well ID & Sample Date & $\begin{array}{c}\text { Ferrous Iron } \\
\text { Result } \\
\text { (mg/L) }\end{array}$ & $\begin{array}{c}\text { MDL } \\
(\mathrm{mg} / \mathrm{L})\end{array}$ & $\begin{array}{c}\text { PQL } \\
\text { (mg/L) }\end{array}$ & $\begin{array}{c}\text { Laboratory } \\
\text { Qualifier }\end{array}$ & $\begin{array}{c}\text { Validation } \\
\text { Qualifier }\end{array}$ & Sample No. & $\begin{array}{c}\text { Analytical } \\
\text { Method }\end{array}$ \\
\hline & & ND & 0.03 & NA & None & None & Field & HACH 8146 \\
\hline \multirow[t]{10}{*}{ Eubank-5 } & 09-Jul-03 & ND & 0.0284 & 0.05 & $\mathrm{U}, \mathrm{H}$ & None & 062587-040 & SM 3500-Fe \\
\hline & \multirow[t]{2}{*}{ 19-Nov-03 } & ND & 0.0284 & 0.05 & $\mathrm{U}, \mathrm{H}$ & None & 063306-040 & $3500 \mathrm{Fe} 2+$ \\
\hline & & ND & 0.03 & NA & None & None & Field & HACH 8146 \\
\hline & \multirow[t]{2}{*}{ 19-Feb-04 } & ND & 0.028 & 0.10 & & None & 063911-012 & $3500 \mathrm{Fe} 2+$ \\
\hline & & ND & 0.03 & NA & None & None & Field & HACH 8146 \\
\hline & \multirow[t]{2}{*}{ 03-May-04 } & ND & 0.028 & 0.10 & $U$ & None & 064607-012 & $3500 \mathrm{Fe} 2+$ \\
\hline & & 0.03 & 0.03 & NA & None & None & Field & HACH 8146 \\
\hline & 13-Jul-04 & ND & 0.028 & 0.10 & None & None & 065420-012 & $3500 \mathrm{Fe} 2+$ \\
\hline & \multirow[t]{2}{*}{ 25-Oct-04 } & ND & 0.028 & 0.10 & & None & 066084-012 & 3500 Fe2+ \\
\hline & & 0.02 & 0.03 & NA & None & None & Field & HACH 8146 \\
\hline \multirow[t]{12}{*}{ PGS-2 } & \multirow[t]{2}{*}{ 22-Jul-03 } & ND & 0.0284 & 0.05 & $\mathrm{U}, \mathrm{H}$ & None & 062678-040 & SM 3500-Fe \\
\hline & & ND & 0.03 & NA & & None & Field & HACH 8146 \\
\hline & \multirow[t]{2}{*}{ 10-Nov-03 } & 0.040 & 0.0284 & 0.05 & $\mathrm{H}, \mathrm{J}$ & None & 063278-040 & $3500 \mathrm{Fe} 2+$ \\
\hline & & ND & 0.03 & NA & None & None & Field & HACH 8146 \\
\hline & \multirow[t]{2}{*}{ 03-Feb-04 } & ND & 0.028 & 0.10 & & None & 063851-012 & $3500 \mathrm{Fe} 2+$ \\
\hline & & ND & 0.03 & NA & None & None & Field & HACH 8146 \\
\hline & \multirow[t]{2}{*}{ 12-May-04 } & ND & 0.028 & 0.10 & U & None & 064551-012 & $3500 \mathrm{Fe} 2+$ \\
\hline & & ND & 0.03 & NA & None & None & Field & HACH 8146 \\
\hline & \multirow[t]{2}{*}{ 28-Jul-04 } & ND & 0.028 & 0.10 & & None & 065360-012 & $3500 \mathrm{Fe} 2+$ \\
\hline & & ND & 0.03 & NA & None & None & Field & HACH 8146 \\
\hline & \multirow[t]{2}{*}{ 05-Oct-04 } & ND & 0.028 & 0.10 & & None & 066025-012 & 3500 Fe2+ \\
\hline & & ND & 0.03 & NA & None & None & Field & HACH 8146 \\
\hline \multirow[t]{12}{*}{ TA1-W-01 } & \multirow[t]{2}{*}{ 22-Jul-03 } & ND & 0.0284 & 0.05 & $\mathrm{U}, \mathrm{H}$ & None & $062680-040$ & SM 3500-Fe \\
\hline & & ND & 0.03 & NA & & None & Field & HACH 8146 \\
\hline & \multirow[t]{2}{*}{ 06-Nov-03 } & ND & 0.0284 & 0.05 & U & None & 063279-040 & $3500 \mathrm{Fe} 2+$ \\
\hline & & ND & 0.03 & NA & None & None & Field & HACH 8146 \\
\hline & \multirow[t]{2}{*}{ 05-Feb-04 } & ND & 0.028 & 0.10 & & None & 063853-012 & $3500 \mathrm{Fe} 2+$ \\
\hline & & 0.01 & 0.03 & NA & None & None & Field & HACH 8146 \\
\hline & \multirow[t]{2}{*}{ 10-May-04 } & ND & 0.028 & 0.10 & $U$ & None & 064553-012 & $3500 \mathrm{Fe} 2+$ \\
\hline & & ND & 0.03 & NA & None & None & Field & HACH 8146 \\
\hline & \multirow[t]{2}{*}{ 17-Aug-04 } & ND & 0.028 & 0.10 & & None & 065362-012 & 3500 Fe2+ \\
\hline & & ND & 0.03 & NA & None & None & Field & HACH 8146 \\
\hline & \multirow[t]{2}{*}{ 06-Oct-04 } & ND & 0.028 & 0.10 & & None & 066027-012 & 3500 Fe2+ \\
\hline & & 0.04 & 0.03 & NA & None & None & Field & HACH 8146 \\
\hline
\end{tabular}




\begin{tabular}{|c|c|c|c|c|c|c|c|c|}
\hline Well ID & Sample Date & $\begin{array}{c}\begin{array}{c}\text { Ferrous Iron } \\
\text { Result } \\
\text { (mg/L) }\end{array} \\
\end{array}$ & $\begin{array}{c}\mathrm{MDL} \\
\text { (mg/L) }\end{array}$ & $\begin{array}{c}\text { PQL } \\
\text { (mg/L) }\end{array}$ & $\begin{array}{c}\text { Laboratory } \\
\text { Qualifier }\end{array}$ & $\begin{array}{c}\text { Validation } \\
\text { Qualifier }\end{array}$ & Sample No. & $\begin{array}{c}\text { Analytical } \\
\text { Method }\end{array}$ \\
\hline \multirow[t]{12}{*}{ TA1-W-02 } & \multirow[t]{2}{*}{ 23-Jul-03 } & ND & 0.0284 & 0.05 & $\mathrm{U}, \mathrm{H}$ & None & 062682-040 & SM 3500-Fe \\
\hline & & ND & 0.03 & NA & & None & Field & HACH 8146 \\
\hline & \multirow[t]{2}{*}{ 08-Oct-03 } & 0.0536 & 0.0284 & 0.05 & $\mathrm{H}$ & None & 063280-040 & 3500 Fe2+ \\
\hline & & 0.01 & 0.03 & NA & None & None & Field & HACH 8146 \\
\hline & \multirow[t]{2}{*}{ 28-Jan-04 } & ND & 0.028 & 0.10 & & None & 063855-012 & 3500 Fe2+ \\
\hline & & ND & 0.03 & NA & None & None & Field & $\mathrm{HACH} 8146$ \\
\hline & \multirow[t]{2}{*}{ 11-May-04 } & ND & 0.028 & 0.10 & U & None & 064556-012 & 3500 Fe2+ \\
\hline & & ND & 0.03 & NA & None & None & Field & HACH 8146 \\
\hline & \multirow[t]{2}{*}{ 13-Aug-04 } & ND & 0.028 & 0.10 & & None & 065364-012 & 3500 Fe2+ \\
\hline & & 0.08 & 0.03 & NA & None & None & Field & HACH 8146 \\
\hline & \multirow[t]{2}{*}{ 11-Oct-04 } & ND & 0.028 & 0.10 & & None & 066029-012 & 3500 Fe2+ \\
\hline & & ND & 0.03 & NA & None & None & Field & $\mathrm{HACH} 8146$ \\
\hline \multirow[t]{12}{*}{ TA1-W-03 } & \multirow[t]{2}{*}{ 24-Jul-03 } & ND & 0.0284 & 0.05 & $\mathrm{U}, \mathrm{H}$ & None & 062684-040 & SM 3500-Fe \\
\hline & & ND & 0.03 & NA & & None & Field & HACH 8146 \\
\hline & \multirow[t]{2}{*}{ 13-Oct-03 } & ND & 0.0284 & 0.05 & $\mathrm{U}, \mathrm{H}$ & None & 063281-040 & 3500 Fe2+ \\
\hline & & 0.01 & 0.03 & NA & None & None & Field & HACH 8146 \\
\hline & \multirow[t]{2}{*}{ 07-Jan-04 } & ND & 0.028 & 0.10 & & None & 063857-012 & 3500 Fe2+ \\
\hline & & 0.26 & 0.03 & NA & None & None & Field & $\mathrm{HACH} 8146$ \\
\hline & \multirow[t]{2}{*}{ 28-Apr-04 } & ND & 0.028 & 0.10 & U & None & 064558-012 & 3500 Fe2+ \\
\hline & & 0.06 & 0.03 & NA & None & None & Field & $\mathrm{HACH} 8146$ \\
\hline & \multirow[t]{2}{*}{ 18-Aug-04 } & ND & 0.028 & 0.10 & & None & 065366-012 & $3500 \mathrm{Fe} 2+$ \\
\hline & & 0.29 & 0.03 & NA & None & None & Field & HACH 8146 \\
\hline & \multirow[t]{2}{*}{ 19-Oct-04 } & ND & 0.028 & 0.10 & & None & 066031-012 & 3500 Fe2+ \\
\hline & & 0.12 & 0.03 & NA & None & None & Field & $\mathrm{HACH} 8146$ \\
\hline \multirow[t]{12}{*}{ TA1-W-04 } & \multirow[t]{2}{*}{ 29-Jul-03 } & ND & 0.0284 & 0.05 & $\mathrm{U}, \mathrm{H}$ & None & 062686-040 & SM 3500-Fe \\
\hline & & ND & 0.03 & NA & & None & Field & HACH 8146 \\
\hline & \multirow[t]{2}{*}{ 14-Oct-03 } & ND & 0.0284 & 0.05 & $\mathrm{U}, \mathrm{H}$ & None & 063282-040 & 3500 Fe2+ \\
\hline & & ND & 0.03 & NA & None & None & Field & $\mathrm{HACH} 8146$ \\
\hline & \multirow[t]{2}{*}{ 06-Jan-04 } & ND & 0.028 & 0.10 & & None & 063860-012 & 3500 Fe2+ \\
\hline & & ND & 0.03 & NA & None & None & Field & HACH 8146 \\
\hline & \multirow[t]{2}{*}{ 26-Apr-04 } & ND & 0.028 & 0.10 & U & None & 064560-012 & $3500 \mathrm{Fe} 2+$ \\
\hline & & ND & 0.03 & NA & None & None & Field & HACH 8146 \\
\hline & \multirow[t]{2}{*}{ 26-Jul-04 } & ND & 0.028 & 0.10 & & None & 065368-012 & 3500 Fe2+ \\
\hline & & ND & 0.03 & NA & None & None & Field & $\mathrm{HACH} 8146$ \\
\hline & \multirow[t]{2}{*}{ 07-Oct-04 } & ND & 0.028 & 0.10 & & None & 066033-012 & 3500 Fe2+ \\
\hline & & ND & 0.03 & NA & None & None & Field & HACH 8146 \\
\hline
\end{tabular}




\begin{tabular}{|c|c|c|c|c|c|c|c|c|}
\hline Well ID & Sample Date & $\begin{array}{c}\begin{array}{c}\text { Ferrous Iron } \\
\text { Result } \\
\text { (mg/L) }\end{array} \\
\end{array}$ & $\begin{array}{c}\mathrm{MDL} \\
\text { (mg/L) }\end{array}$ & $\begin{array}{c}\text { PQL } \\
(\mathrm{mg} / \mathrm{L})\end{array}$ & $\begin{array}{c}\text { Laboratory } \\
\text { Qualifier }\end{array}$ & $\begin{array}{c}\text { Validation } \\
\text { Qualifier }\end{array}$ & Sample No. & $\begin{array}{c}\text { Analytical } \\
\text { Method }\end{array}$ \\
\hline \multirow[t]{12}{*}{ TA1-W-05 } & 28-Jul-03 & ND & 0.0284 & 0.05 & U & None & 062688-040 & SM 3500-Fe \\
\hline & & ND & 0.03 & NA & & None & Field & HACH 8146 \\
\hline & \multirow[t]{2}{*}{ 20-Oct-03 } & ND & 0.0284 & 0.05 & $\mathrm{U}, \mathrm{H}$ & None & 063283-040 & 3500 Fe2+ \\
\hline & & 0.01 & 0.03 & NA & None & None & Field & HACH 8146 \\
\hline & \multirow[t]{2}{*}{ 12-Feb-04 } & ND & 0.028 & 0.10 & & None & 063862-012 & 3500 Fe2+ \\
\hline & & 0.01 & 0.03 & NA & None & None & Field & $\mathrm{HACH} 8146$ \\
\hline & \multirow[t]{2}{*}{ 07-May-04 } & ND & 0.028 & 0.10 & U & None & $064562-012$ & 3500 Fe2+ \\
\hline & & 0.03 & 0.03 & NA & None & None & Field & HACH 8146 \\
\hline & \multirow[t]{2}{*}{ 20-Aug-04 } & ND & 0.028 & 0.10 & & None & 065370-012 & 3500 Fe2+ \\
\hline & & 0.01 & 0.03 & NA & None & None & Field & HACH 8146 \\
\hline & \multirow[t]{2}{*}{ 26-Oct-04 } & ND & 0.028 & 0.10 & & None & 066035-012 & 3500 Fe2+ \\
\hline & & ND & 0.03 & NA & None & None & Field & $\mathrm{HACH} 8146$ \\
\hline \multirow[t]{12}{*}{ TA1-W-06 } & \multirow[t]{2}{*}{ 29-Jul-03 } & ND & 0.0284 & 0.05 & U & None & 062690-040 & SM 3500-Fe \\
\hline & & ND & 0.03 & NA & & None & Field & HACH 8146 \\
\hline & \multirow[t]{2}{*}{ 09-Oct-03 } & ND & 0.0284 & 0.05 & $\mathrm{U}, \mathrm{H}$ & None & 063284-040 & 3500 Fe2+ \\
\hline & & ND & 0.03 & NA & None & None & Field & HACH 8146 \\
\hline & \multirow[t]{2}{*}{ 09-Feb-04 } & ND & 0.028 & 0.10 & & None & 063864-012 & 3500 Fe2+ \\
\hline & & 0.03 & 0.03 & NA & None & None & Field & $\mathrm{HACH} 8146$ \\
\hline & \multirow[t]{2}{*}{ 21-May-04 } & ND & 0.028 & 0.10 & U & None & 064564-012 & 3500 Fe2+ \\
\hline & & 0.03 & 0.03 & NA & None & None & Field & HACH 8146 \\
\hline & \multirow[t]{2}{*}{ 06-Aug-04 } & ND & 0.028 & 0.10 & & None & $065372-012$ & 3500 Fe2+ \\
\hline & & 0.04 & 0.03 & NA & None & None & Field & HACH 8146 \\
\hline & \multirow[t]{2}{*}{ 26-Oct-04 } & ND & 0.028 & 0.10 & & None & 066037-012 & 3500 Fe2+ \\
\hline & & ND & 0.03 & NA & None & None & Field & HACH 8146 \\
\hline \multirow[t]{12}{*}{ TA1-W-08 } & \multirow[t]{2}{*}{ 30-Jul-03 } & ND & 0.0284 & 0.05 & $\mathrm{U}, \mathrm{H}$ & None & 062692-040 & SM 3500-Fe \\
\hline & & 0.15 & 0.03 & NA & & None & Field & HACH 8146 \\
\hline & \multirow[t]{2}{*}{ 21-Oct-03 } & ND & 0.0284 & 0.05 & U & None & 063285-040 & 3500 Fe2+ \\
\hline & & 0.02 & 0.03 & NA & None & None & Field & $\mathrm{HACH} 8146$ \\
\hline & \multirow[t]{2}{*}{ 10-Feb-04 } & ND & 0.028 & 0.10 & & None & 063866-012 & 3500 Fe2+ \\
\hline & & ND & 0.03 & NA & None & None & Field & HACH 8146 \\
\hline & \multirow[t]{2}{*}{ 23-Apr-04 } & ND & 0.028 & 0.10 & U & None & 064566-012 & 3500 Fe2+ \\
\hline & & ND & 0.03 & NA & None & None & Field & HACH 8146 \\
\hline & \multirow[t]{2}{*}{ 13-Aug-04 } & ND & 0.028 & 0.10 & & None & 065374-012 & 3500 Fe2+ \\
\hline & & 0.14 & 0.03 & NA & None & None & Field & $\mathrm{HACH} 8146$ \\
\hline & \multirow[t]{2}{*}{ 08-Oct-04 } & ND & 0.028 & 0.10 & & None & 066039-012 & 3500 Fe2+ \\
\hline & & 0.03 & 0.03 & NA & None & None & Field & HACH 8146 \\
\hline
\end{tabular}




\begin{tabular}{|c|c|c|c|c|c|c|c|c|}
\hline Well ID & Sample Date & \begin{tabular}{|c|}
$\begin{array}{c}\text { Ferrous Iron } \\
\text { Result } \\
\text { (mg/L) }\end{array}$ \\
\end{tabular} & $\begin{array}{c}\mathrm{MDL} \\
\text { (mg/L) }\end{array}$ & $\begin{array}{c}\text { PQL } \\
\text { (mg/L) }\end{array}$ & $\begin{array}{c}\text { Laboratory } \\
\text { Qualifier }\end{array}$ & $\begin{array}{l}\text { Validation } \\
\text { Qualifier }\end{array}$ & Sample No. & $\begin{array}{l}\text { Analytical } \\
\text { Method }\end{array}$ \\
\hline \multirow{12}{*}{$\begin{array}{l}\text { TA2-NW1- } \\
595 \text { (QED) }\end{array}$} & \multirow[t]{2}{*}{ 30-Jul-03 } & ND & 0.0284 & 0.05 & $\mathrm{U}, \mathrm{H}$ & None & 062695-A40 & SM 3500-Fe \\
\hline & & 0.01 & 0.03 & NA & & None & Field & $\mathrm{HACH} 8146$ \\
\hline & \multirow[t]{2}{*}{ 12-Nov-03 } & ND & 0.0284 & 0.05 & $\mathrm{U}, \mathrm{H}$ & None & 063287-040 & 3500 Fe2+ \\
\hline & & ND & 0.03 & NA & None & None & Field & $\mathrm{HACH} 8146$ \\
\hline & \multirow[t]{2}{*}{ 04-Feb-04 } & ND & 0.028 & 0.10 & & None & 063871-012 & 3500 Fe2+ \\
\hline & & ND & 0.03 & NA & None & None & Field & HACH 8146 \\
\hline & \multirow[t]{2}{*}{ 13-May-04 } & ND & 0.028 & 0.10 & U & None & 064568-012 & 3500 Fe2+ \\
\hline & & ND & 0.03 & NA & None & None & Field & HACH 8146 \\
\hline & \multirow[t]{2}{*}{ 26-Jul-04 } & ND & 0.028 & 0.10 & & None & 065377-012 & $3500 \mathrm{Fe} 2+$ \\
\hline & & ND & 0.03 & NA & None & None & Field & HACH 8146 \\
\hline & \multirow[t]{2}{*}{ 25-Oct-04 } & ND & 0.028 & 0.10 & & None & 066042-012 & $3500 \mathrm{Fe} 2+$ \\
\hline & & 0.01 & 0.03 & NA & None & None & Field & HACH 8146 \\
\hline \multirow{12}{*}{$\begin{array}{l}\text { TA2-NW1- } \\
595 \text { (Bennett) }\end{array}$} & \multirow{2}{*}{ 05-Aug-03 } & ND & 0.0284 & 0.05 & $\mathrm{U}, \mathrm{H}$ & None & 062695-040 & SM 3500-Fe \\
\hline & & ND & 0.03 & NA & & None & Field & $\mathrm{HACH} 8146$ \\
\hline & \multirow[t]{2}{*}{ 11-Nov-03 } & ND & 0.0284 & 0.05 & $U, H$ & None & 063288-040 & $3500 \mathrm{Fe} 2+$ \\
\hline & & ND & 0.03 & NA & None & None & Field & $\mathrm{HACH} 8146$ \\
\hline & \multirow[t]{2}{*}{ 26-Jan-04 } & ND & 0.028 & 0.10 & & None & 063869-012 & $3500 \mathrm{Fe} 2+$ \\
\hline & & ND & 0.03 & NA & None & None & Field & $\mathrm{HACH} 8146$ \\
\hline & \multirow[t]{2}{*}{ 19-May-04 } & ND & 0.028 & 0.10 & $U$ & None & 064568-012 & 3500 Fe2+ \\
\hline & & 0.02 & 0.03 & NA & None & None & Field & $\mathrm{HACH} 8146$ \\
\hline & \multirow[t]{2}{*}{ 23-Aug-04 } & ND & 0.028 & 0.10 & & None & 065379-012 & 3500 Fe2+ \\
\hline & & ND & 0.03 & NA & None & None & Field & HACH 8146 \\
\hline & \multirow[t]{2}{*}{ 07-Oct-04 } & ND & 0.028 & 0.10 & & None & 066044-012 & 3500 Fe2+ \\
\hline & & 0.04 & 0.03 & NA & None & None & Field & $\mathrm{HACH} 8146$ \\
\hline \multirow[t]{10}{*}{$\begin{array}{l}\text { TA2-SW1- } \\
320\end{array}$} & \multirow[t]{2}{*}{ 24-Jul-03 } & ND & 0.0284 & 0.05 & $\mathrm{U}, \mathrm{H}$ & None & 062698-040 & SM 3500-Fe \\
\hline & & 0.02 & 0.03 & NA & & None & Field & HACH 8146 \\
\hline & \multirow[t]{2}{*}{ 11-Nov-03 } & ND & 0.0284 & 0.05 & $\mathrm{U}, \mathrm{H}$ & None & 063289-040 & 3500 Fe2+ \\
\hline & & ND & 0.03 & NA & None & None & Field & $\mathrm{HACH} 8146$ \\
\hline & \multirow[t]{2}{*}{ 29-Jan-04 } & ND & 0.028 & 0.10 & & None & 063873-012 & $3500 \mathrm{Fe} 2+$ \\
\hline & & ND & 0.03 & NA & None & None & Field & HACH 8146 \\
\hline & \multirow[t]{2}{*}{ 14-May-04 } & ND & 0.028 & 0.10 & U & None & 064573-012 & $3500 \mathrm{Fe} 2+$ \\
\hline & & 0.02 & 0.03 & NA & None & None & Field & HACH 8146 \\
\hline & \multirow[t]{2}{*}{ 27-Jul-04 } & ND & 0.028 & 0.10 & & None & 065381-012 & 3500 Fe2+ \\
\hline & & 0.57 & 0.03 & NA & None & None & Field & HACH 8146 \\
\hline
\end{tabular}




\begin{tabular}{|c|c|c|c|c|c|c|c|c|}
\hline Well ID & Sample Date & $\begin{array}{c}\begin{array}{c}\text { Ferrous Iron } \\
\text { Result } \\
\text { (mg/L) }\end{array} \\
\end{array}$ & $\begin{array}{c}\mathrm{MDL} \\
\text { (mg/L) }\end{array}$ & $\begin{array}{c}\text { PQL } \\
\text { (mg/L) }\end{array}$ & $\begin{array}{c}\text { Laboratory } \\
\text { Qualifier }\end{array}$ & $\begin{array}{c}\text { Validation } \\
\text { Qualifier }\end{array}$ & Sample No. & $\begin{array}{c}\text { Analytical } \\
\text { Method }\end{array}$ \\
\hline & \multirow[t]{2}{*}{ 04-Oct-04 } & ND & 0.028 & 0.10 & & None & 066046-012 & 3500 Fe2+ \\
\hline & & 0.01 & 0.03 & NA & None & None & Field & HACH 8146 \\
\hline \multirow[t]{12}{*}{ TA2-W-01 } & \multirow[t]{2}{*}{ 07-Aug-03 } & ND & 0.0284 & 0.05 & $\mathrm{U}, \mathrm{H}$ & None & 062700-040 & SM 3500-Fe \\
\hline & & 0.01 & 0.03 & NA & & None & Field & HACH 8146 \\
\hline & \multirow[t]{2}{*}{ 01-Dec-03 } & ND & 0.0284 & 0.05 & U & None & 063290-040 & 3500 Fe2+ \\
\hline & & 0.02 & 0.03 & NA & None & None & Field & $\mathrm{HACH} 8146$ \\
\hline & \multirow[t]{2}{*}{ 12-Jan-04 } & ND & 0.028 & 0.10 & & None & 063876-012 & 3500 Fe2+ \\
\hline & & 0.03 & 0.03 & NA & None & None & Field & HACH 8146 \\
\hline & \multirow[t]{2}{*}{ 17-May-04 } & ND & 0.028 & 0.10 & U & None & 064575-012 & 3500 Fe2+ \\
\hline & & ND & 0.03 & NA & None & None & Field & HACH 8146 \\
\hline & \multirow[t]{2}{*}{ 12-Aug-04 } & ND & 0.028 & 0.10 & & None & 065383-012 & 3500 Fe2+ \\
\hline & & ND & 0.03 & NA & None & None & Field & $\mathrm{HACH} 8146$ \\
\hline & \multirow[t]{2}{*}{ 18-Oct-04 } & ND & 0.028 & 0.10 & & None & 066048-012 & 3500 Fe2+ \\
\hline & & 0.06 & 0.03 & NA & None & None & Field & HACH 8146 \\
\hline \multirow[t]{12}{*}{ TA2-W-19 } & \multirow[t]{2}{*}{ 04-Aug-03 } & ND & 0.0284 & 0.05 & $\mathrm{U}, \mathrm{H}$ & None & 062702-040 & SM 3500-Fe \\
\hline & & 0.01 & 0.03 & NA & & None & Field & HACH 8146 \\
\hline & \multirow[t]{2}{*}{ 07-Oct-03 } & ND & 0.0284 & 0.05 & $\mathrm{U}, \mathrm{H}$ & None & 063291-040 & 3500 Fe2+ \\
\hline & & ND & 0.03 & NA & None & None & Field & $\mathrm{HACH} 8146$ \\
\hline & \multirow[t]{2}{*}{ 13-Jan-04 } & ND & 0.028 & 0.10 & & None & 063878-012 & 3500 Fe2+ \\
\hline & & ND & 0.03 & NA & None & None & Field & $\mathrm{HACH} 8146$ \\
\hline & \multirow[t]{2}{*}{ 27-Apr-04 } & ND & 0.028 & 0.10 & $U$ & None & 064577-012 & $3500 \mathrm{Fe} 2+$ \\
\hline & & ND & 0.03 & NA & None & None & Field & HACH 8146 \\
\hline & \multirow[t]{2}{*}{ 27-Jul-04 } & ND & 0.028 & 0.10 & & None & 065385-012 & 3500 Fe2+ \\
\hline & & ND & 0.03 & NA & None & None & Field & HACH 8146 \\
\hline & \multirow[t]{2}{*}{ 04-Oct-04 } & ND & 0.028 & 0.10 & & None & 066050-012 & 3500 Fe2+ \\
\hline & & 0.03 & 0.03 & NA & None & None & Field & $\mathrm{HACH} 8146$ \\
\hline \multirow[t]{10}{*}{ TA2-W-26 } & \multirow[t]{2}{*}{ 04-Aug-03 } & ND & 0.0284 & 0.05 & $\mathrm{U}, \mathrm{H}$ & None & 062704-040 & SM 3500-Fe \\
\hline & & 0.19 & 0.03 & NA & & None & Field & $\mathrm{HACH} 8146$ \\
\hline & \multirow[t]{2}{*}{ 16-Oct-03 } & ND & 0.0284 & 0.05 & $\mathrm{U}, \mathrm{H}$ & None & 063292-040 & 3500 Fe2+ \\
\hline & & ND & 0.03 & NA & None & None & Field & HACH 8146 \\
\hline & \multirow[t]{2}{*}{ 20-Jan-04 } & ND & 0.028 & 0.10 & & None & 063880-012 & 3500 Fe2+ \\
\hline & & 0.05 & 0.03 & NA & None & None & Field & $\mathrm{HACH} 8146$ \\
\hline & \multirow[t]{2}{*}{ 21-Apr-04 } & ND & 0.028 & 0.10 & $U$ & None & 064580-012 & 3500 Fe2+ \\
\hline & & ND & 0.03 & NA & None & None & Field & $\mathrm{HACH} 8146$ \\
\hline & \multirow[t]{2}{*}{ 30-Jul-04 } & ND & 0.028 & 0.10 & & None & 065387-012 & 3500 Fe2+ \\
\hline & & ND & 0.03 & NA & None & None & Field & HACH 8146 \\
\hline
\end{tabular}




\begin{tabular}{|c|c|c|c|c|c|c|c|c|}
\hline Well ID & Sample Date & $\begin{array}{c}\begin{array}{c}\text { Ferrous Iron } \\
\text { Result } \\
\text { (mg/L) }\end{array} \\
\end{array}$ & $\begin{array}{c}\mathrm{MDL} \\
\text { (mg/L) }\end{array}$ & $\begin{array}{c}\text { PQL } \\
(\mathrm{mg} / \mathrm{L})\end{array}$ & $\begin{array}{c}\text { Laboratory } \\
\text { Qualifier }\end{array}$ & $\begin{array}{c}\text { Validation } \\
\text { Qualifier }\end{array}$ & Sample No. & $\begin{array}{c}\text { Analytical } \\
\text { Method }\end{array}$ \\
\hline & \multirow[t]{2}{*}{ 13-Oct-04 } & ND & 0.028 & 0.10 & & None & 066053-012 & 3500 Fe2+ \\
\hline & & ND & 0.03 & NA & None & None & Field & HACH 8146 \\
\hline \multirow[t]{12}{*}{ TA2-W-27 } & \multirow[t]{2}{*}{ 06-Aug-03 } & ND & 0.0284 & 0.05 & $\mathrm{U}, \mathrm{H}$ & None & 062707-040 & SM 3500-Fe \\
\hline & & ND & 0.03 & NA & & None & Field & HACH 8146 \\
\hline & \multirow[t]{2}{*}{ 23-Oct-03 } & ND & 0.0284 & 0.05 & $\mathrm{U}, \mathrm{H}$ & None & 063294-040 & 3500 Fe2+ \\
\hline & & ND & 0.03 & NA & None & None & Field & $\mathrm{HACH} 8146$ \\
\hline & \multirow[t]{2}{*}{ 15-Jan-04 } & ND & 0.028 & 0.10 & & None & 063885-012 & 3500 Fe2+ \\
\hline & & ND & 0.03 & NA & None & None & Field & HACH 8146 \\
\hline & \multirow[t]{2}{*}{ 19-Apr-04 } & ND & 0.028 & 0.10 & U & None & 064583-012 & 3500 Fe2+ \\
\hline & & ND & 0.03 & NA & None & None & Field & HACH 8146 \\
\hline & \multirow[t]{2}{*}{ 28-Jul-04 } & ND & 0.028 & 0.10 & & None & 065392-012 & 3500 Fe2+ \\
\hline & & ND & 0.03 & NA & None & None & Field & $\mathrm{HACH} 8146$ \\
\hline & \multirow[t]{2}{*}{ 14-Oct-04 } & ND & 0.028 & 0.10 & & None & 066056-012 & 3500 Fe2+ \\
\hline & & 0.01 & 0.03 & NA & None & None & Field & HACH 8146 \\
\hline \multirow[t]{12}{*}{ TJA-2 } & \multirow[t]{2}{*}{ 31-Jul-03 } & ND & 0.0284 & 0.05 & $\mathrm{U}, \mathrm{H}$ & None & 062709-040 & SM 3500-Fe \\
\hline & & ND & 0.03 & NA & & None & Field & HACH 8146 \\
\hline & \multirow[t]{2}{*}{ 15-Oct-03 } & ND & 0.0284 & 0.05 & $\mathrm{U}, \mathrm{H}$ & None & 063295-040 & 3500 Fe2+ \\
\hline & & ND & 0.03 & NA & None & None & Field & $\mathrm{HACH} 8146$ \\
\hline & \multirow[t]{2}{*}{ 19-Jan-04 } & ND & 0.028 & 0.10 & & None & 063887-012 & 3500 Fe2+ \\
\hline & & ND & 0.03 & NA & None & None & Field & $\mathrm{HACH} 8146$ \\
\hline & \multirow[t]{2}{*}{ 05-May-04 } & ND & 0.028 & 0.10 & $U$ & None & 064585-012 & 3500 Fe2+ \\
\hline & & 0.01 & 0.03 & NA & None & None & Field & HACH 8146 \\
\hline & \multirow[t]{2}{*}{ 16-Aug-04 } & ND & 0.028 & 0.10 & & None & 065394-012 & 3500 Fe2+ \\
\hline & & ND & 0.03 & NA & None & None & Field & HACH 8146 \\
\hline & \multirow[t]{2}{*}{ 11-Oct-04 } & ND & 0.028 & 0.10 & & None & 066059-012 & 3500 Fe2+ \\
\hline & & ND & 0.03 & NA & None & None & Field & $\mathrm{HACH} 8146$ \\
\hline \multirow[t]{10}{*}{ TJA-3 } & \multirow[t]{2}{*}{ 06-Aug-03 } & ND & 0.0284 & 0.05 & $\mathrm{U}, \mathrm{H}$ & None & 062711-040 & SM 3500-Fe \\
\hline & & ND & 0.03 & NA & & None & Field & $\mathrm{HACH} 8146$ \\
\hline & \multirow[t]{2}{*}{ 22-Oct-03 } & ND & 0.0284 & 0.05 & $U$ & None & 063296-040 & 3500 Fe2+ \\
\hline & & ND & 0.03 & NA & None & None & Field & HACH 8146 \\
\hline & \multirow[t]{2}{*}{ 27-Jan-04 } & ND & 0.028 & 0.10 & & None & 063889-012 & 3500 Fe2+ \\
\hline & & ND & 0.03 & NA & None & None & Field & $\mathrm{HACH} 8146$ \\
\hline & \multirow[t]{2}{*}{ 27-Apr-04 } & ND & 0.028 & 0.10 & $U$ & None & 064587-012 & 3500 Fe2+ \\
\hline & & 0.02 & 0.03 & NA & None & None & Field & $\mathrm{HACH} 8146$ \\
\hline & \multirow[t]{2}{*}{ 09-Aug-04 } & ND & 0.028 & 0.10 & & None & 065397-012 & 3500 Fe2+ \\
\hline & & ND & 0.03 & NA & None & None & Field & HACH 8146 \\
\hline
\end{tabular}




\begin{tabular}{|c|c|c|c|c|c|c|c|c|}
\hline Well ID & Sample Date & \begin{tabular}{|c|}
$\begin{array}{c}\text { Ferrous Iron } \\
\text { Result } \\
\text { (mg/L) }\end{array}$ \\
\end{tabular} & $\begin{array}{c}\mathrm{MDL} \\
\text { (mg/L) }\end{array}$ & $\begin{array}{c}\text { PQL } \\
\text { (mg/L) }\end{array}$ & $\begin{array}{c}\text { Laboratory } \\
\text { Qualifier }\end{array}$ & $\begin{array}{c}\text { Validation } \\
\text { Qualifier }\end{array}$ & Sample No. & $\begin{array}{c}\text { Analytical } \\
\text { Method }\end{array}$ \\
\hline & \multirow[t]{2}{*}{ 12-Oct-04 } & ND & 0.028 & 0.10 & & None & 066061-012 & 3500 Fe2+ \\
\hline & & 0.01 & 0.03 & NA & None & None & Field & HACH 8146 \\
\hline \multirow[t]{12}{*}{$T J A-4$} & \multirow[t]{2}{*}{ 06-Aug-03 } & ND & 0.0284 & 0.05 & $\mathrm{U}, \mathrm{H}$ & None & 062713-040 & SM 3500-Fe \\
\hline & & ND & 0.03 & NA & & None & Field & HACH 8146 \\
\hline & \multirow[t]{2}{*}{ 27-Oct-03 } & ND & 0.0284 & 0.05 & U & None & 063297-040 & 3500 Fe2+ \\
\hline & & ND & 0.03 & NA & None & None & Field & $\mathrm{HACH} 8146$ \\
\hline & \multirow[t]{2}{*}{ 29-Jan-04 } & ND & 0.028 & 0.10 & & None & 063891-012 & 3500 Fe2+ \\
\hline & & ND & 0.03 & NA & None & None & Field & HACH 8146 \\
\hline & \multirow[t]{2}{*}{ 20-Apr-04 } & ND & 0.028 & 0.10 & U & None & 064589-012 & 3500 Fe2+ \\
\hline & & ND & 0.03 & NA & None & None & Field & HACH 8146 \\
\hline & \multirow[t]{2}{*}{ 10-Aug-04 } & ND & 0.028 & 0.10 & & None & 065399-012 & 3500 Fe2+ \\
\hline & & ND & 0.03 & NA & None & None & Field & $\mathrm{HACH} 8146$ \\
\hline & \multirow[t]{2}{*}{ 12-Oct-04 } & ND & 0.028 & 0.10 & & None & 066063-012 & 3500 Fe2+ \\
\hline & & ND & 0.03 & NA & None & None & Field & HACH 8146 \\
\hline \multirow[t]{12}{*}{ TJA-6 } & \multirow[t]{2}{*}{ 11-Aug-03 } & ND & 0.0284 & 0.05 & $\mathrm{U}, \mathrm{H}$ & None & 062715-040 & SM 3500-Fe \\
\hline & & 0.10 & 0.03 & NA & & None & Field & HACH 8146 \\
\hline & \multirow[t]{2}{*}{ 05-Nov-03 } & ND & 0.0284 & 0.05 & $\mathrm{U}, \mathrm{H}$ & None & 063298-040 & 3500 Fe2+ \\
\hline & & 0.01 & 0.03 & NA & None & None & Field & $\mathrm{HACH} 8146$ \\
\hline & \multirow[t]{2}{*}{ 04-Feb-04 } & ND & 0.028 & 0.10 & & None & 063893-012 & 3500 Fe2+ \\
\hline & & 0.11 & 0.03 & NA & None & None & Field & $\mathrm{HACH} 8146$ \\
\hline & \multirow[t]{2}{*}{ 22-Apr-04 } & ND & 0.028 & 0.10 & $U$ & None & 064591-012 & $3500 \mathrm{Fe} 2+$ \\
\hline & & ND & 0.03 & NA & None & None & Field & HACH 8146 \\
\hline & \multirow[t]{2}{*}{ 04-Aug-04 } & ND & 0.028 & 0.10 & & None & 065401-012 & 3500 Fe2+ \\
\hline & & ND & 0.03 & NA & None & None & Field & HACH 8146 \\
\hline & \multirow[t]{2}{*}{ 13-Oct-04 } & ND & 0.028 & 0.10 & & None & 066065-012 & 3500 Fe2+ \\
\hline & & 0.06 & 0.03 & NA & None & None & Field & $\mathrm{HACH} 8146$ \\
\hline \multirow[t]{10}{*}{ TJA-7 } & \multirow[t]{2}{*}{ 12-Aug-03 } & ND & 0.0284 & 0.05 & $\mathrm{U}, \mathrm{H}$ & None & 062717-040 & SM 3500-Fe \\
\hline & & 0.05 & 0.03 & NA & & None & Field & $\mathrm{HACH} 8146$ \\
\hline & \multirow[t]{2}{*}{ 28-Oct-03 } & ND & 0.0284 & 0.05 & $\mathrm{U}, \mathrm{H}$ & None & 063299-040 & 3500 Fe2+ \\
\hline & & 0.02 & 0.03 & NA & None & None & Field & HACH 8146 \\
\hline & \multirow[t]{2}{*}{ 22-Jan-04 } & ND & 0.028 & 0.10 & & None & 063895-012 & 3500 Fe2+ \\
\hline & & ND & 0.03 & NA & None & None & Field & $\mathrm{HACH} 8146$ \\
\hline & \multirow[t]{2}{*}{ 30-Apr-04 } & ND & 0.028 & 0.10 & $U$ & None & 064593-012 & 3500 Fe2+ \\
\hline & & 0.03 & 0.03 & NA & None & None & Field & $\mathrm{HACH} 8146$ \\
\hline & \multirow[t]{2}{*}{ 06-Aug-04 } & ND & 0.028 & 0.10 & & None & 065403-012 & 3500 Fe2+ \\
\hline & & ND & 0.03 & NA & None & None & Field & HACH 8146 \\
\hline
\end{tabular}




\begin{tabular}{|c|c|c|c|c|c|c|c|c|}
\hline Well ID & Sample Date & \begin{tabular}{|c|}
$\begin{array}{c}\text { Ferrous Iron } \\
\text { Result } \\
\text { (mg/L) }\end{array}$ \\
\end{tabular} & $\begin{array}{c}\text { MDL } \\
\text { (mg/L) }\end{array}$ & $\begin{array}{c}\text { PQL } \\
\text { (mg/L) }\end{array}$ & $\begin{array}{c}\text { Laboratory } \\
\text { Qualifier } \\
\end{array}$ & $\begin{array}{c}\text { Validation } \\
\text { Qualifier }\end{array}$ & Sample No. & $\begin{array}{l}\text { Analytical } \\
\text { Method }\end{array}$ \\
\hline & \multirow[t]{2}{*}{ 15-Oct-04 } & ND & 0.028 & 0.10 & & None & 066067-012 & $3500 \mathrm{Fe} 2+$ \\
\hline & & 0.04 & 0.03 & NA & None & None & Field & HACH 8146 \\
\hline \multirow[t]{12}{*}{ WYO-3 } & \multirow[t]{2}{*}{ 13-Aug-03 } & ND & 0.0284 & 0.05 & $\mathrm{U}, \mathrm{H}$ & None & 062719-040 & SM 3500-Fe \\
\hline & & ND & 0.03 & NA & & None & Field & $\mathrm{HACH} 8146$ \\
\hline & \multirow[t]{2}{*}{ 29-Oct-03 } & ND & 0.0284 & 0.05 & $\mathrm{U}, \mathrm{H}$ & None & 063300-040 & 3500 Fe2+ \\
\hline & & ND & 0.03 & NA & None & None & Field & HACH 8146 \\
\hline & \multirow[t]{2}{*}{ 21-Jan-04 } & ND & 0.028 & 0.10 & & None & 063897-012 & $3500 \mathrm{Fe} 2+$ \\
\hline & & ND & 0.03 & NA & None & None & Field & HACH 8146 \\
\hline & \multirow[t]{2}{*}{ 28-Apr-04 } & ND & 0.028 & 0.10 & U & None & 064595-012 & $3500 \mathrm{Fe} 2+$ \\
\hline & & ND & 0.03 & NA & None & None & Field & HACH 8146 \\
\hline & \multirow[t]{2}{*}{ 11-Aug-04 } & ND & 0.028 & 0.10 & & None & 065408-012 & 3500 Fe2+ \\
\hline & & ND & 0.03 & NA & None & None & Field & HACH 8146 \\
\hline & \multirow[t]{2}{*}{ 08-Oct-04 } & ND & 0.028 & 0.10 & & None & 066071-012 & $3500 \mathrm{Fe} 2+$ \\
\hline & & ND & 0.03 & NA & None & None & Field & HACH 8146 \\
\hline \multirow[t]{12}{*}{$W Y O-4$} & \multirow[t]{2}{*}{ 14-Aug-03 } & ND & 0.0284 & 0.05 & $\mathrm{U}, \mathrm{H}$ & None & 062721-040 & SM 3500-Fe \\
\hline & & 0.06 & 0.03 & NA & & None & Field & HACH 8146 \\
\hline & \multirow[t]{2}{*}{ 03-Nov-03 } & 0.0288 & 0.0284 & 0.05 & $\mathrm{~B}, \mathrm{H}, \mathrm{J}$ & None & 063301-040 & $3500 \mathrm{Fe} 2+$ \\
\hline & & 0.01 & 0.03 & NA & None & None & Field & HACH 8146 \\
\hline & \multirow[t]{2}{*}{ 03-Feb-04 } & ND & 0.028 & 0.10 & & None & 063899-012 & $3500 \mathrm{Fe} 2+$ \\
\hline & & ND & 0.03 & NA & None & None & Field & HACH 8146 \\
\hline & \multirow[t]{2}{*}{ 30-Apr-04 } & ND & 0.028 & 0.10 & U & None & 064597-012 & 3500 Fe2+ \\
\hline & & 0.02 & 0.03 & NA & None & None & Field & HACH 8146 \\
\hline & \multirow[t]{2}{*}{ 03-Aug-04 } & ND & 0.028 & 0.10 & & None & 065411-012 & $3500 \mathrm{Fe} 2+$ \\
\hline & & ND & 0.03 & NA & None & None & Field & HACH 8146 \\
\hline & \multirow[t]{2}{*}{ 06-Oct-04 } & ND & 0.028 & 0.10 & & None & 066073-012 & $3500 \mathrm{Fe} 2+$ \\
\hline & & ND & 0.03 & NA & None & None & Field & HACH 8146 \\
\hline $\begin{array}{l}\mathrm{mg} / \mathrm{L}=\text { millig } \\
\mathrm{J}=\text { Amount } \mathrm{C} \\
\mathrm{B}=\text { Analyte } \\
\mathrm{H}=\text { The hold } \\
\mathrm{U}=\text { Analyte }\end{array}$ & $\begin{array}{l}\text { s per liter } \\
\text { cted is below } \\
\text { tected in ass } \\
\text { time was exc } \\
\text { detected abov }\end{array}$ & $\begin{array}{l}\text { he practical q } \\
\text { ciated laborat } \\
\text { eded for the a } \\
\text { the MDL. }\end{array}$ & $\begin{array}{l}\text { titation lim } \\
\text { method bl } \\
\text { ciated san }\end{array}$ & $\begin{array}{l}\text { The ass } \\
\text { k. } \\
\text { e analys }\end{array}$ & ated val & an esti & quantity. & \\
\hline
\end{tabular}


Table A-14

Summary of Anion, Cation, and Alkalinity Results

Tijeras Arroyo Groundwater Investigation

Fiscal Year 2003, $4^{\text {th }}$ Quarter

\begin{tabular}{|c|c|c|c|c|c|c|c|c|}
\hline Well ID & Analyte & $\begin{array}{l}\text { Result } \\
\text { (mg/L) }\end{array}$ & $\begin{array}{c}\text { MDL } \\
\text { (mg/L) }\end{array}$ & $\begin{array}{c}\text { PQL } \\
\text { (mg/L) }\end{array}$ & $\begin{array}{l}\text { Laboratory } \\
\text { Qualifier }\end{array}$ & $\begin{array}{c}\text { Validation } \\
\text { Qualifier }\end{array}$ & Sample No. & $\begin{array}{l}\text { Analytical } \\
\text { Method }\end{array}$ \\
\hline \multirow{11}{*}{$\begin{array}{l}\text { EUBANK-1 } \\
\text { 18-Aug-03 }\end{array}$} & Bromide & 0.141 & 0.0978 & 0.2 & $\mathrm{~J}$ & & 062724-013 & SW846 9056 \\
\hline & Chloride & 12.3 & 0.0322 & 0.2 & & & 062724-013 & SW846 9056 \\
\hline & Fluoride & 0.318 & 0.0553 & 0.1 & & & 062724-013 & SW846 9056 \\
\hline & Sulfate & 85.4 & 0.965 & 2 & & & 062724-013 & SW846 9056 \\
\hline & Calcium & 70.9 & 0.04 & 0.1 & & & 062724-009 & SW846 3005 \\
\hline & Magnesium & 9.76 & 0.00633 & 0.01 & & $\mathrm{~J}$ & 062724-009 & SW846 3005 \\
\hline & Potassium & 1.65 & 0.0151 & 0.3 & B & & 062724-009 & SW846 3005 \\
\hline & Sodium & 22.8 & 0.00968 & 0.25 & & $\mathrm{~J}$ & 062724-009 & SW846 3005 \\
\hline & $\begin{array}{l}\text { Alkalinity as } \\
\mathrm{CaCO} 3\end{array}$ & 133 & 1.45 & 2 & & & 062724-014 & EPA 310.1 \\
\hline & $\begin{array}{l}\text { bicarb as } \mathrm{CaCO} 3 \\
\text { Alkalinity }\end{array}$ & 133 & 1.45 & 2 & & & 062724-014 & EPA 310.1 \\
\hline & $\begin{array}{l}\text { carb as } \mathrm{CaCO} 3 \\
\text { Alkalinity }\end{array}$ & ND & 1.45 & 2 & U & & 062724-014 & EPA 310.1 \\
\hline \multirow{11}{*}{$\begin{array}{l}\text { PGS-2 } \\
\text { 22-Jul-03 }\end{array}$} & Bromide & 0.243 & 0.0978 & 0.2 & & & 062678-013 & SW846 9056 \\
\hline & Chloride & 14.2 & 0.0322 & 0.2 & & & 062678-013 & SW846 9056 \\
\hline & Fluoride & 0.212 & 0.0553 & 0.1 & & & 062678-013 & SW846 9056 \\
\hline & Sulfate & 59 & 0.965 & 2 & & & 062678-013 & SW846 9056 \\
\hline & Calcium & 56.7 & 0.04 & 0.1 & & & 062678-009 & SW846 3005 \\
\hline & Magnesium & 12.1 & 0.00633 & 0.01 & & & 062678-009 & SW846 3005 \\
\hline & Potassium & 2.59 & 0.0151 & 0.3 & & & 062678-009 & SW846 3005 \\
\hline & Sodium & 34.4 & 0.00968 & 0.25 & & & 062678-009 & SW846 3005 \\
\hline & $\begin{array}{l}\text { Alkalinity as } \\
\text { CaCO3 }\end{array}$ & 168 & 1.45 & 2 & & & 062678-014 & EPA 310.1 \\
\hline & $\begin{array}{l}\text { bicarb as } \mathrm{CaCO} 3 \\
\text { Alkalinity }\end{array}$ & 165 & 1.45 & 2 & & & 062678-014 & EPA 310.1 \\
\hline & $\begin{array}{l}\text { carb as } \mathrm{CaCO} 3 \\
\text { Alkalinity }\end{array}$ & 2.58 & 1.45 & 2 & & & 062678-014 & EPA 310.1 \\
\hline TA1-W-01 & Bromide & 0.275 & 0.0978 & 0.2 & & & 062680-013 & SW846 9056 \\
\hline \multirow[t]{7}{*}{ 22-Jul-03 } & Chloride & 14.7 & 0.0322 & 0.2 & & & 062680-013 & SW846 9056 \\
\hline & Fluoride & 0.444 & 0.0553 & 0.1 & & & 062680-013 & SW846 9056 \\
\hline & Sulfate & 78.3 & 0.965 & 2 & & & 062680-013 & SW846 9056 \\
\hline & Calcium & 72.7 & 0.04 & 0.1 & & & 062680-009 & SW846 3005 \\
\hline & Magnesium & 14.5 & 0.00633 & 0.01 & & & 062680-009 & SW846 3005 \\
\hline & Potassium & 2.15 & 0.0151 & 0.3 & & & 062680-009 & SW846 3005 \\
\hline & Sodium & 28 & 0.00968 & 0.25 & & & 062680-009 & SW846 3005 \\
\hline
\end{tabular}




\begin{tabular}{|c|c|c|c|c|c|c|c|c|}
\hline Well ID & Analyte & $\begin{array}{l}\text { Result } \\
(\mathrm{mg} / \mathrm{L})\end{array}$ & $\begin{array}{c}\mathrm{MDL} \\
(\mathrm{mg} / \mathrm{L})\end{array}$ & $\begin{array}{c}\mathrm{PQL} \\
(\mathrm{mg} / \mathrm{L})\end{array}$ & $\begin{array}{c}\text { Laboratory } \\
\text { Qualifier }\end{array}$ & $\begin{array}{c}\text { Validation } \\
\text { Qualifier } \\
\end{array}$ & Sample No. & $\begin{array}{c}\text { Analytical } \\
\text { Method }\end{array}$ \\
\hline & $\begin{array}{l}\text { Alkalinity as } \\
\mathrm{CaCO} 3\end{array}$ & 170 & 1.45 & 2 & & & 062680-014 & EPA 310.1 \\
\hline & $\begin{array}{l}\text { bicarb as } \mathrm{CaCO} 3 \\
\text { Alkalinity }\end{array}$ & 170 & 1.45 & 2 & & & 062680-014 & EPA 310.1 \\
\hline & $\begin{array}{l}\text { carb as } \mathrm{CaCO} 3 \\
\text { Alkalinity }\end{array}$ & ND & 1.45 & 2 & $u$ & & 062680-014 & EPA 310.1 \\
\hline TA1-W-02 & Bromide & 0.226 & 0.0978 & 0.2 & & & 062682-013 & SW846 9056 \\
\hline \multirow[t]{10}{*}{ 23-Jul-03 } & Chloride & 14.1 & 0.0322 & 0.2 & & & 062682-013 & SW846 9056 \\
\hline & Fluoride & 0.407 & 0.0553 & 0.1 & & & $062682-013$ & SW846 9056 \\
\hline & Sulfate & 79.7 & 0.965 & 2 & & & 062682-013 & SW846 9056 \\
\hline & Calcium & 76.8 & 0.2 & 0.5 & B & & 062682-009 & SW846 3005 \\
\hline & Magnesium & 14.3 & 0.0317 & 0.05 & & & 062682-009 & SW846 3005 \\
\hline & Potassium & 2.33 & 0.0753 & 1.5 & & & 062682-009 & SW846 3005 \\
\hline & Sodium & 26.5 & 0.0484 & 1.25 & & & 062682-009 & SW846 3005 \\
\hline & $\begin{array}{l}\text { Alkalinity as } \\
\text { CaCO3 }\end{array}$ & 178 & 1.45 & 2 & & & $062682-014$ & EPA 310.1 \\
\hline & $\begin{array}{l}\text { bicarb as } \mathrm{CaCO} 3 \\
\text { Alkalinity }\end{array}$ & 177 & 1.45 & 2 & & & 062682-014 & EPA 310.1 \\
\hline & $\begin{array}{l}\text { carb as } \mathrm{CaCO} 3 \\
\text { Alkalinity }\end{array}$ & ND & 1.45 & 2 & U & & 062682-014 & EPA 310.1 \\
\hline TA1-W-03 & Bromide & 3 & 0.0978 & 0.2 & & & 062684-013 & SW846 9056 \\
\hline \multirow[t]{10}{*}{ 24-Jul-03 } & Chloride & 234 & 1.61 & 10 & & & 062684-013 & SW846 9056 \\
\hline & Fluoride & 0.247 & 0.0553 & 0.1 & & & 062684-013 & SW846 9056 \\
\hline & Sulfate & 469 & 9.65 & 20 & & & 062684-013 & SW846 9056 \\
\hline & Calcium & 299 & 0.2 & 0.5 & B & & 062684-009 & SW846 3005 \\
\hline & Magnesium & 32.7 & 0.0317 & 0.05 & & & 062684-009 & SW846 3005 \\
\hline & Potassium & 2.8 & 0.0753 & 1.5 & & & 062684-009 & SW846 3005 \\
\hline & Sodium & 51 & 0.0484 & 1.25 & & & 062684-009 & SW846 3005 \\
\hline & $\begin{array}{l}\text { Alkalinity as } \\
\text { CaCO3 }\end{array}$ & 74 & 1.45 & 2 & & & 062684-014 & EPA 310.1 \\
\hline & $\begin{array}{l}\text { bicarb as } \mathrm{CaCO} 3 \\
\text { Alkalinity }\end{array}$ & 73.8 & 1.45 & 2 & & & 062684-014 & EPA 310.1 \\
\hline & $\begin{array}{l}\text { carb as } \mathrm{CaCO} 3 \\
\text { Alkalinity }\end{array}$ & ND & 1.45 & 2 & U & & 062684-014 & EPA 310.1 \\
\hline TA1-W-04 & Bromide & 0.256 & 0.0978 & 0.2 & & & 062686-013 & SW846 9056 \\
\hline \multirow[t]{8}{*}{ 29-Jul-03 } & Chloride & 16.8 & 0.0322 & 0.2 & & & 062686-013 & SW846 9056 \\
\hline & Fluoride & 0.372 & 0.0553 & 0.1 & & & 062686-013 & SW846 9056 \\
\hline & Sulfate & 65.4 & 0.965 & 2 & & & 062686-013 & SW846 9056 \\
\hline & Calcium & 70.7 & 0.04 & 0.1 & B & & 062686-009 & SW846 3005 \\
\hline & Magnesium & 13.1 & 0.00633 & 0.01 & & & 062686-009 & SW846 3005 \\
\hline & Potassium & 2.62 & 0.0151 & 0.3 & & & 062686-009 & SW846 3005 \\
\hline & Sodium & 27 & 0.00968 & 0.25 & B & & 062686-009 & SW846 3005 \\
\hline & Alkalinity as & 173 & 1.45 & 2 & & & 062686-014 & EPA 310.1 \\
\hline
\end{tabular}




\begin{tabular}{|c|c|c|c|c|c|c|c|c|}
\hline Well ID & Analyte & $\begin{array}{l}\text { Result } \\
\text { (mg/L) }\end{array}$ & $\begin{array}{c}\text { MDL } \\
\text { (mg/L) }\end{array}$ & $\begin{array}{c}\mathrm{PQL} \\
\text { (mg/L) }\end{array}$ & $\begin{array}{c}\text { Laboratory } \\
\text { Qualifier }\end{array}$ & $\begin{array}{c}\text { Validation } \\
\text { Qualifier }\end{array}$ & Sample No. & $\begin{array}{l}\text { Analytical } \\
\text { Method }\end{array}$ \\
\hline & $\mathrm{CaCO} 3$ & & & & & & & \\
\hline & $\begin{array}{l}\text { bicarb as } \mathrm{CaCO} 3 \\
\text { Alkalinity }\end{array}$ & 172 & 1.45 & 2 & & & 062686-014 & EPA 310.1 \\
\hline & $\begin{array}{l}\text { carb as } \mathrm{CaCO} 3 \\
\text { Alkalinity }\end{array}$ & ND & 1.45 & 2 & $u$ & & 062686-014 & EPA 310.1 \\
\hline TA1-W-05 & Bromide & 0.204 & 0.0978 & 0.2 & & & 062688-013 & SW846 9056 \\
\hline \multirow[t]{10}{*}{ 28-Jul-03 } & Chloride & 11.5 & 0.0322 & 0.2 & & & 062688-013 & SW846 9056 \\
\hline & Fluoride & 0.301 & 0.0553 & 0.1 & & & 062688-013 & SW846 9056 \\
\hline & Sulfate & 101 & 0.965 & 2 & & & 062688-013 & SW846 9056 \\
\hline & Calcium & 87.6 & 0.04 & 0.1 & & & 062688-009 & SW846 3005 \\
\hline & Magnesium & 13.2 & 0.00633 & 0.01 & & & 062688-009 & SW846 3005 \\
\hline & Potassium & 2.08 & 0.0151 & 0.3 & & & 062688-009 & SW846 3005 \\
\hline & Sodium & 31.8 & 0.00968 & 0.25 & & & 062688-009 & SW846 3005 \\
\hline & $\begin{array}{l}\text { Alkalinity as } \\
\mathrm{CaCO} 3\end{array}$ & 207 & 1.45 & 2 & & & 062688-014 & EPA 310.1 \\
\hline & $\begin{array}{l}\text { bicarb as } \mathrm{CaCO} 3 \\
\text { Alkalinity }\end{array}$ & 207 & 1.45 & 2 & & & 062688-014 & EPA 310.1 \\
\hline & $\begin{array}{l}\text { carb as } \mathrm{CaCO} 3 \\
\text { Alkalinity }\end{array}$ & ND & 1.45 & 2 & $u$ & & 062688-014 & EPA 310.1 \\
\hline TA1-W-06 & Bromide & 1.23 & 0.0978 & 0.2 & & & 062690-013 & SW846 9056 \\
\hline \multirow[t]{10}{*}{ 29-Jul-03 } & Chloride & 98.1 & 0.322 & 2 & & & 062690-013 & SW846 9056 \\
\hline & Fluoride & 0.309 & 0.0553 & 0.1 & & & 062690-013 & SW846 9056 \\
\hline & Sulfate & 206 & 1.93 & 4 & & & 062690-013 & SW846 9056 \\
\hline & Calcium & 130 & 0.04 & 0.1 & B & & 062690-009 & SW846 3005 \\
\hline & Magnesium & 16.9 & 0.00633 & 0.01 & & & 062690-009 & SW846 3005 \\
\hline & Potassium & 1.96 & 0.0151 & 0.3 & & & 062690-009 & SW846 3005 \\
\hline & Sodium & 33.8 & 0.00968 & 0.25 & B & & 062690-009 & SW846 3005 \\
\hline & $\begin{array}{l}\text { Alkalinity as } \\
\text { CaCO3 }\end{array}$ & 98.7 & 1.45 & 2 & & & 062690-014 & EPA 310.1 \\
\hline & $\begin{array}{l}\text { bicarb as } \mathrm{CaCO} 3 \\
\text { Alkalinity }\end{array}$ & 98.3 & 1.45 & 2 & & & 062690-014 & EPA 310.1 \\
\hline & $\begin{array}{l}\text { carb as } \mathrm{CaCO} 3 \\
\text { Alkalinity }\end{array}$ & ND & 1.45 & 2 & $u$ & & 062690-014 & EPA 310.1 \\
\hline TA1-W-08 & Bromide & 2.55 & 0.0978 & 0.2 & & & 062692-013 & SW846 9056 \\
\hline \multirow[t]{8}{*}{ 30-Jul-03 } & Chloride & 215 & 1.61 & 10 & & & 062692-013 & SW846 9056 \\
\hline & Fluoride & 0.27 & 0.0553 & 0.1 & & & 062692-013 & SW846 9056 \\
\hline & Sulfate & 672 & 9.65 & 20 & & & 062692-013 & SW846 9056 \\
\hline & Calcium & 330 & 0.2 & 0.5 & & & 062692-009 & SW846 3005 \\
\hline & Magnesium & 38 & 0.00633 & 0.01 & & & 062692-009 & SW846 3005 \\
\hline & Potassium & 2.95 & 0.0151 & 0.3 & B & & 062692-009 & SW846 3005 \\
\hline & Sodium & 70.7 & 0.00968 & 0.25 & & $\mathrm{~J}$ & 062692-009 & SW846 3005 \\
\hline & $\begin{array}{l}\text { Alkalinity as } \\
\text { CaCO3 }\end{array}$ & 94.5 & 1.45 & 2 & & & 062692-014 & EPA 310.1 \\
\hline
\end{tabular}




\begin{tabular}{|c|c|c|c|c|c|c|c|c|}
\hline Well ID & Analyte & $\begin{array}{l}\text { Result } \\
\text { (mg/L) }\end{array}$ & $\begin{array}{c}\mathrm{MDL} \\
(\mathrm{mg} / \mathrm{L})\end{array}$ & $\begin{array}{c}\mathrm{PQL} \\
(\mathrm{mg} / \mathrm{L})\end{array}$ & $\begin{array}{c}\text { Laboratory } \\
\text { Qualifier }\end{array}$ & $\begin{array}{c}\text { Validation } \\
\text { Qualifier } \\
\end{array}$ & Sample No. & $\begin{array}{c}\text { Analytical } \\
\text { Method }\end{array}$ \\
\hline & $\begin{array}{l}\text { bicarb as } \mathrm{CaCO} 3 \\
\text { Alkalinity }\end{array}$ & 94.2 & 1.45 & 2 & & & 062692-014 & EPA 310.1 \\
\hline & $\begin{array}{l}\text { carb as } \mathrm{CaCO} 3 \\
\text { Alkalinity }\end{array}$ & ND & 1.45 & 2 & $u$ & & 062692-014 & EPA 310.1 \\
\hline \multirow{11}{*}{$\begin{array}{l}\text { TA2-NW1-595 } \\
\text { 30-Jul-03 }\end{array}$} & Bromide & 1.19 & 0.0978 & 0.2 & & & 062695-A13 & SW846 9056 \\
\hline & Chloride & 85.1 & 0.322 & 2 & & & 062695-A13 & SW846 9056 \\
\hline & Fluoride & 0.344 & 0.0553 & 0.1 & & & 062695-A13 & SW846 9056 \\
\hline & Sulfate & 120 & 1.93 & 4 & & & 062695-A13 & SW846 9056 \\
\hline & Calcium & 106 & 0.04 & 0.1 & & & 062695-A09 & SW846 3005 \\
\hline & Magnesium & 17 & 0.00633 & 0.01 & & & 062695-A09 & SW846 3005 \\
\hline & Potassium & 2.36 & 0.0151 & 0.3 & B & & 062695-A09 & SW846 3005 \\
\hline & Sodium & 32 & 0.00968 & 0.25 & & $\mathrm{~J}$ & 062695-A09 & SW846 3005 \\
\hline & $\begin{array}{l}\text { Alkalinity as } \\
\mathrm{CaCO} 3\end{array}$ & 188 & 1.45 & 2 & & & 062695-A14 & EPA 310.1 \\
\hline & $\begin{array}{l}\text { bicarb as } \mathrm{CaCO} 3 \\
\text { Alkalinity }\end{array}$ & 187 & 1.45 & 2 & & & 062695-A14 & EPA 310.1 \\
\hline & $\begin{array}{l}\text { carb as } \mathrm{CaCO} 3 \\
\text { Alkalinity }\end{array}$ & ND & 1.45 & 2 & $u$ & & 062695-A14 & EPA 310.1 \\
\hline \multirow{11}{*}{$\begin{array}{l}\text { TA2-NW1-595 } \\
\text { 05-Aug-03 }\end{array}$} & Bromide & 0.985 & 0.0978 & 0.2 & & & 062695-013 & SW846 9056 \\
\hline & Chloride & 65.9 & 0.322 & 2 & & & 062695-013 & SW846 9056 \\
\hline & Fluoride & 0.216 & 0.0553 & 0.1 & & & 062695-013 & SW846 9056 \\
\hline & Sulfate & 92.2 & 1.93 & 4 & & & 062695-013 & SW846 9056 \\
\hline & Calcium & 106 & 0.04 & 0.1 & & & 062695-009 & SW846 3005 \\
\hline & Magnesium & 15.9 & 0.00633 & 0.01 & & & 062695-009 & SW846 3005 \\
\hline & Potassium & 2.34 & 0.0151 & 0.3 & B & & 062695-009 & SW846 3005 \\
\hline & Sodium & 29.2 & 0.00968 & 0.25 & & $\mathrm{~J}$ & 062695-009 & SW846 3005 \\
\hline & $\begin{array}{l}\text { Alkalinity as } \\
\text { CaCO3 }\end{array}$ & 154 & 1.45 & 2 & & & 062695-014 & EPA 310.1 \\
\hline & $\begin{array}{l}\text { bicarb as } \mathrm{CaCO} 3 \\
\text { Alkalinity }\end{array}$ & 154 & 1.45 & 2 & & & 062695-014 & EPA 310.1 \\
\hline & $\begin{array}{l}\text { carb as } \mathrm{CaCO} 3 \\
\text { Alkalinity }\end{array}$ & ND & 1.45 & 2 & $U$ & & 062695-014 & EPA 310.1 \\
\hline \multirow{10}{*}{$\begin{array}{l}\text { TA2-SW1-320 } \\
\text { 24-Jul-03 }\end{array}$} & Bromide & 0.421 & 0.0978 & 0.2 & & & 062698-013 & SW846 9056 \\
\hline & Chloride & 26.3 & 0.0644 & 0.4 & & & 062698-013 & SW846 9056 \\
\hline & Fluoride & 0.454 & 0.0553 & 0.1 & & & 062698-013 & SW846 9056 \\
\hline & Sulfate & 14.1 & 0.193 & 0.4 & & & 062698-013 & SW846 9056 \\
\hline & Calcium & 66.3 & 0.2 & 0.5 & B & & 062698-009 & SW846 3005 \\
\hline & Magnesium & 11.6 & 0.0317 & 0.05 & & & 062698-009 & SW846 3005 \\
\hline & Potassium & 2.05 & 0.0753 & 1.5 & & & 062698-009 & SW846 3005 \\
\hline & Sodium & 19.8 & 0.0484 & 1.25 & & & 062698-009 & SW846 3005 \\
\hline & $\begin{array}{l}\text { Alkalinity as } \\
\mathrm{CaCO} 3\end{array}$ & 109 & 1.45 & 2 & & & 062698-014 & EPA 310.1 \\
\hline & bicarb as $\mathrm{CaCO} 3$ & 108 & 1.45 & 2 & & & 062698-014 & EPA 310.1 \\
\hline
\end{tabular}




\begin{tabular}{|c|c|c|c|c|c|c|c|c|}
\hline Well ID & \begin{tabular}{|l} 
Analyte \\
\end{tabular} & $\begin{array}{l}\text { Result } \\
\text { (mg/L) }\end{array}$ & $\begin{array}{c}\text { MDL } \\
\text { (mg/L) }\end{array}$ & $\begin{array}{c}\mathrm{PQL} \\
(\mathrm{mg} / \mathrm{L})\end{array}$ & $\begin{array}{c}\text { Laboratory } \\
\text { Qualifier }\end{array}$ & $\begin{array}{c}\text { Validation } \\
\text { Qualifier }\end{array}$ & Sample No. & $\begin{array}{l}\text { Analytical } \\
\text { Method }\end{array}$ \\
\hline & Alkalinity & & & & & & & \\
\hline & $\begin{array}{l}\text { carb as } \mathrm{CaCO} 3 \\
\text { Alkalinity }\end{array}$ & ND & 1.45 & 2 & U & & 062698-014 & EPA 310.1 \\
\hline TA2-W-01 & Bromide & 1.43 & 0.0978 & 0.2 & & & 062700-013 & SW846 9056 \\
\hline \multirow[t]{10}{*}{ 07-Aug-03 } & Chloride & 108 & 0.322 & 2 & & & 062700-013 & SW846 9056 \\
\hline & Fluoride & 0.318 & 0.0553 & 0.1 & & & 062700-013 & SW846 9056 \\
\hline & Sulfate & 40.3 & 1.93 & 4 & & & 062700-013 & SW846 9056 \\
\hline & Calcium & 85.6 & 0.04 & 0.1 & & & 062700-009 & SW846 3005 \\
\hline & Magnesium & 11 & 0.00633 & 0.01 & & & 062700-009 & SW846 3005 \\
\hline & Potassium & 1.78 & 0.0151 & 0.3 & B & & 062700-009 & SW846 3005 \\
\hline & Sodium & 21.4 & 0.00968 & 0.25 & & & 062700-009 & SW846 3005 \\
\hline & $\begin{array}{l}\text { Alkalinity as } \\
\text { CaCO3 }\end{array}$ & 114 & 1.45 & 2 & & & 062700-014 & EPA 310.1 \\
\hline & $\begin{array}{l}\text { bicarb as } \mathrm{CaCO} 3 \\
\text { Alkalinity }\end{array}$ & 113 & 1.45 & 2 & & & 062700-014 & EPA 310.1 \\
\hline & $\begin{array}{l}\text { carb as } \mathrm{CaCO} 3 \\
\text { Alkalinity }\end{array}$ & ND & 1.45 & 2 & $U$ & & 062700-014 & EPA 310.1 \\
\hline TA2-W-19 & Bromide & 0.835 & 0.0978 & 0.2 & & & 062702-013 & SW846 9056 \\
\hline \multirow[t]{10}{*}{ 04-Aug-03 } & Chloride & 72.9 & 0.322 & 2 & & & 062702-013 & SW846 9056 \\
\hline & Fluoride & 0.262 & 0.0553 & 0.1 & & & 062702-013 & SW846 9056 \\
\hline & Sulfate & 55.6 & 1.93 & 4 & & & $062702-013$ & SW846 9056 \\
\hline & Calcium & 83.9 & 0.04 & 0.1 & & & 062702-009 & SW846 3005 \\
\hline & Magnesium & 11.6 & 0.00633 & 0.01 & & & 062702-009 & SW846 3005 \\
\hline & Potassium & 1.83 & 0.0151 & 0.3 & B & & 062702-009 & SW846 3005 \\
\hline & Sodium & 23.9 & 0.00968 & 0.25 & & $\mathrm{~J}$ & 062702-009 & SW846 3005 \\
\hline & $\begin{array}{l}\text { Alkalinity as } \\
\text { CaCO3 }\end{array}$ & 101 & 1.45 & 2 & & & 062702-014 & EPA 310.1 \\
\hline & $\begin{array}{l}\text { bicarb as } \mathrm{CaCO} 3 \\
\text { Alkalinity }\end{array}$ & 101 & 1.45 & 2 & & & 062702-014 & EPA 310.1 \\
\hline & $\begin{array}{l}\text { carb as } \mathrm{CaCO} 3 \\
\text { Alkalinity }\end{array}$ & ND & 1.45 & 2 & U & & 062702-014 & EPA 310.1 \\
\hline TA2-W-26 & Bromide & 1.49 & 0.0978 & 0.2 & & & 062704-013 & SW846 9056 \\
\hline \multirow[t]{9}{*}{ 04-Aug-03 } & Chloride & 106 & 0.322 & 2 & & & 062704-013 & SW846 9056 \\
\hline & Fluoride & 0.207 & 0.0553 & 0.1 & & & 062704-013 & SW846 9056 \\
\hline & Sulfate & 197 & 1.93 & 4 & & & 062704-013 & SW846 9056 \\
\hline & Calcium & 156 & 0.04 & 0.1 & & & 062704-009 & SW846 3005 \\
\hline & Magnesium & 19.1 & 0.00633 & 0.01 & & & 062704-009 & SW846 3005 \\
\hline & Potassium & 2.21 & 0.0151 & 0.3 & B & & 062704-009 & SW846 3005 \\
\hline & Sodium & 31 & 0.00968 & 0.25 & & $\mathrm{~J}$ & 062704-009 & SW846 3005 \\
\hline & $\begin{array}{l}\text { Alkalinity as } \\
\mathrm{CaCO} 3\end{array}$ & 95.5 & 1.45 & 2 & & & 062704-014 & EPA 310.1 \\
\hline & $\begin{array}{l}\text { bicarb as } \mathrm{CaCO} 3 \\
\text { Alkalinity }\end{array}$ & 95.2 & 1.45 & 2 & & & 062704-014 & EPA 310.1 \\
\hline
\end{tabular}




\begin{tabular}{|c|c|c|c|c|c|c|c|c|}
\hline Well ID & Analyte & $\begin{array}{l}\text { Result } \\
\text { (mg/L) }\end{array}$ & $\begin{array}{c}\mathrm{MDL} \\
(\mathrm{mg} / \mathrm{L})\end{array}$ & $\begin{array}{c}\mathrm{PQL} \\
(\mathrm{mg} / \mathrm{L})\end{array}$ & $\begin{array}{c}\text { Laboratory } \\
\text { Qualifier }\end{array}$ & $\begin{array}{c}\text { Validation } \\
\text { Qualifier } \\
\end{array}$ & Sample No. & $\begin{array}{c}\text { Analytical } \\
\text { Method }\end{array}$ \\
\hline & $\begin{array}{l}\text { carb as } \mathrm{CaCO} 3 \\
\text { Alkalinity }\end{array}$ & ND & 1.45 & 2 & $\mathrm{U}$ & & 062704-014 & EPA 310.1 \\
\hline TA2-W-27 & Bromide & 1.63 & 0.0978 & 0.2 & & & 062707-013 & SW846 9056 \\
\hline \multirow[t]{10}{*}{ 06-Aug-03 } & Chloride & 126 & 0.322 & 2 & & & 062707-013 & SW846 9056 \\
\hline & Fluoride & 0.292 & 0.0553 & 0.1 & & & 062707-013 & SW846 9056 \\
\hline & Sulfate & 168 & 1.93 & 4 & & & 062707-013 & SW846 9056 \\
\hline & Calcium & 134 & 0.04 & 0.1 & B & & 062707-009 & SW846 3005 \\
\hline & Magnesium & 18.7 & 0.00633 & 0.01 & & $\mathrm{~J}$ & 062707-009 & SW846 3005 \\
\hline & Potassium & 2.46 & 0.0151 & 0.3 & B & & 062707-009 & SW846 3005 \\
\hline & Sodium & 32.7 & 0.00968 & 0.25 & & $\mathrm{~J}$ & 062707-009 & SW846 3005 \\
\hline & $\begin{array}{l}\text { Alkalinity as } \\
\text { CaCO3 }\end{array}$ & 100 & 1.45 & 2 & & & 062707-014 & EPA 310.1 \\
\hline & $\begin{array}{l}\text { bicarb as } \mathrm{CaCO} 3 \\
\text { Alkalinity }\end{array}$ & 99.9 & 1.45 & 2 & & & 062707-014 & EPA 310.1 \\
\hline & $\begin{array}{l}\text { carb as } \mathrm{CaCO} 3 \\
\text { Alkalinity }\end{array}$ & ND & 1.45 & 2 & U & & 062707-014 & EPA 310.1 \\
\hline TJA-2 & Bromide & 0.912 & 0.0978 & 0.2 & & & 062709-013 & SW846 9056 \\
\hline \multirow[t]{10}{*}{ 31-Jul-03 } & Chloride & 70.9 & 0.161 & 1 & & & 062709-013 & SW846 9056 \\
\hline & Fluoride & 0.365 & 0.0553 & 0.1 & & & 062709-013 & SW846 9056 \\
\hline & Sulfate & 58.2 & 0.965 & 2 & & & 062709-013 & SW846 9056 \\
\hline & Calcium & 80.4 & 0.04 & 0.1 & & & 062709-009 & SW846 3005 \\
\hline & Magnesium & 13.1 & 0.00633 & 0.01 & & & 062709-009 & SW846 3005 \\
\hline & Potassium & 1.81 & 0.0151 & 0.3 & B & & 062709-009 & SW846 3005 \\
\hline & Sodium & 24.4 & 0.00968 & 0.25 & & $\mathrm{~J}$ & 062709-009 & SW846 3005 \\
\hline & $\begin{array}{l}\text { Alkalinity as } \\
\text { CaCO3 }\end{array}$ & 134 & 1.45 & 2 & & & 062709-014 & EPA 310.1 \\
\hline & $\begin{array}{l}\text { bicarb as } \mathrm{CaCO} 3 \\
\text { Alkalinity }\end{array}$ & 134 & 1.45 & 2 & & & 062709-014 & EPA 310.1 \\
\hline & $\begin{array}{l}\text { carb as } \mathrm{CaCO} 3 \\
\text { Alkalinity }\end{array}$ & ND & 1.45 & 2 & $u$ & & 062709-014 & EPA 310.1 \\
\hline TJA-3 & Bromide & 0.204 & 0.0978 & 0.2 & & & 062711-013 & SW846 9056 \\
\hline \multirow[t]{10}{*}{ 06-Aug-03 } & Chloride & 13.6 & 0.0322 & 0.2 & & & 062711-013 & SW846 9056 \\
\hline & Fluoride & 0.352 & 0.0553 & 0.1 & & & 062711-013 & SW846 9056 \\
\hline & Sulfate & 74.3 & 0.965 & 2 & & & 062711-013 & SW846 9056 \\
\hline & Calcium & 69 & 0.04 & 0.1 & B & & 062711-009 & SW846 3005 \\
\hline & Magnesium & 11 & 0.00633 & 0.01 & & $\mathrm{~J}$ & 062711-009 & SW846 3005 \\
\hline & Potassium & 2.07 & 0.0151 & 0.3 & B & & 062711-009 & SW846 3005 \\
\hline & Sodium & 26.5 & 0.00968 & 0.25 & & $\mathrm{~J}$ & 062711-009 & SW846 3005 \\
\hline & $\begin{array}{l}\text { Alkalinity as } \\
\text { CaCO3 }\end{array}$ & 184 & 1.45 & 2 & & & 062711-014 & EPA 310.1 \\
\hline & $\begin{array}{l}\text { bicarb as } \mathrm{CaCO} 3 \\
\text { Alkalinity }\end{array}$ & 184 & 1.45 & 2 & & & 062711-014 & EPA 310.1 \\
\hline & carb as $\mathrm{CaCO} 3$ & ND & 1.45 & 2 & $u$ & & 062711-014 & EPA 310.1 \\
\hline
\end{tabular}




\begin{tabular}{|c|c|c|c|c|c|c|c|c|}
\hline Well ID & Analyte & $\begin{array}{l}\text { Result } \\
\text { (mg/L) }\end{array}$ & $\begin{array}{c}\text { MDL } \\
\text { (mg/L) }\end{array}$ & $\begin{array}{c}\mathrm{PQL} \\
\text { (mg/L) }\end{array}$ & $\begin{array}{c}\text { Laboratory } \\
\text { Qualifier }\end{array}$ & $\begin{array}{c}\text { Validation } \\
\text { Qualifier }\end{array}$ & Sample No. & $\begin{array}{l}\text { Analytical } \\
\text { Method }\end{array}$ \\
\hline & Alkalinity & & & & & & & \\
\hline TJA-4 & Bromide & 0.355 & 0.0978 & 0.2 & & & 062713-013 & SW846 9056 \\
\hline \multirow[t]{10}{*}{ 11-Aug-03 } & Chloride & 21.6 & 0.0644 & 0.4 & & & 062713-013 & SW846 9056 \\
\hline & Fluoride & 0.403 & 0.0553 & 0.1 & & & 062713-013 & SW846 9056 \\
\hline & Sulfate & 19 & 0.193 & 0.4 & & & 062713-013 & SW846 9056 \\
\hline & Calcium & 64.5 & 0.04 & 0.1 & & & 062713-009 & SW846 3005 \\
\hline & Magnesium & 12.5 & 0.00633 & 0.01 & & & 062713-009 & SW846 3005 \\
\hline & Potassium & 3.11 & 0.0151 & 0.3 & B & & 062713-009 & SW846 3005 \\
\hline & Sodium & 22.9 & 0.00968 & 0.25 & & & 062713-009 & SW846 3005 \\
\hline & $\begin{array}{l}\text { Alkalinity as } \\
\text { CaCO3 }\end{array}$ & 110 & 1.45 & 2 & & & 062713-014 & EPA 310.1 \\
\hline & $\begin{array}{l}\text { bicarb as } \mathrm{CaCO} 3 \\
\text { Alkalinity }\end{array}$ & 110 & 1.45 & 2 & & & 062713-014 & EPA 310.1 \\
\hline & $\begin{array}{l}\text { carb as } \mathrm{CaCO} 3 \\
\text { Alkalinity }\end{array}$ & ND & 1.45 & 2 & $U$ & & 062713-014 & EPA 310.1 \\
\hline TJA-6 & Bromide & 0.227 & 0.0978 & 0.2 & & & 062715-013 & SW846 9056 \\
\hline \multirow[t]{10}{*}{ 11-Aug-03 } & Chloride & 14.8 & 0.0322 & 0.2 & & & 062715-013 & SW846 9056 \\
\hline & Fluoride & 0.409 & 0.0553 & 0.1 & & & 062715-013 & SW846 9056 \\
\hline & Sulfate & 62.1 & 0.965 & 2 & & & 062715-013 & SW846 9056 \\
\hline & Calcium & 61.3 & 0.04 & 0.1 & & & 062715-009 & SW846 3005 \\
\hline & Magnesium & 11.5 & 0.00633 & 0.01 & & & 062715-009 & SW846 3005 \\
\hline & Potassium & 2.21 & 0.0151 & 0.3 & B & & 062715-009 & SW846 3005 \\
\hline & Sodium & 22.3 & 0.00968 & 0.25 & & & 062715-009 & SW846 3005 \\
\hline & $\begin{array}{l}\text { Alkalinity as } \\
\text { CaCO3 }\end{array}$ & 115 & 1.45 & 2 & & & 062715-014 & EPA 310.1 \\
\hline & $\begin{array}{l}\text { bicarb as } \mathrm{CaCO} 3 \\
\text { Alkalinity }\end{array}$ & 115 & 1.45 & 2 & & & 062715-014 & EPA 310.1 \\
\hline & $\begin{array}{l}\text { carb as } \mathrm{CaCO} 3 \\
\text { Alkalinity }\end{array}$ & ND & 1.45 & 2 & 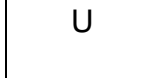 & & 062715-014 & EPA 310.1 \\
\hline TJA-7 & Bromide & 0.373 & 0.978 & 2 & & & 062717-013 & SW846 9056 \\
\hline \multirow[t]{10}{*}{ 12-Aug-03 } & Chloride & 30.3 & 0.322 & 2 & & & 062717-013 & SW846 9056 \\
\hline & Fluoride & 0.273 & 0.0553 & 0.1 & & & 062717-013 & SW846 9056 \\
\hline & Sulfate & 15.7 & 0.193 & 0.4 & & & $062717-013$ & SW846 9056 \\
\hline & Calcium & 71.4 & 0.04 & 0.1 & B & & 062717-009 & SW846 3005 \\
\hline & Magnesium & 11.3 & 0.00633 & 0.01 & & $\mathrm{~J}$ & 062717-009 & SW846 3005 \\
\hline & Potassium & 2.14 & 0.0151 & 0.3 & & & 062717-009 & SW846 3005 \\
\hline & Sodium & 19.7 & 0.00968 & 0.25 & & & 062717-009 & SW846 3005 \\
\hline & $\begin{array}{l}\text { Alkalinity as } \\
\text { CaCO3 }\end{array}$ & 44.8 & 1.45 & 2 & & & 062717-014 & EPA 310.1 \\
\hline & $\begin{array}{l}\text { bicarb as } \mathrm{CaCO} 3 \\
\text { Alkalinity }\end{array}$ & 44.8 & 1.45 & 2 & & & 062717-014 & EPA 310.1 \\
\hline & $\begin{array}{l}\text { carb as } \mathrm{CaCO} 3 \\
\text { Alkalinity }\end{array}$ & ND & 1.45 & 2 & $U$ & & 062717-014 & EPA 310.1 \\
\hline
\end{tabular}




\begin{tabular}{|c|c|c|c|c|c|c|c|c|}
\hline Well ID & Analyte & $\begin{array}{l}\text { Result } \\
\text { (mg/L) }\end{array}$ & $\begin{array}{c}\text { MDL } \\
(\mathrm{mg} / \mathrm{L})\end{array}$ & $\begin{array}{c}\mathrm{PQL} \\
(\mathrm{mg} / \mathrm{L})\end{array}$ & $\begin{array}{c}\text { Laboratory } \\
\text { Qualifier }\end{array}$ & \begin{tabular}{|c|} 
Validation \\
Qualifier \\
\end{tabular} & Sample No. & $\begin{array}{c}\text { Analytical } \\
\text { Method }\end{array}$ \\
\hline WYO-3 & Bromide & 0.147 & 0.0978 & 0.2 & $\mathrm{~J}$ & & 062719-013 & SW846 9056 \\
\hline \multirow[t]{10}{*}{ 13-Aug-03 } & Chloride & 15.2 & 0.0322 & 0.2 & & & 062719-013 & SW846 9056 \\
\hline & Fluoride & 0.309 & 0.0553 & 0.1 & & & 062719-013 & SW846 9056 \\
\hline & Sulfate & 82 & 0.965 & 2 & & & 062719-013 & SW846 9056 \\
\hline & Calcium & 66.5 & 0.04 & 0.1 & B & & 062719-009 & SW846 3005 \\
\hline & Magnesium & 11.6 & 0.00633 & 0.01 & & $\mathrm{~J}$ & 062719-009 & SW846 3005 \\
\hline & Potassium & 2.22 & 0.0151 & 0.3 & & & 062719-009 & SW846 3005 \\
\hline & Sodium & 25.9 & 0.00968 & 0.25 & & & 062719-009 & SW846 3005 \\
\hline & $\begin{array}{l}\text { Alkalinity as } \\
\text { CaCO3 }\end{array}$ & 189 & 1.45 & 2 & & & 062719-014 & EPA 310.1 \\
\hline & $\begin{array}{l}\text { bicarb as } \mathrm{CaCO} 3 \\
\text { Alkalinity }\end{array}$ & 188 & 1.45 & 2 & & & 062719-014 & EPA 310.1 \\
\hline & $\begin{array}{l}\text { carb as } \mathrm{CaCO} 3 \\
\text { Alkalinity }\end{array}$ & 1.69 & 1.45 & 2 & $\mathrm{~J}$ & & 062719-014 & EPA 310.1 \\
\hline WYO-4 & Bromide & 1.04 & 0.0978 & 0.2 & & & 062721-013 & SW846 9056 \\
\hline \multirow[t]{10}{*}{ 14-Aug-03 } & Chloride & 101 & 0.322 & 2 & & & 062721-013 & SW846 9056 \\
\hline & Fluoride & 0.264 & 0.0553 & 0.1 & & & 062721-013 & SW846 9056 \\
\hline & Sulfate & 57 & 1.93 & 4 & & & 062721-013 & SW846 9056 \\
\hline & Calcium & 81.8 & 0.04 & 0.1 & B & & 062721-009 & SW846 3005 \\
\hline & Magnesium & 11.8 & 0.00633 & 0.01 & & $\mathrm{~J}$ & 062721-009 & SW846 3005 \\
\hline & Potassium & 1.93 & 0.0151 & 0.3 & & & 062721-009 & SW846 3005 \\
\hline & Sodium & 20.2 & 0.00968 & 0.25 & & & 062721-009 & SW846 3005 \\
\hline & $\begin{array}{l}\text { Alkalinity as } \\
\text { CaCO3 }\end{array}$ & 97.8 & 1.45 & 2 & & & 062721-014 & EPA 310.1 \\
\hline & $\begin{array}{l}\text { bicarb as } \mathrm{CaCO} 3 \\
\text { Alkalinity }\end{array}$ & 97.5 & 1.45 & 2 & & & 062721-014 & EPA 310.1 \\
\hline & $\begin{array}{l}\text { carb as } \mathrm{CaCO} 3 \\
\text { Alkalinity }\end{array}$ & ND & 1.45 & 2 & $U$ & & 062721-014 & EPA 310.1 \\
\hline
\end{tabular}


Table A-15

Summary of Anion, Cation, and Alkalinity Results

Tijeras Arroyo Groundwater Investigation

Fiscal Year 2004, $1^{\text {st }}$ Quarter

\begin{tabular}{|c|c|c|c|c|c|c|c|c|}
\hline \begin{tabular}{|l} 
Well ID \\
\end{tabular} & Analyte & $\begin{array}{l}\text { Result } \\
\text { (mg/L) }\end{array}$ & $\begin{array}{c}\mathrm{MDL} \\
(\mathrm{mg} / \mathrm{L})\end{array}$ & $\begin{array}{c}\text { PQL } \\
\text { (mg/L) }\end{array}$ & $\begin{array}{l}\text { Laboratory } \\
\text { Qualifier }\end{array}$ & $\begin{array}{c}\text { Validation } \\
\text { Qualifier }\end{array}$ & Sample No. & $\begin{array}{c}\text { Analytical } \\
\text { Method }\end{array}$ \\
\hline Eubank-1 & Bromide & 0.104 & 0.0978 & 0.2 & $\mathrm{~J}$ & & 063303-013 & SW846 9056 \\
\hline \multirow[t]{10}{*}{ 10-Nov-03 } & Chloride & 12.1 & 0.0322 & 0.2 & & & 063303-013 & SW846 9056 \\
\hline & Fluoride & 0.334 & 0.0553 & 0.1 & & & 063303-013 & SW846 9056 \\
\hline & Sulfate & 76.2 & 0.965 & 2 & & & 063303-013 & SW846 9056 \\
\hline & Calcium & 71.1 & 0.04 & 0.1 & & & 063303-009 & SW846 3005 \\
\hline & Magnesium & 10.5 & 0.00633 & 0.01 & & $\mathrm{~J}$ & 063303-009 & SW846 3005 \\
\hline & Potassium & 1.63 & \begin{tabular}{|l|}
0.0151 \\
\end{tabular} & 0.3 & & & |063303-009 & SW846 3005 \\
\hline & Sodium & 24.2 & 0.00968 & 0.25 & & & 063303-009 & SW846 3005 \\
\hline & $\begin{array}{l}\text { Total Alkalinity } \\
\text { as CaCO3 }\end{array}$ & 171 & 1.45 & 2 & & & 063303-014 & EPA 310.1 \\
\hline & \begin{tabular}{|l|} 
Alkalinity as \\
HCO3
\end{tabular} & 169 & 1.45 & 2 & & & 063303-014 & EPA 310.1 \\
\hline & Alkalinity as $\mathrm{CO} 3$ & ND & 1.45 & 2 & U & & 063303-014 & EPA 310.1 \\
\hline Eubank-2 & Bromide & 0.110 & 0.0978 & 0.2 & $\mathrm{~J}$ & & 063304-013 & SW846 9056 \\
\hline \multirow[t]{10}{*}{ 12-Nov-03 } & Chloride & 12.4 & 0.0322 & 0.2 & & & 063304-013 & SW846 9056 \\
\hline & Fluoride & 0.264 & 0.0553 & 0.1 & & & 063304-013 & SW846 9056 \\
\hline & Sulfate & 91.6 & 1.93 & 4 & & & 063304-013 & SW846 9056 \\
\hline & Calcium & 80.8 & 0.04 & 0.1 & & & 063304-009 & SW846 3005 \\
\hline & Magnesium & 12.4 & 0.00633 & 0.01 & & $\mathrm{~J}$ & 063304-009 & SW846 3005 \\
\hline & Potassium & 2.04 & 0.0151 & 0.3 & & & 063304-009 & SW846 3005 \\
\hline & Sodium & 32.8 & 0.00968 & 0.25 & & & 063304-009 & SW846 3005 \\
\hline & $\begin{array}{l}\text { Total Alkalinity } \\
\text { as CaCO3 }\end{array}$ & 237 & 1.45 & 2 & & & 063304-014 & EPA 310.1 \\
\hline & \begin{tabular}{|l|} 
Alkalinity as \\
HCO3
\end{tabular} & 237 & 1.45 & 2 & & & 063304-014 & EPA 310.1 \\
\hline & Alkalinity as $\mathrm{CO} 3$ & ND & 1.45 & 2 & $U$ & & 063304-014 & EPA 310.1 \\
\hline Eubank-3 & Bromide & 0.143 & 0.0978 & 0.2 & $\mathrm{~J}$ & & 063305-013 & SW846 9056 \\
\hline \multirow[t]{10}{*}{ 18-Nov-03 } & Chloride & 21.2 & 0.0644 & 0.4 & & & 063305-013 & SW846 9056 \\
\hline & Fluoride & 0.322 & 0.0553 & 0.1 & & & 063305-013 & SW846 9056 \\
\hline & Sulfate & 93.0 & 0.965 & 2 & & & 063305-013 & SW846 9056 \\
\hline & Calcium & 82.6 & 0.04 & 0.1 & & & 063305-009 & SW846 3005 \\
\hline & Magnesium & 12.9 & 0.00633 & 0.01 & & & 063305-009 & SW846 3005 \\
\hline & Potassium & 2.03 & 0.0151 & 0.3 & $B$ & & 063305-009 & SW846 3005 \\
\hline & Sodium & 32.1 & 0.00968 & 0.25 & $\mathrm{~B}$ & & 063305-009 & SW846 3005 \\
\hline & $\begin{array}{l}\text { Total Alkalinity } \\
\text { as CaCO3 }\end{array}$ & 200 & 1.45 & 2 & & & $063305-014$ & EPA 310.1 \\
\hline & \begin{tabular}{|l|} 
Alkalinity as \\
HCO3
\end{tabular} & 200 & 1.45 & 2 & & & $063305-014$ & EPA 310.1 \\
\hline & Alkalinity as $\mathrm{CO} 3$ & ND & 1.45 & 2 & $U$ & & $063305-014$ & EPA 310.1 \\
\hline Eubank-5 & Bromide & 0.250 & 0.0978 & 0.2 & & & 063306-013 & SW846 9056 \\
\hline \multirow[t]{5}{*}{ 19-Nov-03 } & Chloride & 24.3 & 0.161 & 1 & & & 063306-013 & SW846 9056 \\
\hline & Fluoride & 0.310 & 0.0553 & 0.1 & & & 063306-013 & SW846 9056 \\
\hline & Sulfate & 90.9 & 0.965 & 2 & & & $063306-013$ & SW846 9056 \\
\hline & Calcium & 86.4 & 0.04 & 0.1 & B & & 063306-009 & SW846 3005 \\
\hline & Magnesium & 11.1 & 0.00633 & 0.01 & & & 063306-009 & SW846 3005 \\
\hline
\end{tabular}




\begin{tabular}{|c|c|c|c|c|c|c|c|c|}
\hline Well ID & Analyte & $\begin{array}{l}\text { Result } \\
\text { (mg/L) }\end{array}$ & $\begin{array}{c}\text { MDL } \\
\text { (mg/L) }\end{array}$ & $\begin{array}{c}\text { PQL } \\
\text { (mg/L) }\end{array}$ & $\begin{array}{l}\text { Laboratory } \\
\text { Qualifier }\end{array}$ & $\begin{array}{c}\text { Validation } \\
\text { Qualifier }\end{array}$ & Sample No. & $\begin{array}{c}\text { Analytical } \\
\text { Method }\end{array}$ \\
\hline & Potassium & 1.79 & 0.0151 & 0.3 & & & 063306-009 & SW846 3005 \\
\hline & Sodium & 28.8 & 0.00968 & 0.25 & $B$ & & 063306-009 & SW846 3005 \\
\hline & $\begin{array}{l}\text { Total Alkalinity } \\
\text { as CaCO3 }\end{array}$ & 199 & 1.45 & 2 & & & 063306-014 & EPA 310.1 \\
\hline & $\begin{array}{l}\text { Alkalinity as } \\
\text { HCO3 }\end{array}$ & 198 & 1.45 & 2 & & & 063306-014 & EPA 310.1 \\
\hline & Alkalinity as $\mathrm{CO} 3$ & ND & 1.45 & 2 & $U$ & & 063306-014 & EPA 310.1 \\
\hline \multirow{11}{*}{$\begin{array}{l}\text { PGS-2 } \\
10-\text { Nov-03 }\end{array}$} & Bromide & 0.107 & 0.0978 & 0.2 & $\mathrm{~J}$ & & 063278-013 & SW846 9056 \\
\hline & Chloride & 13.1 & 0.0322 & 0.2 & & & 063278-013 & SW846 9056 \\
\hline & Fluoride & 0.107 & 0.0553 & 0.1 & & & 063278-013 & SW846 9056 \\
\hline & Sulfate & 58.6 & 0.965 & 2 & & & 063278-013 & SW846 9056 \\
\hline & Calcium & 50.9 & 0.04 & 0.1 & & & 063278-009 & SW846 3005 \\
\hline & Magnesium & 10.8 & 0.00633 & 0.01 & & $\mathrm{~J}$ & 063278-009 & SW846 3005 \\
\hline & Potassium & 2.41 & 0.0151 & 0.3 & & & 063278-009 & SW846 3005 \\
\hline & Sodium & 33.4 & 0.00968 & 0.25 & & & 063278-009 & SW846 3005 \\
\hline & $\begin{array}{l}\text { Total Alkalinity } \\
\text { as CaCO3 }\end{array}$ & 159 & 1.45 & 2 & & & 063278-014 & EPA 310.1 \\
\hline & $\begin{array}{l}\text { Alkalinity as } \\
\text { HCO3 }\end{array}$ & 155 & 1.45 & 2 & & & 063278-014 & EPA 310.1 \\
\hline & Alkalinity as CO3 & 3.34 & 1.45 & 2 & & & 063278-014 & EPA 310.1 \\
\hline \multirow{11}{*}{$\begin{array}{l}\text { TA1-W-01 } \\
\text { 06-Nov-03 }\end{array}$} & Bromide & 0.190 & 0.0978 & 0.2 & $\mathrm{~J}$ & B3, J & 063279-013 & SW846 9056 \\
\hline & Chloride & 14.9 & 0.0322 & 0.2 & & & 063279-013 & SW846 9056 \\
\hline & Fluoride & 0.419 & 0.0553 & 0.1 & & & 063279-013 & SW846 9056 \\
\hline & Sulfate & 77.7 & 0.965 & 2 & & & 063279-013 & SW846 9056 \\
\hline & Calcium & 71.7 & 0.04 & 0.1 & & & 063279-009 & SW846 3005 \\
\hline & Magnesium & 12.6 & 0.00633 & 0.01 & & & 063279-009 & SW846 3005 \\
\hline & Potassium & 2.44 & 0.0151 & 0.3 & & & 063279-009 & SW846 3005 \\
\hline & \begin{tabular}{|l|} 
Sodium \\
\end{tabular} & 28.6 & 0.00968 & 0.25 & B & $\mathrm{J}$ & 063279-009 & SW846 3005 \\
\hline & $\begin{array}{l}\text { Total Alkalinity } \\
\text { as CaCO3 }\end{array}$ & 176 & 1.45 & 2 & & & 063279-014 & EPA 310.1 \\
\hline & \begin{tabular}{|l|} 
Alkalinity as \\
HCO3
\end{tabular} & 175 & 1.45 & 2 & & & 063279-014 & EPA 310.1 \\
\hline & Alkalinity as $\mathrm{CO} 3$ & ND & 1.45 & 2 & $\mathrm{U}$ & & 063279-014 & EPA 310.1 \\
\hline \multirow{11}{*}{$\begin{array}{l}\text { TA1-W-02 } \\
\text { o8-Oct-03 }\end{array}$} & Bromide & 0.137 & 0.0978 & 0.2 & $\mathrm{~J}$ & & 063280-013 & SW846 9056 \\
\hline & Chloride & 13.8 & 0.0322 & 0.2 & & & 063280-013 & SW846 9056 \\
\hline & Fluoride & 0.323 & 0.0553 & 0.1 & & & 063280-013 & SW846 9056 \\
\hline & Sulfate & 78.8 & 1.93 & 4 & & & $063280-013$ & SW846 9056 \\
\hline & Calcium & 72.0 & 0.04 & 0.1 & & $\mathrm{~J}$ & 063280-009 & SW846 3005 \\
\hline & Magnesium & 13.2 & 0.00633 & 0.01 & & & 063280-009 & SW846 3005 \\
\hline & Potassium & 2.08 & \begin{tabular}{|l|}
0.0151 \\
\end{tabular} & 0.3 & & & 063280-009 & SW846 3005 \\
\hline & Sodium & 23.4 & 0.00968 & 0.25 & & & 063280-009 & SW846 3005 \\
\hline & $\begin{array}{l}\text { Total Alkalinity } \\
\text { as CaCO3 }\end{array}$ & 165 & 1.45 & 2 & & & $063280-014$ & EPA 310.1 \\
\hline & $\begin{array}{l}\text { Alkalinity as } \\
\mathrm{HCO} 3\end{array}$ & 165 & 1.45 & 2 & & & 063280-014 & EPA 310.1 \\
\hline & Alkalinity as $\mathrm{CO} 3$ & ND & 1.45 & 2 & $\mathrm{U}$ & & 063280-014 & EPA 310.1 \\
\hline \multirow{8}{*}{$\begin{array}{l}\text { TA1-W-03 } \\
13-O c t-03\end{array}$} & Bromide & 3.03 & 0.0978 & 0.2 & & & 063281-013 & SW846 9056 \\
\hline & Chloride & 234 & 1.61 & 10 & & & 063281-013 & SW846 9056 \\
\hline & Fluoride & 0.261 & 0.0553 & 0.1 & & & 063281-013 & SW846 9056 \\
\hline & Sulfate & 461 & 9.65 & 20 & & & 063281-013 & SW846 9056 \\
\hline & Calcium & 298 & 0.2 & 0.5 & & & 063281-009 & SW846 3005 \\
\hline & Magnesium & 31.8 & 0.00633 & 0.01 & & & 063281-009 & SW846 3005 \\
\hline & Potassium & 2.61 & 0.0151 & 0.3 & & & 063281-009 & SW846 3005 \\
\hline & Sodium & 45.0 & 0.00968 & 0.25 & B & & 063281-009 & SW846 3005 \\
\hline
\end{tabular}




\begin{tabular}{|c|c|c|c|c|c|c|c|c|}
\hline Well ID & \begin{tabular}{|l} 
Analyte \\
\end{tabular} & $\begin{array}{l}\text { Result } \\
\text { (mg/L) }\end{array}$ & $\begin{array}{c}\mathrm{MDL} \\
(\mathrm{mg} / \mathrm{L})\end{array}$ & $\begin{array}{c}\mathrm{PQL} \\
(\mathrm{mg} / \mathrm{L})\end{array}$ & $\begin{array}{l}\text { Laboratory } \\
\text { Qualifier }\end{array}$ & $\begin{array}{c}\text { Validation } \\
\text { Qualifier } \\
\end{array}$ & Sample No. & $\begin{array}{c}\text { Analytical } \\
\text { Method }\end{array}$ \\
\hline & $\begin{array}{l}\text { Total Alkalinity } \\
\text { as CaCO3 }\end{array}$ & 67.1 & 1.45 & 2 & & & 063281-014 & EPA 310.1 \\
\hline & \begin{tabular}{|l|} 
Alkalinity as \\
HCO3
\end{tabular} & 66.8 & 1.45 & 2 & & & 063281-014 & EPA 310.1 \\
\hline & Alkalinity as $\mathrm{CO} 3$ & ND & 1.45 & 2 & $\mathrm{U}$ & & 063281-014 & EPA 310.1 \\
\hline TA1-W-04 & Bromide & 0.213 & 0.0978 & 0.2 & & & $063282-013$ & SW846 9056 \\
\hline \multirow[t]{10}{*}{ 14-Oct-03 } & Chloride & 16.7 & 0.0322 & 0.2 & & & 063282-013 & SW846 9056 \\
\hline & Fluoride & 0.360 & 0.0553 & 0.1 & & & 063282-013 & SW846 9056 \\
\hline & Sulfate & 65.0 & 0.965 & 2 & & & $063282-013$ & SW846 9056 \\
\hline & Calcium & 68.2 & 0.04 & 0.1 & & & 063282-009 & SW846 3005 \\
\hline & Magnesium & 11.9 & 0.00633 & 0.01 & & & $063282-009$ & SW846 3005 \\
\hline & Potassium & 2.39 & 0.0151 & 0.3 & & & $063282-009$ & SW846 3005 \\
\hline & Sodium & 24.5 & 0.00968 & 0.25 & B & & 063282-009 & SW846 3005 \\
\hline & $\begin{array}{l}\text { Total Alkalinity } \\
\text { as CaCO3 }\end{array}$ & 186 & 1.45 & 2 & & & $063282-014$ & EPA 310.1 \\
\hline & \begin{tabular}{|l|} 
Alkalinity as \\
HCO3
\end{tabular} & 185 & 1.45 & 2 & & & 063282-014 & EPA 310.1 \\
\hline & Alkalinity as $\mathrm{CO} 3$ & ND & 1.45 & 2 & $U$ & & 063282-014 & EPA 310.1 \\
\hline TA1-W-05 & Bromide & 0.121 & 0.0978 & 0.2 & $\mathrm{~J}$ & & 063283-013 & SW846 9056 \\
\hline \multirow[t]{10}{*}{ 20-Oct-03 } & Chloride & 12.3 & 0.0322 & 0.2 & & & 063283-013 & SW846 9056 \\
\hline & Fluoride & 0.224 & 0.0553 & 0.1 & & & 063283-013 & SW846 9056 \\
\hline & Sulfate & 99.5 & 0.965 & 2 & & & 063283-013 & SW846 9056 \\
\hline & Calcium & 81.6 & 0.04 & 0.1 & & & 063283-009 & SW846 3005 \\
\hline & Magnesium & 11.0 & 0.00633 & 0.01 & & $\mathrm{~J}$ & 063283-009 & SW846 3005 \\
\hline & Potassium & 2.0 & 0.0151 & 0.3 & & & $063283-009$ & SW846 3005 \\
\hline & Sodium & 26.1 & 0.00968 & 0.25 & & & 063283-009 & SW846 3005 \\
\hline & $\begin{array}{l}\text { Total Alkalinity } \\
\text { as CaCO3 }\end{array}$ & 236 & 1.45 & 2 & & & 063283-014 & EPA 310.1 \\
\hline & \begin{tabular}{|l|} 
Alkalinity as \\
HCO3
\end{tabular} & 236 & 1.45 & 2 & & & 063283-014 & EPA 310.1 \\
\hline & Alkalinity as $\mathrm{CO} 3$ & ND & 1.45 & 2 & $\mathrm{U}$ & & 063283-014 & EPA 310.1 \\
\hline TA1-W-06 & Bromide & 1.19 & 0.0978 & 0.2 & & & 063284-013 & SW846 9056 \\
\hline \multirow[t]{10}{*}{ 09-Oct-03 } & Chloride & 100 & 0.322 & 2 & & & 063284-013 & SW846 9056 \\
\hline & Fluoride & 0.291 & 0.0553 & 0.1 & & & 063284-013 & SW846 9056 \\
\hline & Sulfate & 192 & 1.93 & 4 & & & 063284-013 & SW846 9056 \\
\hline & Calcium & 126 & 0.04 & 0.1 & & $\mathrm{~J}$ & 063284-009 & SW846 3005 \\
\hline & Magnesium & 15.6 & 0.00633 & 0.01 & & & 063284-009 & SW846 3005 \\
\hline & Potassium & 2.02 & 0.0151 & 0.3 & & & 063284-009 & SW846 3005 \\
\hline & Sodium & 31.7 & 0.00968 & 0.25 & & & 063284-009 & SW846 3005 \\
\hline & $\begin{array}{l}\text { Total Alkalinity } \\
\text { as CaCO3 }\end{array}$ & 85.1 & 1.45 & 2 & & & 063284-014 & EPA 310.1 \\
\hline & \begin{tabular}{|l|} 
Alkalinity as \\
HCO3
\end{tabular} & 84.7 & 1.45 & 2 & & & 063284-014 & EPA 310.1 \\
\hline & Alkalinity as CO3 & ND & 1.45 & 2 & $\mathrm{U}$ & & 063284-014 & EPA 310.1 \\
\hline TA1-W-08 & Bromide & 2.51 & 0.0978 & 0.2 & & & $063285-013$ & SW846 9056 \\
\hline \multirow[t]{8}{*}{ 21-Oct-03 } & Chloride & 198 & 3.22 & 20 & & & 063285-013 & SW846 9056 \\
\hline & Fluoride & 0.167 & 0.0553 & 0.1 & & & $063285-013$ & SW846 9056 \\
\hline & Sulfate & 600 & 19.3 & 40 & & & 063285-013 & SW846 9056 \\
\hline & Calcium & 321 & 0.2 & 0.5 & & & 063285-009 & SW846 3005 \\
\hline & Magnesium & 40.6 & 0.00633 & 0.01 & & $\mathrm{~J}$ & 063285-009 & SW846 3005 \\
\hline & Potassium & 2.93 & 0.0151 & 0.3 & & & 063285-009 & SW846 3005 \\
\hline & Sodium & 75.3 & 0.00968 & 0.25 & & & 063285-009 & SW846 3005 \\
\hline & $\begin{array}{l}\text { Total Alkalinity } \\
\text { as } \mathrm{CaCO} 3\end{array}$ & 97.8 & 1.45 & 2 & & & $063285-014$ & EPA 310.1 \\
\hline
\end{tabular}




\begin{tabular}{|c|c|c|c|c|c|c|c|c|}
\hline Well ID & Analyte & $\begin{array}{l}\text { Result } \\
\text { (mg/L) }\end{array}$ & $\begin{array}{c}\text { MDL } \\
\text { (mg/L) }\end{array}$ & $\begin{array}{c}\text { PQL } \\
\text { (mg/L) }\end{array}$ & $\begin{array}{c}\text { Laboratory } \\
\text { Qualifier }\end{array}$ & \begin{tabular}{|c|} 
Validation \\
Qualifier
\end{tabular} & Sample No. & $\begin{array}{c}\text { Analytical } \\
\text { Method }\end{array}$ \\
\hline & $\begin{array}{l}\text { Alkalinity as } \\
\text { HCO3 }\end{array}$ & 97.3 & 1.45 & 2 & & & 063285-014 & EPA 310.1 \\
\hline & Alkalinity as $\mathrm{CO} 3$ & ND & 1.45 & 2 & $\mathrm{U}$ & & 063285-014 & EPA 310.1 \\
\hline $\begin{array}{l}\text { TA2-NW1-595 } \\
\text { (QED) }\end{array}$ & Bromide & 0.914 & 0.0978 & 0.2 & & & 063287-013 & SW846 9056 \\
\hline \multirow[t]{10}{*}{ 12-Nov-03 } & Chloride & 88.0 & 0.322 & 2 & & & |063287-013 & SW846 9056 \\
\hline & Fluoride & 0.247 & 0.0553 & 0.1 & & & 063287-013 & SW846 9056 \\
\hline & Sulfate & 121 & 1.93 & 4 & & & 063287-013 & SW846 9056 \\
\hline & Calcium & 110 & 0.04 & 0.1 & & & 063287-009 & SW846 3005 \\
\hline & Magnesium & 18.5 & 0.00633 & 0.01 & & $\mathrm{~J}$ & 063287-009 & SW846 3005 \\
\hline & Potassium & 2.24 & 0.0151 & 0.3 & & & 063287-009 & SW846 3005 \\
\hline & Sodium & 35.4 & 0.00968 & 0.25 & & & 063287-009 & SW846 3005 \\
\hline & $\begin{array}{l}\text { Total Alkalinity } \\
\text { as CaCO3 }\end{array}$ & 147 & 1.45 & 2 & & & 063287-014 & EPA 310.1 \\
\hline & \begin{tabular}{|l|} 
Alkalinity as \\
$\mathrm{HCO} 3$
\end{tabular} & 146 & 1.45 & 2 & & & 063287-014 & EPA 310.1 \\
\hline & Alkalinity as $\mathrm{CO} 3$ & ND & 1.45 & 2 & $U$ & & |063287-014 & EPA 310.1 \\
\hline $\begin{array}{l}\text { TA2-NW1-595 } \\
\text { (Bennett) }\end{array}$ & Bromide & 0.929 & 0.0978 & 0.2 & & & 063288-013 & SW846 9056 \\
\hline \multirow[t]{10}{*}{ 11-Nov-03 } & Chloride & 85.8 & 0.322 & 2 & & & 063288-013 & SW846 9056 \\
\hline & Fluoride & 0.235 & 0.0553 & 0.1 & & & 063288-013 & SW846 9056 \\
\hline & Sulfate & 120 & 1.93 & 4 & & & 063288-013 & SW846 9056 \\
\hline & Calcium & 107 & 0.04 & 0.1 & & & 063288-009 & SW846 3005 \\
\hline & Magnesium & 17.8 & 0.00633 & 0.01 & & $\mathrm{~J}$ & 063288-009 & SW846 3005 \\
\hline & Potassium & 2.11 & 0.0151 & 0.3 & & & 063288-009 & SW846 3005 \\
\hline & Sodium & 32.0 & 0.00968 & 0.25 & & & 063288-009 & SW846 3005 \\
\hline & $\begin{array}{l}\text { Total Alkalinity } \\
\text { as CaCO3 }\end{array}$ & 289 & 2.90 & 4 & & & 063288-014 & EPA 310.1 \\
\hline & \begin{tabular}{|l|} 
Alkalinity as \\
HCO3
\end{tabular} & 288 & 2.90 & 4 & & & 063288-014 & EPA 310.1 \\
\hline & Alkalinity as $\mathrm{CO} 3$ & ND & 2.90 & 4 & $\mathrm{U}$ & & 063288-014 & EPA 310.1 \\
\hline \multirow{11}{*}{$\begin{array}{l}\text { TA2-SW1-320 } \\
11-N o v-03\end{array}$} & Bromide & 0.267 & 0.0978 & 0.2 & & & 063289-013 & SW846 9056 \\
\hline & Chloride & 24.4 & 0.161 & 1 & & & 063289-013 & SW846 9056 \\
\hline & Fluoride & 0.379 & 0.0553 & 0.1 & & & 063289-013 & SW846 9056 \\
\hline & Sulfate & 15.9 & 0.193 & 0.4 & & & 063289-013 & SW846 9056 \\
\hline & Calcium & 64.9 & 0.04 & 0.1 & & & 063289-009 & SW846 3005 \\
\hline & Magnesium & 11.5 & 0.00633 & 0.01 & & $\mathrm{~J}$ & 063289-009 & SW846 3005 \\
\hline & Potassium & 1.78 & 0.0151 & 0.3 & & & 063289-009 & SW846 3005 \\
\hline & Sodium & 19.6 & 0.00968 & 0.25 & & & 063289-009 & SW846 3005 \\
\hline & $\begin{array}{l}\text { Total Alkalinity } \\
\text { as CaCO3 } \\
\end{array}$ & 229 & 2.90 & 4 & & & 063289-014 & EPA 310.1 \\
\hline & \begin{tabular}{|l|} 
Alkalinity as \\
HCO3
\end{tabular} & 228 & 2.90 & 4 & & & 063289-014 & EPA 310.1 \\
\hline & Alkalinity as $\mathrm{CO} 3$ & ND & 2.90 & 4 & $\mathrm{U}$ & & 063289-014 & EPA 310.1 \\
\hline TA2-W-01 & Bromide & 1.34 & 0.0978 & 0.2 & & & 063290-013 & SW846 9056 \\
\hline \multirow[t]{9}{*}{ 01-Dec-03 } & Chloride & 110 & 0.322 & 2 & & & 063290-013 & SW846 9056 \\
\hline & Fluoride & ND & 0.0553 & 0.1 & $\mathrm{U}$ & & 063290-013 & SW846 9056 \\
\hline & Sulfate & 47.1 & 1.93 & 4 & & & 063290-013 & SW846 9056 \\
\hline & Calcium & 82.1 & 0.04 & 0.1 & & & 063290-009 & SW846 3005 \\
\hline & Magnesium & 9.77 & 0.00633 & 0.01 & & & 063290-009 & SW846 3005 \\
\hline & Potassium & 1.80 & 0.0151 & 0.3 & $B$ & & 063290-009 & SW846 3005 \\
\hline & Sodium & 19.5 & 0.00968 & 0.25 & B & $\mathrm{J}$ & 063290-009 & SW846 3005 \\
\hline & $\begin{array}{l}\text { Total Alkalinity } \\
\text { as } \mathrm{CaCO} 3\end{array}$ & 88.8 & 1.45 & 2 & & & 063290-014 & EPA 310.1 \\
\hline & Alkalinity as & 88.2 & 1.45 & 2 & & & 063290-014 & EPA 310.1 \\
\hline
\end{tabular}




\begin{tabular}{|c|c|c|c|c|c|c|c|c|}
\hline Well ID & Analyte & $\begin{array}{l}\text { Result } \\
\text { (mg/L) }\end{array}$ & $\begin{array}{c}\text { MDL } \\
\text { (mg/L) }\end{array}$ & $\begin{array}{c}\mathrm{PQL} \\
\text { (mg/L) }\end{array}$ & $\begin{array}{l}\text { Laboratory } \\
\text { Qualifier }\end{array}$ & $\begin{array}{c}\text { Validation } \\
\text { Qualifier }\end{array}$ & Sample No. & $\begin{array}{l}\text { Analytical } \\
\text { Method }\end{array}$ \\
\hline & $\mathrm{HCO} 3$ & & & & & & & \\
\hline & Alkalinity as $\mathrm{CO} 3$ & ND & 1.45 & 2 & $\mathrm{U}$ & & 063290-014 & EPA 310.1 \\
\hline TA2-W-19 & Bromide & 0.904 & 0.0978 & 0.2 & & B3, J & 063291-013 & SW846 9056 \\
\hline \multirow[t]{10}{*}{ 07-Oct-03 } & Chloride & 78.8 & 0.322 & 2 & & & 063291-013 & SW846 9056 \\
\hline & Fluoride & 0.287 & 0.0553 & 0.1 & & & 063291-013 & SW846 9056 \\
\hline & Sulfate & 48.3 & 1.93 & 4 & & & 063291-013 & SW846 9056 \\
\hline & Calcium & 83.9 & $\begin{array}{ll}0.04 \\
\end{array}$ & 0.1 & & $\mathrm{~J}$ & 063291-009 & SW846 3005 \\
\hline & Magnesium & 12.2 & 0.00633 & 0.01 & & & 063291-009 & SW846 3005 \\
\hline & Potassium & 1.82 & 0.0151 & 0.3 & & & 063291-009 & SW846 3005 \\
\hline & Sodium & 22.8 & 0.00968 & 0.25 & & & 063291-009 & SW846 3005 \\
\hline & $\begin{array}{l}\text { Total Alkalinity } \\
\text { as CaCO3 }\end{array}$ & 98.1 & 1.45 & 2 & & & 063291-014 & EPA 310.1 \\
\hline & \begin{tabular}{|l|} 
Alkalinity as \\
HCO3
\end{tabular} & 97.7 & 1.45 & 2 & & & 063291-014 & EPA 310.1 \\
\hline & Alkalinity as $\mathrm{CO} 3$ & ND & 1.45 & 2 & $U$ & & 063291-014 & EPA 310.1 \\
\hline TA2-W-26 & Bromide & 1.62 & 0.0978 & 0.2 & & & 063292-013 & SW846 9056 \\
\hline \multirow[t]{10}{*}{$16-$ Oct-03 } & Chloride & 134 & 0.322 & 2 & & & 063292-013 & SW846 9056 \\
\hline & Fluoride & 0.218 & 0.0553 & 0.1 & & & 063292-013 & SW846 9056 \\
\hline & Sulfate & 248 & 1.93 & 4 & & & 063292-013 & SW846 9056 \\
\hline & Calcium & 164 & 0.04 & 0.1 & B & & 063292-009 & SW846 3005 \\
\hline & Magnesium & 19.8 & 0.00633 & 0.01 & & $\mathrm{~J}$ & 063292-009 & SW846 3005 \\
\hline & Potassium & 2.08 & 0.0151 & 0.3 & & & 063292-009 & SW846 3005 \\
\hline & Sodium & 29.8 & 0.00968 & 0.25 & B & & 063292-009 & SW846 3005 \\
\hline & $\begin{array}{l}\text { Total Alkalinity } \\
\text { as CaCO3 }\end{array}$ & 89.8 & 1.45 & 2 & & & 063292-014 & EPA 310.1 \\
\hline & \begin{tabular}{|l|} 
Alkalinity as \\
HCO3
\end{tabular} & 89.3 & 1.45 & 2 & & & 063292-014 & EPA 310.1 \\
\hline & Alkalinity as CO3 & ND & 1.45 & 2 & $\mathrm{U}$ & & 063292-014 & EPA 310.1 \\
\hline TA2-W-27 & Bromide & 1.62 & 0.0978 & 0.2 & & & 063294-013 & SW846 9056 \\
\hline \multirow[t]{10}{*}{ 23-Oct-03 } & Chloride & 129 & 0.322 & 2 & & & 063294-013 & SW846 9056 \\
\hline & Fluoride & 0.311 & 0.0553 & 0.1 & & & 063294-013 & SW846 9056 \\
\hline & Sulfate & 164 & 1.93 & 4 & & & 063294-013 & SW846 9056 \\
\hline & Calcium & 135 & \begin{tabular}{|l|}
0.04 \\
\end{tabular} & 0.1 & & & 063294-009 & SW846 3005 \\
\hline & Magnesium & 17.5 & 0.00633 & 0.01 & & $\mathrm{~J}$ & 063294-009 & SW846 3005 \\
\hline & Potassium & 2.12 & 0.0151 & 0.3 & & & 063294-009 & SW846 3005 \\
\hline & Sodium & 32.0 & 0.00968 & 0.25 & & & 063294-009 & SW846 3005 \\
\hline & $\begin{array}{l}\text { Total Alkalinity } \\
\text { as CaCO3 }\end{array}$ & 98.8 & 1.45 & 2 & & & 063294-014 & EPA 310.1 \\
\hline & \begin{tabular}{|l|} 
Alkalinity as \\
HCO3
\end{tabular} & 98.2 & 1.45 & 2 & & & 063294-014 & EPA 310.1 \\
\hline & Alkalinity as CO3 & ND & 1.45 & 2 & $U$ & & 063294-014 & EPA 310.1 \\
\hline TJA-2 & Bromide & 0.915 & 0.0978 & 0.2 & & & 063295-013 & SW846 9056 \\
\hline \multirow[t]{10}{*}{ 15-Oct-03 } & Chloride & 72.2 & 0.161 & 1 & & & 063295-013 & SW846 9056 \\
\hline & Fluoride & 0.352 & 0.0553 & 0.1 & & & 063295-013 & SW846 9056 \\
\hline & Sulfate & 56.1 & 0.965 & 2 & & & 063295-013 & SW846 9056 \\
\hline & Calcium & 85.0 & \begin{tabular}{|l|}
0.04 \\
\end{tabular} & 0.1 & $B$ & & 063295-009 & SW846 3005 \\
\hline & Magnesium & 12.8 & 0.00633 & 0.01 & & $\mathrm{~J}$ & 063295-009 & SW846 3005 \\
\hline & Potassium & 1.74 & 0.0151 & 0.3 & & & 063295-009 & SW846 3005 \\
\hline & Sodium & 22.9 & 0.00968 & 0.25 & B & & 063295-009 & SW846 3005 \\
\hline & $\begin{array}{l}\text { Total Alkalinity } \\
\text { as CaCO3 }\end{array}$ & 114 & 1.45 & 2 & & & 063295-014 & EPA 310.1 \\
\hline & $\begin{array}{l}\text { Alkalinity as } \\
\text { HCO3 }\end{array}$ & 113 & 1.45 & 2 & & & 063295-014 & EPA 310.1 \\
\hline & Alkalinity as $\mathrm{CO} 3$ & ND & 1.45 & 2 & $\mathrm{U}$ & & $\mid 063295-014$ & EPA 310.1 \\
\hline
\end{tabular}




\begin{tabular}{|c|c|c|c|c|c|c|c|c|}
\hline Well ID & Analyte & $\begin{array}{l}\text { Result } \\
\text { (mg/L) }\end{array}$ & $\begin{array}{c}\mathrm{MDL} \\
(\mathrm{mg} / \mathrm{L})\end{array}$ & $\begin{array}{c}\mathrm{PQL} \\
\text { (mg/L) }\end{array}$ & $\begin{array}{l}\text { Laboratory } \\
\text { Qualifier }\end{array}$ & $\begin{array}{c}\text { Validation } \\
\text { Qualifier }\end{array}$ & Sample No. & $\begin{array}{c}\text { Analytical } \\
\text { Method }\end{array}$ \\
\hline TJA-3 & Bromide & 0.126 & 0.0978 & 0.2 & $\mathrm{~J}$ & & 063296-013 & SW846 9056 \\
\hline \multirow[t]{10}{*}{ 22-Oct-03 } & Chloride & 13.4 & 0.0322 & 0.2 & & & |063296-013 & SW846 9056 \\
\hline & Fluoride & 0.278 & 0.0553 & 0.1 & & & 063296-013 & SW846 9056 \\
\hline & Sulfate & 73.4 & 0.965 & 2 & & & 063296-013 & SW846 9056 \\
\hline & Calcium & 68.4 & 0.04 & 0.1 & & & |063296-009 & SW846 3005 \\
\hline & Magnesium & 11.7 & 0.00633 & 0.01 & & $\mathrm{~J}$ & 063296-009 & SW846 3005 \\
\hline & Potassium & 1.82 & 0.0151 & 0.3 & & & 063296-009 & SW846 3005 \\
\hline & Sodium & 24.4 & 0.00968 & 0.25 & & & 063296-009 & SW846 3005 \\
\hline & $\begin{array}{l}\text { Total Alkalinity } \\
\text { as } \mathrm{CaCO} 3\end{array}$ & 169 & 1.45 & 2 & & & 063296-014 & EPA 310.1 \\
\hline & \begin{tabular}{|l|} 
Alkalinity as \\
HCO3
\end{tabular} & 168 & 1.45 & 2 & & & 063296-014 & EPA 310.1 \\
\hline & Alkalinity as CO3 & ND & 1.45 & 2 & $\mathrm{U}$ & & 063296-014 & EPA 310.1 \\
\hline TJA-4 & Bromide & 0.243 & 0.0978 & 0.2 & & & 063297-013 & SW846 9056 \\
\hline \multirow[t]{10}{*}{ 27-Oct-03 } & Chloride & 21.1 & 0.0644 & 0.4 & & & 063297-013 & SW846 9056 \\
\hline & Fluoride & 0.322 & 0.0553 & 0.1 & & & 063297-013 & SW846 9056 \\
\hline & Sulfate & 19.4 & 0.193 & 0.4 & & & \begin{tabular}{|l|}
$063297-013$ \\
\end{tabular} & SW846 9056 \\
\hline & Calcium & 65.3 & 0.04 & 0.1 & & & 063297-009 & SW846 3005 \\
\hline & Magnesium & 12.0 & 0.00633 & 0.01 & & & |063297-009 & SW846 3005 \\
\hline & Potassium & 3.0 & 0.0151 & 0.3 & $B$ & & 063297-009 & SW846 3005 \\
\hline & Sodium & 24.1 & 0.00968 & 0.25 & B & & 063297-009 & SW846 3005 \\
\hline & $\begin{array}{l}\text { Total Alkalinity } \\
\text { as } \mathrm{CaCO} 3 \\
\end{array}$ & 140 & 1.45 & 2 & & & 063297-014 & EPA 310.1 \\
\hline & \begin{tabular}{|l|} 
Alkalinity as \\
HCO3
\end{tabular} & 139 & 1.45 & 2 & & & 063297-014 & EPA 310.1 \\
\hline & Alkalinity as $\mathrm{CO} 3$ & ND & 1.45 & 2 & $\mathrm{U}$ & & 063297-014 & EPA 310.1 \\
\hline TJA-6 & Bromide & ND & 0.0978 & 0.2 & $U$ & & 063298-013 & SW846 9056 \\
\hline \multirow[t]{10}{*}{ 05-Nov-03 } & Chloride & 14.6 & 0.0322 & 0.2 & & & 063298-013 & SW846 9056 \\
\hline & Fluoride & 0.322 & 0.0553 & 0.1 & & & 063298-013 & SW846 9056 \\
\hline & Sulfate & 61.1 & 0.965 & 2 & & & 063298-013 & SW846 9056 \\
\hline & Calcium & 63.2 & 0.04 & 0.1 & & & 063298-009 & SW846 3005 \\
\hline & Magnesium & 11.2 & 0.00633 & 0.01 & & & 063298-009 & SW846 3005 \\
\hline & Potassium & 2.43 & 0.0151 & 0.3 & & & 063298-009 & SW846 3005 \\
\hline & Sodium & 24.7 & 0.00968 & 0.25 & B & $\mathrm{J}$ & 063298-009 & SW846 3005 \\
\hline & $\begin{array}{l}\text { Total Alkalinity } \\
\text { as } \mathrm{CaCO} 3\end{array}$ & 174 & 1.45 & 2 & & & 063298-014 & EPA 310.1 \\
\hline & \begin{tabular}{|l|} 
Alkalinity as \\
$\mathrm{HCO} 3$
\end{tabular} & 173 & 1.45 & 2 & & & 063298-014 & EPA 310.1 \\
\hline & Alkalinity as $\mathrm{CO} 3$ & ND & 1.45 & 2 & $U$ & & 063298-014 & EPA 310.1 \\
\hline TJA-7 & Bromide & 0.344 & 0.0978 & 0.2 & & & 063299-013 & SW846 9056 \\
\hline \multirow[t]{10}{*}{ 28-Oct-03 } & Chloride & 30.8 & 0.161 & 1 & & & 063299-013 & SW846 9056 \\
\hline & Fluoride & 0.294 & 0.0553 & 0.1 & & & 063299-013 & SW846 9056 \\
\hline & Sulfate & 15.9 & 0.193 & 0.4 & & & 063299-013 & SW846 9056 \\
\hline & Calcium & 71.0 & 0.04 & 0.1 & & & 063299-009 & SW846 3005 \\
\hline & Magnesium & 12.3 & 0.00633 & 0.01 & & & 063299-009 & SW846 3005 \\
\hline & Potassium & 2.06 & 0.0151 & 0.3 & $B$ & & 063299-009 & SW846 3005 \\
\hline & Sodium & 19.1 & 0.00968 & 0.25 & B & & 063299-009 & SW846 3005 \\
\hline & $\begin{array}{l}\text { Total Alkalinity } \\
\text { as } \mathrm{CaCO} 3\end{array}$ & 135 & 1.45 & 2 & & & 063299-014 & EPA 310.1 \\
\hline & \begin{tabular}{|l|} 
Alkalinity as \\
$\mathrm{HCO} 3$
\end{tabular} & 134 & 1.45 & 2 & & & 063299-014 & EPA 310.1 \\
\hline & Alkalinity as $\mathrm{CO} 3$ & ND & 1.45 & 2 & $U$ & & 063299-014 & EPA 310.1 \\
\hline
\end{tabular}




\begin{tabular}{|c|c|c|c|c|c|c|c|c|}
\hline Well ID & Analyte & $\begin{array}{l}\text { Result } \\
\text { (mg/L) }\end{array}$ & $\begin{array}{c}\text { MDL } \\
\text { (mg/L) }\end{array}$ & $\begin{array}{c}\mathrm{PQL} \\
\text { (mg/L) }\end{array}$ & $\begin{array}{l}\text { Laboratory } \\
\text { Qualifier }\end{array}$ & $\begin{array}{l}\text { Validation } \\
\text { Qualifier }\end{array}$ & Sample No. & $\begin{array}{l}\text { Analytical } \\
\text { Method }\end{array}$ \\
\hline WYO-3 & Bromide & ND & 0.0978 & 0.2 & U & & $063300-013$ & SW846 9056 \\
\hline \multirow[t]{10}{*}{ 29-Oct-03 } & Chloride & 16.8 & 0.0322 & 0.2 & & & $063300-013$ & SW846 9056 \\
\hline & Fluoride & 0.376 & 0.0553 & 0.1 & & & 063300-013 & SW846 9056 \\
\hline & Sulfate & 93.8 & 0.965 & 2 & & & 063300-013 & SW846 9056 \\
\hline & Calcium & 68.3 & 0.04 & 0.1 & & & 063300-009 & SW846 3005 \\
\hline & Magnesium & 13.3 & 0.00633 & 0.01 & & & 063300-009 & SW846 3005 \\
\hline & Potassium & 2.19 & 0.0151 & 0.3 & $\mathrm{~B}$ & & 063300-009 & SW846 3005 \\
\hline & Sodium & 25.6 & 0.00968 & 0.25 & $\mathrm{~B}$ & & 063300-009 & SW846 3005 \\
\hline & $\begin{array}{l}\text { Total Alkalinity } \\
\text { as CaCO3 }\end{array}$ & 172 & 1.45 & 2 & & & $063300-014$ & EPA 310.1 \\
\hline & $\begin{array}{l}\text { Alkalinity as } \\
\text { HCO3 }\end{array}$ & 171 & 1.45 & 2 & & & $063300-014$ & EPA 310.1 \\
\hline & Alkalinity as $\mathrm{CO} 3$ & ND & 1.45 & 2 & U & & 063300-014 & EPA 310.1 \\
\hline WYO-4 & Bromide & 1.05 & 0.0978 & 0.2 & & & $063301-013$ & SW846 9056 \\
\hline \multirow[t]{10}{*}{ 03-Nov-03 } & Chloride & 104 & 0.322 & 2 & & & 063301-013 & SW846 9056 \\
\hline & Fluoride & 0.319 & 0.0553 & 0.1 & & & 063301-013 & SW846 9056 \\
\hline & Sulfate & 54.3 & 1.93 & 4 & & & 063301-013 & SW846 9056 \\
\hline & Calcium & 81.3 & 0.04 & 0.1 & $\mathrm{~B}$ & & 063301-009 & SW846 3005 \\
\hline & Magnesium & 11.7 & 0.00633 & 0.01 & & $\mathrm{~J}$ & 063301-009 & SW846 3005 \\
\hline & Potassium & 1.69 & 0.0151 & 0.3 & & & 063301-009 & SW846 3005 \\
\hline & Sodium & 21.3 & 0.00968 & 0.25 & & & 063301-009 & SW846 3005 \\
\hline & $\begin{array}{l}\text { Total Alkalinity } \\
\text { as CaCO3 }\end{array}$ & 95.8 & 1.45 & 2 & & & 063301-014 & EPA 310.1 \\
\hline & \begin{tabular}{|l|} 
Alkalinity as \\
$\mathrm{HCO} 3$
\end{tabular} & 95.2 & 1.45 & 2 & & & $063301-014$ & EPA 310.1 \\
\hline & Alkalinity as $\mathrm{CO} 3$ & ND & 1.45 & 2 & $\mathrm{U}$ & & $063301-014$ & EPA 310.1 \\
\hline \multicolumn{9}{|c|}{$\begin{array}{l}\mathrm{mg} / \mathrm{L}=\text { milligrams per liter } \\
\mathrm{J}=\text { Amount detected is below the practical quantitation limit. The associated value is an estimated quantity. } \\
\mathrm{B}=\text { Analyte is detected in associated laboratory method blank. } \\
\mathrm{B} 3=\text { Analyte is detected in associated laboratory calibration blank. } \\
\mathrm{U}=\text { Analyte not detected above the MDL. }\end{array}$} \\
\hline
\end{tabular}


Table A-16

Summary of Anion, Cation, and Alkalinity Results

Tijeras Arroyo Groundwater Investigation

Fiscal Year 2004, $2^{\text {nd }}$ Quarter

\begin{tabular}{|c|c|c|c|c|c|c|c|c|}
\hline Well ID & Analyte & $\begin{array}{l}\text { Result } \\
\text { (mg/L) }\end{array}$ & $\begin{array}{c}\mathrm{MDL} \\
(\mathrm{mg} / \mathrm{L})\end{array}$ & $\begin{array}{c}\text { PQL } \\
\text { (mg/L) }\end{array}$ & $\begin{array}{c}\text { Laboratory } \\
\text { Qualifier }\end{array}$ & $\begin{array}{c}\text { Validation } \\
\text { Qualifier }\end{array}$ & Sample No. & $\begin{array}{l}\text { Analytical } \\
\text { Method }\end{array}$ \\
\hline Eubank-1 & Bromide & 0.243 & 0.0978 & 0.2 & & & 063904-013 & SW846 9056 \\
\hline \multirow[t]{10}{*}{$16-F e b-04$} & Chloride & 13.0 & 0.0322 & 0.2 & & & 063904-013 & SW846 9056 \\
\hline & Fluoride & 0.430 & 0.0553 & 0.1 & & & 063904-013 & SW846 9056 \\
\hline & Sulfate & 74.2 & 1.93 & 4 & & & 063904-013 & SW846 9056 \\
\hline & Calcium & 70.0 & 0.04 & 0.1 & & & 063904-014 & SW846 3005 \\
\hline & Magnesium & 8.77 & 0.00633 & 0.01 & & $\mathrm{~J}$ & 063904-014 & SW846 3005 \\
\hline & Potassium & 1.67 & 0.0151 & 0.3 & & & 063904-014 & SW846 3005 \\
\hline & Sodium & 22.2 & 0.00968 & 0.25 & $\mathrm{~B}$ & $\mathrm{~J}$ & 063904-014 & SW846 3005 \\
\hline & $\begin{array}{l}\text { Total Alkalinity as } \\
\mathrm{CaCO} 3\end{array}$ & 161 & 1.45 & 2 & & & 063904-018 & EPA 310.1 \\
\hline & $\begin{array}{l}\text { Alkalinity as } \\
\text { HCO3 }\end{array}$ & 160 & 1.45 & 2 & & & 063904-018 & EPA 310.1 \\
\hline & Alkalinity as $\mathrm{CO} 3$ & ND & 1.45 & 2 & U & & 063904-018 & EPA 310.1 \\
\hline Eubank-2 & Bromide & 0.217 & 0.0978 & 0.2 & & & 063906-013 & SW846 9056 \\
\hline \multirow[t]{10}{*}{ 18-Feb-04 } & Chloride & 11.7 & 0.0322 & 0.2 & & & 063906-013 & SW846 9056 \\
\hline & Fluoride & 0.271 & 0.0553 & 0.1 & & & 063906-013 & SW846 9056 \\
\hline & Sulfate & 83.2 & 1.93 & 4 & & & 063906-013 & SW846 9056 \\
\hline & Calcium & 82.0 & 0.04 & 0.1 & & & 063906-014 & SW846 3005 \\
\hline & Magnesium & 11.3 & 0.00633 & 0.01 & & & 063906-014 & SW846 3005 \\
\hline & Potassium & 2.22 & 0.0151 & 0.3 & $B$ & & 063906-014 & SW846 3005 \\
\hline & Sodium & 28.3 & 0.00968 & 0.25 & & & 063906-014 & SW846 3005 \\
\hline & $\begin{array}{l}\text { Total Alkalinity as } \\
\mathrm{CaCO} 3\end{array}$ & 202 & 1.45 & 2 & & & 063906-018 & EPA 310.1 \\
\hline & $\begin{array}{l}\text { Alkalinity as } \\
\text { HCO3 }\end{array}$ & 201 & 1.45 & 2 & & & 063906-018 & EPA 310.1 \\
\hline & Alkalinity as CO3 & ND & 1.45 & 2 & $\mathrm{U}$ & & 063906-018 & EPA 310.1 \\
\hline Eubank-3 & Bromide & ND & 0.0978 & 0.2 & U & & 063909-013 & SW846 9056 \\
\hline \multirow[t]{10}{*}{ 17-Feb-04 } & Chloride & 2.56 & 0.0322 & 0.2 & & & 063909-013 & SW846 9056 \\
\hline & Fluoride & 0.795 & 0.0553 & 0.1 & & & 063909-013 & SW846 9056 \\
\hline & Sulfate & 8.07 & 0.193 & 0.4 & & & 063909-013 & SW846 9056 \\
\hline & Calcium & 86.4 & 0.04 & 0.1 & & & 063909-014 & SW846 3005 \\
\hline & Magnesium & 11.4 & 0.00633 & 0.01 & & $\mathrm{~J}$ & 063909-014 & SW846 3005 \\
\hline & Potassium & 1.89 & 0.0151 & 0.3 & & & 063909-014 & SW846 3005 \\
\hline & Sodium & 31.8 & 0.00968 & 0.25 & $\mathrm{~B}$ & & 063909-014 & SW846 3005 \\
\hline & $\begin{array}{l}\text { Total Alkalinity as } \\
\mathrm{CaCO} 3\end{array}$ & 189 & 1.45 & 2 & & & 063909-018 & EPA 310.1 \\
\hline & $\begin{array}{l}\text { Alkalinity as } \\
\text { HCO3 }\end{array}$ & 188 & 1.45 & 2 & & & 063909-018 & EPA 310.1 \\
\hline & Alkalinity as $\mathrm{CO} 3$ & ND & 1.45 & 2 & $U$ & & 063909-018 & EPA 310.1 \\
\hline Eubank-5 & Bromide & 0.277 & 0.0978 & 0.2 & & & 063911-013 & SW846 9056 \\
\hline \multirow[t]{5}{*}{ 19-Feb-04 } & Chloride & 22.6 & 0.161 & 1 & & & 063911-013 & SW846 9056 \\
\hline & Fluoride & 0.348 & 0.0553 & 0.1 & & & 063911-013 & SW846 9056 \\
\hline & Sulfate & 85.6 & 0.965 & 2 & & & 063911-013 & SW846 9056 \\
\hline & Calcium & 86.1 & 0.04 & 0.1 & B & & 063911-014 & SW846 3005 \\
\hline & Magnesium & 11.5 & 0.00633 & 0.01 & & $\mathrm{~J}$ & 063911-014 & SW846 3005 \\
\hline
\end{tabular}




\begin{tabular}{|c|c|c|c|c|c|c|c|c|}
\hline Well ID & Analyte & $\begin{array}{l}\text { Result } \\
\text { (mg/L) }\end{array}$ & $\begin{array}{c}\text { MDL } \\
\text { (mg/L) }\end{array}$ & $\begin{array}{c}\text { PQL } \\
\text { (mg/L) }\end{array}$ & $\begin{array}{l}\text { Laboratory } \\
\text { Qualifier }\end{array}$ & $\begin{array}{c}\text { Validation } \\
\text { Qualifier }\end{array}$ & Sample No. & $\begin{array}{l}\text { Analytical } \\
\text { Method }\end{array}$ \\
\hline & Potassium & 2.11 & 0.0151 & 0.3 & $\mathrm{~B}$ & & 063911-014 & SW846 3005 \\
\hline & Sodium & 30.2 & 0.00968 & 0.25 & & & 063911-014 & SW846 3005 \\
\hline & $\begin{array}{l}\text { Total Alkalinity as } \\
\text { CaCO3 }\end{array}$ & 190 & 1.45 & 2 & & & 063911-018 & EPA 310.1 \\
\hline & \begin{tabular}{|l|} 
Alkalinity as \\
HCO3
\end{tabular} & 189 & 1.45 & 2 & & & 063911-018 & EPA 310.1 \\
\hline & Alkalinity as CO3 & ND & 1.45 & 2 & $\mathrm{U}$ & & 063911-018 & EPA 310.1 \\
\hline PGS-2 & Bromide & 0.204 & 0.0978 & 0.2 & & & 063851-013 & SW846 9056 \\
\hline \multirow[t]{10}{*}{ 03-Feb-04 } & Chloride & 14.0 & 0.0322 & 0.2 & & & 063851-013 & SW846 9056 \\
\hline & Fluoride & 0.089 & 0.0553 & 0.1 & $\mathrm{~J}$ & & 063851-013 & SW846 9056 \\
\hline & Sulfate & 63.1 & 0.965 & 2 & & & 063851-013 & SW846 9056 \\
\hline & Calcium & 52.7 & 0.04 & 0.1 & & & 063851-014 & SW846 3005 \\
\hline & Magnesium & 12.8 & 0.00633 & 0.01 & & & 063851-014 & SW846 3005 \\
\hline & Potassium & 2.96 & 0.0151 & 0.3 & & & 063851-014 & SW846 3005 \\
\hline & Sodium & 41.3 & 0.00968 & 0.25 & & & 063851-014 & SW846 3005 \\
\hline & $\begin{array}{l}\text { Total Alkalinity as } \\
\text { CaCO3 }\end{array}$ & 129 & 1.45 & 2 & & & 063851-018 & EPA 310.1 \\
\hline & \begin{tabular}{l|} 
Alkalinity as \\
$\mathrm{HCO} 3$
\end{tabular} & 129 & 1.45 & 2 & & & 063851-018 & EPA 310.1 \\
\hline & Alkalinity as CO3 & ND & 1.45 & 2 & $\mathrm{U}$ & & 063851-018 & EPA 310.1 \\
\hline TA1-W-01 & Bromide & 0.240 & 0.0978 & 0.2 & & & 063853-013 & SW846 9056 \\
\hline \multirow[t]{10}{*}{ 05-Feb-04 } & Chloride & 15.1 & 0.0322 & 0.2 & & & 063853-013 & SW846 9056 \\
\hline & Fluoride & 0.429 & 0.0553 & 0.1 & & & 063853-013 & SW846 9056 \\
\hline & Sulfate & 79.9 & 0.965 & 2 & & & 063853-013 & SW846 9056 \\
\hline & Calcium & 64.0 & 0.04 & 0.1 & B & $\mathrm{J}$ & 063853-014 & SW846 3005 \\
\hline & Magnesium & 10.9 & 0.00633 & 0.01 & & $\mathrm{~J}$ & 063853-014 & SW846 3005 \\
\hline & Potassium & 2.01 & 0.0151 & 0.3 & & & 063853-014 & SW846 3005 \\
\hline & Sodium & 21.7 & 0.00968 & 0.25 & & $\mathrm{~J}$ & 063853-014 & SW846 3005 \\
\hline & $\begin{array}{l}\text { Total Alkalinity as } \\
\text { CaCO3 }\end{array}$ & 167 & 1.45 & 2 & & & 063853-018 & EPA 310.1 \\
\hline & \begin{tabular}{|l|} 
Alkalinity as \\
$\mathrm{HCO} 3$
\end{tabular} & 167 & 1.45 & 2 & & & 063853-018 & EPA 310.1 \\
\hline & Alkalinity as $\mathrm{CO} 3$ & ND & 1.45 & 2 & $U$ & & 063853-018 & EPA 310.1 \\
\hline TA1-W-02 & Bromide & 0.906 & 0.0978 & 0.2 & B & & 063855-013 & SW846 9056 \\
\hline \multirow[t]{10}{*}{ 28-Jan-04 } & Chloride & 14.3 & 0.0322 & 0.2 & & & 063855-013 & SW846 9056 \\
\hline & Fluoride & 0.320 & 0.0553 & 0.1 & & & 063855-013 & SW846 9056 \\
\hline & Sulfate & 82.1 & 0.965 & 2 & & & 063855-013 & SW846 9056 \\
\hline & Calcium & 68.2 & 0.04 & 0.1 & $\mathrm{~B}$ & & 063855-014 & SW846 3005 \\
\hline & Magnesium & 11.1 & 0.00633 & 0.01 & & $\mathrm{~J}$ & 063855-014 & SW846 3005 \\
\hline & Potassium & 2.20 & 0.0151 & 0.3 & & & 063855-014 & SW846 3005 \\
\hline & Sodium & 20.4 & 0.00968 & 0.25 & & $\mathrm{~J}$ & 063855-014 & SW846 3005 \\
\hline & $\begin{array}{l}\text { Total Alkalinity as } \\
\mathrm{CaCO} 3\end{array}$ & 165 & 1.45 & 2 & & & 063855-018 & EPA 310.1 \\
\hline & \begin{tabular}{l|} 
Alkalinity as \\
HCO3
\end{tabular} & 165 & 1.45 & 2 & & & 063855-018 & EPA 310.1 \\
\hline & Alkalinity as $\mathrm{CO} 3$ & ND & 1.45 & 2 & $\mathrm{U}$ & & 063855-018 & EPA 310.1 \\
\hline TA1-W-03 & Bromide & 2.50 & 0.0978 & 0.2 & & & 063857-013 & SW846 9056 \\
\hline \multirow[t]{7}{*}{ 07-Jan-04 } & Chloride & 226 & 1.61 & 10 & & & 063857-013 & SW846 9056 \\
\hline & Fluoride & 0.152 & 0.0553 & 0.1 & & & 063857-013 & SW846 9056 \\
\hline & Sulfate & 473 & 9.65 & 20 & & & $063857-013$ & SW846 9056 \\
\hline & Calcium & 286 & 0.2 & 0.5 & & & 063857-014 & SW846 3005 \\
\hline & Magnesium & 28.9 & 0.00633 & 0.01 & & $\mathrm{~J}$ & 063857-014 & SW846 3005 \\
\hline & Potassium & 2.74 & 0.0151 & 0.3 & $B$ & & 063857-014 & SW846 3005 \\
\hline & Sodium & 42.3 & 0.00968 & 0.25 & $\mathrm{~B}$ & & 063857-014 & SW846 3005 \\
\hline
\end{tabular}




\begin{tabular}{|c|c|c|c|c|c|c|c|c|}
\hline Well ID & Analyte & $\begin{array}{l}\text { Result } \\
\text { (mg/L) }\end{array}$ & $\begin{array}{c}\text { MDL } \\
\text { (mg/L) }\end{array}$ & $\begin{array}{c}\text { PQL } \\
\text { (mg/L) }\end{array}$ & $\begin{array}{c}\text { Laboratory } \\
\text { Qualifier }\end{array}$ & $\begin{array}{c}\text { Validation } \\
\text { Qualifier } \\
\end{array}$ & Sample No. & $\begin{array}{c}\text { Analytical } \\
\text { Method }\end{array}$ \\
\hline & $\begin{array}{l}\text { Total Alkalinity as } \\
\mathrm{CaCO} 3\end{array}$ & 109 & 1.45 & 2 & & & 063857-018 & EPA 310.1 \\
\hline & \begin{tabular}{|l|} 
Alkalinity as \\
HCO3
\end{tabular} & 108 & 1.45 & 2 & & & 063857-018 & EPA 310.1 \\
\hline & Alkalinity as $\mathrm{CO} 3$ & ND & 1.45 & 2 & $\mathrm{U}$ & & 063857-018 & EPA 310.1 \\
\hline TA1-W-04 & Bromide & 0.242 & 0.0978 & 0.2 & & B3, J & 063860-013 & SW846 9056 \\
\hline \multirow[t]{10}{*}{ 06-Jan-04 } & Chloride & 16.6 & 0.0322 & 0.2 & & & $063860-013$ & SW846 9056 \\
\hline & Fluoride & 0.322 & 0.0553 & 0.1 & & & $063860-013$ & SW846 9056 \\
\hline & Sulfate & 63.6 & 0.965 & 2 & & & 063860-013 & SW846 9056 \\
\hline & Calcium & 63.5 & 0.04 & 0.1 & B & & 063860-014 & SW846 3005 \\
\hline & Magnesium & 10.6 & 0.00633 & 0.01 & & $\mathrm{~J}$ & 063860-014 & SW846 3005 \\
\hline & Potassium & 2.37 & 0.0151 & 0.3 & & & 063860-014 & SW846 3005 \\
\hline & Sodium & 22.3 & 0.00968 & 0.25 & & & 063860-014 & SW846 3005 \\
\hline & $\begin{array}{l}\text { Total Alkalinity as } \\
\mathrm{CaCO} 3\end{array}$ & 193 & 1.45 & 2 & & & 063860-018 & EPA 310.1 \\
\hline & \begin{tabular}{|l|} 
Alkalinity as \\
HCO3
\end{tabular} & 193 & 1.45 & 2 & & & 063860-018 & EPA 310.1 \\
\hline & Alkalinity as $\mathrm{CO} 3$ & ND & 1.45 & 2 & $U$ & & 063860-018 & EPA 310.1 \\
\hline TA1-W-05 & Bromide & 0.988 & 0.0978 & 0.2 & B & & 063862-013 & SW846 9056 \\
\hline \multirow[t]{10}{*}{ 12-Feb-04 } & Chloride & 11.5 & 0.0322 & 0.2 & & & $063862-013$ & SW846 9056 \\
\hline & Fluoride & 0.253 & 0.0553 & 0.1 & & & 063862-013 & SW846 9056 \\
\hline & Sulfate & 98.7 & 0.965 & 2 & & & 063862-013 & SW846 9056 \\
\hline & Calcium & 82.1 & 0.04 & 0.1 & & & 063862-014 & SW846 3005 \\
\hline & Magnesium & 11.0 & 0.00633 & 0.01 & & & $063862-014$ & SW846 3005 \\
\hline & Potassium & 2.20 & 0.0151 & 0.3 & & & $063862-014$ & SW846 3005 \\
\hline & Sodium & 28.5 & 0.00968 & 0.25 & B & & 063862-014 & SW846 3005 \\
\hline & $\begin{array}{l}\text { Total Alkalinity as } \\
\text { CaCO3 }\end{array}$ & 199 & 1.45 & 2 & & & 063862-018 & EPA 310.1 \\
\hline & \begin{tabular}{|l|} 
Alkalinity as \\
HCO3
\end{tabular} & 198 & 1.45 & 2 & & & 063862-018 & EPA 310.1 \\
\hline & Alkalinity as CO3 & ND & 1.45 & 2 & $\mathrm{U}$ & & 063862-018 & EPA 310.1 \\
\hline TA1-W-06 & Bromide & 1.23 & 0.0978 & 0.2 & & & 063864-013 & SW846 9056 \\
\hline \multirow[t]{9}{*}{ 09-Feb-04 } & Chloride & 94.4 & 0.322 & 2 & & & 063864-013 & SW846 9056 \\
\hline & Fluoride & 0.298 & 0.0553 & 0.1 & & & 063864-013 & SW846 9056 \\
\hline & Sulfate & 194 & 1.93 & 4 & & & 063864-013 & SW846 9056 \\
\hline & Calcium & 133 & 0.04 & 0.1 & $\mathrm{~B}$ & & 063864-014 & SW846 3005 \\
\hline & Magnesium & 15.9 & 0.00633 & 0.01 & & $\mathrm{~J}$ & 063864-014 & SW846 3005 \\
\hline & Potassium & 2.12 & 0.0151 & 0.3 & & & 063864-014 & SW846 3005 \\
\hline & Sodium & 31.7 & 0.00968 & 0.25 & & $\mathrm{~J}$ & 063864-014 & SW846 3005 \\
\hline & $\begin{array}{l}\text { Total Alkalinity as } \\
\text { CaCO3 }\end{array}$ & 87.1 & 1.45 & 2 & & & 063864-018 & EPA 310.1 \\
\hline & $\begin{array}{l}\text { Alkalinity as } \\
\text { HCO3 }\end{array}$ & 86.5 & 1.45 & 2 & & & 063864-018 & EPA 310.1 \\
\hline TA1-W-08 & Alkalinity as $\mathrm{CO} 3$ & ND & 1.45 & 2 & $U$ & & 063864-018 & EPA 310.1 \\
\hline \multirow[t]{9}{*}{ 10-Feb-04 } & Bromide & 2.52 & 0.0978 & 0.2 & & & 063866-013 & SW846 9056 \\
\hline & Chloride & 202 & 1.61 & 10 & & & 063866-013 & SW846 9056 \\
\hline & Fluoride & 0.230 & 0.0553 & 0.1 & & & $063866-013$ & SW846 9056 \\
\hline & Sulfate & 641 & 9.65 & 20 & & & 063866-013 & SW846 9056 \\
\hline & Calcium & 348 & 0.4 & 1 & $B$ & & 063866-014 & SW846 3005 \\
\hline & Magnesium & 40.8 & 0.00633 & 0.01 & & $\mathrm{~J}$ & 063866-014 & SW846 3005 \\
\hline & Potassium & 3.18 & 0.0151 & 0.3 & & & 063866-014 & SW846 3005 \\
\hline & Sodium & 74.2 & 0.00968 & 0.25 & & $\mathrm{~J}$ & 063866-014 & SW846 3005 \\
\hline & $\begin{array}{l}\text { Total Alkalinity as } \\
\mathrm{CaCO} 3\end{array}$ & 82.0 & 1.45 & 2 & & & 063866-018 & EPA 310.1 \\
\hline
\end{tabular}




\begin{tabular}{|c|c|c|c|c|c|c|c|c|}
\hline Well ID & Analyte & $\begin{array}{l}\text { Result } \\
\text { (mg/L) }\end{array}$ & $\begin{array}{c}\mathrm{MDL} \\
(\mathrm{mg} / \mathrm{L})\end{array}$ & $\begin{array}{c}\mathrm{PQL} \\
(\mathrm{mg} / \mathrm{L})\end{array}$ & $\begin{array}{c}\text { Laboratory } \\
\text { Qualifier }\end{array}$ & $\begin{array}{c}\text { Validation } \\
\text { Qualifier } \\
\end{array}$ & Sample No. & $\begin{array}{c}\text { Analytical } \\
\text { Method }\end{array}$ \\
\hline & $\begin{array}{l}\text { Alkalinity as } \\
\mathrm{HCO} 3\end{array}$ & 81.2 & 1.45 & 2 & & & 063866-018 & EPA 310.1 \\
\hline & Alkalinity as CO3 & ND & 1.45 & 2 & $\mathrm{U}$ & & 063866-018 & EPA 310.1 \\
\hline TA2-NW1-595 & Bromide & 1.76 & 0.0978 & 0.2 & B & & 063869-013 & SW846 9056 \\
\hline \multirow{10}{*}{$\begin{array}{l}\text { 26-Jan-04 } \\
\text { (Bennett) }\end{array}$} & Chloride & 88.0 & 0.322 & 2 & & & 063869-013 & SW846 9056 \\
\hline & Fluoride & 0.223 & 0.0553 & 0.1 & & & 063869-013 & SW846 9056 \\
\hline & Sulfate & 119 & 1.93 & 4 & & & 063869-013 & SW846 9056 \\
\hline & Calcium & 107 & 0.04 & 0.1 & B & & 063869-014 & SW846 3005 \\
\hline & Magnesium & 16.9 & 0.00633 & 0.01 & & & 063869-014 & SW846 3005 \\
\hline & Potassium & 2.43 & 0.0151 & 0.3 & & & 063869-014 & SW846 3005 \\
\hline & Sodium & 28.2 & 0.00968 & 0.25 & $B$ & & 063869-014 & SW846 3005 \\
\hline & $\begin{array}{l}\text { Total Alkalinity as } \\
\mathrm{CaCO} 3\end{array}$ & 143 & 1.45 & 2 & & & 063869-018 & EPA 310.1 \\
\hline & $\begin{array}{l}\text { Alkalinity as } \\
\text { HCO3 }\end{array}$ & 142 & 1.45 & 2 & & & 063869-018 & EPA 310.1 \\
\hline & Alkalinity as CO3 & ND & 1.45 & 2 & $\mathrm{U}$ & & 063869-018 & EPA 310.1 \\
\hline \multirow[t]{11}{*}{ TA2-NW1-595 } & Bromide & 1.12 & 0.0978 & 0.2 & & & 063871-013 & SW846 9056 \\
\hline & Chloride & 85.2 & 0.322 & 2 & & & 063871-013 & SW846 9056 \\
\hline & Fluoride & 0.307 & 0.0553 & 0.1 & & & 063871-013 & SW846 9056 \\
\hline & Sulfate & 114 & 1.93 & 4 & & & 063871-013 & SW846 9056 \\
\hline & Calcium & 98.0 & 0.04 & 0.1 & & $\mathrm{~J}$ & 063871-014 & SW846 3005 \\
\hline & Magnesium & 15.2 & 0.00633 & 0.01 & & & 063871-014 & SW846 3005 \\
\hline & Potassium & 2.19 & 0.0151 & 0.3 & & & 063871-014 & SW846 3005 \\
\hline & Sodium & 24.8 & 0.00968 & 0.25 & B & $\mathrm{J}$ & 063871-014 & SW846 3005 \\
\hline & $\begin{array}{l}\text { Total Alkalinity as } \\
\mathrm{CaCO} 3\end{array}$ & 140 & 1.45 & 2 & & & 063871-018 & EPA 310.1 \\
\hline & $\begin{array}{l}\text { Alkalinity as } \\
\mathrm{HCO} 3\end{array}$ & 139 & 1.45 & 2 & & & 063871-018 & EPA 310.1 \\
\hline & Alkalinity as CO3 & ND & 1.45 & 2 & $\mathrm{U}$ & & 063871-018 & EPA 310.1 \\
\hline \multirow{11}{*}{$\begin{array}{l}\text { TA2-SW1-320 } \\
\text { 29-Jan-04 }\end{array}$} & Bromide & 0.397 & 0.0978 & 0.2 & & & 063873-013 & SW846 9056 \\
\hline & Chloride & 26.2 & 0.0644 & 0.4 & & & 063873-013 & SW846 9056 \\
\hline & Fluoride & 0.444 & 0.0553 & 0.1 & & & 063873-013 & SW8469056 \\
\hline & Sulfate & 13.6 & 0.193 & 0.4 & & & 063873-013 & SW846 9056 \\
\hline & Calcium & 67.3 & 0.04 & 0.1 & & & 063873-014 & SW846 3005 \\
\hline & Magnesium & 11.3 & 0.00633 & 0.01 & & & 063873-014 & SW846 3005 \\
\hline & Potassium & 2.02 & 0.0151 & 0.3 & & & 063873-014 & SW846 3005 \\
\hline & Sodium & 19.6 & 0.00968 & 0.25 & $B$ & $\mathrm{~J}$ & 063873-014 & SW846 3005 \\
\hline & $\begin{array}{l}\text { Total Alkalinity as } \\
\text { CaCO3 }\end{array}$ & 109 & 1.45 & 2 & & & 063873-018 & EPA 310.1 \\
\hline & $\begin{array}{l}\text { Alkalinity as } \\
\text { HCO3 }\end{array}$ & 108 & 1.45 & 2 & & & 063873-018 & EPA 310.1 \\
\hline & Alkalinity as $\mathrm{CO} 3$ & ND & 1.45 & 2 & $\mathrm{U}$ & & 063873-018 & EPA 310.1 \\
\hline TA2-W-01 & Bromide & 1.57 & 0.0978 & 0.2 & & & 063876-013 & SW846 9056 \\
\hline \multirow[t]{10}{*}{ 12-Jan-04 } & Chloride & 103 & 0.322 & 2 & & & 063876-013 & SW846 9056 \\
\hline & Fluoride & 0.300 & 0.0553 & 0.1 & & & $063876-013$ & SW846 9056 \\
\hline & Sulfate & 45.5 & 1.93 & 4 & & & 063876-013 & SW846 9056 \\
\hline & Calcium & 89.9 & 0.04 & 0.1 & $B$ & & 063876-014 & SW846 3005 \\
\hline & Magnesium & 11.5 & 0.00633 & 0.01 & & & 063876-014 & SW846 3005 \\
\hline & Potassium & 2.11 & 0.0151 & 0.3 & $\mathrm{~B}$ & & 063876-014 & SW846 3005 \\
\hline & Sodium & 24.2 & 0.00968 & 0.25 & & $\mathrm{~J}$ & 063876-014 & SW846 3005 \\
\hline & $\begin{array}{l}\text { Total Alkalinity as } \\
\text { CaCO3 }\end{array}$ & 94.1 & 1.45 & 2 & & & 063876-018 & EPA 310.1 \\
\hline & \begin{tabular}{|l} 
Alkalinity as \\
$\mathrm{HCO} 3$
\end{tabular} & 93.2 & 1.45 & 2 & & & 063876-018 & EPA 310.1 \\
\hline & Alkalinity as CO3 & ND & 1.45 & 2 & $\bar{U}$ & & $063876-018$ & EPA 310.1 \\
\hline
\end{tabular}




\begin{tabular}{|c|c|c|c|c|c|c|c|c|}
\hline Well ID & Analyte & $\begin{array}{l}\text { Result } \\
\text { (mg/L) }\end{array}$ & $\begin{array}{c}\mathrm{MDL} \\
(\mathrm{mg} / \mathrm{L})\end{array}$ & $\begin{array}{c}\mathrm{PQL} \\
(\mathrm{mg} / \mathrm{L})\end{array}$ & $\begin{array}{c}\text { Laboratory } \\
\text { Qualifier }\end{array}$ & $\begin{array}{c}\text { Validation } \\
\text { Qualifier }\end{array}$ & Sample No. & $\begin{array}{c}\text { Analytical } \\
\text { Method }\end{array}$ \\
\hline TA2-W-19 & Bromide & 0.966 & 0.0978 & 0.2 & & & 063878-013 & SW846 9056 \\
\hline \multirow[t]{10}{*}{ 13-Jan-04 } & Chloride & 71.9 & 0.322 & 2 & & & 063878-013 & SW846 9056 \\
\hline & Fluoride & 0.333 & 0.0553 & 0.1 & & & 063878-013 & SW846 9056 \\
\hline & Sulfate & 56.8 & 1.93 & 4 & & & $063878-013$ & SW846 9056 \\
\hline & Calcium & 81.4 & 0.04 & 0.1 & & & $063878-014$ & SW846 3005 \\
\hline & Magnesium & 11.0 & 0.00633 & 0.01 & & & 063878-014 & SW846 3005 \\
\hline & Potassium & 1.75 & 0.0151 & 0.3 & & & 063878-014 & SW846 3005 \\
\hline & Sodium & 20.1 & 0.00968 & 0.25 & & & 063878-014 & SW846 3005 \\
\hline & $\begin{array}{l}\text { Total Alkalinity as } \\
\mathrm{CaCO} 3\end{array}$ & 100 & 1.45 & 2 & & & 063878-018 & EPA 310.1 \\
\hline & \begin{tabular}{|l|} 
Alkalinity as \\
HCO3
\end{tabular} & 99.1 & 1.45 & 2 & & & 063878-018 & EPA 310.1 \\
\hline & Alkalinity as $\mathrm{CO} 3$ & ND & 1.45 & 2 & $U$ & & 063878-018 & EPA 310.1 \\
\hline TA2-W-26 & Bromide & 1.83 & 0.0978 & 0.2 & B & & 063880-013 & SW846 9056 \\
\hline \multirow[t]{10}{*}{ 20-Jan-04 } & Chloride & 146 & 0.322 & 2 & & & $063880-013$ & SW846 9056 \\
\hline & Fluoride & 0.216 & 0.0553 & 0.1 & & & $063880-013$ & SW846 9056 \\
\hline & Sulfate & 268 & 1.93 & 4 & & & $063880-013$ & SW846 9056 \\
\hline & Calcium & 175 & 0.2 & 0.5 & & & 063880-014 & SW846 3005 \\
\hline & Magnesium & 23.2 & 0.00633 & 0.01 & & $\mathrm{~J}$ & 063880-014 & SW846 3005 \\
\hline & Potassium & 2.51 & 0.0151 & 0.3 & & & $063880-014$ & SW846 3005 \\
\hline & Sodium & 32.0 & 0.00968 & 0.25 & & $\mathrm{~J}$ & 063880-014 & SW846 3005 \\
\hline & $\begin{array}{l}\text { Total Alkalinity as } \\
\mathrm{CaCO} 3\end{array}$ & 93.1 & 1.45 & 2 & & & 063880-018 & EPA 310.1 \\
\hline & \begin{tabular}{|l|} 
Alkalinity as \\
HCO3
\end{tabular} & 92.7 & 1.45 & 2 & & & 063880-018 & EPA 310.1 \\
\hline & Alkalinity as $\mathrm{CO} 3$ & ND & 1.45 & 2 & $U$ & & 063880-018 & EPA 310.1 \\
\hline TA2-W-27 & Bromide & 2.19 & 0.0978 & 0.2 & B & & 063885-013 & SW846 9056 \\
\hline \multirow[t]{10}{*}{ 15-Jan-04 } & Chloride & 118 & 0.644 & 4 & & & 063885-013 & SW846 9056 \\
\hline & Fluoride & 0.220 & 0.0553 & 0.1 & & & 063885-013 & SW846 9056 \\
\hline & Sulfate & 160 & 3.86 & 8 & & & $063885-013$ & SW846 9056 \\
\hline & Calcium & 128 & 0.04 & 0.1 & B & & 063885-014 & SW846 3005 \\
\hline & Magnesium & 15.9 & 0.00633 & 0.01 & & & 063885-014 & SW846 3005 \\
\hline & Potassium & 2.11 & 0.0151 & 0.3 & & & 063885-014 & SW846 3005 \\
\hline & Sodium & 28.3 & 0.00968 & 0.25 & B & & 063885-014 & SW846 3005 \\
\hline & $\begin{array}{l}\text { Total Alkalinity as } \\
\mathrm{CaCO} 3\end{array}$ & 92 & 1.45 & 2 & & & 063885-018 & EPA 310.1 \\
\hline & $\begin{array}{l}\text { Alkalinity as } \\
\mathrm{HCO} 3\end{array}$ & 91.7 & 1.45 & 2 & & & 063885-018 & EPA 310.1 \\
\hline & Alkalinity as $\mathrm{CO} 3$ & ND & 1.45 & 2 & $\mathrm{U}$ & & 063885-018 & EPA 310.1 \\
\hline TJA-2 & Bromide & 1.41 & 0.0978 & 0.2 & B & & 063887-013 & SW846 9056 \\
\hline \multirow[t]{10}{*}{ 19-Jan-04 } & Chloride & 70.2 & 0.322 & 2 & & & 063887-013 & SW846 9056 \\
\hline & Fluoride & 0.278 & 0.0553 & 0.1 & & & 063887-013 & SW846 9056 \\
\hline & Sulfate & 54.6 & 1.93 & 4 & & & 063887-013 & SW846 9056 \\
\hline & Calcium & 81.1 & 0.04 & 0.1 & & & 063887-014 & SW846 3005 \\
\hline & Magnesium & 12.8 & 0.00633 & 0.01 & & & 063887-014 & SW846 3005 \\
\hline & Potassium & 1.85 & 0.0151 & 0.3 & $\mathrm{~B}$ & & 063887-014 & SW846 3005 \\
\hline & Sodium & 25 & 0.00968 & 0.25 & & & 063887-014 & SW846 3005 \\
\hline & $\begin{array}{l}\text { Total Alkalinity as } \\
\mathrm{CaCO} 3\end{array}$ & 107 & 1.45 & 2 & & & 063887-018 & EPA 310.1 \\
\hline & \begin{tabular}{|l} 
Alkalinity as \\
$\mathrm{HCO} 3$
\end{tabular} & 106 & 1.45 & 2 & & & 063887-018 & EPA 310.1 \\
\hline & Alkalinity as $\mathrm{CO} 3$ & ND & 1.45 & 2 & $U$ & & 063887-018 & EPA 310.1 \\
\hline
\end{tabular}




\begin{tabular}{|c|c|c|c|c|c|c|c|c|}
\hline Well ID & Analyte & $\begin{array}{l}\text { Result } \\
\text { (mg/L) }\end{array}$ & $\begin{array}{c}\text { MDL } \\
\text { (mg/L) }\end{array}$ & $\begin{array}{c}\text { PQL } \\
\text { (mg/L) }\end{array}$ & $\begin{array}{l}\text { Laboratory } \\
\text { Qualifier }\end{array}$ & $\begin{array}{c}\text { Validation } \\
\text { Qualifier }\end{array}$ & Sample No. & $\begin{array}{l}\text { Analytical } \\
\text { Method }\end{array}$ \\
\hline TJA-3 & Bromide & 0.824 & 0.0978 & 0.2 & B & & 063889-013 & SW846 9056 \\
\hline \multirow[t]{10}{*}{ 27-Jan-04 } & Chloride & 13.6 & 0.0322 & 0.2 & & & 063889-013 & SW846 9056 \\
\hline & Fluoride & 0.280 & 0.0553 & 0.1 & & & 063889-013 & SW846 9056 \\
\hline & Sulfate & 74.1 & 0.965 & 2 & & & 063889-013 & SW846 9056 \\
\hline & Calcium & 67.6 & 0.04 & 0.1 & $B$ & & 063889-014 & SW846 3005 \\
\hline & Magnesium & 10.3 & 0.00633 & 0.01 & & $\mathrm{~J}$ & 063889-014 & SW846 3005 \\
\hline & Potassium & 1.86 & 0.0151 & 0.3 & $B$ & & 063889-014 & SW846 3005 \\
\hline & Sodium & 21.6 & 0.00968 & 0.25 & & & 063889-014 & SW846 3005 \\
\hline & $\begin{array}{l}\text { Total Alkalinity as } \\
\text { CaCO3 }\end{array}$ & 160 & 1.45 & 2 & & & 063889-018 & EPA 310.1 \\
\hline & \begin{tabular}{l|} 
Alkalinity as \\
$\mathrm{HCO} 3$
\end{tabular} & 160 & 1.45 & 2 & & & 063889-018 & EPA 310.1 \\
\hline & Alkalinity as $\mathrm{CO} 3$ & ND & 1.45 & 2 & $\mathrm{U}$ & & 063889-018 & EPA 310.1 \\
\hline TJA-4 & Bromide & 0.354 & 0.0978 & 0.2 & & & 063891-013 & SW846 9056 \\
\hline \multirow[t]{10}{*}{ 29-Jan-04 } & Chloride & 21.7 & 0.0644 & 0.4 & & & 063891-013 & SW846 9056 \\
\hline & Fluoride & 0.404 & 0.0553 & 0.1 & & & 063891-013 & SW846 9056 \\
\hline & Sulfate & 18.5 & 0.193 & 0.4 & & & 063891-013 & SW846 9056 \\
\hline & Calcium & 73.6 & 0.04 & 0.1 & & & 063891-014 & SW846 3005 \\
\hline & Magnesium & 15.4 & 0.00633 & 0.01 & & & 063891-014 & SW846 3005 \\
\hline & Potassium & 3.46 & 0.0151 & 0.3 & & & 063891-014 & SW846 3005 \\
\hline & Sodium & 27.8 & 0.00968 & 0.25 & B & $\mathrm{J}$ & 063891-014 & SW846 3005 \\
\hline & $\begin{array}{l}\text { Total Alkalinity as } \\
\mathrm{CaCO} 3\end{array}$ & 133 & 1.45 & 2 & & & 063891-018 & EPA 310.1 \\
\hline & \begin{tabular}{l|} 
Alkalinity as \\
$\mathrm{HCO} 3$
\end{tabular} & 133 & 1.45 & 2 & & & 063891-018 & EPA 310.1 \\
\hline & Alkalinity as $\mathrm{CO} 3$ & ND & 1.45 & 2 & $\mathrm{U}$ & & 063891-018 & EPA 310.1 \\
\hline TJA-6 & Bromide & 0.255 & 0.0978 & 0.2 & & & 063893-013 & SW846 9056 \\
\hline \multirow[t]{10}{*}{ 04-Feb-04 } & Chloride & 15.1 & 0.0322 & 0.2 & & & 063893-013 & SW846 9056 \\
\hline & Fluoride & 0.418 & 0.0553 & 0.1 & & & 063893-013 & SW846 9056 \\
\hline & Sulfate & 61.5 & 0.965 & 2 & & & 063893-013 & SW846 9056 \\
\hline & Calcium & 60.7 & 0.04 & 0.1 & & $\mathrm{~J}$ & 063893-014 & SW846 3005 \\
\hline & Magnesium & 10.9 & 0.00633 & 0.01 & & & 063893-014 & SW846 3005 \\
\hline & Potassium & 2.24 & 0.0151 & 0.3 & & & 063893-014 & SW846 3005 \\
\hline & Sodium & 20.4 & 0.00968 & 0.25 & $B$ & $\mathrm{~J}$ & 063893-014 & SW846 3005 \\
\hline & $\begin{array}{l}\text { Total Alkalinity as } \\
\mathrm{CaCO} 3\end{array}$ & 160 & 1.45 & 2 & & & 063893-018 & EPA 310.1 \\
\hline & $\begin{array}{l}\text { Alkalinity as } \\
\mathrm{HCO} 3\end{array}$ & 160 & 1.45 & 2 & & & 063893-018 & EPA 310.1 \\
\hline & Alkalinity as $\mathrm{CO} 3$ & ND & 1.45 & 2 & $\mathrm{U}$ & & 063893-018 & EPA 310.1 \\
\hline TJA-7 & Bromide & 0.565 & 0.0978 & 0.2 & B & $\mathrm{B}, \mathrm{B} 3, \mathrm{~J}$ & 063895-013 & SW846 9056 \\
\hline \multirow[t]{10}{*}{ 22-Jan-04 } & Chloride & 30.9 & 0.322 & 2 & & & 063895-013 & SW846 9056 \\
\hline & Fluoride & 0.310 & 0.0553 & 0.1 & & & 063895-013 & SW846 9056 \\
\hline & Sulfate & 18.2 & 0.193 & 0.4 & & & 063895-013 & SW846 9056 \\
\hline & Calcium & 72.1 & 0.04 & 0.1 & $\mathrm{~B}$ & $\mathrm{~J}$ & 063895-014 & SW846 3005 \\
\hline & Magnesium & 12.5 & 0.00633 & 0.01 & & $\mathrm{~J}$ & 063895-014 & SW846 3005 \\
\hline & Potassium & 2.14 & 0.0151 & 0.3 & $\mathrm{~B}$ & & 063895-014 & SW846 3005 \\
\hline & Sodium & 17.6 & 0.00968 & 0.25 & $B$ & $\mathrm{~J}$ & 063895-014 & SW846 3005 \\
\hline & $\begin{array}{l}\text { Total Alkalinity as } \\
\text { CaCO3 }\end{array}$ & 130 & 1.45 & 2 & & & 063895-014 & EPA 310.1 \\
\hline & \begin{tabular}{l|} 
Alkalinity as \\
$\mathrm{HCO} 3$
\end{tabular} & 130 & 1.45 & 2 & & & 063895-014 & EPA 310.1 \\
\hline & Alkalinity as $\mathrm{CO} 3$ & ND & 1.45 & 2 & $\mathrm{U}$ & & 063895-014 & EPA 310.1 \\
\hline
\end{tabular}




\begin{tabular}{|c|c|c|c|c|c|c|c|c|}
\hline Well ID & Analyte & $\begin{array}{l}\text { Result } \\
\text { (mg/L) }\end{array}$ & $\begin{array}{l}\text { MDL } \\
\text { (mg/L) }\end{array}$ & $\begin{array}{c}\mathrm{PQL} \\
\text { (mg/L) }\end{array}$ & $\begin{array}{l}\text { Laboratory } \\
\text { Qualifier }\end{array}$ & $\begin{array}{l}\text { Validation } \\
\text { Qualifier }\end{array}$ & Sample No. & $\begin{array}{l}\text { Analytical } \\
\text { Method }\end{array}$ \\
\hline WYO-3 & Bromide & 0.900 & 0.0978 & 0.2 & B & $\mathrm{B}, \mathrm{J}$ & 063897-013 & SW846 9056 \\
\hline \multirow[t]{10}{*}{ 21-Jan-04 } & Chloride & 16.3 & 0.0322 & 0.2 & & & 063897-013 & SW846 9056 \\
\hline & Fluoride & 0.398 & 0.0553 & 0.1 & & & 063897-013 & SW846 9056 \\
\hline & Sulfate & 88.6 & 1.93 & 4 & & & $063897-013$ & SW846 9056 \\
\hline & Calcium & 67.4 & 0.04 & 0.1 & & & 063897-014 & SW846 3005 \\
\hline & Magnesium & 13.3 & 0.00633 & 0.01 & & & 063897-014 & SW846 3005 \\
\hline & Potassium & 2.25 & 0.0151 & 0.3 & & & 063897-014 & SW846 3005 \\
\hline & Sodium & 24.3 & 0.00968 & 0.25 & & & 063897-014 & SW846 3005 \\
\hline & $\begin{array}{l}\text { Total Alkalinity as } \\
\text { CaCO3 }\end{array}$ & 172 & 1.45 & 2 & & & 063897-018 & EPA 310.1 \\
\hline & $\begin{array}{l}\text { Alkalinity as } \\
\text { HCO3 }\end{array}$ & 171 & 1.45 & 2 & & & 063897-018 & EPA 310.1 \\
\hline & Alkalinity as $\mathrm{CO} 3$ & ND & 1.45 & 2 & U & & 063897-018 & EPA 310.1 \\
\hline WYO-4 & Bromide & 1.15 & 0.0978 & 0.2 & & & 063899-013 & SW846 9056 \\
\hline \multirow[t]{10}{*}{ 03-Feb-04 } & Chloride & 97.2 & 0.322 & 2 & & & 063899-013 & SW846 9056 \\
\hline & Fluoride & 0.365 & 0.0553 & 0.1 & & & $063899-013$ & SW846 9056 \\
\hline & Sulfate & 49.2 & 1.93 & 4 & & & 063899-013 & SW846 9056 \\
\hline & Calcium & 89.3 & 0.04 & 0.1 & & & 063899-014 & SW846 3005 \\
\hline & Magnesium & 15.5 & 0.00633 & 0.01 & & & 063899-014 & SW846 3005 \\
\hline & Potassium & 2.01 & 0.0151 & 0.3 & & & 063899-014 & SW846 3005 \\
\hline & Sodium & 21.6 & 0.00968 & 0.25 & & & 063899-014 & SW846 3005 \\
\hline & $\begin{array}{l}\text { Total Alkalinity as } \\
\text { CaCO3 }\end{array}$ & 95.1 & 1.45 & 2 & & & 063899-018 & EPA 310.1 \\
\hline & $\begin{array}{l}\text { Alkalinity as } \\
\mathrm{HCO} 3\end{array}$ & 94.3 & 1.45 & 2 & & & 063899-018 & EPA 310.1 \\
\hline & Alkalinity as $\mathrm{CO} 3$ & ND & \begin{tabular}{|l|}
1.45 \\
\end{tabular} & 2 & $\mathrm{U}$ & & 063899-018 & EPA 310.1 \\
\hline \multicolumn{9}{|c|}{$\begin{array}{l}\mathrm{mg} / \mathrm{L}=\text { milligrams per liter } \\
\mathrm{J}=\text { Amount detected is below the practical quantitation limit. The associated value is an estimated quantity. } \\
\mathrm{B}=\text { Analyte is detected in associated laboratory method blank. } \\
\mathrm{B} 3=\text { Analyte is detected in associated laboratory calibration blank. } \\
\mathrm{U}=\text { Analyte not detected above the MDL. }\end{array}$} \\
\hline
\end{tabular}


Table A-17

Summary of Anion, Cation, and Alkalinity Results

Tijeras Arroyo Groundwater Investigation

Fiscal Year 2004, $3^{\text {rd }}$ Quarter

\begin{tabular}{|c|c|c|c|c|c|c|c|c|}
\hline \begin{tabular}{|l} 
Well ID \\
\end{tabular} & Analyte & $\begin{array}{l}\text { Result } \\
\text { (mg/L) }\end{array}$ & $\begin{array}{c}\mathrm{MDL} \\
(\mathrm{mg} / \mathrm{L})\end{array}$ & $\begin{array}{c}\mathrm{PQL} \\
\text { (mg/L) }\end{array}$ & $\begin{array}{l}\text { Laboratory } \\
\text { Qualifier }\end{array}$ & $\begin{array}{l}\text { Validation } \\
\text { Qualifier }\end{array}$ & Sample No. & $\begin{array}{l}\text { Analytical } \\
\text { Method }\end{array}$ \\
\hline Eubank-1 & Bromide & 0.14 & 0.02 & 0.25 & $\mathrm{~J}$ & & 064600-013 & SW846 9056 \\
\hline \multirow[t]{10}{*}{ 20-May-04 } & Chloride & 12.7 & 0.43 & 2 & & & 064600-013 & SW846 9056 \\
\hline & Fluoride & 0.35 & 0.0032 & 0.10 & & & 064600-013 & SW846 9056 \\
\hline & Sulfate & 78.9 & 0.37 & 5 & & & $064600-013$ & SW846 9056 \\
\hline & Calcium & 65.8 & 0.035 & 0.50 & & & $064600-014$ & SW846 6020 \\
\hline & Magnesium & 9.8 & 0.0022 & 0.10 & B & & 064600-014 & SW846 6020 \\
\hline & Potassium & 1.6 & 0.013 & 0.50 & $B$ & & $064600-014$ & SW846 6020 \\
\hline & Sodium & 24.6 & 0.0064 & 0.50 & $\mathrm{~B}$ & & 064600-014 & SW846 6020 \\
\hline & $\begin{array}{l}\text { Total Alkalinity as } \\
\text { CaCO3 }\end{array}$ & 164 & 1.2 & 5 & & & 064600-018 & EPA 310.1 \\
\hline & $\begin{array}{l}\text { Alkalinity as } \\
\text { HCO3 }\end{array}$ & 164 & 1.2 & 5 & & & 064600-018 & EPA 310.1 \\
\hline & Alkalinity as CO3 & ND & 1.2 & 5 & $\mathrm{U}$ & & 064600-018 & EPA 310.1 \\
\hline Eubank-2 & Bromide & 0.15 & 0.02 & 0.25 & $\mathrm{~J}$ & & 064602-013 & SW846 9056 \\
\hline \multirow[t]{10}{*}{ 06-May-04 } & Chloride & 11.9 & 0.43 & 2 & & & $064602-013$ & SW846 9056 \\
\hline & Fluoride & 0.23 & 0.0032 & 0.10 & & & $064602-013$ & SW846 9056 \\
\hline & Sulfate & 93.1 & 0.37 & 5 & & & 064602-013 & SW846 9056 \\
\hline & Calcium & 73 & 0.035 & 0.50 & & $\mathrm{~J}$ & 064602-014 & SW846 6020 \\
\hline & Magnesium & 11.3 & 0.0022 & 0.10 & & & 064602-014 & SW846 6020 \\
\hline & Potassium & 2.1 & 0.013 & 0.50 & & & $064602-014$ & SW846 6020 \\
\hline & Sodium & 29.9 & 0.0064 & 0.50 & & & $064602-014$ & SW846 6020 \\
\hline & $\begin{array}{l}\text { Total Alkalinity as } \\
\mathrm{CaCO} 3 \\
\end{array}$ & 199 & 1.2 & 5 & & & 064602-018 & EPA 310.1 \\
\hline & $\begin{array}{l}\text { Alkalinity as } \\
\text { HCO3 }\end{array}$ & 199 & 1.2 & 5 & & & 064602-018 & EPA 310.1 \\
\hline & Alkalinity as $\mathrm{CO} 3$ & ND & 1.2 & 5 & $U$ & & 064602-018 & EPA 310.1 \\
\hline \multirow{11}{*}{$\begin{array}{l}\text { Eubank-3 } \\
\text { 04-May-04 }\end{array}$} & Bromide & 0.19 & 0.02 & 0.25 & $\mathrm{~J}$ & & 064604-013 & SW846 9056 \\
\hline & Chloride & 18.1 & 0.43 & 2 & & & 064604-013 & SW846 9056 \\
\hline & Fluoride & 0.31 & 0.0032 & 0.10 & & & 064604-013 & SW846 9056 \\
\hline & Sulfate & 82.6 & 0.37 & 5 & & & 064604-013 & SW846 9056 \\
\hline & Calcium & 72.9 & 0.035 & 0.50 & & $\mathrm{~J}$ & 064604-014 & SW846 6020 \\
\hline & Magnesium & 11.8 & 0.0022 & 0.10 & & & 064604-014 & SW846 6020 \\
\hline & Potassium & 1.8 & 0.013 & 0.50 & & & 064604-014 & SW846 6020 \\
\hline & Sodium & 29.8 & 0.0064 & 0.50 & & & 064604-014 & SW846 6020 \\
\hline & $\begin{array}{l}\text { Total Alkalinity as } \\
\mathrm{CaCO} 3 \\
\end{array}$ & 188 & 1.2 & 5 & & & 064604-018 & EPA 310.1 \\
\hline & $\begin{array}{l}\text { Alkalinity as } \\
\mathrm{HCO} 3\end{array}$ & 188 & 1.2 & 5 & & & 064604-018 & EPA 310.1 \\
\hline & Alkalinity as $\mathrm{CO} 3$ & ND & 1.2 & 5 & $\mathrm{U}$ & & 064604-018 & EPA 310.1 \\
\hline \multirow{6}{*}{$\begin{array}{l}\text { Eubank-5 } \\
\text { 03-May-04 }\end{array}$} & Bromide & 0.22 & 0.02 & 0.25 & $\mathrm{~J}$ & & 064607-013 & SW846 9056 \\
\hline & Chloride & 23.4 & 0.43 & 2 & & & 064607-013 & SW846 9056 \\
\hline & Fluoride & 0.28 & 0.0032 & 0.10 & & & 064607-013 & SW846 9056 \\
\hline & Sulfate & 84.7 & 0.37 & 5 & & & 064607-013 & SW846 9056 \\
\hline & Calcium & 77.0 & 0.035 & 0.50 & & & 064607-014 & SW846 6020 \\
\hline & Magnesium & 11.8 & 0.0022 & 0.10 & & & 064607-014 & SW846 6020 \\
\hline
\end{tabular}




\begin{tabular}{|c|c|c|c|c|c|c|c|c|}
\hline Well ID & Analyte & $\begin{array}{l}\text { Result } \\
\text { (mg/L) }\end{array}$ & $\begin{array}{c}\text { MDL } \\
\text { (mg/L) }\end{array}$ & $\begin{array}{c}\text { PQL } \\
\text { (mg/L) }\end{array}$ & $\begin{array}{c}\text { Laboratory } \\
\text { Qualifier }\end{array}$ & $\begin{array}{c}\text { Validation } \\
\text { Qualifier }\end{array}$ & Sample No. & $\begin{array}{c}\text { Analytical } \\
\text { Method }\end{array}$ \\
\hline & Potassium & 1.9 & 0.013 & 0.50 & & & 064607-014 & SW846 6020 \\
\hline & Sodium & 30.9 & 0.0064 & 0.50 & & & 064607-014 & SW846 6020 \\
\hline & $\begin{array}{l}\text { Total Alkalinity as } \\
\text { CaCO3 }\end{array}$ & 195 & 1.2 & 5 & & & 064607-018 & EPA 310.1 \\
\hline & $\begin{array}{l}\text { Alkalinity as } \\
\mathrm{HCO} 3\end{array}$ & 195 & 1.2 & 5 & & & 064607-018 & EPA 310.1 \\
\hline & Alkalinity as CO3 & ND & 1.2 & 5 & $U$ & & $064607-018$ & EPA 310.1 \\
\hline \multirow{11}{*}{$\begin{array}{l}\text { PGS-2 } \\
\text { 12-May-04 }\end{array}$} & Bromide & 0.18 & 0.02 & 0.25 & $\mathrm{~J}$ & & 064551-013 & SW846 9056 \\
\hline & Chloride & 14.1 & 0.43 & 2 & $B$ & & 064551-013 & SW846 9056 \\
\hline & Fluoride & ND & 0.0032 & 0.10 & $\mathrm{U}$ & & 064551-013 & SW846 9056 \\
\hline & Sulfate & 64.1 & 0.37 & 5 & & & 064551-013 & SW846 9056 \\
\hline & Calcium & 50.9 & 0.035 & 0.50 & B & & 064551-014 & SW846 6020 \\
\hline & Magnesium & 11.5 & 0.0022 & 0.10 & & $\mathrm{~J}$ & 064551-014 & SW846 6020 \\
\hline & Potassium & 2.7 & 0.013 & 0.50 & & & 064551-014 & SW846 6020 \\
\hline & Sodium & 39.9 & 0.0064 & 0.50 & & & 064551-014 & SW846 6020 \\
\hline & $\begin{array}{l}\text { Total Alkalinity as } \\
\mathrm{CaCO} 3\end{array}$ & 179 & 1.2 & 5.0 & & & 064551-018 & EPA 310.1 \\
\hline & \begin{tabular}{|l|} 
Alkalinity as \\
HCO3
\end{tabular} & 179 & 1.2 & 5.0 & & & 064551-018 & EPA 310.1 \\
\hline & Alkalinity as CO3 & ND & 1.2 & 5.0 & $\mathrm{U}$ & & 064551-018 & EPA 310.1 \\
\hline \multirow{11}{*}{$\begin{array}{l}\text { TA1-W-01 } \\
\text { 10-May-04 }\end{array}$} & Bromide & 0.18 & 0.02 & 0.25 & $\mathrm{~J}$ & & 064553-013 & SW846 9056 \\
\hline & Chloride & 14.7 & 0.43 & 2 & & & 064553-013 & SW846 9056 \\
\hline & Fluoride & 0.40 & 0.0032 & 0.10 & & & 064553-013 & SW846 9056 \\
\hline & Sulfate & 78.0 & 0.37 & 5 & & & 064553-013 & SW846 9056 \\
\hline & Calcium & 61.0 & 0.035 & 0.50 & & $\mathrm{~J}$ & 064553-014 & SW846 6020 \\
\hline & Magnesium & 12.4 & 0.0022 & 0.10 & & & 064553-014 & SW846 6020 \\
\hline & Potassium & 2.2 & 0.013 & 0.50 & & & 064553-014 & SW846 6020 \\
\hline & Sodium & 24.7 & 0.0064 & 0.50 & & & 064553-014 & SW846 6020 \\
\hline & $\begin{array}{l}\text { Total Alkalinity as } \\
\mathrm{CaCO} 3\end{array}$ & 165 & 1.2 & 5.0 & & & 064553-018 & EPA 310.1 \\
\hline & $\begin{array}{l}\text { Alkalinity as } \\
\mathrm{HCO} 3\end{array}$ & 165 & 1.2 & 5.0 & & & 064553-018 & EPA 310.1 \\
\hline & Alkalinity as CO3 & ND & 1.2 & 5.0 & $\mathrm{U}$ & & 064553-018 & EPA 310.1 \\
\hline \multirow{11}{*}{$\begin{array}{l}\text { TA1-W-02 } \\
\text { 11-May-04 }\end{array}$} & Bromide & 0.16 & 0.02 & 0.25 & $\mathrm{~J}$ & & 064556-013 & SW846 9056 \\
\hline & Chloride & 13.7 & 0.43 & 2 & & & 064556-013 & SW846 9056 \\
\hline & Fluoride & 0.34 & 0.0032 & 0.10 & & & 064556-013 & SW846 9056 \\
\hline & Sulfate & 81.0 & 0.37 & 5 & & & $064556-013$ & SW846 9056 \\
\hline & Calcium & 67.3 & 0.035 & 0.50 & B & & 064556-014 & SW846 6020 \\
\hline & Magnesium & 12.8 & 0.0022 & 0.10 & & $\mathrm{~J}$ & 064556-014 & SW846 6020 \\
\hline & Potassium & 2.1 & 0.013 & 0.50 & & & 064556-014 & SW846 6020 \\
\hline & Sodium & 23.2 & 0.0064 & 0.50 & & & 064556-014 & SW846 6020 \\
\hline & $\begin{array}{l}\text { Total Alkalinity as } \\
\text { CaCO3 }\end{array}$ & 173 & 1.2 & 5.0 & & & 064556-018 & EPA 310.1 \\
\hline & $\begin{array}{l}\text { Alkalinity as } \\
\mathrm{HCO} 3\end{array}$ & 173 & 1.2 & 5.0 & & & 064556-018 & EPA 310.1 \\
\hline & Alkalinity as $\mathrm{CO} 3$ & ND & 1.2 & 5.0 & $U$ & & 064556-018 & EPA 310.1 \\
\hline \multirow{8}{*}{$\begin{array}{l}\text { TA1-W-03 } \\
\text { 28-Apr-04 }\end{array}$} & Bromide & 3.0 & 0.02 & 0.25 & & & 064558-013 & SW846 9056 \\
\hline & Chloride & 230 & 4.3 & 20 & & & 064558-013 & SW846 9056 \\
\hline & Fluoride & 0.21 & 0.0032 & 0.10 & & & $064558-013$ & SW846 9056 \\
\hline & Sulfate & 449 & 3.7 & 50 & & & 064558-013 & SW846 9056 \\
\hline & Calcium & 227 & 0.01745 & 0.50 & $\mathrm{~N}$ & & 064558-014 & SW846 6020 \\
\hline & Magnesium & 29.9 & 0.001099 & 0.10 & & & 064558-014 & SW846 6020 \\
\hline & Potassium & 2.6 & 0.006374 & 0.50 & $E$ & & 064558-014 & SW846 6020 \\
\hline & Sodium & 44.4 & 0.003203 & 0.50 & & & 064558-014 & SW846 6020 \\
\hline
\end{tabular}




\begin{tabular}{|c|c|c|c|c|c|c|c|c|}
\hline Well ID & \begin{tabular}{|l} 
Analyte \\
\end{tabular} & $\begin{array}{l}\text { Result } \\
\text { (mg/L) }\end{array}$ & $\begin{array}{c}\text { MDL } \\
\text { (mg/L) }\end{array}$ & $\begin{array}{c}\text { PQL } \\
\text { (mg/L) }\end{array}$ & $\begin{array}{l}\text { Laboratory } \\
\text { Qualifier }\end{array}$ & $\begin{array}{c}\text { Validation } \\
\text { Qualifier }\end{array}$ & Sample No. & $\begin{array}{c}\text { Analytical } \\
\text { Method }\end{array}$ \\
\hline & $\begin{array}{l}\text { Total Alkalinity as } \\
\text { CaCO3 }\end{array}$ & 70 & 1.2 & 5.0 & & & 064558-018 & EPA 310.1 \\
\hline & $\begin{array}{l}\text { Alkalinity as } \\
\text { HCO3 }\end{array}$ & 70 & 1.2 & 5.0 & & & 064558-018 & EPA 310.1 \\
\hline & Alkalinity as $\mathrm{CO} 3$ & ND & 1.2 & 5.0 & U & & 064558-018 & EPA 310.1 \\
\hline TA1-W-04 & Bromide & 0.15 & 0.02 & 0.25 & B & & 064560-013 & SW846 9056 \\
\hline \multirow[t]{10}{*}{ 26-Apr-04 } & Chloride & 14.3 & 0.43 & 2 & & & 064560-013 & SW846 9056 \\
\hline & Fluoride & 0.31 & 0.0032 & 0.10 & & & 064560-013 & SW846 9056 \\
\hline & Sulfate & 60.3 & 0.37 & 5 & & & 064560-013 & SW846 9056 \\
\hline & Calcium & 61.2 & 0.01745 & 0.50 & $\mathrm{~N}$ & & 064560-014 & SW846 6020 \\
\hline & Magnesium & 10.9 & 0.001099 & 0.10 & & & 064560-014 & SW846 6020 \\
\hline & Potassium & 2.4 & 0.006374 & 0.50 & $\mathrm{E}$ & & 064560-014 & SW846 6020 \\
\hline & Sodium & 23.2 & 0.003203 & 0.50 & & & 064560-014 & SW846 6020 \\
\hline & $\begin{array}{l}\text { Total Alkalinity as } \\
\mathrm{CaCO} 3\end{array}$ & 170 & 1.2 & 5.0 & & & 064560-018 & EPA 310.1 \\
\hline & $\begin{array}{l}\text { Alkalinity as } \\
\text { HCO3 }\end{array}$ & 170 & 1.2 & 5.0 & & & 064560-018 & EPA 310.1 \\
\hline & Alkalinity as $\mathrm{CO} 3$ & ND & 1.2 & 5.0 & $U$ & & 064560-018 & EPA 310.1 \\
\hline TA1-W-05 & Bromide & 0.13 & 0.02 & 0.25 & $\mathrm{~J}$ & & $064562-013$ & SW846 9056 \\
\hline \multirow[t]{10}{*}{ 07-May-04 } & Chloride & 11.5 & 0.43 & 2 & & & 064562-013 & SW846 9056 \\
\hline & Fluoride & 0.27 & 0.0032 & 0.10 & & & 064562-013 & SW846 9056 \\
\hline & Sulfate & 99.2 & 0.37 & 5 & & & $064562-013$ & SW846 9056 \\
\hline & Calcium & 75.9 & 0.035 & 0.50 & & $\mathrm{~J}$ & 064562-014 & SW846 6020 \\
\hline & Magnesium & 11.7 & 0.0022 & 0.10 & & & 064562-014 & SW846 6020 \\
\hline & Potassium & 2.1 & 0.013 & 0.50 & & & 064562-014 & SW846 6020 \\
\hline & Sodium & 29.9 & 0.0064 & 0.50 & & & 064562-014 & SW846 6020 \\
\hline & $\begin{array}{l}\text { Total Alkalinity as } \\
\text { CaCO3 }\end{array}$ & 201 & 1.2 & 5.0 & & & 064562-018 & EPA 310.1 \\
\hline & $\begin{array}{l}\text { Alkalinity as } \\
\text { HCO3 }\end{array}$ & 201 & 1.2 & 5.0 & & & 064562-018 & EPA 310.1 \\
\hline & Alkalinity as $\mathrm{CO} 3$ & ND & 1.2 & 5.0 & $U$ & & 064562-018 & EPA 310.1 \\
\hline TA1-W-06 & Bromide & 1.2 & 0.02 & 0.25 & & & 064564-013 & SW846 9056 \\
\hline \multirow[t]{10}{*}{ 21-May-04 } & Chloride & 101 & 4.3 & 20 & & & 064564-013 & SW846 9056 \\
\hline & Fluoride & 0.32 & 0.0032 & 0.10 & & & 064564-013 & SW846 9056 \\
\hline & Sulfate & 195 & 3.7 & 50 & & & 064564-013 & SW846 9056 \\
\hline & Calcium & 98.7 & 0.035 & 0.50 & & & 064564-014 & SW846 6020 \\
\hline & Magnesium & 12.2 & 0.0022 & 0.10 & $\mathrm{~B}$ & & 064564-014 & SW846 6020 \\
\hline & Potassium & 1.7 & 0.013 & 0.50 & B & & 064564-014 & SW846 6020 \\
\hline & Sodium & 27.3 & 0.0064 & 0.50 & $B$ & & 064564-014 & SW846 6020 \\
\hline & $\begin{array}{l}\text { Total Alkalinity as } \\
\mathrm{CaCO} 3\end{array}$ & 85 & 1.2 & 5.0 & & & 064564-018 & EPA 310.1 \\
\hline & $\begin{array}{l}\text { Alkalinity as } \\
\text { HCO3 }\end{array}$ & 85 & 1.2 & 5.0 & & & 064564-018 & EPA 310.1 \\
\hline & Alkalinity as $\mathrm{CO} 3$ & ND & 1.2 & 5.0 & $U$ & & 064564-018 & EPA 310.1 \\
\hline \multirow{9}{*}{$\begin{array}{l}\text { TA1-W-08 } \\
\text { 23-Apr-04 }\end{array}$} & Bromide & 2.4 & 0.02 & 0.25 & & & 064566-013 & SW846 9056 \\
\hline & Chloride & 190 & 4.3 & 20 & & & 064566-013 & SW8469056 \\
\hline & Fluoride & 0.19 & 0.0032 & 0.10 & & & 064566-013 & SW846 9056 \\
\hline & Sulfate & 570 & 3.7 & 50 & & & 064566-013 & SW846 9056 \\
\hline & Calcium & 285 & 0.01745 & 0.50 & $\mathrm{~N}$ & & 064566-014 & SW846 6020 \\
\hline & Magnesium & 37.3 & 0.001099 & 0.10 & & & 064566-014 & SW846 6020 \\
\hline & Potassium & 3.0 & 0.006374 & 0.50 & $\mathrm{E}$ & & 064566-014 & SW846 6020 \\
\hline & Sodium & 69.9 & 0.003203 & 0.50 & & & 064566-014 & SW846 6020 \\
\hline & $\begin{array}{l}\text { Total Alkalinity as } \\
\text { CaCO3 }\end{array}$ & 86 & 1.2 & 5.0 & & & 064566-018 & EPA 310.1 \\
\hline
\end{tabular}




\begin{tabular}{|c|c|c|c|c|c|c|c|c|}
\hline Well ID & Analyte & $\begin{array}{l}\text { Result } \\
\text { (mg/L) }\end{array}$ & $\begin{array}{c}\mathrm{MDL} \\
(\mathrm{mg} / \mathrm{L})\end{array}$ & $\begin{array}{c}\mathrm{PQL} \\
\text { (mg/L) }\end{array}$ & $\begin{array}{l}\text { Laboratory } \\
\text { Qualifier }\end{array}$ & $\begin{array}{c}\text { Validation } \\
\text { Qualifier }\end{array}$ & Sample No. & $\begin{array}{c}\text { Analytical } \\
\text { Method }\end{array}$ \\
\hline & $\begin{array}{l}\text { Alkalinity as } \\
\text { HCO3 }\end{array}$ & 86 & 1.2 & 5.0 & & & 064566-018 & EPA 310.1 \\
\hline & Alkalinity as CO3 & ND & 1.2 & 5.0 & $U$ & & 064566-018 & EPA 310.1 \\
\hline TA2-NW1-595 & Bromide & 1.2 & 0.02 & 0.25 & & & 064568-013 & SW846 9056 \\
\hline \multirow{10}{*}{$\begin{array}{l}\text { 13-May-04 } \\
\text { (QED) }\end{array}$} & Chloride & 92.8 & 4.3 & 20 & & & 064568-013 & SW846 9056 \\
\hline & Fluoride & 0.26 & 0.0032 & 0.10 & & & 064568-013 & SW846 9056 \\
\hline & Sulfate & 117 & 3.7 & 50 & & & 064568-013 & SW846 9056 \\
\hline & Calcium & 99.3 & 0.035 & 0.50 & B & & 064568-014 & SW846 6020 \\
\hline & Magnesium & 16.4 & 0.0022 & 0.10 & & & 064568-014 & SW846 6020 \\
\hline & Potassium & 2.3 & 0.013 & 0.50 & & & 064568-014 & SW846 6020 \\
\hline & Sodium & 30 & 0.0064 & 0.50 & & & 064568-014 & SW846 6020 \\
\hline & $\begin{array}{l}\text { Total Alkalinity as } \\
\mathrm{CaCO} 3 \\
\end{array}$ & 144 & 1.2 & 5.0 & & & 064568-018 & EPA 310.1 \\
\hline & $\begin{array}{l}\text { Alkalinity as } \\
\mathrm{HCO} 3\end{array}$ & 144 & 1.2 & 5.0 & & & 064568-018 & EPA 310.1 \\
\hline & Alkalinity as $\mathrm{CO} 3$ & ND & 1.2 & 5.0 & $U$ & & 064568-018 & EPA 310.1 \\
\hline \multirow[t]{11}{*}{ TA2-NW1-595 } & Bromide & 1.2 & 0.02 & 0.25 & & & 064571-013 & SW846 9056 \\
\hline & Chloride & 86.2 & 4.3 & 20 & & & 064571-013 & SW846 9056 \\
\hline & Fluoride & 0.25 & 0.0032 & 0.10 & & & 064571-013 & SW846 9056 \\
\hline & Sulfate & 111 & 3.7 & 50 & & & 064571-013 & SW846 9056 \\
\hline & Calcium & 98.1 & 0.035 & 0.50 & & & 064571-014 & SW846 6020 \\
\hline & Magnesium & 15.9 & 0.0022 & 0.10 & $B$ & & 064571-014 & SW846 6020 \\
\hline & Potassium & 2.2 & 0.013 & 0.50 & $\mathrm{~B}$ & & 064571-014 & SW846 6020 \\
\hline & Sodium & 28.9 & 0.0064 & 0.50 & B & & 064571-014 & SW846 6020 \\
\hline & $\begin{array}{l}\text { Total Alkalinity as } \\
\text { CaCO3 } \\
\end{array}$ & 137 & 1.2 & 5.0 & & & 064571-018 & EPA 310.1 \\
\hline & $\begin{array}{l}\text { Alkalinity as } \\
\mathrm{HCO} 3\end{array}$ & 137 & 1.2 & 5.0 & & & 064571-018 & EPA 310.1 \\
\hline & Alkalinity as CO3 & ND & 1.2 & 5.0 & $\mathrm{U}$ & & 064571-018 & EPA 310.1 \\
\hline \multirow{11}{*}{$\begin{array}{l}\text { TA2-SW1-320 } \\
\text { 14-May-04 }\end{array}$} & Bromide & 0.38 & 0.02 & 0.25 & & & 064573-013 & SW846 9056 \\
\hline & Chloride & 27.1 & 0.87 & 4 & & & 064573-013 & SW846 9056 \\
\hline & Fluoride & 0.39 & 0.0032 & 0.10 & & & 064573-013 & SW846 9056 \\
\hline & Sulfate & 14.8 & 0.75 & 10 & & & 064573-013 & SW846 9056 \\
\hline & Calcium & 56.9 & 0.035 & 0.50 & & & 064573-014 & SW846 6020 \\
\hline & Magnesium & 10 & 0.0022 & 0.10 & B & & 064573-014 & SW846 6020 \\
\hline & Potassium & 1.7 & 0.013 & 0.50 & B & & 064573-014 & SW846 6020 \\
\hline & Sodium & 17 & 0.0064 & 0.50 & $B$ & & 064573-014 & SW846 6020 \\
\hline & $\begin{array}{l}\text { Total Alkalinity as } \\
\text { CaCO3 }\end{array}$ & 109 & 1.2 & 5.0 & & & 064573-018 & EPA 310.1 \\
\hline & $\begin{array}{l}\text { Alkalinity as } \\
\mathrm{HCO} 3\end{array}$ & 109 & 1.2 & 5.0 & & & 064573-018 & EPA 310.1 \\
\hline & Alkalinity as $\mathrm{CO} 3$ & ND & 1.2 & 5.0 & $U$ & & 064573-018 & EPA 310.1 \\
\hline \multirow{11}{*}{ 17-May-04 } & Bromide & 1.8 & 0.02 & 0.25 & & & 064575-013 & SW846 9056 \\
\hline & Chloride & 108 & 4.3 & 20 & & & 064575-013 & SW846 9056 \\
\hline & Fluoride & 0.42 & 0.0032 & 0.10 & & & 064575-013 & SW846 9056 \\
\hline & Sulfate & 52.3 & 0.37 & 5.0 & & & 064575-013 & SW846 9056 \\
\hline & Calcium & 82.7 & 0.035 & 0.50 & & & 064575-014 & SW846 6020 \\
\hline & Magnesium & 11.1 & 0.0022 & 0.10 & $B$ & & 064575-014 & SW846 6020 \\
\hline & Potassium & 1.8 & 0.013 & 0.50 & $B$ & & 064575-014 & SW846 6020 \\
\hline & Sodium & 20.9 & 0.0064 & 0.50 & $B$ & & 064575-014 & SW846 6020 \\
\hline & $\begin{array}{l}\text { Total Alkalinity as } \\
\mathrm{CaCO} 3\end{array}$ & 95 & 1.2 & 5.0 & & & 064575-018 & EPA 310.1 \\
\hline & $\begin{array}{l}\text { Alkalinity as } \\
\mathrm{HCO} 3\end{array}$ & 95 & 1.2 & 5.0 & & & 064575-018 & EPA 310.1 \\
\hline & Alkalinity as CO3 & ND & 1.2 & 5.0 & $U$ & & 064575-018 & EPA 310.1 \\
\hline
\end{tabular}




\begin{tabular}{|c|c|c|c|c|c|c|c|c|}
\hline \begin{tabular}{|l} 
Well ID \\
\end{tabular} & Analyte & $\begin{array}{l}\text { Result } \\
\text { (mg/L) }\end{array}$ & $\begin{array}{c}\mathrm{MDL} \\
(\mathrm{mg} / \mathrm{L})\end{array}$ & $\begin{array}{c}\mathrm{PQL} \\
\text { (mg/L) }\end{array}$ & $\begin{array}{l}\text { Laboratory } \\
\text { Qualifier }\end{array}$ & $\begin{array}{c}\text { Validation } \\
\text { Qualifier }\end{array}$ & Sample No. & $\begin{array}{c}\text { Analytical } \\
\text { Method }\end{array}$ \\
\hline TA2-W-19 & Bromide & 0.90 & 0.02 & 0.25 & & & 064577-013 & SW846 9056 \\
\hline \multirow[t]{10}{*}{ 27-Apr-04 } & Chloride & 74.6 & 0.87 & 4 & & & $064577-013$ & SW846 9056 \\
\hline & Fluoride & 0.28 & 0.0032 & 0.10 & & & $064577-013$ & SW846 9056 \\
\hline & Sulfate & 57.5 & 0.75 & 10 & & & $064577-013$ & SW846 9056 \\
\hline & Calcium & 71.5 & 0.01745 & 0.50 & $\mathrm{~N}$ & & 064577-014 & SW846 6020 \\
\hline & Magnesium & 11.3 & 0.001099 & 0.10 & & & 064577-014 & SW846 6020 \\
\hline & Potassium & 1.8 & 0.006374 & 0.50 & $E$ & & 064577-014 & SW846 6020 \\
\hline & Sodium & 22 & 0.003203 & 0.50 & & & 064577-014 & SW846 6020 \\
\hline & $\begin{array}{l}\text { Total Alkalinity as } \\
\text { CaCO3 }\end{array}$ & 104 & 1.2 & 5.0 & & & 064577-018 & EPA 310.1 \\
\hline & $\begin{array}{l}\text { Alkalinity as } \\
\text { HCO3 }\end{array}$ & 104 & 1.2 & 5.0 & & & 064577-018 & EPA 310.1 \\
\hline & Alkalinity as CO3 & ND & 1.2 & 5.0 & 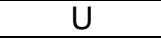 & & 064577-018 & EPA 310.1 \\
\hline TA2-W-26 & Bromide & 1.7 & 0.02 & 0.25 & & & 064580-013 & SW846 9056 \\
\hline \multirow[t]{10}{*}{ 21-Apr-04 } & Chloride & 130 & 4.3 & 20 & & & 064580-013 & SW846 9056 \\
\hline & Fluoride & 0.23 & 0.0032 & 0.10 & & & 064580-013 & SW846 9056 \\
\hline & Sulfate & 246 & 3.7 & 50 & & & 064580-013 & SW846 9056 \\
\hline & Calcium & 175 & 0.01745 & 0.50 & & & 064580-014 & SW846 6020 \\
\hline & Magnesium & 21.6 & 0.001099 & 0.10 & & & 064580-014 & SW846 6020 \\
\hline & Potassium & 2.3 & 0.006374 & 0.50 & & & 064580-014 & SW846 6020 \\
\hline & Sodium & 33.8 & 0.003203 & 0.50 & $B$ & & 064580-014 & SW846 6020 \\
\hline & $\begin{array}{l}\text { Total Alkalinity as } \\
\text { CaCO3 }\end{array}$ & 104 & 1.2 & 5.0 & & & 064580-018 & EPA 310.1 \\
\hline & \begin{tabular}{|l|} 
Alkalinity as \\
HCO3
\end{tabular} & 104 & 1.2 & 5.0 & & & 064580-018 & EPA 310.1 \\
\hline & Alkalinity as $\mathrm{CO} 3$ & ND & 1.2 & 5.0 & $\mathrm{U}$ & & 064580-018 & EPA 310.1 \\
\hline TA2-W-27 & Bromide & 1.6 & 0.02 & 0.25 & & & 064583-013 & SW846 9056 \\
\hline \multirow[t]{10}{*}{ 19-Apr-04 } & Chloride & 200 & 4.3 & 20 & & & 064583-013 & SW846 9056 \\
\hline & Fluoride & 0.24 & 0.0032 & 0.10 & & & 064583-013 & SW846 9056 \\
\hline & Sulfate & 164 & 3.7 & 50 & & & 064583-013 & SW846 9056 \\
\hline & Calcium & 131 & \begin{tabular}{|l|}
0.01745 \\
\end{tabular} & 0.50 & & & 064583-014 & SW846 6020 \\
\hline & Magnesium & 17.2 & 0.001099 & 0.10 & & & 064583-014 & SW846 6020 \\
\hline & Potassium & 2.1 & 0.006374 & 0.50 & & & 064583-014 & SW846 6020 \\
\hline & Sodium & 29.1 & 0.003203 & 0.50 & B & & 064583-014 & SW846 6020 \\
\hline & $\begin{array}{l}\text { Total Alkalinity as } \\
\text { CaCO3 }\end{array}$ & 93 & 1.2 & 5 & & & 064583-018 & EPA 310.1 \\
\hline & $\begin{array}{l}\text { Alkalinity as } \\
\mathrm{HCO} 3\end{array}$ & 93 & 1.2 & 5 & & & 064583-018 & EPA 310.1 \\
\hline & Alkalinity as $\mathrm{CO} 3$ & ND & 1.2 & 5 & $\mathrm{U}$ & & 064583-018 & EPA 310.1 \\
\hline TJA-2 & Bromide & 1.1 & 0.02 & 0.25 & & & 064585-013 & SW846 9056 \\
\hline \multirow[t]{10}{*}{ 05-May-04 } & Chloride & 69.8 & 0.87 & 4 & & & 064585-013 & SW846 9056 \\
\hline & Fluoride & 0.28 & 0.0032 & 0.10 & & & 064585-013 & SW846 9056 \\
\hline & Sulfate & 52.9 & 0.75 & 10 & & & 064585-013 & SW846 9056 \\
\hline & Calcium & 70.8 & 0.035 & 0.50 & & $\mathrm{~J}$ & 064585-014 & SW846 6020 \\
\hline & Magnesium & 11.7 & 0.0022 & 0.10 & & & 064585-014 & SW846 6020 \\
\hline & Potassium & 1.7 & 0.013 & 0.50 & & & 064585-014 & SW846 6020 \\
\hline & Sodium & 22 & 0.0064 & 0.50 & & & 064585-014 & SW846 6020 \\
\hline & $\begin{array}{l}\text { Total Alkalinity as } \\
\text { CaCO3 }\end{array}$ & 104 & 1.2 & 5.0 & & & 064585-018 & EPA 310.1 \\
\hline & $\begin{array}{l}\text { Alkalinity as } \\
\text { HCO3 }\end{array}$ & 104 & 1.2 & 5.0 & & & 064585-018 & EPA 310.1 \\
\hline & Alkalinity as $\mathrm{CO} 3$ & ND & 1.2 & 5.0 & $U$ & & 064585-018 & EPA 310.1 \\
\hline
\end{tabular}




\begin{tabular}{|c|c|c|c|c|c|c|c|c|}
\hline Well ID & Analyte & $\begin{array}{l}\text { Result } \\
\text { (mg/L) }\end{array}$ & $\begin{array}{c}\text { MDL } \\
\text { (mg/L) }\end{array}$ & $\begin{array}{c}\text { PQL } \\
\text { (mg/L) }\end{array}$ & $\begin{array}{l}\text { Laboratory } \\
\text { Qualifier }\end{array}$ & $\begin{array}{l}\text { Validation } \\
\text { Qualifier }\end{array}$ & Sample No. & $\begin{array}{l}\text { Analytical } \\
\text { Method }\end{array}$ \\
\hline TJA-3 & Bromide & 0.17 & 0.02 & 0.25 & B & & 064587-013 & SW846 9056 \\
\hline \multirow[t]{10}{*}{ 27-Apr-04 } & Chloride & 12.5 & 0.43 & 2 & & & 064587-013 & SW846 9056 \\
\hline & Fluoride & 0.30 & 0.0032 & 0.10 & & & 064587-013 & SW846 9056 \\
\hline & Sulfate & 71.1 & 0.37 & 5 & & & 064587-013 & SW846 9056 \\
\hline & Calcium & 60.9 & \begin{tabular}{|l|l|}
0.01745 \\
\end{tabular} & 0.50 & $\mathrm{~N}$ & & 064587-014 & SW846 6020 \\
\hline & Magnesium & 11.1 & 0.001099 & 0.10 & & & 064587-014 & SW846 6020 \\
\hline & Potassium & 1.9 & 0.006374 & 0.50 & $E$ & & 064587-014 & SW846 6020 \\
\hline & Sodium & 23.4 & 0.003203 & 0.50 & & & 064587-014 & SW846 6020 \\
\hline & $\begin{array}{l}\text { Total Alkalinity as } \\
\mathrm{CaCO} 3\end{array}$ & 98 & 1.2 & 5.0 & & & 064587-018 & EPA 310.1 \\
\hline & $\begin{array}{l}\text { Alkalinity as } \\
\mathrm{HCO} 3\end{array}$ & 98 & 1.2 & 5.0 & & & 064587-018 & EPA 310.1 \\
\hline & Alkalinity as $\mathrm{CO} 3$ & ND & 1.2 & 5.0 & $\mathrm{U}$ & & 064587-018 & EPA 310.1 \\
\hline \multirow{11}{*}{$\begin{array}{l}\text { TJA-4 } \\
\text { 20-Apr-04 }\end{array}$} & Bromide & 0.30 & 0.02 & 0.25 & & & 064589-013 & SW846 9056 \\
\hline & Chloride & 20 & 0.43 & 2 & & & 064589-013 & SW846 9056 \\
\hline & Fluoride & 0.34 & 0.0032 & 0.10 & & & 064589-013 & SW846 9056 \\
\hline & Sulfate & 19.1 & 0.037 & 0.50 & & & 064589-013 & SW846 9056 \\
\hline & Calcium & 93.4 & 0.01745 & 0.50 & & & 064589-014 & SW846 6020 \\
\hline & Magnesium & 39.1 & 0.001099 & 0.10 & & & 064589-014 & SW846 6020 \\
\hline & Potassium & 28.3 & 0.006374 & 0.50 & & & 064589-014 & SW846 6020 \\
\hline & Sodium & 50.6 & 0.003203 & 0.50 & B & & 064589-014 & SW846 6020 \\
\hline & $\begin{array}{l}\text { Total Alkalinity as } \\
\mathrm{CaCO} 3\end{array}$ & 134 & 1.2 & 5 & & & 064589-018 & EPA 310.1 \\
\hline & $\begin{array}{l}\text { Alkalinity as } \\
\mathrm{HCO} 3\end{array}$ & 134 & 1.2 & 5 & & & 064589-018 & EPA 310.1 \\
\hline & Alkalinity as $\mathrm{CO} 3$ & ND & 1.2 & 5 & $U$ & & 064589-018 & EPA 310.1 \\
\hline TJA-6 & Bromide & 0.18 & 0.02 & 0.25 & $\mathrm{~J}$ & & 064591-013 & SW846 9056 \\
\hline \multirow[t]{10}{*}{ 22-Apr-04 } & Chloride & 14.6 & 0.43 & 2 & & & 064591-013 & SW846 9056 \\
\hline & Fluoride & 0.33 & 0.0032 & 0.10 & & & 064591-013 & SW846 9056 \\
\hline & Sulfate & 61.8 & 0.37 & 5 & & & 064591-013 & SW846 9056 \\
\hline & Calcium & 65.2 & 0.01745 & 0.50 & & & 064591-014 & SW846 6020 \\
\hline & Magnesium & 11.7 & 0.001099 & 0.10 & & & 064591-014 & SW846 6020 \\
\hline & Potassium & 2.3 & 0.006374 & 0.50 & & & 064591-014 & SW846 6020 \\
\hline & Sodium & 23.5 & 0.003203 & 0.50 & $B$ & & 064591-014 & SW846 6020 \\
\hline & $\begin{array}{l}\text { Total Alkalinity as } \\
\mathrm{CaCO} 3\end{array}$ & 158 & 1.2 & 5 & & & 064591-018 & EPA 310.1 \\
\hline & $\begin{array}{l}\text { Alkalinity as } \\
\mathrm{HCO} 3\end{array}$ & 158 & 1.2 & 5 & & & 064591-018 & EPA 310.1 \\
\hline & Alkalinity as $\mathrm{CO} 3$ & ND & 1.2 & 5 & $\mathrm{U}$ & & 064591-018 & EPA 310.1 \\
\hline \multirow{11}{*}{$\begin{array}{l}\text { TJA-7 } \\
\text { 30-Apr-04 }\end{array}$} & Bromide & 0.42 & 0.02 & 0.25 & & & 064593-013 & SW846 9056 \\
\hline & Chloride & 29.0 & 0.43 & 2 & & & 064593-013 & SW846 9056 \\
\hline & Fluoride & 0.30 & 0.0032 & 0.10 & & & 064593-013 & SW846 9056 \\
\hline & Sulfate & 16.2 & 0.037 & 0.50 & & & 064593-013 & SW846 9056 \\
\hline & Calcium & 63.6 & 0.035 & 0.50 & & & 064593-014 & SW846 6020 \\
\hline & Magnesium & 12.1 & 0.0022 & 0.10 & & & 064593-014 & SW846 6020 \\
\hline & Potassium & 1.9 & 0.013 & 0.50 & & & 064593-014 & SW846 6020 \\
\hline & Sodium & 18.4 & 0.0064 & 0.50 & & & 064593-014 & SW846 6020 \\
\hline & $\begin{array}{l}\text { Total Alkalinity as } \\
\mathrm{CaCO} 3\end{array}$ & 128 & 1.2 & 5 & & & 064593-018 & EPA 310.1 \\
\hline & $\begin{array}{l}\text { Alkalinity as } \\
\mathrm{HCO} 3\end{array}$ & 128 & 1.2 & 5 & & & 064593-018 & EPA 310.1 \\
\hline & Alkalinity as $\mathrm{CO} 3$ & ND & 1.2 & 5 & $U$ & & 064593-018 & EPA 310.1 \\
\hline
\end{tabular}




\begin{tabular}{|c|c|c|c|c|c|c|c|c|}
\hline Well ID & Analyte & $\begin{array}{l}\text { Result } \\
\text { (mg/L) }\end{array}$ & $\begin{array}{l}\text { MDL } \\
(\mathrm{mg} / \mathrm{L})\end{array}$ & $\begin{array}{l}\mathrm{PQL} \\
(\mathrm{mg} / \mathrm{L})\end{array}$ & $\begin{array}{l}\text { Laboratory } \\
\text { Qualifier }\end{array}$ & $\begin{array}{c}\text { Validation } \\
\text { Qualifier }\end{array}$ & Sample No. & $\begin{array}{l}\text { Analytical } \\
\text { Method }\end{array}$ \\
\hline WYO-3 & Bromide & 0.18 & 0.02 & 0.25 & B & & 064595-013 & SW846 9056 \\
\hline \multirow[t]{10}{*}{ 28-Apr-04 } & Chloride & 14.1 & 0.43 & 2 & & & 064595-013 & SW846 9056 \\
\hline & Fluoride & 0.37 & 0.0032 & 0.10 & & & $064595-013$ & SW846 9056 \\
\hline & Sulfate & 82.8 & 0.37 & 5 & & & 064595-013 & SW846 9056 \\
\hline & Calcium & 63.8 & 0.01745 & 0.50 & $\mathrm{~N}$ & & 064595-014 & SW846 6020 \\
\hline & Magnesium & 11.8 & 0.001099 & 0.10 & & & 064595-014 & SW846 6020 \\
\hline & \begin{tabular}{|l} 
Potassium \\
\end{tabular} & 2.2 & 0.006374 & 0.50 & $E$ & & 064595-014 & SW846 6020 \\
\hline & Sodium & 24.4 & 0.003203 & 0.50 & & & 064595-014 & SW846 6020 \\
\hline & $\begin{array}{l}\text { Total Alkalinity as } \\
\text { CaCO3 }\end{array}$ & 156 & 1.2 & 5.0 & & & 064595-018 & EPA 310.1 \\
\hline & $\begin{array}{l}\text { Alkalinity as } \\
\mathrm{HCO} 3\end{array}$ & 156 & 1.2 & 5.0 & & & 064595-018 & EPA 310.1 \\
\hline & Alkalinity as CO3 & ND & 1.2 & 5.0 & $\mathrm{U}$ & & 064595-018 & EPA 310.1 \\
\hline WYO-4 & Bromide & 0.49 & 0.02 & 0.25 & & & 064597-013 & SW846 9056 \\
\hline \multirow[t]{10}{*}{ 30-Apr-04 } & Chloride & 84.4 & 0.87 & 4 & & & $064597-013$ & SW846 9056 \\
\hline & Fluoride & 0.14 & 0.0032 & 0.10 & & & 064597-013 & SW846 9056 \\
\hline & Sulfate & 38 & 0.75 & 10 & & & 064597-013 & SW846 9056 \\
\hline & Calcium & 75.2 & 0.035 & 0.50 & & & 064597-014 & SW846 6020 \\
\hline & Magnesium & 12.6 & 0.0022 & 0.10 & & & 064597-014 & SW846 6020 \\
\hline & Potassium & 1.8 & 0.013 & 0.50 & & & 064597-014 & SW846 6020 \\
\hline & Sodium & 19.2 & 0.0064 & 0.50 & & & 064597-014 & SW846 6020 \\
\hline & $\begin{array}{l}\text { Total Alkalinity as } \\
\text { CaCO3 }\end{array}$ & 96 & 1.2 & 5.0 & & & 064597-018 & EPA 310.1 \\
\hline & $\begin{array}{l}\text { Alkalinity as } \\
\mathrm{HCO} 3\end{array}$ & 96 & 1.2 & 5.0 & & & 064597-018 & EPA 310.1 \\
\hline & Alkalinity as CO3 & ND & 1.2 & 5.0 & U & & 064597-018 & EPA 310.1 \\
\hline \multicolumn{9}{|c|}{$\begin{array}{l}\mathrm{mg} / \mathrm{L}=\text { milligrams per liter } \\
\mathrm{J}=\text { Amount detected is below the practical quantitation limit. The associated value is an estimated quantity. } \\
\mathrm{B}=\text { Analyte is detected in associated laboratory method blank. } \\
\mathrm{U}=\text { Analyte not detected above the MDL. } \\
\mathrm{E}=\text { Concentration exceeds calibration range of instrument and/or estimated quantity due to matrix interference. }\end{array}$} \\
\hline
\end{tabular}


Table A-18

Summary of Anion, Cation, and Alkalinity Results

Tijeras Arroyo Groundwater Investigation

Fiscal Year 2004, $4^{\text {th }}$ Quarter

\begin{tabular}{|c|c|c|c|c|c|c|c|c|}
\hline Well ID & Analyte & $\begin{array}{l}\text { Result } \\
\text { (mg/L) }\end{array}$ & $\begin{array}{c}\text { MDL } \\
\text { (mg/L) }\end{array}$ & $\begin{array}{c}P Q L \\
(\mathrm{mg} / \mathrm{L})\end{array}$ & $\begin{array}{l}\text { Laboratory } \\
\text { Qualifier }\end{array}$ & $\begin{array}{c}\text { Validation } \\
\text { Qualifier }\end{array}$ & Sample No. & $\begin{array}{c}\text { Analytical } \\
\text { Method }\end{array}$ \\
\hline Eubank-1 & Bromide & 0.17 & 0.02 & 0.25 & $\mathrm{~J}$ & & 065416-013 & SW846 9056 \\
\hline \multirow[t]{10}{*}{ 18-Aug-04 } & Chloride & 12.3 & 0.43 & 2 & & & 065416-013 & SW846 9056 \\
\hline & Fluoride & 0.34 & 0.01 & 0.10 & & & 065416-013 & SW846 9056 \\
\hline & Sulfate & 75.5 & 0.37 & 5 & & & 065416-013 & SW846 9056 \\
\hline & Calcium & 66.6 & 0.035 & 0.50 & B & & 065416-014 & SW846 6020 \\
\hline & Magnesium & 9.7 & 0.0022 & 0.10 & $B$ & & 065416-014 & SW846 6020 \\
\hline & Potassium & 1.6 & 0.013 & 0.50 & $B$ & & 065416-014 & SW846 6020 \\
\hline & Sodium & 24.6 & 0.0064 & 0.50 & $B$ & & 065416-014 & SW846 6020 \\
\hline & $\begin{array}{l}\text { Total Alkalinity as } \\
\text { CaCO3 }\end{array}$ & 166 & 1.2 & 5 & & & 065416-018 & EPA 310.1 \\
\hline & $\begin{array}{l}\text { Alkalinity as } \\
\text { HCO3 }\end{array}$ & 166 & 1.2 & 5 & & & 065416-018 & EPA 310.1 \\
\hline & Alkalinity as $\mathrm{CO} 3$ & ND & 1.2 & 5 & U & & 065416-018 & EPA 310.1 \\
\hline \multirow{11}{*}{$\begin{array}{l}\text { PGS-2 } \\
\text { 28-Jul-04 }\end{array}$} & Bromide & 0.18 & 0.02 & 0.25 & $\mathrm{~J}$ & & 065360-013 & SW846 9056 \\
\hline & Chloride & 14.6 & 0.43 & 2 & & & $065360-013$ & SW846 9056 \\
\hline & Fluoride & 0.089 & 0.01 & 0.10 & $\mathrm{~J}$ & & 065360-013 & SW846 9056 \\
\hline & Sulfate & 61.4 & 0.37 & 5 & & & 065360-013 & SW846 9056 \\
\hline & Calcium & 50 & 0.035 & 0.50 & B & $\mathrm{J}$ & 065360-014 & SW846 6020 \\
\hline & Magnesium & 2.3 & 0.0022 & 0.10 & $B$ & $\mathrm{~J}$ & 065360-014 & SW846 6020 \\
\hline & Potassium & 10.5 & 0.013 & 0.50 & $B$ & & 065360-014 & SW846 6020 \\
\hline & Sodium & 30.6 & 0.0064 & 0.50 & B & $\mathrm{J}$ & 065360-014 & SW846 6020 \\
\hline & $\begin{array}{l}\text { Total Alkalinity as } \\
\text { CaCO3 }\end{array}$ & 98 & 1.2 & 5 & & & 065360-018 & EPA 310.1 \\
\hline & $\begin{array}{l}\text { Alkalinity as } \\
\text { HCO3 }\end{array}$ & 98 & 1.2 & 5 & & & 065360-018 & EPA 310.1 \\
\hline & Alkalinity as $\mathrm{CO} 3$ & ND & 1.2 & 5 & U & & 065360-018 & EPA 310.1 \\
\hline TA1-W-01 & Bromide & 0.16 & 0.02 & 0.25 & $\mathrm{~J}$ & & 065362-013 & SW846 9056 \\
\hline \multirow{10}{*}{ 17-Aug-04 } & Chloride & 14.1 & 0.43 & 2 & B & & 065362-013 & SW846 9056 \\
\hline & Fluoride & 0.35 & 0.01 & 0.10 & & & 065362-013 & SW846 9056 \\
\hline & Sulfate & 76.1 & 0.37 & 5 & & & 065362-013 & SW846 9056 \\
\hline & Calcium & 64.7 & 0.035 & 0.50 & B & & 065362-014 & SW846 6020 \\
\hline & Magnesium & 12.6 & 0.0022 & 0.10 & $B$ & & 065362-014 & SW846 6020 \\
\hline & Potassium & 2.2 & 0.013 & 0.50 & B & & 065362-014 & SW846 6020 \\
\hline & Sodium & 25.3 & 0.0064 & 0.50 & B & & 065362-014 & SW846 6020 \\
\hline & $\begin{array}{l}\text { Total Alkalinity as } \\
\mathrm{CaCO} 3\end{array}$ & 170 & 1.2 & 5 & & & 065362-018 & EPA 310.1 \\
\hline & $\begin{array}{l}\text { Alkalinity as } \\
\mathrm{HCO} 3\end{array}$ & 170 & 1.2 & 5 & & & 065362-018 & EPA 310.1 \\
\hline & Alkalinity as CO3 & ND & 1.2 & 5 & $\mathrm{U}$ & & 065362-018 & EPA 310.1 \\
\hline TA1-W-02 & Bromide & 0.16 & 0.02 & 0.25 & $\mathrm{~J}$ & & 065364-013 & SW846 9056 \\
\hline \multirow[t]{6}{*}{ 13-Aug-04 } & Chloride & 13.9 & 0.43 & 2 & $B$ & & 065364-013 & SW846 9056 \\
\hline & Fluoride & 0.32 & 0.01 & 0.10 & & & 065364-013 & SW846 9056 \\
\hline & Sulfate & 82.4 & 0.37 & 5 & & & 065364-013 & SW846 9056 \\
\hline & Calcium & 67.5 & 0.035 & 1 & B & $A 2, J, P 1$ & 065364-014 & SW846 6020 \\
\hline & Magnesium & 13.1 & 0.0022 & 0.2 & B & $\mathrm{A}, \mathrm{J}, \mathrm{P} 1$ & 065364-014 & SW846 6020 \\
\hline & Potassium & 2.0 & 0.013 & 1 & B & & 065364-014 & SW846 6020 \\
\hline
\end{tabular}




\begin{tabular}{|c|c|c|c|c|c|c|c|c|}
\hline Well ID & Analyte & $\begin{array}{l}\text { Result } \\
\text { (mg/L) }\end{array}$ & $\begin{array}{c}\text { MDL } \\
\text { (mg/L) }\end{array}$ & $\begin{array}{c}\text { PQL } \\
\text { (mg/L) }\end{array}$ & $\begin{array}{l}\text { Laboratory } \\
\text { Qualifier }\end{array}$ & \begin{tabular}{|c|} 
Validation \\
Qualifier
\end{tabular} & Sample No. & $\begin{array}{l}\text { Analytical } \\
\text { Method }\end{array}$ \\
\hline & Sodium & 23.2 & 0.0064 & 1 & B & & 065364-014 & SW846 6020 \\
\hline & $\begin{array}{l}\text { Total Alkalinity as } \\
\mathrm{CaCO} 3\end{array}$ & 171 & 1.2 & 5 & & & 065364-018 & EPA 310.1 \\
\hline & $\begin{array}{l}\text { Alkalinity as } \\
\mathrm{HCO} 3\end{array}$ & 171 & 1.2 & 5 & & & 065364-018 & EPA 310.1 \\
\hline & Alkalinity as $\mathrm{CO} 3$ & ND & 1.2 & 5 & $u$ & & 065364-018 & EPA 310.1 \\
\hline |TA1-W-03 & Bromide & 3.5 & 0.02 & 0.25 & & & 065366-013 & SW846 9056 \\
\hline \multirow[t]{10}{*}{ 18-Aug-04 } & Chloride & 245 & 4.3 & 20 & & & 065366-013 & SW846 9056 \\
\hline & Fluoride & 0.25 & 0.01 & 0.10 & & & 065366-013 & SW846 9056 \\
\hline & Sulfate & 470 & 3.7 & 50 & & & 065366-013 & SW846 9056 \\
\hline & Calcium & 280 & 0.035 & 0.50 & B & & 065366-014 & SW846 6020 \\
\hline & Magnesium & 33.1 & 0.0022 & 0.10 & $B$ & & 065366-014 & SW846 6020 \\
\hline & Potassium & 2.7 & 0.013 & 0.50 & B & & 065366-014 & SW846 6020 \\
\hline & Sodium & 49.9 & 0.0064 & 0.50 & $\mathrm{~B}$ & & 065366-014 & SW846 6020 \\
\hline & $\begin{array}{l}\text { Total Alkalinity as } \\
\text { CaCO3 }\end{array}$ & 65 & 1.2 & 5 & & & 065366-018 & EPA 310.1 \\
\hline & \begin{tabular}{|l|} 
Alkalinity as \\
$\mathrm{HCO} 3$
\end{tabular} & 65 & 1.2 & 5 & & & 065366-018 & EPA 310.1 \\
\hline & Alkalinity as CO3 & ND & 1.2 & 5 & $u$ & & 065366-018 & EPA 310.1 \\
\hline TA1-W-04 & Bromide & 0.16 & 0.02 & 0.25 & $\mathrm{~J}$ & & 065368-013 & SW846 9056 \\
\hline \multirow[t]{10}{*}{ 26-Jul-04 } & Chloride & 16.2 & 0.43 & 2 & & & 065368-013 & SW846 9056 \\
\hline & Fluoride & 0.27 & 0.01 & 0.10 & & & 065368-013 & SW846 9056 \\
\hline & Sulfate & 61.7 & 0.37 & 5 & & & 065368-013 & SW846 9056 \\
\hline & Calcium & 61.9 & 0.035 & 0.50 & B & & 065368-014 & SW846 6020 \\
\hline & Magnesium & 9.6 & 0.0022 & 0.10 & $B$ & $\mathrm{~J}$ & 065368-014 & SW846 6020 \\
\hline & Potassium & 2.1 & 0.013 & 0.50 & $B$ & & 065368-014 & SW846 6020 \\
\hline & Sodium & 22.5 & 0.0064 & 0.50 & $\mathrm{~B}$ & & 065368-014 & SW846 6020 \\
\hline & $\begin{array}{l}\text { Total Alkalinity as } \\
\text { CaCO3 }\end{array}$ & 168 & 1.2 & 5 & & & 065368-018 & EPA 310.1 \\
\hline & $\begin{array}{l}\text { Alkalinity as } \\
\text { HCO3 }\end{array}$ & 168 & 1.2 & 5 & & & 065368-018 & EPA 310.1 \\
\hline & Alkalinity as $\mathrm{CO} 3$ & ND & 1.2 & 5 & $\mathrm{U}$ & & 065368-018 & EPA 310.1 \\
\hline TA1-W-05 & Bromide & 0.13 & 0.02 & 0.25 & $\mathrm{~J}$ & & 065370-013 & SW846 9056 \\
\hline \multirow[t]{10}{*}{ 20-Aug-04 } & Chloride & 11.5 & 0.43 & 2 & & & 065370-013 & SW846 9056 \\
\hline & Fluoride & 0.24 & 0.01 & 0.10 & & & 065370-013 & SW846 9056 \\
\hline & Sulfate & 97.2 & 0.37 & 5 & & & 065370-013 & SW846 9056 \\
\hline & Calcium & 78.6 & 0.035 & 0.50 & B & & 065370-014 & SW846 6020 \\
\hline & Magnesium & 12.2 & 0.0022 & 0.10 & B & & 065370-014 & SW846 6020 \\
\hline & Potassium & 2.2 & 0.013 & 0.50 & B & & 065370-014 & SW846 6020 \\
\hline & Sodium & 31.2 & 0.0064 & 0.50 & $\mathrm{~B}$ & & 065370-014 & SW846 6020 \\
\hline & $\begin{array}{l}\text { Total Alkalinity as } \\
\text { CaCO3 }\end{array}$ & 202 & 1.2 & 5 & & & 065370-018 & EPA 310.1 \\
\hline & $\begin{array}{l}\text { Alkalinity as } \\
\mathrm{HCO} 3\end{array}$ & 202 & 1.2 & 5 & & & 065370-018 & EPA 310.1 \\
\hline & Alkalinity as $\mathrm{CO} 3$ & ND & 1.2 & 5 & $\mathrm{U}$ & & 065370-018 & EPA 310.1 \\
\hline TA1-W-06 & Bromide & 1.4 & 0.02 & 0.25 & & & 065372-013 & SW846 9056 \\
\hline \multirow[t]{8}{*}{ 06-Aug-04 } & Chloride & 98.1 & 4.3 & 20 & & & 065372-013 & SW846 9056 \\
\hline & Fluoride & 0.28 & 0.01 & 0.10 & & & $065372-013$ & SW846 9056 \\
\hline & Sulfate & 188 & 0.037 & 50 & & & 065372-013 & SW846 9056 \\
\hline & Calcium & 150 & 0.035 & 1 & B & $A 2, J$ & 065372-014 & SW846 6020 \\
\hline & Magnesium & 19.2 & 0.0022 & 0.2 & $B$ & $\mathrm{~J}$ & $065372-014$ & SW846 6020 \\
\hline & Potassium & 2.3 & 0.013 & 1 & $B$ & & 065372-014 & SW846 6020 \\
\hline & Sodium & 39.5 & 0.0064 & 1 & $B$ & & 065372-014 & SW846 6020 \\
\hline & Total Alkalinity as & 87 & 1.2 & 5 & & & 065372-018 & EPA 310.1 \\
\hline
\end{tabular}




\begin{tabular}{|c|c|c|c|c|c|c|c|c|}
\hline \multirow[t]{4}{*}{ Well ID } & Analyte & $\begin{array}{l}\text { Result } \\
\text { (mg/L) }\end{array}$ & $\begin{array}{c}\text { MDL } \\
\text { (mg/L) }\end{array}$ & $\begin{array}{c}\text { PQL } \\
\text { (mg/L) }\end{array}$ & $\begin{array}{c}\text { Laboratory } \\
\text { Qualifier }\end{array}$ & \begin{tabular}{|c|} 
Validation \\
Qualifier
\end{tabular} & Sample No. & $\begin{array}{l}\text { Analytical } \\
\text { Method }\end{array}$ \\
\hline & $\mathrm{CaCO} 3$ & & & & & & & \\
\hline & $\begin{array}{l}\text { Alkalinity as } \\
\text { HCO3 }\end{array}$ & 87 & 1.2 & 5 & & & 065372-018 & EPA 310.1 \\
\hline & Alkalinity as $\mathrm{CO} 3$ & ND & 1.2 & 5 & U & & 065372-018 & EPA 310.1 \\
\hline TA1-W-08 & Bromide & 2.8 & 0.02 & 0.25 & & & 065374-013 & SW846 9056 \\
\hline \multirow{10}{*}{ 13-Aug-04 } & Chloride & 213 & 4.3 & 20 & B & & 065374-013 & SW846 9056 \\
\hline & Fluoride & 0.38 & 0.01 & 0.10 & & & 065374-013 & SW846 9056 \\
\hline & Sulfate & 666 & 3.7 & 50 & & & 065374-013 & SW846 9056 \\
\hline & Calcium & 336 & 0.035 & 1 & B & $\mathrm{A} 2, \mathrm{~J}, \mathrm{P} 1$ & 065374-014 & SW846 6020 \\
\hline & Magnesium & 44.7 & 0.0022 & 0.2 & $B$ & $A, J, P 1$ & 065374-014 & SW846 6020 \\
\hline & Potassium & 3.2 & 0.013 & 1 & $B$ & & 065374-014 & SW846 6020 \\
\hline & Sodium & 83 & 0.0064 & 1 & $\mathrm{~B}$ & $\mathrm{~J}$ & 065374-014 & SW846 6020 \\
\hline & $\begin{array}{l}\begin{array}{l}\text { Total Alkalinity as } \\
\mathrm{CaCO} 3\end{array} \\
\end{array}$ & 82 & 1.2 & 5 & & & 065374-018 & EPA 310.1 \\
\hline & \begin{tabular}{|l|} 
Alkalinity as \\
$\mathrm{HCO} 3$
\end{tabular} & 82 & 1.2 & 5 & & & 065374-018 & EPA 310.1 \\
\hline & Alkalinity as $\mathrm{CO} 3$ & ND & 1.2 & 5 & $\mathrm{U}$ & & 065374-018 & EPA 310.1 \\
\hline \multirow{11}{*}{$\begin{array}{l}\text { TA2-NW1-595 } \\
\text { 26-Jul-04 } \\
\text { (QED) }\end{array}$} & Bromide & 1.1 & 0.02 & 0.25 & & & 065377-013 & SW846 9056 \\
\hline & Chloride & 0.88 & 0.43 & 2 & & & 065377-013 & SW846 9056 \\
\hline & Fluoride & 0.23 & 0.01 & 0.10 & & & $065377-013$ & SW846 9056 \\
\hline & Sulfate & 122 & 0.37 & 5 & & & $065377-013$ & SW846 9056 \\
\hline & Calcium & 96.7 & 0.035 & 0.50 & B & & 065377-014 & SW846 6020 \\
\hline & Magnesium & 14.6 & 0.0022 & 0.10 & $B$ & $\mathrm{~J}$ & 065377-014 & SW846 6020 \\
\hline & Potassium & 2.0 & 0.013 & 0.50 & $B$ & & 065377-014 & SW846 6020 \\
\hline & Sodium & 26.9 & 0.0064 & 0.50 & B & $\mathrm{J}$ & 065377-014 & SW846 6020 \\
\hline & $\begin{array}{l}\text { Total Alkalinity as } \\
\mathrm{CaCO} 3\end{array}$ & 149 & 1.2 & 5 & & & 065377-018 & EPA 310.1 \\
\hline & \begin{tabular}{l|} 
Alkalinity as \\
HCO3
\end{tabular} & 149 & 1.2 & 5 & & & 065377-018 & EPA 310.1 \\
\hline & Alkalinity as $\mathrm{CO} 3$ & ND & 1.2 & 5 & U & & 065377-018 & EPA 310.1 \\
\hline \multirow{11}{*}{\begin{tabular}{|l} 
TA2-NW1-595 \\
23-Aug-04 \\
(Bennett)
\end{tabular}} & Bromide & 1.2 & 0.02 & 0.25 & & & 065379-013 & SW846 9056 \\
\hline & Chloride & 90.7 & 4.3 & 20 & & & 065379-013 & SW846 9056 \\
\hline & Fluoride & 0.24 & 0.01 & 0.10 & & & 065379-013 & SW846 9056 \\
\hline & Sulfate & 113 & 3.7 & 50 & & & 065379-013 & SW846 9056 \\
\hline & Calcium & 99.2 & 0.035 & 0.50 & B & & 065379-014 & SW846 6020 \\
\hline & Magnesium & 18.4 & 0.0022 & 0.10 & B & & 065379-014 & SW846 6020 \\
\hline & Potassium & 2.4 & 0.013 & 0.50 & B & & 065379-014 & SW846 6020 \\
\hline & Sodium & 32.9 & 0.0064 & 0.50 & B & & 065379-014 & SW846 6020 \\
\hline & $\begin{array}{l}\text { Total Alkalinity as } \\
\text { CaCO3 }\end{array}$ & 140 & 1.2 & 5 & & & 065379-018 & EPA 310.1 \\
\hline & $\begin{array}{l}\text { Alkalinity as } \\
\text { HCO3 }\end{array}$ & 140 & 1.2 & 5 & & & 065379-018 & EPA 310.1 \\
\hline & Alkalinity as CO3 & ND & 1.2 & 5 & $\mathrm{U}$ & & 065379-018 & EPA 310.1 \\
\hline \multirow{10}{*}{$\begin{array}{l}\text { TA2-SW1-320 } \\
\text { 27-Jul-04 }\end{array}$} & Bromide & 0.38 & 0.02 & 0.25 & & & 065381-013 & SW846 9056 \\
\hline & Chloride & 27.2 & 0.43 & 2 & & & 065381-013 & SW846 9056 \\
\hline & Fluoride & 0.36 & 0.01 & 0.10 & & & 065381-013 & SW846 9056 \\
\hline & Sulfate & 14.9 & 0.037 & 0.50 & & & 065381-013 & SW846 9056 \\
\hline & Calcium & 59.5 & 0.035 & 0.50 & B & $\mathrm{J}$ & 065381-014 & SW846 6020 \\
\hline & Magnesium & 9.5 & 0.0022 & 0.10 & B & $\mathrm{J}$ & 065381-014 & SW846 6020 \\
\hline & Potassium & 1.6 & 0.013 & 0.50 & B & & 065381-014 & SW846 6020 \\
\hline & Sodium & 16.4 & 0.0064 & 0.50 & $B$ & $\mathrm{~J}$ & 065381-014 & SW846 6020 \\
\hline & $\begin{array}{l}\text { Total Alkalinity as } \\
\text { CaCO3 }\end{array}$ & 114 & 1.2 & 5 & & & 065381-018 & EPA 310.1 \\
\hline & Alkalinity as & 114 & 1.2 & 5 & & & 065381-018 & EPA 310.1 \\
\hline
\end{tabular}




\begin{tabular}{|c|c|c|c|c|c|c|c|c|}
\hline Well ID & \begin{tabular}{|l} 
Analyte \\
\end{tabular} & $\begin{array}{l}\text { Result } \\
\text { (mg/L) }\end{array}$ & $\begin{array}{c}\mathrm{MDL} \\
\text { (mg/L) }\end{array}$ & $\begin{array}{c}\text { PQL } \\
\text { (mg/L) }\end{array}$ & $\begin{array}{c}\text { Laboratory } \\
\text { Qualifier }\end{array}$ & \begin{tabular}{|c|} 
Validation \\
Qualifier \\
\end{tabular} & Sample No. & $\begin{array}{l}\text { Analytical } \\
\text { Method }\end{array}$ \\
\hline & $\mathrm{HCO} 3$ & & & & & & & \\
\hline & Alkalinity as $\mathrm{CO} 3$ & ND & 1.2 & 5 & U & & 065381-018 & EPA 310.1 \\
\hline TA2-W-01 & Bromide & 1.5 & 0.02 & 0.25 & & & 065383-013 & SW846 9056 \\
\hline \multirow[t]{10}{*}{ 12-Aug-04 } & Chloride & 105 & 4.3 & 20 & & & 065383-013 & SW846 9056 \\
\hline & Fluoride & 0.23 & 0.01 & 0.10 & & & 065383-013 & SW846 9056 \\
\hline & Sulfate & 48.1 & 0.37 & 5 & & & 065383-013 & SW846 9056 \\
\hline & Calcium & 93.2 & 0.035 & 1 & B & $\mathrm{A} 2, \mathrm{~J}$ & 065383-014 & SW846 6020 \\
\hline & Magnesium & 13 & 0.0022 & 0.2 & $B$ & $\mathrm{~J}$ & 065383-014 & SW846 6020 \\
\hline & Potassium & 2.0 & 0.013 & 1 & $B$ & & 065383-014 & SW846 6020 \\
\hline & Sodium & 23.9 & 0.0064 & 1 & $\mathrm{~B}$ & & 065383-014 & SW846 6020 \\
\hline & $\begin{array}{l}\text { Total Alkalinity as } \\
\text { CaCO3 }\end{array}$ & 106 & 1.2 & 5 & & & 065383-018 & EPA 310.1 \\
\hline & $\begin{array}{l}\text { Alkalinity as } \\
\text { HCO3 }\end{array}$ & 106 & 1.2 & 5 & & & 065383-018 & EPA 310.1 \\
\hline & Alkalinity as CO3 & ND & 1.2 & 5 & $\mathrm{U}$ & & 065383-018 & EPA 310.1 \\
\hline TA2-W-19 & Bromide & 1.0 & 0.02 & 0.25 & & & 065385-013 & SW846 9056 \\
\hline \multirow[t]{10}{*}{ 27-Jul-04 } & Chloride & 75.6 & 4.3 & 20 & & & 065385-013 & SW846 9056 \\
\hline & Fluoride & 0.26 & 0.01 & 0.10 & & & 065385-013 & SW846 9056 \\
\hline & Sulfate & 58.5 & 0.37 & 5 & & & 065385-013 & SW846 9056 \\
\hline & Calcium & 75.8 & 0.035 & 0.50 & B & $\mathrm{J}$ & 065385-014 & SW846 6020 \\
\hline & Magnesium & 10.3 & 0.0022 & 0.10 & $B$ & $\mathrm{~J}$ & 065385-014 & SW846 6020 \\
\hline & Potassium & 1.6 & 0.013 & 0.50 & B & & 065385-014 & SW846 6020 \\
\hline & Sodium & 19.8 & 0.0064 & 0.50 & B & $\mathrm{J}$ & 065385-014 & SW846 6020 \\
\hline & $\begin{array}{l}\text { Total Alkalinity as } \\
\text { CaCO3 }\end{array}$ & 106 & 1.2 & 5 & & & 065385-018 & EPA 310.1 \\
\hline & $\begin{array}{l}\text { Alkalinity as } \\
\mathrm{HCO} 3\end{array}$ & 106 & 1.2 & 5 & & & 065385-018 & EPA 310.1 \\
\hline & Alkalinity as $\mathrm{CO} 3$ & ND & 1.2 & 5 & $\mathrm{U}$ & & 065385-018 & EPA 310.1 \\
\hline TA2-W-26 & Bromide & 1.9 & 0.02 & 0.25 & & & 065387-013 & SW846 9056 \\
\hline \multirow{10}{*}{ 30-Jul-04 } & Chloride & 140 & 4.3 & 20 & & & 065387-013 & SW846 9056 \\
\hline & Fluoride & 0.22 & 0.01 & 0.10 & & & 065387-013 & SW846 9056 \\
\hline & Sulfate & 245 & 3.7 & 50 & & & 065387-013 & SW846 9056 \\
\hline & Calcium & 161 & 0.035 & 0.50 & B & & 065387-014 & SW846 6020 \\
\hline & Magnesium & 18.9 & 0.0022 & 0.10 & B & $\mathrm{J}$ & 065387-014 & SW846 6020 \\
\hline & Potassium & 2.0 & 0.013 & 0.50 & B & & 065387-014 & SW846 6020 \\
\hline & Sodium & 30.1 & 0.0064 & 0.50 & B & $\mathrm{J}$ & 065387-014 & SW846 6020 \\
\hline & $\begin{array}{l}\text { Total Alkalinity as } \\
\text { CaCO3 }\end{array}$ & 90 & 1.2 & 5 & & & 065387-018 & EPA 310.1 \\
\hline & $\begin{array}{l}\text { Alkalinity as } \\
\mathrm{HCO} 3\end{array}$ & 90 & 1.2 & 5 & & & 065387-018 & EPA 310.1 \\
\hline & Alkalinity as CO3 & ND & 1.2 & 5 & $\mathrm{U}$ & & 065387-018 & EPA 310.1 \\
\hline TA2-W-27 & Bromide & 1.7 & 0.02 & 0.25 & & & 065392-013 & SW846 9056 \\
\hline \multirow[t]{10}{*}{ 28-Jul-04 } & Chloride & 119 & 4.3 & 20 & & & 065392-013 & SW846 9056 \\
\hline & Fluoride & 0.26 & 0.01 & 0.10 & & & 065392-013 & SW846 9056 \\
\hline & Sulfate & 172 & 0.37 & 5 & & & 065392-013 & SW846 9056 \\
\hline & Calcium & 120 & 0.035 & 0.50 & B & $\mathrm{J}$ & 065392-014 & SW846 6020 \\
\hline & Magnesium & 15.1 & 0.0022 & 0.10 & B & $\mathrm{J}$ & 065392-014 & SW846 6020 \\
\hline & Potassium & 1.8 & 0.013 & 0.50 & B & & 065392-014 & SW846 6020 \\
\hline & Sodium & 26.2 & 0.0064 & 0.50 & B & $\mathrm{J}$ & 065392-014 & SW846 6020 \\
\hline & $\begin{array}{l}\text { Total Alkalinity as } \\
\text { CaCO3 }\end{array}$ & 159 & 1.2 & 5 & & & 065392-018 & EPA 310.1 \\
\hline & $\begin{array}{l}\text { Alkalinity as } \\
\mathrm{HCO} 3\end{array}$ & 159 & 1.2 & 5 & & & 065392-018 & EPA 310.1 \\
\hline & Alkalinity as CO3 & ND & 1.2 & 5 & $\mathrm{U}$ & & 065392-018 & EPA 310.1 \\
\hline
\end{tabular}




\begin{tabular}{|c|c|c|c|c|c|c|c|c|}
\hline Well ID & Analyte & $\begin{array}{l}\text { Result } \\
\text { (mg/L) }\end{array}$ & $\begin{array}{c}\text { MDL } \\
\text { (mg/L) }\end{array}$ & $\begin{array}{c}\text { PQL } \\
\text { (mg/L) }\end{array}$ & $\begin{array}{c}\text { Laboratory } \\
\text { Qualifier }\end{array}$ & \begin{tabular}{|c|} 
Validation \\
Qualifier
\end{tabular} & Sample No. & $\begin{array}{c}\text { Analytical } \\
\text { Method }\end{array}$ \\
\hline TJA-2 & Bromide & 0.93 & 0.02 & 0.25 & & & 065394-013 & SW846 9056 \\
\hline \multirow{10}{*}{ 16-Aug-04 } & Chloride & 66.3 & 4.3 & 20 & B & & 065394-013 & SW846 9056 \\
\hline & Fluoride & 0.25 & 0.01 & 0.10 & & & 065394-013 & SW846 9056 \\
\hline & Sulfate & 55.2 & 0.37 & 5 & & & 065394-013 & SW846 9056 \\
\hline & Calcium & 76.1 & 0.035 & 1 & B & $\mathrm{A} 2, \mathrm{~J}, \mathrm{P} 1$ & 065394-014 & SW846 6020 \\
\hline & Magnesium & 12.5 & 0.0022 & 0.2 & $B$ & $\mathrm{~A}, \mathrm{~J}, \mathrm{P} 1$ & 065394-014 & SW846 6020 \\
\hline & Potassium & 1.7 & 0.013 & 1 & B & & 065394-014 & SW846 6020 \\
\hline & Sodium & 24.4 & 0.0064 & 1 & B & & 065394-014 & SW846 6020 \\
\hline & $\begin{array}{l}\text { Total Alkalinity as } \\
\text { CaCO3 }\end{array}$ & 104 & 1.2 & 5 & & & 065394-018 & EPA 310.1 \\
\hline & $\begin{array}{l}\text { Alkalinity as } \\
\mathrm{HCO} 3\end{array}$ & 104 & 1.2 & 5 & & & 065394-018 & EPA 310.1 \\
\hline & Alkalinity as $\mathrm{CO} 3$ & ND & 1.2 & 5 & $\mathrm{U}$ & & 065394-018 & EPA 310.1 \\
\hline TJA-3 & Bromide & 0.15 & 0.02 & 0.25 & $\mathrm{~J}$ & & 065397-013 & SW846 9056 \\
\hline \multirow[t]{10}{*}{ 09-Aug-04 } & Chloride & 13.1 & 0.43 & 2 & & & 065397-013 & SW846 9056 \\
\hline & Fluoride & 0.26 & 0.01 & 0.10 & & & 065397-013 & SW846 9056 \\
\hline & Sulfate & 71.6 & 0.37 & 5 & & & 065397-013 & SW846 9056 \\
\hline & Calcium & 68.7 & 0.035 & 1 & B & $\mathrm{A} 2, \mathrm{~J}, \mathrm{P} 1$ & 065397-014 & SW846 6020 \\
\hline & Magnesium & 11.8 & 0.0022 & 0.2 & B & $A, J, P 1$ & 065397-014 & SW846 6020 \\
\hline & Potassium & 1.8 & 0.013 & 1 & B & & 065397-014 & SW846 6020 \\
\hline & Sodium & 25.6 & 0.0064 & 1 & B & & 065397-014 & SW846 6020 \\
\hline & $\begin{array}{l}\text { Total Alkalinity as } \\
\text { CaCO3 }\end{array}$ & 165 & 1.2 & 5 & & & 065397-018 & EPA 310.1 \\
\hline & $\begin{array}{l}\text { Alkalinity as } \\
\text { HCO3 }\end{array}$ & 165 & 1.2 & 5 & & & 065399-018 & EPA 310.1 \\
\hline & Alkalinity as $\mathrm{CO} 3$ & ND & 1.2 & 5 & $\mathrm{U}$ & & 065399-018 & EPA 310.1 \\
\hline TJA-4 & Bromide & 0.28 & 0.02 & 0.25 & & & 065399-013 & SW846 9056 \\
\hline \multirow[t]{10}{*}{ 10-Aug-04 } & Chloride & 20.9 & 0.43 & 2 & & & 065399-013 & SW846 9056 \\
\hline & Fluoride & 0.26 & 0.01 & 0.10 & & & 065399-013 & SW846 9056 \\
\hline & Sulfate & 17.9 & 0.37 & 5 & & & 065399-013 & SW846 9056 \\
\hline & Calcium & 65.8 & 0.035 & 1 & $\mathrm{~B}$ & $\mathrm{~A} 2, \mathrm{~J}, \mathrm{P} 1$ & 065399-014 & SW846 6020 \\
\hline & Magnesium & 14.1 & 0.0022 & 0.2 & B & $\mathrm{A}, \mathrm{J}, \mathrm{P} 1$ & 065399-014 & SW846 6020 \\
\hline & Potassium & 3.0 & 0.013 & 1 & B & $\mathrm{J}$ & 065399-014 & SW846 6020 \\
\hline & Sodium & 25.4 & 0.0064 & 1 & B & $\mathrm{J}$ & 065399-014 & SW846 6020 \\
\hline & $\begin{array}{l}\text { Total Alkalinity as } \\
\text { CaCO3 }\end{array}$ & 135 & 1.2 & 5 & & & 065399-018 & EPA 310.1 \\
\hline & $\begin{array}{l}\text { Alkalinity as } \\
\mathrm{HCO} 3\end{array}$ & 135 & 1.2 & 5 & & $\mathrm{~J}, \mathrm{P} 1$ & 065399-018 & EPA 310.1 \\
\hline & Alkalinity as $\mathrm{CO} 3$ & ND & 1.2 & 5 & $\mathrm{U}$ & & 065399-018 & EPA 310.1 \\
\hline \multirow{11}{*}{$\begin{array}{l}\text { TJA-6 } \\
\text { 04-Aug-04 }\end{array}$} & Bromide & 0.15 & 0.02 & 0.25 & $\mathrm{~J}$ & & 065401-013 & SW846 9056 \\
\hline & Chloride & 14.5 & 0.43 & 2 & & & 065401-013 & SW846 9056 \\
\hline & Fluoride & 0.30 & 0.01 & 0.10 & & & 065401-013 & SW846 9056 \\
\hline & Sulfate & 61.8 & 0.37 & 5 & & & 065401-013 & SW846 9056 \\
\hline & Calcium & 58.2 & 0.035 & 0.50 & B & & 065401-014 & SW846 6020 \\
\hline & Magnesium & 10.1 & 0.0022 & 0.10 & B & $\mathrm{J}$ & 065401-014 & SW846 6020 \\
\hline & Potassium & 2.0 & 0.013 & 0.50 & B & & 065401-014 & SW846 6020 \\
\hline & Sodium & 20.4 & 0.0064 & 0.50 & B & & 065401-014 & SW846 6020 \\
\hline & $\begin{array}{l}\text { Total Alkalinity as } \\
\mathrm{CaCO} 3\end{array}$ & 161 & 1.2 & 5 & & & 065401-018 & EPA 310.1 \\
\hline & $\begin{array}{l}\text { Alkalinity as } \\
\text { HCO3 }\end{array}$ & 161 & 1.2 & 5 & & & 065401-018 & EPA 310.1 \\
\hline & Alkalinity as CO3 & ND & 1.2 & 5 & $\mathrm{U}$ & & 065401-018 & EPA 310.1 \\
\hline TJA-7 & Bromide & 0.43 & 0.02 & 0.25 & & & 065403-013 & SW846 9056 \\
\hline 06-Aug-04 & Chloride & 31.8 & 0.43 & 2 & & & 065403-013 & SW846 9056 \\
\hline
\end{tabular}




\begin{tabular}{|c|c|c|c|c|c|c|c|c|}
\hline \multirow[t]{10}{*}{ Well ID } & Analyte & $\begin{array}{l}\text { Result } \\
\text { (mg/L) }\end{array}$ & $\begin{array}{c}\text { MDL } \\
\text { (mg/L) }\end{array}$ & $\begin{array}{c}\mathrm{PQL} \\
(\mathrm{mg} / \mathrm{L})\end{array}$ & $\begin{array}{l}\text { Laboratory } \\
\text { Qualifier }\end{array}$ & \begin{tabular}{|c|} 
Validation \\
Qualifier
\end{tabular} & Sample No. & $\begin{array}{c}\text { Analytical } \\
\text { Method }\end{array}$ \\
\hline & Fluoride & 0.30 & 0.01 & 0.10 & & & 065403-013 & SW846 9056 \\
\hline & Sulfate & 20.4 & 0.37 & 5 & & & 065403-013 & SW846 9056 \\
\hline & Calcium & 72.5 & 0.035 & 1 & B & $A 2, \mathrm{~J}$ & 065403-014 & SW846 6020 \\
\hline & Magnesium & 13.9 & 0.0022 & 0.2 & $B$ & $\mathrm{~J}$ & 065403-014 & SW846 6020 \\
\hline & Potassium & 1.9 & 0.013 & 1 & $B$ & & 065403-014 & SW846 6020 \\
\hline & Sodium & 20.3 & 0.0064 & 1 & $B$ & & 065403-014 & SW846 6020 \\
\hline & $\begin{array}{l}\text { Total Alkalinity as } \\
\text { CaCO3 }\end{array}$ & 124 & 1.2 & 5 & & & 065403-018 & EPA 310.1 \\
\hline & $\begin{array}{l}\text { Alkalinity as } \\
\text { HCO3 }\end{array}$ & 124 & 1.2 & 5 & & & 065403-018 & EPA 310.1 \\
\hline & Alkalinity as $\mathrm{CO} 3$ & ND & 1.2 & 5 & U & & 065403-018 & EPA 310.1 \\
\hline WYO-3 & Bromide & ND & 0.02 & 0.25 & $U$ & & 065408-013 & SW846 9056 \\
\hline \multirow[t]{10}{*}{ 11-Aug-04 } & Chloride & 15 & 0.43 & 2 & & & 065408-013 & SW846 9056 \\
\hline & Fluoride & 0.31 & 0.01 & 0.10 & & & 065408-013 & SW846 9056 \\
\hline & Sulfate & 86.5 & 0.37 & 5 & & & 065408-013 & SW846 9056 \\
\hline & Calcium & 70.4 & 0.035 & 1 & B & $\mathrm{A} 2, \mathrm{~J}, \mathrm{P} 1$ & 065408-014 & SW846 6020 \\
\hline & Magnesium & 13.9 & 0.0022 & 0.2 & $B$ & $\mathrm{~A}, \mathrm{~J}, \mathrm{P} 1$ & 065408-014 & SW846 6020 \\
\hline & Potassium & 2.2 & 0.013 & 1 & B & & 065408-014 & SW846 6020 \\
\hline & Sodium & 27.1 & 0.0064 & 1 & B & & 065408-014 & SW846 6020 \\
\hline & $\begin{array}{l}\text { Total Alkalinity as } \\
\text { CaCO3 }\end{array}$ & 173 & 1.2 & 5 & & & 065408-018 & EPA 310.1 \\
\hline & $\begin{array}{l}\text { Alkalinity as } \\
\text { HCO3 }\end{array}$ & 173 & 1.2 & 5 & & & 065408-018 & EPA 310.1 \\
\hline & Alkalinity as $\mathrm{CO} 3$ & ND & 1.2 & 5 & U & & 065408-018 & EPA 310.1 \\
\hline WYO-4 & Bromide & 1.2 & 0.02 & 0.25 & & & 065411-013 & SW846 9056 \\
\hline \multirow{10}{*}{ 03-Aug-04 } & Chloride & 105 & 4.3 & 20 & & & 065411-013 & SW846 9056 \\
\hline & Fluoride & 0.28 & 0.01 & 0.10 & & & 065411-013 & SW846 9056 \\
\hline & Sulfate & 45.7 & 0.37 & 5 & & & 065411-013 & SW846 9056 \\
\hline & Calcium & 79.1 & 0.035 & 0.50 & B & & 065411-014 & SW846 6020 \\
\hline & Magnesium & 12.4 & 0.0022 & 0.10 & B & $\mathrm{J}$ & 065411-014 & SW846 6020 \\
\hline & Potassium & 1.6 & 0.013 & 0.50 & B & & 065411-014 & SW846 6020 \\
\hline & Sodium & 18.9 & 0.0064 & 0.50 & $B$ & & 065411-014 & SW846 6020 \\
\hline & $\begin{array}{l}\text { Total Alkalinity as } \\
\text { CaCO3 }\end{array}$ & 93 & 1.2 & 5 & & & 065411-018 & EPA 310.1 \\
\hline & $\begin{array}{l}\text { Alkalinity as } \\
\text { HCO3 }\end{array}$ & 93 & 1.2 & 5 & & & 065411-018 & EPA 310.1 \\
\hline & Alkalinity as $\mathrm{CO} 3$ & ND & 1.2 & 5 & U & & 065411-018 & EPA 310.1 \\
\hline \multicolumn{9}{|c|}{$\begin{array}{l}\mathrm{mg} / \mathrm{L}=\text { milligrams per liter } \\
\mathrm{A}=\text { Laboratory accuracy and/or bias measurements do not meet acceptance criteria. } \\
\text { A2 = Laboratory accuracy and/or bias measurements for the associated matrix spike and/or duplicate do not meet acceptance } \\
\text { criteria. } \\
\mathrm{J}=\text { = Amount detected is below the practical quantitation limit. The associated value is an estimated quantity. } \\
\mathrm{B}=\text { Analyte is detected in associated laboratory method blank. } \\
\mathrm{B} 3=\text { Analyte is detected in associated laboratory calibration blank. } \\
\text { Pr = Laboratory precision measurement for the associated matrix spike and/or duplicate samples do not meet acceptance } \\
\text { criteria. } \\
\mathrm{U}=\text { Analyte not detected above the MDL. }\end{array}$} \\
\hline
\end{tabular}


Table A-19

Summary of Anion, Cation, and Alkalinity Results

Tijeras Arroyo Groundwater Investigation

Fiscal Year 2005, $\mathbf{1}^{\text {st }}$ Quarter

\begin{tabular}{|c|c|c|c|c|c|c|c|c|}
\hline Well ID & Analyte & $\begin{array}{l}\text { Result } \\
\text { (mg/L) }\end{array}$ & $\begin{array}{c}\text { MDL } \\
\text { (mg/L) }\end{array}$ & $\begin{array}{c}\text { PQL } \\
\text { (mg/L) }\end{array}$ & $\begin{array}{l}\text { Laboratory } \\
\text { Qualifier }\end{array}$ & $\begin{array}{c}\text { Validation } \\
\text { Qualifier }\end{array}$ & Sample No. & $\begin{array}{c}\text { Analytical } \\
\text { Method }\end{array}$ \\
\hline Eubank-1 & Bromide & ND & 0.0978 & 0.20 & $U$ & & 066077-013 & SW846 9056 \\
\hline \multirow[t]{10}{*}{ 20-Oct-04 } & Chloride & 13.0 & 0.0322 & 0.20 & & & $066077-013$ & SW846 9056 \\
\hline & Fluoride & 0.294 & 0.0553 & 0.10 & & & $066077-013$ & SW846 9056 \\
\hline & Sulfate & 78.4 & 0.965 & 2.0 & & & $066077-013$ & SW846 9056 \\
\hline & Calcium & 70.9 & 0.010 & 0.10 & & & $066077-014$ & SW846 6020 \\
\hline & Magnesium & 10.1 & 0.00633 & 0.01 & & $\mathrm{~J}$ & 066077-014 & SW846 6020 \\
\hline & Potassium & 1.72 & 0.0151 & 0.30 & & & 066077-014 & SW846 6020 \\
\hline & Sodium & 27.2 & 0.00968 & 0.25 & $\mathrm{~B}$ & & 066077-014 & SW846 6020 \\
\hline & $\begin{array}{l}\text { Total Alkalinity as } \\
\text { CaCO3 }\end{array}$ & 160 & 1.45 & 2.0 & & & 066077-018 & EPA 310.1 \\
\hline & \begin{tabular}{|l|} 
Alkalinity as \\
HCO3
\end{tabular} & 159 & 1.45 & 2.0 & & & 066077-018 & EPA 310.1 \\
\hline & Alkalinity as $\mathrm{CO} 3$ & ND & 1.45 & 2.0 & $\mathrm{U}$ & & 066077-018 & EPA 310.1 \\
\hline Eubank-2 & Bromide & ND & 0.0978 & 0.20 & u & & 066080-013 & SW846 9056 \\
\hline \multirow[t]{10}{*}{ 21-Oct-04 } & Chloride & 11.6 & 0.0322 & 0.20 & & & 066080-013 & SW846 9056 \\
\hline & Fluoride & 0.158 & 0.0553 & 0.10 & & & $066080-013$ & SW846 9056 \\
\hline & Sulfate & 90.9 & 0.965 & 2.0 & & & $066080-013$ & SW846 9056 \\
\hline & Calcium & 80.1 & 0.040 & 0.10 & & & 066080-014 & SW846 6020 \\
\hline & Magnesium & 12.0 & 0.00633 & 0.01 & & & 066080-014 & SW846 6020 \\
\hline & Potassium & 2.21 & \begin{tabular}{|l|}
0.0151 \\
\end{tabular} & 0.30 & & & 066080-014 & SW846 6020 \\
\hline & Sodium & 31.7 & 0.00968 & 0.25 & B & & 066080-014 & SW846 6020 \\
\hline & $\begin{array}{l}\text { Total Alkalinity as } \\
\mathrm{CaCO} 3\end{array}$ & 205 & 1.45 & 2.0 & & & 066080-018 & EPA 310.1 \\
\hline & \begin{tabular}{|l|} 
Alkalinity as \\
HCO33
\end{tabular} & 205 & 1.45 & 2.0 & & & 066080-018 & EPA 310.1 \\
\hline & Alkalinity as CO3 & ND & 1.45 & 2.0 & $\mathrm{U}$ & & 066080-018 & EPA 310.1 \\
\hline \multirow{11}{*}{$\begin{array}{l}\text { Eubank-3 } \\
\text { 20-Oct-04 }\end{array}$} & Bromide & ND & 0.0978 & 0.20 & $\mathrm{U}$ & & 066082-013 & SW846 9056 \\
\hline & Chloride & 18.6 & 0.161 & 1.0 & & & 066082-013 & SW846 9056 \\
\hline & Fluoride & 0.240 & 0.0553 & 0.10 & & & $066082-013$ & SW846 9056 \\
\hline & Sulfate & 88.4 & 0.965 & 2.0 & & & 066082-013 & SW846 9056 \\
\hline & Calcium & 81.8 & 0.010 & 0.10 & & & $066082-014$ & SW846 6020 \\
\hline & Magnesium & 12.1 & 0.00633 & 0.01 & & $\mathrm{~J}$ & $066082-014$ & SW846 6020 \\
\hline & Potassium & 1.93 & 0.0151 & 0.30 & & & $066082-014$ & SW846 6020 \\
\hline & Sodium & 34.7 & 0.00968 & 0.25 & $\mathrm{~B}$ & & 066082-014 & SW846 6020 \\
\hline & $\begin{array}{l}\text { Total Alkalinity as } \\
\mathrm{CaCO} 3\end{array}$ & 190 & 1.45 & 2.0 & & & 066082-018 & EPA 310.1 \\
\hline & $\begin{array}{l}\text { Alkalinity as } \\
\text { HCO3 }\end{array}$ & 189 & 1.45 & 2.0 & & & 066082-018 & EPA 310.1 \\
\hline & Alkalinity as $\mathrm{CO} 3$ & ND & 1.45 & 2.0 & $\mathrm{U}$ & & 066082-018 & EPA 310.1 \\
\hline \multirow{6}{*}{$\begin{array}{l}\text { Eubank-5 } \\
\text { 25-Oct-04 }\end{array}$} & Bromide & ND & 0.0978 & 0.20 & U & & 066084-013 & SW846 9056 \\
\hline & Chloride & 24.6 & 0.161 & 1.0 & & & 066084-013 & SW846 9056 \\
\hline & Fluoride & 0.216 & 0.0553 & 0.10 & & & 066084-013 & SW846 9056 \\
\hline & Sulfate & 91.2 & 0.965 & 2.0 & & & 066084-013 & SW846 9056 \\
\hline & Calcium & 83.9 & 0.040 & 0.10 & & & 066084-014 & SW846 6020 \\
\hline & Magnesium & 12.7 & 0.00633 & 0.01 & & $\mathrm{~J}$ & 066084-014 & SW846 6020 \\
\hline
\end{tabular}




\begin{tabular}{|c|c|c|c|c|c|c|c|c|}
\hline Well ID & Analyte & $\begin{array}{l}\text { Result } \\
\text { (mg/L) }\end{array}$ & $\begin{array}{c}\text { MDL } \\
\text { (mg/L) }\end{array}$ & $\begin{array}{c}\text { PQL } \\
\text { (mg/L) }\end{array}$ & $\begin{array}{l}\text { Laboratory } \\
\text { Qualifier }\end{array}$ & $\begin{array}{c}\text { Validation } \\
\text { Qualifier }\end{array}$ & Sample No. & $\begin{array}{c}\text { Analytical } \\
\text { Method }\end{array}$ \\
\hline & Potassium & 2.01 & 0.0151 & 0.30 & & & 066084-014 & SW846 6020 \\
\hline & Sodium & 32.6 & 0.00968 & 0.25 & B & & 066084-014 & SW846 6020 \\
\hline & $\begin{array}{l}\text { Total Alkalinity as } \\
\text { CaCO3 }\end{array}$ & 186 & 1.45 & 2.0 & & & 066084-018 & EPA 310.1 \\
\hline & $\begin{array}{l}\text { Alkalinity as } \\
\text { HCO3 }\end{array}$ & 186 & 1.45 & 2.0 & & & 066084-018 & EPA 310.1 \\
\hline & Alkalinity as $\mathrm{CO} 3$ & ND & 1.45 & 2.0 & $\mathrm{U}$ & & 066084-018 & EPA 310.1 \\
\hline \multirow{11}{*}{$\begin{array}{l}\text { PGS-2 } \\
\text { 05-Oct-04 }\end{array}$} & Bromide & 0.253 & 0.0978 & 0.20 & & & 066025-013 & SW846 9056 \\
\hline & Chloride & 13.1 & 0.0322 & 0.20 & & & $066025-013$ & SW846 9056 \\
\hline & Fluoride & 0.213 & 0.0553 & 0.10 & & & 066025-013 & SW846 9056 \\
\hline & Sulfate & 57.5 & 0.965 & 2.0 & & & $066025-013$ & SW846 9056 \\
\hline & Calcium & 46.5 & 0.040 & 0.10 & & & $066025-014$ & SW846 6020 \\
\hline & Magnesium & 10.5 & 0.00633 & 0.01 & & & 066025-014 & SW846 6020 \\
\hline & Potassium & 2.34 & 0.0151 & 0.30 & & & 066025-014 & SW846 6020 \\
\hline & Sodium & 28.3 & 0.00968 & 0.25 & & & $066025-014$ & SW846 6020 \\
\hline & $\begin{array}{l}\text { Total Alkalinity as } \\
\mathrm{CaCO} 3\end{array}$ & 147 & 1.45 & 2.0 & & & 066025-018 & EPA 310.1 \\
\hline & \begin{tabular}{|l|} 
Alkalinity as \\
$\mathrm{HCO} 3$
\end{tabular} & 145 & 1.45 & 2.0 & & & 066025-018 & EPA 310.1 \\
\hline & Alkalinity as CO3 & ND & 1.45 & 2.0 & $U$ & & 066025-018 & EPA 310.1 \\
\hline \multirow{11}{*}{$\begin{array}{l}\text { TA1-W-01 } \\
\text { 06-Oct-04 }\end{array}$} & Bromide & 0.247 & 0.0978 & 0.20 & & & 066027-013 & SW846 9056 \\
\hline & Chloride & 14.6 & 0.0322 & 0.20 & & & $066027-013$ & SW846 9056 \\
\hline & Fluoride & 0.432 & 0.0553 & 0.10 & & & 066027-013 & SW846 9056 \\
\hline & Sulfate & 75.0 & 0.965 & 2.0 & & & $066027-013$ & SW846 9056 \\
\hline & Calcium & 69.0 & 0.040 & 0.10 & & & $066027-014$ & SW846 6020 \\
\hline & Magnesium & 13.6 & 0.00633 & 0.01 & & & $066027-014$ & SW846 6020 \\
\hline & Potassium & 2.16 & 0.0151 & 0.30 & & & $066027-014$ & SW846 6020 \\
\hline & Sodium & 25.9 & 0.00968 & 0.25 & & & $066027-014$ & SW846 6020 \\
\hline & $\begin{array}{l}\text { Total Alkalinity as } \\
\text { CaCO3 }\end{array}$ & 166 & 1.45 & 2.0 & & & 066027-018 & EPA 310.1 \\
\hline & \begin{tabular}{|l|} 
Alkalinity as \\
$\mathrm{HCO} 3$
\end{tabular} & 165 & 1.45 & 2.0 & & & 066027-018 & EPA 310.1 \\
\hline & Alkalinity as $\mathrm{CO} 3$ & ND & 1.45 & 2.0 & $\mathrm{U}$ & & 066027-018 & EPA 310.1 \\
\hline \multirow{11}{*}{$\mid \begin{array}{l}\text { TA1-W-02 } \\
\text { 11-Oct-04 }\end{array}$} & Bromide & 0.254 & 0.0978 & 0.20 & & & 066029-013 & SW846 9056 \\
\hline & Chloride & 13.8 & 0.0322 & 0.20 & & & $066029-013$ & SW846 9056 \\
\hline & Fluoride & 0.423 & 0.0553 & 0.10 & & & 066029-013 & SW846 9056 \\
\hline & Sulfate & 78.2 & 0.965 & 2.0 & & & $066029-013$ & SW846 9056 \\
\hline & Calcium & 68.8 & 0.040 & 0.10 & & & 066029-014 & SW846 6020 \\
\hline & Magnesium & 13.5 & 0.00633 & 0.01 & & & 066029-014 & SW846 6020 \\
\hline & Potassium & 2.29 & 0.0151 & 0.30 & & & 066029-014 & SW846 6020 \\
\hline & Sodium & 23.3 & 0.00968 & 0.25 & & & 066029-014 & SW846 6020 \\
\hline & $\begin{array}{l}\text { Total Alkalinity as } \\
\text { CaCO3 }\end{array}$ & 177 & 104 & 1.45 & & & 066029-018 & EPA 310.1 \\
\hline & \begin{tabular}{|l|} 
Alkalinity as \\
$\mathrm{HCO} 3$
\end{tabular} & 177 & 104 & 1.45 & & & 066029-018 & EPA 310.1 \\
\hline & Alkalinity as $\mathrm{CO} 3$ & ND & 104 & 1.45 & $\mathrm{U}$ & & 066029-018 & EPA 310.1 \\
\hline \multirow{8}{*}{$\begin{array}{l}\text { TA1-W-03 } \\
\text { 19-Oct-04 }\end{array}$} & Bromide & 2.63 & 0.0978 & 0.20 & & & 066031-013 & SW846 9056 \\
\hline & Chloride & 263 & 0.644 & 4.0 & & & 066031-013 & SW846 9056 \\
\hline & Fluoride & 0.076 & 0.0553 & 0.10 & $\mathrm{~J}$ & & 066031-013 & SW846 9056 \\
\hline & Sulfate & 505 & 3.86 & 8.0 & & & 066031-013 & SW846 9056 \\
\hline & Calcium & 294 & 0.20 & 0.50 & & & 066031-014 & SW846 6020 \\
\hline & Magnesium & 30.7 & 0.00633 & 0.01 & & $\mathrm{~J}$ & 066031-014 & SW846 6020 \\
\hline & Potassium & 2.61 & 0.0151 & 0.30 & & & 066031-014 & SW846 6020 \\
\hline & Sodium & 48.2 & 0.00968 & 0.25 & $B$ & & 066031-014 & SW846 6020 \\
\hline
\end{tabular}




\begin{tabular}{|c|c|c|c|c|c|c|c|c|}
\hline Well ID & \begin{tabular}{|l} 
Analyte \\
\end{tabular} & $\begin{array}{l}\text { Result } \\
\text { (mg/L) }\end{array}$ & $\begin{array}{c}\text { MDL } \\
\text { (mg/L) }\end{array}$ & $\begin{array}{c}\text { PQL } \\
\text { (mg/L) }\end{array}$ & $\begin{array}{l}\text { Laboratory } \\
\text { Qualifier }\end{array}$ & $\begin{array}{c}\text { Validation } \\
\text { Qualifier } \\
\end{array}$ & Sample No. & $\begin{array}{c}\text { Analytical } \\
\text { Method }\end{array}$ \\
\hline & $\begin{array}{l}\text { Total Alkalinity as } \\
\text { CaCO3 }\end{array}$ & 68.0 & 1.45 & 2.0 & & & 066031-018 & EPA 310.1 \\
\hline & \begin{tabular}{|l|} 
Alkalinity as \\
HCO3
\end{tabular} & 67.7 & 1.45 & 2.0 & & & 066031-018 & EPA 310.1 \\
\hline & Alkalinity as $\mathrm{CO} 3$ & ND & 1.45 & 2.0 & $\mathrm{U}$ & & 066031-018 & EPA 310.1 \\
\hline TA1-W-04 & Bromide & 0.276 & 0.0978 & 0.20 & & & 066033-013 & SW846 9056 \\
\hline \multirow[t]{10}{*}{ 07-Oct-04 } & Chloride & 15.5 & 0.0322 & 0.20 & & & 066033-013 & SW846 9056 \\
\hline & Fluoride & 0.382 & 0.0553 & 0.10 & & & 066033-013 & SW846 9056 \\
\hline & Sulfate & 59.3 & 0.965 & 2.0 & & & 066033-013 & SW846 9056 \\
\hline & Calcium & 65.9 & 0.040 & 0.10 & & & 066033-014 & SW846 6020 \\
\hline & Magnesium & 11.5 & 0.00633 & 0.01 & & & 066033-014 & SW846 6020 \\
\hline & Potassium & 2.39 & 0.0151 & 0.30 & & & 066033-014 & SW846 6020 \\
\hline & Sodium & 23.5 & 0.00968 & 0.25 & & & 066033-014 & SW846 6020 \\
\hline & $\begin{array}{l}\text { Total Alkalinity as } \\
\mathrm{CaCO} 3\end{array}$ & 168 & 1.45 & 2.0 & & & 066033-018 & EPA 310.1 \\
\hline & \begin{tabular}{l|} 
Alkalinity as \\
HCO3
\end{tabular} & 167 & 1.45 & 2.0 & & & 066033-018 & EPA 310.1 \\
\hline & Alkalinity as $\mathrm{CO} 3$ & ND & 1.45 & 2.0 & $U$ & & 066033-018 & EPA 310.1 \\
\hline TA1-W-05 & Bromide & ND & 0.0978 & 0.20 & $u$ & & 066035-013 & SW846 9056 \\
\hline \multirow[t]{10}{*}{ 26-Oct-04 } & Chloride & 11.7 & 0.0322 & 0.20 & & & $066035-013$ & SW846 9056 \\
\hline & Fluoride & 0.198 & 0.0553 & 0.10 & & & $066035-013$ & SW846 9056 \\
\hline & Sulfate & 102 & 0.965 & 2.0 & & & $066035-013$ & SW846 9056 \\
\hline & Calcium & 79.8 & 0.040 & 0.10 & B & & 066035-014 & SW846 6020 \\
\hline & Magnesium & 10.9 & 0.00633 & 0.01 & & $\mathrm{~J}$ & 066035-014 & SW846 6020 \\
\hline & Potassium & 2.02 & 0.0151 & 0.30 & & & 066035-014 & SW846 6020 \\
\hline & Sodium & 33.6 & 0.00968 & 0.25 & $B$ & & 066035-014 & SW846 6020 \\
\hline & $\begin{array}{l}\text { Total Alkalinity as } \\
\text { CaCO3 }\end{array}$ & 199 & 1.45 & 2.0 & & & 066035-018 & EPA 310.1 \\
\hline & \begin{tabular}{l|} 
Alkalinity as \\
HCO3
\end{tabular} & 198 & 1.45 & 2.0 & & & 066035-018 & EPA 310.1 \\
\hline & Alkalinity as $\mathrm{CO} 3$ & ND & 1.45 & 2.0 & $\mathrm{U}$ & & 066035-018 & EPA 310.1 \\
\hline TA1-W-06 & Bromide & 0.880 & 0.0978 & 0.20 & & & 066037-013 & SW846 9056 \\
\hline \multirow[t]{10}{*}{ 26-Oct-04 } & Chloride & 103 & 0.322 & 2.0 & & & $066037-013$ & SW846 9056 \\
\hline & Fluoride & 0.206 & 0.0553 & 0.10 & & & $066037-013$ & SW846 9056 \\
\hline & Sulfate & 211 & 1.93 & 4.0 & & & $066037-013$ & SW846 9056 \\
\hline & Calcium & 119 & 0.040 & 0.10 & B & & 066037-014 & SW846 6020 \\
\hline & Magnesium & 14.8 & 0.00633 & 0.01 & & $\mathrm{~J}$ & 066037-014 & SW846 6020 \\
\hline & Potassium & 1.91 & 0.0151 & 0.30 & & & 066037-014 & SW846 6020 \\
\hline & Sodium & 34.6 & 0.00968 & 0.25 & $\mathrm{~B}$ & & $066037-014$ & SW846 6020 \\
\hline & $\begin{array}{l}\text { Total Alkalinity as } \\
\mathrm{CaCO} 3\end{array}$ & 88.9 & 1.45 & 2.0 & & & 066037-018 & EPA 310.1 \\
\hline & $\begin{array}{l}\text { Alkalinity as } \\
\mathrm{HCO} 3\end{array}$ & 88.4 & 1.45 & 2.0 & & & 066037-018 & EPA 310.1 \\
\hline & Alkalinity as $\mathrm{CO} 3$ & ND & 1.45 & 2.0 & $\mathrm{U}$ & & 066037-018 & EPA 310.1 \\
\hline TA1-W-08 & Bromide & ND & 0.0978 & 0.20 & U & & 066039-013 & SW846 9056 \\
\hline \multirow[t]{8}{*}{ 08-Oct-04 } & Chloride & 202 & 1.61 & 10.0 & & & $066039-013$ & SW846 9056 \\
\hline & Fluoride & 0.260 & 0.0553 & 0.10 & & & 066039-013 & SW846 9056 \\
\hline & Sulfate & 650 & 9.65 & 20.0 & & & 066039-013 & SW846 9056 \\
\hline & Calcium & 334 & 0.20 & 0.50 & & & 066039-014 & SW846 6020 \\
\hline & Magnesium & 41.1 & 0.00633 & 0.01 & & & 066039-014 & SW846 6020 \\
\hline & Potassium & 3.25 & 0.0151 & 0.30 & & & 066039-014 & SW846 6020 \\
\hline & Sodium & 76.7 & 0.00968 & 0.25 & & & 066039-014 & SW846 6020 \\
\hline & $\begin{array}{l}\text { Total Alkalinity as } \\
\mathrm{CaCO} 3\end{array}$ & 53.6 & 1.45 & 2.0 & & & 066039-018 & EPA 310.1 \\
\hline
\end{tabular}




\begin{tabular}{|c|c|c|c|c|c|c|c|c|}
\hline Well ID & Analyte & $\begin{array}{l}\text { Result } \\
\text { (mg/L) }\end{array}$ & $\begin{array}{c}\mathrm{MDL} \\
(\mathrm{mg} / \mathrm{L})\end{array}$ & $\begin{array}{c}\text { PQL } \\
(\mathrm{mg} / \mathrm{L})\end{array}$ & $\begin{array}{l}\text { Laboratory } \\
\text { Qualifier }\end{array}$ & $\begin{array}{c}\text { Validation } \\
\text { Qualifier }\end{array}$ & Sample No. & $\begin{array}{c}\text { Analytical } \\
\text { Method }\end{array}$ \\
\hline & $\begin{array}{l}\text { Alkalinity as } \\
\text { HCO3 }\end{array}$ & 53.5 & 1.45 & 2.0 & & & 066039-018 & EPA 310.1 \\
\hline & Alkalinity as CO3 & ND & 1.45 & 2.0 & $\mathrm{U}$ & & 066039-018 & EPA 310.1 \\
\hline TA2-NW1-595 & Bromide & 0.761 & 0.0978 & 0.20 & & & 066042-013 & SW846 9056 \\
\hline \multirow{10}{*}{$\begin{array}{l}\text { 25-Oct-04 } \\
\text { (QED) }\end{array}$} & Chloride & 89.4 & 0.322 & 2.0 & & & $066042-013$ & SW846 9056 \\
\hline & Fluoride & 0.183 & 0.0553 & 0.10 & & & 066042-013 & SW846 9056 \\
\hline & Sulfate & 119 & 1.93 & 4.0 & & & $066042-013$ & SW846 9056 \\
\hline & Calcium & 103 & 0.040 & 0.10 & & & 066042-014 & SW846 6020 \\
\hline & Magnesium & 17.0 & 0.00633 & 0.01 & & $\mathrm{~J}$ & 066042-014 & SW846 6020 \\
\hline & Potassium & 2.40 & 0.0151 & 0.30 & & & $066042-014$ & SW846 6020 \\
\hline & Sodium & 31.3 & 0.00968 & 0.25 & $B$ & & $066042-014$ & SW846 6020 \\
\hline & $\begin{array}{l}\text { Total Alkalinity as } \\
\mathrm{CaCO} 3 \\
\end{array}$ & 137 & 1.45 & 2.0 & & & 066042-018 & EPA 310.1 \\
\hline & $\begin{array}{l}\text { Alkalinity as } \\
\mathrm{HCO} 3\end{array}$ & 137 & 1.45 & 2.0 & & & 066042-018 & EPA 310.1 \\
\hline & Alkalinity as $\mathrm{CO} 3$ & ND & 1.45 & 2.0 & $U$ & & 066042-018 & EPA 310.1 \\
\hline \multirow[t]{11}{*}{ TA2-NW1-595 } & Bromide & ND & 0.0978 & 0.20 & $u$ & & 066044-013 & SW846 9056 \\
\hline & Chloride & 83.3 & 0.322 & 2.0 & & & 066044-013 & SW846 9056 \\
\hline & Fluoride & 0.299 & 0.0553 & 0.10 & & & 066044-013 & SW846 9056 \\
\hline & Sulfate & 118 & 1.93 & 4.0 & & & $066044-013$ & SW846 9056 \\
\hline & Calcium & 104 & 0.040 & 0.10 & & & 066044-014 & SW846 6020 \\
\hline & Magnesium & 17.4 & 0.00633 & 0.01 & & & 066044-014 & SW846 6020 \\
\hline & Potassium & 2.32 & 0.0151 & 0.30 & & & 066044-014 & SW846 6020 \\
\hline & Sodium & 29.5 & 0.00968 & 0.25 & & & 066044-014 & SW846 6020 \\
\hline & $\begin{array}{l}\text { Total Alkalinity as } \\
\mathrm{CaCO} 3\end{array}$ & 138 & 1.45 & 2.0 & & & 066044-018 & EPA 310.1 \\
\hline & $\begin{array}{l}\text { Alkalinity as } \\
\mathrm{HCO} 3\end{array}$ & 137 & 1.45 & 2.0 & & & 066044-018 & EPA 310.1 \\
\hline & Alkalinity as CO3 & ND & 1.45 & 2.0 & $\mathrm{U}$ & & 066044-018 & EPA 310.1 \\
\hline \multirow{11}{*}{$\begin{array}{l}\text { TA2-SW1-320 } \\
\text { 04-Oct-04 }\end{array}$} & Bromide & 0.467 & 0.0978 & 0.20 & & & 066046-013 & SW846 9056 \\
\hline & Chloride & 28.2 & 0.161 & 1.0 & & & 066046-013 & SW846 9056 \\
\hline & Fluoride & 0.444 & 0.0553 & 0.10 & & & 066046-013 & SW846 9056 \\
\hline & Sulfate & 13.7 & 0.193 & 0.40 & & & 066046-013 & SW846 9056 \\
\hline & Calcium & 60.9 & 0.040 & 0.10 & & & 066046-014 & SW846 6020 \\
\hline & Magnesium & 11.2 & 0.00633 & 0.01 & & & 066046-014 & SW846 6020 \\
\hline & Potassium & 1.70 & 0.0151 & 0.30 & & & 066046-014 & SW846 6020 \\
\hline & Sodium & 17.5 & 0.00968 & 0.25 & & & 066046-014 & SW846 6020 \\
\hline & $\begin{array}{l}\text { Total Alkalinity as } \\
\mathrm{CaCO} 3\end{array}$ & 104 & 1.45 & 2.0 & $\mathrm{H}$ & $\mathrm{HT}, \mathrm{J}$ & 066046-018 & EPA 310.1 \\
\hline & $\begin{array}{l}\text { Alkalinity as } \\
\text { HCO3 }\end{array}$ & 104 & 1.45 & 2.0 & $\mathrm{H}$ & $\mathrm{HT}, \mathrm{J}$ & 066046-018 & EPA 310.1 \\
\hline & Alkalinity as CO3 & ND & 1.45 & 2.0 & $\mathrm{H}, \mathrm{U}$ & $\mathrm{HT}, \mathrm{UJ}$ & 066046-018 & EPA 310.1 \\
\hline \multirow{11}{*}{$\begin{array}{l}\text { TA2-W-01 } \\
\text { 18-Oct-04 }\end{array}$} & Bromide & 1.19 & 0.0978 & 0.20 & & & 066048-013 & SW846 9056 \\
\hline & Chloride & 113 & 0.322 & 2.0 & & & 066048-013 & SW846 9056 \\
\hline & Fluoride & 0.145 & 0.0553 & 0.10 & & & 066048-013 & SW846 9056 \\
\hline & Sulfate & 81.4 & 1.93 & 4.0 & & & 066048-013 & SW846 9056 \\
\hline & Calcium & 84.2 & 0.040 & 0.10 & & & 066048-014 & SW846 6020 \\
\hline & Magnesium & 10.8 & 0.00633 & 0.01 & & $\mathrm{~J}$ & 066048-014 & SW846 6020 \\
\hline & Potassium & 1.72 & 0.0151 & 0.30 & & & 066048-014 & SW846 6020 \\
\hline & Sodium & 21.9 & 0.00968 & 0.25 & $B$ & & 066048-014 & SW846 6020 \\
\hline & $\begin{array}{l}\text { Total Alkalinity as } \\
\text { CaCO3 }\end{array}$ & 81.6 & 1.45 & 2.0 & & & 066048-018 & EPA 310.1 \\
\hline & \begin{tabular}{|l|} 
Alkalinity as \\
HCO3
\end{tabular} & 81.4 & 1.45 & 2.0 & & & 066048-018 & EPA 310.1 \\
\hline & Alkalinity as CO3 & ND & 1.45 & 2.0 & $\bar{U}$ & & 066048-018 & EPA 310.1 \\
\hline
\end{tabular}




\begin{tabular}{|c|c|c|c|c|c|c|c|c|}
\hline Well ID & Analyte & $\begin{array}{l}\text { Result } \\
\text { (mg/L) }\end{array}$ & $\begin{array}{c}\mathrm{MDL} \\
(\mathrm{mg} / \mathrm{L})\end{array}$ & $\begin{array}{c}\mathrm{PQL} \\
(\mathrm{mg} / \mathrm{L})\end{array}$ & $\begin{array}{c}\text { Laboratory } \\
\text { Qualifier }\end{array}$ & $\begin{array}{c}\text { Validation } \\
\text { Qualifier } \\
\end{array}$ & Sample No. & $\begin{array}{c}\text { Analytical } \\
\text { Method }\end{array}$ \\
\hline TA2-W-19 & Bromide & 0.966 & 0.0978 & 0.20 & & & 066050-013 & SW846 9056 \\
\hline \multirow[t]{10}{*}{ 04-Oct-04 } & Chloride & 70.2 & 0.322 & 2.0 & & & $066050-013$ & SW846 9056 \\
\hline & Fluoride & 0.343 & 0.0553 & 0.10 & & & $066050-013$ & SW846 9056 \\
\hline & Sulfate & 58.4 & 1.93 & 4.0 & & & $066050-013$ & SW846 9056 \\
\hline & Calcium & 76.7 & 0.040 & 0.10 & & & 066050-014 & SW846 6020 \\
\hline & Magnesium & 11.3 & 0.00633 & 0.01 & & & $066050-014$ & SW846 6020 \\
\hline & Potassium & 1.61 & 0.0151 & 0.30 & & & 066050-014 & SW846 6020 \\
\hline & Sodium & 21.1 & 0.00968 & 0.25 & & & 066050-014 & SW846 6020 \\
\hline & $\begin{array}{l}\text { Total Alkalinity as } \\
\mathrm{CaCO} 3 \\
\end{array}$ & 100 & 1.45 & 2.0 & & & 066050-018 & EPA 310.1 \\
\hline & $\begin{array}{l}\text { Alkalinity as } \\
\mathrm{HCO} 3\end{array}$ & 99.9 & 1.45 & 2.0 & & & 066050-018 & EPA 310.1 \\
\hline & Alkalinity as $\mathrm{CO} 3$ & ND & 1.45 & 2.0 & $\mathrm{U}$ & & 066050-018 & EPA 310.1 \\
\hline TA2-W-26 & Bromide & 1.38 & 0.0978 & 0.20 & & & 066053-013 & SW846 9056 \\
\hline \multirow[t]{10}{*}{ 13-Oct-04 } & Chloride & 143 & 0.644 & 4.0 & & & 066053-013 & SW846 9056 \\
\hline & Fluoride & 0.146 & 0.0553 & 0.10 & & & 066053-013 & SW846 9056 \\
\hline & Sulfate & 268 & 3.86 & 8.0 & & & 066053-013 & SW846 9056 \\
\hline & Calcium & 160 & 0.040 & 0.10 & B & & 066053-014 & SW846 6020 \\
\hline & Magnesium & 21.6 & 0.00633 & 0.01 & & & 066053-014 & SW846 6020 \\
\hline & Potassium & 2.26 & 0.0151 & 0.30 & & & 066053-014 & SW846 6020 \\
\hline & Sodium & 31.4 & 0.00968 & 0.25 & B & $\mathrm{J}$ & 066053-014 & SW846 6020 \\
\hline & $\begin{array}{l}\text { Total Alkalinity as } \\
\mathrm{CaCO} 3\end{array}$ & 66.8 & 1.45 & 2.0 & & & 066053-018 & EPA 310.1 \\
\hline & \begin{tabular}{|l|} 
Alkalinity as \\
HCO3
\end{tabular} & 66.6 & 1.45 & 2.0 & & & 066053-018 & EPA 310.1 \\
\hline & Alkalinity as $\mathrm{CO} 3$ & ND & 1.45 & 2.0 & $\mathrm{U}$ & & 066053-018 & EPA 310.1 \\
\hline TA2-W-27 & Bromide & 1.27 & 0.0978 & 0.20 & & & 066056-013 & SW846 9056 \\
\hline \multirow[t]{10}{*}{ 14-Oct-04 } & Chloride & 132 & 0.322 & 2.0 & & & 066056-013 & SW846 9056 \\
\hline & Fluoride & 0.109 & 0.0553 & 0.10 & & & 066056-013 & SW846 9056 \\
\hline & Sulfate & 174 & 1.93 & 4.0 & & & 066056-013 & SW846 9056 \\
\hline & Calcium & 123 & 0.040 & 0.10 & $B$ & & 066056-014 & SW846 6020 \\
\hline & Magnesium & 18.9 & 0.00633 & 0.01 & & & 066056-014 & SW846 6020 \\
\hline & Potassium & 1.99 & 0.0151 & 0.30 & $\mathrm{~B}$ & & 066056-014 & SW846 6020 \\
\hline & Sodium & 29.8 & 0.00968 & 0.25 & B & & 066056-014 & SW846 6020 \\
\hline & $\begin{array}{l}\text { Total Alkalinity as } \\
\mathrm{CaCO} 3\end{array}$ & 74.6 & 1.45 & 2.0 & & & 066056-018 & EPA 310.1 \\
\hline & $\begin{array}{l}\text { Alkalinity as } \\
\mathrm{HCO} 3\end{array}$ & 74.2 & 1.45 & 2.0 & & & 066056-018 & EPA 310.1 \\
\hline & Alkalinity as CO3 & ND & 1.45 & 2.0 & $U$ & & 066056-018 & EPA 310.1 \\
\hline TJA-2 & Bromide & ND & 0.0978 & 0.20 & U & & 066059-013 & SW846 9056 \\
\hline \multirow[t]{10}{*}{ 11-Oct-04 } & Chloride & 70.1 & 0.161 & 1.0 & & & 066059-013 & SW846 9056 \\
\hline & Fluoride & 0.343 & 0.0553 & 0.10 & & & 066059-013 & SW846 9056 \\
\hline & Sulfate & 53.2 & 0.965 & 2.0 & & & 066059-013 & SW846 9056 \\
\hline & Calcium & 79.3 & 0.040 & 0.10 & & & 066059-014 & SW846 6020 \\
\hline & Magnesium & 12.5 & 0.00633 & 0.01 & & & 066059-014 & SW846 6020 \\
\hline & Potassium & 1.86 & 0.0151 & 0.30 & & & 066059-014 & SW846 6020 \\
\hline & Sodium & 24.0 & 0.00968 & 0.25 & & & $066059-014$ & SW846 6020 \\
\hline & $\begin{array}{l}\text { Total Alkalinity as } \\
\mathrm{CaCO} 3\end{array}$ & 98.2 & 1.45 & 2.0 & & & 066059-018 & EPA 310.1 \\
\hline & $\begin{array}{l}\text { Alkalinity as } \\
\mathrm{HCO} 3\end{array}$ & 97.6 & 1.45 & 2.0 & & & 066059-018 & EPA 310.1 \\
\hline & Alkalinity as $\mathrm{CO} 3$ & ND & 1.45 & 2.0 & $U$ & & 066059-018 & EPA 310.1 \\
\hline TJA-3 & Bromide & 0.267 & 0.0978 & 0.20 & & & 066061-013 & SW846 9056 \\
\hline 12-Oct-04 & Chloride & 13.0 & 0.0322 & 0.20 & & & 066061-013 & SW846 9056 \\
\hline
\end{tabular}




\begin{tabular}{|c|c|c|c|c|c|c|c|c|}
\hline Well ID & Analyte & $\begin{array}{l}\text { Result } \\
\text { (mg/L) }\end{array}$ & $\begin{array}{c}\text { MDL } \\
\text { (mg/L) }\end{array}$ & $\begin{array}{c}\text { PQL } \\
\text { (mg/L) }\end{array}$ & $\begin{array}{l}\text { Laboratory } \\
\text { Qualifier }\end{array}$ & \begin{tabular}{|c|} 
Validation \\
Qualifier
\end{tabular} & Sample No. & $\begin{array}{c}\text { Analytical } \\
\text { Method }\end{array}$ \\
\hline & Fluoride & 0.353 & 0.0553 & 0.10 & & & 066061-013 & SW846 9056 \\
\hline & Sulfate & 71.7 & 0.965 & 2.0 & & & 066061-013 & SW846 9056 \\
\hline & Calcium & 65.3 & 0.040 & 0.10 & & & 066061-014 & SW846 6020 \\
\hline & Magnesium & 11.6 & 0.00633 & 0.01 & & & 066061-014 & SW846 6020 \\
\hline & Potassium & 1.83 & 0.0151 & 0.30 & & & 066061-014 & SW846 6020 \\
\hline & Sodium & 24.4 & 0.00968 & 0.25 & & & 066061-014 & SW846 6020 \\
\hline & $\begin{array}{l}\text { Total Alkalinity as } \\
\text { CaCO3 }\end{array}$ & 187 & 1.45 & 2.0 & & & 066061-018 & EPA 310.1 \\
\hline & \begin{tabular}{|l|} 
Alkalinity as \\
$\mathrm{HCO} 3$
\end{tabular} & 187 & 1.45 & 2.0 & & & 066061-018 & EPA 310.1 \\
\hline & Alkalinity as $\mathrm{CO} 3$ & ND & 1.45 & 2.0 & $\mathrm{U}$ & & 066061-018 & EPA 310.1 \\
\hline TJA-4 & Bromide & 0.418 & 0.0978 & 0.20 & & & 066063-013 & SW846 9056 \\
\hline \multirow{10}{*}{ 12-Oct-04 } & Chloride & 20.1 & 0.0553 & 0.10 & & & 066063-013 & SW846 9056 \\
\hline & Fluoride & 0.402 & 0.0553 & 0.10 & & & 066063-013 & SW846 9056 \\
\hline & Sulfate & 18.0 & 0.193 & 0.40 & & & 066063-013 & SW846 9056 \\
\hline & Calcium & 65.5 & 0.040 & 0.10 & & & 066063-014 & SW846 6020 \\
\hline & Magnesium & 13.7 & 0.00633 & 0.01 & & & 066063-014 & SW846 6020 \\
\hline & Potassium & 3.08 & 0.0151 & 0.30 & & & 066063-014 & SW846 6020 \\
\hline & Sodium & 25.2 & 0.00968 & 0.25 & & & 066063-014 & SW846 6020 \\
\hline & $\begin{array}{l}\text { Total Alkalinity as } \\
\text { CaCO3 }\end{array}$ & 98.2 & 1.45 & 2.0 & & & 066063-018 & EPA 310.1 \\
\hline & \begin{tabular}{|l|} 
Alkalinity as \\
$\mathrm{HCO} 3$
\end{tabular} & 97.9 & 1.45 & 2.0 & & & 066063-018 & EPA 310.1 \\
\hline & Alkalinity as $\mathrm{CO} 3$ & ND & 1.45 & 2.0 & $\mathrm{U}$ & & 066063-018 & EPA 310.1 \\
\hline TJA-6 & Bromide & ND & 0.0978 & 0.20 & U & & 066065-013 & SW846 9056 \\
\hline \multirow[t]{10}{*}{ 13-Oct-04 } & Chloride & 15.2 & 0.0322 & 0.20 & & & 066065-013 & SW846 9056 \\
\hline & Fluoride & 0.165 & 0.0553 & 0.10 & & & 066065-013 & SW846 9056 \\
\hline & Sulfate & 65.9 & 0.965 & 2.0 & & & 066065-013 & SW846 9056 \\
\hline & Calcium & 63.8 & 0.040 & 0.10 & $B$ & & 066065-014 & SW846 6020 \\
\hline & Magnesium & 12.6 & 0.00633 & 0.01 & & & 066065-014 & SW846 6020 \\
\hline & Potassium & 2.37 & 0.0151 & 0.30 & & & 066065-014 & SW846 6020 \\
\hline & Sodium & 24.9 & 0.00968 & 0.25 & $\mathrm{~B}$ & $\mathrm{~J}$ & 066065-014 & SW846 6020 \\
\hline & $\begin{array}{l}\text { Total Alkalinity as } \\
\text { CaCO3 }\end{array}$ & 127 & 1.45 & 2.0 & & & 066065-018 & EPA 310.1 \\
\hline & \begin{tabular}{|l|} 
Alkalinity as \\
HCO3
\end{tabular} & 126 & 1.45 & 2.0 & & & 066065-018 & EPA 310.1 \\
\hline & Alkalinity as CO3 & ND & 1.45 & 2.0 & $U$ & & 066065-018 & EPA 310.1 \\
\hline TJA-7 & Bromide & ND & 0.0978 & 0.20 & $u$ & & 066067-013 & SW846 9056 \\
\hline \multirow[t]{10}{*}{ 15-Oct-04 } & Chloride & 30.7 & 0.161 & 1.0 & & & 066067-013 & SW846 9056 \\
\hline & Fluoride & 0.137 & 0.0553 & 0.10 & & & 066067-013 & SW846 9056 \\
\hline & Sulfate & 16.9 & 0.193 & 0.40 & & & 066067-013 & SW846 9056 \\
\hline & Calcium & 68.7 & 0.040 & 0.10 & & & 066067-014 & SW846 6020 \\
\hline & Magnesium & 12.7 & 0.00633 & 0.01 & & $\mathrm{~J}$ & 066067-014 & SW846 6020 \\
\hline & Potassium & 1.90 & 0.0151 & 0.30 & & & 066067-014 & SW846 6020 \\
\hline & Sodium & 20.9 & 0.00968 & 0.25 & B & & 066067-014 & SW846 6020 \\
\hline & $\begin{array}{l}\text { Total Alkalinity as } \\
\text { CaCO3 }\end{array}$ & 98.4 & 1.45 & 2.0 & & & 066067-018 & EPA 310.1 \\
\hline & $\begin{array}{l}\text { Alkalinity as } \\
\text { HCO3 }\end{array}$ & 97.6 & 1.45 & 2.0 & & & 066067-018 & EPA 310.1 \\
\hline & Alkalinity as $\mathrm{CO} 3$ & $\mathrm{ND}$ & 1.45 & 2.0 & $\mathrm{U}$ & & 066067-018 & EPA 310.1 \\
\hline WYO-3 & Bromide & 0.263 & 0.0978 & 0.20 & & & 066071-013 & SW846 9056 \\
\hline \multirow[t]{3}{*}{ 08-Oct-04 } & Chloride & 14.7 & 0.0322 & 0.20 & & & 066071-013 & SW846 9056 \\
\hline & Fluoride & 0.415 & 0.0553 & 0.10 & & & 066071-013 & SW846 9056 \\
\hline & Sulfate & 84.9 & 0.965 & 2.0 & & & 066071-013 & SW846 9056 \\
\hline
\end{tabular}




\begin{tabular}{|c|c|c|c|c|c|c|c|c|}
\hline \multirow[t]{8}{*}{ Well ID } & Analyte & $\begin{array}{l}\text { Result } \\
\text { (mg/L) }\end{array}$ & $\begin{array}{c}\text { MDL } \\
\text { (mg/L) }\end{array}$ & $\begin{array}{c}\text { PQL } \\
\text { (mg/L) }\end{array}$ & $\begin{array}{l}\text { Laboratory } \\
\text { Qualifier }\end{array}$ & $\begin{array}{c}\text { Validation } \\
\text { Qualifier }\end{array}$ & Sample No. & $\begin{array}{l}\text { Analytical } \\
\text { Method }\end{array}$ \\
\hline & Calcium & 71.3 & 0.040 & 0.10 & & & 066071-014 & SW846 6020 \\
\hline & Magnesium & 14.7 & 0.00633 & 0.01 & & & 066071-014 & SW846 6020 \\
\hline & Potassium & 2.41 & 0.0151 & 0.30 & & & 066071-014 & SW846 6020 \\
\hline & Sodium & 25.7 & 0.00968 & 0.25 & & & 066071-014 & SW846 6020 \\
\hline & $\begin{array}{l}\text { Total Alkalinity as } \\
\text { CaCO3 }\end{array}$ & 169 & 1.45 & 2.0 & & & 066071-018 & EPA 310.1 \\
\hline & \begin{tabular}{|l|} 
Alkalinity as \\
HCO3
\end{tabular} & 168 & 1.45 & 2.0 & & & 066071-018 & EPA 310.1 \\
\hline & Alkalinity as CO3 & ND & 1.45 & 2.0 & $\mathrm{U}$ & & 066071-018 & EPA 310.1 \\
\hline WYO-4 & Bromide & 1.24 & 0.0978 & 0.20 & & & 066073-013 & SW846 9056 \\
\hline \multirow[t]{10}{*}{ 06-Oct-04 } & Chloride & 99.4 & 0.322 & 2.0 & & & 066073-013 & SW846 9056 \\
\hline & Fluoride & 0.368 & 0.0553 & 0.10 & & & $066073-013$ & SW846 9056 \\
\hline & Sulfate & 51.4 & 1.93 & 4.0 & & & 066073-013 & SW846 9056 \\
\hline & Calcium & 80.3 & \begin{tabular}{|l|}
0.040 \\
\end{tabular} & 0.10 & & & 066073-014 & SW846 6020 \\
\hline & Magnesium & 13.6 & 0.00633 & 0.01 & & & $066073-014$ & SW846 6020 \\
\hline & Potassium & 1.88 & 0.0151 & 0.30 & & & 066073-014 & SW846 6020 \\
\hline & Sodium & 21.1 & 0.00968 & 0.25 & & & \begin{tabular}{|l|}
$066073-014$ \\
\end{tabular} & SW846 6020 \\
\hline & $\begin{array}{l}\text { Total Alkalinity as } \\
\text { CaCO3 }\end{array}$ & 95.1 & 1.45 & 2.0 & & & 066073-018 & EPA 310.1 \\
\hline & $\begin{array}{l}\text { Alkalinity as } \\
\text { HCO3 }\end{array}$ & 94.5 & 1.45 & 2.0 & & & 066073-018 & EPA 310.1 \\
\hline & Alkalinity as CO3 & ND & \begin{tabular}{|l|l}
1.45 \\
\end{tabular} & 2.0 & $\mathrm{U}$ & & 066073-018 & EPA 310.1 \\
\hline \multicolumn{9}{|c|}{$\begin{array}{l}\mathrm{mg} / \mathrm{L}=\text { milligrams per liter } \\
\mathrm{J}=\text { Amount detected is below the practical quantitation limit. The associated value is an estimated quantity. } \\
\mathrm{B}=\text { Analyte is detected in associated laboratory method blank. } \\
\mathrm{U}=\text { Analyte not detected above the MDL. } \\
\mathrm{H} / \mathrm{HT} \text { = The holding time was exceeded for the associated sample analysis. }\end{array}$} \\
\hline
\end{tabular}


Table A-20

\section{Summary of Ammonia, Total Kjeldahl Nitrogen, Total Organic Carbon, and Phosphate Detections}

\section{Tijeras Arroyo Groundwater Investigation}

July 2003 through December 2004

\begin{tabular}{|c|c|c|c|c|c|c|c|c|}
\hline Well ID & Analyte & $\begin{array}{l}\text { Result } \\
\text { (mg/L) }\end{array}$ & $\begin{array}{l}\text { MDL } \\
\text { (mg/L) }\end{array}$ & $\begin{array}{c}\mathrm{PQL} \\
(\mathrm{mg} / \mathrm{L})\end{array}$ & $\begin{array}{l}\text { Laboratory } \\
\text { Qualifier }\end{array}$ & $\begin{array}{c}\text { Validation } \\
\text { Qualifier }\end{array}$ & Sample No. & $\begin{array}{l}\text { Analytical } \\
\text { Method }\end{array}$ \\
\hline TA1-W-03 & $\begin{array}{l}\text { Total Organic } \\
\text { carbon }\end{array}$ & 0.764 & 0.025 & 0.2 & B & & 062684-048 & EPA 415.1 \\
\hline 24-Jul-03 & $\begin{array}{l}\text { Total Phosphate } \\
\text { as phosphorus }\end{array}$ & 0.0448 & 0.0162 & 0.05 & $\mathrm{~J}, \mathrm{~B}$ & $\mathrm{~B}, \mathrm{~B} 3, \mathrm{~J}$ & 062684-042 & EPA 365.4 \\
\hline TA1-W-08 & $\begin{array}{l}\text { Total Organic } \\
\text { carbon }\end{array}$ & 0.924 & 0.025 & 0.2 & B & & 062692-048 & SW846 9060 \\
\hline 30-Jul-03 & $\begin{array}{l}\text { Total Phosphate } \\
\text { as phosphorus }\end{array}$ & ND & 0.0162 & 0.05 & $U, B$ & & 062692-042 & EPA 365.4 \\
\hline TJA-7 & Ammonia & ND & 0.024 & 0.05 & U & & 062717-019 & EPA 350.1 \\
\hline \multirow[t]{3}{*}{ 12-Aug-03 } & $\begin{array}{l}\text { Total Kjeldahl } \\
\text { Nitrogen }\end{array}$ & 0.338 & 0.0375 & 0.125 & & & 062717-046 & EPA 351.2 \\
\hline & $\begin{array}{l}\text { Total Organic } \\
\text { carbon }\end{array}$ & 0.431 & 0.025 & 0.2 & B & & 062717-048 & EPA 415.1 \\
\hline & $\begin{array}{l}\text { Total Phosphate } \\
\text { as phosphorus }\end{array}$ & 0.0449 & 0.0162 & 0.05 & $\mathrm{~J}, \mathrm{~B}$ & $\mathrm{~B}, \mathrm{~B} 3, \mathrm{~J}$ & 062717-042 & EPA 365.4 \\
\hline TJA-7 & Ammonia & ND & 0.024 & 0.05 & $U$ & & 063299-019 & EPA 350.1 \\
\hline 28-Oct-03 & $\begin{array}{l}\text { Total Kjeldahl } \\
\text { Nitrogen }\end{array}$ & 3.33 & 0.09 & 0.3 & & & 063299-046 & EPA 351.2 \\
\hline TA1-W-03 & $\begin{array}{l}\text { Total Organic } \\
\text { Carbon }\end{array}$ & 0.790 & 0.025 & 0.2 & & & 063857-004 & EPA 415.1 \\
\hline 07-Jan-04 & $\begin{array}{l}\text { Total } \\
\text { Phosphorus }\end{array}$ & 0.011 & 0.011 & 0.05 & $\mathrm{~B}, \mathrm{~J}$ & $\mathrm{~B}, \mathrm{~B} 3, \mathrm{~J}$ & 063857-024 & EPA 365.4 \\
\hline TA1-W-08 & $\begin{array}{l}\text { Total Organic } \\
\text { Carbon }\end{array}$ & 0.599 & 0.025 & 0.2 & B & B3, J & 063866-004 & EPA 415.1 \\
\hline 10-Feb-04 & $\begin{array}{l}\text { Total } \\
\text { Phosphorus }\end{array}$ & 0.016 & 0.011 & 0.05 & $\mathrm{~J}$ & & $063866-024$ & EPA 365.4 \\
\hline TJA-7 & $\begin{array}{l}\text { Total Organic } \\
\text { Carbon }\end{array}$ & 0.335 & 0.025 & 0.2 & & & 063895-004 & EPA 415.1 \\
\hline 22-Jan-04 & Ammonia & 0.080 & 0.024 & 0.05 & & & 063895-017 & EPA 350.1 \\
\hline & $\begin{array}{l}\text { Total Kjeldahl } \\
\text { Nitrogen }\end{array}$ & 0.560 & 0.030 & 0.1 & & & 063895-019 & EPA 351.2 \\
\hline
\end{tabular}




\begin{tabular}{|c|c|c|c|c|c|c|c|c|}
\hline Well ID & Analyte & $\begin{array}{l}\text { Result } \\
\text { (mg/L) }\end{array}$ & $\begin{array}{c}\text { MDL } \\
\text { (mg/L) }\end{array}$ & $\begin{array}{c}\mathrm{PQL} \\
(\mathrm{mg} / \mathrm{L})\end{array}$ & $\begin{array}{c}\text { Laboratory } \\
\text { Qualifier }\end{array}$ & \begin{tabular}{|c|} 
Validation \\
Qualifier
\end{tabular} & Sample No. & $\begin{array}{c}\text { Analytical } \\
\text { Method }\end{array}$ \\
\hline & $\begin{array}{l}\text { Total } \\
\text { Phosphorus }\end{array}$ & ND & 0.011 & 0.05 & U & & 063895-024 & EPA 365.4 \\
\hline \multirow{2}{*}{$\begin{array}{l}\text { TJA-7 } \\
\text { 30-Apr-04 }\end{array}$} & $\begin{array}{l}\text { Total Kjeldahl } \\
\text { Nitrogen }\end{array}$ & ND & 0.061 & 0.10 & U & & 064593-017 & EPA 350.1 \\
\hline & Ammonia & ND & 0.0216 & 0.05 & $U$ & UJ, A2 & 064593-019 & EPA 351.2 \\
\hline \multirow{2}{*}{$\begin{array}{l}\text { TA1-W-03 } \\
\text { 18-Aug-04 }\end{array}$} & $\begin{array}{l}\text { Total Organic } \\
\text { Carbon }\end{array}$ & 0.64 & 0.39 & 1.0 & $\mathrm{~J}$ & & 065366-004 & EPA 415.1 \\
\hline & $\begin{array}{l}\text { Total } \\
\text { Phosphorus }\end{array}$ & 0.0288 & 0.010 & 0.050 & $\mathrm{~J}$ & & $065366-024$ & EPA 365.4 \\
\hline \multirow{2}{*}{$\begin{array}{l}\text { TA1-W-08 } \\
13-A u g-04\end{array}$} & $\begin{array}{l}\text { Total Organic } \\
\text { Carbon }\end{array}$ & 1.1 & 0.39 & 1.0 & & & $065374-004$ & EPA 415.1 \\
\hline & \begin{tabular}{|l} 
Total \\
Phosphorus
\end{tabular} & 0.0237 & 0.010 & 0.050 & $\mathrm{~J}$ & & $065374-024$ & EPA 365.4 \\
\hline \multirow{4}{*}{$\begin{array}{l}\text { TJA-7 } \\
\text { 06-Aug-04 }\end{array}$} & $\begin{array}{l}\text { Total Organic } \\
\text { Carbon }\end{array}$ & ND & 0.39 & 1.0 & U & & 065403-004 & EPA 415.1 \\
\hline & Ammonia & ND & 0.0216 & 0.050 & U & & 065403-019 & EPA 350.1 \\
\hline & $\begin{array}{l}\text { Total Kjeldahl } \\
\text { Nitrogen }\end{array}$ & ND & 0.061 & 0.10 & U & $A 2, R$ & 065403-017 & EPA 351.2 \\
\hline & $\begin{array}{l}\text { Total } \\
\text { Phosphorus }\end{array}$ & 0.0361 & 0.010 & 0.050 & $\mathrm{~J}$ & & 065403-024 & EPA 365.4 \\
\hline \multirow{2}{*}{$\begin{array}{l}\text { TJA-7 } \\
15-O c t-04\end{array}$} & Ammonia & ND & 0.0159 & 0.05 & $U$ & B3, UJ & $066067-019$ & EPA 350.1 \\
\hline & $\begin{array}{l}\text { Total Kjeldahl } \\
\text { Nitrogen }\end{array}$ & 0.130 & 0.044 & 0.10 & & & 066067-017 & EPA 351.2 \\
\hline \multicolumn{9}{|c|}{$\begin{array}{l}\mathrm{mg} / \mathrm{L}=\text { milligrams per liter } \\
\mathrm{A} 2=\text { Laboratory accuracy and/or bias measurements for the associated matrix spike and/or duplicate do not meet acceptance } \\
\text { criteria. } \\
\mathrm{J}=\text { Amount detected is below the practical quantitation limit. The associated value is an estimated quantity. } \\
\mathrm{B}=\text { Analyte is detected in associated laboratory method blank. } \\
\mathrm{B} 3=\text { Analyte is detected in associated laboratory calibration blank. } \\
\mathrm{U}=\text { Analyte not detected above the MDL. } \\
\mathrm{R}=\text { Data rejected. }\end{array}$} \\
\hline
\end{tabular}


Table A-21

Summary of Manganese 2+ Results (Method C2_150.mtw)

Tijeras Arroyo Groundwater Investigation

July 2003 through December 2004

\begin{tabular}{|c|c|c|c|c|c|c|c|}
\hline Well ID & Sample Date & $\begin{array}{c}\text { Manganese 2+ } \\
\text { Result } \\
\text { (mg/L) }\end{array}$ & $\begin{array}{c}\mathrm{MDL} \\
\text { (mg/L) }\end{array}$ & $\begin{array}{c}\mathrm{PQL} \\
\text { (mg/L) }\end{array}$ & $\begin{array}{c}\text { Laboratory } \\
\text { Qualifier }\end{array}$ & $\begin{array}{c}\text { Validation } \\
\text { Qualifier }\end{array}$ & Sample No. \\
\hline \multirow{6}{*}{ Eubank-1 } & 18-Aug-03 & 0.002 & 0.0007 & NR & & None & $062724-040$ \\
\hline & 10-Nov-03 & ND & 0.05 & NR & $U$ & None & 063303-041 \\
\hline & $16-F e b-04$ & ND & 0.05 & NR & $U$ & None & 063904-011 \\
\hline & 20-May-04 & ND & 0.05 & NR & $U$ & None & 064600-011 \\
\hline & 19-Aug-04 & ND & 0.05 & NR & $U$ & None & 065416-011 \\
\hline & 20-Oct-04 & ND & 0.05 & NR & U & None & 066077-011 \\
\hline \multirow[t]{6}{*}{ Eubank-2 } & 09-Jul-03 & ND & 0.05 & NR & $U$ & None & 062585-040 \\
\hline & 12-Nov-03 & ND & 0.05 & NR & U & None & 063304-041 \\
\hline & 18-Feb-04 & ND & 0.05 & NR & $U$ & None & 063906-011 \\
\hline & 06-May-04 & ND & 0.05 & NR & U & None & 064602-011 \\
\hline & 07-Jul-04 & ND & 0.05 & NR & U & None & 065418-011 \\
\hline & 21-Oct-04 & ND & 0.05 & NR & $U$ & None & 066080-011 \\
\hline \multirow[t]{6}{*}{ Eubank-3 } & 10-Jul-03 & ND & 0.05 & NR & U & None & 062586-040 \\
\hline & 18-Nov-03 & ND & 0.05 & NR & U & None & 063305-041 \\
\hline & 17-Feb-04 & ND & 0.05 & NR & U & None & 063909-011 \\
\hline & 04-May-04 & ND & 0.05 & NR & U & None & 064604-011 \\
\hline & 07-Jul-04 & ND & 0.05 & NR & U & None & 065419-011 \\
\hline & 20-Oct-04 & ND & 0.05 & NR & $U$ & None & 066082-011 \\
\hline \multirow[t]{4}{*}{ Eubank-5 } & 09-Jul-03 & ND & 0.05 & NR & $U$ & None & 062587-040 \\
\hline & 19-Nov-03 & ND & 0.05 & NR & $U$ & None & 063306-041 \\
\hline & 19-Feb-04 & ND & 0.05 & NR & U & None & 063911-011 \\
\hline & 03-May-04 & ND & 0.05 & NR & U & None & 064607-011 \\
\hline
\end{tabular}




\begin{tabular}{|c|c|c|c|c|c|c|c|}
\hline Well ID & Sample Date & $\begin{array}{c}\text { Manganese 2+ } \\
\text { Result } \\
\text { (mg/L) }\end{array}$ & $\begin{array}{c}\text { MDL } \\
\text { (mg/L) }\end{array}$ & $\begin{array}{c}\text { PQL } \\
\text { (mg/L) }\end{array}$ & $\begin{array}{c}\text { Laboratory } \\
\text { Qualifier }\end{array}$ & $\begin{array}{c}\text { Validation } \\
\text { Qualifier }\end{array}$ & Sample No. \\
\hline & 07-Jul-04 & ND & 0.05 & NR & $U$ & None & 065420-011 \\
\hline & 25-Oct-04 & ND & 0.05 & NR & U & None & 066084-011 \\
\hline \multirow{6}{*}{ PGS-2 } & 22-Jul-03 & ND & 0.05 & NR & $u$ & None & 062678-041 \\
\hline & 10-Nov-03 & ND & 0.05 & NR & $U$ & None & 063278-041 \\
\hline & 03-Feb-04 & ND & 0.05 & NR & $U$ & None & 063851-011 \\
\hline & 12-Мау-04 & ND & 0.05 & $\mathrm{NR}$ & $U$ & None & 064551-011 \\
\hline & 28-Jul-04 & ND & 0.05 & NR & $\mathrm{U}$ & None & 065360-011 \\
\hline & 05-Oct-04 & ND & 0.05 & NR & U & None & 066025-011 \\
\hline \multirow{6}{*}{ TA1-W-01 } & 22-Jul-03 & ND & 0.05 & NR & $U$ & None & 062680-041 \\
\hline & 06-Nov-03 & ND & 0.05 & NR & $U$ & None & 063279-041 \\
\hline & 05-Feb-04 & ND & 0.05 & NR & $U$ & None & 063853-011 \\
\hline & 10-May-04 & ND & 0.05 & $\mathrm{NR}$ & $U$ & None & 064553-011 \\
\hline & 17-Aug-04 & ND & 0.05 & NR & $U$ & None & $065362-011$ \\
\hline & 06-Oct-04 & ND & 0.05 & NR & $U$ & None & 066027-011 \\
\hline \multirow[t]{6}{*}{ TA1-W-02 } & 23-Jul-03 & ND & 0.05 & NR & $U$ & None & 062682-041 \\
\hline & 08-Oct-03 & ND & 0.05 & NR & U & None & 063280-041 \\
\hline & \begin{tabular}{|l|}
$28-J a n-04$ \\
\end{tabular} & ND & 0.05 & NR & $U$ & None & 063855-011 \\
\hline & 11-May-04 & ND & 0.05 & NR & $U$ & None & 064556-011 \\
\hline & 13-Aug-04 & ND & 0.05 & NR & $\mathrm{U}$ & None & 065364-011 \\
\hline & 11-Oct-04 & ND & 0.05 & NR & $U$ & None & 066029-011 \\
\hline \multirow{6}{*}{ TA1-W-03 } & 24-Jul-03 & ND & 0.05 & NR & U & None & 062684-041 \\
\hline & 13-Oct-03 & ND & 0.05 & NR & U & None & 063281-041 \\
\hline & 07-Jan-04 & ND & 0.05 & NR & $U$ & None & $063857-011$ \\
\hline & $28-A p r-04$ & ND & 0.05 & NR & $U$ & None & 064558-011 \\
\hline & 18-Aug-04 & ND & 0.05 & NR & $U$ & None & 065366-011 \\
\hline & 19-Oct-04 & ND & 0.05 & NR & U & None & 066031-011 \\
\hline \multirow[t]{5}{*}{ TA1-W-04 } & 29-Jul-03 & ND & 0.05 & NR & U & None & 062686-041 \\
\hline & 14-Oct-03 & ND & 0.05 & NR & $U$ & None & 063282-041 \\
\hline & \begin{tabular}{|l|}
$06-J a n-04$ \\
\end{tabular} & ND & 0.05 & NR & $U$ & None & $063860-011$ \\
\hline & 26-Apr-04 & ND & 0.05 & $\mathrm{NR}$ & $\mathrm{U}$ & None & 064560-011 \\
\hline & 26-Jul-04 & ND & 0.05 & NR & $U$ & None & $065368-011$ \\
\hline
\end{tabular}




\begin{tabular}{|c|c|c|c|c|c|c|c|}
\hline Well ID & Sample Date & $\begin{array}{c}\text { Manganese 2+ } \\
\text { Result } \\
\text { (mg/L) }\end{array}$ & $\begin{array}{c}\text { MDL } \\
\text { (mg/L) }\end{array}$ & $\begin{array}{c}\text { PQL } \\
(\mathrm{mg} / \mathrm{L})\end{array}$ & $\begin{array}{c}\text { Laboratory } \\
\text { Qualifier }\end{array}$ & $\begin{array}{c}\text { Validation } \\
\text { Qualifier }\end{array}$ & Sample No. \\
\hline & 07-Oct-04 & ND & 0.05 & NR & U & None & 066033-011 \\
\hline \multirow{6}{*}{ TA1-W-05 } & 28-Jul-03 & ND & 0.05 & NR & U & None & 062688-041 \\
\hline & 20-Oct-03 & ND & 0.05 & NR & U & None & 063283-041 \\
\hline & 12-Feb-04 & ND & 0.05 & NR & U & None & 063862-011 \\
\hline & 07-May-04 & ND & 0.05 & NR & $\mathrm{U}$ & None & 064562-011 \\
\hline & 20-Aug-04 & ND & 0.05 & NR & U & None & 065370-011 \\
\hline & 26-Oct-04 & ND & 0.05 & NR & U & None & 066035-011 \\
\hline \multirow{6}{*}{ TA1-W-06 } & 29-Jul-03 & ND & 0.05 & NR & $U$ & None & 062690-041 \\
\hline & 09-Oct-03 & ND & 0.05 & NR & U & None & 063284-041 \\
\hline & 09-Feb-04 & ND & 0.05 & NR & $U$ & None & 063864-011 \\
\hline & 21-May-04 & ND & 0.05 & NR & $\mathrm{U}$ & None & 064564-011 \\
\hline & 06-Aug-04 & ND & 0.05 & NR & U & None & 065372-011 \\
\hline & 26-Oct-04 & ND & 0.05 & NR & U & None & 066037-011 \\
\hline \multirow{6}{*}{ TA1-W-08 } & 30-Jul-03 & ND & 0.05 & NR & U & None & 062692-041 \\
\hline & 21-Oct-03 & ND & 0.05 & NR & U & None & 063285-041 \\
\hline & 10-Feb-04 & ND & 0.05 & NR & $\mathrm{U}$ & None & 063866-011 \\
\hline & 23-Apr-04 & ND & 0.05 & NR & U & None & 064566-011 \\
\hline & 13-Aug-04 & ND & 0.05 & NR & $U$ & None & 065374-011 \\
\hline & 08-Oct-04 & ND & 0.05 & NR & U & None & 066039-011 \\
\hline \multirow{5}{*}{$\begin{array}{l}\text { TA2-NW1-595 } \\
\text { (QED) }\end{array}$} & 12-Nov-03 & ND & 0.05 & NR & U & None & 063287-041 \\
\hline & 04-Feb-04 & ND & 0.05 & NR & $\mathrm{U}$ & None & 063871-011 \\
\hline & 13-May-04 & ND & 0.05 & NR & U & None & 064568-011 \\
\hline & 26-Jul-04 & ND & 0.05 & NR & $\mathrm{U}$ & None & 065377-011 \\
\hline & 25-Oct-04 & ND & 0.05 & NR & U & None & 066042-011 \\
\hline \multirow{6}{*}{$\begin{array}{l}\text { TA2-NW1-595 } \\
\text { (Bennett) }\end{array}$} & 05-Aug-03 & ND & 0.05 & NR & U & None & 062695-041 \\
\hline & 11-Nov-03 & ND & 0.05 & NR & $U$ & None & 063288-041 \\
\hline & 26-Jan-04 & ND & 0.05 & NR & $\mathrm{U}$ & None & 063869-011 \\
\hline & 19-May-04 & ND & 0.05 & NR & $U$ & None & 064568-011 \\
\hline & 23-Aug-04 & ND & 0.05 & NR & $\mathrm{U}$ & None & 065379-011 \\
\hline & 07-Oct-04 & ND & 0.05 & NR & $U$ & None & 066044-011 \\
\hline \multirow{3}{*}{ TA2-SW1-320 } & 24-Jul-03 & ND & 0.05 & NR & U & None & 062698-041 \\
\hline & 11-Nov-03 & ND & 0.05 & NR & U & None & 063289-041 \\
\hline & 29-Jan-04 & ND & 0.05 & NR & $\mathrm{U}$ & None & 063873-011 \\
\hline
\end{tabular}




\begin{tabular}{|c|c|c|c|c|c|c|c|}
\hline Well ID & Sample Date & $\begin{array}{c}\text { Manganese 2+ } \\
\text { Result } \\
\text { (mg/L) }\end{array}$ & $\begin{array}{c}\text { MDL } \\
\text { (mg/L) }\end{array}$ & $\begin{array}{c}\text { PQL } \\
\text { (mg/L) }\end{array}$ & $\begin{array}{c}\text { Laboratory } \\
\text { Qualifier }\end{array}$ & $\begin{array}{c}\text { Validation } \\
\text { Qualifier }\end{array}$ & Sample No. \\
\hline & 14-May-04 & ND & 0.05 & NR & $\mathrm{U}$ & None & 064573-011 \\
\hline & 27-Jul-04 & ND & 0.05 & NR & $\mathrm{U}$ & None & 065381-011 \\
\hline & 04-Oct-04 & ND & 0.05 & NR & U & None & 066046-011 \\
\hline \multirow{6}{*}{ TA2-W-01 } & 07-Aug-03 & ND & 0.05 & NR & $u$ & None & 062700-041 \\
\hline & 01-Dec-03 & ND & 0.05 & NR & U & None & 063290-041 \\
\hline & 12-Jan-04 & ND & 0.05 & NR & $U$ & None & 063876-011 \\
\hline & 17-May-04 & ND & 0.05 & NR & $U$ & None & 064575-011 \\
\hline & 12-Aug-04 & ND & 0.05 & NR & $\mathrm{U}$ & None & 065383-011 \\
\hline & 18-Oct-04 & ND & 0.05 & NR & $u$ & None & 066048-011 \\
\hline \multirow{6}{*}{ TA2-W-19 } & 04-Aug-03 & ND & 0.05 & NR & U & None & 062702-041 \\
\hline & 07-Oct-03 & ND & 0.05 & NR & $u$ & None & 063291-041 \\
\hline & 13-Jan-04 & ND & 0.05 & NR & $U$ & None & 063878-011 \\
\hline & 27-Apr-04 & ND & 0.05 & NR & $\mathrm{U}$ & None & 064577-011 \\
\hline & 27-Jul-04 & ND & 0.05 & $\mathrm{NR}$ & $\mathrm{U}$ & None & 065385-011 \\
\hline & 04-Oct-04 & ND & 0.05 & NR & U & None & 066050-011 \\
\hline \multirow[t]{6}{*}{ TA2-W-26 } & 04-Aug-03 & ND & 0.05 & NR & $u$ & None & 062704-041 \\
\hline & 16-Oct-03 & 0.031 & 0.05 & NR & & None & 063292-041 \\
\hline & 20-Jan-04 & ND & 0.05 & NR & $U$ & None & 063880-011 \\
\hline & 21-Apr-04 & ND & 0.05 & $\mathrm{NR}$ & $U$ & None & 064580-011 \\
\hline & 30-Jul-04 & ND & 0.05 & NR & $\mathrm{U}$ & None & 065387-011 \\
\hline & 13-Oct-04 & ND & 0.05 & NR & $u$ & None & 066053-011 \\
\hline \multirow{6}{*}{ TA2-W-27 } & 06-Aug-03 & ND & 0.05 & NR & $u$ & None & 062707-041 \\
\hline & 23-Oct-03 & ND & 0.05 & NR & U & None & 063294-041 \\
\hline & 15-Jan-04 & ND & 0.05 & NR & $U$ & None & 063885-011 \\
\hline & 19-Apr-04 & ND & 0.05 & NR & $U$ & None & 064583-011 \\
\hline & 28-Jul-04 & ND & 0.05 & NR & $\mathrm{U}$ & None & $065392-011$ \\
\hline & 14-Oct-04 & ND & 0.05 & NR & $U$ & None & 066056-011 \\
\hline \multirow[t]{5}{*}{ TJA-2 } & 31-Jul-03 & 0.06 & 0.05 & NR & & None & 062709-041 \\
\hline & 15-Oct-03 & ND & 0.05 & NR & $U$ & None & 063295-041 \\
\hline & 19-Jan-04 & ND & 0.05 & NR & $U$ & None & 063887-011 \\
\hline & 05-May-04 & ND & 0.05 & NR & $U$ & None & 064585-011 \\
\hline & 16-Aug-04 & ND & 0.05 & NR & U & None & 065394-011 \\
\hline
\end{tabular}




\begin{tabular}{|c|c|c|c|c|c|c|c|}
\hline Well ID & Sample Date & $\begin{array}{c}\text { Manganese 2+ } \\
\text { Result } \\
\text { (mg/L) }\end{array}$ & $\begin{array}{c}\mathrm{MDL} \\
\text { (mg/L) }\end{array}$ & $\begin{array}{c}\mathrm{PQL} \\
\text { (mg/L) }\end{array}$ & $\begin{array}{c}\text { Laboratory } \\
\text { Qualifier }\end{array}$ & $\begin{array}{c}\text { Validation } \\
\text { Qualifier }\end{array}$ & Sample No. \\
\hline & 11-Oct-04 & ND & 0.05 & NR & $U$ & None & 066059-011 \\
\hline \multirow{6}{*}{ TJA-3 } & 06-Aug-03 & 0.078 & 0.05 & NR & & None & 062711-041 \\
\hline & 22-Oct-03 & ND & 0.05 & NR & U & None & 063296-041 \\
\hline & 27-Jan-04 & ND & 0.05 & NR & $U$ & None & 063889-011 \\
\hline & 27-Apr-04 & ND & 0.05 & NR & $U$ & None & 064587-011 \\
\hline & 09-Aug-04 & ND & 0.05 & $\mathrm{NR}$ & $U$ & None & 065397-011 \\
\hline & $12-O c t-04$ & ND & 0.05 & NR & U & None & 066061-011 \\
\hline \multirow[t]{6}{*}{ TJA-4 } & 11-Aug-03 & ND & 0.05 & NR & $U$ & None & 062713-041 \\
\hline & 27-Oct-03 & ND & 0.05 & NR & U & None & 063297-041 \\
\hline & 29-Jan-04 & ND & 0.05 & NR & $U$ & None & 063891-011 \\
\hline & 20-Apr-04 & ND & 0.05 & NR & $U$ & None & 064589-011 \\
\hline & 10-Aug-04 & ND & 0.05 & NR & $\mathrm{U}$ & None & 065399-011 \\
\hline & 12-Oct-04 & ND & 0.05 & NR & U & None & 066063-011 \\
\hline \multirow[t]{6}{*}{ TJA-6 } & 11-Aug-03 & ND & 0.05 & NR & U & None & 062715-041 \\
\hline & 05-Nov-03 & ND & 0.05 & NR & $U$ & None & 063298-041 \\
\hline & 04-Feb-04 & ND & 0.05 & NR & $U$ & None & 063893-011 \\
\hline & 22-Apr-04 & ND & 0.05 & NR & U & None & 064591-011 \\
\hline & 04-Aug-04 & ND & 0.05 & NR & $U$ & None & 065401-011 \\
\hline & 13-Oct-04 & ND & 0.05 & NR & U & None & 066065-011 \\
\hline \multirow[t]{6}{*}{ TJA-7 } & 12-Aug-03 & ND & 0.05 & NR & $U$ & None & 062717-041 \\
\hline & 28-Oct-03 & ND & 0.05 & NR & U & None & 063299-041 \\
\hline & 22-Jan-04 & ND & 0.05 & NR & $\mathrm{U}$ & None & 063895-011 \\
\hline & $30-A p r-04$ & ND & 0.05 & NR & $U$ & None & 064593-011 \\
\hline & 06-Aug-04 & ND & 0.05 & NR & $U$ & None & 065403-011 \\
\hline & $15-O c t-04$ & ND & 0.05 & NR & U & None & 066067-011 \\
\hline \multirow[t]{5}{*}{ WYO-3 } & 13-Aug-03 & ND & 0.05 & NR & $U$ & None & 062719-041 \\
\hline & 29-Oct-03 & ND & 0.05 & NR & U & None & 063300-041 \\
\hline & 21-Jan-04 & ND & 0.05 & NR & $U$ & None & 063897-011 \\
\hline & 28-Apr-04 & ND & 0.05 & $\mathrm{NR}$ & $U$ & None & 064595-011 \\
\hline & 11-Aug-04 & ND & 0.05 & NR & $\mathrm{U}$ & None & $065408-011$ \\
\hline
\end{tabular}




\begin{tabular}{|c|c|c|c|c|c|c|c|}
\hline Well ID & Sample Date & $\begin{array}{c}\text { Manganese 2+ } \\
\text { Result } \\
\text { (mg/L) }\end{array}$ & $\begin{array}{c}\text { MDL } \\
\text { (mg/L) }\end{array}$ & $\begin{array}{c}\text { PQL } \\
\text { (mg/L) }\end{array}$ & $\begin{array}{c}\text { Laboratory } \\
\text { Qualifier }\end{array}$ & $\begin{array}{c}\text { Validation } \\
\text { Qualifier }\end{array}$ & Sample No. \\
\hline & 08-Oct-04 & ND & 0.05 & NR & U & None & 066071-011 \\
\hline \multirow{6}{*}{ WYO-4 } & 14-Aug-03 & 0.098 & 0.05 & NR & & None & 062721-041 \\
\hline & 03-Nov-03 & ND & 0.05 & NR & $U$ & None & 063301-041 \\
\hline & 03-Feb-04 & ND & 0.05 & NR & $\mathrm{U}$ & None & 063899-011 \\
\hline & 30-Apr-04 & ND & 0.05 & NR & $\mathrm{U}$ & None & 064597-011 \\
\hline & 03-Aug-04 & ND & 0.05 & NR & $\mathrm{U}$ & None & 065411-011 \\
\hline & 06-Oct-04 & ND & 0.05 & NR & U & None & 066073-011 \\
\hline
\end{tabular}


Table A-22

Summary of Field parameters

Tijeras Arroyo Groundwater Investigation

Last Quarter 2003 to First Quarter 2005

\begin{tabular}{|c|c|c|c|c|c|}
\hline Well ID & Sample Date & $\begin{array}{c}\text { Temperature } \\
\left({ }^{\circ} \mathrm{C}\right)\end{array}$ & $\begin{array}{c}\text { Oxidation } \\
\text { Reduction } \\
\text { Potential (mV) }\end{array}$ & $\mathrm{pH}$ & $\begin{array}{c}\text { Dissolved } \\
\text { Oxygen } \\
\text { (mg/L) }\end{array}$ \\
\hline \multirow[t]{6}{*}{ Eubank-1 } & 18-Aug-03 & 20.55 & 230.5 & 7.48 & 7.40 \\
\hline & 10-Nov-03 & 19.00 & 328.1 & 7.44 & 6.34 \\
\hline & 16-Feb-04 & 18.60 & 193.5 & 7.73 & 7.73 \\
\hline & 20-May-04 & 20.76 & 133.8 & 7.43 & 7.07 \\
\hline & 19-Aug-04 & 19.93 & 169.7 & 7.81 & 4.67 \\
\hline & 20-Oct-04 & 19.59 & 187.8 & 7.06 & 7.93 \\
\hline \multirow[t]{4}{*}{ Eubank-2 } & 12-Nov-03 & 17.93 & 309.5 & 7.30 & 7.03 \\
\hline & 18-Feb-04 & 16.96 & 187.3 & 7.56 & 7.53 \\
\hline & 6-May-04 & 20.74 & 152.1 & 7.16 & 6.95 \\
\hline & 21-Oct-04 & 18.74 & 193.3 & 6.87 & 5.20 \\
\hline \multirow[t]{4}{*}{ Eubank-3 } & 18-Nov-03 & 15.50 & 262.9 & 7.29 & 8.75 \\
\hline & 17-Feb-04 & 17.31 & 178.7 & 7.54 & 7.99 \\
\hline & 4-May-04 & 18.67 & 117.0 & 7.14 & 7.60 \\
\hline & 20-Oct-04 & 18.27 & 134.8 & 7.19 & 6.39 \\
\hline \multirow[t]{4}{*}{ Eubank-5 } & 19-Nov-03 & 16.70 & 305.7 & 7.26 & 8.19 \\
\hline & 19-Feb-04 & 16.44 & 191.4 & 7.56 & 8.14 \\
\hline & 3-May-04 & 18.70 & 130.9 & 7.14 & 7.88 \\
\hline & 25-Oct-04 & 18.33 & 182.9 & 6.91 & 1.72 \\
\hline \multirow[t]{6}{*}{ PGS-2 } & 22-Jul-03 & 22.00 & 128.8 & 8.31 & NM \\
\hline & 10-Nov-03 & 17.25 & 170.1 & 8.48 & 1.15 \\
\hline & 3-Feb-04 & 14.01 & 120.7 & 8.27 & 1.60 \\
\hline & 12-May-04 & 19.04 & 129.5 & 7.85 & 0.99 \\
\hline & 28-Jul-04 & 20.95 & 133.4 & 8.16 & 1.28 \\
\hline & 5-Oct-04 & 17.44 & 125.4 & 8.47 & 2.60 \\
\hline \multirow[t]{6}{*}{ TA1-W-01 } & 22-Jul-03 & 21.40 & 187.2 & 7.11 & NM \\
\hline & 6-Nov-03 & 19.89 & 346.1 & 7.33 & 6.23 \\
\hline & 5-Feb-04 & 17.90 & 249.3 & 7.32 & NM \\
\hline & 10-May-04 & 22.07 & 169.2 & 7.27 & 6.21 \\
\hline & 17-Aug-04 & 21.46 & 189.6 & 7.70 & 6.42 \\
\hline & 6-Oct-04 & 18.98 & 216.2 & 7.51 & 7.32 \\
\hline \multirow[t]{4}{*}{ TA1-W-02 } & 23-Jul-03 & 21.80 & 223.4 & 7.17 & 5.89 \\
\hline & 8-Oct-03 & 18.68 & 224.1 & 7.28 & 6.24 \\
\hline & 28-Jan-04 & 17.51 & 268.2 & 7.27 & 4.01 \\
\hline & 11-May-04 & 21.19 & 148.5 & 7.23 & 5.00 \\
\hline
\end{tabular}




\begin{tabular}{|c|c|c|c|c|c|}
\hline Well ID & Sample Date & $\begin{array}{c}\text { Temperature } \\
\left({ }^{\circ} \mathrm{C}\right)\end{array}$ & $\begin{array}{c}\text { Oxidation } \\
\text { Reduction } \\
\text { Potential (mV) }\end{array}$ & $\mathrm{pH}$ & $\begin{array}{c}\text { Dissolved } \\
\text { Oxygen } \\
\text { (mg/L) }\end{array}$ \\
\hline & 13-Aug-04 & 21.38 & 130.9 & 7.32 & 5.83 \\
\hline & 11-Oct-04 & 18.48 & 190.6 & 7.25 & 6.41 \\
\hline \multirow[t]{6}{*}{ TA1-W-03 } & 24-Jul-03 & 19.96 & 168.3 & 7.26 & 7.60 \\
\hline & 13-Oct-03 & 17.60 & 229.2 & 7.34 & 7.39 \\
\hline & 7-Jan-04 & 15.22 & 190.7 & 7.39 & 5.39 \\
\hline & 28-Apr-04 & 17.84 & 102.1 & 7.23 & 7.17 \\
\hline & 18-Aug-04 & 18.41 & 158.7 & 7.65 & 7.89 \\
\hline & 19-Oct-04 & 16.96 & 174.3 & 6.94 & 8.05 \\
\hline \multirow[t]{6}{*}{ TA1-W-04 } & 29-Jul-03 & 21.01 & 192.8 & 7.32 & 6.09 \\
\hline & 14-Oct-03 & 18.50 & 229.0 & 7.33 & 5.60 \\
\hline & 6-Jan-04 & 17.46 & 247.8 & 7.08 & 5.02 \\
\hline & 26-Apr-04 & 19.37 & 97.9 & 7.26 & 5.53 \\
\hline & 26-Jul-04 & 19.86 & 180.0 & 7.49 & 2.78 \\
\hline & 7-Oct-04 & 18.55 & 224.3 & 7.51 & 6.89 \\
\hline \multirow[t]{6}{*}{ TA1-W-05 } & 28-Jul-03 & 21.91 & 194.1 & 7.26 & 5.38 \\
\hline & 20-Oct-03 & 19.80 & 257.9 & 7.20 & 7.46 \\
\hline & 12-Feb-04 & 17.01 & 202.3 & 7.47 & 7.29 \\
\hline & 7-May-04 & 20.04 & 174.8 & 7.11 & 6.69 \\
\hline & 20-Aug-04 & 20.94 & 173.7 & 7.47 & 6.51 \\
\hline & $26-$-ct-04 & 18.72 & 196.0 & 6.89 & 1.66 \\
\hline \multirow[t]{6}{*}{ TA1-W-06 } & 29-Jul-03 & 21.41 & 205.4 & 7.45 & 7.35 \\
\hline & 9-Oct-03 & 18.89 & 184.1 & 7.45 & 7.31 \\
\hline & 9-Feb-04 & 16.05 & 175.3 & 7.79 & 7.27 \\
\hline & 21-May-04 & 20.44 & 146.9 & 7.46 & 6.54 \\
\hline & 6-Aug-04 & 20.09 & 143.6 & 7.44 & 6.98 \\
\hline & 26-Oct-04 & 17.40 & 128.4 & 7.43 & 6.87 \\
\hline \multirow[t]{6}{*}{ TA1-W-08 } & 30-Jul-03 & 19.57 & 206.2 & 7.30 & 7.22 \\
\hline & 21-Oct-03 & 17.48 & 242.0 & 7.32 & 7.49 \\
\hline & 10-Feb-04 & 14.97 & 172.3 & 7.57 & 6.29 \\
\hline & 23-Apr-04 & 16.84 & 109.9 & 7.16 & 7.80 \\
\hline & 13-Aug-04 & 18.60 & 173.1 & 7.53 & 7.35 \\
\hline & 8-Oct-04 & 17.31 & 180.4 & 7.24 & 9.04 \\
\hline TA2-NW1-595 & 30-Jul-03 & 20.30 & 187.2 & 7.07 & 7.61 \\
\hline TA2-NW1-595 & 5-Aug-03 & 20.86 & 189.1 & 7.31 & 6.98 \\
\hline \multirow[t]{5}{*}{$\begin{array}{l}\text { TA2-NW1-595 } \\
\text { (Bennett) }\end{array}$} & 11-Nov-03 & 19.45 & 269.9 & 7.30 & 6.92 \\
\hline & 26-Jan-04 & 16.55 & 218.7 & 7.29 & 4.30 \\
\hline & 19-May-04 & 19.98 & 139.9 & 7.28 & 7.19 \\
\hline & 23-Aug-04 & 20.02 & 170.7 & 7.64 & 7.49 \\
\hline & 7-Oct-04 & 18.78 & 220.7 & 6.81 & 6.51 \\
\hline TA2-NW1-595 & 12-Nov-03 & 16.20 & 245.3 & 7.48 & 8.53 \\
\hline
\end{tabular}




\begin{tabular}{|c|c|c|c|c|c|}
\hline Well ID & Sample Date & $\begin{array}{c}\text { Temperature } \\
\left({ }^{0} \mathrm{C}\right)\end{array}$ & $\begin{array}{c}\text { Oxidation } \\
\text { Reduction } \\
\text { Potential (mV) }\end{array}$ & $\mathrm{pH}$ & $\begin{array}{c}\text { Dissolved } \\
\text { Oxygen } \\
\text { (mg/L) }\end{array}$ \\
\hline \multicolumn{6}{|l|}{ (QED) } \\
\hline & 4-Feb-04 & 13.29 & 142.7 & 7.59 & 8.45 \\
\hline & 13-May-04 & 16.78 & 208.6 & 7.19 & 7.47 \\
\hline & 26-Jul-04 & 17.87 & 180.3 & 7.14 & 6.56 \\
\hline & 25-Oct-04 & 15.79 & 109.9 & 7.40 & 5.74 \\
\hline \multirow[t]{6}{*}{ TA2-SW1-320 } & 24-Jul-03 & 21.60 & 147.3 & 7.70 & 8.52 \\
\hline & 11-Nov-03 & 16.80 & 233.9 & 7.77 & 8.53 \\
\hline & 29-Jan-04 & 14.08 & 158.4 & 7.91 & 11.92 \\
\hline & 14-May-04 & 15.99 & 163.6 & 7.50 & 8.20 \\
\hline & 27-Jul-04 & 19.28 & 168.0 & 7.49 & 7.36 \\
\hline & 4-Oct-04 & 18.39 & 191.5 & 7.76 & 10.61 \\
\hline \multirow[t]{6}{*}{ TA2-W-01 } & 7-Aug-03 & 19.92 & 203.6 & 7.54 & 7.83 \\
\hline & 1-Dec-03 & 16.63 & 290.3 & 7.53 & 8.74 \\
\hline & 12-Jan-04 & 17.13 & 224.8 & 7.52 & 4.17 \\
\hline & 17-May-04 & 22.03 & 182.2 & 7.40 & 7.32 \\
\hline & 12-Aug-04 & 20.40 & 177.6 & 7.82 & 7.81 \\
\hline & 18-Oct-04 & 17.91 & 159.7 & 7.12 & 7.21 \\
\hline \multirow[t]{7}{*}{ TA2-W-19 } & 4-Aug-03 & 19.64 & 211.5 & 7.52 & 7.99 \\
\hline & 23-Sep-03 & 19.71 & 205.9 & 7.61 & 8.29 \\
\hline & 7-Oct-03 & 18.12 & 216.6 & 7.41 & 8.08 \\
\hline & 13-Jan-04 & 17.16 & 234.7 & 7.54 & 4.91 \\
\hline & 27-Apr-04 & 18.43 & 152.4 & 7.77 & 8.61 \\
\hline & 27-Jul-04 & 19.76 & 181.5 & 7.26 & 7.65 \\
\hline & 4-Oct-04 & 18.75 & 183.4 & 7.00 & 2.07 \\
\hline \multirow[t]{6}{*}{ TA2-W-26 } & 4-Aug-03 & 20.51 & 197.4 & 7.41 & 7.88 \\
\hline & 16-Oct-03 & 17.79 & 232.1 & 7.39 & 7.65 \\
\hline & 20-Jan-04 & 15.98 & 226.6 & 7.43 & 4.54 \\
\hline & 21-Apr-04 & 17.36 & 103.6 & 7.28 & 8.76 \\
\hline & 30-Jul-04 & 19.24 & 147.5 & 7.18 & 7.58 \\
\hline & 13-Oct-04 & 18.17 & 176.2 & 6.95 & 5.23 \\
\hline \multirow[t]{6}{*}{ TA2-W-27 } & 6-Aug-03 & 20.14 & 204.2 & 7.43 & 8.22 \\
\hline & 23-Oct-03 & 18.77 & 234.7 & 7.44 & 8.32 \\
\hline & 15-Jan-04 & 16.19 & 233.9 & 7.44 & 4.91 \\
\hline & 19-Apr-04 & 18.01 & 117.9 & 7.29 & 8.51 \\
\hline & 28-Jul-04 & 18.82 & 166.5 & 7.19 & 8.50 \\
\hline & 14-Oct-04 & 17.49 & 200.9 & 7.32 & 8.25 \\
\hline \multirow[t]{5}{*}{ TJA-2 } & 31-Jul-03 & 19.52 & 204.9 & 7.49 & 7.37 \\
\hline & 15-Oct-03 & 17.74 & 238.7 & 7.49 & 7.42 \\
\hline & 19-Jan-04 & 15.98 & 217.1 & 7.54 & 6.48 \\
\hline & 5-May-04 & 19.30 & 144.6 & 7.40 & 7.47 \\
\hline & 16-Aug-04 & 18.99 & 181.1 & 7.92 & 7.67 \\
\hline
\end{tabular}




\begin{tabular}{|c|c|c|c|c|c|}
\hline Well ID & Sample Date & $\begin{array}{c}\text { Temperature } \\
\left({ }^{0} \mathrm{C}\right)\end{array}$ & $\begin{array}{c}\text { Oxidation } \\
\text { Reduction } \\
\text { Potential (mV) }\end{array}$ & $\mathrm{pH}$ & $\begin{array}{c}\text { Dissolved } \\
\text { Oxygen } \\
\text { (mg/L) }\end{array}$ \\
\hline & 11-Oct-04 & 16.51 & 168.3 & 7.10 & 5.71 \\
\hline \multirow[t]{6}{*}{ TJA-3 } & 6-Aug-03 & 20.97 & 194.5 & 7.41 & 6.68 \\
\hline & 22-Oct-03 & 18.73 & 249.0 & 7.41 & 6.35 \\
\hline & 27-Jan-04 & 16.89 & 250.1 & 7.36 & 4.28 \\
\hline & 27-Apr-04 & 18.93 & 126.8 & 7.29 & 6.38 \\
\hline & 9-Aug-04 & 20.78 & 209.7 & 7.65 & 6.93 \\
\hline & $12-$-Oct-04 & 17.77 & 208.1 & 7.27 & 6.72 \\
\hline \multirow[t]{6}{*}{ TJA-4 } & 11-Aug-03 & 19.32 & 206.4 & 7.52 & 5.19 \\
\hline & $27-$ Oct-03 & 17.58 & 225.7 & 7.49 & 5.41 \\
\hline & 29-Jan-04 & 16.76 & 235.1 & 7.49 & 1.68 \\
\hline & 20-Apr-04 & 16.83 & 154.0 & 7.33 & 5.51 \\
\hline & 10-Aug-04 & 19.20 & 170.5 & 7.75 & 5.06 \\
\hline & 12-Oct-04 & 17.88 & 196.0 & 6.98 & 4.16 \\
\hline \multirow[t]{6}{*}{ TJA-6 } & 11-Aug-03 & 22.32 & 217.0 & 7.47 & 4.48 \\
\hline & 5-Nov-03 & 19.55 & 329.5 & 7.42 & 4.47 \\
\hline & 4-Feb-04 & 17.90 & 232.0 & 7.39 & 2.31 \\
\hline & 22-Apr-04 & 20.64 & 112.5 & 7.25 & 4.66 \\
\hline & 4-Aug-04 & 21.60 & 171.4 & 7.18 & 4.91 \\
\hline & 13-Oct-04 & 19.21 & 224.5 & 7.29 & 4.95 \\
\hline \multirow[t]{6}{*}{ TJA-7 } & 12-Aug-03 & 22.40 & 233.9 & 7.54 & 7.60 \\
\hline & 28-Oct-03 & 17.11 & 234.6 & 7.53 & 8.08 \\
\hline & 22-Jan-04 & 13.68 & 229.5 & 7.51 & 5.13 \\
\hline & 30-Apr-04 & 17.39 & 136.6 & 7.40 & 7.64 \\
\hline & 6-Aug-04 & 18.80 & 158.4 & 7.28 & 8.07 \\
\hline & 15-Oct-04 & 16.86 & 154.9 & 7.20 & 4.10 \\
\hline \multirow[t]{6}{*}{ WYO-3 } & 13-Aug-03 & 20.05 & 227.5 & 7.48 & 0.28 \\
\hline & 29-Oct-03 & 18.89 & 323.7 & 7.42 & 7.20 \\
\hline & 21-Jan-04 & 16.51 & 233.1 & 7.42 & 4.24 \\
\hline & 28-Apr-04 & 19.43 & 119.7 & 7.68 & 7.14 \\
\hline & 11-Aug-04 & 20.00 & 171.3 & 7.74 & 7.04 \\
\hline & 8-Oct-04 & 19.27 & 177.2 & 7.00 & 1.06 \\
\hline \multirow[t]{6}{*}{ WYO-4 } & 14-Aug-03 & 19.12 & 173.4 & 7.65 & 7.45 \\
\hline & 3-Nov-03 & 16.85 & 263.7 & 7.63 & 8.15 \\
\hline & 3-Feb-04 & 14.90 & 194.3 & 7.72 & 3.81 \\
\hline & 30-Apr-04 & 17.20 & 157.7 & 7.88 & 8.21 \\
\hline & 3-Aug-04 & 19.50 & 158.7 & 7.42 & 7.61 \\
\hline & 6-Oct-04 & 16.11 & 145.8 & 7.39 & 7.09 \\
\hline \multicolumn{6}{|c|}{$\begin{array}{l}\mathrm{mg} / \mathrm{L}=\text { milligrams per liter } \\
\mathrm{mV}=\text { millivolt } \\
{ }^{\circ} \mathrm{C}=\text { degrees Celsius }\end{array}$} \\
\hline
\end{tabular}


This Page Intentionally Left Blank 
Attachment E

Evaluation of an Intrinsic Aerobic Degradation Mechanism 
This Page Intentionally Left Blank 


\section{Evaluation of an Intrinsic Aerobic Degradation Mechanism in Tijeras Arroyo Groundwater, Sandia National Laboratories / New Mexico}

\section{April 2005}

Prepared by

Sandia National Laboratories

Albuquerque, New Mexico 87185 and Livermore, California 94550

Sandia is a multiprogram laboratory operated by Sandia Corporation,

a Lockheed Martin Company, for the United States Department of Energy's

National Nuclear Security Administration under Contract DE-AC04-94AL85000.

Approved for public release; further dissemination unlimited.

\section{Sandia National Laboratories}




\begin{abstract}
This evaluation is an informal report that documents the application of enzyme activity probes and control studies to evaluate the potential for cometabolic activity to degrade trichloroethene (TCE) at the Sandia National Laboratories/New Mexico (SNL/NM) Tijeras Arroyo Groundwater area of responsibility. The contaminants of concern include nitrate and TCE. Positive results from the application of probes to samples from both the perched groundwater system and the regional aquifer provide direct evidence of cometabolic enzymatic activity in all but one of the wells sampled. The enzyme activity probe data provide defensible, direct evidence that intrinsic aerobic cometabolism by indigenous microbial populations is an existing mechanism for natural attenuation of TCE in Tijeras Arroyo Groundwater.
\end{abstract}




\section{CONTENTS}

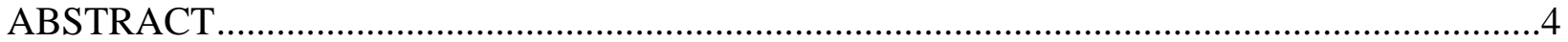

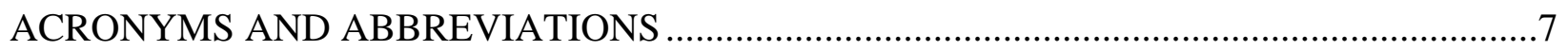

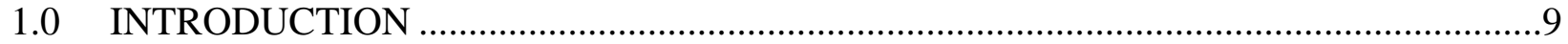

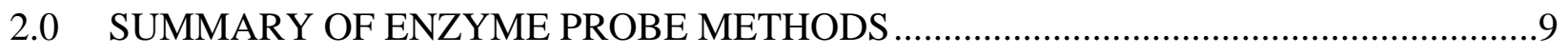

$2.1 \quad$ Sample Collection.............................................................................................10

$2.2 \quad$ Laboratory Methods......................................................................................... 10

2.2.1 Enzyme Activity Determination ............................................................. 13

2.2.2 Control Studies....................................................................................... 13

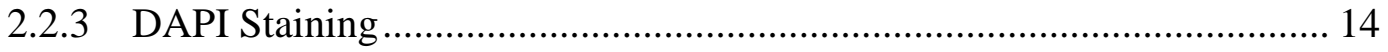

2.2.4 DNA Analysis ............................................................................ 14

2.2.5 Inhibition Control Studies ........................................................................... 14

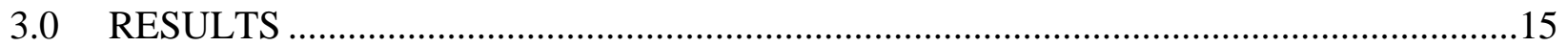

3.1 Enzyme Probe Sample Results ..............................................................................15

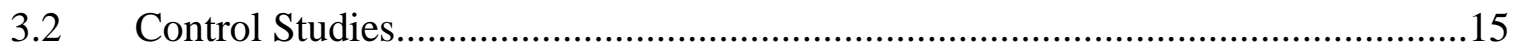

4.0 SUMMARY AND CONCLUSIONS ……………....................................................

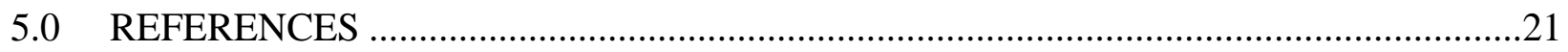

Appendix A. Enzyme Probe Data

\section{FIGURES}

1. Monitoring and Water Supply Wells and Potential Release Sites in the Area of

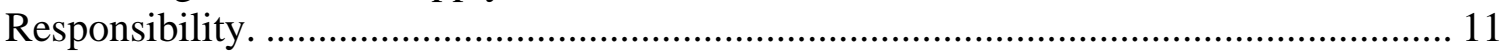

2. Micrographs of Sample TJA-2 within the perched groundwater system at TAG. ............ 15

\section{TABLES}

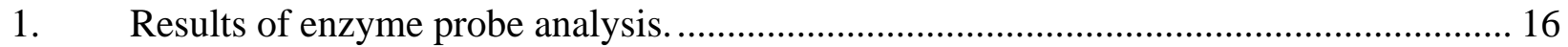

2. Results of control studies from wells at the TAG wells. .................................................... 17

3. Results of the sMMO inhibitor study from TAG wells...................................................... 18

4. Results of the toluene inhibitor study from TAG wells...................................................... 18 
This Page Intentionally Left Blank 


\section{ACRONYMS AND ABBREVIATIONS}

\begin{tabular}{|c|c|}
\hline 3НPA & 3-hydroxyphenylacetylene \\
\hline Cinn & trans-cinnamonitrile \\
\hline CME & Corrective Measures Evaluation \\
\hline $\mathrm{COC}$ & chain of custody \\
\hline $\mathrm{COOC}$ & Compliance Order on Consent \\
\hline DAPI & 4,6-diamindino-phenylindole \\
\hline DCE & dichloroethene \\
\hline DNA & deoxyribonucleic acid \\
\hline F1 & Pseudomonas putida \\
\hline G4 & Burkholderia cepacia \\
\hline MCL & maximum contaminant level \\
\hline MNA & monitored natural attenuation \\
\hline NMED & New Mexico Environment Department \\
\hline Ob3B & Methylosinus trichosporium \\
\hline PA & phenylacetylene \\
\hline PCE & tetrachloroethene \\
\hline PCR & polymerase chain reaction \\
\hline PHE & phenol monooxygenase \\
\hline PK01 & Ralstonia picketti \\
\hline RMO & toluene monooxygenase \\
\hline sMMO & soluble methane monooxygenase \\
\hline SNL/NM & Sandia National Laboratories/New Me \\
\hline
\end{tabular}


TAG

TCE

TOD

UV

VC

VOC

W31
Tijeras Arroyo Groundwater

trichloroethene

toluene dioxygenase

ultraviolet light

vinyl chloride

volatile organic compounds

Pseudomonas sp. 


\subsection{INTRODUCTION}

The Corrective Measures Evaluation (CME) Work Plan Tijeras Arroyo Groundwater (SNL/NM 2004a) was prepared as directed by the Compliance Order on Consent (COOC) issued by the New Mexico Environment Department (NMED) (NMED 2004). The CME Work Plan outlines a process for evaluating remedial alternatives in order to identify a corrective measure for the contaminants of concern at the Sandia National Laboratories/New Mexico (SNL/NM) Tijeras Arroyo Groundwater (TAG) area of responsibility. The contaminants of concern at TAG include the volatile organic compound (VOC) trichloroethene (TCE) and nitrate. The CME Work Plan identified a four stage data collection and interpretation process: (1) paper study, (2) numerical modeling, (3) laboratory studies, and (4) field scale studies. The field-scale studies stage includes establishing mechanisms for contaminant degradation at TAG. One such mechanism is aerobic cometabolic oxidation, a process by which a microbial cell metabolizes a substrate (in this case, TCE) in the presence of a second organic compound that is used as the primary source of carbon and energy. This paper presents results and interpretations of enzyme probe analyses applied to TAG samples. Enzyme activity probes are research tools that provide direct evidence of aerobic cometabolic oxidation of contaminants, including VOCs such as TCE.

\subsection{SUMMARY OF ENZYME PROBE METHODS}

Studies have shown that subsurface microbial communities are metabolically active and produce enzymes that catalyze diverse biochemical reactions, including cometabolism of a wide variety of chlorinated hydrocarbons (Wilson and Wilson, 1985; Fogel et al., 1986; Little et al., 1988; Oldenhuis et al., 1989; 1991; Tsien et al., 1989; Alvarez-Cohen and McCarty, 1991; Speitel and Alley, 1991; Brockman et al., 1995; Pfiffner et al., 1997). In contrast to anaerobic microbial populations that reductively dechlorinate TCE, many aerobic microorganisms cometabolically degrade TCE via oxygenase-catalyzed reactions, including organisms that use methane, propane, benzene, phenol, toluene, and ammonia as natural growth substrates (Ensley, 1991). Thus, aerobic cometabolism requires the presence of a primary substrate and oxygen but can fortuitously transform a cometabolic substrate if both requirements are met. If the primary substrate is absent, the enzyme required for cometabolic transformation will not be induced and the cometabolic transformation will not occur. TCE, cis-dichloroethene (DCE), trans-DCE, and vinyl chloride (VC) have all been shown to be susceptible to cometabolic oxidation under aerobic conditions (Wilson and Wilson, 1985; Semprini et al., 1990). For more details of cometabolic enzyme and pathways, refer to Final Quick Win Vertical Profile Sampling Effort (Wymore et al., 2004).

Enzyme activity probes are research tools that provide direct evidence that the mechanism for aerobic cometabolic oxidation of chlorinated ethenes, most notably TCE, is present and active in the aquifer. Enzyme activity probes that serve as alternative substrates for TCE-cometabolizing enzymes have been developed for four separate toluene oxygenases (Keener and Watwood, 1997; Keener et al., 1998; Kauffman et al., 2003; Clingenpeel et al., 2005a) and for the soluble methane monooxygenase (sMMO; Miller et al., 2002). These non-fluorescent probes are transformed by either the toluene or methane oxygenase enzymes into strongly fluorescent products. A clear, quantifiable signal (i.e., fluorescent probe product) is detected only when the enzyme of interest is actively functioning. If the appropriate enzyme is not present or is present but not active in a given sample, then the probes will not be transformed and no fluorescence will be detected. This class of probes provides direct evidence of specific cometabolic enzyme activity toward chlorinated solvents at remediation sites; this evidence is useful for documenting that intrinsic bioremediation is occurring in a given environment (Madsen, 1991; Madsen, 1998). 
The nomenclature "toluene oxygenase" is derived from early laboratory studies and the presence of these enzymes is not an indication that toluene is present in the groundwater. The toluene enzymes may, under ambient conditions, be induced by the presence of any number of aromatic substances. Genes that code for toluene oxygenases have highly conserved overlap regions with genes for other aromatic oxygenases, including phenol and benzene (Fries et al., 1997; Mesarch et al., 2000; Parales et al., 2000; Baldwin et al., 2003). While the activity detected with the enzyme probe is derived from toluene induced pathways (fluorescent products are specific to degradation by the toluene induced enzymes), laboratory studies have suggested that these enzymes are not limited to degradation of or induction by toluene (Wackett, 1984; Parales et al., 2000).

\subsection{Sample Collection}

Water samples were collected from 12 TAG monitoring wells (Figure 1) in conjunction with the current voluntary monitoring program for TAG by SNL/NM sampling crews. One third of the samples originated in the regional aquifer (TJA-3, TJA-6, TA1-W-02, and TA1-W-05), while two-thirds were from the perched groundwater system (TA2-W-19, WYO-4, TA2-W-01, TA2-W26, TA1-W-08, TJA-2, TA2-SW1-320, and TJA-7). Samples were shipped to Northern Arizona University for analysis.

\subsection{Laboratory Methods}

This section describes the analytical techniques used, including enzyme probe analysis, total cell count (DAPI), and control studies. DAPI (4,6-diamindino-phenylindole) staining provides a total microbial cell count for a given sample. This number provides a relative means of quantifying the number of cells that have active enzymes, as determined by enzyme probe analysis. Enzyme probes provide a direct measure of the activity of both the toluene and methane monooxygenases, while the control studies further provide evidence of the targeted enzyme. The following techniques are widely accepted for use in laboratory studies (Keener et al., 1998; 2001; Miller et al., 2002; Kauffman et al., 2003; Clingenpeel et al., 2005a) but have been modified herein for assessment of a contaminated field site (Wymore et al., 2004; Howard et al., 2005). The sequence for analysis is as follows:

1. Enzyme activity probe analysis,

2. Negative and positive control studies,

3. DAPI staining,

4. DNA analysis, and

5. Inhibition control studies. 


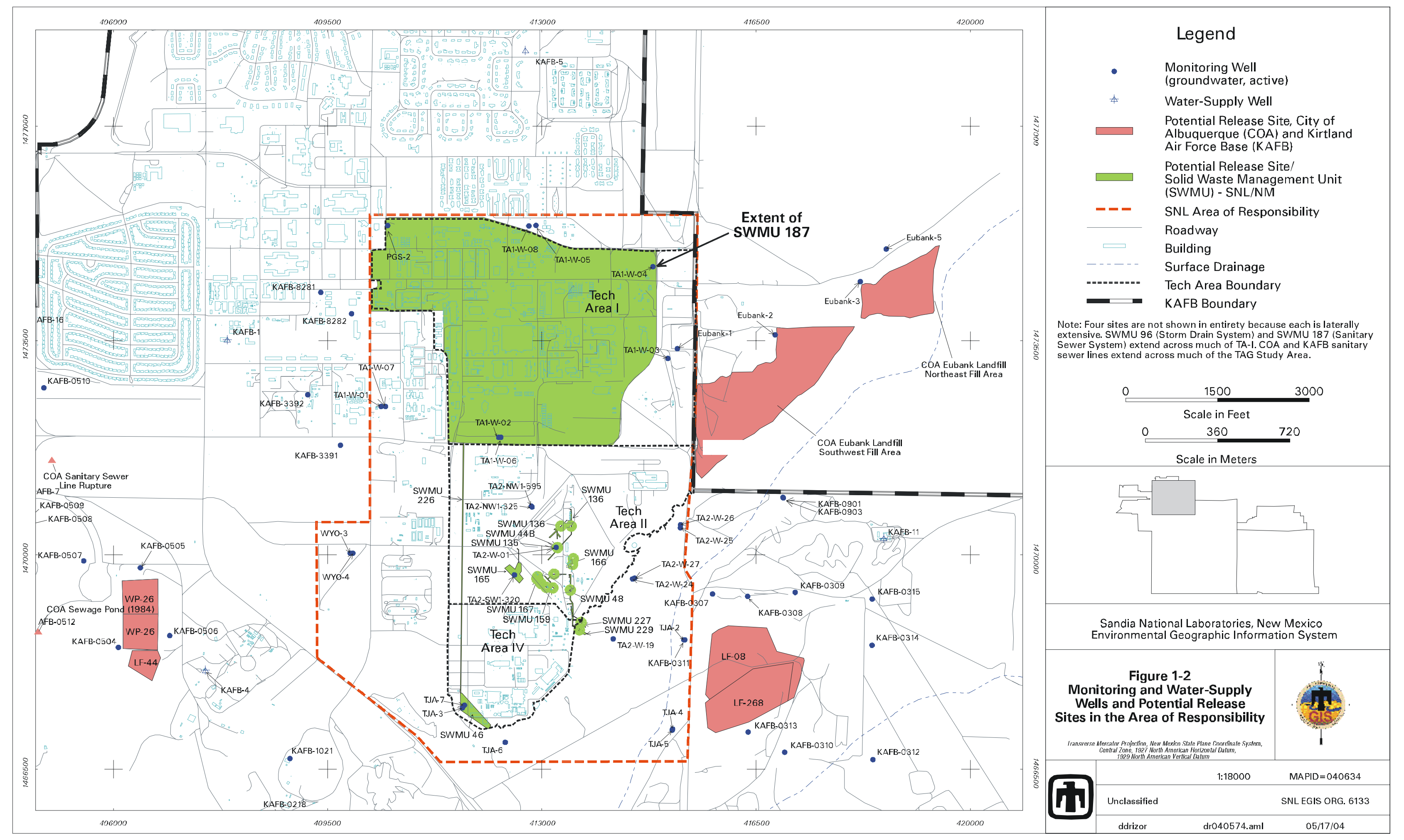

Figure 1. Monitoring and Water Supply Wells and Potential Release Sites in the Area of Responsibility. 
This Page Intentionally Left Blank 


\subsubsection{Enzyme Activity Determination}

Enzyme activity was determined using two methods, toluene probes and the sMMO probe, for 12 TAG monitoring locations. Evaluation with the toluene probes is performed by filtering $10 \mathrm{~mL}$ of groundwater onto black, polycarbonate filters on a vacuum manifold. One $\mathrm{mL}$ of an enzyme activity probe (5mM phenylacetylene (PA), 5mM trans-cinnamonitrile (Cinn), and 5mM 3-hydroxyphenylacetylene (3HPA)) was pipetted onto the surface of the filter and incubated at room temperature for 10 minutes. PA and 3HPA label cells, with varying affinities, that express the following toluene enzymes: 2,3 dioxygenase, toluene 2-monooxygenase, and toluene 3-monooxygenase (Keener et al., 1998; Kauffman et al., 2003), while trans-cinnamonitrile labels cells with active toluene-2,3 dioxygenase enzymes with the highest affinity and cells with the toluene-3-monooxygenase to a lesser degree. A separate filter was used for each of the three probes. After 10 minutes, vacuum was reapplied to remove the solution and the filter was washed with buffer to remove any residual substrate that could potentially interfere with epifluorescent imaging. The filter was mounted on a glass microscope slide and examined for fluorescent cells by epifluorescent microscopy. If any of the toluene enzymes were active, a clear fluorescent signal would be seen when looking at the filter under the microscope. However, if no enzyme was active, the filter would appear black and no fluorescent signal would be seen.

Evaluation with the sMMO probe was similar to the toluene probes with the following modifications. Water samples were filtered onto Supor filters to prevent background interference from polycarbonate filters. In addition, the product of coumarin transformation by the sMMO enzyme is highly soluble (7-hydroxycoumarin, Miller et al., 2002); therefore, the fluorescence was measured fluorometrically (i.e., in solution) rather than by epifluorescent microscopy.

\subsubsection{Control Studies}

Both negative and positive controls were carried out for the enzyme activity probe analysis. The negative controls were as follows:

1. Cells filtered onto a black polycarbonate filter with no stain or probe added,

2. Filtering each of the enzyme probes onto black polycarbonate filters, with no bacterial cells, and

3. $1 \mathrm{~mL}$ of stationary-phase Escherichia coli cells, which do not express any toluene oxygenase gene, exposed to each of the enzyme probes as described above.

Positive controls consisted of exposing laboratory grown strains (expressing various toluene oxygenases or sMMO), under toluene or methane induction conditions, to the appropriate enzyme probe. Specifically, Burkholderia cepacia (G4), which has the toluene-2monoxygenase, and Ralstonia picketti (PK01), which has the toluene-3-monooxygenase as controls for the 3HPA probe; Pseudomonas putida (F1), which has the 2,3-dioxygenase, and Pseudomonas sp. (W31), having the toluene-3-monooxygenase, as positive test organisms for the PA probe; F1 as a positive test organism for the cinnamonitrile probe; and Methylosinus trichosporium (OB3b) as a positive control for the coumarin probe (sMMO). 


\subsubsection{DAPI Staining}

DAPI is a general fluorescent stain that binds to the DNA of bacterial cells. The total number of cells is determined by the number of cells that can be stained and counted using epifluorescent microscopy. Groundwater samples $(10 \mathrm{~mL})$ were filtered onto black polycarbonate filters. DAPI was added onto the surface of the filter and incubated for 5 minutes $(60 \mu \mathrm{l} / \mathrm{ml}$; final concentration $3 \mu \mathrm{g} / \mathrm{ml}$ ) at room temperature. Following the staining protocol, samples were washed with $1 \mathrm{~mL}$ of nanopure water and vacuum-filter dried. Filters were mounted on glass microscope slides, covered with immersion oil and a coverslip, and viewed using an epifluorescent microscope equipped with ultraviolet (UV) capabilities.

\subsubsection{DNA Analysis}

In addition to the enzyme probes, a series of molecular probes have been developed or adapted to investigate the genetic potential of toluene and methane-oxidizing microbial populations (McDonald et al., 1995; Baldwin et al., 2003). These techniques are designed to look for the presence of the genes coding for toluene or methane oxygenases and are considered indirect or supporting evidence for the enzyme activity measurements. Enzyme activity probes provide direct evidence of degradative activity, while DNA analysis determines the potential for degradative activity. A sufficient amount of DNA could not be extracted from the volume of groundwater taken at TAG wells; therefore, this supporting evidence for the enzyme activity is not available.

\subsubsection{Inhibition Control Studies}

In addition to the control studies discussed in Section 2.2.2, several inhibitory controls were performed to support the enzyme activity probe findings. Phenylacetylene, an irreversible inhibitor, was applied to a sub-set of TAG samples (TJA-3, TJA-6, TA1-W-02, TA2-W-26, TA2SW1-320, and TA1-W-05). Groundwater samples ( 900 mL) were filtered onto a 47-mm Supor filter. Filters were cut, using a sterile razor blade, into four quadrants. One of the quadrants was exposed to $250 \mu \mathrm{M}$ PA at room temperature for 10 minutes. The filter was placed onto the tower, washed with $1 \mathrm{~mL}$ of nanopure water, and then exposed to the enzyme probe (coumarin), as described above. The filters were viewed and counted with an epifluorescent microscope.

Many of the toluene pathways are irreversibly inhibited by the presence of 1-pentyne (10\% v/v), the only exception being the toluene dioxygenase enzyme (Keener et al., 2001). Select samples (TA2-W-19, TJA-6, TJA-2, TA2-SW1-320, TJA-7, and TA1-W-05) were incubated in the presence of 1-pentyne and subsequently assessed for enzyme activity. Briefly, $5 \mathrm{~mL}$ of groundwater was filtered onto two Supor filters. One filter was exposed to 1-pentyne (vapor form) for 2 hours, the other for 2 days; both in a vacuum desiccator. Following exposure, filters were assessed for enzyme probe response, as described in Section 2.2.1. 


\subsection{RESULTS}

This section presents the enzyme probe and control study results. Section 3.1 presents the results of the enzyme probe (fluorescence data), while Section 3.2 presents the results of the control studies.

\subsection{Enzyme Probe Sample Results}

Table 1 presents the results of the enzyme probe sample analyses. For each result, the sample date, well location, Administrative Record/Chain of Custody (COC) number, and SNL/NM Sample ID are listed. For the toluene probes (3HPA, PA, Cinn) and sMMO probe (coumarin), a positive response with the probe and the presence of active enzymes in the sample is designated as yes $(\mathrm{Y})$. A no $(\mathrm{N})$ indicates there was no probe response detected. More details, primarily about the fraction of the total cells that were probe positive, can be found in Appendix A. The DAPI column shows the total number of microorganisms in a given groundwater sample, as determined by DAPI staining.

Figure 2 shows the results of applying enzyme probes to a sample from well TJA-2 (Sample ID 066763-042); the figure shows both a negative (PA) and positive (3HPA) response to application of the toluene enzyme probes. The micrograph on the left represents the DAPI-stained or total number of microbial cells present in the sample, the center micrograph shows a negative response, and the right micrograph represents the cells that transformed the probe into a fluorescent product.
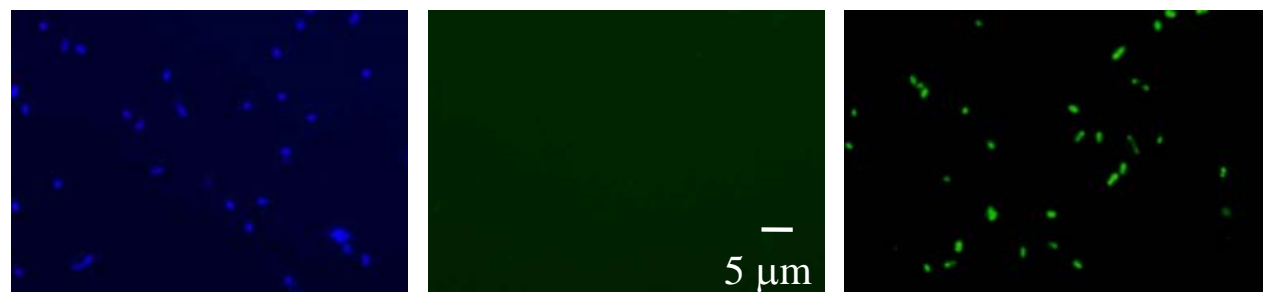

Figure 2. Micrographs of Sample TJA-2 within the perched groundwater system.

\subsection{Control Studies}

Since a sufficient amount of microbial DNA could not be extracted from the volume of groundwater taken, control studies were performed to confirm that observed results were not artificial or influenced by outside factors (i.e., inducers). The series of negative controls were designed to determine if the probes provided a false positive response. The results for two of the three controls are presented in Table 2. Enzyme probes pipetted onto filters without cells resulted in no fluorescent signal. E.coli cells (no toluene oxygenase enzymes) exposed to each of the enzyme probes also resulted in no fluorescent signal (Table 2 rows 1 and 2). The third negative control consisted of filtering every sample onto a black polycarbonate filter to determine if there was background fluorescence (data not shown). In all cases, no fluorescence was observed in the absence of the enzyme probes. These results show that the probes did not give a false positive result. 
Table 1. Results of enzyme probe analysis.

\begin{tabular}{|c|c|c|c|c|c|c|c|c|c|}
\hline \multirow[b]{2}{*}{ Date } & \multirow[b]{2}{*}{ Well Location } & \multirow[b]{2}{*}{ Aquifer } & \multirow[b]{2}{*}{ COC \# } & \multirow[b]{2}{*}{ Sample ID } & \multicolumn{3}{|c|}{ Toluene probes ${ }^{a}$} & \multirow{2}{*}{$\begin{array}{c}\text { sMMO probe }^{a} \\
\text { Coumarin } \\
\end{array}$} & \multirow{2}{*}{$\begin{array}{c}\text { DAPI } \\
\text { Cells/mL }\end{array}$} \\
\hline & & & & & 3HPA & PA & Cinn & & \\
\hline 01.04 .05 & TA2-W-19 & Perched & 608124 & 066752-042 & $\mathrm{Y}$ & $\mathrm{Y}$ & $\mathrm{Y}$ & $\mathrm{N}$ & $3.20 \mathrm{E}+03$ \\
\hline 01.05 .05 & TJA-3 & Regional & 608132 & 066765-042 & $\mathrm{Y}$ & $\mathrm{N}$ & $\mathrm{Y}$ & $\mathrm{Y}$ & $5.00 \mathrm{E}+03$ \\
\hline 01.06 .05 & TJA-6 & Regional & 608135 & 066769-042 & $\mathrm{Y}$ & $\mathrm{Y}$ & $\mathrm{Y}$ & $\mathrm{Y}$ & $2.30 \mathrm{E}+04$ \\
\hline 01.11 .05 & WYO-4 & Perched & 608143 & 066778-042 & $\mathrm{N}$ & $\mathrm{N}$ & $\mathrm{N}$ & $\mathrm{N}$ & $2.34 \mathrm{E}+03$ \\
\hline 01.11 .05 & TA1-W-02 & Regional & 608109 & 066731-042 & $\mathrm{N}$ & $\mathrm{Y}$ & $\mathrm{Y}$ & $\mathrm{Y}$ & $1.19 \mathrm{E}+04$ \\
\hline 01.12 .05 & TA2-W-01 & Perched & 608122 & 066750-042 & $\mathrm{N}$ & $\mathrm{N}$ & $\mathrm{Y}$ & $\mathrm{N}$ & $4.60 \mathrm{E}+03$ \\
\hline 01.12 .05 & TA1-W-08 & Perched & 608116 & 066742-042 & $\mathrm{N}$ & $\mathrm{Y}$ & $\mathrm{Y}$ & $\mathrm{N}$ & $5.50 \mathrm{E}+03$ \\
\hline 01.13 .05 & TA2-W-26 & Perched & 608126 & 066755-042 & $\mathrm{Y}$ & $\mathrm{N}$ & $\mathrm{Y}$ & $\mathrm{Y}$ & $7.10 \mathrm{E}+03$ \\
\hline 01.13 .05 & TJA-2 & Perched & 608130 & 066763-042 & $\mathrm{Y}$ & $\mathrm{N}$ & $\mathrm{Y}$ & $\mathrm{N}$ & $2.37 \mathrm{E}+03$ \\
\hline 01.17.05 & TA2-SW1-320 & Perched & 608120 & 066748-042 & $\mathrm{Y}$ & $\mathrm{Y}$ & $\mathrm{Y}$ & $\mathrm{Y}$ & $2.35 E+03$ \\
\hline 01.20 .05 & TJA-7 & Perched & 608139 & 066771-042 & $\mathrm{Y}$ & $\mathrm{Y}$ & $\mathrm{Y}$ & $\mathrm{N}$ & $9.65 E+03$ \\
\hline 01.25 .05 & TA1-W-05 & Regional & 608113 & 066737-042 & $\mathrm{Y}$ & $\mathrm{Y}$ & $\mathrm{Y}$ & $\mathrm{Y}$ & $7.54 \mathrm{E}+03$ \\
\hline
\end{tabular}

a- $\quad$ Yes (Y) indicates the presence of an active toluene or sMMO enzyme in the groundwater sample; no (N) indicates no probe response. 
Table 2. Results of control studies from wells at the TAG wells.

\begin{tabular}{c|c|c|c|c|c}
\hline $\begin{array}{c}\text { Control/Bacterial } \\
\text { Strain }\end{array}$ & Enzyme & PA & 3HPA & Cinn & Coumarin \\
\hline Filter $^{a}$ & N/A & - & - & - & - \\
\hline E.coli $^{b}$ & N/A & - & - & - & - \\
\hline $\mathrm{G4}^{c}$ & 2-monooxygenase & + & + & - & - \\
\hline $\mathrm{PK01}^{c}$ & 3-monooxygenase & - & + & - & - \\
\hline $\mathrm{F} 1^{c}$ & 2,3-dioxygenase & + & + & + & - \\
\hline${\mathrm{W} 31^{c}}^{c}$ & 3-monooxygenase & + & - & + & - \\
\hline${\mathrm{OB} 3 b^{d}}^{c}$ & sMMO & - & - & - & + \\
\hline
\end{tabular}

a- Cells on a black filter, no probe.

b- E.coli cells (no toluene genes) exposed to enzyme probes specific for toluene oxygenases.

c- Laboratory strains with toluene oxygenase enzymes and exposed to enzyme probes.

d- Laboratory strains with sMMO enzyme and exposed to the coumarin probe.

The + symbol designates that a positive response (fluorescent signal) was achieved. The - symbol means that there was no response.

The second series of controls were those which used laboratory strains exposed to enzyme probes to provide confirmation that each of the probes was functioning as expected (i.e., that a positive response is produced in actively degrading organisms with the appropriate enzyme). In all cases, the bacterial cells with the appropriate enzyme responded positively (fluorescent signal) to the application of the enzyme probe (Table 2). Each of these strains also responded negatively to probes targeted at other toluene oxygenase enzymes. The results show that the probes were accurately detecting active enzymes.

In addition to these controls, several other inhibitory controls were performed. PA, an irreversible inhibitor, was applied to TAG samples that showed activity as determined by the coumarin assay. At the chosen concentration, PA has been shown to differentially inhibit the soluble versus the particulate form of the enzyme as well as the methane oxygenase enzyme in comparison to other enzymes (Lontoh et al., 2000). Deactivation of the sMMO enzyme by exposure to PA should therefore result in the loss of the fluorescent response to coumarin. Table 3 indicates that inhibition of the fluorescent signal (I) was observed in all of the samples to which the inhibitor was applied. 
Table 3. Results of the sMMO inhibitor study from TAG wells.

\begin{tabular}{c|c|c|c|c|c|c}
\hline Date & Well Location & Aquifer & COC \# & Sample ID & $\begin{array}{c}\text { sMMO } \\
\text { activity }\end{array}$ & PA $^{\boldsymbol{a}}$ \\
\hline $01 / 05 / 05$ & TJA-3 & Regional & 608132 & $066765-042$ & $\mathrm{Y}$ & $\mathrm{I}$ \\
\hline $01 / 06 / 05$ & TJA-6 & Regional & 608135 & $066769-042$ & $\mathrm{Y}$ & $\mathrm{I}$ \\
\hline $01 / 11 / 05$ & TA1-W-02 & Regional & 608109 & $066731-042$ & $\mathrm{Y}$ & $\mathrm{I}$ \\
\hline $01 / 13 / 05$ & TA2-W-26 & Perched & 608126 & $066755-042$ & $\mathrm{Y}$ & $\mathrm{I}$ \\
\hline $01 / 17 / 05$ & TA2-SW1-320 & Perched & 608120 & $066748-042$ & $\mathrm{Y}$ & $\mathrm{I}$ \\
\hline $01 / 25 / 05$ & TA1-W-05 & Regional & 608113 & $066737-042$ & $\mathrm{Y}$ & $\mathrm{I}$ \\
\hline
\end{tabular}

a- $\quad$ Phenylacetylene was used as an inhibitor of the sMMO enzyme; Inhibition (I) indicates that the sample was inhibited and no fluorescent signal was detected; Yes (Y) indicates the presence of an active sMMO enzyme in the groundwater sample.

A study based on laboratory cultures showed that many of the toluene pathways are irreversibly inhibited by the presence of 1-pentyne (Keener et al., 2001). Select samples were incubated in the presence of 1-pentyne and subsequently assessed for enzyme activity with the probes. Table 4 shows the results of the inhibition of the toluene enzymes; all of the samples were inhibited and showed no fluorescent signal following exposure.

Table 4. Results of the toluene inhibitor study from TAG wells.

\begin{tabular}{c|c|c|c|c|c|c}
\hline Date & Well Location & Aquifer & COC \# & Sample ID & $\begin{array}{c}\text { Toluene } \\
\text { activity }\end{array}$ & 1-pentyne \\
\hline $01 / 04 / 05$ & TA2-W-19 & Perched & 608124 & $066752-042$ & Y & I \\
\hline $01 / 06 / 05$ & TJA-6 & Regional & 608135 & $066769-042$ & Y & I \\
\hline $01 / 13 / 05$ & TJA-2 & Perched & 608130 & $066763-042$ & Y & I \\
\hline $01 / 17 / 05$ & TA2-SW1-320 & Perched & 608120 & $066748-042$ & Y & I \\
\hline $01 / 20 / 05$ & TJA-7 & Perched & 608139 & $066771-042$ & Y & I \\
\hline $01 / 25 / 05$ & TA1-W-05 & Regional & 608113 & $066737-042$ & Y & I \\
\hline
\end{tabular}

a- 1-pentyne was used as an inhibitor of the toluene oxygenase enzymes. Inhibition (I) indicates that the sample was inhibited and no fluorescent signal was detected; Yes (Y) indicates the presence of an active toluene enzyme in the groundwater sample. 


\subsection{SUMMARY AND CONCLUSIONS}

The purpose of these studies was to investigate biodegradation of TCE in the perched groundwater system. The primary goal was to identify an active aerobic degradation mechanism through the use of enzyme activity probes.

A suite of probes has been developed that indicate activity of enzymes responsible for cometabolic degradation of TCE. Three toluene degradation pathways and the sMMO degradation pathway were evaluated. Enzymes responsible for degradation of these compounds have been shown to cometabolically degrade TCE and have been found in all groundwater systems investigated thus far, including the Test Area North site of the Idaho National Laboratory, Technical Area V (TA-V) site of the Sandia National Laboratories, and the Arizona Department of Environmental Quality Park-Euclid WQARF (PE) site (Wymore et al., 2004; Clingenpeel et al., 2005b; Howard et al., 2005).

The results of the TAG enzyme probe analysis ascertains the presence and activity of at least one toluene oxygenase or sMMO enzyme in all but one of the wells sampled (WYO-4) based on the application of enzyme activity probes. Fifty percent of the wells showed activity with the sMMO enzyme probe, while $92 \%$ (11 out of 12) showed a response with the toluene probes. Any positive response, even with one probe, provides direct evidence of enzyme activity in the groundwater sample. Control studies confirmed the findings of the enzyme probe data, specifically that the probes accurately and efficiently targeted specific oxidative pathways. Inhibition studies confirmed that the activity measured was a result of the enzyme targeted and not as a result of other oxygenase enzymes.

The detection of both sMMO and toluene oxygenase enzyme activity (as determined by enzyme activity probes) in TAG samples identifies cometabolism as a mechanism of natural attenuation. Active enzymes were found throughout the tested area, including samples taken from both inside and outside the TCE contamination area, in the perched groundwater system and at all regional aquifer wells. This demonstrates that the process is not driven by constituents in the contaminated groundwater but by the presence of the enzymes and oxygen. These data provide conclusive evidence of active enzyme systems capable of TCE degradation at the TAG SNL/NM are of responsibility and more importantly represent an active mechanism for the natural attenuation of contaminants. 
This Page Intentionally Left Blank

E-20 


\subsection{REFERENCES}

10. Alexander, M. (1967). In “Agriculture and the Quality of Our Environment” (N.C. Brady, ed.), American Association for the Advancement of Science, Washington D.C., pp. 331-342.

11. Alvarez-Cohen, L., and McCarty, P. L. (1991). "Effects of toxicity, aeration, and reductant supply on trichloroethylene transformation by a mixed methanotrophic culture." Appl. Environ. Microbiol., 57, 228-235.

12. Baldwin, B. R., Nakatsu, C. H., and Nies, L. (2003). "Detection and enumeration of aromatic oxygenase genes by multiplex and real-time PCR." Appl. Environ. Microbiol., 69(6), 33503358.

13. Brockman, F. J. (1995). "Nucleic-acid based methods for monitoring the performance of in situ bioremediation." Molec. Ecol., 4, 567-578.

14. Clingenpeel, S. R., Keener, W. K., Keller, C. R., De Jesus, K., Howard, M. H., and Watwood, M. E. (2005a). "Activity-dependent fluorescent labeling of bacterial cells expressing the TOL pathway." Journal of Microb. Meth., 60, 41-46.

15. Clingenpeel, S.R., Howard, M.H., Wymore, R.A., Sorenson, K.S, and Watwood, M.E. (2005b). "Evaluation of Enzyme Activity Probes for Detection of Contaminant-Degrading Microorganisms in Trichloroethylene-Contaminated Groundwater at Three Field Sites.” Abstr. $105^{\text {th }}$ Gen. Meet. Am. Soc. Microbiol., O-004.

16. Ensley, B. D. (1991). "Biochemical diversity of trichloroethylene metabolism." Annu. Rev. Microbiol., 45, 283-299.

17. Fogel, M. M., Taddeo, A. R., and Fogel, S. (1986). "Biodegradation of chlorinated ethenes by a methane-utilizing mixed culture." Appl. Environ. Microbiol., 51, 720-724.

18. Fries, M. R., Forney, L. J., and Tiedje, J. M. (1997). "Phenol- and Toluene-degrading microbial populations from an aquifer in which successful trichloroethene cometabolism is observed." Appl. Environ. Microbiol., 63(4), 1523-1530.

19. Howard, M.H., Clingenpeel, S.C., Leiser, O.P. and Watwood, M.E. (2005). “Molecular and Physiological Characterization of Aerobic TCE Degradation Potential.” Eighth International In Situ and On-Site Bioremediation Symposium. Battelle Press, Columbus, $\mathrm{OH}$.

20. Kauffman, M. E., Keener, W. K., Watwood, M. E., and Lehman, R. M. (2003). "Use of 3hydroxyphenylacetylene for activity-dependent, fluorescent labeling of bacteria that degrade toluene via 3-methylcatechol.” Journal of Microb. Meth. 55, 801-805.

21. Keener, W. K., Watwood, M. E., and Apel, W. A. (1997). Probes for enzyme-dependent fluorescent labeling of bacteria degrading trichloroethylene, Battelle Press, Columbus, Ohio. 
22. Keener, W. K., Watwood, M. E., and Apel, W. A. (1998). "Activity-dependent fluorescent labeling of bacteria that degrade toluene 2,3-dioxygenase." Appl. Microbiol. Biotech., 49, 455-462.

23. Little, C. D., Palumbo, A. V., Herbes, S. E., Lidstom, M. E., Tyndall, R. L., and Gilmer, P. J. (1988). "Trichloroethylene biodegradation by a methane-oxidizing bacterium." Appl. Environ. Microbiol., 951-956.

24. Lontoh, S., DiSpirito, A.A., Krema, C.L., Whittaker, M.R., Hooper, A.B., and Semrau, J.D. (2000). "Differential inhibition in vivo of ammonia monooxygenase, soluble methane monooxygenase and membrane-associated methane monooxygenase by phenylacetylene." Environ. Microbiol., 2(5), 485-494.

25. Madsen, E. L. (1991). "Determining in situ biodegradation: facts and challenges." Environ. Sci. Technol., 25, 1662-1673.

26. Madsen, E. L. (1998). "Epistemology of environmental microbiology." Environ. Sci. Technol., 32, 429-539.

27. McDonald, I. R., Kenna, E. M., and Murrell, J. C. (1995). "Detection of methanotrophic bacteria in environmental samples with PCR." Appl. Environ. Microbiol, 61(1), 116-121.

28. Mesarch, M. B., Nakatsu, C. H., and Nies, L. (2000). "Development of Catechol 2,3dioxygenase-specific primers for monitoring bioremediation by competitive quantitative PCR." Appl. Environ. Microbiol., 66(2), 678-683.

29. Miller, A. R., Keener, W. K., Watwood, M. E., and Roberto, F. F. (2002). "A rapid fluorescence-based assay for detecting soluble methane monooxygenase." Appl. Microbiol. Biotechnol., 58, 183-188.

30. NMED, 2004, "Compliance Order on Consent Pursuant to the New Mexico Hazardous Waste Act 74-4-10: Sandia National Laboratories Consent Order,” New Mexico Environment Department, April 29, 2004.

31. Oldenhuis, R., Oedzes, J. Y., Waarde, J. J. v. d., and Janssen, D. B. (1991). "Kinetics of chlorinated degradation by Methylosinus trichosporium OB3b and toxicity of trichloroethylene." Appl. Environ. Microbiol, 57, 7-14.

32. Oldenhuis, R. R. L., Vink, J. M., Jannsen, D. B., and Wiltholt, B. (1989). "Degradation of chlorinated aliphatic hydrocarbons by Methylosinus trichosporium OB3b expressing soluble methane monooxygenase." Appl. Environ. Microbiol, 55, 2819-2826.

33. Orr, B.R. and Dettmers, D.L. (2004). "Current conceptual model of groundwater flow and contaminant transport at Sandia National Laboratories/New Mexico Technical Area V,”, SAND2004-11470, Sandia National Laboratories, New Mexico. 
34. Parales, R. E., Ditty, J. L., and Harwood, C. S. (2000). "Toluene-degrading bacteria are chemotactic towards the environmental pollutants benzene, toluene, and trichloroethylene." Appl. Environ. Microbiol., 66(9), 4098-4104.

35. Pfiffner, S. M., Phelps, T. J., Palumbo, A. V., and Hazen, T. C. (1997). "The effects of nutrient dosing on subsurface methanotrophic populations and TCE degradation capabilities." Journal of Industrial Microbiology, 18, 204-212.

36. SNL/NM, 2004a, "Corrective Measures Evaluation Work Plan Technical Area-V Groundwater,” SAND2004-1471, Sandia National Laboratories/New Mexico.

37. Speitel, G. E., and Alley, E. R. (1991). "Bioremediation of unsaturated soils contaminated with chlorinated solvents." Journal of Hazardous Materials, 28, 81-90.

38. Tsien, H.-C., Brusseau, G. A., Hanson, R. S., and Wackett, L. P. (1989). "Biodegradation of trichloroethylene by Methylosinus trichosporium OB3b." Appl. Environ. Microbiol, 55(12), 3155-3161.

39. Wackett, L.P. (1984). "P.h.D. Dissertation” The University of Texas, Austin.

40. Wilson, J.T. and Wilson, B.H. (1985). "Biotransformation of Trichloroethylene in soil." Appl. Environ. Microbiol, 49, 242-243.

41. Wymore, R.A., Harris, K.L., and Sorenson, K.S. (2004). "Final Quick Win Vertical Profile Sampling Report” NEW-ID-2003-046, Revision 0, North Wind, Inc. 
This Page Intentionally Left Blank 
Appendix A

Enzyme Probe Data

E-25 
This Page Intentionally Left Blank 
Table A-1. Results of enzyme probe analysis.

\begin{tabular}{c|c|c|c|c|c|c|c|c}
\hline \multicolumn{2}{c|}{} & \multicolumn{3}{|c|}{$\begin{array}{c}\text { Toluene } \\
\text { probes }\end{array}$} & $\begin{array}{c}\text { sMMO } \\
\text { probe }\end{array}$ & $\begin{array}{c}\text { Total DAPI } \\
\text { count }\end{array}$ \\
\hline Date & Well Location & COC \# & Sample ID & 3HPA & PA & Cinn & Coumarin & Cells/mL \\
\hline $01 / 04 / 05$ & TA2-W-19 & 608124 & $066752-042$ & ++ & + & + & - & $3.20 \mathrm{E}+03$ \\
\hline $01 / 05 / 05$ & TJA-3 & 608132 & $066765-042$ & + & - & + & + & $5.00 \mathrm{E}+03$ \\
\hline $01 / 06 / 05$ & TJA-6 & 608135 & $066769-042$ & +++ & ++ & +++ & + & $2.30 \mathrm{E}+04$ \\
\hline $01 / 11 / 05$ & WYO-4 & 608143 & $066778-042$ & - & - & - & - & $2.34 \mathrm{E}+03$ \\
\hline $01 / 11 / 05$ & TA1-W-02 & 608109 & $066731-042$ & - & + & + & + & $1.19 \mathrm{E}+04$ \\
\hline $01 / 12 / 05$ & TA2-W-01 & 608122 & $066750-042$ & - & - & + & - & $4.60 \mathrm{E}+03$ \\
\hline $01 / 12 / 05$ & TA1-W-08 & 608116 & $066742-042$ & - & + & + & - & $5.50 \mathrm{E}+03$ \\
\hline $01 / 13 / 05$ & TA2-W-26 & 608126 & $066755-042$ & + & - & + & + & $7.10 \mathrm{E}+03$ \\
\hline $01 / 13 / 05$ & TJA-2 & 608130 & $066763-042$ & ++ & - & + & - & $2.37 \mathrm{E}+03$ \\
\hline $01 / 17 / 05$ & TA2-SW1-320 & 608120 & $066748-042$ & ++ & + & + & + & $2.35 \mathrm{E}+03$ \\
\hline $01 / 20 / 05$ & TJA-7 & 608139 & $066771-042$ & + & + & ++ & - & $9.65 \mathrm{E}+03$ \\
\hline $01 / 25 / 05$ & TA1-W-05 & 608113 & $066737-042$ & + & + & + & + & $7.54 \mathrm{E}+03$ \\
\hline
\end{tabular}

a The number of plus signs designated the percentage of positive response resulting from each probe. For example, a single plus sign indicates that between $10-25 \%$ of the total cells in the sample demonstrated a clear quantifiable response when exposed to that particular probe; Two plus signs represents $25-50 \%$; three, $50-75 \%$; and four $75-100 \%$ of the total microbial population were probe positive, verifying enzyme activity.

b A plus sign indicates that sMMO activity was detected. A minus sign indicates that no enzyme activity was determined; no fluorescence was detected. 
This Page Intentionally Left Blank 


\section{Distribution:}

\section{External:}

Joe Rothermel (6)

North Wind, Inc.

1425 Higham Street

Idaho Falls, ID 83405

Robert Ferry (1)

CE2 Corporation

2702 Gelding Lane

Livermore, CA 94551

Karren Suesz (4)

DOE/SNL Community Resources Information Office

c/o Epsilon Systems Solutions

2017 Yale Boulevard SE, Suite E

Albuquerque, NM 87106

Kim Ong (1)

316 Dartmouth SE

Albuquerque, NM 87106

Internal:

$\begin{array}{llll}1 & \text { MS-0750 } & \text { P. Brady } & 6118 \\ 1 & \text { MS-1042 } & \text { F. Lauffer } & 6331 \\ 1 & \text { MS-1087 } & \text { J. Copland } & 6146 \\ 1 & \text { MS-0754 } & \text { S. Collins } & 6118 \\ 1 & \text { MS-1087 } & \text { T. Jackson } & 6146 \\ 1 & \text { MS-1087 } & \text { M. Skelly } & 6146 \\ 10 & \text { MS-1089 } & \text { M. Bachicha } & 6031 \\ & & & \\ 2 & \text { MS-0899 } & \text { Technical Library } & 9616 \\ 1 & \text { MS-9018 } & \text { Central Tech Files } & 8945-1\end{array}$

